Національна академія педагогічних наук України Інститут вищої освіти

\title{
Механізми реалізації ефективного врядування в університетах України в умовах євроінтеграції
}

Колективна монографія 
ISBN 978-617-7486-37-3

УДК 378.112:303.823

https://doi.org/10.31874/978-617-7486-37-3-2020

Механізми реалізації ефективного врядування в університетах України в умовах євроінтеграції: Колективна монографія / Авторський колектив: І. Драч, С. Калашнікова, О. Паламарчук, В. Рябченко, Л. Червона; за заг. ред.С. Калашнікової. - Київ: Інститут вищої освіти НАПН України, 2020. - 223 с.

Рекомендовано до друку Вченою радою Інституту вищої освіти НАПН України (протокол № 7/4 від 23 листопада 2020 р.)

Рецензенти:

Галус О.М. - доктор педагогічних наук, професор, проректор з наукової роботи Хмельницької гуманітарно-педагогічної академії

Слюсар В.М. - доктор філософських наук, доцент, професор кафедри філософії та політології Житомирського державного університету імені Івана Франка

Дане видання підготовлено авторським колективом Відділу лідерства та інституційного розвитку вищої освіти Інституту вищої освіти НАПН України за результатами виконання НДР «Механізми реалізації ефективного врядування в університетах України в умовах євроінтеграції» (2018-2020рр.).

У монографії обґрунтовано теоретичні основи реалізації ефективного врядування в університетах, проаналізовано провідний вітчизняний та зарубіжний досвід реалізації ефективного врядування в університетах та на основі вище зазначеного визначено механізми реалізації ефективного врядування в університетах та сформульовано практичні рекомендації для їх імплементації у вищій освіті України.

Акцентовано, що однією з фундаментальних вимог до успішної євроінтеграції університетів України $\epsilon$ забезпечення ними у своєму соціальному середовищі сповідування європейських цінностей, дотримання академічних свобод, соціальної справедливості, відповідальності та доброчесності. Запропоновано розглядати розвиток особистісного потенціалу суб'єктів діяльності університету як інтегральний критерій результативності й ефективності врядування та визначальний чинник забезпечення його конкурентоспроможності. Обгрунтовано, що найсприятливіші умови для розвитку особистісного потенціалу, отже й людського капіталу, створюються лишень у демократичному середовищі, формування якого забезпечується врядуванням.

Авторський колектив висловлює надію, що представлені у монографії результати, висновки та рекомендації сприятимуть розвитку досліджень за відповідною тематикою, а також практиці розвитку ефективного врядування в університетах України.

(C) Інститут вищої освіти НАПН України, 2020

(C) Авторський колектив, 2020 


\section{Зміст}

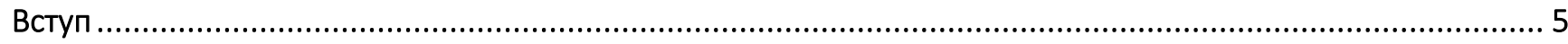

Розділ 1. Фактори забезпечення ефективного університетського врядування ........................................ 6

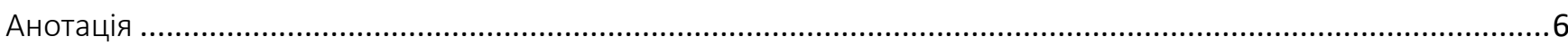

Актуальність проблеми забезпечення ефективного врядування у вищій освіті .............................................

Теоретичні основи реалізації ефективного врядування в університетах …...................................................14

Фактори забезпечення ефективного врядування у вищій освіті ...................................................................19

Механізми забезпечення ефективного університетського врядування …......................................................21

Реалізація врядування у вищій освіті: приклади зарубіжних практик ..........................................................25

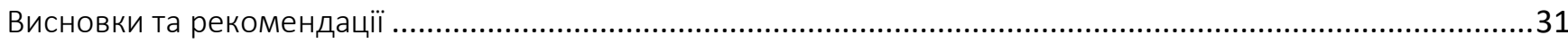

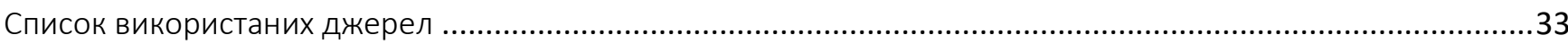

Розділ 2. Вплив соціального середовища на ефективне врядування в українських університетах: світоглядно-

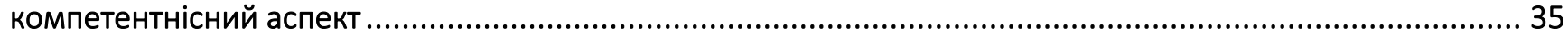

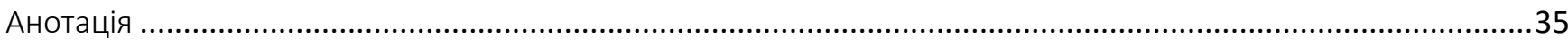

Актуальність дослідження проблеми врядування у вищій освіті ...............................................................36

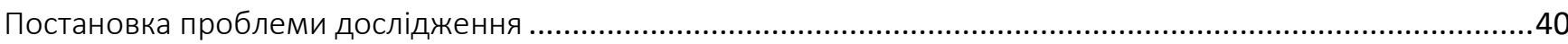

Теоретичне обґрунтування сутності врядування та впливу на нього суспільства й соціального середовища

Теоретичне обґрунтування впливу соціального середовища ЗВО на запровадження в ньому механізмів ефективного врядування

Залежність конкурентоспроможності й успішності України та їі закладів вищої освіти від рівня розвитку демократії: порівняльний аналіз з країнами з усталеними демократіями і правовими державами.

Критерії результативності та ефективності діяльності закладів вищої освіти, на які має орієнтуватись їх врядування в умовах євроінтеграції.......

Рекомендації щодо демократизації українського суспільства та його закладів вищої освіти . .94

Висновки .98

Зауваження та пропозиції до проєкту Стратегії розвитку вищої освіти в Україні на 2021-2030 роки. 102

Список використаних джерел 104

Розділ 3. Управління дослідницькою діяльністю в системі університетського врядування 109

Анотація 109

Актуальність проблеми дослідницького врядування в сучасному університеті 110

Аналіз документів, вітчизняних і зарубіжних публікацій з проблем дослідницького врядування. .114

Моделі університетського врядування в європейських системах вищої освіти 120

Особливості дослідницького врядування в сучасному університеті 125

Інституційна політика та органи дослідницького врядування в європейських університетах .127

Підтримка дослідницької доброчесності в університетах на національному рівні: досвід Великої Британії 
Модель дослідницького врядування в університеті 143

Висновки 147

Список використаних джерел

Розділ 4. Роль студентської спільноти у забезпеченні ефективного університетського врядування 154

Анотація 154

Актуальність проблеми дослідження .... 155

Аналіз наукових джерел з проблем участі студентів в університетському врядуванні. 159

Теоретичне підґрунтя участі студентів в університетському врядуванні 163

Участь студентів в університетському врядуванні: основні механізми та інструменти. 173

Висновки 184

Список використаних джерел 186

Розділ 5. Участь академічного персоналу в ефективному врядуванні університету 190

Анотація 190

Актуальність проблеми залучення академічного персоналу до врядування в університеті в Європейському просторі вищої освіти та в Україні

Аналіз зарубіжних наукових публікацій з проблеми участі академічного персоналу в ефективному врядуванні університету

Теоретичні основи дослідження проблеми участі академічного персоналу в ефективному врядуванні університету. 199

Університетське врядування у Великій Британії: участь академічного персоналу .204

Участь науково-педагогічних працівників в університетському врядуванні: досвід України. .216

Висновки 220

Список використаних джерел 


\section{Вступ}

Колективна монографія «Механізми реалізації ефективного врядування в університетах України» $\epsilon$ фінальним результатом виконання наукового дослідження з аналогічною назвою, що здійснювалося протягом 2018-2020 років колективом Відділу лідерства та інституційного розвитку Інституту вищої освіти Національної академії педагогічних наук України у складі:

- керівник наукового дослідження: Рябченко Володимир Іванович - доктор філософських наук, старший науковий співробітник;

- виконавці:

○ Драч Ірина Іванівна - доктор педагогічних наук, доцент-;

○ Калашнікова Світлана Андріївна - доктор педагогічних наук, професор, член-кореспондент НАПН України;

- Паламарчук Ольга Федорівна - кандидат педагогічних наук;

○ Червона Леся Миколаївна - кандидат філософських наук, старший науковий співробітник.

Мета наукового дослідження полягала у тому, щоб визначити та обґрунтувати механізми реалізації ефективного врядування в університетах України.

\section{Дослідження здійснювалося у три етапи.}

Перший етап (2018 рік) спрямовано на обґрунтування теоретичних основ реалізації ефективного врядування в університетах. Результати виконання першого етапу представлені у публікації «Аналіз провідного вітчизняного та зарубіжного досвіду розвитку щодо механізмів реалізації ефективного врядування в університетах: препринт (аналітичні матеріали) (частина I)» ${ }^{1}$.

Другий етап дослідження (2019 рік) присвячено аналізу провідного вітчизняного та зарубіжного досвіду реалізації ефективного врядування в університетах. Результати виконання другого етапу представлено у публікації «Аналіз провідного вітчизняного та зарубіжного досвіду щодо механізмів реалізації ефективного врядування в університетах: препринт (аналітичні матеріали) (частина II)»².

Останній третій етап здійснювався протягом 2020 року задля визначення та обґрунтування механізмів реалізації ефективного врядування в університетах.

\section{Всі три етапи наукового дослідження реалізовувалися за такими змістовними напрямками:}

- Фактори забезпечення ефективного університетського врядування (виконавець С. Калашнікова).

- Влив соціального середовища на ефективність університетського врядування (світоглядний аспект) (виконавець - В. Рябченко).

- Управління дослідницькою діяльністю в системі університетського врядування (виконавець - І. Драч).

- Участь академічного персоналу в університетському врядуванні (виконавець О. Паламарчук).

- Роль студентської спільноти у забезпеченні ефективного університетського врядування (виконавець - Л. Червона).

\footnotetext{
${ }^{1}$ Аналіз провідного вітчизняного та зарубіжного досвіду розвитку щодо механізмів реалізації ефективного врядування в університетах: препринт (аналітичні матеріали) (частина I) / Авторський колектив: І. Драч, С. Калашнікова, О. Паламарчук, В. Рябченко, Л. Червона; за заг. ред. С. Калашнікової. - Київ: Інститут вищої освіти НАПН України, 2018. - 147 c. URL: https://ihed.org.ua/wpcontent/uploads/2019/09/Analiz_dosvidu_vriaduvania_v_univer_ch1_analit_IVO-2018-147p_avtors-kolektiv.pdf

${ }^{2}$ Аналіз провідного вітчизняного та зарубіжного досвіду щодо механізмів реалізації ефективного врядування в університетах: препринт (аналітичні матеріали) (частина II) / Авторський колектив: І. Драч, О. Паламарчук, В. Рябченко, Л. Червона; за заг. ред. С. Калашнікової - Київ: Інститут вищої освіти НАПН України, 2019. - 96 с. URL: https://ihed.org.ua/wpcontent/uploads/2020/04/Analiz dosvidu vriaduvania v univer ch2 analit IVO-2019-96p avtors-kolektiv.pdf
} 


\title{
Розділ 1. Фактори забезпечення ефективного університетського врядування
}

\author{
Світлана Калашнікова, \\ доктор педагогічних наук, професор, \\ член-кореспондент НАПН України, \\ директор Інституту вищої освіти НАПН України, \\ член Національної команди експертів з реформування вищої освіти \\ https://orcid.org/0000-0002-3836-1915
}

\begin{abstract}
Анотація
У розділі засвідчено актуальність дослідження проблеми забезпечення ефективного врядування у вищій освіті через аналіз змісту останніх політичних та аналітичних матеріалів Європейського простору вищої освіти (ЄПВО), а саме: Великої Хартії Університетів 2020 (Magna Charta Universitatum 2020); Римського комюніке (Rome Ministerial Communiqué); Болонського звіту 2020 (The European Higher Education Area in 2020. Bologna Process Implementation Report). Визначено та обґрунтовано теоретичні основи реалізації ефективного врядування в університетах, до яких віднесено: ключові понятяя (врядування у вищій освіті; університетське врядування; ефективне врядування у вищій освіті; фактори забезпечення ефективного університетського врядування; механізми забезпечення ефективного університетського врядування); характеристики та принципи врядування у вищій освіті; відображення врядування через призму індикаторів для оцінювання рівня організаційної автономії університетів; опис моделей університетського врядування. Ідентифіковано фактори та механізми забезпечення ефективного врядування у вищій освіті. Здійснено огляд зарубіжних практик врядування у вищій освіті. Сформульовано рекомендації для впровадження ефективного врядування у вищій освіті України.
\end{abstract}




\section{Актуальність проблеми забезпечення ефективного врядування у вищій освіті}

у наших попередніх публікаціях $(3,4,6,7)$ ми засвідчили актуальність дослідження проблеми забезпечення ефективного врядування у вищій освіті через аналіз змісту декларацій та комюніке Європейського простору вищої освіти (European Higher Education Area, ЕНЕА) (далі - ЄПВО) включно з Паризьким комюніке (2018 р.) ${ }^{8}$.

У межах цієї публікації ми звернемося лише до аналізу змісту останніх політичних та аналітичних матеріалів ЄПВО, а саме:

- Великої Хартії Університетів 2020 (Magna Charta Universitatum 2020) 9 ;

- Римського комюніке (Rome Ministerial Communiqué) ${ }^{10}$;

- Болонського звіту 2020 (The European Higher Education Area in 2020. Bologna Process Implementation Report) ${ }^{11}$.

\footnotetext{
${ }^{3}$ Автономія та врядування у вищій освіті: збірник наукових праць / авторський колектив: О.П. Воробйова, К.О. Жданова, І.Б. Зарубінська, С.А. Калашнікова, О.І. Козієвська, І.О. Линьова, В.І. Луговий, О.М. Слюсаренко, Ж.В. Таланова / За ред. С.А. Калашнікової, В.І. Лугового, Ж.В. Таланової. - K.: , 2014. - 236 c. URL: https://ihed.org.ua/wp-content/uploads/2018/09/zbirnik Avtonomiya-ta-vraduv-Vish-osv IVONAPN-2014-236s.pdf

${ }^{4}$ Автономія та врядування у вищій освіті: монографія / Авт.: Воробйова О.П., Горецька Т.О., Дем'яненко Н.М., Калашнікова С.А., Коваленко О.М., Луговий В.І., Сич О., Слюсаренко О.М., Таланова Ж.В., Ткаченко В.П. - К.: Інститут вищої освіти НАПН України, 2015. 192 c. URL: https://ihed.org.ua/wp-content/uploads/2018/09/Avtonomiya-ta-vryaduv-VO monogr IVO-2015-192p_avtors-kolektiv.pdf

5 Правові засади реалізації Болонського процесу в Україні: монографія / Колектив авторів: Бугров В., Гожик А., Жданова К. та ін. ; за заг. ред. В. Лугового, С. Калашнікової. - К.: ДП «НВЦ «Пріоритети», 2014. - 156 с.

${ }^{6}$ Аналіз провідного вітчизняного та зарубіжного досвіду розвитку щодо механізмів реалізації ефективного врядування в університетах: препринт (аналітичні матеріали) (частина I) / Авторський колектив: І. Драч, С. Калашнікова, О. Паламарчук, В. Рябченко, Л. Червона; за заг. ред. С. Калашнікової. - Київ: Інститут вищої освіти НАПН України, 2018. - 147 c. URL: https://ihed.org.ua/wpcontent/uploads/2019/09/Analiz dosvidu vriaduvania v univer ch1_analit IVO-2018-147p_avtors-kolektiv.pdf

${ }_{7}^{7}$ Аналіз провідного вітчизняного та зарубіжного досвіду щодо механізмів реалізації ефективного врядування в університетах: препринт (аналітичні матеріали) (частина II) / Авторський колектив: І. Драч, О. Паламарчук, В. Рябченко, Л. Червона; за заг. ред. С. Калашнікової - Київ: Інститут вищої освіти НАПН України, 2019. - 96 c. URL: https://ihed.org.ua/wpcontent/uploads/2020/04/Analiz dosvidu vriaduvania $v$ univer ch2 analit IVO-2019-96p avtors-kolektiv.pdf

8 Paris Communiqué. URL: https://ihed.org.ua/wp-content/uploads/2019/02/Bologna_Conference_27.11.2018_Full_document_47p.pdf

9 Magna Charta Universitatum 2020. URL: http://www.magna-charta.org/magna-charta-universitatum/mcu-2020

10 Rome Ministerial Communique. November 19 2020. URL: https://ehea2020rome.it/storage/uploads/5d29d1cd-4616-4dfe-a2af29140a02ec09/BFUG Final Draft Rome Communique-link.pdf ; https://erasmusplus.org.ua/novyny/3254-zaproshuiemo-doluchytys-do-ixmizhnarodnoi-naukovo-praktychnoi-konferentsii.html (переклад українською мовою Національного Еразмус+ офісу в Україні)

${ }^{11}$ The European Higher Education Area in 2020. Bologna Process Implementation Report. - Luxemburg: Publications Office of European Union, 2020. - 201 p. URL: https://eacea.ec.europa.eu/national-policies/eurydice/sites/eurydice/files/ehea bologna 2020 0.pdf
} 


\section{Велика Хартія Університетів 2020 (Magna Charta Universitatum 2020) ${ }^{12}$}

У березні 2020 року була схвалена нова версія Великої Хартії Університетів (попередня версія 1988 року слугувала основою для розбудови університетської спільноти протягом понад 30 років). Враховуючи непересічний вплив, який створює ця ініціатива на розвиток університетів Європи та і світу в цілому, звернемося до аналізу тексту цього документу.

У Преамбулі документу визначені три фундаментальні принципи, що первинно були покладені в основу місії університетів: незалежність досліджень і викладання, інтеграція досліджень і викладання та залученість у цей процес студентів, відкритість та толерантність обміну думками. Незважаючи на всі радикальні та постійні зміни, притаманні сучасному світу, зазначені принципи залишаються актуальними, а роль університетів лише зростає та є визначальною для суспільного розвитку, що відображено у новій редакції Хартії таким чином ${ }^{13}$ :

\begin{tabular}{l} 
Universities acknowledge that they have a \\
responsibility to engage with and respond to the \\
aspirations and challenges of the world and to the \\
communities they serve, to benefit humanity and \\
contribute to sustainability. \\
Intellectual and moral autonomy is the hallmark of \\
any university and a precondition for the fulfilment of \\
its responsibilities to society. That independence \\
needs to be recognised and protected by \\
governments and society at large, and defended \\
vigorously by institutions themselves. \\
\hline To fulfil their potential, universities require a reliable \\
social contract with civil society, one which supports \\
pursuit of the highest possible quality of academic \\
work, with full respect for institutional autonomy
\end{tabular}

As they create and disseminate knowledge, universities question dogmas and established doctrines and encourage critical thinking in all students and scholars.

Academic freedom is their lifeblood; open enquiry and dialogue their nourishment. Universities embrace their duty to teach and undertake research ethically and with

integrity, producing reliable, trustworthy and accessible results.

Universities have a civic role and responsibility. They are part of global, collegial networks of scientific enquiry and scholarship, building on shared bodies of knowledge and contributing to their further development. They also are embedded in local cultures

and crucially relevant to their future and enrichment. While they are immersed in and connected with global developments, they engage fully with and assume leading roles in local communities and ecosystems.

\begin{abstract}
Університети визнають, що вони несуть відповідальність за взаємодію та реагування на очікування і виклики світу та спільнот, яким вони служать, приносять користь людству та сприяють стійкому розвитку.

Інтелектуальна та моральна автономія є ознакою університету та передумовою для виконання його зобов'язань перед суспільством. Ця незалежність повинна бути визнана і захищена урядами та суспільством у цілому, а також активно захищатися самими закладами вищої освіти.

Щоб реалізувати свій потенціал, університети потребують надійного соціального договору 3 суспільством, договору, що підтримує досягнення найвищої якості академічної діяльності з повною повагою до інституційної автономії.
\end{abstract}

Створюючи та поширюючи знання, університети ставлять під сумнів догми і усталені доктрини, а також заохочують критичне мислення у всіх студентів та академічних працівників.

Академічна свобода - їх життєва сила; відкритий пошук і діалог - їх живлення. Університети покладаються на свій обов'язок викладати та проводити дослідження етично та цілісно, забезпечуючи релевантні, надійні та доступні результати.

Університети мають громадянську роль і відповідальність. Вони $€$ частиною глобальних, колегіальних мереж, що реалізують дослідження, спираючись на спільні знання і сприяючи подальшому розвитку. Вони також вбудовані у місцеві культури і критично впливають на їх майбутнє та розквіт. Поки університети є зануреними і пов'язаними 3 глобальним розвитком, вони повністю залучені та виконують провідні ролі в житті місцевих громад і екосистем.

\footnotetext{
12 Magna Charta Universitatum 2020. URL: http://www.magna-charta.org/magna-charta-universitatum/mcu-2020

13 Magna Charta Universitatum 2020. URL: $\underline{\text { http://www.magna-charta.org/magna-charta-universitatum/mcu-2020 }}$
} 


\begin{tabular}{|c|c|}
\hline $\begin{array}{l}\text { Universities are non-discriminatory spaces of } \\
\text { tolerance and respect where diversity of perspectives } \\
\text { flourishes and where inclusivity, anchored in } \\
\text { principles of equity and fairness, prevails. They } \\
\text { therefore commit themselves to advance equity and } \\
\text { fairness in all aspects of academic life including } \\
\text { admissions, hiring and promotion practices. }\end{array}$ & $\begin{array}{l}\text { Університети є недискримінаційним простором } \\
\text { толерантності та поваги там, де різноманітність } \\
\text { перспектив процвітає і там, де інклюзивність, } \\
\text { закріплена у принципах рівності та справедливості, } \\
\text { домінує. Тому вони зобов'язуються сприяти рівності та } \\
\text { справедливості в усіх аспектах академічного життя, } \\
\text { включаючи вступ на навчання, прийняття на роботу та } \\
\text { підвищення кваліфікації. }\end{array}$ \\
\hline $\begin{array}{l}\text { Education is a human right, a public good, and should } \\
\text { be available to all. Universities recognise that learning } \\
\text { is a lifelong activity with tertiary education as one part } \\
\text { of a continuum. Within that one part, universities } \\
\text { serve diverse learners at all stages of their lives. }\end{array}$ & $\begin{array}{l}\text { Освіта - це право людини, суспільне благо, що має } \\
\text { бути доступним для всіх. Університети визнають } \\
\text { навчання як діяльність впродовж усього життя, а вищу } \\
\text { освіту як частину цього процесу. У рамках цієї частини } \\
\text { (вища освіта) університети служать різним особам, які } \\
\text { навчаються на всіх етапах їх життя. }\end{array}$ \\
\hline $\begin{array}{l}\text { Universities acknowledge that individuals and } \\
\text { communities, often due to inequitable circumstances, } \\
\text { have difficulty gaining access to higher education or } \\
\text { influencing the modes and matter of academic study. } \\
\text { To realise human potential everywhere, universities } \\
\text { deliberately seek ways to welcome and engage with } \\
\text { diverse voices and perspectives. }\end{array}$ & $\begin{array}{l}\text { Університети визнають, що люди та громади, часто } \\
\text { через нерівність умов / обставин, мають труднощі в } \\
\text { отриманні доступу до вищої освіти чи форм і змісту } \\
\text { академічного навчання. Задля реалізації людського } \\
\text { потенціалу без обмежень університети свідомо } \\
\text { шукають шляхи для комунікації та залучення різних } \\
\text { представників і різних поглядів. }\end{array}$ \\
\hline
\end{tabular}

Констатовані вище принципи, цінності та обов'язки, приналежні університетській спільноті, безпосередньо визначають і вливають на реалізацію та трансформацію / розвиток моделі управління, притаманні вищій освіті, у форматі врядуванню, в основі якого колегіальність, розподілена відповідальність, відкритість і взаємодія. 


\section{Римське комюніке (Rome Ministerial Communiqué) ${ }^{14}$}

У вступній частині Римського комюніке відмітимо три положення важливі щодо висвітлення питання врядування у вищій освіті:

Європейський простір вищої освіти визначається як «унікальна співпраця, де органи державної влади й стейкголдери вищої освіти працюють разом над визначенням і досягненням спільних цілей» ${ }^{15}$.

Акцентована роль закладів вищої освіти у допомозі суспільству відповідати «на численні загрози глобальному миру, демократичним цінностям, свободі інформації, здоров'ю та добробуту, на рівні з тими, що спричинені пандемією» 16 .

Висловлена рішуча налаштованість на «заохочення ефективнішої співпраці та тіснішого діалогу між нашими країнами, нашими системами вищої освіти та інституціями й з більш широкою спільнотою вищої освіти» ${ }^{17}$.

Визначаючи візію Європейського простору вищої освіти 2030 як «інклюзивний, інноваційний та взаємопов'язаний ЄПВО на підтримку стійкої, згуртованої та мирної Європи» ${ }^{18}$ підкреслено, що в основу розвитку ЄПВО покладено «фундаментальні цінності вищої освіти, демократії та верховенства права» 19. Ключовими критеріями реалізації запропонованої візії означено «якісну освіту» як «стандарт ЄПВО» та «стійку культуру академічної та наукової доброчесності», яку «підтримуватимуть усі заклади вищої освіти й усі органи державної влади» ${ }^{20}$.

Важливим посилом Комюніке $є$ уточнення визначення поняття «академічна свобода» як «свободи академічних працівників і студентів займатися дослідженнями, викладанням, навчанням і комунікацією в суспільстві без остраху репресій» ${ }^{21}$.

Акцент на забезпечення врядування у вищій освіті констатовано у розділі «Фундаментальні цінності» наступним чином ${ }^{22}$ :

«Ми знову підтверджуємо своє зобов’язання сприяти й захищати фундаментальні академічні цінності в усьому ЄПВО шляхом інтенсивного політичного діалогу й співпраці як незмінної основи для якісного навчання, викладання і досліджень, а також демократичних суспільств. Ми зобов'язуємося дотримуватися інституційної автономії, академічної свободи та доброчесності, участі студентів і працівників у врядуванні

14 Rome Ministerial Communique. November 19 2020. URL: https://ehea2020rome.it/storage/uploads/5d29d1cd-4616-4dfe-a2af29140a02ec09/BFUG Final Draft Rome Communique-link.pdf ; https://erasmusplus.org.ua/novyny/3254-zaproshuiemo-doluchytys-do-ixmizhnarodnoi-naukovo-praktychnoi-konferentsii.html (переклад українською мовою Національного Еразмус+ офісу в Україні)

15 Rome Ministerial Communique. November 19 2020. URL: https://ehea2020rome.it/storage/uploads/5d29d1cd-4616-4dfe-a2af29140a02ec09/BFUG_Final_Draft_Rome_Communique-link.pdf ; https://erasmusplus.org.ua/novyny/3254-zaproshuiemo-doluchytys-do-ixmizhnarodnoi-naukovo-praktychnoi-konferentsii.html (переклад українською мовою Національного Еразмус+ офісу в Україні)

16 Rome Ministerial Communique. November 19 2020. URL: https://ehea2020rome.it/storage/uploads/5d29d1cd-4616-4dfe-a2af29140a02ec09/BFUG_Final_Draft_Rome_Communique-link.pdf ; https://erasmusplus.org.ua/novyny/3254-zaproshuiemo-doluchytys-do-ixmizhnarodnoi-naukovo-praktychnoi-konferentsii.html (переклад українською мовою Національного Еразмус+ офісу в Україні)

17 Rome Ministerial Communique. November 19 2020. URL: https://ehea2020rome.it/storage/uploads/5d29d1cd-4616-4dfe-a2af29140a02ec09/BFUG_Final_Draft_Rome_Communique-link.pdf ; https://erasmusplus.org.ua/novyny/3254-zaproshuiemo-doluchytys-do-ixmizhnarodnoi-naukovo-praktychnoi-konferentsii.html (переклад українською мовою Національного Еразмус+ офісу в Україні)

18 Rome Ministerial Communique. November 19 2020. URL: https://ehea2020rome.it/storage/uploads/5d29d1cd-4616-4dfe-a2af29140a02ec09/BFUG Final Draft Rome Communique-link.pdf ; https://erasmusplus.org.ua/novyny/3254-zaproshuiemo-doluchytys-do-ixmizhnarodnoi-naukovo-praktychnoi-konferentsii.html (переклад українською мовою Національного Еразмус+ офісу в Україні)

19 Rome Ministerial Communique. November 19 2020. URL: https://ehea2020rome.it/storage/uploads/5d29d1cd-4616-4dfe-a2af29140a02ec09/BFUG Final Draft Rome Communique-link.pdf ; https://erasmusplus.org.ua/novyny/3254-zaproshuiemo-doluchytys-do-ixmizhnarodnoi-naukovo-praktychnoi-konferentsii.html (переклад українською мовою Національного Еразмус+ офісу в Україні)

20 Rome Ministerial Communique. November 19 2020. URL: https://ehea2020rome.it/storage/uploads/5d29d1cd-4616-4dfe-a2af29140a02ec09/BFUG Final Draft Rome Communique-link.pdf ; https://erasmusplus.org.ua/novyny/3254-zaproshuiemo-doluchytys-do-ixmizhnarodnoi-naukovo-praktychnoi-konferentsii.html (переклад українською мовою Національного Еразмус+ офісу в Україні)

21 Rome Ministerial Communique. November 19 2020. URL: https://ehea2020rome.it/storage/uploads/5d29d1cd-4616-4dfe-a2af29140a02ec09/BFUG Final Draft Rome_Communique-link.pdf ; https://erasmusplus.org.ua/novyny/3254-zaproshuiemo-doluchytys-do-ixmizhnarodnoi-naukovo-praktychnoi-konferentsii.html (переклад українською мовою Національного Еразмус+ офісу в Україні)

22 Rome Ministerial Communique. November 19 2020. URL: https://ehea2020rome.it/storage/uploads/5d29d1cd-4616-4dfe-a2af29140a02ec09/BFUG Final Draft Rome Communique-link.pdf ; https://erasmusplus.org.ua/novyny/3254-zaproshuiemo-doluchytys-do-ixmizhnarodnoi-naukovo-praktychnoi-konferentsii.html (переклад українською мовою Національного Еразмус+ офісу в Україні) 
вищої освіти, а також публічної відповідальності як за вищу освіту, так і самої вищої освіти» ${ }^{23}$. Задля посилення впливу фундаментальних цінностей на розвиток ЄПВО, забезпечення вимірності цього впливу Групі супроводу Болонського процесу (BFUG) поставлено завдання розробити відповідну рамку, яка «буде сприяти саморефлексії, конструктивному діалогу та колегіальному навчанню ... » ${ }^{24}$. Етика, прозорість і доброчесність розглядається як основа для «всіх членів, консультативних членів та партнерів ЄПВО співпрацювати заради досягнення ... мети» ${ }^{25}$.

Основна частина змісту Римського комюніке присвячена розкриттю змісту запропонованої візії ЄПВО через виміри: інклюзивний, інноваційний та взаємопов'язаний.

У світлі забезпечення інклюзивності ЄПВО важливим здобутком Римського комюніке $є$ прийняття «Принципів зміцнення соціального виміру вищої освіти» та їх інтеграція в інституційну культуру закладів вищої освіти та їх діяльність, включаючи «інституційне врядування та менеджмент» ${ }^{26}$. Важливість взаємодії університетів із локальними спільнотами відображена у наступному положенні Комюніке: «Наші заклади вищої освіти повинні об'єднуватися зі своїми спільнотами задля взаємовигідної та соціально відповідальної спільної діяльності» ${ }^{27}$.

Через призму забезпечення інноваційності ЄПВО актуалізовано питання кадрової політики у вищій освіті, зокрема підтримки персоналу шляхом створення «можливостей щодо стабільного працевлаштування та кар'єрного розвитку ...» ${ }^{28}$. Ключовим напрямком для забезпечення інноваційності вищої освіти у черговий раз визначено вдосконалення викладання і навчання, задля реалізації якого розроблені та ухвалені «Рекомендації для національної / урядової підтримки / діяльності для покращення навчання і викладання у вищій освіті ЄПВО» 29.

Співпраця, прямі контакти та синергія формують взаємопов'язаний ЄПВО за допомогою реалізації широкого спектру інструментів (мобільність, обмін даними, Європейський студентський квиток, Ініціатива європейських університетів та ін.).

У розділі «Імплементація» відображено основні досягнення та визначено наступні кроки для виконання «ключових зобов'язань» для функціонування ЄПВО ${ }^{30}$ : Рамки кваліфікацій, ЄКТС, Лісабонської конвенції про визнання, Додатку до диплому та Стандартів і рекомендацій із забезпечення якості в Європейському просторі вищої освіти (ESG). Успішна імплементація визначених амбітних завдань $є$ можливою за умови ефективного залучення у процеси реформ академічної та студентської когорти: «Ми ставимо за мету побудову тісніше взаємопов'язаної спільноти вищої освіти, що плекає інклюзивність, комунікацію, співпрацю та солідарність, основоположні для релевантності та досконалості майбутнього ЄПВО. Щоб досягнути цього, ми зобов'язуємося інформувати наші національні сектори вищої освіти та залучати до процесів ЄПвО, а також

\footnotetext{
23 Rome Ministerial Communique. November 19 2020. URL: https://ehea2020rome.it/storage/uploads/5d29d1cd-4616-4dfe-a2af29140a02ec09/BFUG Final Draft Rome Communique-link.pdf; https://erasmusplus.org.ua/novyny/3254-zaproshuiemo-doluchytys-do-ixmizhnarodnoi-naukovo-praktychnoi-konferentsii.html (переклад українською мовою Національного Еразмус+ офісу в Україні)

24 Rome Ministerial Communique. November 19 2020. URL: https://ehea2020rome.it/storage/uploads/5d29d1cd-4616-4dfe-a2af29140a02ec09/BFUG_Final_Draft_Rome_Communique-link.pdf ; https://erasmusplus.org.ua/novyny/3254-zaproshuiemo-doluchytys-do-ixmizhnarodnoi-naukovo-praktychnoi-konferentsii.html (переклад українською мовою Національного Еразмус+ офісу в Україні)

25 Rome Ministerial Communique. November 19 2020. URL: https://ehea2020rome.it/storage/uploads/5d29d1cd-4616-4dfe-a2af29140a02ec09/BFUG_Final_Draft_Rome_Communique-link.pdf ; https://erasmusplus.org.ua/novyny/3254-zaproshuiemo-doluchytys-do-ixmizhnarodnoi-naukovo-praktychnoi-konferentsii.html (переклад українською мовою Національного Еразмус+ офісу в Україні)

26 Rome Ministerial Communique. November 19 2020. URL: https://ehea2020rome.it/storage/uploads/5d29d1cd-4616-4dfe-a2af29140a02ec09/BFUG Final Draft Rome Communique-link.pdf ; https://erasmusplus.org.ua/novyny/3254-zaproshuiemo-doluchytys-do-ixmizhnarodnoi-naukovo-praktychnoi-konferentsii.html (переклад українською мовою Національного Еразмус+ офісу в Україні)

27 Rome Ministerial Communique. November 19 2020. URL: https://ehea2020rome.it/storage/uploads/5d29d1cd-4616-4dfe-a2af29140a02ec09/BFUG Final Draft Rome Communique-link.pdf ; https://erasmusplus.org.ua/novyny/3254-zaproshuiemo-doluchytys-do-ixmizhnarodnoi-naukovo-praktychnoi-konferentsii.html (переклад українською мовою Національного Еразмус+ офісу в Україні)

28 Rome Ministerial Communique. November 19 2020. URL: https://ehea2020rome.it/storage/uploads/5d29d1cd-4616-4dfe-a2af29140a02ec09/BFUG Final Draft Rome Communique-link.pdf ; https://erasmusplus.org.ua/novyny/3254-zaproshuiemo-doluchytys-do-ixmizhnarodnoi-naukovo-praktychnoi-konferentsii.html (переклад українською мовою Національного Еразмус+ офісу в Україні)

29 Rome Ministerial Communique. November 19 2020. URL: https://ehea2020rome.it/storage/uploads/5d29d1cd-4616-4dfe-a2af29140a02ec09/BFUG Final Draft Rome_Communique-link.pdf ; https://erasmusplus.org.ua/novyny/3254-zaproshuiemo-doluchytys-do-ixmizhnarodnoi-naukovo-praktychnoi-konferentsii.html (переклад українською мовою Національного Еразмус+ офісу в Україні)

30 Rome Ministerial Communique. November 19 2020. URL: https://ehea2020rome.it/storage/uploads/5d29d1cd-4616-4dfe-a2af29140a02ec09/BFUG Final Draft Rome Communique-link.pdf; https://erasmusplus.org.ua/novyny/3254-zaproshuiemo-doluchytys-do-ixmizhnarodnoi-naukovo-praktychnoi-konferentsii.html (переклад українською мовою Національного Еразмус+ офісу в Україні)
} 
тісно співпрацювати з асоціаціями студентів та університетів над розробленням й імплементацією національних реформ» ${ }^{31}$.

Таким чином, Римське комюніке, визначаючи ключові пріоритети розвитку Європейського простору вищої освіти (у перспективі 2030 року), обумовлює базові цінності та принципи даного розвитку та характеристики ключових процесів, що є передумовами цього розвитку, у тому числі процесів врядування вищою освітою.

31 Rome Ministerial Communique. November 19 2020. URL: https://ehea2020rome.it/storage/uploads/5d29d1cd-4616-4dfe-a2af29140a02ec09/BFUG Final Draft Rome Communique-link.pdf ; https://erasmusplus.org.ua/novyny/3254-zaproshuiemo-doluchytys-do-ixmizhnarodnoi-naukovo-praktychnoi-konferentsii.html (переклад українською мовою Національного Еразмус+ офісу в Україні) 


\section{Болонський звіт 2020 \\ (The European Higher Education Area in 2020. Bologna Process Implementation Report) ${ }^{32}$}

Аналіз змісту Звіту дозволив нам виявити кілька позицій, які є важливими для дослідження проблеми врядування у вищій освіті та виявлення тенденцій його розвитку / трансформації.

Першим таким важливим посилом, на наш погляд, є акцент на довірі як єдино можливому шляху розбудови вищої освіти в цілому та Європейського простору вищої освіти зокрема. Про це у Передмові до Звіту зазначила Комісар з інновацій, досліджень, культури, освіти та молоді Mariya Gabriel: «Для руху вперед найкращий шлях посилити довіру є практикувати довіру (As a way forward, the best way to strengthen trust is to practice trust» ${ }^{33}$.

Питання врядування у вищій освіті позиціоноване у Розділі 6 «Future Developments» через призму фундаментальних цінностей (п. 6.2) - академічна свобода та доброчесність, інституційна автономія, участь студентів і персоналу у процесах врядування, публічна відповідальність за вищу освіту та вищої освіти - як «базису для партнерства та співпраці» ${ }^{34}$. Положення Звіту 2020 року апелюють до відповідних положень попередніх комюніке Єреванського та Паризького) , засвідчуючи їх актуальність.

Не зайвим буде нагадати, що у Болонському звіті 2018 року (The European Higher Education Area in 2018. Bologna Process Implementation Report) ${ }^{35}$ було виділено кілька положень важливих у світлі дослідження процесу забезпечення ефективного університетського врядування, а саме такі:

- принциповість зв'язку між врядуванням у вищій освіті та ключовими цінностями EHEA - академічна свобода, інституційна автономія закладів вищої освіти, доброчесність і відповідальність ${ }^{36}$;

- верховенство права у забезпеченні академічної свободи та інституційної автономії ${ }^{37}$;

- наявність різних моделей врядування у вищій освіті ${ }^{38}$.

\section{Висновок}

Вища освіта України є частиною Європейського простору вищої освіти. Тенденції розвитку Європейського простору вищої освіти спричинюють відповідні зміни у системі вищої освіти України. Поряд із цим, ключовими критеріями успішного розвитку вищої освіти України та реформ, що реалізуються задля їі покращення, є системність і послідовність національної політики, базисом якої поряд із національними пріоритетами та національними особливостями розвитку мають слугувати вище зазначені фундаментальні цінності Європейського простору вищої освіти - академічна свобода, інституційна автономія закладів вищої освіти, доброчесність, відповідальність і довіра.

\footnotetext{
32 The European Higher Education Area in 2020. Bologna Process Implementation Report. - Luxemburg: Publications Office of European Union, 2020. - 201 p. URL: https://eacea.ec.europa.eu/national-policies/eurydice/sites/eurydice/files/ehea_bologna_2020_0.pdf

33 The European Higher Education Area in 2020. Bologna Process Implementation Report. - Luxemburg: Publications Office of European Union, 2020. - 201 p. - P. 3. URL: https://eacea.ec.europa.eu/national-policies/eurydice/sites/eurydice/files/ehea_bologna_2020_0.pdf

34 The European Higher Education Area in 2020. Bologna Process Implementation Report. - Luxemburg: Publications Office of European Union, 2020. - 201 p. - P. 158. URL: https://eacea.ec.europa.eu/national-policies/eurydice/sites/eurydice/files/ehea bologna 2020 0.pdf

35 The European Higher Education Area in 2018. Bologna Process Implementation Report. - URL:// https://eacea.ec.europa.eu/nationalpolicies/eurydice/sites/eurydice/files/bologna_internet_0.pdf

36 The European Higher Education Area in 2018. Bologna Process Implementation Report. - URL:// https://eacea.ec.europa.eu/nationalpolicies/eurydice/sites/eurydice/files/bologna internet_0.pdf - P. 40.

37 The European Higher Education Area in 2018. Bologna Process Implementation Report. - URL:// https://eacea.ec.europa.eu/nationalpolicies/eurydice/sites/eurydice/files/bologna internet 0.pdf - P. 41-43.

38 The European Higher Education Area in 2018. Bologna Process Implementation Report. - URL:// https://eacea.ec.europa.eu/nationalpolicies/eurydice/sites/eurydice/files/bologna internet 0.pdf - P. 43-45.
} 
Аналіз низки наукових публікацій зарубіжних дослідників (J. Fielden ${ }^{39}$; L. Delgado ${ }^{40}$; R. Muller-Terpitz ${ }^{41}$; S. Noorda ${ }^{42}$; M. Fiol ma D. Samoilovich ${ }^{43}$; J. Pedrosa ${ }^{44}$; R. Harmsen ${ }^{45}$; A. Magalhaes; A. Veiga ${ }^{46}$; N. Frolich ma J. Caspersen ${ }^{47}$; T. Estermann ma E. Pruvot ${ }^{48}$; M. Vukasovic, J. Jungblut, M.-H. Chou, M. Elken ma P. Ravinet ${ }^{49}$ ) дозволив нам визначити та обґрунтувати теоретичні основи реалізації ефективного врядування в університетах ${ }^{50}$.

\section{Ключові поняття}

Врядування у вищій освіті - це система: правил (політики, закони, регуляції, норми тощо); структур (інституції, органи); учасників - суб'єктів врядування та відносин між ними; процесів (комунікація, прийняття рішень, планування, моніторинг тощо); механізмів та інструментів; яка створюється, функціонує та розвивається для реалізації місії вищої освіти на основі академічної свободи та університетської автономії.

Університетське врядування - це система інституційних: правил (політики, закони, регуляції, норми тощо); структур (інституції, органи); учасників - суб'єктів врядування та відносин між ними; процесів (комунікація, прийняття рішень, планування, моніторинг тощо); механізмів та інструментів; яка створюється, функціонує та розвивається для реалізації місії закладу вищої освіти на основі академічної свободи та університетської автономії.

Врядування у вищій освіті є багаторівневим, багатоакторним та багатосекторальним та базується на певних принципах. Зміст зазначених характеристик розкрито нижче.

(1) Врядування у вищій освіті є багаторівневим. А саме, виділяють такі рівні:

наднаціональний (європейський у випадку Європейського простору вищої освіти, до якого належить система вищої освіти України);

39 J. Fielden. Global Trends in University Governance. - The World Bank, 2008. - 65 p. - URL: http://siteresources.worldbank.org/EDUCATION/Resources/278200-1099079877269/547664$1099079956815 /$ Global Trends University Governance webversion.pdf

40 L. Delgado. Good Governance in Higher Education. The Right to Education / ResearchGate. - URL: https://www.researchgate.net/publication/234136496_Good_Governance_in_Higher_Education_The_Right to_Education

${ }^{41}$ R. Muller-Terpitz. Conflict between Freedom of Research and Teaching and New Models of Governance and Leadership // Leadership and Governance in Higher Education for Decision-makers and Administrators. - 2013. - \# 2. - P. 57-70.

42 S. Noorda. Academic Autonomy as a Lifelong Learning Process for Universities // Leadership and Governance in Higher Education for Decision-makers and Administrators. - 2013. - \# 4. - P. 1-15.

${ }^{43}$ M. Fiol, D. Samoilovich. University Management: A Necessary Debate // Leadership and Governance in Higher Education for Decision-makers and Administrators. - 2014. - \# 1. - P. 1-22.

$44 \mathrm{~J}$. Pedrosa. Autonomy and Accountability in University Governance // Leadership and Governance in Higher Education for Decision-makers and Administrators. - 2014. - \# 1. - P. 22-39.

45 R. Harmsen. The Governance of the Global University: Leadership and Policy Challenges // Leadership and Governance in Higher Education for Decision-makers and Administrators. - 2014. - \# 3. - P. 35-52.

46 A. Magalhaes, A. Veiga. Governance and Management Dilemmas Arising from Substructuring in Higher Education // Leadership and Governance in Higher Education for Decision-makers and Administrators. - 2014. - \# 2. - P. 27-47.

${ }^{47}$ N. Frolich, J. Caspersen. How does policy change universities? // State of Higher Education 2015-16 / Edited by C. Sarrico, A. McQueen and S. Samuelson. - The OECD Higher Education Programme, 2017. - P. 127-132.

48 T. Estermann, E. Bennetot Pruvot. University Governance: Autonomy, Structures and Inclusiveness / European Higher Education Area: The Impact of Past and Future Policies, Volume II. - EUA, 2018. - P. 619-631. - URL: https: //link.springer.com/chapter/10.007/978-3-319-77407$\underline{737}$

${ }^{49}$ M. Vukasovic, J. Jungblut, M.-H. Chou, M. Elken, P. Ravinet. Multi-Level, Multi-Actor and Multi-Issues Dimensions of Governance of the European Higher Education Area, and Beyond / European Higher Education Area: The Impact of Past and Future Policies, Volume I. - EUA, 2018. -406 p. - P. 307-320.

50 С. Калашнікова. Розділ 5. Фактори забезпечення ефективного університетського врядування: теоретико-методологічні основи // Аналіз провідного вітчизняного та зарубіжного досвіду розвитку щодо механізмів реалізації ефективного врядування в університетах: препринт (аналітичні матеріали) (частина I) / Авторський колектив: І. Драч, С. Калашнікова, О. Паламарчук, В. Рябченко, Л. Червона; за заг. ред. С. Калашнікової. - Київ: Інститут вищої освіти НАПН України, 2018. - 147 с. - С. 115-147. URL: https://ihed.org.ua/wpcontent/uploads/2019/09/Analiz dosvidu vriaduvania v univer ch1 analit IVO-2018-147p avtors-kolektiv.pdf 
- національний (уряд, профільні міністерства, інші центральні органи влади, до компетенції яких належить вища освіта);

- регіональний (органи влади регіонального рівня, наприклад муніципалітети, які є засновниками комунальних закладів вищої освіти);

- інституційний (рівень закладу вищої освіти);

- індивідуальний (рівень окремих учасників процесу врядування).

(2) Врядування у вищій освіті $\epsilon$ багатоакторним. А саме, вирізняють таких ключових учасників врядування:

- зовнішні стейкхолдери (політики, представники органів влади, бізнесу, громадянського суспільства);

- внутрішні стейкхолдери (управлінці, дослідники, викладачі, інший персонал закладу, студенти).

(3) Врядування у вищій освіті є багатосекторальним:

- зовнішній вимір - діяльність на національному / регіональному рівні, пов'язана зі взаємодією сектора вищої освіти в цілому з сектором охорони здоров'я, соціальною та молодіжною політикою, сектором економіки та фінансів тощо;

- внутрішній вимір - діяльність на рівні університету, пов'язана зі стратегуванням, плануванням, управлінням фінансами, вдосконаленням викладання, управлінням дослідженнями, забезпеченням якості, розвитком персоналу, взаємодією зі студентами тощо.

(4) Врядування у вищій освіті базується на принципах: академічної свободи, університетської автономії, колегіальності, партнерства, розподіленої відповідальності, підзвітності, балансування та динамічності.

Ефективне університетське врядування визначаємо як врядування, що забезпечує підвищення / зростання ефективності університетської діяльності відповідно до суспільних очікувань та на основі визначених місії, візії та цінностей, що поділяються університетською спільнотою.

Фактори забезпечення ефективного університетського врядування визначаємо як умови, створення, дотримання та наявність яких сприяє / спричинює покращенню(я) якості врядування, що, у свою чергу, веде до підвищення / зростання ефективності університетської діяльності. До факторів забезпечення ефективного університетського врядування відносимо, зокрема, і відповідні принципи.

Механізми забезпечення ефективного університетського врядування визначаємо як прочеси, засоби, технології, спрямовані на покращення якості врядування, імплементація / впровадження яких у практику веде до підвищення / зростання ефективності університетської діяльності. Ідентифікація факторів і механізмів забезпечення ефективного університетського врядування, на наш погляд, має здійснюватися через аналіз кращих практик врядування у вищій освіті на основі теоретичної матриці, що формує концепцію «розподіленого лідерства у вищій освіті» ${ }^{51}$.

\footnotetext{
${ }^{51}$ R. Bolden, S. Jones, H. Davis, P. Gentle. Development and Sustaining Shared Leadership in Higher Education. - London: LFHE, 2015. - 47 p.
} 


\section{Відображення врядування через призму індикаторів для оцінювання рівня організаційної автономії університетів 52}

Відповідно до «The Autonomy Scorecard 2010», яку розробила European University Association (EUA) ${ }^{53}$ та представила для подальшого моніторингу рівня автономії закладів вищої освіти у публікації «University Autonomy in Europe II» ${ }^{54}$, параметри, пов'язані з процесами врядування у вищій освіті, відносяться до організаційної автономії університетів (табл. 1).

Табличя 1

Індикатори для оцінювання рівня організаційної автономії університетів ${ }^{55}$

\begin{tabular}{|c|c|c|}
\hline $\begin{array}{l}\text { Складова } \\
\text { автономії }\end{array}$ & Параметри & Індикатори та обмеження \\
\hline \multirow[t]{14}{*}{$\begin{array}{l}\text { Організачійна } \\
\text { автономія }\end{array}$} & \multirow{2}{*}{$\begin{array}{l}\text { Процедура } \\
\text { для обрання } \\
\text { виконавчого } \\
\text { керівника }\end{array}$} & $\begin{array}{l}\text { Обрання виконавчого керівника не легітимізується зовнішнім органом влади } \\
\text { Selection of the executive head is not validated by an external authority }\end{array}$ \\
\hline & & $\begin{array}{l}\text { Обрання виконавчого керівника легітимізується зовнішнім органом влади } \\
\text { Selection of the executive head is validated by an external authority }\end{array}$ \\
\hline & \multirow{5}{*}{$\begin{array}{l}\text { Критерії для } \\
\text { обрання } \\
\text { виконавчого } \\
\text { керівника }\end{array}$} & $\begin{array}{l}\text { Критерії для обрання виконавчого керівника не визначені в законі } \\
\text { Selection criteria for executive head are not stated in the law }\end{array}$ \\
\hline & & $\begin{array}{l}\text { Закон визначає, що виконавчий керівник повинен займати академічну посаду } \\
\text { Law states that the executive head must hold an academic } \\
\text { position }\end{array}$ \\
\hline & & $\begin{array}{l}\text { Закон визначає, що виконавчий керівник повинен мати докторський ступінь } \\
\text { Law states that the executive head must hold a doctoral degree }\end{array}$ \\
\hline & & $\begin{array}{l}\text { Закон визначає, що виконавчий керівник повинен бути з університету } \\
\text { Law states that the executive head must come from within the university }\end{array}$ \\
\hline & & $\begin{array}{l}\text { Iнші обмеження } \\
\text { Other restrictions }\end{array}$ \\
\hline & \multirow{6}{*}{$\begin{array}{l}\text { Звільнення } \\
\text { виконавчого } \\
\text { керівника }\end{array}$} & $\begin{array}{l}\text { Процедури для звільнення виконавчого керівника не визначені у законі } \\
\text { Procedures for the dismissal of the executive head are not stated in the law }\end{array}$ \\
\hline & & $\begin{array}{l}\text { Звільнення підтверджується зовнішнім органом влади, але процедура визначена і } \\
\text { рішення приймається університетом } \\
\text { Confirmation of dismissal by an external authority but the procedure is decided by the } \\
\text { university }\end{array}$ \\
\hline & & $\begin{array}{l}\text { Звільнення здійснює зовнішній орган влади, але процедура вирішується } \\
\text { університетом } \\
\text { Dismissal by an external authority but the procedure is decided by the university }\end{array}$ \\
\hline & & $\begin{array}{l}\text { Звільнення підтверджується зовнішнім органом влади і процедура визначена } \\
\text { законом } \\
\text { Confirmation of dismissal by an external authority and the procedure is stated in the law }\end{array}$ \\
\hline & & $\begin{array}{l}\text { Звільнення здійснює зовнішній орган влади відповідно до процедури, визначеної в } \\
\text { законі } \\
\text { Dismissal by an external authority according to a procedure stated in the law }\end{array}$ \\
\hline & & $\begin{array}{l}\text { Інші обмеження } \\
\text { Other restrictions }\end{array}$ \\
\hline & $\begin{array}{l}\text { Терміни } \\
\text { перебування }\end{array}$ & $\begin{array}{l}\text { Термін перебування на посаді виконавчого керівника не визначено в законі } \\
\text { Length of the executive head's term of office is not stated in the law }\end{array}$ \\
\hline
\end{tabular}

\footnotetext{
52 С. Калашнікова. Розділ 5. Фактори забезпечення ефективного університетського врядування: теоретико-методологічні основи // Аналіз провідного вітчизняного та зарубіжного досвіду розвитку щодо механізмів реалізації ефективного врядування в університетах: препринт (аналітичні матеріали) (частина I) / Авторський колектив: І. Драч, С. Калашнікова, О. Паламарчук, В. Рябченко, Л. Червона; за заг. ред. С. Калашнікової. - Київ: Інститут вищої освіти НАПН України, 2018. - 147 с. - С. 125-127. URL: https://ihed.org.ua/wpcontent/uploads/2019/09/Analiz_dosvidu_vriaduvania_v_univer_ch1_analit_IVO-2018-147p_avtors-kolektiv.pdf

53 EUA. - URL://www.eua.be

54 University Autonomy in Europe II. The Scorecard / by Thomas Estermann, Terhi Nokkala \& Monika Steinel. - EUA, 2011. - 81 p. - URL: http://eua.be/publications/eua-reports-studies-and-occasional-papers.aspx

55 University Autonomy in Europe II. The Scorecard / by Thomas Estermann, Terhi Nokkala \& Monika Steinel. - EUA, 2011. - 81 p. - URL: http://eua.be/publications/eua-reports-studies-and-occasional-papers.aspx - P. 72-76
} 


\begin{tabular}{|c|c|c|}
\hline \multirow[t]{3}{*}{$\begin{array}{l}\text { на посаді } \\
\text { виконавчого } \\
\text { керівника }\end{array}$} & \multicolumn{2}{|c|}{$\begin{array}{l}\text { Максимальна тривалість терміну перебування на посаді виконавчого керівника } \\
\text { визначена в законі } \\
\text { Maximum or range of length is stated in the law }\end{array}$} \\
\hline & \multicolumn{2}{|c|}{$\begin{array}{l}\text { Мінімальна тривалість терміну перебування на посаді виконавчого керівника } \\
\text { визначена в законі } \\
\text { Minimum range of length is stated in the law }\end{array}$} \\
\hline & \multicolumn{2}{|c|}{$\begin{array}{l}\text { Чітка тривалість терміну перебування на посаді виконавчого керівника визначена в } \\
\text { законі } \\
\text { Exact length is stated in the law }\end{array}$} \\
\hline \multirow{8}{*}{$\begin{array}{l}\text { Зовнішні } \\
\text { члени у } \\
\text { керуючих } \\
\text { органах }\end{array}$} & \multirow{4}{*}{$\begin{array}{l}\text { Включення } \\
\text { зовнішніх } \\
\text { членів до } \\
\text { керуючих } \\
\text { органів }\end{array}$} & $\begin{array}{l}\text { Університети не можуть вирішувати, оскільки вони не можуть включати } \\
\text { зовнішніх членів } \\
\text { Universities cannot decide as they cannot include external members }\end{array}$ \\
\hline & & $\begin{array}{l}\text { Університети не можуть вирішувати, оскільки вони повинні включати } \\
\text { зовнішніх членів } \\
\text { Universities cannot decide as they must include external members }\end{array}$ \\
\hline & & $\begin{array}{l}\text { Університети можуть вирішувати питання щодо включення зовнішніх } \\
\text { членів } \\
\text { Universities can decide to include external members }\end{array}$ \\
\hline & & $\begin{array}{l}\text { Університети можуть вільно вирішувати питання щодо зовнішніх членів } \\
\text { University can decide freely on external members }\end{array}$ \\
\hline & \multirow{4}{*}{$\begin{array}{l}\text { Відбір } \\
\text { зовнішніх } \\
\text { членів до } \\
\text { керуючих } \\
\text { органів }\end{array}$} & $\begin{array}{l}\text { Пропонуються університетом і призначаються зовнішнім органом влади } \\
\text { Proposal by university and appointment by an external authority }\end{array}$ \\
\hline & & $\begin{array}{l}\text { Частина членів призначається університетом і частина призначається } \\
\text { зовнішнім органом влади } \\
\text { Part of the members appointed by the university and part appointed by an } \\
\text { external authority }\end{array}$ \\
\hline & & $\begin{array}{l}\text { Призначення повністю контролюється зовнішнім органом влади } \\
\text { Appointment completely controlled by an external authority }\end{array}$ \\
\hline & & $\begin{array}{l}\text { Інші обмеження процесу } \\
\text { Other appointment process }\end{array}$ \\
\hline \multirow{4}{*}{$\begin{array}{l}\text { Компетенція } \\
\text { покладати } \\
\text { рішення на } \\
\text { академічні } \\
\text { структури }\end{array}$} & \multicolumn{2}{|c|}{$\begin{array}{l}\text { Університети можуть вирішувати питання щодо своїх організаційних академічних } \\
\text { структур без обмежень } \\
\text { Universities can decide on their academic structures without constraint }\end{array}$} \\
\hline & \multicolumn{2}{|c|}{$\begin{array}{l}\text { Рекомендації визначені у законі } \\
\text { Guidelines exist in the law }\end{array}$} \\
\hline & \multicolumn{2}{|c|}{$\begin{array}{l}\text { Факультети, інші академічні структури перераховані у законі } \\
\text { Faculties / other academic structures are listed in the law }\end{array}$} \\
\hline & \multicolumn{2}{|c|}{$\begin{array}{l}\text { Iнші обмеження } \\
\text { Other restrictions }\end{array}$} \\
\hline \multirow{4}{*}{$\begin{array}{l}\text { Компетенція } \\
\text { створювати } \\
\text { юридичну } \\
\text { особу }\end{array}$} & \multicolumn{2}{|c|}{$\begin{array}{l}\text { Університети можуть створювати юридичні особи без обмежень } \\
\text { Universities can create legal entities without constraint }\end{array}$} \\
\hline & \multicolumn{2}{|c|}{$\begin{array}{l}\text { Університетам дозволено створювати лише не прибуткові юридичні особи } \\
\text { Universities are only allowed to create not-for-profit legal entities }\end{array}$} \\
\hline & \multicolumn{2}{|c|}{$\begin{array}{l}\text { Університетам не дозволяється створювати будь-які юридичні особи } \\
\text { Universities are not allowed to create any type of legal entity }\end{array}$} \\
\hline & \multicolumn{2}{|c|}{$\begin{array}{l}\text { Iнші обмеження } \\
\text { Other restrictions }\end{array}$} \\
\hline
\end{tabular}




\section{Унітарна та дуальна модель університетського врядування 56}

T. Estermann та E. Pruvot ${ }^{57}$ для аналізу моделей університетського врядування пропонують використовувати відповідні показники Autonomy Scorecard $2017^{58}$ (про які ми вже згадували раніше), зокрема у частині організаційної автономії закладів вищої освіти. Автори дослідження виділяють 2 основні групи моделей університетського врядування ${ }^{59}$ :

- унітарну (unitary governance models);

- дуальну (dual governance models), яка у свою чергу поділяється на «традиційну» та «асиметричну».

Для унітарної моделі характерним є наявність одного органу врядування на рівні університетуб:

- Типу «сенат» (senate-type) (орієнтація на вирішення академічних питань; значний розмір; члени переважно представники академічної спільноти університету).

- Типу «рада» (board-type) (орієнтація на вирішення стратегічних питань, у т.ч. фінансові; порівняно невеликий розмір; більш різнорідний склад членів).

Дуальна модель характеризується функціонуванням двох органів врядування на рівні університету ${ }^{61}$ «тип сенат» і «тип рада», між якими розподілені повноваження щодо прийняття рішень.

Дуальна традиційна модель має такі особливості:

- Кожний орган має чіткий, але рівноважливий портфоліо повноважень.

- Орган «типу сенат» відповідає за академічні питання.

- Орган «типу рада» відповідає за стратегічний напрям та формування бюджету університету.

Дуальна асиметрична модель, у свою чергу, характеризується такими рисами:

- Кожний із двох органів має повноваження у певній сфері, але при цьому, один із органів є «більш центральним» у процесі прийняття рішень.

- у більшості випадків домінує орган «типу рада», при цьому орган «типу сенат» має повноваження у певних випадках.

Щодо останньої характеристики T. Estermann та E. Pruvot зазначають: «Така модель $є$ дещо схожою на унітарну модель, де орган врядування може мати «асистентів» у формі дорадчих органів, які не мають формальних повноважень щодо прийняття рішень» ${ }^{62}$.

Таким чином, основою для запропонованої класифікації моделей університетського врядування слугує структура органів врядування - їх комбінація, повноваження та зв'язки між ними.

\footnotetext{
56 С. Калашнікова. Розділ 5. Фактори забезпечення ефективного університетського врядування: теоретико-методологічні основи // Аналіз провідного вітчизняного та зарубіжного досвіду розвитку щодо механізмів реалізації ефективного врядування в університетах: препринт (аналітичні матеріали) (частина I) / Авторський колектив: І. Драч, С. Калашнікова, О. Паламарчук, В. Рябченко, Л. Червона; за заг. ред. С. Калашнікової. - Київ: Інститут вищої освіти НАПН України, 2018. - 147 с. - С. 131-134. URL: https://ihed.org.ua/wpcontent/uploads/2019/09/Analiz_dosvidu_vriaduvania_v_univer_ch1_analit_IVO-2018-147p_avtors-kolektiv.pdf

57 T. Estermann, E. Pruvot. University Governance: Autonomy, Structures and Inclusiveness / European Higher Education Area: The Impact of Past and Future Policies, Volume II. - EUA, 2018. - P. 619-631. - URL: https://link.springer.com/chapter/10.007/978-3-319-77407-7 37

58 University Autonomy in Europe $\quad$ III: The Scorecard $2017 . \quad$ URL:
https://eua.eu/downloads/publications/university\%20autonomy\%20in\%20europe\%20iii\%20the\%20scorecard\%202017.pdf

59 T. Estermann, E. Pruvot. University Governance: Autonomy, Structures and Inclusiveness / European Higher Education Area: The Impact of Past and Future Policies, Volume II. - EUA, 2018. - P. 619-631. - URL: https://link.springer.com/chapter/10.007/978-3-319-77407-7 37 - P. $8 / 28$.

60 T. Estermann, E. Pruvot. University Governance: Autonomy, Structures and Inclusiveness / European Higher Education Area: The Impact of Past and Future Policies, Volume II. - EUA, 2018. - P. 619-631. - URL: https://link.springer.com/chapter/10.007/978-3-319-77407-7_37 . - P. $8 / 28$.

61 T. Estermann, E. Pruvot. University Governance: Autonomy, Structures and Inclusiveness / European Higher Education Area: The Impact of Past and Future Policies, Volume II. - EUA, 2018. - P. 619-631. - URL: https://link.springer.com/chapter/10.007/978-3-319-77407-7 37 . - P. $9 / 28$.

62 T T. Estermann, E. Pruvot. University Governance: Autonomy, Structures and Inclusiveness / European Higher Education Area: The Impact of Past and Future Policies, Volume II. - EUA, 2018. - P. 619-631. - URL: https://link.springer.com/chapter/10.007/978-3-319-77407-7_37 . P. 10/28.
} 
Відповідно до запропонованого нами вище визначення: фактори забезпечення ефективного університетського врядування - це умови, створення, дотримання та наявність яких сприяє / спричинює покращенню(я) якості врядування, що, у свою чергу, веде до підвищення / зростання ефективності університетської діяльності.

До факторів забезпечення ефективного університетського врядування відносимо, зокрема, і відповідні принципи. У нашій попередній публікації з цього питання ${ }^{63}$ ми зробили проаналізували позиції зарубіжних експертів та організацій щодо визначення принципів ефективного врядування взагалі та ефективного врядування у вищій освіті зокрема.

Базуючись на запропонованих нами визначеннях понять "університетське врядування» (система інституційних правил (політики, закони, регуляції, норми тощо); структур (інституції, органи); учасників суб'єктів врядування та відносин між ними; процесів (комунікація, прийняття рішень, планування, моніторинг тощо); механізмів та інструментів; яка створюється, функціонує та розвивається для реалізації місії закладу вищої освіти на основі академічної свободи та університетської автономії) та «ефективне університетське врядування» (врядування, що забезпечує підвищення / зростання ефективності університетської діяльності відповідно до суспільних очікувань та на основі визначених місії, візії та цінностей, що поділяються університетською спільнотою), а також розумінні ефрективності університетської діяльності як співвідношення досягнутих результатів і використаних ресурсів, визначимо ключові фактори забезпечення ефективного університетського врядування (табл. 2).

Табличя 2

Умови та принципи забезпечення ефективного університетського врядування

\begin{tabular}{|c|c|c|}
\hline $\begin{array}{c}\text { Складові } \\
\text { університетського } \\
\text { врядування }\end{array}$ & $\begin{array}{c}\text { Умови, що сприяють підвищенню ефективності } \\
\text { функціонування }\end{array}$ & Принцип \\
\hline $\begin{array}{l}\text { Інституційні правила } \\
\text { (політики, закони, } \\
\text { регуляції, } \\
\text { тощо) }\end{array}$ & $\begin{array}{l}\text { Інституційні правила, що визначають процеси } \\
\text { університетського врядування, є чітко визначеними та } \\
\text { узгдженими між ключовими учасниками, зрозумілими, } \\
\text { об'єктивними та досяжними. }\end{array}$ & $\begin{array}{l}\text { Оптимальності } \\
\text { Об'єктивності } \\
\text { Узгодженості } \\
\text { Досяжності }\end{array}$ \\
\hline $\begin{array}{l}\text { Структури } \\
\text { (інституції, органи) }\end{array}$ & 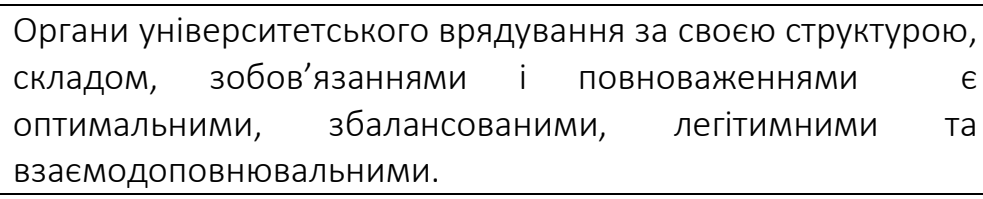 & $\begin{array}{l}\text { Оптимальності } \\
\text { Легітимності }\end{array}$ \\
\hline $\begin{array}{l}\text { Учасники - суб'єкти } \\
\text { врядування та } \\
\text { відносини між ними }\end{array}$ & $\begin{array}{l}\text { Учасники, залучені у процеси університетського } \\
\text { врядування, є компетентними та користуються довірою } \\
\text { відповідних представників університетської спільноти. } \\
\text { Відносини між учасниками університетського врядування } € \\
\text { доброзичливими, професійними, відкритими та етичними. }\end{array}$ & $\begin{array}{l}\text { Професійності } \\
\text { Довіри } \\
\text { Відкритості }\end{array}$ \\
\hline
\end{tabular}

\footnotetext{
63 С. Калашнікова. Розділ 5. Фактори забезпечення ефективного університетського врядування: теоретико-методологічні основи // Аналіз провідного вітчизняного та зарубіжного досвіду розвитку щодо механізмів реалізації ефективного врядування в університетах: препринт (аналітичні матеріали) (частина I) / Авторський колектив: І. Драч, С. Калашнікова, О. Паламарчук, В. Рябченко, Л. Червона; за заг. ред. С. Калашнікової. - Київ: Інститут вищої освіти НАПН України, 2018. - 147 c. - C. 137-139. URL: https://ihed.org.ua/wpcontent/uploads/2019/09/Analiz dosvidu vriaduvania v univer ch1 analit IVO-2018-147p avtors-kolektiv.pdf
} 


\begin{tabular}{|c|c|c|c|}
\hline $\begin{array}{c}\text { Складові } \\
\text { університетського } \\
\text { врядування }\end{array}$ & $\begin{array}{c}\text { Умови, що сприяють підвищенню ефективності } \\
\text { функціонування }\end{array}$ & Принцип & \\
\hline $\begin{array}{l}\text { Процеси } \\
\text { (комунікація, } \\
\text { прийняття рішень, } \\
\text { планування, } \\
\text { моніторингтощо) }\end{array}$ & $\begin{array}{l}\text { Процеси університетського врядування } € \text { прозорими, } \\
\text { доцільними, системними та результат-орієнтованими. }\end{array}$ & $\begin{array}{l}\text { Прозорості } \\
\text { Доцільності } \\
\text { Системності } \\
\text { Зорієнтованості } \\
\text { результат }\end{array}$ & на \\
\hline $\begin{array}{ll}\text { Механізми } & \text { та } \\
\text { інструменти }\end{array}$ & $\begin{array}{l}\text { Механізми та інструменти університетського врядування } € \\
\text { оптимальними, доцільними та динамічними з точки зору їх } \\
\text { оновлення. }\end{array}$ & $\begin{array}{l}\text { Оптимальності } \\
\text { Доцільності } \\
\text { Інноваційності }\end{array}$ & \\
\hline
\end{tabular}

у світлі констатації принципів, що забезпечують ефективність університетського врядування, доцільним є нагадування базових принципів врядування у вищій освіті, які ми вже зазначали вище, а саме принципи: академічної свободи, університетської автономії, колегіальності, партнерства, розподіленої відповідальності, підзвітності, балансування та динамічності. 
Відповідно до запропонованого нами визначення механізми забезпечення ефективного університетського врядування - це процеси, засоби, технології, спрямовані на покращення якості врядування, імплементація / впровадження яких у практику веде до підвищення / зростання ефективності університетської діяльності.

Ідентифікацію ключових механізмів забезпечення ефективного університетського врядування здійснимо на основі виявлених у попередній публікації ${ }^{4}$ закономірностей і зв'язків.

\footnotetext{
${ }^{64}$ С. Калашнікова. Розділ 5. Фактори забезпечення ефективного університетського врядування: теоретико-методологічні основи // Аналіз провідного вітчизняного та зарубіжного досвіду розвитку щодо механізмів реалізації ефективного врядування в університетах: препринт (аналітичні матеріали) (частина I) / Авторський колектив: І. Драч, С. Калашнікова, О. Паламарчук, В. Рябченко, Л. Червона; за заг. ред. С. Калашнікової. - Київ: Інститут вищої освіти НАПН України, 2018. - 147 с. - С. 137-139. URL: https://ihed.org.ua/wpcontent/uploads/2019/09/Analiz dosvidu vriaduvania v univer ch1 analit IVO-2018-147p avtors-kolektiv.pdf
} 


\section{Розподілене лідерство}

Оскільки за своєю суттю університетське врядування є проявом / модифікаціє «управління в цілому» через призму специфіки вищої освіти, тенденції, що впливають на трансформацію «управління в цілому», про які ми вже багато разів зазначали у наших публікаціях ${ }^{65},{ }^{66}$, безпосередньо відображаються і на розвитку процесів університетського врядування.

А тому абсолютно логічним та обґрунтованим є визначення "розподіленого лідерства у вищій освіті» ${ }^{67}$ як одного із ключових механізмів забезпечення ефективного університетського врядування.

Сутність, принципи, виміри, критерії та інструменти реалізації розподіленого лідерства (як управлінської технології) корелюють із раніше озвученими принципами університетського врядування та факторами для забезпечення ефективного університетського врядування.

Нагадаємо коротко опис цих вище зазначених складових розподіленого лідерства ${ }^{68},{ }^{69}$ :

1. В основі моделі розподіленого лідерства (shared leadership ${ }^{70}$ ) - залучення та розподіл відповідальності за інституційне лідерство членів всієї академічної спільноти, а не тільки управлінського персоналу. В основу моделі розподіленого лідерства покладено твердження, відповідно до якого лідерство розглядається як «процес (набір функцій і дій), які реалізуються групою» на відміну від розуміння лідерства як «набору індивідуальних якостей чи характеристик особистості». Звідси слідує висновок, що лідерство - це «робота колективу» з розвитку навичок вибудовування ефективних взаємовідносин. Іншими словами, в основі розподіленого лідерства - групова якість (колективна компетентність), що виступає альтернативою «героїчного індивідуального лідерства». Розробники теорії розподіленого лідерства у вищій освіті вбачають потенціал цієї парадигми у можливості запропонувати нову перспективу «ведення» (leading) та «слідування» (following), що $є$ більш відповідною (релевантною) сучасному академічному та освітянському контекстам. Іншими словами, модель розподіленого лідерства пропонує переосмилення потенціалу академічної спільноти з акцентом на колегіальність, громадянську активність та активність громади (останнє, як бачимо, є прямим відображенням сутності університетського врядування).

2. Автори моделі виділяють 4 виміри розподіленого лідерства, які є такими:

- контекст - ґрунтується не на посадах, а на довірі та експертному потенціалі;

- культура - передбачає не контроль, а повагу до досвіду та експертизи;

- зміна - реалізується багатьма учасниками за векторами - зверху-вниз, знизу-вверх та по горизонталях, та $є$ багаторівневим;

- взаємовідносини - базується на співпраці між особистостями, які разом формують колективну ідентичність/самобутність.

3. Розробники моделі виділяють 4 взаємопов'язані критерії розподіленого лідерства:

- люди - залучення широкого спектру експертів із їх різнорідним досвідом / експертизою;

- процеси - підтримка експертів у розповсюдженні та реалізації ї досвіду / експертизи серед структурних підрозділів для реалізації організаційних функцій;

\footnotetext{
65 Роль університету у розвитку лідерського потенціалу суспільства: концептуальні засади / Авторський колектив: О. Аарна, Д. Гудонієне, О. Гузар та ін.; за заг. ред. С. Калашнікової. - Київ: ДП «НВЦ «Пріоритети», 2014. - 100 c. https://ihed.org.ua/wpcontent/uploads/2018/09/Rol_Univ_v_Leaders._Avtors-kolektiv_zr.Kalashnikova_2014-100p.pdf

66 С. Калашнікова. Розвиток лідерського потенціалу сучасного університету: основи та інструменти: Навчальний посібник / С. Калашнікова. - К. : ДП «НВЦ «Пріоритети», $2016 . \quad$ - $44 \quad$ c. content/uploads/2018/09/rozvitok lidersk_potencialu_Universitets. Kalashnikova.S_2016 46c.pdf

${ }^{67}$ R. Bolden, S. Jones, H. Davis, P. Gentle. Development and Sustaining Shared Leadership in Higher Education: Stimulus paper. - London: LFHE, 2015. $-47 p$

${ }^{68}$ R. Bolden, S. Jones, H. Davis, P. Gentle. Development and Sustaining Shared Leadership in Higher Education: Stimulus paper. - London: LFHE, 2015. $-47 p$

69 С. Калашнікова. Розвиток лідерського потенціалу сучасного університету: основи та інструменти: Навчальний посібник / С. Калашнікова. -
} content/uploads/2018/09/rozvitok lidersk potencialu Universitets. Kalashnikova.S 2016 46c.pdf

70 Development and Sustaining Shared Leadership in Higher Education: Stimulus paper / R. Bolden, S. Jones, H. Davis, P. Gentle. - London: LFHE, 2015. -47 p. - P. 12. 
- професіональний розвиток - сприяння розвитку індивідуальних і колективних компетентностей, рис та зміни поведінки;

- ресурси - сприяння посиленню партнерства, розвитку мереж та співпраці.

4. Розробники моделі розподіленого лідерства для ії реалізації пропонують використовувати чотирьохетапний процес: 1 - планування; 2 - діяльність; 3 - оцінювання; 4 - рефлексія. Кожний етап, у свою чергу, передбачає використання відповідних / релевантних підходів і механізмів.

\section{«М'який» вплив держави в умовах дерегуляції вищої освіти}

Зазначена особливість - дерегуляція на національному рівні, притаманна сучасним процесам управління вищою освітою, описується як рух від моделі «держава-регулятор» / або «держава-контролер» до моделі «держава-фасилітатор» / «держава-координатор мережі» / «держава-наглядач».

Функції, які залишаються за профільним міністерством щодо вищої освіти в умовах такого переходу $\epsilon$ наступними ${ }^{71}$ : формування загальної політики; стратегічне планування для сектору; перемовини щодо фінансування вищої освіти (з міністерством фінансів); координація дій з іншими міністерствами (наприклад, охорони здоров'я) щодо питань вищої освіти. Однією з ключових особливостей такої зміни $\epsilon$ перехід домінування від функції контролю до функції моніторингу та регулювання університетів ${ }^{72}$.

J. Fielden ${ }^{73}$ визначає два основні шляхи, які використовують уряди для здійснення «непрямого» / "м'якого» впливу на ефективність університетського врядування ${ }^{74}$ : врядування.

Вимога до закладів вищої освіти відповідати певним визначеним критеріям щодо ефективного врядування.

Надання рекомендацій, порад та інструкцій рекомендаційного характеру щодо ефективного

При цьому дослідник особливо наголошує на тому, що метою такого впливу держави є не пряме регулювання управлінням автономних інституцій, а завдання «допомогти закладам врядовувати себе та управляти собою ефективно» ${ }^{75}$.

До переліку інструментів "м'якого» впливу держави на ефективність університетського врядування також відносимо вплив на процес відбору зовнішніх членів до органів університетського врядування, зокрема у частині їх професійності, через визначення вимог, яким претенденти мають відповідати (наприклад, досвід в управлінні, певні фахові знання тощо) ${ }^{76}$. Такі вимоги, як правило, обумовлені та легітимізовані у відповідних нормативно-правових документах.

71 J. Fielden. Global Trends in University Governance. - The World Bank, 2008. - 65 p. - C. $16 . \quad$ - URL: http://siteresources.worldbank.org/EDUCATION/Resources/278200-1099079877269/547664$1099079956815 /$ Global Trends University Governance webversion.pdf

72 J. Fielden. Global Trends in University Governance. - The World Bank, 2008. - 65 p. - C. $2 . \quad$ - URL: http://siteresources.worldbank.org/EDUCATION/Resources/278200-1099079877269/547664$1099079956815 /$ Global_Trends_University_Governance_webversion.pdf

73 J. Fielden. Global Trends in University Governance. - The World Bank, 2008. - 65 p. - URL: http://siteresources.worldbank.org/EDUCATION/Resources/278200-1099079877269/5476641099079956815/Global Trends University Governance webversion.pdf

74 J. Fielden. Global Trends in University Governance. - The World Bank, 2008. - 65 p. - C. $41 . \quad$ - URL: http://siteresources.worldbank.org/EDUCATION/Resources/278200-1099079877269/547664$1099079956815 /$ Global Trends University Governance webversion.pdf

75 J. Fielden. Global Trends in University Governance. - The World Bank, 2008. - 65 p. - C. $42 . \quad$ - URL: http://siteresources.worldbank.org/EDUCATION/Resources/278200-1099079877269/547664-

$1099079956815 /$ Global Trends University Governance webversion.pdf

76 T. Estermann, E. Pruvot. University Governance: Autonomy, Structures and Inclusiveness / European Higher Education Area: The Impact of Past and Future Policies, Volume II. - EUA, 2018. - P. 619-631. - URL: https://link.springer.com/chapter/10.007/978-3-319-77407-7_37 . - P. 20/28. 
Серед сучасних механізмів «м'якого» впливу держави на ефективність діяльності університетів, і у тому числі ефективність університетського врядування, які активно запроваджуються та розвиваються у багатьох провідних країнах ${ }^{77}, \epsilon$ так звані «цільові угоди» (target agreements) ma «ключові індикатори досягнень» (КPls - key performance indicators). Узгоджені цілі / індикатори досягнень фіксуються у відповідному документі та слугують орієнтиром для розвитку закладу. Механізмом, який дозволяє засвідчити для держави досягнення результатів з боку закладів вищої освіти, $є$ періодичне оцінювання закладів вищої освіти, а його результати у свою чергу слугують основою для прийняття подальших рішень (стратегічних, фінансових, кадрових тощо) ${ }^{78}$.

Таким чином, на основі аналізу наукових джерел нами визначено та обґрунтовано теоретичні основи реалізації ефективного університетського врядування, до яких ми віднесли:

- базові поняття;

- принципи;

- закономірності;

- тенденції.

Подальший науковий пошук з даної проблеми потребує звернення до аналізу наявних провідних практик реалізації врядування у вищій освіті. Такий аналіз дозволить, з одного боку, розширити та поглибити теоретичні рамки дослідження, з іншого - засвідчити запропоновані теоретичні положення конкретними прикладами.

\footnotetext{
77 Власова І.В. Розширення фінансової автономії університетів: політичний та управлінський виміри / Дисертація на здобуття наукового ступеня доктора педагогічних наук: 13.00.06 - теорія та методика управління освітою. - Інститут вищої освіти НАПН України, 2020 p. - 463 c. https://ihed.org.ua/wp-content/uploads/2020/11/Vlasova 25-11-2020 disser.pdf

${ }^{78}$ R. Muller-Terpitz. Conflict between Freedom of Research and Teaching and New Models of Governance and Leadership // Leadership and Governance in Higher Education for Decision-makers and Administrators. - 2013. - \# 2. - P. 59.
} 


\section{Велика Британія}

\section{The Higher Education Code of Governance ${ }^{79}$}

Даний документ (Код врядування у вищій освіті) розроблений та схвалений Committee of University Chairs - CUC (Велика Британія) у вересні 2020 року (попередня версія Коду була схвалена у грудні 2014 року). Код визначає ключові цінності та елементи, які формують рамку ефективного врядування для університетів.

Щодо шляхів застосування Коду на практиці конкретного університету зазначається:

«Однак практика належного врядування є складною і виходить за рамки прийняття Кодексу. Ефективне врядування:

- потребує організаційної культури, яка дає свободу дій;

- визначає повноваження та підзвітність;

- і в своїй основі сприяє розвитку відносин, заснованих на взаємній повазі, довірі та чесності» ${ }^{80}$.

До ключових цінностей врядування у вищій освіті Великої Британії віднесено наступні ${ }^{81}$ :

- Цілісність: прозорість, підзвітність, чесність, свобода слова та академічна свобода (Integrity: transparency, accountability, honesty, freedom of speech and academic freedom).

- Стійкість: фінансова та середовища (Sustainability: financial and environmental).

- Іклюзивність: рівність, різноманітність, доступність, участь та справедливі умови для всіх). (Inclusivity: equality, diversity, accessibility, participation and fair outcomes for all).

- Досконалість: високоякісні дослідження, стипендії та викладання (Excellence: high-quality research, scholarship and teaching).

- Інновації та зростання: соціальне, економічне та культурне (Innovation and growth: social, economic and cultural).

- Спільнота: державна служба, громадянство, колегіальність, співпраця (Community: public service, citizenship, collegiality, collaboration).

Зазначені принципи разом з Принципами Нолана формують етичну рамку, на яку мають орієнтуватися у своїй поведінці учасники університетського врядування.

Кодекс визначає ключові цілі університетського врядування ${ }^{82}$ :

- визначати, спрямовувати та забезпечувати досягнення інституційної місії та успіху у стійкий спосіб (фінансовий, соціальний та щодо середовища);

- захищати та сприяти колективному студентському інтересу та важливості якісного студентського досвіду;

- гарантувати, що результати студентів демонструють гарну соціальну, економічну цінність та цінність для середовища;

- ефективно управляти можливостями та

- ефективно управляти можливостями та пом'якшувати ризики для захисту репутації закладу, забезпечуючи фінансову стійкість та підзвітність за державне фінансування;

- сприяти та розвивати позитивну культуру, яка підтримує етичну поведінку та рівність, різноманітність та інклюзивні практики;

- сприяти досконалості у навчанні, викладанні та дослідженнях, забезпечуючи моніторинг інституційних досягнень та результатів врядування;

- оприлюднювати точну та прозору інформацію, яка є широко доступною;

- вести своїм прикладом, бути гнучким та адаптивним, щоб створювати стійке майбутнє;

\footnotetext{
79 The Higher Education Code of Governance. URL: https://www.universitychairs.ac.uk/wp-content/uploads/2020/09/CUC-HE-Code-ofGovernance-publication-final.pdf

80 The Higher Education Code of Governance. URL: https://www.universitychairs.ac.uk/wp-content/uploads/2020/09/CUC-HE-Code-ofGovernance-publication-final.pdf. - P. 4.

81 The Higher Education Code of Governance. URL: https://www.universitychairs.ac.uk/wp-content/uploads/2020/09/CUC-HE-Code-ofGovernance-publication-final.pdf. - P. 6.

82 The Higher Education Code of Governance. URL: https://www.universitychairs.ac.uk/wp-content/uploads/2020/09/CUC-HE-Code-ofGovernance-publication-final.pdf. - P. 6-7.
} 
- забезпечити наявність механізмів значущої взаємодії зі стейкхолдерами (особливо студентами та персоналом) на локальному, регіональному, національному та глобальному рівнях.

Досягнення вище зазначених цілей потребує чіткого усвідомлення того, що: «Ефективне управління вимагає більше, ніж розвиток процесів, оскільки воно будується на міцних відносинах, чесному діалозі та взаємоповазі» ${ }^{83}$.

До ключових елементів ефективного університетського врядування віднесено наступні:

1) підзвітність;

2) стійкість;

3) репутація;

4) інклюзивність та різнорідність;

5) результативність;

6) залученість.

Кодекс детально розкриває сутність кожного елементу та деталізує їх через опис вимог, зобов'язань, прав і поведінки членів органів врядування та правил діяльності самих органів.

83 The Higher Education Code of Governance. URL: https://www.universitychairs.ac.uk/wp-content/uploads/2020/09/CUC-HE-Code-ofGovernance-publication-final.pdf. - P. 7. 


\section{Іспанія}

\section{Governance of Higher Education in Spain ${ }^{84}$}

Автономія університетів утверджена на рівні ст. 27. Конституції Іспанії 85 .

Система управління закладами вищої освіти у країні $\epsilon$ децентралізованою, компетенція щодо управління освітою, у тому числі й вищої віднесена на рівень регіонів і належить Autonomous Communities ${ }^{86}$. Але при цьому базове законодавство та координація залишаються на національному рівні ${ }^{87}$.

На національному рівні у структурі парламенту діє Commission on education and Sport. Ця Комісія має повноваження встановлювати загальні правила щодо вищої освіти. Окрім законодавчих ініціатив до компетенції Комісії віднесено питання звітування перед нею членів Уряду країни, які відповідають за вищу освіту, а саме: Minister of Education; State Secretary on Education, Professional Education and Universities; General Secretary of Universities ${ }^{88}$.

Центральний уряд зберігає контроль над законодавчою рамкою задля того, щоб гарантувати однорідність і справедливість у всій системі освіти країни в цілому. Центральний уряд також відповідає за загальне планування щодо інвестицій в освіту. Центральний зберігає за собою право регулювати умови для отримання, надання та валідації академічних і професійних кваліфікацій 89.

На національному рівні врядування у вищій освіті представлено трьома органами: University Council, General Conference of University Policy, State University Student Council.

University Council очолює профільний міністр. До складу Ради входять ректори всіх університетів країни та President of the Economic and Social Council of Spanish Universities. Рада виконує дорадчі функції, сприяє співпраці та координації університетів щодо академічних справ ${ }^{90}$.

General Conference of University Policy також очолює профільний міністр. До складу цього органу врядування входять представники університетів. Що представляють регіональні Autonomous Communities. Конференція встановлює та затверджує загальну політику щодо університетів, забезпечуючи ії узгодження 3 Європейським простором вищої освіти та політикою у галузі досліджень. Конференція здійснює загальне та довготермінове планування у питаннях управління вищою освітою, включаючи людські, матеріальні та фінансові ресурси. Серед іншого Конференція: схвалює критерії для оцінювання, сертифікації та акредитації; пропонує заходи для гарантування зв'язків між університетами та бізнесом у сфері трансферу знань та інновацій, зв'язку з ринком праці; встановлює діапазон для плати за навчання ${ }^{91}$.

State University Student Council - орган для обговорення, консультування зі студентських питань та представництва студентів університетів на національному рівні ${ }^{92}$.

На рівні регіонів Autonomous Communities мають повноваження щодо регулювання та управління освітою. До їх юрисдикції належать питання легалізації та контролю діяльності закладів освіти, найму та оплати персоналу, будівництва та обладнання нових освітніх об'єктів та реновації існуючих ${ }^{93}$.

\footnotetext{
${ }^{84}$ L. Delgado. Governance in Specific Higher Education Systems. Governance of Higher Education in Spain // Leadership and Governance in Higher Education. - 2014. - \# 1. - P. 119-146.

85 L. Delgado. Governance in Specific Higher Education Systems. Governance of Higher Education in Spain // Leadership and Governance in Higher Education. - 2014. - \# 1. - P. 119-146. - P. 143.

${ }^{86}$ L. Delgado. Governance in Specific Higher Education Systems. Governance of Higher Education in Spain // Leadership and Governance in Higher Education. - 2014. - \# 1. - P. 119-146. - P. 120.

${ }^{87}$ L. Delgado. Governance in Specific Higher Education Systems. Governance of Higher Education in Spain // Leadership and Governance in Higher Education. - 2014. - \# 1. - P. 119-146. - P. 126.

88 L. Delgado. Governance in Specific Higher Education Systems. Governance of Higher Education in Spain // Leadership and Governance in Higher Education. - 2014. - \# 1. - P. 119-146. - P. 126.

89 L. Delgado. Governance in Specific Higher Education Systems. Governance of Higher Education in Spain // Leadership and Governance in Higher Education. - 2014. - \# 1. - P. 119-146. - P. 127.

90 L. Delgado. Governance in Specific Higher Education Systems. Governance of Higher Education in Spain // Leadership and Governance in Higher Education. - 2014. - \# 1. - P. 119-146. - P. 127.

91 L. Delgado. Governance in Specific Higher Education Systems. Governance of Higher Education in Spain // Leadership and Governance in Higher Education. - 2014. - \# 1. - P. 119-146. - P. 134.

92 L. Delgado. Governance in Specific Higher Education Systems. Governance of Higher Education in Spain // Leadership and Governance in Higher Education. - 2014. - \# 1. - P. 119-146. - P. 134.

93 L. Delgado. Governance in Specific Higher Education Systems. Governance of Higher Education in Spain // Leadership and Governance in Higher Education. - 2014. - \# 1. - P. 119-146. - P. 128.
} 
Інституиійний рівень врядування обумовлюється рамками базового державного законодавства, регіональних законодавчих рамок та статуту кожного окремого закладу вищої освіти. При цьому статути всіх державних університетів базуються на трьох головних принципах: автономія, самоврядування та підзвітність. На інституційному рівні у процеси врядування залучені ${ }^{94}$ :

- на індивідуальному рівні - Rector, Vice-rector, General Secretary, Manager, Dean, Director of Department;

- на колегіальному рівні - Social Council, Governing Council, University Senate, Faculty Boards, Department Councils.

Social Council - орган, що забезпечує зв'язок університету з суспільством. До повноважень Ради належать питання: економічна діяльність, підзвітність університету суспільству, забезпечення фінансування університетської діяльності з боку суспільства. До складу Ради, окрім Rector, General Secretary та Manager університету, входять як обрані члени, так і номіновані Autonomous Communities, включаючи зовнішніх стейкхолдерів. Autonomous Communities також визначає Президента цієї Ради ${ }^{95}$.

Governing Council очолює Rector університету, а до його складу входять:

- Vice-rectors, General Secretary, Manager, Deans, Directors of Department4

- представники академічного персоналу та студентів;

- 3 представника від Social Council, які не є членами академічної спільноти.

Governing Council визначає стратегічні та операційні цілі університету у питаннях викладання та досліджень, людських та економічних ресурсів, розроблення бюджету ${ }^{96}$.

University Senate $€$ найвищим представницьким органом університетської спільноти. Сенат очолюється Ректором університету та включає General Secretary, Manager та до 300 членів університетської спільноти, включаючи академічний, адміністративний і технічний персонал та студентів ${ }^{97}$.

\footnotetext{
94 L. Delgado. Governance in Specific Higher Education Systems. Governance of Higher Education in Spain // Leadership and Governance in Higher Education. - 2014. - \# 1. - P. 119-146. - P. 143-144.

95 L. Delgado. Governance in Specific Higher Education Systems. Governance of Higher Education in Spain // Leadership and Governance in Higher Education. - 2014. - \# 1. - P. 119-146. - P. 144.

96 L. Delgado. Governance in Specific Higher Education Systems. Governance of Higher Education in Spain // Leadership and Governance in Higher Education. - 2014. - \# 1. - P. 119-146. - P. 144.

97 L. Delgado. Governance in Specific Higher Education Systems. Governance of Higher Education in Spain // Leadership and Governance in Higher Education. - 2014. - \# 1. - P. 119-146. - P. 144.
} 


\section{Governance in the Italian Higher Education System ${ }^{98}$}

Академічна свобода та автономія закладів вищої освіти визначені положеннями Конституції країни ${ }^{99}$.

Відповідно до Конституції Італії законодавче право делеговано двом Палатам у Парламенті - Палаті представників і Сенату. Комітети з освіти, культури та науки є в обох Палатах. Комітети співпрацюють 3 профільними міністрами при підготовці урядових актів з вищої освіти та з Президентом Республіки щодо номінації членів Керівної ради Національного агентства забезпечення якості. Комітети також моніторять внутрішню організацію профільних міністерств, діяльність Уряду у галузі, основні результати реалізації процедур забезпечення якості як для викладання, так і для досліджень ${ }^{100}$.

Ключові повноваження щодо вищої освіти та науки у країні належать Міністерству освіти, університетів та досліджень. Міністерство серед іншого відповідає за:

- визначення та розподіл фінансових ресурсів з державного бюджету;

- оцінювання освітньої системи;

- політику щодо досліджень та інновацій;

- визнання кваліфікацій та сертифікацію;

- Європейську та міжнародні політики у освіти.

У галузі вищої освіти, де визначальним є принцип інституційної автономії, Міністерство забезпечує: планування загального ландшафту вищої освіти, керівництво та координацію, загальне регулювання, фінансування закладів вищої освіти та дослідницьких установ, планування та координацію фундаментальних і прикладних досліджень, моніторинг та оцінювання результатів діяльності, імплементацію Європейської та міжнародних політик і регуляцій, Європейську інтеграцію та участь у Програмах $Є С$, визначення загальних правил і процедур доступу до вищої освіти, координацію системи студентського добробуту ${ }^{101}$.

На наступному рівні врядування функціонує National University Council (NUC). До складу Ради входять: обрані академічними спільнотами представники, які представляють 14 галузей знань; представники студентів, профспілок; представник Rectors' Conference. Рада обирається кожні 4 роки та є консультаційним органом для профільного міністра та впливає на державну політику у вищій освіті у питаннях врядування, фінансування, структури ступенів, управління персоналом тощо ${ }^{102}$.

National Council of University Students oб'єднує 30 обраних студентів, що представляють заклади вищої освіти. Рада має консультативні повноваження зі справ студентської політики. Рада також щорічно готує звіт щодо студентів і студентського досвіду у закладах вищої освіти Італії ${ }^{103}$.

Conference of the Rectors of Italian Universities за статусом $€$ неурядовою організацією. Головна місія організації визначена як забезпечення координації та підтримка членів організації, представлення їх інтересів перед партнерами. Conference of the Rectors of Italian Universities є членом European University Association ${ }^{104 .}$

Інституційний рівень врядування на рівні закладу вищої освіти обумовлений тим, що держава має повноваження визначати головні характеристики інституційного врядування. Кожний університет зобов'язаний прийняти власний статут, де визначені особливості університетського врядування.

На рівні університету основними гравцями у процесах врядування $є$ : Rector, Academic Senate, Administrative Board, Internal Evaluation Union, Director General ${ }^{105}$.

\footnotetext{
98 M. Foroni. Governance in the Italian Higher Education System // Leadership and Governance in Higher Education. - 2014. - \# 2. - P. 117148.

${ }_{99}$ M. Foroni. Governance in the Italian Higher Education System // Leadership and Governance in Higher Education. - 2014. - \# 2. - P. 117148. - P. 132.

100 M. Foroni. Governance in the Italian Higher Education System // Leadership and Governance in Higher Education. - 2014. - \# 2. - P. 117148. - P. 123.

101 M. Foroni. Governance in the Italian Higher Education System // Leadership and Governance in Higher Education. - 2014. - \# 2. - P. 117148. - P. 124.

102 M. Foroni. Governance in the Italian Higher Education System // Leadership and Governance in Higher Education. - 2014. - \# 2. - P. 117148. - P. 128.

103 M. Foroni. Governance in the Italian Higher Education System // Leadership and Governance in Higher Education. - 2014. - \# 2. - P. 117148. - P. 129.

104 M. Foroni. Governance in the Italian Higher Education System // Leadership and Governance in Higher Education. - 2014. - \# 2. - P. 117148. - P. 129.

105 M. Foroni. Governance in the Italian Higher Education System // Leadership and Governance in Higher Education. - 2014. - \# 2. - P. 117148. - P. 142.
} 


\section{Governance of Higher Education in Germany ${ }^{106}$}

Відповідно до федеральної системи Німеччини відповідальність за освіту, включаючи вищу освіту, повністю покладена на регіональний рівень - Землі. Уряд кожної Землі відповідає за базове фінансування та організацію закладів вищої освіти. Кожна Земля має власні закони, що скеровують вищу освіту ${ }^{107}$. Кожна Земля також визначає статус закладу вищої освіти ${ }^{108}$.

I хоча відповідно до освітнього федералізму ступінь незалежності у вищій освіті різниться у межах країни від Землі до Землі, спільним для всієї системи $є$ гарантування академічної свободи та інституційної автономії. Ці принципи засвідчені як у законах з вищої освіти на рівні Земель, так і федеральній Конституції ${ }^{109}$. Конституційний принцип (ст. 5, п. 3) щодо академічної свободи гарантує автономію та право на самоврядність закладам вищої освіти ${ }^{110}$.

На рівні країни функціонує German Rectors' Conference, яка формує базові принципи щодо університетської автономії та врядування, але не втручається на рівень конкретних моделей ${ }^{111}$.

На рівні Земель діють профрільні міністерства, які розробляють політику у сфері вищої освіти та науки, здійснюють адаптацію законодавчих норм і регуляцій до галузі, співпрацюють з вищими органами влади на національному рівні та рівні Земель. Для того, щоб допомогти профільним міністерства у виконанні їх функцій, Землі створюють дослідницькі інститути з вищої освіти ${ }^{112}$.

На рівні країни профільні міністри від усіх Земель об'єднані у Standing Conference, головне завдання якої забезпечити координацію зусиль у галузі на рівні країни в цілому. Серед ключових питань цього органу серед іншого і питання академічної мобільності у межах країни. Засідання цього координаційного органу проводяться у вигляді пленарних сесій 3-4 рази на рік, рішення приймаються на засадах консенсусу та співпраці ${ }^{113}$.

На рівні університету (інституційний рівень врядування) діє Senate. Повноваження сенатів різняться від Землі до Землі. В цілому наявна тенденція до зведення повноважень сенатів до визначення загальних норм, обрання та консультування ректора / президента університету ${ }^{114}$.

106 B. Gobbels - Dreyling. H. Rockmann. Governance of Higher Education System // Leadership and Governance in Higher Education. - 2015. \# 1. - P. 157-178.

107 B. Gobbels - Dreyling. H. Rockmann. Governance of Higher Education System // Leadership and Governance in Higher Education. - 2015. \# 1. - P. 157-178. - P. 164.

108 B. Gobbels - Dreyling. H. Rockmann. Governance of Higher Education System // Leadership and Governance in Higher Education. - 2015. \# 1. - P. 157-178. - P. 171.

109 B. Gobbels - Dreyling. H. Rockmann. Governance of Higher Education System // Leadership and Governance in Higher Education. - 2015. \# 1. - P. 157-178. - P. 164.

110 B. Gobbels - Dreyling. H. Rockmann. Governance of Higher Education System // Leadership and Governance in Higher Education. - 2015. \# 1. - P. 157-178. - P. 165.

111 B. Gobbels - Dreyling. H. Rockmann. Governance of Higher Education System // Leadership and Governance in Higher Education. - 2015. \# 1. - P. 157-178. - P. 164

112 B. Gobbels - Dreyling. H. Rockmann. Governance of Higher Education System // Leadership and Governance in Higher Education. - 2015. \# 1. - P. 157-178. - P. 165.

113 B. Gobbels - Dreyling. H. Rockmann. Governance of Higher Education System // Leadership and Governance in Higher Education. - 2015. \# 1. - P. 157-178. - P. 166.

114 B. Gobbels - Dreyling. H. Rockmann. Governance of Higher Education System // Leadership and Governance in Higher Education. - 2015. \# 1. - P. 157-178. - P. 177. 


\section{Висновки та рекомендації}

Завдання нашого дослідження полягало у тому, щоб визначити теоретико-методологічні основи дослідження факторів забезпечення ефективного університетського врядування, через їх призму проаналізувати діючі практики врядування у вищій освіті та сформулювати відповідні рекомендації для запровадження моделі ефективного врядування в університетах України.

Здійснений аналіз дозволяє нам сформулювати наступні висновки.

1. Проблема забезпечення ефективного врядування у вищій освіті є однією із ключових серед вимірів і реформ Болонського процесу. Це засвідчує аналіз змісту декларацій та комюніке, які формують політичну рамку Європейського простору вищої освіти (European Higher Education Area, EHEA) (далі - ЄПВО).

2. Вища освіта України як складова Європейського простору вищої освіти у своєму розвитку керується політиками (policies) європейського рівня та відповідним чином відчуває вплив тенденцій і реформ Болонського процесу та відповідає на зазначені виклики. Актуалізація проблеми забезпечення ефективного університетського врядування також спричинена національними особливостями, пов'язаними 3 імплементацією Закону України «Про вищу освіту» (2014р.). Закон значною мірою розширив автономію університетів і, як наслідок, актуалізував проблему підвищення інституційної відповідальності закладів вищої освіти за якість вищої освіти. Це, у свою чергу, загострює потребу постійного розвитку інституційної спроможності закладів вищої освіти, у тому числі для забезпечення ефективного університетського врядування.

3. До теоретико-методологічних основ дослідження факторів забезпечення ефективного університетського врядування відносимо поняття, принципи, закономірності, тенденції, які дозволяють запропонувати системний підхід до визначення, обгрунтування та подальшого прикладного аналізу факторів забезпечення ефективного університетського врядування.

4. До ключових характеристик врядування у вищій освіті відносимо багаторівневість, багатоакторність, багатосекторальність.

5. Врядування у вищій освіті $€$ багаторівневим. А саме, виділяють такі рівні: наднаціональний (європейський у випадку Європейського простору вищої освіти, до якого належить система вищої освіти України); національний (уряд, профільні міністерства, інші центральні органи влади, до компетенції яких належить вища освіта); регіональний (органи влади регіонального рівня, наприклад муніципалітети, які $\epsilon$ засновниками комунальних закладів вищої освіти); інституційний (рівень закладу вищої освіти); індивідуальний (рівень окремих учасників процесу врядування).

6. Врядування у вищій освіті $\epsilon$ багатоакторним. А саме, вирізняють таких ключових учасників врядування: зовнішні стейкхолдери (політики, представники органів влади, бізнесу, громадянського суспільства); внутрішні стейкхолдери (управлінці, дослідники, викладачі, інший персонал закладу, студенти).

7. Врядування у вищій освіті $€$ багатосекторальним: зовнішній вимір - діяльність на національному / регіональному рівні, пов'язана зі взаємодією сектора вищої освіти в цілому з сектором охорони здоров'я, соціальною та молодіжною політикою, сектором економіки та фінансів тощо; внутрішній вимір - діяльність на рівні університету, пов'язана зі стратегуванням, плануванням, управлінням фінансами, вдосконаленням викладання, управлінням дослідженнями, забезпеченням якості, розвитком персоналу, взаємодією зі студентами тощо.

8. Теорія та практика сучасного управління університетами засвідчують наявність різних моделей університетського врядування. Виділення у ролі критерію тієї чи іншої особливості процесу врядування дозволяє запропонувати відповідні класифікації моделей врядування та відповідно веде до пошуку шляхів забезпечення ефективного університетського врядування. 
9. Ідентифікація факторів і механізмів забезпечення ефективного університетського врядування має здійснюватися через аналіз кращих практик врядування у вищій освіті на основі теоретичної матриці, що формує концепцію «розподіленого лідерства у вищій освіті».

10. Здійсненний аналіз дозволив виявити тенденцію трансформації моделей врядування у вищій освіті у напрямі «ціннісно-базованого врядування» та «врядування, що базується на довірі».

11. Здійсненний аналіз дозволив запропонувати практичні кроки для імплементації у систему вищої освіти України парадигми ефективного врядування у форматі:

- пропозицій до проєкту Стратегії розвитку вищої освіти України до 2031 року;

- пропозиції щодо цільових показників діяльності закладу вищої освіти, які включаються до контракту з керівником, за напрямом «Ефективне врядування та розвиток кадрового потенціалу 3ВО».

Пропозищії до проєкту Стратегії розвитку вищої освіти України до 2031 року

Розділ «Ефективне врядування» у проєкті Стратегії розвитку вищої освіти України

Ціль: Розвиток системи управління вищою освітою в Україні на засадах університетської автономії та ефективного врядування

Пріоритети: Розширення університетської автономії; Розвиток інституційної спроможності 3ВО; Перехід від моделі «держава - регулятор» до моделі «держава - модератор» мережі 3ВО; Посилення ролі академічної спільноти (студенти, викладачі, дослідники) та роботодавців в управлінні ЗВО; Посилення спроможності Наглядової ради 3ВО; Професіоналізація управління 3ВО.

Цінності та принципи: Академічна свобода; Академічна доброчесність; Довіра та згуртованість; Підзвітність, прозорість та відкритість; Колегіальність та залученість; Розподілена відповідальність та командне лідерство; Партнерство.

Механізми: Розширення університетської автономії 3ВО (індикатори Європейської асоціації університетів, ЄАУ); Статус 3ВО; Децентралізація, дебюрократизація та дерегуляція управління вищою освітою; Розбудова моделі дуального врядування (Наглядова рада - Вчена рада) в 3ВО; Розбудова мережі колегіальних органів управління із широким залученням стейкхолдерів (внутрішніх і зовнішніх); Популяризація кращих практик реалізації університетської автономії та ефективного врядування; Професійна підготовка керівників 3ВО, університетських команд; Оцінювання ефективності діяльності 3 ВО.

Індикатори для моніторингу прогресу: Рівень університетської автономії (академічна, організаційна, кадрова, фінансова); Рівень впливу колегіальних органів на діяльність 3 ВО та МОНУ; Рівень прозорості діяльності ЗВО та МОНУ; Рівень довіри між ключовими стейкхолдерами у вищій освіті.

Пропозиції щодо цільових показників діяльності закладу вищої освіти, які включаються до контракту з керівником, за напрямом «Ефекттивне врядування та розвиток кадрового потенціалу ЗВО», до яких віднесено:

НПП, які працюють у ЗВО за основним місцем роботи (\% від загальної кількості НПП та \% зростання; Дані офіційної статистичної звітності).

НПП, які працюють у ЗВО за основним місцем роботи та мають науковий ступінь / ступінь доктора мистецтва та / або вчене (почесне для мистецьких 3ВО) звання (\% від загальної кількості НПП та \% зростання; Дані офіційної статистичної звітності).

Співвідношення кількості НПП (ом) з науковим ступенем / ступенем доктора мистецтва та / або вченим (почесне для мистецьких 3ВО) званням до кількості здобувачів вищої освіти (\% зростання; Дані офіційної статистичної звітності).

Обсяг коштів, спрямованих на підвищення кваліфікації НПП (\% зростання та фактичний показник на одного НПП; Дані офіційної статистичної звітності).

Зв'язок з роботодавцями (\% здобувачів вищої освіти, які проходять практику на підприємствах поза 3ВО, від загальної кількості здобувачів вищої освіти та \% зростання). 
1. Bolden R., Jones S., Davis H., Gentle P. Development and Sustaining Shared Leadership in Higher Education. - London: LFHE, 2015. - 47 p.

2. Delgado L. Good Governance in Higher Education. The Right to Education / ResearchGate. - URL: https://www.researchgate.net/publication/234136496 Good Governance in Higher Education The Rig ht to Education

3. Delgado L. Governance in Specific Higher Education Systems. Governance of Higher Education in Spain // Leadership and Governance in Higher Education. - 2014. - \# 1. - P. 119-146.

4. Development and Sustaining Shared Leadership in Higher Education: Stimulus paper / R. Bolden, S. Jones, H. Davis, P. Gentle. - London: LFHE, 2015. - 47 p.

5. Estermann T., Bennetot Pruvot E. University Governance: Autonomy, Structures and Inclusiveness / European Higher Education Area: The Impact of Past and Future Policies, Volume II. - EUA, 2018. - P. 619631. - URL: https: //link.springer.com/chapter/10.007/978-3-319-77407-7 37

6. EUA. - URL://www.eua.be

7. Fielden J. Global Trends in University Governance. - The World Bank, 2008. - 65 p. - URL: http://siteresources.worldbank.org/EDUCATION/Resources/278200-1099079877269/547664$1099079956815 /$ Global Trends University Governance webversion.pdf

8. Fiol M., Samoilovich D. University Management: A Necessary Debate // Leadership and Governance in Higher Education for Decision-makers and Administrators. - 2014. - \# 1. - P. 1-22.

9. Foroni M. Governance in the Italian Higher Education System // Leadership and Governance in Higher Education. - 2014. - \# 2. - P. 117-148.

10. Frolich N., Caspersen J. How does policy change universities? // State of Higher Education 2015-16 / Edited by Sarrico C., McQueen A. and Samuelson S.. - The OECD Higher Education Programme, 2017. - P. 127-132.

11. Gobbels - Dreyling B., Rockmann H. Governance of Higher Education System // Leadership and Governance in Higher Education. - 2015. - \# 1. - P. 157-178.

12. Harmsen R.. The Governance of the Global University: Leadership and Policy Challenges // Leadership and Governance in Higher Education for Decision-makers and Administrators. - 2014. - \# 3. - P. 35-52.

13. Magalhaes A., Veiga A. Governance and Management Dilemmas Arising from Substructuring in Higher Education // Leadership and Governance in Higher Education for Decision-makers and Administrators. 2014. - \# 2. - P. 27-47.

14. Magna Charta Universitatum 2020. URL: http://www.magna-charta.org/magna-charta-universitatum/mcu$\underline{2020}$

15. Muller-Terpitz R.. Conflict between Freedom of Research and Teaching and New Models of Governance and Leadership // Leadership and Governance in Higher Education for Decision-makers and Administrators. 2013. - \# 2. - P. 57-70.

16. Noorda S. Academic Autonomy as a Lifelong Learning Process for Universities // Leadership and Governance in Higher Education for Decision-makers and Administrators. - 2013. - \# 4. - P. 1-15.

17. Paris Communiqué. URL: https://ihed.org.ua/wpcontent/uploads/2019/02/Bologna Conference 27.11.2018 -Full document 47p.pdf

18. Pedrosa J. Autonomy and Accountability in University Governance // Leadership and Governance in Higher Education for Decision-makers and Administrators. - 2014. - \# 1. - P. 22-39.

19. Rome Ministerial Communique. November 19 2020. URL: https://ehea2020rome.it/storage/uploads/5d29d1cd-4616-4dfe-a2af-

29140a02ec09/BFUG Final Draft Rome Communique-link.pdf; https://erasmusplus.org.ua/novyny/3254zaproshuiemo-doluchytys-do-ix-mizhnarodnoi-naukovo-praktychnoi-konferentsii.html (переклад українською мовою Національного Еразмус+ офісу в Україні)

20. The European Higher Education Area in 2020. Bologna Process Implementation Report. - Luxemburg: Publications Office of European Union, 2020. - 201 p. URL: https://eacea.ec.europa.eu/nationalpolicies/eurydice/sites/eurydice/files/ehea_bologna_2020 0.pdf 
21. The Higher Education Code of Governance. URL: https://www.universitychairs.ac.uk/wpcontent/uploads/2020/09/CUC-HE-Code-of-Governance-publication-final.pdf

22. University Autonomy in Europe II. The Scorecard / by Thomas Estermann, Terhi Nokkala \& Monika Steinel. EUA, 2011. - 81 p. - URL: http://eua.be/publications/eua-reports-studies-and-occasional-papers.aspx

23. Vukasovic M., Jungblut J., Chou M.-H., Elken M., Ravinet P. Multi-Level, Multi-Actor and Multi-Issues Dimensions of Governance of the European Higher Education Area, and Beyond / European Higher Education Area: The Impact of Past and Future Policies, Volume I. - EUA, 2018. - 406 p. - P. 307-320.

24. Автономія та врядування у вищій освіті: монографія / Авт.: Воробйова О.П., Горецька Т.О., Дем'яненко Н.М., Калашнікова С.А., Коваленко О.М., Луговий В.І., Сич О., Слюсаренко О.М., Таланова Ж.В., Ткаченко В.П. - К.: Інститут вищої освіти НАПН України, 2015. - 192 с. URL: https://ihed.org.ua/wpcontent/uploads/2018/09/Avtonomiya-ta-vryaduv-VO monogr IVO-2015-192p avtors-kolektiv.pdf

25. Автономія та врядування у вищій освіті: збірник наукових праць / авторський колектив: О.П. Воробйова, К.О. Жданова, І.Б. Зарубінська, С.А. Калашнікова, О.І. Козієвська, І.О. Линьова, В.І. Луговий, О.М. Слюсаренко, Ж.В. Таланова / За ред. С.А. Калашнікової, В.І. Лугового, Ж.В. Таланової. - К.: , 2014. - 236 c. URL: https://ihed.org.ua/wp-content/uploads/2018/09/zbirnik Avtonomiya-ta-vraduv-Vishosv IVO-NAPN-2014-236s.pdf

26. Аналіз провідного вітчизняного та зарубіжного досвіду розвитку щодо механізмів реалізації ефективного врядування в університетах: препринт (аналітичні матеріали) (частина I) / Авторський колектив: І. Драч, С. Калашнікова, О. Паламарчук, В. Рябченко, Л. Червона; за заг. ред. С. Калашнікової. - Київ: Інститут вищої освіти НАПН України, 2018. - 147 с. URL: https://ihed.org.ua/wpcontent/uploads/2019/09/Analiz dosvidu vriaduvania_v univer_ch1_analit IVO-2018-147p_avtorskolektiv.pdf

27. Аналіз провідного вітчизняного та зарубіжного досвіду щодо механізмів реалізації ефективного врядування в університетах: препринт (аналітичні матеріали) (частина II) / Авторський колектив: І. Драч, О. Паламарчук, В. Рябченко, Л. Червона; за заг. ред. С. Калашнікової - Київ: Інститут вищої освіти НАПН України, 2019. $\quad$ - $296 \quad$ c. 96 URL: content/uploads/2020/04/Analiz dosvidu vriaduvania v univer ch2 analit IVO-2019-96p avtorskolektiv.pdf

28. Власова І.В. Розширення фінансової автономії університетів: політичний та управлінський виміри / Дисертація на здобуття наукового ступеня доктора педагогічних наук: 13.00 .06 - теорія та методика управління освітою. - Інститут вищої освіти НАПН України, 2020 р. - 463 c. https://ihed.org.ua/wpcontent/uploads/2020/11/Vlasova_25-11-2020_disser.pdf

29. Калашнікова С. Розвиток лідерського потенціалу сучасного університету: основи та інструменти: Навчальний посібник / С. Калашнікова. - К. : ДП «НВЦ «Пріоритети», 2016. - 44 c. https://ihed.org.ua/wpcontent/uploads/2018/09/rozvitok lidersk potencialu Universitets. Kalashnikova.S 2016 46c.pdf

30. Калашнікова С. Розділ 5. Фактори забезпечення ефективного університетського врядування: теоретико-методологічні основи // Аналіз провідного вітчизняного та зарубіжного досвіду розвитку щодо механізмів реалізації ефективного врядування в університетах: препринт (аналітичні матеріали) (частина I) / Авторський колектив: І. Драч, С. Калашнікова, О. Паламарчук, В. Рябченко, Л. Червона; за заг. ред. С. Калашнікової. - Київ: Інститут вищої освіти HAПН України, 2018. - 147 с. - C. 115-147. URL: https://ihed.org.ua/wp-content/uploads/2019/09/Analiz dosvidu vriaduvania v univer ch1 analit IVO2018-147p avtors-kolektiv.pdf

31. Правові засади реалізації Болонського процесу в Україні: монографія / Колектив авторів: Бугров В., Гожик А., Жданова К. та ін. ; за заг. ред. В. Лугового, С. Калашнікової. - К.: ДП «НВЦ «Пріоритети», 2014. -156 c.

32. Роль університету у розвитку лідерського потенціалу суспільства: концептуальні засади / Авторський колектив: О. Аарна, Д. Гудонієне, О. Гузар та ін.; за заг. ред. С. Калашнікової. - Київ: ДП «НВЦ «Пріоритети», $2014.2 \quad-\quad 100 \quad$ c. $\quad$ https://ihed.org.ua/wpcontent/uploads/2018/09/Rol Univ v Leaders. Avtors-kolektiv zr.Kalashnikova 2014-100p.pdf 


\title{
Розділ 2. Вплив соціального середовища на ефективне врядування в українських університетах: світоглядно-компетентнісний аспект
}

\author{
Володимир Рябченко, \\ доктор філософських наук, \\ старший науковий співробітник, \\ завідувач Відділу лідерства \\ та інституційного розвитку вищої освіти, \\ Інститут вищої освіти НАПН України \\ https://orcid.org/0000-0001-8445-3813
}

\section{Анотація}

У цьому розділі монографії актуалізовано проблему впливу соціального середовища на ефективне врядування у закладах вищої освіти України в умовах євроінтеграції. Інтерпретовано сутність врядування й досліджено його генезис. Запропоноване авторське визначення механізмів врядування. Теоретично обґрунтовано вплив соціального середовища закладу вищої освіти на запровадження в ньому механізмів ефективного врядування. Проаналізовано публікації, в яких віддзеркалюється теоретичний дискурс 3 проблеми впливу середовища закладів вищої освіти на результати їх діяльності та ефективності. Встановлено залежність конкурентоспроможності й успішності України та ії закладів вищої освіти від рівня розвитку демократії на підставі порівняння з країнами, у яких $€$ реальні демократично-правові держави. Акцентовано протекціонізм некомпетентності, який системно культивується в сучасному українському суспільстві і буквально «рубає під корінь» конкурентоспроможність України та їі університетів. Доведено, що протекціонізм некомпетентності $€$ наслідком відсутності цивілізованого конкурентного середовища в Україні, яке включає механізми здорової соціальної селекції. Вказано, що формування цивілізованого конкурентного середовища в українському суспільстві блокує монополізація його політичної та економічної сфер, яка виникла у результаті симбіозу бізнесу й політики, що породив гібридний режим влади олігархічного штибу. Встановлено, що це все $\epsilon$ наслідком так званого «порочного кола», яке виникає в умовах відсутності демократії, зокрема дієвих механізмів врядування в українському суспільстві, які б стримували владу від свавілля, зловживань і корупції. Акцентовано, що олігархічні режими влади не піддаються вдосконаленню, а країни з такими владними режимами приречені на деградацію й відставання у своєму цивілізаційному розвиткові. Виявлено тенденції, які гальмують підвищення якості вищої освіти, а відтак, потребують блокування шляхом запровадження механізмів ефективного врядування. Сформульовано найважливіші методологічні положення результативності та ефективності університетської діяльності. Обгрунтовано критерії результативності та ефективності діяльності закладів вищої освіти, на які має орієнтуватися врядування в умовах євроінтеграції. Запропоновано рекомендації щодо демократизації українського суспільства та його закладів вищої освіти. Зроблено критичні зауваження щодо проєкту Стратегії розвитку вищої освіти України на 2021-2030 роки. Ідентифіковано актуальні проблеми, що не фігурують у змісті Стратегії, до розв'язання яких має долучатися українське суспільство як головний стейкхолдер, щоб забезпечити успішний розвиток вищої освіти. 


\section{Актуальність дослідження проблеми врядування у вищій освіті}

При обгрунтуванні актуальності та розв'язанні проблеми запровадження механізмів ефективного врядування у закладах вищої освіти України необхідно брати до уваги як внутрішньо інституційні, так і зовнішні чинники, що знаходяться за межами їхнього соціального середовища, але значуще впливають на результативність та ефективність університетської діяльності.

Перші два етапи нашого наукового дослідження підтвердили логічність і доцільність такого методологічного підходу та засвідчили кілька ключових висновків.

По-перше, діяльність закладів вищої освіти (далі - ЗВО), їі зміст і результативність безпосередньо залежать від запитів суспільства, в якому вони функціонують.

По-друге, в соціальному середовищі ЗВО віддзеркалюється все, що робиться і твориться у суспільстві, зокрема цінності, які в ньому сповідуються, а також шляхи і способи досягнення успіху тощо. Саме цінності та зразки поведінки, що сповідуються і демонструються у соціальному середовищі, є визначальною умовою, яка уможливлює чи навпаки блокує запровадження в ньому механізмів ефективного врядування. Дослідження попередніх етапів показали, що відсутність культивування й дотримання демократичних цінностей і норм у соціальному середовищі, а також нечесність у ньому роблять врядування недієвим, від якого годі очікувати ефективності.

По-третє, заклади вищої освіти України є відкритими для комунікацій, взаємодії та співробітництва із зарубіжними університетами та іншими інституціями, зокрема країн Європейського простору вищої освіти. Щоб успішно інтегруватися у цей простір наші університети мусять демократизувати своє соціальне середовище. Останнє $є$ базовою передумовою для розвитку конкурентоспроможного людського капіталу, якого вкрай бракує Україні. Наслідком чого $€$ катастрофічне відставання України у своєму суспільноекономічному й цивілізаційному розвиткові від країн з усталеними демократіями і правовими державами.

Те, що Україна після розвалу Радянського Союзу, маючи серед колишніх його республік та постсоціалістичних країн один із найвищих рівнів розвитку економіки та забезпеченості людськими, територіальними і природними ресурсами, провалилася у своєму цивілізаційному розвиткові й «пасе задніх» у європейській спільноті, єпрямим і безпосереднім наслідком відсутності на ї̈ теренах реальної демократичноправової держави. Це своєю чергою зумовлено тим, що держава як суспільний інститут влади в Україні на початковому етапі своєї незалежності була захоплена олігархічно-клановими угрупуваннями і використовується ними донині як засіб власного збагачення. Симбіоз бізнесу та політики сформував і включив на повну потужність механізми системного соціального паразитування, які знекровлюють українське суспільство, роблять його немічним і деградуючим. Не здолавши відчуження суспільної влади від українського народу, годі сподіватись не лише на успішний цивілізований розвиток України, а й на ії історичне майбутнє.

Історія сучасної цивілізації протягом останніх століть, починаючи зі Славетної революції (1688-1689рр.) у Великій Британії, із беззаперечною переконливістю довела, що процвітають ті нації та країни, які стали на демократичний шлях розвитку, а занепадають ті країни, у яких суспільна влада відчужена від народу ${ }^{115}$. Не бачити такі закономірності цивілізаційного розвитку неможливо. Тим паче, протягом майже трьох десятиліть державної незалежності України, які змарновані на винахід якогось унікального «українського велосипеда демократії», «ходові характеристики» якого мають задовольняти можновладців і підконтрольних їм суб'єктів суспільної влади. На такому «велосипеді демократії» Україна неухильно скочується у стан країн так званого третього світу, прикладом і символом занепаду яких нині $\in$ Ангола, Зімбабве, Камерун, Конго, Ліберія, Судан, Сьєрра-Леоне та ін. ${ }^{116}$

І те, що в Україні нехтується напрацьований цивілізаційний досвід розбудови демократично-правових держав, $\epsilon$ проявом не політичної сліпоти, а браку громадянської компетентності, базовою основою якої $\epsilon$ демократичні цінності й державницький світогляд, що спонукають до зайняття принципової громадянської позиції. Ця риса притаманна як особам, які заходять у структури суспільної влади, так і особам, які активно чи пасивно сприяють заходженню та перебуванню у владі суб'єктів з браком громадянської компетентності. Наразі маємо на увазі не лише можновладців, яким підконтрольна українська держава, та політичні партії, що

\footnotetext{
115 Аджемоглу Дарон, Робінсон Джеймс. Чому нації занепадають. Походження влади, багатства та бідності / пер. $з$ англ. Олександр Дем'янчук. 4-те вид. К. : Наш формат, 2019. 440 с.

116 Аджемоглу Дарон, Робінсон Джеймс. Чому нації занепадають. Походження влади, багатства та бідності / пер. з англ. Олександр Дем'янчук. 4-те вид. К. : Наш формат, 2019. С. 325.
} 
формують на свій розсуд списки кандидатів на вибори, а й усіх громадян України, які беруть участь у виборах чи ігнорують їх.

І якщо входження у структури української влади у процесі виборів забезпечується певними демократичними механізмами, що надають можливості громадянам України реалізувати у цьому сенсі своє волевиявлення, то перебування суб'єктів у владі та їхня діяльність залишається незалежним від широкого загалу громадян, навіть на рівнях місцевого управління. Про підконтрольність поточної діяльності суб'єктів української влади з боку громадян на регіональному тим паче на суспільному рівні годі вести мову. Саме відсутність механізмів дієвого контролю за поточною діяльністю владних суб'єктів на всіх рівнях суспільної ієрархії України й породжують їх безвідповідальність, свавілля, корупцію та інші прояви соціального паразитування, що й веде до занепаду нашу країну. Нації, які процвітають довели, що безальтернативною формою дієвого контролю за поточною діяльністю суб'єктів влади є врядування.

У світлі вище означеного цілком логічним і обґрунтованим є позиція:

«Для того, щоб Україна могла стати конкурентоспроможною та успішною країною за рівнем благополуччя свого народу й бути рівною серед країн-лідерів світової спільноти, їй конче необхідні конкурентоспроможні фахівці та справжня національна еліта, яка керується демократичними цінностями та державницьким світоглядом. Останнє, у свою чергу, актуалізує демократизацію соціального середовища вітчизняних закладів вищої освіти як передумов розвитку особистісного потенціалу суб'єктів його діяльності.

Врядування демократизує соціальне середовище, а демократизоване середовище, у свою чергу, сприяє ефективності врядування через запровадження його механізмів. Демократизація має слугувати засобом підвищення ефективності соціальної системи, яка проявляється в ії емерджентності. Системний вияв закладу вищої освіти як соціальної системи постає у результативності його діяльності, рівень якої визначально залежить від особистісного потенціалу ї̈ суб'єктів. Цим актуалізується адекватне визначення критеріїв результативності та ефективності діяльності ЗВО та управління нею.

Демократію розглядаємо як безальтернативну форму влаштування суспільних відносин, яка своєю чергою $€$ цивілізованою альтернативою авторитаризму. Історія світової цивілізації підтвердила, що демократичне соціальне середовище не лише найліпшим чином стримує прояви свавілля суб'єктів влади, а й створює найсприятливіші можливості для розвитку й самореалізації особистості у ньому, перш за все, завдяки свободі вибору та цивілізованій конкуренції. Демократичне середовище розкріпачує ініціативу, креативність особистості людини, пробуджує та виховує у ній соціальну відповідальність» 117.

На необхідності демократизації університетської діяльності та управління нею послідовно й наполегливо робиться наголос у документах, які започаткували й регламентують Болонський процес.

Зокрема, Велика хартія універсuтетів (Magna Charta Universitatum) серед основних принципів, якими мають керуватися університети, визначає наступне ${ }^{118}$ :

« ... дослідницька та викладацька діяльність має бути морально й інтелектуально незалежною від будьякої політичної й економічної влади»;

«Свобода в дослідницькій і викладацькій діяльності $є$ основним принципом університетського життя. Керівні органи й університети, кожний у межах своєї компетенції, повинні гарантувати дотримання цієї фундаментальної вимоги».

А серед способів, за допомогою яких мають реалізовуватися основні принципи університетської діяльності, Хартія визначила: «Кожен університет, з урахуванням конкретних обставин, має гарантувати своїм студентам дотримання свобод і умов, за яких вони могли б досягти своїх цілей у культурі й освіті» ${ }^{119}$.

\footnotetext{
117 Рябченко В. Аналіз з позицій світоглядно-компетентнісного підходу впливу соціального середовища на ефективне врядування в університетах України в умовах євроінтеграції. Аналіз провідного вітчизняного та зарубіжного досвіду розвитку щодо механізмів реалізації ефективного врядування в університетах: препринт (аналітичні матеріали) (частина II) / Авторський колектив: І. Драч, С. Калашнікова, О. Паламарчук, В. Рябченко, Л. Червона; за заг. ред. С. Калашнікової. Київ: Інститут вищої освіти НАПН України, 2019. C. 6. URL: https://ihed.org.ua/wp-content/uploads/2020/04/Analiz dosvidu vriaduvania $v$ univer ch2 analit IVO-2019-96p avtorskolektiv.pdf.

118 Велика хартія університетів (Magna Charta Universitatum). URL: http://www.edupolicy.org.ua/files/Magna Charta Universitatum.pdf 119 Велика хартія університетів (Magna Charta Universitatum). URL: http://www.edupolicy.org.ua/files/Magna Charta Universitatum.pdf
} 
У Комюніке конференції міністрів, відповідальних за вищу освіту (Бельгія, Льовен та Лювен-ля-Ньов, 28-29 квітня 2009 р.) визначено: «Ми залишаємося цілковито відданими цілям Європейського простору вищої освіти, який є простором, де вища освіта перебуває у сфері державної та суспільної відповідальності (public responsibility), і де усі інституції вищої освіти, крізь розмаїття своїх місій, відповідають на ширші потреби суспільства. Наша мета полягає у забезпеченні того, аби інституції вищої освіти мали потрібні ресурси для продовження реалізації повного спектру своїх цілей - підготування студентів до їхнього подальшого життя в якості активних громадян у демократичному суспільстві; створювання та підтримування широкої та найсучаснішої бази знань, а також стимулювання дослідницької діяльності та інноваційності. Впроваджувана нині необхідна реформа систем та політик вищої освіти продовжуватиме бути тісно пов'язаною із європейськими цінностями інституційної автономії, академічної свободи та соціальної справедливості, і вимагатиме повного залучення студентів та адміністрації до цих процесів» ${ }^{120}$.

У Будапештсько-Віденській декларації про створення Європейського простору вищої освіти (ЄПВО) зазначено: «Ми, Міністри, ще раз засвідчуємо прихильність до академічної свободи, так само як і до автономності та відповідальності вищих навчальних закладів, як принципів Європейського простору вищої освіти, і підкреслюємо роль вищих навчальних закладів, яку вони відіграють у зміцненні мирних демократичних суспільств і посиленні суспільної єдності» ${ }^{121}$.

У Паризькому комюніке, яке міністри підписали 25 травня 2018 року, зроблено застереження країнамучасницям Болонського процесу щодо неприпустимості нехтування базовими демократичними цінностями: «Академічна свобода і доброчесність, інституційна автономія, участь студентів і працівників у врядуванні вищої освіти та громадська відповідальність вищої освіти й за вищу освіту становлять основу ЄПвО. Спостерігаючи, як останніми роками деякі з цих фундаментальних цінностей заперечувалися в деяких з наших країн, ми рішуче беремо на себе обов'язок пропагувати й захищати їх у всьому ЄПвО через інтенсивний політичний діалог і співпрацю» ${ }^{122}$.

Це застереження особливо актуальне для нашого суспільства в цілому і для вищої освіти зокрема, оскільки авторитаризм домінує у ключових сферах діяльності суспільства й непогано почуває себе у вітчизняних закладах вищої освіти. Наразі ми апелюємо до критичної оцінки стану демократії у вищій освіті, яку зробив В. Бахрушин (голова Національної команди експертів з реформування вищої освіти ${ }^{123}$ ) у своїй публікації «Авторитаризм або хаос: куди рухатися вищій освіті?» 124: «Обвал економіки в 1990-х роках призвів до знищення зв'язків між вищими навчальними закладами і ринком праці, а відтак і до зникнення орієнтирів для оновлення змісту освіти і методів навчання. Іншим його наслідком стало суттєве зменшення фінансування і ресурсного забезпечення вищої освіти з боку держави. Сподівання на те, що це буде скомпенсоване підтримкою з боку недержавного сектора економіки, досі не виправдовуються. Як наслідок цих процесів, система вищої освіти почала працювати не на потреби суспільства, а сама на себе. Як говорять у техніці, вона зараз працює в режимі холостого ходу. Це призвело до істотного погіршення якості вищої освіти і поширення багатьох негативних явищ, зокрема, корупції, фальсифікації звітності та результатів досліджень, академічного плагіату, проявів так званого феодалізму у вищих навчальних закладах тощо. Ми маємо сьогодні відірвану від потреб суспільства, а іноді і від здорового глузду систему оцінювання закладів вищої освіти, науково-педагогічних працівників, здобувачів освіти. Ми маємо систему управління вищою освітою, функціонування якої через недосконалість законодавства значною мірою регулюється не Законами України і чинними нормативними документами, а домовленостями між учасниками процесу».

\footnotetext{
120 Комюніке конференції європейських міністрів вищої освіти, Льовен та Лювен-ля-Ньов, $28-29$ квітня 2009 року. URL: http://www.edupolicy.org.ua/files/Magna Charta Universitatum.pdf

121 Будапештсько-Віденська декларація про створення Європейського простору вищої освіти (12 березня 2010 року). URL: http://www.edupolicy.org.ua/files/Budapest-Vienna_Declaration(2010).pdf

122 Паризьке $\quad$ комюніке. $25 \quad$ травня 2018.

https://mon.gov.ua/storage/app/media/news/\%D0\%9D\%D0\%BE\%D0\%B2\%D0\%B8\%D0\%BD\%D0\%B8/2018/06/06/12/paris-

communiqueenua2018.pdf

123 Національна команда експертів з реформування вищої освіти 2019. URL: https://erasmusplus.org.ua/erasmus/ka3-pidtrymkareform/natsionalna-komanda-ekspertiv-here.html

124 Бахрушин В. Авторитаризм або хаос: куди рухатися вищій освіті? URL: http://education-ua.org/ru/articles/487-avtoritarizm-abo-khaoskudi-rukhatisya-vishchij-osviti
} 
У проєкті Cтратегії розвитку вищої освіти в Україні на 2021-2030 рр. акцентовано: «Узагальненою проблемою системи вищої освіти $€$ незатребуваність вищої освіти українським суспільством як інституту і головного ресурсу розвитку країни, що у поєднанні з масифікацією вищої освіти викликає спотворення освітнього процесу і незадовільні результати діяльності 3ВО» 125. 


\section{Постановка проблеми дослідження}

У країнах зі сталими демократіями і правовими державами на нинішньому етапі їх цивілізаційного розвитку врядування (як прийнятна й цілком органічна для них форма децентралізованого управління) використовується з метою підвищення результативності й ефективності діяльності соціальних систем. Це здійснюється завдяки створенню сприятливих умов для розвитку та реалізації особистісного потенціалу суб'єктів діяльності та раціонального використання ресурсів.

Для системи управління, яка сформувалася в сучасному українському суспільстві, врядування не $\epsilon$ прийнятним, оскільки воно суперечить діючій моделі, обмежуючи зловживання владою у приватних інтересах. Ця ключова суперечність гальмує, а то й зовсім блокує запровадження у вітчизняну практику механізмів врядування, які продемонстрували свою результативність та ефективність у західноєвропейських країнах. Така ситуація, у свою чергу, актуалізує необхідність формування умов соціального середовища, які б сприяли успішному запровадженню механізмів ефективного врядування.

Розв'язання означеної проблеми потребує адекватного теоретико-методологічного з'ясування сутності врядування і механізмів його реалізації та обґрунтування умов соціального середовища, за яких ця реалізація стає можливою.

За індивідуальною темою наукового дослідження на початку його першого етапу ${ }^{126}$ визначено об'єкт і предмет, що своїм форматом охоплюють контекст, в якому здійснюється управління університетською діяльністю і запроваджуються механізми врядування, а також сформульована робоча гіпотеза. Такий методологічний підхід зумовлений необхідністю адекватного визначення умов і можливостей запровадження ефективного врядування в університетах України. Адже університет хоча й є самодостатньою соціальною системою, але його діяльність й управління нею залежать від впливу соціального середовища, в контексті якого він функціонує. Тому, щоб дослідження проблем вдосконалення управління університетською діяльністю шляхом запровадження механізмів ефективного врядування було методологічно коректним, необхідно визначити та проаналізувати основні чинники соціального середовища, від яких залежить функціонування університету й управління ним.

Об'єктом дослідження окреслено соціальне середовище інституційного, суспільного, європейського та глобального форматів, від впливу чинників якого залежить діяльність університетів України.

Предметом дослідження визначено чинники впливу соціального середовища на управління в цілому та на механізми врядування, зокрема в університетах України.

Mema дослідження полягає у висвітленні світоглядно-компетентнісного аспекту впливу соціального середовища інституційного, суспільного, європейського та глобального рівнів на ефективне врядування в українських університетах.

\footnotetext{
126 Рябченко В. Теоретичні основи впливу соціального середовища на ефективне врядування в українських університетах: світогляднокомпетентнісний аспект. Аналіз провідного вітчизняного та зарубіжного досвіду щодо механізмів реалізації ефективного врядування в університетах: препринт (аналітичні матеріали) (частина I) / за заг. ред. С. Калашнікової. Київ: Інститут вищої освіти НАПН України, 2018. С. 7-8. URL: https://ihed.org.ua/wp-content/uploads/2019/09/Analiz dosvidu vriaduvania v univer ch1 analit IVO2018-147p avtors-kolektiv.pdf
} 
етоди дослідження. 3 метою забезпечення адекватності й достовірності наукових результатів використано сукупність необхідних для цього загальнонаукових, філософських і спеціальних методів дослідження, зокрема таких, як:

- діалектичний - для дослідження глобального, суспільного й інституційного процесів у їхньому розвитку та взаємозв'язку;

- індукція - для узагальнення на підставі очевидних фактів і ознак, які не потребують емпіричних доказів, тенденцій, що відбуваються в соціальній дійсності й достовірно репрезентують цивілізаційний, суспільний та інституційний процеси;

- дедукція - для переходу в дослідженні від загального до одиничного із загального;

- теоретичний аналіз різноманітних джерел (наукових публікацій, нормативно-правових документів, аналітичних оглядів тощо) - з метою визначення стану розробленості окресленої проблеми та окремих ї̈ аспектів;

- системний підхід і аналіз, синергетичний підхід - у розгляді університетів як відкритих систем, здатних до самоорганізації та самоврядування;

- термінологічний аналіз - для визначення основних базових понять дослідження, їх уточнення та конкретизації;

- порівняння, систематизація - з метою з'ясування різних поглядів на механізми реалізації ефективного врядування в університетах України;

- абстрагування та прогнозування - з метою визначення умов дослідження та формулювання гіпотези;

- моделювання - для розроблення моделей реалізації ефективного врядування в університетах України.

Гіпотезою дослідження передбачалося, що запровадження механізмів реалізації ефективного врядування в університетах України створить в їхньому середовищі сприятливі умови для розвитку особистісного потенціалу керівників, науково-педагогічних працівників і студентів, що в кінцевому підсумку має підвищити результативність й ефективність університетської діяльності та рівень їх конкурентоспроможності як у вітчизняному, так і в європейському соціальному просторі.

У цьому розділі переважно в концептуальній формі висвітлюються результати всіх трьох етапів наукового дослідження за індивідуальною темою автора, що дозволяє отримати цілісне уявлення про вплив соціального середовища на запровадження в ньому механізмів ефективного врядування. 
При теоретичному обґрунтуванні сутності врядування у вищій освіті бралися до уваги ієрархія соціальних систем і чинники причинно-наслідкового зв'язку, від яких залежне соціальне середовище закладів вищої освіти й те, на що воно реально впливає, а саме:

1. Соціальне середовище вітчизняних ЗВО знаходиться під безпосереднім впливом свого суспільства й опосередковано під впливом зовнішнього по відношенню до України цивілізаційного контексту. Цим зумовлюється проблема успішної імплементації кращих зарубіжних практик врядування в університетах України в умовах євроінтеграції: адже, чим менш українське суспільство за своїми ціннісними орієнтаціями та рівнем розвитку правової держави / демократії є відповідним суспільствам країн з усталеними демократіями і верховенством права (зокрема, західноєвропейських країн), тим складніше запроваджувати механізми врядування у ньому, у т. ч. у його закладах вищої освіти.

2. Врядування не замінює університетське управління, а є його частиною у найбільш демократичній формі. Чим дієвіше врядування, тим демократичніше управління, і навпаки.

3. Запровадження механізмів врядування в університетах України слід розглядати не як самоціль чи альтернативу управління їхньою діяльністю, а як засіб демократизації управління й соціального середовища університетів заради підвищення їх результативності та ефективності, а отже і конкурентоспроможності.

4. Інтегрованим критерієм результативності та ефективності діяльності університетів є якість вищої освіти (носіями якої є студенти) і компетентність випускників, яку ті репрезентують на ринках праці.

5. Управління університетською діяльністю здійснюється у контексті соціального середовища, а не над ним. Цим зумовлюється взаємозалежність між урядуванням та умовами й можливостями соціального середовища для його запровадження.

6. Механізми ефективного врядування не будуть реально працювати в тому соціальному середовищі, яке не забезпечує достатньої академічної свободи науково-педагогічним працівникам і здобувачам вищої освіти. Незалежність науково-педагогічних працівників і студентів від адміністрації у зайнятті ними конструктивної та принципової позиції у системі університетського врядування $€$ базовою передумовою його дієвості й результативності.

7. Принципи ефективного врядування як базові складові його механізмів можуть реально працювати лише у доброчесному соціальному середовищі, оскільки результативність внутрішньої системи забезпечення якості вищої освіти в кінцевому підсумку залежить не від нормативних документів, які їі регламентують і формалізують, а від совісті кожного із суб'єктів університетської діяльності. Досвід західноєвропейських університетів демонструє результативність і ефективність внутрішньої системи забезпечення якості вищої освіти саме завдяки тому, що вона базується на довірі до сумлінності суб'єктів університетської спільноти, яка не допускає суттєвих розходжень між тим, що виписано в нормативних документах цієї системи, і тим, що роблять реально ці суб'єкти.

На першому етапі дослідження акцентовано принципову в методологічному сенсі відмінність, яка полягає у тому, що врядування в західноєвропейських університетах (досвід якого ми вивчаємо та запроваджуємо в управління ЗВО України) здійснюється у країнах з усталеними демократіями і правовими державами. Тоді як вітчизняні ЗВО функціонують у суспільстві, де панує гібридний режим влади 127 олігархічного штибу, який прикривається демократичними інститутами як своєрідним «камуфляжом» у користуванні державою як своєю власністю. А про верховенство права в Україні залишається лишень мріяти: «В Україні, незважаючи на Євромайдан 2013 року, усе ще залишається пострадянська спадщина - слабке

\footnotetext{
127 Дарчук С. Демократичний рейтинг України дещо зріс, але перед нею стоять виклики в дотриманні демократії - Freedom House. 06 травня 2020. Радіо Свобода. Політика. URL: https://www.radiosvoboda.org/a/freedom-house-nations-in-transit/30594646.html
} 
верховенство права та високий рівень шахрайства. Судова влада, зокрема, традиційно сприймається як одна з найбільш корумпованих установ у країні. У червні 2016 року влада розпочала багаторічну реформу сектору правосуддя, було внесено поправки до Конституції України та прийнято нові закони. Незважаючи на ці спроби реформування, правозастосування залишається упередженим, а групи високопоставлених чиновників та багатих бізнесменів, здається, користуються низьким рівнем відповідальності та високим рівнем незаконних привілеїв. Зміни до сектору правосуддя планується запроваджувати поступово протягом наступних кількох років, тому до 2020 року суду присяжних не буде» ${ }^{128}$.

Проблема демократизації нашого суспільства ускладнюється ще й тим, що ми не маємо традицій власної державності у новітній історії українського народу: «Історія свідчить, що народ України впродовж віків так і не зміг сформуватися як цілісна спільнота в умовах відсутності демократії. Упродовж багатьох століть Україна поза демократією була немислима, і тільки в третьому тисячолітті, коли певного розвитку в усьому світі набули демократичні процеси, український народ отримав реальний шанс будувати свою власну країну на принципово інших демократичних засадах, відмінних навіть від тих, на яких здійснювалася демократизація державного будівництва й управління в багатьох країнах світу, в тому числі, в країнах Європи і в США. А це, безумовно, потребує розробки інноваційних підходів до теорії державного будівництва і формування стратегії демократичного розвитку нової держави - держави XXI ст.» ${ }^{129}$.

Як наслідок вище зазначеного стверджуємо: «Звідси постає концептуальна різниця в можливостях запровадження механізмів врядування в управління університетами в західноєвропейських країнах і в Україні. Якщо західноєвропейські університети запроваджують їх під впливом і навіть тиском своїх держав і транснаціональних компаній, які зацікавлені в тих чи інших результатах діяльності конкретних університетів, то українські 3ВО покликані запроваджувати врядування як засіб демократизації свого соціального середовища всупереч несприятливому для цього суспільному контексту. Й завдяки цьому ставати осередками та своєрідними розсадниками демократії. Тому, переймаючи суто університетський досвід, ми повинні аналізувати та фіксувати увагу на контексті, який посприяв демократизації університетського управління в західноєвропейських країнах. Саме на зміну суспільного контексту шляхом його демократизації мають бути зорієнтовані світоглядно здобувачі вищої освіти протягом перебування в соціальному середовищі вітчизняних 3ВО» ${ }^{130}$.

Справа в тому, що врядування у своїй сучасній модифікації як форма децентралізації та демократизації управління актуалізувалося спочатку в наддержавних утвореннях. Це було зумовлено ускладненням соціальних систем у результаті глобалізації земної цивілізації. Зокрема, першими потребу в децентралізації управління відчули транснаціональні компанії (ТНК), які розпростерли свою діяльність на різних континентах і у різних часових поясах. Централізоване управління в таких організаціях виявилося неефективним, оскільки блокувало своєчасне прийняття необхідних і невідкладних рішень у ситуаціях, що виникали у віддалених структурних підрозділах і потребували узгодження з керівництвом центрального офісу. Для розв'язання цієї проблеми ТНК перейшли від вертикальних структур управління до мережевих. Така зміна управління суттєво підвищила продуктивність та ефективність використання задіяних ресурсів, перш за все, людських і фінансових. Згодом парадигма децентралізації у формах врядування набула поширення в державному управлінні країн Західноєвропейської цивілізації, до яких належать США, Канада й Австралія (далі - країн Заходу). Західноєвропейські університети, досвід врядування яких ми вивчаємо й переймаємо, включилися у цей процес під впливом тренду децентралізації державного управління.

Вітчизняним же закладам вищої освіти, як було зазначено вище, належить у цьому сенсі випереджувати українське суспільство. Ця принципова відмінність потребує порівняльного аналізу стану демократії в Україні та їі закладах вищої освіти для того, щоб адекватно підходити до розв'язання проблеми врядування в нашому суспільстві. Такий порівняльний аналіз буде висвітлено в наступному підрозділі.

\footnotetext{
128 Нодія Г., Ченуша Д., Мінаков М. На шляху до демократії європейського зразка. Боротьба за належне врядування у Східній Європі. Центр європейських політичних досліджень (CEPS). Брюссель. 2018. С. 3-4.

129 Мартиненко В. Демократичне врядування: проблеми теорії і практики. Публічне управління. URL: http://www.kbuapa.kharkov.ua/ebook/putp/2010-1/doc/1/03.pdf

130 Рябченко В. Теоретичні основи впливу соціального середовища на ефективне врядування в українських університетах: світогляднокомпетентнісний аспект. Аналіз провідного вітчизняного та зарубінного досвіду щодо механізмів реалізації ефективного врядування в університетах: препринт (аналітичні матеріали) (частина I) / за заг. ред. С. Калашнікової. Київ: Інститут вищої освіти НАПН України, 2018. С. 13. URL: https://ihed.org.ua/wp-content/uploads/2019/09/Analiz dosvidu vriaduvania $v$ univer ch1 analit IVO2018-147p avtors-kolektiv.pdf
} 


\section{3'ясування генезису врядування та його сутності}

У межах цього пункту звернемо увагу на еволюцію новітнього врядування, що нині застосовується у країнах з усталеними демократіями і правовими державами та яке транслюється у вітчизняну теорію і практику.

Словосполучення «новітнє врядування» актуальне з позицій критичного сприйняття й аналізу його сутності, що транслюється у теоретичну і практичну свідомість, зокрема у публікаціях, які репрезентують його як сучасний соціальний винахід.

Насправді ж врядування як соціальний феномен і різновид управління та механізм демократії не $\epsilon$ новітнім винаходом: «Поняття «урядування» не нове. Воно так само давнє, як і людська цивілізація» ${ }^{131}$. Понад це, врядування як форма правління застосовувалася у первісних соціумах задовго до виникнення перших цивілізаційних утворень, одним із проявів яких стало відчуження влади та перетворення їі на владу-власність тих, хто займав керівні позиції у суспільній ієрархії. Саме з моменту привласнення влади в соціумі панівною верствою й актуалізується проблема його демократизації, отже запровадження механізмів врядування. Оскільки перші цивілізаційні утворення з'явилися приблизно десять тисяч років тому, то й проблема демократизації шляхом врядування для земної спільноти актуалізувалася саме тоді, а не наприкінці XX століття, як дехто акцентує це у своїх публікаціях.

3 історії відомо, що перші спроби подолати відчуження влади за допомогою врядування були зроблені в містах-державах Стародавньої Греції. Зокрема, Солон, дід Платона, будучи правителем Афін, перший зробив спробу започаткувати у них демократію. Справжній же розквіт демократії в Стародавніх Афінах відбувся за часів правління Перікла. Саме цей період іменують золотим віком демократії та вважають його взірцем влаштування суспільного життя. Хоча насправді підстав для такої міфологізованої ідеалізації тієї демократії немає. Адже хіба можна з позицій Загальної декларації прав людини ${ }^{132}$ вважати ідеальною демократію, за якої право голосу мала лишень приблизно восьма частка населення міста-держави так званих вільних громадян до того ж афінського походження. Тоді як жінки у т. ч. й дружини вільних громадян, а також мешканці неафінського походження й безумовно раби, які складали найчисельнішу верству населення полісу, такого права голосу в місцевому врядуванні були позбавлені. Як відомо, давньогрецька демократія в історичному вимірі проіснувала недовго. Вона поступилася авторитарним режимам влади, зокрема олігархії.

Після того як цей промінчик демократії згас, у цивілізаційних людських спільнотах протягом щонайменше двох тисячоліть поспіль суцільно панувала влада-власність. І лише в новітній історії світової цивілізації, починаючи зі Славетної революції (1688-1689рр.) у Великій Британії, як було раніше згадано, почали з'являтися проміні демократії. Тієї реальної демократії, яка почала витісняти від тотального панування владу-власність і долучати до врядування широкий загал тієї спільноти, у якій вона утверджувалася. Наразі Велика Британія стала однією з перших країн, у якій паростки демократії не лишень проросли, а й забуяли, поступово відтіснивши монархію від реальної до номінальної влади.

Протягом XIX і XX століть променів демократії у земній цивілізації суттєво побільшало. А чи зійшло повністю сонце демократії над земною спільнотою? Це питання поки що залишається відкритим, оскільки у більшості країн світу, у т. ч. із задекларованими конституційно демократичними республіками панує владавласність у різноманітних формах авторитарних режимів. На жаль, Україна теж належить до таких країн як за визначенням міжнародних експертів демократії, так і за реальним відчуттям та оцінкою ії громадян. Найбільше проміння цього метафоричного сонця у країнах з усталеними демократіями та правовими державами, населення якого відносять до так званого золотого мільярда всієї земної спільноти, загальна чисельність якої сягає понад 7,8 мільярдів осіб ${ }^{133}$. Тож 6,8 мільярдів мешканців земної цивілізації живуть у країнах, де панує влада-власність. Така влада свавільна, оскільки вона відчужена від народу, а тому не належить йому. Будь-які форми демократичного управління, зокрема врядування, чужорідні для влади-власності.

Тож витіснення врядування як демократичної форми управління у людських спільнотах і відчуження влади у них відбулося в цивілізаційний період, що пов'язано з осілим способом життя людських спільнот, виробленням ними додаткового продукту, який підлягав перерозподілу (редиструбуції) між членами соціуму, збільшенням чисельності соціумів, ускладненням їх структур, опосередкуванням соціальних зв'язків тощо:

\footnotetext{
131 Нодія Г., Ченуша Д., Мінаков М. На шляху до демократії європейського зразка. Боротьба за належне врядування у Східній Європі. Центр європейських політичних досліджень (CEPS). Брюссель. 2018. С. 3-4.

132 Загальна декларація прав людини. URL: // https://zakon.rada.gov.ua/laws/show/995 015

133 Чисельність населення Землі сягнула

млрд осіб.

URL:
}

https://lb.ua/world/2020/07/10/461598 chiselnist naselennya zemli syagnula.html 
«Виникнення й утвердження експлуататорських суспільств у світовій історії пов'язують з монополізацією ключових суспільних посад правлячою верхівкою, яка переймалася редистрибуцією додаткового продукту, виробленого членами цього соціуму (суспільства). Напевно, що на перших порах здобуття й закріплення влади у своїх руках як монопольної суспільної власності такий перерозподіл владною верхівкою здійснювався більшменш справедливо, коли пріоритетом було забезпечення загальносуспільних потреб, а задоволення власних потреб владними суб'єктами здійснювалось на паритетних засадах зі своїми одноплеменцями. Маючи уявлення про природу й сутність влади, погодьмось, що такий ідилічний стан суспільних відносин владних суб'єктів із рядовими громадянами не міг зберегтися в умовах монополізації влади, тобто за її повного відчуження від народу. Звідси постає феномен влади-власності, яка переймається влаштуванням престижного власного життя за рахунок загальносуспільних надбань» ${ }^{134}$.

Ось що з цього питання зазначає сучасний український дослідник історії світової цивілізації Ю. Павленко: «Сьогодні можна вважати твердо встановленим, що не поява приватної власності на засоби виробництва тягла за собою народження експлуатації й соціальної нерівності, а навпаки, ускладнення суспільної організації, пов'язане з посиленою диференціацією сфер діяльності, вело до ділення людей на дві основні групи: керуючих і керованих. Перші, які монополізують владу-власність на суспільні ресурси, організовуючи виробництво і перерозподіл матеріальних благ, концентрують у своїх руках додатковий продукт і витрачають його, в значній мірі, для престижних цілей. Суспільний розподіл праці веде до соціального розшарування, експлуатації та майнової нерівності» ${ }^{135}$. Генезис відчуження влади, що породжує такий соціальний феномен, як владавласність детальніше висвітлений автором у методичних рекомендаціях ${ }^{136}$.

Цей короткий екскурс в історію врядування не як теорії, а як суспільної практики першочергово адресується тим авторам сучасних і зовсім новітніх публікацій, в яких ця історія не береться до уваги, а принципи врядування транслюються як винахід останньої чверті XX століття. У таких публікаціях, як правило, автори обмежуються переповіданням переліку й змісту принципів врядування з одних і тих же джерел, не обтяжуючи при цьому себе власним осмисленням і тлумаченням сутності цих принципів та критичним аналізом можливостей їх запровадження в українській соціальній дійсності. Переповідання чужих думок без їх переосмислення не лише не поглиблює їх новими смислами, а навпаки, подрібнює їх зміст, а відповідно і смисл. А про віддалення від глибин смислу першоджерел через транслювання змісту неоригінальних текстів, вирваних з оригінальних контекстів, годі й мовити.

А щоб переконатись у глибині змісту й смислу першоджерел теорії врядування, до яких необхідно долучатись для розуміння сутності врядування, процитуємо Джона Стюарта Мілля - одного з фундаторів теорії лібералізму, в парадигмі якого відроджувалось і запроваджувалось врядування у країнах розвинутих демократій, досвід яких ми нині прагнемо запровадити в нашу соціальну дійсність.

Дж. Мілль ще понад півтора століття тому сформулював теоретичні положення врядування й обґрунтував умови, за наявності яких воно стає можливим:

«Добре врядування неможливе, коли кожен індивід переймається тільки власними егоїстичними інтересами, не концентруючи зусиль на своїй частці інтересів суспільства й ніяк на них не зважаючи. Немає потреби ілюструвати те, що брак належного рівня розумових здібностей погіршує функціонування всіх складових елементів доброго врядування, або ті, хто таких людей обирає, або ті, кому вони підзвітні, а також своєрідні наглядачі, чия думка має впливати на політичні процеси та контролювати їх, сповнені невігластва,

\footnotetext{
134 Рябченко В. І. Вища школа України в загальноцивілізаційному контексті: соціально-філософський аналіз з позицій світогляднокомпетентнісного підходу. $\quad$ K. $\quad$ : http://dglib.nubip.edu.ua:8080/bitstream/123456789/2770/1/monogr Visha shkola UA v zagalncivilizac konteksti Ryabchenko 2015 674s.pdf

135 Рябченко В. І. Вища школа України в загальноцивілізаційному контексті: соціально-філософський аналіз з позицій світогляднокомпетентнісного підходу. $\quad$ K. $\quad$ : http://dglib.nubip.edu.ua:8080/bitstream/123456789/2770/1/monogr Visha shkola UA v zagalncivilizac_konteksti_Ryabchenko_2015_674s.pdf

136 Рябченко В. Вплив соціального середовища на ефективне врядування в українських університетах: світоглядно-компетентнісний аспект. Механізми реалізації ефективного врядування в університетах України в умовах євроінтеграції : методичні рекомендації / І. Драч, С. Калашнікова, О. Паламарчук, В. Рябченко, Л. Червона; за ред. С.Калашнікової. Київ : Інститут вищої освіти НАПН України, 2019. C. 25-33. URL: https://ihed.org.ua/wp-content/uploads/2020/07/Mekhanizmy vriaduvania univ UA metodychni IVO-2019-93p avtorskolektiv.pdf
} 
глупоти і злісних упереджень, то врядування буде жахливим; натомість підвищуючи інтелектуальний рівень людей, дотичних до нього, також можна поліпшувати урядування, доводячи його аж до пункту досконалості, якої хоч і можна досяпи, та досі ще ніде не досягнуто. Досконале врядування здійснюють люди, яким притаманний найвищий ступінь чеснот і розуму та які працюють в атмосфері доброчесної та освіченої громадської думки.

Оскільки добре врядування передбачає, насамперед, чесноти й розум кожного члена суспільства, то найбільша досконалість, якої може набути будь-яка форма врядування, полягає у розвиткові чеснот і розуму самих людей. Перше запитання про будь-яку політичну інституцію має стосуватися того, якою мірою вона дбає про виховання у членів спільноти різноманітних моральних, інтелектуальних та діяльнісних рис. Урядування, що найкраще впорається з цим завданням, найімовірніше буде найкращим і в решті аспектів, оскільки саме від наявності цих рис залежить те, якою мірою його практичні заходи сприятимуть досягненню добра.

Тому одним із критеріїв доброго врядування можна вважати міру, якою воно культивує серед усіх своїх підданих та в кожній окремій людині позитивні риси: адже крім того, що добробут людей - єдина мета врядування, їхні позитивні риси становлять рушійну силу, завдяки якій функціонує державний механізм. Отже, тут підвищується якість самого механізму (ще одного складового елементу доброго врядування), тобто його здатність скористатися з наявних позитивних рис та примусити їх служити потрібній меті» ${ }^{137}$.

Погодьмось, що кожна з процитованих умов для здійснення доброго врядування не втратила своєї актуальності й нині та не втратить їі і в майбутньому. Нині це актуально не стільки в західних країнах усталеної демократії, як у нашому сучасному суспільстві, що знаходиться на початковому шляху розбудови демократії, який демократично-правові держави проходили щонайменше півтора століття тому, коли жив Дж. Мілль. Зазначені вимоги такого врядування надзвичайно актуальні для демократизації як нашого суспільства, так і соціального середовища вітчизняних закладів вищої освіти. Про те, що стан і перебіг української демократії мало чим відрізняється від того, що переживали західноєвропейські країни у XIX столітті засвідчує наступний текст Дж. Мілля:

«Якщо запитати, що є критерієм визначення якості врядування в усіх його аспектах - від найскромніших до найглобальніших, - то ми з'ясуємо, що критерій, який має найбільше значення та виходить за межі всіх інших, полягає у рисах, притаманних людям, які становлять суспільство і над яким здійснюється врядування.

Першим прикладом могла б служити сфера судочинства; цей приклад доволі доречний, оскільки не існує жодної іншої сфери державної діяльності, у якій такого важливого життєвого значення набув би суто механічний бік справи, тобто правила та механізми, що контролюють деталі процесу. Перш за все тут важливі риси задіяних людей. Чи будуть ефективними процедурні правила, призначені забезпечити мету правосуддя, якщо внаслідок низького морального рівня народу свідки, як правило, брешуть, а судді та їхні підлеглі беруть хабарі? । далі: яким чином інституції можуть добре муніципальне врядування, якщо до своїх функцій урядовці ставляться так байдуже, що тих, хто керував би чесно та вміло, неможливо заохотити виконувати ці обов'язки; натомість ці обов'язки віддано тим, хто, виконуючи їх, домагається утвердження власних інтересів? Яка користь від системи найширшого народного представництва, якщо виборці обирають до парламенту не найкращих, а тих, хто витратить більше грошей задля свого обрання? Як представницькі збори можуть давати користь, якщо їхніх членів можна купити або якщо внаслідок свого надмірного темпераменту, неприборканого громадянською дисципліною чи особистою стриманістю, вони не здатні спокійно обговорювати проблеми й під дахом парламенту вдаються до бійки чи стріляють один в одного з гвинтівок? як люди, такі сповнені заздрощів, що, коли хтось із них досягає в чомусь успіху, його колеги нишком чинять усе, аби він зазнав невдачі, можуть урядувати або взагалі співпрацювати бодай трохи ефективно?» ${ }^{138}$.

У цій короткій цитаті зосереджена стисла характеристика стану соціального середовища сучасного українського суспільства. Складається враження, що Дж. Мілль наш сучасник, який живе не десь далеко у Британії чи Франції, а серед нас і формулює свої теоретичні положення врядування, критично аналізуючи наш негативний досвід у розбудові демократії.

Те, що Дж. Мілль розпочав свій критичний аналіз зі сфери судочинства, не є випадковим, оскільки від судової влади першочергово залежить дотримання справедливості у суспільстві, що $є$ основою демократії в цілому і врядування зокрема. Саме криза судової влади, яка повинна у своєму здійсненні неухильно керуватись принципом справедливості та стояти на сторожі дотримання справедливості в суспільстві, $є$ однією з ключових і найболючіших проблем у розбудові демократично-правової держави в Україні, відсутність якої

\footnotetext{
137 Джон С. Мілль. Представницьке врядування. Демократія: Антологія. К.: Смолоскип, 2005. XXVIII. 1108 с.

138 Джон С. Мілль. Представницьке врядування. Демократія: Антологія. К.: Смолоскип, 2005. XXVIII. С. 417-418.
} 
блокує ї̈ успішний цивілізований розвиток. Усі, хто живе в сучасному українському суспільстві, достеменно знають, що проблема суддів полягає не стільки у недостатній їхній професійній грамотності, як у цінностях, якими вони керуються у здійсненні судочинства. В основі світоглядної компетентності суддів мають лежати цінності, що визначені кодексом суддівської етики ${ }^{139}$, які більшість з них добре знає, але не керується ними у своїй професійній діяльності.

А зараз з'ясуємо сутність врядування як соціального феномену за результатами критичного аналізу публікацій, який детально висвітлюється в аналітичних матеріалах першого етапу дослідження ${ }^{140}$. Нами проаналізовано публікації низки авторів (А. Ахмад ${ }^{141}$; Н. Грицяк ${ }^{142}$; А. Єзеров і Ю. Батан ${ }^{143}$; I. Білей ${ }^{144}$; В. Зозуля ${ }^{145}$; К. Козлов ${ }^{146}$; А. Колодій ${ }^{147}$; А. Колодій, М. Буник, П. Шевчук та ін. ${ }^{148}$; А. Красносільськка ${ }^{149}$; Г. Кухарева ${ }^{150}$; В. Мартиненко ${ }^{151}$; В. Толкованов ${ }^{152}$; О. Хмара ${ }^{153}$ та ін.), які доволі релевантно репрезентують зміст сучасного вітчизняного дискурсу з проблем врядування.

Аналіз вище зазначених публікацій, присвячених врядуванню виявив такі його різновиди, як: відкрите врядування, демократичне врядування, добре врядування, ефективне врядування, належне врядування, нове врядування, публічне врядування, розподілене врядування, чутливе врядування. 3 такого плюралізму першочергово постало питання не стільки стосовно того, що являє собою кожен із названих різновидів урядування, як того, що їх різнить між собою. А слідом логічно виникло питання щодо вибору того чи іншого різновиду врядування для впровадження в управління вітчизняними закладами вищої освіти.

Але спочатку необхідно було з'ясувати критерії, за якими можна розмежувати назви видів врядувань, що знаходяться у термінологічному обігові публікацій. Це, на наш погляд, є принциповим методологічним завданням, без вирішення якого дослідження стає некоректним за своєю невизначеністю:

«Така невизначеність постає, коли дослідники однакових предметів позначають їх різними термінами або навпаки, однаковим терміном називають різні за своїм змістом предмети. Наразі в зазначеному переліку термінів поняття врядування розрізняються між собою за прикметниками. Навіть поверховий логікосмисловий аналіз різновидів врядування виявляє певні смислові колізії не лише між прикметниками, за якими вони різняться між собою, а й за сутністю врядування як форми управління.

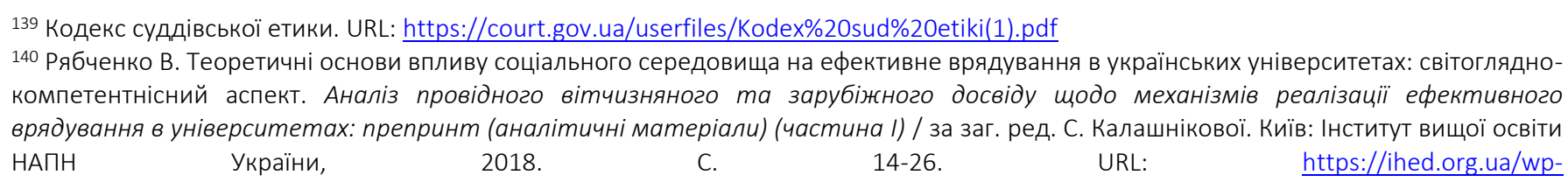
content/uploads/2019/09/Analiz dosvidu vriaduvania v univer ch1 analit IVO-2018-147p avtors-kolektiv.pdf

141 Алалі Ахмад. Ефективне врядування («Good Governance») у контексті розвитку сучасного політичного менеджменту. Вісник Львівського університету. Серія філос.-політол. студіі. 2018. Випуск 18. С. 245-250.

142 Грицяк Н.В. Демократичне врядування: політико-правові засади. Розвиток публічного адміністрування на засадах менеджменту: європейський контекст : матер. наук.-практ. конф., Дніпропетровськ, 15-16 трав. 2009 р. Дніпропетр.: ДРІДУ НАДУ, 2009. С. 37-38.

143 Єзеров А., Батан Ю. Належне врядування й надання адміністративних послуг органами місцевого самоврядування. Юридичний вісник. 2016. № 2. С. 109-116.

144 Белей І. Зарубіжний досвід демократичного врядування та можливості його застосування в українській практиці. Державне управління та місцеве самоврядування. Збірник наукових праць. Дніпропетровський регіональний інститут державного управління. 2010. Вип. 2(5). URL: http://www.dridu.dp.ua/vidavnictvo/2010/2010_02(5)/10bimzup.pdf

145 Зозуля В.О. Демократичне врядування: сутність, основні концепції, підходи. Вісник НАДУ при Президентові України (Серія «Державне управління»). 2017. № 3. C. 32-37. URL: file:///D:/documents/desktop/Врядування/Демократичне\%20врядування....pdf

146 Козлов К. Нове публічне врядування та спільне вироблення благ. Харківський національний університет радіоелектроніки. Науковий журнал «Новий колегіум». 2017. №2 . С. 30-32.

147 Колодій А. Концепція публічного (нового) врядування в ії застосуванні до демократичних і перехідних систем. «Демократичне врядування». Науковий вісник. 2012. Вип. 10. URL: http://nbuv.gov.ua/UJRN/DeVr_2012_10_3.

148 Публічна політика, публічне врядування й адміністрування: питання теорії, методології, практики: наук. розробка / авт. кол. : А. Ф. Колодій, М. З. Буник, П. І. Шевчук, та ін.. К.: НАДУ, 2015. 48 с.

149 Відкрите врядування в Україні: як це відбувається на практиці? Анастасія Красносільська, Український незалежний центр політичних досліджень. URL: https://ti-ukraine.org/wp-content/uploads/2016/11/zvit za rezultatamy doslidzhennya.pdf

150 Кухарева Г.П. Належне урядування як шлях до становлення дієвої системи публічного управління в Україні. C. 2. URL: http://www.kbuapa.kharkov.ua/e-book/tpdu/2015-3/doc/1/12.pdf

151 Мартиненко В. Демократичне врядування: проблеми теорії і практики. URL: http://www.kbuapa.kharkov.ua/e-book/putp/2010$1 / \mathrm{doc} / 1 / 03 . \mathrm{pdf}$

152 Толкованов В.В. Стандарти та принципи доброго врядування на місцевому і регіональному рівнях як загальноєвропейська цінність. Електронний журнал «Державне управління: удосконалення та розвиток». URL: http://www.dy.nayka.com.ua/?op=1\&z=565

153 Хмара О. Що робити, аби в Україні врядування насправді стало відкритим. Transparency International Україна, спеціально для УП. 01 квітня 2015. URL: https://www.pravda.com.ua/columns/2015/04/1/7063290/ 
Наприклад, виокремлення врядування прикметником «відкрите» вказує на те, що відкритість є тією особливою чи визначальною ознакою, яка відмежовує його від інших видів врядувань. Але ж відкритість, отже, прозорість є одним з базових принципів будь-якого врядування. Хіба може врядування бути закритим для спільноти, в соціальному середовищі якої воно запроваджується та здійснюється? Ні й ще раз ні. Далі із зазначеного переліку за такою ж логікою смислового аналізу ставимо під сумнів доцільність виділення в окремий вид демократичного врядування. Адже врядування апріорі демократичне, оскільки воно є однією з визначальних форм прояву демократії. Тому інші види врядування не можуть бути недемократичними за визначенням. А раз вони демократичні, тоді постає питання стосовно критеріїв, за якими одне з переліку різновидів врядувань виділяється як демократичне, а інші ні. Добре врядування, напевно ж має бути не лише відкритим, демократичним, але й ефективним, належним, завжди повинно відповідати новим умовам та вимогам і, безумовно, бути публічним і т. д. " ${ }^{154}$

Виявлені попередньо смислові суперечності у термінах врядування потребували поглибленого аналізу публікацій, в яких даються визначення цих термінів та робляться певні інтерпретації їх сутності. 3 цією метою здійснений поглиблений логіко-смисловий аналіз визначень цих термінів та інтерпретацій їх смислу у названих публікаціях. У результаті аналізу зроблений наступний методологічний висновок:

«Цитовані публікації репрезентують трансляцію у вітчизняний дискурс результатів досліджень досвіду врядування в країнах розвинених демократій, які проводились протягом останніх двох десятиліть. Проведений аналіз цих публікацій показав термінологічну невизначеність у предметному полі проблематики врядування. Це $€$ концептуальною методологічною перешкодою у розвитку як теорії, так і практики врядування. Підтвердженням такої перешкоди в розробці теорії врядування є власне сам термінологічний дискурс з цієї проблематики, який розтягнувся на два десятиліття й дотепер не припиняється. При зануренні в тексти як процитованих, так й інших публікацій, присвячених врядуванню, мимоволі кидається в очі те, що їх зміст не виходить за межі термінологічного дискурсу. Вже після третьої прочитаної публікації закралось враження ходіння по колу, яке мірою заглиблення в тексти інших публікацій не лише не зникло, а навпаки, утвердилось. Такий термінологічний дискурс, який нікуди не рухається, асоціюється з товченням води в ступі. Адже зі змісту публікації цілком очевидно, що дискусія з проблематики врядування точиться не навколо з'ясування його сутності, а застряла в прикметниках, якими його позначають.

Логіка підказує, щоб вийти із замкненого кола такої неконструктивної термінологічної дискусії, необхідно відмовитись від цих прикметників, обмежившись простим терміном, а саме, «врядуванням» , який необтяжений ніякими додатковими визначниками. Якщо така пропозиція видається надзвичайно категоричною, можливий компромісний варіант, як то часто допускається в науковій термінології, коли якийсь усталений термін уточняється додатковим визначником. Але в цьому разі автор, який запобігає до такого термінологічного словосполучення, має логічно обґрунтувати або пояснити смисл свого уточнення, запобігши цим неоднозначному розумінню і тлумаченню сутності того, що позначається обраним ним терміном. Коли ж автор публікації не обтяжує себе такими уточненнями або взагалі використовує довільно декілька термінів, позначаючи ними одне й теж, це збиває з пантелику» ${ }^{155}$.

Така термінологічна невизначеність у позначенні врядування спонукала заглибитися в аналіз сутності врядування, апелюючи до його визначальних принципів, ознак, властивостей. У переважній більшості публікацій, які присвяченні різним за прикметниками видам врядувань, автори, визначаючі базові принципи врядування, посилаються на Білу Книгу «Європейське врядування»: «Ця Біла Книга виділяє п'ять принципів ефективного врядування: відкритість, участь, підзвітність, ефективність та злагодженість. Кожен принцип $є$ важливим для більш демократичного врядування. Вони підтримують демократію та принцип верховенства

\footnotetext{
154 Рябченко В. Теоретичні основи впливу соціального середовища на ефективне врядування в українських університетах: світогляднокомпетентнісний аспект. Аналіз провідного вітчизняного та зарубіжного досвіду щодо механізмів реалізації ефективного врядування в університетах: препринт (аналітичні матеріали) (частина I) / за заг. ред. С. Калашнікової. Київ: Інститут вищої освіти HАПН України, 2018. С. 19. URL: https://ihed.org.ua/wp-content/uploads/2019/09/Analiz_dosvidu_vriaduvania_v_univer_ch1_analit_IVO2018-147p avtors-kolektiv.pdf

155 Рябченко В. Теоретичні основи впливу соціального середовища на ефективне врядування в українських університетах: світогляднокомпетентнісний аспект. Аналіз провідного вітчизняного та зарубіжного досвіду щодо механізмів реалізації ефективного врядування в університетах: препринт (аналітичні матеріали) (частина I) / за заг. ред. С. Калашнікової. Київ: Інститут вищої освіти HАПН України, 2018. С. 26. URL: https://ihed.org.ua/wp-content/uploads/2019/09/Analiz dosvidu vriaduvania v univer ch1 analit IVO2018-147p avtors-kolektiv.pdf
} 
права у державах-членах ЄС, але можуть бути застосовані на усіх рівнях влади - світовому, Європейському, національному, регіональному і місцевому» 156.

У попередніх публікаціях ми коротко презентували сутність визначених Європейським Союзом принципів ефективного врядування:

«1) Відкритість націлює на те, щоб усі інституції працювали прозоро, що стосується й закладів вищої освіти на їхньому інституційному рівні. Це $є$ основоположним принципом врядування, оскільки будь-яка закритість у його здійсненні підриватиме довіру до нього. А без довіри з боку співучасників соціального середовища, в якому запроваджується врядування, воно не зможе бути ефективним. Понад це, без відкритості врядування як таке взагалі не зможе відбутися. Саме за критерієм відкритості, прозорості у своєму здійсненні врядування сприймається як альтернатива закритості, ізольованості, відчуженості недемократичних форм влади й управління як їі прояву, від яких потерпає українське суспільство.

2) Участь передбачає залучення якомога ширшого кола осіб в соціальному середовищі до врядування у ньому. Участь залучає до співпраці у врядуванні, спонукає до пробудження соціальної активності його суб'єктів, прояву ініціативи й відповідальності з їхнього боку. Це сприяє розвитку особистісного потенціалу суб'єктів врядування, формуванню у них здатності до прояву активної та принципової громадянської позиції. А в кінцевому підсумку чим вища активність співучасників діяльності закладу вищої освіти та чим більше ініціативи й відповідальності, тим результативнішим й ефективнішим буде такий 3 ВО.

3) Підзвітність виховує у суб'єктів врядування соціальну відповідальність і застерігає їх від можливих зловживань у користуванні владою. Це саме те, чого так бракує в українському суспільстві на всіх рівнях його соціальної ієрархії. Підзвітність безпосередньо корелює з відкритістю та прозорістю здійснення врядування.

4) Ефективність логічно розглядати як інтегрований критерій врядування. Адже врядування не $\epsilon$ самоціллю. Тому, коли діяльність, яку забезпечує врядування, не стає чи перестає бути ефективною, то воно втрачає свій сенс.

5) Злагодженість передбачає цілеспрямовану відповідно до критеріїв ефективності узгоджену в часі й просторі взаємодію усіх складових врядування.

Названі п'ять принципів, є всі підстави вважати атрибутами врядування, оскільки воно без їх дотримання в соціальному середовищі унеможливлюється. 3 цього твердження виходить, що цими принципами керувались завжди всі людські спільноти, в яких було врядування, протягом соціальної еволюції людства, починаючи з глибин його первісності доісторичного періоду розвитку. Ці принципи влаштування суспільного життя лежать у підвалинах первісної моралі й природного права, якими унормовувалось життя первісних людських спільнот, у яких влада не була відчуженою. Усвідомлюючи глибинний зміст кожного з цих принципів, неважко уявити проблеми, які могли виникати в первісних соціумах у разі порушення хоча б одного з цих принципів.

Наприклад, неефективне врядування у первісній спільноті людей прирікало цю спільноту, як мінімум, на сутужне життя, а як максимум, на загибель. Без злагоджених дій у будь-якій спільноті, а не лише первісній, неможливо досягти ефективної результативності в їі діяльності. Порушення принципу відкритості кимось із членів первісних соціумів навіть важко уявити, оскільки життя кожного з них цілодобово проходило у всіх на виду. Й зовсім неважко уявити неминучу відповідальність, до якої у первісній спільноті притягували тих, хто порушував цей принцип. Неухильне дотримання принципу підзвітності було зумовлено все тією ж відкритістю життя кожного з членів спільноти. В таких умовах первісного соціального цілого, відособлення індивіда від одноплеменців супроводжувалось його відторгненням з боку спільноти. За межами такого соціального цілого індивід у первісних умовах самостійно не міг вижити. Тому порушення принципів відкритості, участі й підзвітності в первісних соціумах актуалізували перед тим, у кого виникав намір їх зробити, вибір між життям і смертю. Тож у первісних соціумах непереливки було тому, хто брехав, ледарював, хитрував, чинив несправедливість. Таким чином природне почуття справедливості в людини формувалось і закріплювалось генетично на рівні підсвідомості десятками тисяч років соціальної еволюції людського роду як основоположний принцип і запорука його виживання та продовження» ${ }^{157}$.

\footnotetext{
156 Європейське врядування. Біла книга. Брюссель. 2001. С. 11-12. URL: http://brdo.com.ua/wp-content/uploads/2016/01/Bila-knygaYEvropey-ske-vryaduvannya.pdf

157 Рябченко В. Теоретичні основи впливу соціального середовища на ефективне врядування в українських університетах: світогляднокомпетентнісний аспект. Аналіз провідного вітчизняного та зарубіжного досвіду щодо механізмів реалізації ефективного врядування в університетах: препринт (аналітичні матеріали) (частина I) / за заг. ред. С. Калашнікової. Київ: Інститут вищої освіти HАПН України, 2018. С. 27. URL: https://ihed.org.ua/wp-content/uploads/2019/09/Analiz dosvidu vriaduvania v univer ch1 analit IVO2018-147p avtors-kolektiv.pdf
} 
У 2007 році у Валенсії Конференція європейських міністрів, які відповідають за місцеве врядування, схвалила Європейську стратегію інновацій і врядування на місцевому рівні. Цією Стратегією визначено 12 принципів, якими має неухильно керуватись місцеве врядування:

«Мета Стратегії - мобілізувати та стимулювати діяльність національних та місцевих зацікавлених сторін таким чином, щоб громадяни в усіх країнах Європи могли отримати переваги від доброго демократичного управління на місцевому рівні через постійне підвищення якості послуг на місцевому рівні, залучення населення та впровадження політики, спрямованої на реалізацію їх законних інтересів.

Для досягнення цієї мети Стратегія має наступні три завдання:

1. Громадяни - в центрі всіх демократичних інститутів та процесів;

2. Органи місцевого самоврядування постійно покращують управління за 12-ма принципами, викладеними нижче;

3. Держави (або регіональні влади, залежно від інституційного устрою держав-членів) створюють та підтримують інституційні передумови для вдосконалення управління на місцевому рівні, виходячи при цьому з їхніх чинних зобов'язань стосовно Європейської хартії місцевого самоврядування та інших стандартів Ради Європи» 158 .

Принципи доброго врядування, визначені у Стратегії, є наступними:

«1. Участь. Прийняття рішень, чесні вибори на місцевому рівні.

2. Зворотний зв'язок. Послуги відповідають очікуванням і потребам громадян.

3. Результативність та ефективність. Наявні ресурси використовуються найкращим чином.

4. Прозорість та відкритість. Доступ до публічної інформації.

5. Верховенство закону. Місцева влада поважає закон та рішення суду.

6. Етична поведінка. Місцева влада діє в інтересах громади й бореться з корупцією.

7. Компетентність та спроможність. Місцева влада постійно покращує навички та методи роботи.

8. Новаторство та відкритість до змін.

9. Сталий розвиток. Місцева влада враховує потреби наступних поколінь.

10. Добре управління фінансами. Міжмуніципальна співпраця.

11. Місцева влада поважає права людини та культурне різноманіття.

12. Підзвітність. Місцева влада відповідає за свої рішення» ${ }^{159}$.

Як бачимо, у цей перелік включено чотири з п'яти принципів, які були попередньо виділені Білою Книгою «Європейське врядування» ${ }^{160}$. Зовсім нелогічно відсутній / не згаданий у цьому переліку принцип злагодженості, якого неодмінно повинно дотримуватись управління, щоб бути результативним та ефективним, а тим паче врядування як найменш централізована форма управління. Відома закономірність управління - чим воно більш централізоване, тим легше досягається злагодженість функціонування системи (наприклад, військова організація). А при децентралізації управління, навпаки, посилюється проблема злагодженості між елементами системи.

Спільноти закладів вищої освіти, особливо провідних університетів, що мають відокремлені містечка й розгалужену інфраструктуру, $€$ всі підстави відносити до місцевих самоврядних громад, які за своєю соціальною структурою і специфікою діяльності та функціонування $є$ значно складнішими в управлінні ніж, наприклад, нинішні укрупнені сільські громади. Тому цими принципами має керуватись й університетське управління.

C. Калашнікова і К. Жданова, спираючись на відповідні положення широкого спектру міжнародних нормативно-правових документів, що регламентують вищу освіту та орієнтують на демократизацію управління в ній шляхом запровадження механізмів ефективного врядування, а також на підставі аналізу публікацій зарубіжних авторів, в яких висвітлюються дослідження проблематики врядування дійшли таких висновків:

«1. Врядування $€$ наступним еволюційним етапом у розвитку моделей соціального управління, що відповідає викликам і потребам сучасного суспільства.

\footnotetext{
158 Вивчаємо Стратегію доброго врядування разом! Громадська організація «Філософія серия». URL: http://fs.edukit.vn.ua/news/id/327/vn

159 Добре демократичне врядування на місцевому рівні. Centre of expertise forlokal government reformCouncil of Europe. URL: https://www.youtube.com/watch?v=75RCUFtSMRw

160 Європейське врядування. Біла книга. Брюссель. 2001. С. 11-12. URL: http://brdo.com.ua/wp-content/uploads/2016/01/Bila-knygaYEvropey-ske-vryaduvannya.pdf
} 
2. Врядування вищою освітою:

- $є$ багаторівневим і багатовимірним процесом;

- здійснюється за участі багатьох акторів;

- базується на принципах партнерства, відкритості, відповідальності та лідерства.

3. Складовими врядування у вищій освіті $є$ структури та процеси, за допомогою яких зреалізовується багатогранна місія сучасного університету. Вирізняють зовнішнє врядування (структури та процеси поза університетом) і внутрішнє врядування (структури та процеси в університеті).

4 Ефективне врядування вищою освітою передбачає застосування результат-орієнтованого та компетентнісного підходів і забезпечення професіоналізації управління.

5. Ознайомлення з досвідом врядування систем управління вищою освітою країн Європи та існуючими моделями врядування вищою освітою зарубіжних країн $€$ необхідною передумовою визначення теоретикометодологічних основ для розроблення вітчизняної моделі врядування вищою освітою. Запровадження моделі врядування у вищу освіту України потребує реалізації відповідних заходів на законодавчому та організаційному рівнях, а також відповідну підготовку всіх учасників цього процесу» 161.

Для подолання термінологічної суперечливості, пропонуємо зупинитись на терміні «врядування». У нашому науковому дослідженні керуємось наступним визначенням цього терміну:

«Врядування - це демократична форма соціального управління, яке базується на принципах відкритості, відповідальності, партнерства, порядності, справедливості та розподіленого лідерства».

Словосполучення «ефективне врядування», яке присутнє в темі наукового дослідження та уживається в тексті автором, слід сприймати й тлумачити не як окремий різновид врядування, а як врядування, що спрямоване на забезпечення ефективної діяльності закладів вищої освіти. Оскільки на всіх рівнях суспільного управління домінантне положення займають особи з вищою освітою, тому інтегрованим критерієм результативності та ефективності університетської діяльності логічно вважати розвиток особистісного потенціалу здобувачів вищої освіти.

161 Калашнікова С.А., Жданова К.О. Врядування у вищій освіті: сутність, виміри, тенденції. Вища освіта України. 2013. №3 (дод. 2). Тематичний випуск «Європейська інтеграція вищої освіти України в контексті Болонського процесу». С. 73. 
Перш ніж обгрунтувати вплив будь-якого соціального середовища, а не лише закладу вищої освіти, необхідне адекватне розуміння сутності того, на що це середовище впливає. Наразі маємо на увазі «механізми врядування» як ключове словосполучення у темі нашого наукового дослідження. Сутність поняття «врядування» була висвітлена вище. Нижче з'ясуємо сутність механізму. Оскільки ми досліджуємо механізми, які діють у соціальному середовищі, це дає підстави визначити механізми врядування як різновиди соціальних механізмів.

Спочатку розглянемо дефініцію поняття «механізм соціальний». Зокрема в соціології знаходимо наступне визначення: «Механізм соціальний - сукупність дій, вчинків, відносин, невід'ємних від їх суб'єктів носіїв, завдяки яким відбувається те чи інше соціальне явище, здійснюється соціальний процес, і які становлять внутрішній каркас їх (явища, процесу) існування (функціонування) або перетворення. Структура М. с. складається з таких чинників (елементів), як субстрат дії чи процесу (суб'єкт - носій) у вигляді окремих індивідів чи спільнот; взаємодія індивідів і спільнот у межах певної діяльності чи певного процесу в об'єктивно (спонтанно) чи свідомо заданому напрямі; способи і засоби дій індивідів і спільнот, за допомогою яких здійснюється соціальний процес або сукупна діяльність. Останній чинник поєднує в собі систему набутих норм і цінностей, організацію (як діяльність і стан), а також соціальні ін-ти. Інтегруючим, структуро-утворювальним елементом М. с. є взаємодія соціальних суб'єктів, до якої залучаються всі інші його елементи й чинники мотивація поведінки, правові й моральні норми, політ, переконання, соціальний статус і соціальна позиція, організаційно-управлінські дії, інституціальні засоби» ${ }^{162}$.

3 такого академічного широкоформатного багатоаспектного визначення складно чітко визначити сутність соціального механізму. Тож виникає потреба у простішому визначенні та поясненні сутності цього соціального феномену. У спрощеному визначенні механізм можна розглядати як системне утворення із взаємопов'язаних між собою чинників, яке своїм емерджентним виявом забезпечує здійснення певної діяльності та ії результативності й ефективності. Сам термін за своєю етимологією має технічне походження. Але він широко використовується у соціально-гуманітарному лексиконі. Наскільки він $є$ доречним у тому чи іншому контексті, залежить від того, хто його вживає і який смисл у цей термін вкладає. Якщо цей смисл корелює позитивно зі смислом контексту, тоді застосування терміну «механізм» доречне. Коли ж навпаки, то недоречне. Власне така логіка доречності використання притаманна будь-яким іншим термінам, що включаються в тексти і не лише у наукові.

Зважаючи на походження терміну «механізм», унаочнити його сутність легше на прикладах технічних, аніж соціальних механізмів. Але перед цим зробимо деякі теоретичні уточнення ключового словосполучення у запропонованій спрощеній дефініції, зокрема «системне утворення», що рівнозначно терміну «система». Апелюємо при цьому до загальновідомих визначальних ознак системи:

1. Цілісність, коли ми можемо бачити в об'єкті, який уважаємо чи сприймаємо як систему, деяке ціле. Це необхідна ознака, але її однієї недостатньо, щоб зробити висновок про наявність системи.

2. Наявність складових елементів чи компонентів цієї цілісності теж $\epsilon$ необхідною ознакою, за якою визначається система, але цього недостатньо, коли між елементами не буде виявлено взаємозв'язків, що $\epsilon$ критерієм неприналежності до даної цілісності.

3. Наявність взаємозв'язків між виявленими елементами цілісності. Але, щоб переконатись в тому, що ці взаємозв'язки є системними, треба виявити наступну ознаку цілісності.

4. Вплив, зміна стану одного чи декількох елементів цілісності призводить до зміни стану інших елементів, які з ними пов'язані в межах виявленої цілісності. Навіть наявність усіх чотирьох названих ознак не дасть підстав певну цілісність розглядати як систему, коли не буде виявлено інтегральної властивості системи.

5. Емерджентність і $€$ тією ознакою, яка свідчить про наявність системи, коли цілісність набуває такої властивості, прояв якої не можливо забезпечити будь-яким окремим складовим компонентом, чи простою сумою властивостей усіх елементів, що до неї входять.

\footnotetext{
162 Соціологія: короткий енциклопедичний словник /уклад.: В.І. Волович, В.І. Тарасенко, М.В. Захаренко та ін.; під заг. ред. В.І. Воловича. К.: Укр. Центр духовн. Культури, 1998. С.320.
} 
Технічні системи жорстко зумовлені й детерміновані наявністю необхідних елементів та взаємозв'язками між ними. Тому вони миттєво реагують на відсутність чи вихід з ладу будь-якого необхідного для функціонування елемента, а також на втрату взаємозв'язку між ними.

Соціальні системи на відміну від технічних не мають такої жорсткої зумовленості й детермінованості своїми елементами та взаємозв'язками між ними. Їм у цьому сенсі притаманна певна стохастичність, надзвичайна пластичність, здатність до самовідновлення, що в кінцевому підсумку зберігає їх спроможність до функціонування навіть тоді, коли в них руйнуються окремі елементи чи деформуються або зовсім пропадають деякі системні взаємозв'язки. При цьому залишаємо відкритим питання щодо результативності та ефективності функціонування таких внутрішньо деформованих соціальних систем.

Власне цією принциповою відмінністю властивостей технічних і соціальних систем зумовлюється різниця у поводженні людини з цими системами і вимогах до їі компетентності у цьому сенсі.

Оскільки технічні системи безпосередньо детерміновані своєю структурою та умовами, в яких вони можуть функціонувати, то будь-яке некомпетентне поводження з ними стає очевидним відразу. Звідси постають підвищенні вимоги до компетентності тих, хто конструює та експлуатує технічні системи. При цьому мірою ускладнення технічної системи підвищується рівень вимог до суб'єктів їх створення та використання. Шанобливе ставлення до компетентності у поводженні з технічними системами базується на інстинкті самозбереження людини і неминучості відповідальності за наслідки некомпетентності.

На тлі високих вимог, що слугують підставою для формального допуску до управління технічними системами, парадоксальною виглядає ситуація з вимогами до компетентності суб'єктів, які беруться за управління соціальними системами. Сутність цього парадоксу полягає у тому, що соціальні системи значно складніші за будь-які природні та штучно створені системи. Це зумовлено тим, що визначальним елементом соціальних систем $є$ людина як біо-психо-соціальна система, яка сама по собі $є$ найскладнішою від усіх інших систем. Окрім людей соціальні системи включають у себе інші системи живої та неживої природи, у т. ч. технічні. Однією з визначальних ознак вищої складності соціальних систем, як було вже зазначено, є їхня стохастичність, що зумовлює невизначеність у їх функціонуванні й цим самим знижує можливості визначення та прогнозування їх наступного стану. Наприклад, два колеги-астрономи, що працюють пліч-о-пліч, спостерігають за небесною механікою, яка вочевидь складніша за земну. Вони можуть з високою достовірністю вирахувати на сотні й тисячі років вперед, де буде знаходитися те чи інше небесне тіло. Але вони позбавлені можливості зробити достовірний прогноз щодо того, якими будуть їх міжособистісні відносини у найближчий рік і далі.

Щоб отримати допуск до управління транспортним засобом, необхідно мати права водія відповідної категорії, що юридично засвідчують достатню для цього компетентність. Той, хто має права на водіння легковим автомобілем, не допускається до управління пасажирським автотранспортом, якщо в нього на це немає прав відповідної категорії та необхідного водійського досвіду. А в соціальних системах можуть ставати керівниками особи, які не мають для цього необхідної компетентності й достатнього досвіду. Зокрема в нашому суспільстві ця парадоксальна тенденція набула системного характеру, починаючи з його найвищих ієрархічних рівнів і завершуючи керівниками низового рівня. В сучасному українському суспільстві можуть ставати керівниками галузей вчорашні студенти, особи без відповідної галузі професійної досвіду й досвіду роботи в ній. Наслідком такої некомпетентності, як правило, стає подальша криза галузі / організації.

В умовах техногенної цивілізації формальним пропуском у «соціальні ліфти», отже до зайняття посад у соціальних системах $є$ диплом про вищу освіту. В суспільствах з цивілізованим конкурентним середовищем, що є у країнах з усталеними демократіями і правовими державами, за формальної наявності такого диплому в претендента на зайняття посади вимагається необхідна для цього компетентність. Тож у цивілізованому конкурентному середовищі шанується реальна компетентність. У такому середовищі малоймовірне потрапляння на посади випадкових осіб, як то суцільно спостерігається в Україні, що є наслідком відсутності у неї реальної демократії та правової держави.

Саме дієві механізми врядування є тими противагами, які здатні стримувати владних суб'єктів від свавільних рішень, суб'єктивізму й упередженості у підборі й розстановці кадрів тощо. Якраз відсутність дієвого врядуванні в Україні й дозволяє протекціонізм некомпетентності, який здійснює соціальну селекцію навиворіт. Залежність конкурентоспроможності України та ії закладів вищої освіти від рівня розвитку демократії аналізується в наступному підрозділі. 
У цьому ж контексті зробимо інтерпретацію сутності механізмів врядування та розглянемо на теоретичному рівні значущі чинники впливу соціального середовища зво на іх запровадження, дієвість, результативність та ефективність. При цьому зіпремось на визначення терміну «механізм соціальний» (М. с.) і апелюємо для предметного унаочнення до сутності технічних механізмів, яку ми щойно розглянули.

Для кращого сприйняття і розуміння структуруємо процитоване вище академічне визначення терміну «механізм соціальний» на окремі смислові складові, зокрема:

- суб'єкт (у вигляді окремих індивідів чи спільнот) дії чи процесу;

- взаємодія індивідів і спільнот у межах певної діяльності чи певного процесу в об'єктивно (спонтанно) чи свідомо заданому напрямі;

- способи і засоби дій індивідів і спільнот, за допомогою яких здійснюється соціальний процес або сукупна діяльність. Цей чинник поєднує у собі систему набутих норм і цінностей, організацію (як діяльність і стан), а також соціальні інститути.

Розвиваючи далі запропонований підхід, звернемося до твердження: «Інтегруючим, структуроутворювальним елементом М. с. є взаємодія соціальних суб'єктів, до якої залучаються всі інші його елементи й чинники - мотивація поведінки, правові й моральні норми, політ, переконання, соціальний статус і соціальна позиція, організаційно-управлінські дії, інституціальні засоби» 163.

Аналітичний погляд через запропоновану структуру як своєрідну теоретичну матрицю на врядування як таке дозволяє у загальному вигляді збагнути основні чинники його механізмів, зокрема:

- суб'єкти врядування, здатні для його ефективної реалізації шляхом злагодженої та результативної взаємодії, керуючись нормами моралі та права, іншими цінностями, мотивацією, що не суперечать принципам, завданням і цілям врядування;

- принципи врядування;

- цілі й завдання врядування.

Таким чином, механізми врядування будуть дієвими, результативними та ефективними, коли його суб'єкти будуть здатними для його реалізації шляхом злагодженої та результативної взаємодії, керуючись при цьому мораллю та іншими доброчесностями і мотиваціями, що не суперечать принципам врядування і дозволяють виконати необхідні завдання, щоб досягти його цілей.

На підставі розглянутих положень, запобігаючи до спрощеного варіанту дефініції терміну «механізм», зробимо визначення механізму врядування у наступній редакції: «Механізм врядування - це система чинників, яка здатна забезпечити результативне й ефективне врядування у відповідності до його принципів і цілей».

3 огляду на те, що механізм - це система, маємо пам'ятати, що діючими механізми врядування будуть лишень за умови збереження всіх властивостей їх як системи. Це означає, що відсутність чи недієвість будь-якого чинника як необхідного системного елемента цього механізму, як мінімум, робить врядування неефективним, а як максимум, позбавляє його дієвості за аналогією з технічним механізмом. Дієвість механізмів врядування, їх результативність та ефективність залежить від соціального середовища, в якому вони реалізуються. Усвідомлення цієї базової умови $€$ відправним методологічним моментом як у дослідженнях соціальних механізмів, так і в практичній їх реалізації. Нехтування впливом соціального середовища на соціальні механізми прирікає на неадекватність як їх теорію, так і практику.

Ідеальних соціальних середовищ не буває, навіть на мікрорівнях в установах, організаціях, місцевих соціумах, не говорячи вже за формат суспільства. Але попри всі можливі негаразди в тому ж людському вимірі бувають соціальні середовища, у яких комфортно перебувати, а у яких зовсім кепсько. Так і соціальне середовище одного закладу вищої освіти може сприятливо впливати на запровадження в ньому механізмів врядування, де вони будуть ефективними у покращенні результатів діяльності цього закладу. А в іншому, навпаки, соціальне середовище блокуватиме дію таких механізмів, робитиме їх номінальними, отже не результативними. Коли немає результату, то про ефективність нелогічно вести мову.

\footnotetext{
163 Соціологія: короткий енциклопедичний словник / уклад.: В.І. Волович, В.І. Тарасенко, М.В. Захаренко та ін.; під заг. ред. В.І. Воловича. К.: Укр. Центр духовн. Культури, 1998. С. 320.
} 
Якщо підходити до проблеми врядування в університетах, особливо класичних, суто з формальних позицій, то може постати відповідь, що такої проблеми не може бути за визначенням. Адже врядування з часів виникнення перших університетів сприймається як їх атрибут, тобто невід'ємна властивість, з утратою якої вони перестають бути такими інституціями.

Тому формально врядування нині $€$ в усіх вітчизняних закладах вищої освіти не лише за традицією, а й відповідно до положень Закону України «Про вищу освіту» ${ }^{164}$ та інших нормативно-правових актів. Але при цьому залишається відкритим питання щодо того, наскільки реально дієвим, результативним та ефективним $\epsilon$ врядування у кожному зокрема українському закладі вищої освіти. У скількох вітчизняних ЗВО воно існує формально і має суто номінальний характер, як ті дипломи про вищу освіту, що видаються особам, які не підтверджують їхню реальність своєю фаховою компетентністю.

Вочевидь, яке в дійсності врядування в кожному 3ВО, достеменно знають суб'єкти їхньої діяльності, зокрема, керівники, науково-педагогічні працівники та здобувачі вищої освіти. Щоб дати оцінку дійсному, треба мати уявлення про належне. Достовірність такої оцінки забезпечується умовою, коли суб'єкт оцінювання має адекватне уявлення про стан дійсного і про належне, до відповідності якого має прагнути дійсне. Логіка підказує, чим менша розбіжність дійсного з належним, тим вищою має бути оцінка. При цьому усвідомлюємо, що образ належного - це певною мірою ідеал, на досягнення якого орієнтується розвиток дійсного. Ідеал як цінність та орієнтир завжди попереду дійсного. Тому між образом належного і станом дійсного завжди $\epsilon$ відстань. Чим коротше відстань, тим ближче до належного і навпаки. Найдальше від належного знаходиться той, хто на це належне зовсім не орієнтується. Наприклад, авторитаризм має інші орієнтири у своєму розвиткові, ніж демократія. Авторитаризм є формою реалізації влади-власності й у своєму розвиткові еволюціонує в сторону тоталітаризму, а не демократії. Тому він за своєю природою не може орієнтуватись на врядування як прояв демократії.

Наразі постає питання щодо визначення достовірної оцінки дійсного стану врядування у конкретному закладі вищої освіти. В руслі тренду автономізації ЗВО України, що передбачає зміщення акцентів із зовнішнього контролю за їх діяльністю на самоконтроль, актуалізується питання здійснення закладами самооцінювання. Показовим прикладом у цьому сенсі $\epsilon$ орієнтація системи зовнішнього забезпечення освітньої діяльності ЗВО та якості вищої освіти на систему внутрішнього забезпечення якості освітньої діяльності та якості вищої освіти ${ }^{165}$. Інакше й бути не може. Адже будь-який зовнішній контроль безсилий адекватно оцінити якість освітньої діяльності та якості вищої освіти. Тому система забезпечення якості вищої освіти мусить базуватися на довірі до самооцінки, яку робить кожен заклад вищої освіти.

На цьому ключовому моменті у контексті автономізації вітчизняних ЗВО і децентралізації управління в українському суспільстві зробив наголос C. Kвim: «Повна академічна автономія, якої домоглися українські університети, лише тоді дасть свої позитивні наслідки, коли її можна буде капіталізувати за принципом: «хто добре працює, той добре живе». Відповідно мають фінансуватися найкращі університети та освітні програми, що усвідомлюють власні місію і цінності, розвивають унікальну внутрішню культуру, у т.ч. стосовно забезпечення академічної якості. Сьогодні ми ведемо мову про лише один сегмент реформування української вищої освіти, пов'язаний з очікуваннями від Національного агентства із забезпечення якості вищої освіти. Ми почали працювати з останніх днів лютого 2019 року. Слід розуміти, що ця політика якості буде успішною лише в контексті піднесення національної економіки та успіху інших ключових реформ, таких, як децентралізація, «Нова українська школа», декомунізація, подальша євроінтеграція України. Від імені Національного агентства я хочу підкреслити, що головна ідея, яку $б$ ми хотіли поширити - це взаємна повага і довіра. Без довіри не відбуваються ніякі великі перетворення. Так само, лише на довірі можна будувати нову систему акредитації та забезпечення якості вищої освіти» ${ }^{166}$.

Оскільки всі процедури системи внутрішнього забезпечення якості освітньої діяльності та якості вищої освіти і критерії її оцінювання чітко регламентовані й прописані, починаючи із Закону України «Про вищу освіту» ${ }^{167}$, то суб'єкти здійснення такої самооцінки мають адекватне уявлення як про дійсне тобто про реальний стан освітньої діяльності та якості вищої освіти, так і про належне тобто про вимоги і критерії до

\footnotetext{
164 Закон України «Про вищу освіту» від 1 липня 2014 року № 1556-VII. URL: https://zakon.rada.gov.ua/laws/show/1556-18\#Text

165 Закон України «Про вищу освіту» : станом на 29 жовтня 2014 року. Право, 2014. С. 23-32.

166 Квіт С. Якісна вища освіта. Виступ на Міжнародній конференції. «Розбудова системи забезпечення якості вищої освіти в Україні», 11-12 червня 2019, KHTEY. URL: http://education-ua.org/ru/articles/1343-yakisna-vishcha-osvita-vistup-na-mizhnarodnij-konferentsijirozbudova-sistemi-zabezpechennya-yakosti-vishchoji-osviti-v-ukrajini-11-12-chervnya-2019-knteu

167 Закон України «Про вищу освіту» : станом на 29 жовтня 2014 року. Право, 2014. С. 23-32.
} 
якості освітньої діяльності та якості вищої освіти. Наскільки адекватною буде відображена для зовнішнього контролю така самооцінка дійсного, це залишається на совісті суб'єктів системи внутрішнього забезпечення якості й довірі до неї з боку суб'єктів системи зовнішнього забезпечення якості.

Що ж стосується адекватної оцінки стану врядування у вітчизняних ЗВО як визначального чинника підвищення результативності й ефективності їхньої діяльності, інтегральним критерієм чого є якість вищої освіти, яку вони забезпечують, то така оцінка нормативно не передбачена. Хоча, як було підкреслено в обгрунтуванні актуальності теми нашого дослідження, демократизація соціального середовища закладів вищої освіти за допомогою запровадження механізмів ефективного врядування $є$ однією з ключових вимог євроінтеграції. Вочевидь це $є$ базовою умовою й підвищення тієї ж якості освітньої діяльності та якості вищої освіти як їі інтегрального результату. Оскільки системи зовнішнього контролю й відповідних критеріїв щодо демократизації соціального середовища вітчизняних $3 В 0$ не передбачено, то адекватне уявлення про належне врядування, яке б відповідало вимогам Європейського простору вищої освіти, залишилось проблемою, що віддана на відкуп самим ЗВО і дослідникам, які переймаються розв'язанням цієї проблеми.

Наразі одним із завдань нашого наукового дослідження $\in$ сформувати у теоретичній свідомості 168 вітчизняної спільноти, причетної до вищої освіти, адекватне уявлення про:

- сутність врядування;

- про те яким воно має бути;

- про умови соціального середовища, за яких воно може ефективно реалізуватись;

- про шляхи створення умов для ефективного врядування в українських ЗВО з огляду на вимоги євроінтеграції.

Сподіваємося, що сформульовані світоглядно-методологічні засади й теоретичні положення цього та інших розділів монографії послугують певною теоретичною матрицею того належного врядування, на яке можуть орієнтуватися заклади вищої освіти України, демократизуючи своє соціальне середовище.

Наклавши таку теоретичну матрицю на реальний стан певного конкретного середовища, можна крізь призму відповідності дійсного належному критично проаналізувати й більш менш адекватно оцінити рівень демократичності й урядування у конкретному закладі вищої освіти. Принаймні, однозначно визначитись із тим, що домінує у даному закладі - авторитаризм чи демократія. Це задача-мінімум, але й вона нині актуальна для тих закладів вищої освіти, в яких авторитаризм прикривається формами демократії, коли суто зовнішньо процедури демократії виконуються, а реальної демократії немає.

Сутність врядування та його механізмів ми вже розглянули. При цьому зробили важливий акцент на тому, що запровадження механізмів врядування в соціальне середовище закладів вищої освіти $€$ не самоціллю, а засобом поліпшення їхньої діяльності й першочергово якості вищої освіти. Теоретично було обґрунтовано, що результативність й ефективність врядування визначально залежить від стану й умов соціального середовища, в якому запроваджуються його механізми.

Нижче розглянемо точки зору щодо визначення ролі середовища 3 вО у забезпеченні його результативної діяльності, інтегральним критерієм якої є рівень розвитку особистості та якості вищої освіти. Зокрема, плюралізм таких точок зору репрезентується в сучасному науковому дискурсі публікаціями М. Братко ${ }^{169}$, Л. Пан ${ }^{170}$, Г. Полякової ${ }^{171}$, О. Керницькиго ${ }^{172}$ та інших авторів.

\footnotetext{
168 Філософія розмежовує теоретичну й буденну свідомість. Теоретична свідомість відображає суспільне буття в його істотних зв'язках і закономірностях, виявляється у науці та інших формах свідомості. Якщо буденна свідомість формується стихійно, то теоретична свідомо і цілеспрямовано.

169 Братко М. Структура освітнього середовища вищого навчального закладу. Наукові записки Кіровоградського державного педагогічного університету імені Володимира Винниченка. Сер. : Педагогічні науки, 2015. Вип. 135. С. 67-72.

170 Пан Л. В. Роль дослідження середовища функціонування вищого навчального закладу у системі управління. Бізнес-освіта як бізнес : якість послуг і соціальна відповідальність : матеріали п'ятої щоріч. міжнар. конф. «Розбудова менеджмент-освіти в Україні». (м. Харків, 13-15 листоп. 2003 р.). К. : Консорціум із удосконалення менеджмент-освіти в Україні, 2003. С. 23-35.

171 Полякова Г. Розвиток середовищного підходу у вищій освіті в умовах глобальних змін. Педагогічні науки: теорія, історія, інноваційні технології, 2018. №4 (78). С. 189-199. URL: https://pedscience.sspu.sumy.ua/wp-content/uploads/2018/09/19.pdf

172 Керницький О.М. Освітнє середовище вищого навчального закладу як педагогічний феномен. Проблеми інженерно-педагогічної освітu, 2013. № 38-39. C. 43-50. URL: http://library.uipa.edu.ua/images/data/zbirnik/kernskiy.pdf
} 
На наш погляд, досить системно й багатогранно висвітлює освітнє середовище закладу вищої освіти вітчизняна дослідниця М. Братко у публікації «Структура освітнього середовища вищого навчального закладу» ${ }^{173}$, яке вона ототожнює із соціальним середовищем. Останнє, з нашої точки зору, є приводом для окремої дискусії, оскільки освітнє середовище не осягає все соціальне середовище закладу вищої освіти.

М. Братко актуалізує зміст поняття «освітнє середовище» та обгрунтовує структуру освітнього середовища закладу вищої освіти. На підставі аналізу доволі ємкої джерельної бази вчена зазначає, «що проблема усебічного вивчення впливу освітнього середовища на розвиток особистості актуалізувалась у 7090 роки XX століття. Досліджуючи існуючі підходи до вивчення освітнього середовища можна зробити висновок, що вони представляють два основних підходи: соціально-психологічний (освітнє середовище визначається як умова конструювання людиною смислів у процесі взаємодії з оточуючим світом) і соціальнопедагогічний (освітнє середовище визначається як багатомірне соціально-педагогічне явище, яке ситуативно впливає на розвиток ціннісних орієнтацій, способів поведінки)» 174.

Заслуговує на увагу визначення освітнього середовища закладу вищої освіти, яке дає М. Братко: «Освітнє середовище вищого навчального закладу, на нашу думку, це комплекс умов-можливостей та ресурсів (матеріальних, фінансових, особистісних, технологічних, організаційних, репутаційних) для освіти особистості, що склались цілеспрямовано в установі, яка виконує освітні функції щодо надання вищої фахової освіти, забезпечує можливості для загальнокультурного та особистісного розвитку суб'єктів освітнього процесу» ${ }^{175}$. Дослідниця слушно зауважує, що таке визначення дозволяє розглядати «фактором впливу» на особу здобувача вищої освіти будь-яку з умов або будь-який ресурс освітнього середовища закладу. Бачення й усвідомлення таких чинників дозволяє здійснювати опосередкований вплив на всі складові освітнього процесу. Надзвичайно важливим у зробленому М. Братко визначенні освітнього середовища $\epsilon$ те, що вона відносить репутацію закладу вищої освіти до його основних ресурсів. Нижче додатково зупинимося на розгляді важливості цього ресурсу, яким недопустимо нехтувати, оскільки репутація $€$ однією з базових складових цивілізованого конкурентного середовища.

Важливим як у теоретичному, так і в практичному сенсі $\in$ бачення М. Братко структури освітнього середовища ЗВО та їі впливу на розвиток особистісного потенціалу здобувачів вищої освіти: «Ми дотримуємось думки, що структура освітнього середовища вищого навчального закладу покликана забезпечувати професійну підготовку майбутнього фахівця у поєднанні з особистісним розвитком, сприяти задоволенню потреб особистості у саморозвитку, самовдосконаленні, самореалізації, створювати підґрунтя для формування ціннісних орієнтирів та мотивів діяльності. Особлива увага має приділятись створенню можливостей для формування і розвитку якостей особистості, які необхідні для побудови та реалізації успішної життєвої траєкторії: мотивація досягнення успіху, подолання труднощів, активної життєвої позиції» ${ }^{176}$.

Л. Пан у публікації «Роль дослідження середовища функціонування вищого навчального закладу у системі управління» ${ }^{177}$ актуалізувала необхідність зміщення акцентів з технократичних чинників середовища ЗВО на соціальні: «На сьогодні, на жаль, аналіз середовища - не зовсім звична діяльність для вітчизняних ВНЗ. Однак оволодіння прийомами та методами аналізу - одне з найважливіших завдань, що стоїть перед керівниками навчальних закладів, оскільки параметри середовища функціонування організації - це унікальна комбінація факторів, що перебувають у постійному русі. Перенесення акцентів з технократичних факторів середовища на соціальні визначає нову роль освіти в сучасну епоху. На зміну інформаційній системі освіти приходить система освіти, що розвивається. Але традиційна форма та методи підготовки фахівців у більшості

\footnotetext{
173 Братко М. Структура освітнього середовища вищого навчального закладу. Наукові записки Кіровоградського державного педагогічного університету імені Володимира Винниченка. Сер. : Педагогічні науки, 2015. Вип. 135. С. 67-72.

174 Братко М. Структура освітнього середовища вищого навчального закладу. Наукові записки Кіровоградського державного педагогічного університету імені Володимира Винниченка. Сер. : Педагогічні науки, 2015. Вип. 135. С. 69.

175 Братко М. Структура освітнього середовища вищого навчального закладу. Наукові записки Кіровоградського державного педагогічного університету імені Володимира Винниченка. Сер. : Педагогічні науки, 2015. Вип. 135. С. 71.

176 Братко М. Структура освітнього середовища вищого навчального закладу. Наукові записки Кіровоградського державного педагогічного університету імені Володимира Винниченка. Сер. : Педагогічні науки, 2015. Вип. 135. С. 67-72. С. 71.

177 Пан Л. В. Роль дослідження середовища функціонування вищого навчального закладу у системі управління. Бізнес-освіта як бізнес : якість послуг і соціальна відповідальність : матеріали п'ятої щоріч. міжнар. конф. «Розбудова менеджмент-освіти в Україні». (м. Харків, 13-15 листоп. 2003 р.). К. : Консорціум із удосконалення менеджмент-освіти в Україні, 2003. С. 23-35.
} 
ВН3 України не відповідають цій зміні, що свідчить про невідповідність внутрішнього середовища ВНЗ зовнішньому» 178 .

Л. Пан розглядає заклад вищої освіти як відкриту, складну і динамічну систему, «яка змінює у часі та просторі свої параметри, підлягає впливам з боку зовнішнього середовища і справляє вплив на це середовище за принципом зворотного зв'язку» ${ }^{179}$. Дослідниця визначає інтегральний показник оцінки діяльності зВО, з яким ми цілком погоджуємося, який є наступним: «Сьогодні при розробці стратегії розвитку ВНЗ перевага повинна надаватися особистісному підходу. Головною метою кожного ВНЗ має бути досягнення дедалі вищої якості освітніх послуг і забезпечення на цій основі високої конкурентоспроможності випускників. Саме якість повинна виступати як інтегральний показник оцінки діяльності ВН3, найважливіший чинник формування його «інституціонального» іміджу в освітянському середовищі та суспільстві в цілому» ${ }^{180}$. На наш погляд, те, що Л. Пан у цьому контексті назвала іміджем, логічно вважати репутацією. Обґрунтоване розмежування понять «імідж» та «репутація» закладу вищої освіти зроблено в останньому підрозділі цього розділу.

Г. Полякова у статті «Розвиток середовищного підходу у вищій освіті в умовах глобальних змін» 181 дослідила етапи становлення та розвитку зазначеного вище підходу, виявила його характеристики з урахуванням глобальних змін і тенденцій розвитку вищої освіти. Важливим у контексті нашого дослідження $є$ наступний висновок Г. Полякової: «В умовах глобальних змін середовищний підхід стає стратегією розвитку вищої освіти, методом пізнання й інструментом вирішення теоретичних і практичних проблем (завдань) підготовки професіоналів нового покоління, підтримки особистісно-професійного успіху та самореалізації здобувачів вищої освіти для побудови коеволюції індивідуального, інституційного, суспільного розвитку шляхом перетворення освітнього середовища закладу вищої освіти на локальному рівні, використовуючи його феноменальні можливості (соціокультурні, освітні, інформаційно-ресурсні, соціально-психологічні)» ${ }^{182}$.

У публікації О. Керницького «Освітнє середовище вищого навчального закладу як педагогічний феномен» ${ }^{183}$ важливими для нашого дослідження $€$ наступні теоретичні положення: «Освітнє середовище як педагогічний феномен - це освітнє середовище вищого навчального закладу як педагогічний феномен являє собою континуум, що розвивається, який складається з просторово-тимчасових, соціально-культурних, діяльнісних, комунікативних, інформаційних та інших факторів, які з'являються як цілеспрямовано створювані й спонтанні умови взаємодії особистості, що розвивається, й об'єктивного світу вищої школи. Фактори освітнього середовища можна розділити на керовані й некеровані. Керованими є ті фактори середовища, наявність яких і їх вплив можна передбачати. У структурі середовища нами виділені: фактори прямої дії, які при цьому стають тотожними засобам навчання, і фактори непрямої дії, що опосередковано впливають на засвоєння знань і розвиток студентів» ${ }^{184}$.

\footnotetext{
178 Пан Л. В. Роль дослідження середовища функціонування вищого навчального закладу у системі управління. Бізнес-освіта як бізнес : якість послуг і соціальна відповідальність : матеріали п'ятої щоріч. міннар. конф. "Розбудова менеджмент-освіти в Україні». (м. Харків, 13-15 листоп. 2003 р.). К. : Консорціум із удосконалення менеджмент-освіти в Україні, 2003. С. 24.

179 Пан Л. В. Роль дослідження середовища функціонування вищого навчального закладу у системі управління. Бізнес-освіта як бізнес : якість послуг і сочіальна відповідальність : матеріали п'ятої щоріч. міжнар. конф. «Розбудова менеджмент-освіти в Україні». (м. Харків, 13-15 листоп. 2003 р.). К. : Консорціум із удосконалення менеджмент-освіти в Україні, 2003. С. 24.

180 Пан Л. В. Роль дослідження середовища функціонування вищого навчального закладу у системі управління. Бізнес-освіта як бізнес : якість послуг і соціальна відповідальність : матеріали п'ятої щоріч. міжнар. конф. «Розбудова менеджмент-освіти в Україні». (м. Харків, 13-15 листоп. 2003 р.). К. : Консорціум із удосконалення менеджмент-освіти в Україні, 2003. С. 25.

181 Полякова Г. Розвиток середовищного підходу у вищій освіті в умовах глобальних змін. Педагогічні науки: теорія, історія, інноваційні технології, 2018. №4 (78). С. 189-199. URL: https://pedscience.sspu.sumy.ua/wp-content/uploads/2018/09/19.pdf

182 Полякова Г. Розвиток середовищного підходу у вищій освіті в умовах глобальних змін. Педагогічні науки: теорія, історія, інноваційні технології, 2018. №4 (78). С. 189-199. URL: https://pedscience.sspu.sumy.ua/wp-content/uploads/2018/09/19.pdf

183 Керницький О.М. Освітнє середовище вищого навчального закладу як педагогічний феномен. Проблеми інженерно-педагогічної oсвimu, 2013. № 38-39. С. 43-50. URL: http://library.uipa.edu.ua/images/data/zbirnik/kernskiy.pdf

184 Керницький О.М. Освітнє середовище вищого навчального закладу як педагогічний феномен. Проблеми інженерно-педагогічної oсвimu, 2013. № 38-39. C. 43-50. URL: http://library.uipa.edu.ua/images/data/zbirnik/kernskiy.pdf
} 


\section{Проблема доброчесності у соціальному середовищі закладів вищої освіти України}

Проблема доброчесності у соціальному середовищі закладів вищої освіти України має займати ключове місце, оскільки без їі розв'язання годі сподіватись на успішне запровадження механізмів ефективного врядування у вищій освіті. Ця проблема є однією з центральних не лише у науковому, а й у суспільному дискурсі. Нових публікацій, присвячених висвітленню проблеми академічної доброчесності, надзвичайно багато з'явилося саме в останні роки.

На тлі десятків публікацій із зазначеної проблеми, зі змістом яких довелося нам познайомитися, надзвичайно вагомою в методологічному і світоглядно-просвітницькому сенсі вважаємо працю «Академічна чесність як основа сталого розвитку університету» ${ }^{185}$, назву якої цілком доречно, на наш погляд, можна доповнити словом «і суспільства», в якому університет функціонує. Адже між університетом і суспільством існує пряма взаємозалежність. Розглянемо певні положення даної праці, які є актуальними у контексті нашого наукового дослідження.

T. Фініков , автор першого розділу монографії відзначив, що послугувало поштовхом для ії підготовки: «Головну роль, на нашу думку, тут зіграло три обставини. Першою виступило те, що академічна недоброчесність, більше того відкрита та латентна корупція, системно руйнують професійну і суспільну мораль, підривають правові, політичні, соціальні та економічні засади існування вітчизняної вищої школи і української держави взагалі. Другою стала поява груп людей, потенційних лідерів змін у наших університетах, які тверезо віддають собі звіт, що без радикальних змін у моральній атмосфері, прийняття нової хартії корпоративних взаємовідносин, координації університетських зусиль та дій інших акторів громадянського суспільства, наша вища школа продовжить свій рух по шляху подальшої деградації та втрати репутації в публічному просторі. Третім чинником стало надзвичайно вдале співпадіння двох цікавих міжнародних освітніх проектів: польсько-українського проекту «/нноваційний університет і лідерство» (2014-2016рр.) та американо-української програми «Academic integrity in the U.S.» (2015р.). Саме учасники цих програм, обрані серед найбільш активних та креативних менеджерів українських вищих навчальних закладів і стали авторами статей нашої публікації» ${ }^{186}$. Власне ці обставини, які охарактеризував Т. Фініков, доволі концептуально актуалізують проблему академічної доброчесності в сучасному українському суспільстві.

Важливим як у сенсі актуалізації цієї проблеми, так і у поясненні системних причин, що ії породжують, $\epsilon$ наступне твердження Т. Фінікова: «В умовах українського суспільства корупція, самоорганізація академічного середовища на хибних моральних засадах, масова девіантна поведінка акторів та стейкхолдерів цієї сфери отримують постійні імпульси для свого розвитку з-за різких змін та невизначеності соціальних ідеалів та орієнтирів, професійних норм та регуляцій, суттєвої втрати керованості суспільством, дисбалансу в діях державних інститутів управління, слабкості громадянського суспільства» 187.

T. Добко і В. Турчинський, посилаючись на вислів Горація «Закони без звичаїв не діють», концептуально визначили системні причини проблеми нечесності у нашому суспільстві, а отже, і в його закладах вищої освіти, оскільки вони від нього безпосередньо залежні. Так як свого часу сказав Горацій, на думку дослідників, «мало 6 сьогодні звучати гасло кожного українського університету, який прагне готувати нові покоління громадян для нової України. Адже не лише інституційні проблеми й економічні труднощі, не лише війна і зовнішня агресія гальмують трансформацію і перезавантаження нашої країни. Великим гальмом для появи нової України $\epsilon$ спосіб мислення людей, котрі ухвалюють рішення і формують обличчя країни, а також чималої маси громадян, які орієнтуються на них. Недостатньо замінити одні процедури на інші. Потрібна докорінна зміна культури суспільної взаємодії. Страх перед змінами, толерантність до корупції, пристосуванство і створення «для себе улюбленого» зони комфорту при будь-якій владі, зловживання патріотичною риторикою без реального

\footnotetext{
185 Академічна чесність як основа сталого розвитку університету / за заг. ред. Т.В. Фінікова, А.Є. Артюхова. К. : Таксон, 2016. 234 с.

186 Фініков Т. Академічна доброчесність: глобальний контекст та національна потреба. Академічна чесність як основа сталого розвитку університету / за заг. ред. Т.В. Фінікова, А.Є. Артюхова. К. : Таксон, 2016. С. 32.

187 Фініков Т. Академічна доброчесність: глобальний контекст та національна потреба. Академічна чесність як основа сталого розвитку університету / за заг. ред. Т.В. Фінікова, А.Є. Артюхова. К. : Таксон, 2016. С. 32. С. 20.
} 
патріотизму і «зацикленість» на матеріальному споживанні не дозволяють нам перейти від Революції Гідності до країни гідності - економіки гідності, політики гідності, освіти гідності, медицини гідності, тощо» 188.

T. Добко і В. Турчинський не лише критично аналізують проблему академічної доброчесності, а й визначають орієнтири, якими треба керуватись на шляху подолання цієї проблеми, зокрема, це людина й людське у ній:

«Найбільша інновація - це людина, а найважливіша реформа це - зміна ментальності, яка виявляє себе у відкритості до нових цінностей та нових суспільних стандартів. Стануть іншими університети, іншим стане усе суспільство» ${ }^{189 .}$

«Університет має бути місцем, де молода людина зможе розвинути свою гідність і прагнення до інтелектуального життя» 190

Методологічно важливим у розв'язанні проблеми академічної доброчесності, на наш погляд, $є$ наступне положення авторів публікації: «Академічна культура не може бути перенесена чи запозичена. Як правило, вона вистраждана ціною спроб і помилок, ціною постійної комунікації та саморефлексії університетської спільноти над собою і своїм проєктом. Вона не є раз і назавжди сформованою і сталою, а потребує постійного оновлення і підживлення. Але наполеглива праця над нею, як показує досвід УКУ, себе виправдовує стократ. Упізнавана академічна культура $\epsilon$ не лише візитною карткою, а й відчутною конкурентною перевагою університету» ${ }^{191}$. УкУ - це Український католицький університет, який попри всі негаразди, що породжуються нечесністю в нашому суспільстві, зумів створити на території України своєрідний анклав європейських цінностей, які реально у ньому сповідуються. Т. Добко і В. Турчинський висвітлюють досвід УКУ з формування академічної культури та пропонують його до впровадження у вітчизняних закладах вищої освіти.

У розділі В. Хмарського монографії знаходимо інтерпретацію сутності чесності і порядності, що надзвичайно важливо у методології як дослідження, так і розв'язання проблеми академічної доброчесності: «Втім останніми роками у віртуальному просторі розгорнулась дискусія щодо спільного і відмінного між «honesty» та «integrity», причому у широкому діапазоні суспільного використання - від комерції до теології. Вважаємо за потрібне звернути увагу на нюанси у використанні обох термінів у згаданій дискусії. Для зручності «honesty» перекладатимемо як «чесність», а «integrity» як «порядність», наприклад:

Honesty is being true in what you say, while integrity is being true in what you do (Чесність - бути правдивим у тому, що ти говориш, а порядність - у тому, що ти робиш);

Honesty is giving your word, integrity is keep in git (Чесність - давати слово, порядність - дотримуватись його);

Honesty is about adherence to the facts. Integrity is about conduct (Чесність - це про дотримування фактів. Порядність - це про поведінку);

Honesty is the quality of being truthful and sincere, when a person refrains from lying to others and cheating. Integrity refers to doing the right thing at all times (Чесність - це якість бути правдивим і щирим, коли особа утримується від брехні іншим та омани. Порядність - робити правильні речі завжди);

You can have honesty without integrity, but you can not have integrity without honesty (Ви можете бути чесним без порядності, але не можете бути порядним без чесності).

Отже, «honesty» можна визначити як правдивість у словах, а «integrity» - як чесність або порядність у поведінці. У подальшому будемо використовувати словосполучення «академічна порядність» та «академічна чесність» як синонімічні. Вважаємо, що відрізняти їх і перекладати двома різними термінами доречно лише у випадках, коли обидва слова - «honesty» та «integrity» наявні в одному твердженні. Для розуміння поняття «academic integrity» сьогодні у віртуальному просторі запропоноване таке формулювання: академічна порядність - це моральний кодекс або етична політика академічного середовища, що включає такі цінності як

\footnotetext{
188 Добко Т., Турчиновський В. Академічна культура та доброчесність як соціальний капітал сучасного університету. Академічна чесність як основа сталого розвитку університету / за заг. ред. Т.В. Фінікова, А.Є. Артюхова. К. : Таксон, $2016 . С .37$.

189 Добко Т., Турчиновський В. Академічна культура та доброчесність як соціальний капітал сучасного університету. Академічна чесність як основа сталого розвитку університету / за заг. ред. Т.В. Фінікова, А.Є .Артюхова. К. : Таксон, 2016. С. $41-42$.

190 Добко Т., Турчиновський В. Академічна культура та доброчесність як соціальний капітал сучасного університету. Академічна чесність як основа сталого розвитку університету / за заг. ред. Т.В. Фінікова, А.Є. Артюхова. К.; Таксон, 2016. С. 48.

191 Добко Т., Турчиновський В. Академічна культура та доброчесність як соціальний капітал сучасного університету. Академічна чесність як основа сталого розвитку університету / за заг. ред. Т.В. Фінікова, А.Є. Артюхова. К. : Таксон, 2016. С. 37.
} 
уникнення омани чи плагіату, дотримання академічних стандартів, чесності і ретельності у дослідженнях та академічних публікаціях» ${ }^{192}$.

М. Дойчик у своєму розділі монографії акцентує залежність професійної компетентності особи з вищою освітою від їі світогляду та доброчесності академічного середовища, в якому особа здобуває цю освіту: «Говорячи про академічну чесність слід підкреслити, що у всьому цивілізованому академічному світі давно вже прийшли до висновку: професійний розвиток неможливий без загальносвітоглядного, який формує не просто фахівця, а соціально активного і відповідального громадянина, лідера, який здатен змінювати світ на краще. Саме цей процес не може стати реальністю без академічної доброчесності» ${ }^{193}$. Надзвичайно важливим для методології дослідження проблеми доброчесності є і наступне твердження М. Дойчика: «Вища школа - це своєрідна модель суспільства. Тому процес впровадження ідей і постулатів академічної чесності є поступовим, складним і довготривалим, тож повинен постійно вдосконалюватися, оскільки досягнення освітніх, виховних, навчальних та науково-пошукових цілей можливе лише за умови дотримання етичних стандартів» ${ }^{194 .}$

Важливою методологічною та світоглядною установкою на прищеплення чесності в особистостях студентів є наступне положення із М. Дойчика: «Особистісна чесність - це якість не вроджена, а набута, її слід розвивати і практикувати щодня. Пошук нових знань уже сам по собі передбачає чесність в академічному середовищі. Тому постійне заохочення до етичної поведінки під час аудиторної роботи, в лабораторіях, бібліотеках і навіть на спортивних майданчиках закладає фундамент для довготривалої академічної доброчесності. Студент повинен бути вмотивованим обирати складніший, але чесний шлях опрацювання інформації і пошуку нових знань, оскільки «академічна свобода процвітає тільки у середовищі дотримання принципів інтелектуальної чесності з усіма ії правами і обов'язками». Чесність $є$ передумовою і основою довіри, яка $є$ фундаментальною цінністю наукового дослідження. Воно не може вестися без віри у результати інших дослідників, можливості спиратися на їх здобутки. Таким чином, чесність і довіра - це ті базові цінності, котрі уможливлюють науково-дослідний процес як такий, оскільки без їх дотримання він не має сенсу» 195.

A. Мельниченко характеризує різновиди академічної нечесності та визначає причини, які ії породжують у соціальному середовищі ЗВО. Зокрема, на переконання вченого, «однією з головних причин існування та поширення проявів феномену академічної нечесності $€$ розповсюдження та узвичаєння імітації освітньонаукової діяльності як особливого виду соціальної псевдоактивності, коли співпраця науково-педагогічних працівників зі студентами здійснюється за принципом «одні роблять вигляд, що навчають, а інші - що навчаються» 196. Дослідником на підставі відповідної джерельної бази зроблена характеристика таких різновидів академічної нечесності, як плагіат, академічне шахрайство та його форми - фабрикація і фальсифікація, несанкціонована співпраця (придбання на замовлення у сторонніх осіб рефератів, контрольних, курсових і дипломних робіт, дисертацій тощо, які потім видаються як власні) і корупція, а також подані критерії так званого «Списку Білла», за якими визначаються «хижі» видавництва відкритого доступу, що публікують статті без процесу належного наукового рецензування та прискорюють їх опублікування за гроші.

У підсумку А. Мельниченко зазначив, «що проведений аналіз проявів академічної нечесності не претендує на цілковиту повноту, проте дозволяє виявити основні і найбільш поширені їі форми. Комплекс заходів щодо протидії проявам академічної нечесності повинен здійснюватися на всіх рівнях управління у сфері освіти і науки. У протилежному випадку, за влучним висловом М. Згуровського, країну чекає невідворотне формування індустрії ««дипломованої псевдоосвіти» 3 набором несприятливих сценаріїв розвитку» 197.

\footnotetext{
192 Хмарський В. Academic integrity в США: кілька спостережень 2015 року. Академічна чесність як основа сталого розвитку університету /за заг. ред. Т.В. Фінікова, А.Є. Артюхова. К. : Таксон, 2016. С. 57-58.

193 Дойчик М. Академічна чесність: данина моді чи життєва позиція? Академічна чесність як основа сталого розвитку університету /за заг. ред. Т.В. Фінікова, А.Є. Артюхова. К. : Таксон, 2016. С. 97-98.

194 Дойчик М. Академічна чесність: данина моді чи життєва позиція? Академічна чесність як основа сталого розвитку університету /за заг. ред. Т.В. Фінікова, А.Є. Артюхова. К. : Таксон, 2016. С. 98.

195 Дойчик М. Академічна чесність: данина моді чи життєва позиція? Академічна чесність як основа сталого розвитку університету /за заг. ред. Т.В. Фінікова, А.Є. Артюхова. К. : Таксон, 2016. С. 99.

196 Мельниченко А. Прояви академічної нечесності. Академічна чесність як основа сталого розвитку університету /за заг. ред. Т.В. Фінікова, А.Є. Артюхова. К. : Таксон, 2016. С. 108.

197 Мельниченко А. Прояви академічної нечесності. Академічна чесність як основа сталого розвитку університету /за заг. ред. Т.В. Фінікова, А.Є. Артюхова. К. : Таксон, 2016. С. 116.
} 


\section{Умови соціального середовища 3ВО, за яких уможливлюється реалізація в ньому базових принципів врядування}

Проаналізовані вище наукові публікації, не дивлячись на плюралізм точок зору їх авторів у розумінні й тлумаченні сутності середовища закладу вищої освіти, сходяться та резонують у визначенні умов соціального середовища, за яких уможливлюється реалізація в ньому базових принципів врядування, що робить його дієвим і результативним. Узагальнюючи розглянутий теоретичний дискурс, до таких умов сочіального середовища належать ті, які:

- сприяють самоактуалізації, саморозвитку, самовдосконаленню, самореалізації особистості;

- мотивують особистість до досягнення успіху, подолання труднощів, зайняття активної життєвої позиції;

- створюють можливості для набуття конкурентоспроможної компетентності здобувачами вищої освіти;

- забезпечують коеволюцію індивідуального, інституційного та суспільного розвитку;

- формують доброчесне соціальне середовище як основу сталого розвитку закладу вищої освіти;

- блокують культивування подвійних моральних стандартів та ескалацію цинічного прагматизму;

- сприяють формуванню соціально активного і відповідального громадянина, лідера, який здатний змінювати світ на краще та ін.

Такі умови неможливо створити в авторитарному соціальному середовищі. Названі та інші умови, що сприяють повноцінному розвиткові особистісного потенціалу, створюються лише у демократичному середовищі, формування якого забезпечується дієвими механізмами врядування. А дієвими й результативними механізми врядування будуть тоді, коли повною мірою будуть реалізовуватися принципи врядування. Така реалізація стає можливою лишень у доброчесному соціальному середовищі, яке забезпечується визначеними у розглянутих публікаціях умовами.

Брак доброчесності в соціальному середовищі закладу вищої освіти неможливо компенсувати моральними настановами або так званим виховальним навчанням і всілякими позаурочними виховними заходами, якими зазвичай у нас позначається виховна робота зі студентами.

Нині в системі вищої освіти України загострено увагу на подоланні проблеми академічної нечесності, у фокусі якої знаходиться плагіат. Розгорнуту кампанію з блокування цього негативного явища в науковому й освітньому середовищі слід вітати й робити ії результативною. Але однією лише відсутністю плагіату не забезпечиться доброчесність соціального середовища в цілому, якщо в ньому буде допускатися чи взагалі культивуватися нечесність в інших відносинах і видах діяльності, зокрема в освітньому процесі.

Проблему плагіату легше здолати, ніж нечесність в освітньому процесі, яка зумовлюється попитом на номінальну вищу освіту в сучасному українському суспільстві й освітніми послугами, що задовольняють цей попит.

Це пояснюється, по-перше, тим, що запобігання до плагіату робиться індивідуально, а попит на номінальну вищу освіту та його задоволення здійснюється колективно чи корпоративно.

По-друге, плагіат не $є$ проблемою для доброчесних науковців, викладачів і здобувачів вищої освіти, оскільки незапобігання до нього $€$ справою їньої совісті, честі й порядності, а не загрози зовнішнього контролю і відповідних санкцій. Тоді як у подоланні корпоративної нечесності в освітньому процесі особи, які не запобігають до плагіату за власним моральним вибором, можуть виявитися безсилими. Понад це доброчесні у своїх публікаціях викладачі, які задіяні в освітньому процесі, що системно культивує протекціонізм некомпетентності, стають вільними чи невільними, активними чи пасивними співучасниками такої корпоративної академічної нечесності. У цьому сенсі можуть складатися такі ситуації для доброчесних і принципових викладачів, коли вони змушені покидати такий освітній процес щоб залишитися в злагоді з власною совістю. Позбавлення можливостей викладача справедливо оцінювати результати навчання студентів - це не що інше, як обмеження його академічної свободи. А це базова засада, без якої вища освіта як інституція перестає виконувати свою суспільну місію. Несправедливе оцінювання результатів навчання прищеплює студентам схильність до нечесної конкуренції та соціального паразитизму.

Культивування нечесності в освітньому процесі вітчизняних закладів вищої освіти зумовлюється попитом сучасного українського суспільства на номінальну вищу освіту або на дипломи про вищу освіту безвідносно реальної компетентності їх власників. Оскільки першопричини академічної нечесності вкорінені в контексті 
нашого суспільства, то цю проблему неможливо адекватно дослідити, а тим паче розв'язати у межах предметного поля педагогіки. Цю проблему неможливо здолати внутрішньо інституційно у суспільстві, яке системно культивує цинічний прагматизм, брутально нехтуючи нормами моралі, першочергово доброчесності. Ця проблема є комплексною, а тому потребує системного міждисциплінарного підходу як у її дослідженні, так і розв'язанні.

Першопричиною актуалізованої проблеми є відсутність в Україні розвиненої демократії та правової держави як визначального чинника формування цивілізованого конкурентного середовища, яке включає механізми здорової соціальної селекції і цим блокує попит на номінальну вищу освіту. Тому у цьому сенсі є цілком логічним наступний підрозділ, у якому висвітлюється системний аналіз причин, що вкорінені в сучасному українському суспільстві, які породжують нечесність і непорядність як у суспільному контексті, так і в соціальному середовищі закладів вищої освіти, що в ньому функціонують і безпосередньо від нього залежні. 
Цей порівняльний аналіз має важливе методологічне значення для визначення адекватних підходів у дослідженнях не лише врядування у ЗВО, а й інших проблем вітчизняної вищої освіти, зокрема:

- інституційного реформування вищої освіти України у відповідності до вимог Болонського процесу;

- підвищення якості вищої освіти та конкурентоспроможності вітчизняних 3ВО;

- імплементації успішного досвіду діяльності західноєвропейських університетів у вітчизняну практику;

- тощо.

Зазвичай дослідники успішних практик університетів Західноєвропейської цивілізації, прискіпливо вивчають їх деталі й залишають поза увагою конструкцію та базові особливості суспільного організму, тобто те, завдяки чому такі практики уможливлюються, і не переймаються розумінням та усвідомленням відмінностей нашого суспільства, які нівелюють або й зовсім блокують успішне впровадження цих практик в Україні.

А такими базовими особливостями суспільств країн Заходу, якими вони кардинально відрізняються від України і завдяки яким у них якість вищої освіти відповідає сучасним світовим вимогам і робить їх лідерами світової спільноти, є наступні:

- наявність усталеної демократії та правової держави, визначальним індикатором чого $є$ рівність усіх членів суспільства перед законом, незалежно від їх соціальних статусів;

- цивілізоване конкурентне середовище як наслідок наявності демократично-правової держави, що включає механізми здорової соціальної селекції в усіх сферах суспільної діяльності та спонукає до здобуття конкурентоспроможної компетентності суб'єктами цієї діяльності;

- сповідування демократичних цінностей як суб'єктами суспільної влади, так і пересічними громадянами, на основі яких консолідується і розвивається суспільство;

- актуалізовані мораль і совість як зовнішній і внутрішній регулятори поведінки людини, якою вона відрізняється від інших живих істот, що керуються інстинктами;

- репутація цінується більше ніж гроші, а тому в таких суспільствах бути моральним і порядним вигідно та ін.

Демократія, з якою її затяті супротивники та невігласи пов'язують всі лихоліття українського народу у період державної незалежності, в Україні ще не встигла «навіть переночувати» за майже три десятиліття її блукань навколо цивілізованого простору.

За визначенням правозахисної організації Freedom House («Дім свободи») зі США у їі щорічній доповіді за 2020 рік "Держави перехідного періoду» (Nations in Transit) в Україні панує гібридний режим влади 198 олігархічного штибу. Це щось невизначене або середнє між напівусталеною демократією та напівусталеним авторитарним режимом, за яким слідує усталений авторитарний режим влади, до якого легше скотитися, ніж підніматися з потугами до демократії (спочатку до напівусталеної й аж потім до усталеної). Як наслідок такого тривалого зависання України у перехідному стані між демократією й авторитаризмом на тлі перманентного обману українського народу й дискредитації демократії як форми влади її суб'єктами, демократичні цінності не стали домінуючими світоглядними орієнтирами у свідомості широкого загалу їі громадян.

Представникам вітчизняного істеблішменту, які, потрапляючи у владу, автоматично позиціонують себе суспільною елітою, вкрай бракує державницького світогляду, отже, світоглядної компетентності. А без належної світоглядної компетентності професійна компетентність владного суб'єкта, як показує досвід, може набувати деструктивного характеру й руйнівного спрямування у соціальному середовищі, на яке той має вплив. Тому суб'єкти влади, які не керуються державницьким світоглядом у своїй життєдіяльності, за визначенням не можуть вважатися елітою тобто найкращими членами суспільства. У кінцевому підсумку в

\footnotetext{
198 Дарчук С. Демократичний рейтинг України дещо зріс, але перед нею стоять виклики в дотриманні демократії - Freedom House. 06 травня 2020. Радіо Свобода. Політика. URL: https://www.radiosvoboda.org/a/freedom-house-nations-in-transit/30594646.html
} 
Україні влада відчужена від народу, про що зокрема свідчить низький рівень суспільної довіри до її інститутів, а суспільство неконсолідоване ${ }^{199}$.

До утвердження реальної правової держави на своїх теренах Україна знаходиться ще далі, ніж від усталеної демократії. Індикаторами такої віддаленості є криза системи правосуддя, розгул корупції, нерівність перед законом тощо. За індексами верховенства права Україна посідає 77 місце серед 126 країн, сприйняття корупції - 120, свободи преси - 101 та економічної свободи 147 місце серед 180 країн світу 200. Наслідком відсутності реальної демократії та правової держави в Україні $€$ її низькі конкурентоспроможність - 83 місце серед 137 країн, людський розвиток - 88 місце серед 189 та соціальний розвиток - 64 місце серед 125 країн земної спільноти ${ }^{201}$. Соціальна нерівність в Україні зростає, а середній клас у ній скорочується 202.

Загальновідомо, що середній клас слугує соціально-економічним базисом демократії, оскільки його представники, з однієї сторони, матеріально незалежні від держави, а з іншої - найбільше зацікавлені у підтримці держави як гаранта суспільної справедливості й цивілізованої конкуренції. Як підтверджує світовий досвід, середній клас формується з найактивніших і з найпродуктивніших громадян, які за умов рівності всіх перед законом та однакових для всіх правил конкуренції здатні не лише до самозабезпечення, а й забезпечення держави шляхом наповнення бюджету. На визначальній ролі середнього класу в розвитку держави свого часу наголошував ще Арістотель: «Таким чином, з природного стану держави неминуче випливає, що вона матиме найкращий державний устрій, коли їі складатимуть «середні» громадяни. Ці середні громадяни здебільшого й застережені від певної шкоди. Вони-бо не зазіхають на чуже добро, як бідняки; інші ж люди не заздрять їм через їхні статки, подібно до того як бідняки заздрять на статки заможних. Знову ж таки, вони не чинять нікому зла, як і їм решта, тому їхнє життя минає в безпеці. Ось чому Фокілід висловив чудове побажання (мати) багато «середнього» - найбільше благо; жити в державі я бажаю середнім» ${ }^{203}$.

На превеликий жаль, середній клас як базис демократії в Україні так і не розвинувся за своєю чисельністю у дієву продуктивну соціально-економічну силу цивілізованого розвитку українського суспільства. Мільйони активних, підприємливих, конкурентоспроможних на цивілізованих ринках праці українських громадян свою продуктивність демонструють за межами України і розвивають економіку інших країн, оскільки на рідних теренах не створені суспільно-політичні умови для гідної реалізації їхнього особистісного потенціалу як людського капіталу. Починаючи з 2010 року з України виїхало та не повернулося близько 4 млн українців, що складає майже 10 \% населення ${ }^{204}$. А якщо взяти до уваги, що у зарубіжну міграцію для заробітчанства виїжджають не повними сім'ями, а лишень ті, хто може працевлаштуватися і щось заробити для сім'ї, то у співвідношенні до працездатного населення цей відсоток суттєво більший. Можливо у два чи навіть більше разів. Таким чином, відсутність розвиненого середнього класу й масова міграція продуктивного населення засвідчують про нездорове конкурентне середовище в Україні, що є наслідком відсутності на ії теренах демократично-правової держави.

Це призвело до тотального культивування в сучасному українському суспільстві протекціонізму некомпетентності, який не мотивує широкий загал молоді здобувати якісну вищу освіту:

«Протекціонізм у нашому вітчизняному застосуванні вигідний із позицій задоволення власних, приватних і корпоративних інтересів, але не суспільних і державних. Такий протекціонізм нівелює, зводить нанівець компетентність, робить її незатребуваною в суспільстві. Свідченням цього є всенародна погоня не за знаннями, а за оцінками й дипломами та прибутковими суспільними статусами, де реальна компетентність у розрахунок не береться. Така негативна тенденція є згубною в державотворенні, оскільки підриває конкурентну спроможність нашої молодої держави серед цивілізованих країн світу, яка має міцно стати на власні ноги й історично утвердитись у своїй державності та бути запорукою для успішного життя всього українського народу.

\footnotetext{
199 Рівень довіри до суспільних інститутів та електоральні орієнтації громадян України. Разумков Центр, 27 березня 2019. Соціологія. URL: gromadian-ukrainy-2 http://razumkov.org.ua/napriamky/sotsiologichni-doslidzhennia/riven-doviry-do-suspilnykh-instytutiv-ta-elektoralni-oriientatsii200 Зручний доступ до актуальних даних про позиції України у ключових міжнародних рейтингах. URL: https://voxukraine.org/longreads/ratings/index.html

201 Зручний доступ до актуальних даних про позиції України у ключових міжнародних рейтингах. URL: https://voxukraine.org/longreads/ratings/index.html

202 В Україні скорочується середній клас, - доповідь ПРОOH. URL: https://rubryka.com/2020/01/11/v-ukrayini-skorochuyetsya-serednijklas-dopovid-proon/

203 Аристотель. Природа людини і форми державного устрою. Демократія: Антологія / упоряд. О. Проценко. К. : Смолоскип, 2005. C. 230.

204 В уряді підрахували, скільки українців виїхало за кордон від початку десятиліття. URL: https://hromadske.ua/posts/majzhe-10naselennya-v-uryadi-pidrahuvali-skilki-ukrayinciv-viyihalo-za-kordon-vid-pochatku-desyatilittya
} 
Привідним механізмом вітчизняного протекціонізму є не розмежовані політичні та адміністративні функції, залежність бізнесу та будь-якої іншої господарської діяльності від політики й владних структур, використання держави у приватних інтересах. Така тотальна залежність суспільства від політики спонукає до критичного аналізу їі негативних наслідків та до з'ясування механізмів, що їх породжують. Адже студенти є повноправними громадянами свого суспільства, що гарантує Конституція України, і мають право для адекватного сприйняття, розуміння й усвідомлення соціальної дійсності, у якій вони живуть. А громадянська позиція викладача зобов' язує у силу своїх можливостей давати пояснення тому, що, як і чому відбувається насправді в цій дійсності, принаймні у тих їі контекстах, які перебувають в ракурсі предметного поля навчальної дисципліни, яку він викладає. Адекватний критичний аналіз соціальної дійсності має слугувати запорукою її оздоровлення та покращення. На брехні та лицемірстві неможливо виховати справжню людську особистість, яка була б здатною успішно творити свою державу та не руйнувати її в історичному зародку» 205.

«Протекціонізм некомпетентності - це не лише сприяння працевлаштуванню менш компетентним особам у порівнянні з іншими претендентами на зайняття тієї чи іншої посади, а й безпідставне усунення 3 посад осіб, які за рівнем своєї компетентності відповідають займаній посаді. Це визначення охоплює собою й утримання в лавах тих студентів, які нездатні або не прагнуть здобути якісну вищу освіту, а також толерантність до різновидів академічної нечесності, фальсифікації результатів навчання, тощо.

Широкі можливості завдяки протекціонізму працевлаштовуватись за формальними ознаками наявності вищої освіти, а не за рівнем реальної компетентності цивілізовано конкурувати на паритетних засадах з іншими претендентами, породила черги у вітчизняних закладах вищої освіти за отриманням дипломів. Такий попит включив механізми корупції в освітньому процесі, коли на вимогу студента виставляються необхідні оцінки незалежно від того, як він навчається й чи взагалі навчається. Потреба в дипломах про вищу освіту тих суб'єктів, які не здатні здобути ії самотужки чи лінуються це робити, сформувала пропозицію, яку залюбки дають заклади вищої освіти, що заробляють на такому протекціонізмі некомпетентності. Цілком закономірно, що таке заробляння розгорнулося на найменш ресурсних спеціальностях, які окрім викладачів і приміщень для занять та навчальної літератури більше нічого не потребують. Це призвело до гіпертрофованого розростання ліцензованих обсягів прийому на такі спеціальності й невиправданого реальними суспільними потребами збільшення чисельності на вітчизняних теренах закладів вищої освіти, багато з яких стали себе називати університетами. Наприклад, у Києві до 90-х років був один університет, а нині у столиці щонайменше сорок 3ВО, в назві яких присутнє слово «університет»» 206.

Слушною з цього приводу є рефлексія В. Петруняка: «Ми випускаємо дипломованого спеціаліста, який навіть на пари не ходить або приходить в кінці семестру й на автоматі все здає на 60 і отримує свого диплома бакалавра, а то й магістра! Задумайтеся, якщо це філолог (не хочу їх образити), то, можливо, це й не так страшно, але якщо такий хірург буде вас оперувати, чи архітектор побудує вам оселю, чи юрист, що захищатиме вас в суді, то хіба з такими «спеціалістами» ми хочемо мати справу? I проблема не в самих студентах, а в ставленні до вищої освіти, коли, як за Радянського Союзу, батьки пишаються, що дитина вступила до ЗВО. Але тоді дипломом про вищу освіту міг похвалитися зовсім не кожен, бо лише кращі з кращих навчалися в університетах. Й дійсно батьки переконані, що діти мають здобути вищу освіту, але ніхто не думає, що для більшості з тих дітей, що навчаються у 3ВО, диплом потрібний лише формально. А фактично, з тієї маси випускників лише одиниці підуть працювати за спеціальністю» 207.

\footnotetext{
205 Рябченко В. І. Світоглядно-методологічні засади формування й використання поняттєво-термінологічного апарату в науковій, освітній та суспільно-практичній діяльності: монографія. К. : Фітосоціоцентр, 2011. С. 425-426.

206 Рябченко В. Протекціонізм некомпетентності в українському суспільстві як чинник демотивації студентів у здобутті ними якісної вищої освіти. Збірник наукових праць IV Всеукраїнської науково-практичної конференції. Особистість студента та соціокультурне середовище університету в суспільному контексті. Київ, 2020. С. 90. URL: https://ihed.org.ua/wpcontent/uploads/2020/07/IV Vseukr.konf 18-05-2020 Zbirnyk.pdf

207 Петруняк В. Основні проблеми вищої освіти і навчального процесу в Україні: причини, наслідки та способи подолання. Науковоаналітичний журнал «Наша перспектива». січень-березень 2016. №16-18. C. 26. URL: https://www.perspektyva.in.ua/2016-rik/13-1516-18-sichen-berezen-2016-r/
} 
У такому контексті цілком логічно постає питання щодо можливостей працевлаштування випускників вітчизняних закладів вищої освіти, яке може відбутися на різних ринках праці, зокрема: у західноєвропейських країнах; у приватному бізнесі в Україні; у вітчизняних бюджетних сферах діяльності (державна служба, політика, фіскальні органи, силові структури, освіта, наука, охорона здоров'я тощо). Наше бачення з цього приводу є наступним:

«У західноєвропейських країнах за отриманою кваліфікацією в українських ЗВО можуть працевлаштуватися лише ті випускники, компетентність яких виявиться конкурентоспроможною на європейських ринках праці. Цілком очевидно, що дипломованим неукам двері на ці ринки наглухо зачинені. Вони це прекрасно усвідомлюють, а тому туди й не рипнуться. Приватний бізнес в Україні теж не буде тримати на роботі некомпетентних осіб, хіба що своїх родичів. Тож основними місцями працевлаштування осіб з неякісною вищою освітою залишаються бюджетні сфери діяльності України. Неякісна вища освіта - це неконкурентоспроможна за критеріями цивілізованих ринків праці компетентність особи, яка такою освітою володіє. Коли конкурентоспроможні громадяни за неможливістю гідно реалізувати свій людський капітал на рідних теренах мігрують закордон в пошуках пристойної реалізації, а у владних державних структурах за протекцією з року в рік накопичується все більше неуків з дипломами про вищу освіту, тоді годі сподіватись на конкурентоспроможність України, яка б забезпечила їй гідне місце серед країн-лідерів світової спільноти» ${ }^{208}$.

Ті ж випускники вітчизняних 3ВО, які не мають протекції, поповнюють лави безробітних або влаштовуються на роботу, що не потребує вищої освіти. У наших суспільних умовах серед таких безробітних або серед тих, хто працює не за фахом, можуть опинитися й ті, хто має суттєво вищий рівень компетентності у порівнянні з тими, хто працевлаштувався по протекції. Адже ми є свідками того, коли після чергової зміни влади здійснюється тотальна зачистка так званих попередників без огляду на їхню компетентність і заведення на ключові владні посади своїх довірених осіб, навіть за умови, що їх компетентність на порядок нижча від тих, кого вони замінили. А далі ставленики (в межах підвладного їм суспільного сектора) роблять заміну «чужих» на «своїх» по вертикалі та горизонталях ієрархії, керуючись тим же принципом: «Свій за визначенням кращий ніж чужий». Реальна компетентність і суспільна корисність «своїх і чужих» у такій спотвореній кадровій політиці, що культивується в сучасному українському суспільстві десятиліттями поспіль, брутально нехтуються. Це вказує на те, що підбір і розстановка кадрів за таким принципом здійснюється не в суспільних, а у приватних інтересах.

Такий підхід включив на вітчизняних теренах механізм негативної соціальної селекції, коли у суспільну ієрархію з кожною ротацією владних суб'єктів залучаються за рівнем світоглядної та професійної компетентності громадяни України не кращі з кращих, а навпаки гірші, які потім за собою тягнуть ще гірших. Цим власне й пояснюється нинішній кадровий голод в Україні, коли бажаючих потрапити в суспільну владу багато, але тих, хто міг би бути суспільно корисним, система влади олігархічного штибу не потребує, оскільки таке залучення суперечить інтересам можновладців.

Тож цілком закономірно й маємо парадокс, коли Україні об'єктивно вкрай бракує компетентності, а суб'єктивно компетентність у ній нехтується. Суб'єктивно компетентність в Україні не затребувана державою як суспільним інститутом влади, оскільки вона захоплена олігархічно-клановими угрупуваннями й використовується ними для власного збагачення, а не в інтересах українського народу. Очевидними індикаторами захоплення держави в українському суспільстві $€$ монополізація його політичної та економічної сфер діяльності, наслідками якої є свавілля і безвідповідальність суб'єктів влади перед народом, відсутність цивілізованого конкурентного середовища, де-факто закрита кадрова політика, корупція тощо.

Ось як характеризує розвиток демократії в Україні, у процесі якого її держава потрапила під контроль олігархічних угрупувань, М. Мінаков: «Вже у перші роки незалежності відбувається поєднання політичних інституцій на формальні та неформальні. Перші були описані в законах, а пізніше й у Конституції (президент, парламент, місцеве самоврядування, незалежне судочинство, партії тощо). Натомість другі були поза офіційними санкціями чи риторикою, однак дедалі більше визначали доступ до центрів влади і контролювали найважливіші економічні ресурси країни (неопатримальні групи, фінансово-політичні групи, олігархічні національні та регіональні «клани»). Так, $є$ всі підстави стверджувати, що у драматичного перехідного періоду 1990-х років політична система України набула поєднання демократичного фасаду та закулісних олігархічних

\footnotetext{
208 Рябченко В. Протекціонізм некомпетентності в українському суспільстві як чинник демотивації студентів у здобутті ними якісної вищої освіти. Збірник наукових праць IV Всеукраїнської науково-практичної конференції. Особистість студента та соціокультурне середовище університету в суспільному контексті. Київ, 2020. С. 90. URL: https://ihed.org.ua/wpcontent/uploads/2020/07/IV Vseukr.konf 18-05-2020 Zbirnyk.pdf
} 
інституцій. Співіснування цих двох типів політичних інституцій визначало наш розвиток весь цей час. Суперечності між цими двома шарами політичної системи стали передумовами революційних циклів у 19922004 та 2005-2014 роках. У ході кожного з цих циклів на зміну періоду демократичних спроб приходила олігархічна конкуренція й суспільна дезорієнтація, а згодом і спроби авторитарної консолідації влади, яка призводила до громадянського протесту на межі з повстанням і зміни режиму (Помаранчева революція та Євромайдан)» 209.

Олігархічні режими влади, як показує світовий досвід, не піддаються вдосконаленню й неухильно ведуть суспільство до занепаду. Що це саме так, переконливо доводять у своєму дослідженні «Чому нації занепадають. Походження влади, багатства ma бідності» 210 Д. Аджемоглу та Д. Робінсон, ілюструючи це на прикладах країн, які занепадають, занепали і деградують. Занепад і деградацію дослідники пов'язують з домінуванням у суспільстві екстрактивних політичних та економічних інститутів. Тоді як розвиток і процвітання нації забезпечують інклюзивні інститути. На жаль, у зазначеному дослідженні не вдалося знайти чітких дефініцій термінів «екстрактивні інститути» та «інклюзивні інститути». Але зі змісту праці і розлогих характеристик, які їі автори дають цим інститутам та наслідкам, що ті породжують у суспільстві, нескладно зробити інтерпретацію сутності екстрактивних та інклюзивних інститутів. Найпростіше тлумачення цієї сутності, що не суперечитиме змісту праці, можна зробити, апелюючи до первинного смислу слів «екстракт» та «інклюзія» і похідних від них прикметників «екстрактивний» та «інклюзивний», якими визначені політичні й економічні інститути.

Екстракт як іншомовне слово походить від extractum, що у перекладі з латині означає витягнуте 211 . Тому цілком логічно, що синонімом «екстракту» як вживаного в українській мові іншомовного слова $є$ українське слово «витяжка». Екстрактивний на латині extractus у перекладі означає вилучення ${ }^{212}$. Таким чином, виходячи з буквального смислу слів «екстракт» та «екстрактивний», можна визначити екстрактивні інститути як такі, за допомогою яких відбувається витяжка, а точніше вилучення наразі суспільних надбань тими суб'єктами, що мають можливості запроваджувати і використовувати їх у своїх приватних чи корпоративних цілях, брутально нехтуючи при цьому інтересами народу. Адекватність такого розуміння сутності екстрактивних інститутів підтверджує наступне твердження Д. Аджемоглу та Д. Робінсона: «Між економічними та політичними інститутами існує потужна синергія. Екстрактивні політичні інститути зосереджують владу в руках вузької еліти й накладають слабкі обмеження на здійснення ними влади. Тоді економічні інститути структуруються цією елітою задля відбирання ресурсів у решти суспільства. Тобто екстрактивні економічні інститути природно супроводжують екстрактивні політичні. Справді, щоб вижити, екстрактивні економічні інститути мають бути нерозривно пов'язані з екстрактивними політичними. Інклюзивні політичні інститути, широко розподіляючи владу, схильні викорінювати такі економічні інститути, які експропріюють ресурси багатьох, зводять бар'єри для виходу на ринок і придушують ринки, щоб вигоду отримували лиш одиниці» ${ }^{213}$.

Сутність інклюзивних інститутів зрозуміліша, що підтверджується наведеною цитатою. Слово «інклюзія» має англомовне походження і у перекладі з англійської «іnclusion» означає «включення». Наразі у контексті змісту книжки Д. Аджемоглу та Д. Робінсона таке включення пояснюється як широке залучення громадян до врядування або плюралістичний розподіл влади у суспільстві, що уможливлюється лише в умовах демократії. Тому автори дослідження роблять наголос на первинності або провідній ролі інклюзивних політичних інститутів у забезпеченні процвітання нації: «Інклюзивні економічні інститути створюються на основі, закладеній інклюзивними політичними інститутами, що забезпечують широкий розподіл політичної влади в суспільстві й обмежують їі довільне здійснення. Такі політичні інститути також ускладнюють узурпацію влади та руйнування основ інклюзивних інститутів. Ті, хто контролює політичну владу, не можуть легко використовувати їі для встановлення екстрактивних економічних інститутів, що сприятимуть власному

\footnotetext{
209 Мінаков М. Поступ демократії в Україні (1991-2019). URL: http://sg-sofia.com.ua/postup-demokratii-v-ukraini-1991-2019

210 Аджемоґлу Дарон, Робінсон Джеймс. Чому нації занепадають. Походження влади, багатства та бідності / пер. з англ. Олександр Дем'янчук. 4-те вид. К. : Наш формат, 2019. 440 с.

211 Словник іншомовних слів: 23000 слів та термінологічних словосполучень / уклад. Л. О. Пустовіт та ін. К.: Довіра, 2000. 1018 с. (Б-ка держ. службовця. Держ. мова і діловодство). С. 411.

212 Словник іншомовних слів: 23000 слів та термінологічних словосполучень / уклад. Л. О. Пустовіт та ін. К.: Довіра, 2000. 1018 с. (Б-ка держ. службовця. Держ. мова і діловодство). С. 411.

213 Аджемоґлу Дарон, Робінсон Джеймс. Чому нації занепадають. Походження влади, багатства та бідності / пер. з англ. Олександр Дем'янчук. 4-те вид. К. : Наш формат, 2019. С. 73-74.
} 
збагаченню. Інклюзивні економічні інститути забезпечують справедливий розподіл ресурсів, підтримуючи існування інклюзивних політичних інститутів» 214.

Адекватне розуміння сутності екстрактивних та інклюзивних політичних й економічних інститутів та їх визначальної ролі в цивілізаційному розвиткові суспільства надзвичайно актуальне в контексті сучасної української соціальної дійсності, оскільки це розуміння дозволяє збагнути чому ми маємо те, що маємо, і чому ми не маємо того, що мають наші найближчі сусіди. Наприклад, Польща та країни Балтії, які на старті нашої державної незалежності не мали й близько тих можливостей для успішного цивілізованого розвитку, які були тоді в України. Зокрема, розвинений і не розпорошений по всьому світу людський капітал, левова частка якого через незатребуваність у власному суспільстві розвиває економіку тієї ж Польщі, причому випереджувальними темпами у порівнянні з українською економікою ${ }^{215}$. За даними Світового банку у 2018 році ВВП на душу населення в Україні був у 5 разів нижчим від Польщі, що у грошовому вираженні складало відповідно 3095 і 15575 доларів США ${ }^{216}$. Цією різницею красномовно підтверджується суттєво вища продуктивність та конкурентоспроможність плюралістичної економіки (продуцентами якої є чисельні суб'єкти середнього й малого бізнесу) від монополізованої економіки декількох олігархів, яка паралізувала успішний суспільноекономічний розвиток Україні й прирекла ії на відставання та стагнацію.

За умови, що темпи зростання економіки України будуть такими як у 2018 році, нам потрібно 36 років, щоб досягти рівня економічного розвитку Польщі, який вона мала у тому ж 2018 році. Але ж польська економіка не заклякне, а буде нарощувати свій розвиток. Якщо Україна за три десятиліття відстала від неї настільки, то виникають глибокі сумніви щодо ії наближення до рівня економічного розвитку Польщі у наступні чотири десятиліття, протягом яких народиться й увійде в доросле життя ще два покоління українських громадян. Невже і в майбутні сорок років найпродуктивніші молоді українці, рівень конкурентоспроможності яких дозволятиме їм працевлаштовуватись на цивілізованих ринках праці, будуть приречені шукати кращої долі в чужих країнах, зокрема в Польщі? Експерти розрахували, що наздогнати Польщу можна за один рік, якщо економіка України зросте протягом року на $236 \%{ }^{217}$. Зауважимо, що у 2019 році ВВП України зріс лише на 3,2\%, що 0,2\% нижче приросту у 2018 році ${ }^{218}$. 3 такою динамікою розвитку економіки Україна приречена на вічний навздогін з постійним відставанням від країн, які своєчасно стали на шлях демократичного розвитку. А про рівень розвитку країн з усталеними демократіями і правовими державами годі й мріяти.

Така різниця цивілізаційного розвитку зумовлена тим, що в Польщі і країнах Балтії, які вирвалися, як і Україна, з лабетів Радянського Союзу, були запроваджені інклюзивні політичні й відповідні їм економічні інститути. Тоді як в Україні відбулася трансформація екстрактивних інститутів радянського режиму влади в екстрактивні інститути олігархічного штибу. Олігархів в Україні до 1991 року не було, що є цілковито очевидним фактом. А очевидне не потребує доказів, тобто $є$ аксіомою. Такою ж аксіомою $€$ й те, що трансформація як політичних, так й економічних інститутів безпосередньо залежить від суспільної влади й тих їі суб'єктів, які визначально впливають на повне скасування чи зміну старих і започаткування нових інститутів. Тож те, що Україна зі старту незалежності своєї держави від метрополії ступила на шлях існування так званих «бананових республік», які звільнилися від колоніальної залежності, $\epsilon$ результатом вибору напряму трансформації їі політичних та економічних інститутів, зроблений тоді тими суб'єктами влади, від яких визначально залежав цей вибір. А сумнозвісний для українського народу вислів «маємо те, що маємо» - це від лукавого, а точніше цинічна іронія над нашим народом, держава якого захоплена олігархічно-клановими угрупуваннями й використовується ними для власного збагачення.

Не знаходиться достатньо підстав, щоб такий історичний вибір шляху цивілізаційного розвитку України пов'язувати з якоюсь однією чи бодай декількома найвпливовішими у той період суспільними особами. Але точно не можна такий вибір вважати неусвідомленою історичною політичною помилкою та списувати на професійну некомпетентність тих, від кого залежав цей вибір. У такому разі треба визнати, що лідери Польщі та колишніх прибалтійських республік Радянського Союзу були професійно компетентніші за тодішніх лідерів

\footnotetext{
214 Аджемоглу Дарон, Робінсон Джеймс. Чому нації занепадають. Походження влади, багатства та бідності / пер. з англ. Олександр Дем'янчук. 4-те вид. К. : Наш формат, 2019. С.74-75.

215 Ломоносова Т. 11\% зростання ВВП Польщі забезпечили українські мігранти. 24 грудня, 2019. Політична критика. Видання на перетині політики, науки та культури. URL: https://politkrytyka.org/2019/12/24/11-zrostannya-vvp-polshhi-zabezpechyly-ukrayinski$\underline{\text { migranty/ }}$

216 Список країн за ВВП (номінал) на душу населення. URL: https://cutt.ly/ohyg8xa

217 Від соціалізму до заможної країни: 16 графіків про економіку Польщі. Опубліковано 26 лютого 2019 в 2:01. Украина в инфографике. URL: https://businessviews.com.ua/ru/economy/id/ekonomika-polschi-1930/

218 Винокуров В. Економіка України у 2019 році зросла на 3,2\% - Держстат. 20 березня, 2020 17:03. URL: https://hromadske.ua/posts/ekonomika-ukrayini-u-2019-roci-zrosla-na-32-derzhstat
} 
України. Важко припустити, що наші лідери були настільки політично неграмотні, що не могли відрізнити цивілізований шлях розвитку, яким рухаються країни-лідери світової спільноти, від напряму трансформації суспільства, який веде до країн так званого третього світу. Отже, це є цілком усвідомлений історичний вибір. І вибір цей є проявом усвідомлено хибної свідомості. Тому, на превеликий і тепер уже історичний жаль, цей вибір відбувся не на користь українського народу. Державницький світогляд перемогла клептоманія, для задоволення якої суспільна влада (як власність тих, хто нею користується) відкрила найліпші можливості. Тож нашим лідерам, які зробили такий історичний вибір напряму трансформації політичних та економічних інститутів українського суспільства, бракувало світоглядної компетентності.

Ще у 1992 році в Україні всі громадяни за майновим цензом були рівні чи майже рівні. У спадок від попереднього режиму влади ці громадяни отримали всенародну власність, яка належала всьому українському народові, а не тим, хто у цей історичний момент був причетний чи наближений до суспільної влади. Аж раптом, уже із середини 90-х років буквально через декілька років після набуття державної незалежності в Україні з'явилися можновладці та запанувала на її теренах соціальна нерівність, яка з кожним роком трансформації українського суспільства набуває все більш жахливих форм соціальної несправедливості.

Цілком очевидним $€$ те, що така соціальна стратифікація не $є$ наслідком кропіткої праці тих, хто так стрімко розбагатів, і лінню тих, хто зненацька збіднів чи зовсім опинився у злиднях: «Стрімка стратифікація українського суспільства відбулася вже на початку 1990-х років, коли різка зміна умов господарювання і масштабна приватизація спричинили концентрацію ресурсів і національного багатства в руках відносно нечисленної групи людей при зубожінні та низькооплачуваній зайнятості переважної більшості населення. В Україні з'явилися дійсно багаті родини, причому їх статки були сформовані в основному завдяки доступу до державної власності та приватизації найбільш прибуткових ї̈ об'єктів. Надзвичайно короткий термін накопичення цього багатства значною мірою вплинув на бажання всіляко демонструвати свої доходи, часто навіть завищуючи їх. Одночасно відбулося катастрофічне падіння рівня життя більшості українців. У першу чергу постраждали безробітні й ті, хто з різних причин виявилися неготовими до різких соціально-економічних зрушень» ${ }^{219}$.

Широкий загал громадян України, які репрезентують ії народ, за якихось 3-5 років через гіперінфляцію та ваучеризацію втратив свої грошові заощадження і частки всенародної власності. I у цей же стислий строк величезні фінанси і цілісні комплекси донедавна всенародного майна опинилися у власності та розпорядженні незначної купки громадян України, яких стали іменувати можновладцями. Спираючись на закон збереження матерії у формулюванні М. Ломоносова («Всі зміни, що трапляються в натурі, такого суть стану, що скільки чого в одного тіла віднімається, стільки додається до іншого. Так, коли де убуде трохи матерії, то збільшиться в іншому місці» ${ }^{220}$ ), можна зробити цілком релевантну інтерпретацію майнового розшарування українського народу в процесі трансформації українського суспільства з планової економіки в ринкову із запровадженням в ньому інституту приватної власності.

Не потребує доказів за своєю очевидністю те, що віднялося у населення України: «Менш доказово з позицій юридичної казуїстики упередженого штибу, але цілком очевидно, де чи в кого збільшилося на те, що віднялося в українського народу шляхом гіперінфляції та ваучеризації. Панівна верства так раптово виникла в українському суспільстві саме завдяки оволодінню фінансовими й матеріальними ресурсами, які належали всьому народові, у такі віртуальні способи. Як виявилось, в епоху знань, щоб неймовірно збагатитися одним, а збідніти іншим, не потрібно йти війною для загарбання півсвіту, а достатньо використати грамотно вибудувані «кидкові» схеми, з допомогою яких у сучасних фінансових системах знеособлене знаковими вираженнями багатство дуже швидко в межах чинного правового простору перекочувало з одних рук в інші та набуло в них, як і в епохи завойовницьких війн і грабіжницьких походів, натурального вигляду й адекватної розмірам могутності» 221 .

\footnotetext{
219 Лібанова Е.М. Нерівність в українському суспільстві: витоки та сучасність. «Економіка України». 2014. №3 (628). C.8-9. URL: file:///C:/Users/user/AppData/Local/Temp/EkUk 20143 2.pdf

${ }^{220}$ Филиппова Е. Сколько лет закону сохранения материи. Парламентская газета. Издание Федерального собрания Российской Федерации. URL: https://www.pnp.ru/social/skolko-let-zakonu-o-sokhranenii-materii.html

221 Рябченко В. Вплив соціального середовища на ефективне врядування в українських університетах: світоглядно-компетентнісний аспект. Механізми реалізації ефективного врядування в університетах України в умовах євроінтеграції : методичні рекомендації / І. Драч, С. Калашнікова, О. Паламарчук, В. Рябченко, Л. Червона; за ред. С.Калашнікової. Київ : Інститут вищої освіти НАПН України, 2019. C. 28. URL: https://ihed.org.ua/wp-content/uploads/2020/07/Mekhanizmy vriaduvania univ UA metodychni IVO-2019-93p avtorskolektiv.pdf
} 
Ставши на такий шлях суспільно-економічної трансформації, Україна потрапила в порочне коло, що веде ії неухильно до деградації і зовсім не до прогресу у своєму цивілізаційному розвиткові доти, доки вона з цього кола не вирветься. Вже згадані нами раніше Д. Аджемоґлу та Д. Робінсон пояснюють, що порочне коло утворюється екстрактивними політичними й економічними інститутами, тоді як інклюзивні інститути формують доброчесне коле, яке сприяє успішному цивілізованому розвиткові та процвітанню нації ${ }^{222}$. Наразі Польща, Латвія, Литва й Естонія, з якими ми порівнюємо Україну, утворили в себе доброчесні кола, які ведуть їхні народи до процвітання.

Україні щоб вирватись із порочного кола, необхідно зімкнути у своєму суспільстві розірване коло демократії: «Таким чином, щоб розірвати замкнуте коло соціальних пороків та болячок, якими системно вражений український соціум, необхідно зімкнути в систему розірване коло демократії на його теренах. Для цього треба вилікувати інститут влади від синдрому набутого імунодефіциту. Імунітет влади демократичної держави формується самодостатністю їі народу у здійсненні контролю і збалансуванні адекватною відповідальністю свободи владних суб'єктів в їхній поточній діяльності на всіх ієрархічних щаблях соціуму. Така самодостатність народу неможлива без вільних і незалежних, у тому числі від влади, громадян. Шлях до такої волі й незалежності пролягає через здійснення продуктивної праці, суспільно-корисної діяльності, які дозволяють громадянам не лише виживати животіючи, а відтворювати себе повноцінно, як людину, у всіх життєвих вимірах. А це залежить від тих умов і рівних можливостей за принципами справедливості та невідчужуваних громадянських прав, які має створювати в соціумі держава, як інститут влади. Коло зімкнулось» 223. Тепер вже майже на тридцятому році державної незалежності України від колишньої метрополії актуальність обґрунтованої нами ще у 2006 році пропозиції, на жаль не відпала, а навпаки, лише загострилася. І все тому, що держава як політичний інститут українського суспільства незалежна від свого народу, який її започаткував своїм референдумом 1 грудня 1991 року і якому за Конституцією України вона має служити й бути йому підконтрольною, отже й підзвітною.

Це по-перше, підтверджується наведеною сумною статистикою, що унаочнює катастрофічне відставання України у світових перегонах цивілізаційного розвитку. А по-друге, ілюструє залізний закон олігархії, нещадною дією якого пояснюють занепад націй Д. Аджемоґлу та Д. Робінсон: «Суть залізного закону олігархії, цього особливого образу порочного кола, полягає в тому, що нові лідери, скидаючи старих з обіцянками радикальних змін, не приносять нічого нового, лише те саме, що було» 224 . Посилаючись на німецького соціолога P. Міхельса, який визначив цей закон, дослідники пояснюють: «Внутрішня логіка олігархій, а фактично і всіх ієрархічних організацій, полягає в тому, стверджував Р. Міхельс, що вони відтворюють самі себе не лише в тій самій групі, що перебуває при владі, а й навіть тоді, коли цілком нова група перехоплює владу» 225

Надзвичайно актуальним для України $€$ і наступне застереження: «Якщо екстрактивні інститути створюють величезну нерівність у суспільстві, надають величезні статки і необмежену владу для правителів, буде багато охочих боротися за перехоплення контролю над державою й інститутами. Тоді екстрактивні інститути не лише торують шлях для наступного режиму, що буде більш екстрактивним, а й породжують постійну боротьбу й громадянські війни. Останні, своєю чергою, приводять до ще більших людських страждань і руйнують навіть те, чого досягла слабка централізація держави в цих країнах. Це також часто спричинює сповзання в беззаконня, руйнування держави та політичний хаос, розбиваючи всі надії на економічне процвітання...» ${ }^{226}$. Адже саме така закономірність проявляється в українській соціальній дійсності не лише тоді, коли державна влада переходить від одних олігархічно-кланових угрупувань до інших, а й тоді, коли в українському політикумі з'являються так звані «нові обличчя». Навіть і тоді, коли ці обличчя молоді, розумні, патріотичні, популярні й героїчні.

\footnotetext{
222 Аджемоглу Дарон, Робінсон Джеймс. Чому нації занепадають. Походження влади, багатства та бідності / пер. з англ. Олександр Дем'янчук. 4-те вид. К. : Наш формат, 2019. 440 с.

223 Рябченко В.І. Технократизм і доля українського села: Занепад сучасного села як системна криза укр. соціуму: соц.-філос. аналіз проблеми. К.: Знання України, 2006. С. 67.

224 Аджемоґлу Дарон, Робінсон Джеймс. Чому нації занепадають. Походження влади, багатства та бідності / пер. $з$ англ. Олександр Дем'янчук. 4-те вид. К. : Наш формат, 2019. С. 315.

225 Аджемоглу Дарон, Робінсон Джеймс. Чому нації занепадають. Походження влади, багатства та бідності / пер. з англ. Олександр Дем'янчук. 4-те вид. К. : Наш формат, 2019. С. 314.

226 Аджемоглу Дарон, Робінсон Джеймс. Чому нації занепадають. Походження влади, багатства та бідності / пер. з англ. Олександр Дем'янчук. 4-те вид. К. : Наш формат, 2019. С. 320.
} 
Індикатором небезпечного прояву «залізного закону олігархії» в Україні є зростання соціальної нерівності на її теренах 227 , ескалація прагматичного цинізму й протекціонізму некомпетентності, використання влади як засобу соціального паразитування тощо. Демонстрація найкоротшого шляху до статків і збагачення за допомогою влади не мотивує до продуктивної праці, інфікує свідомість соціальним паразитизмом і не лише дорослих працездатних громадян, а й дітей та студентську молодь. А це найстрашніше для суспільства, оскільки за молоддю і підростаючими поколіннями майбутнє Українського суспільства.

З цього приводу постає ціла низка прагматичних запитань щодо продуктивного розвитку суспільства, у якому значна чисельність його панівної верстви стала заможною неправедним шляхом, зокрема зловживанням влади:

Чи стануть на праведний шлях заробляння собі на хліб насущний ті діти й онуки, які виросли в родинах такої верстви?

А які світоглядні орієнтири у цьому сенсі формуються у дітей з незаможних чи взагалі бідних сімей, від очей і свідомості яких неможливо приховати розкішне життя їхніх однолітків, батьки яких займають владні статуси й офіційно живуть на зарплату, що аж ніяк не дозволяє так розкошувати?

І якими освітніми стандартами та програмами й педагогічними методами, технологіями та моральними настановами можна переформувати соціально-паразитичний світогляд у громадянсько-державницький?

Наша відповідь на означені запитання є наступною: «Навіть першокласник не повірить у мораль, що мовиться у проповідях і повчаннях, якщо вона не буде підтверджуватися у його реальному житті. Він прагматично зметикує, виходячи з наших суспільних реалій, що той, хто смиренно дотримується моралі, до якої його закликають, приречений на жебрацький рівень життя, а по-справжньому розкошує той, хто її нахабно й цинічно порушує» ${ }^{228}$.

Тож цілком актуальною настановою у цьому сенсі і в нашій соціальній дійсності залишається відома давня англійська приказка: «Не виховуйте дітей, все одно вони будуть схожі на вас. Виховуйте себе». Ця настанова актуальна не лише для батьків, вихователів у дошкільних закладах освіти, вчителів у школах та викладачів у закладах вищої освіти, а першочергово для суб'єктів суспільної влади, починаючи з вершини її піраміди й завершуючи низовими ієрархічними рівнями. Адже годі очікувати моральність у тому соціальному середовищі, керівник якого у своєму стилі життя й поведінці демонструє нехтування нормами моралі.

За подвійними моральними стандартами неможливо сформувати доброчесне соціальне середовище. Суспільство не може бути консолідованим, коли його народ має жити за писаними законами, а для влади ці закони не писані і вона живе за своїми поняттями. Неконсолідоване і деморалізоване суспільство приречене на деградацію. Цю закономірність народ визначив загальновідомою приказкою: «Риба гниє з голови».

Менш відомою для широкого загалу у синергетиці є теорія фракталів, яка дає наукове пояснення зазначеної закономірності. Концептуально сутність цієї теорії зводиться до того, що в соціальній системі відбувається самовідтворення самоподібних взаємопов'язаних між собою структур (фракталів) за зразком, який формується на верхньому щаблі ієрархії системи ${ }^{229}$. Простіше кажучи або повертаючись до вже згаданої приказки, те, що твориться на верхах, за образом і подобою відтворюється по вертикалі ієрархії у низах. Зокрема, системна корупція як найбільший та найзагрозливіший прояв соціального паразитування відбувається у відповідності до теорії фракталів: «як системне утворення розвинута корупція зазвичай має фрактальну структуру дендритного типу, що визначається ієрархічною системою стягування та розподілу предметів хабара (грошей, матеріальних цінностей, послуг та інших майнових вигід) у формі поборів тощо. Така структура вибудовується в процесі самоорганізації корупційної діяльності, причому корупційна «субординація» відповідає субординації легальній. На вищому рівні корупційної «драбини» перебуває, переважно, високопосадовець, на нижчому рівні - підпорядковані їй посадові особи, теж наділені владними повноваженнями, які безпосередньо спілкуються з хабародавцями. Корупціонер вимушений ділитися 3 начальником, оскільки начальник має можливості позбавити його джерела додаткового доходу. Таким чином, системна корупція «вбудовується» в механізм держави. Корупційний фрактал суспільних відносин «накладається» на їхню «нормальну» структуру, спотворюючи ії (так само, як ракова пухлина деформує здорову фрактальну структуру біологічних тканин), призводить до хаотизації суспільних відносин. Що

227 Українців визнали однією 3 найбідніших націй у світі. Слово $і$ діло. Аналітичний портал. URL: https://www.slovoidilo.ua/2018/10/19/novyna/suspilstvo/ukrayincziv-vyznaly-odniyeyu-najbidnishyx-naczij-sviti

228 Рябченко В.І. Світоглядно-методологічні засади формування й використання поняттєво-термінологічного апарату в науковій, освітній та суспільно-практичній діяльності: Монографія. Київ: Фітосоціоцентр, 2011. С. 324.

229 Князева Е. Н. Основания синергетики. Режимы обострения, самоорганизация, темпомиры / Е. Н. Князева, С. П. Курдюмов. - СПб. : Алетейя, 2002. - С. 84-87. 
розвинутішою є корупційна система, то пригнобленішими є функції державного механізму. Хаотизація врегульованих правом суспільних відносин, спричинена корупцією, впливає на правову систему суспільства: органи виконавчої, законодавчої й судової влади належно не функціонують, система права не виконує функцій регулювання суспільних відносин, правовідносини підміняють неправовими зв'язками, у буденній правосвідомості спотворюються уявлення про належну поведінку» 230.

Теорія фракталів дозволяє збагнути рушійні сили, завдяки яким корупція у суспільстві стає системною, отже і нездоланою доти, доки залишається непорушною система суспільних відносин, яка спонукає до активної чи пасивної корупції тих, хто до неї долучається, або відторгає тих, хто противиться корупції. Наразі маємо на увазі відторгнення доброчесних громадян, що виявляють так звану нульову толерантність до корупції, яку цинічно декларують ті, хто реально в корупцію занурений. Системна корупція $€$ одним з визначальних рушіїв механізму негативної соціальної селекції, оскільки вона здійснює відбір кадрів навиворіт - абсорбує в ієрархічних структурах охочих до соціального паразитування та відторгає і виштовхує з цих структур тих, хто не толерує корупцію й чинить їй активний супротив.

Протекціонізм некомпетентності $€$ складовою механізму негативної соціальної селекції, який $€$ деструктивним і самовбивчим для суспільства. Інтегральною причиною наявності механізму негативної соціальної селекції в сучасному українському суспільстві $€$ відсутність адекватної відповідальності за некомпетентність і зловживання владою:

«Справедливість не може запанувати у тому соціумі, де владі легше, ніж народу. Цей древній принцип справедливого влаштування людського соціуму, як максиму, можна розлого проінтерпретувати, але у контексті нашого дискурсу ми обмежимось лише наголосом на проблемі сумірності свободи і відповідальності громадян у суспільстві. Якби відповідальність владних суб'єктів у нашому суспільстві була вищою за ті можливості, які дозволяють їм влаштовувати своє благополуччя з допомогою влади, у порівнянні 3 відповідальністю та аналогічними можливостями громадян, які не маючи ніякого відношення до влади і незалежно від неї могли $б$ забезпечувати не нижчий рівень свого життя власною продуктивною суспільною працею відповідно до своєї компетентності, то в нинішніх умовах ми 6 не спостерігали такого стовпотворіння вихідців з народу у структури влади, серед яких значна кількість представників не має достатнього рівня компетентності для зайняття чинних місць, на які вони не лише претендують, а й обіймають їх, як та кухарка на зорі радянської влади. Але ж це для соціуму явно контрпродуктивний шлях підвищення добробуту його громадян.

По-перше, сама влада нічого не виробляє, а лише покликана оптимізувати продуктивний процес свого соціуму, чим і має виправдовувати своє існування та за це ж отримувати адекватну оцінку і винагороду від суспільства.

По-друге, на всіх громадян не вистачить владних місць, якщо навіть влаштувати всенародну чергу тотальних ротацій в її структурах з необхідною щодо загальної чисельності народу мінімізацією міжротаційного періоду.

По-третє, від некомпетентних владних суб'єктів страждає весь соціальний простір, який потрапляє під їнній ієрархічний вплив. Безвідповідальність абсорбує некомпетентних людей в управлінських і функціональних структурах соціальних систем, які, до речі, як відомо, є найскладнішими в управлінні, а відповідальність виштовхує їх звідти, оскільки вона є непосильною для них ношею.

По-четверте, в цілому такий шлях множить соціальний паразитизм у соціумі, оскільки кількість «робочих бджілок» в ньому скорочується. Але на відміну від бджолиної сім'ї, де такі скорочення компенсуються більш напруженою роботою бджіл, що залишаються, у людському соціумі подібні тенденції деморалізують громадян, які здатні займатись продуктивною і суспільно корисною діяльністю» 231.

3 огляду на українське суспільне сьогодення стає цілком очевидним те, що за чотирнадцять років після опублікування процитованого щойно висновку, зробленого нами на підставі критичного аналізу тодішньої соціальної дійсності, проникнення у владні структури й присутність у них некомпетентних і безвідповідальних суб'єктів не зменшується.

А в кінцевому підсумку це свідчить про неухильну дію «залізного закону олігархії», наслідком чого $€$ перебування України в полоні порочного кола, яке вона ніяк не може розірвати щоб вийти на стовповий шлях цивілізованого розвитку. Вітчизняному істеблішменту вкрай бракує як професійної, так і (що значно

\footnotetext{
230 Орлов Ю.Ю. Запобігання корупції: синергетичний вимір. URL: https://cutt.ly/ChyhfNb

231 Рябченко В.І. Технократизм і доля українського села: Занепад сучасного села як системна криза укр. соціуму: соц.-філос. аналіз проблеми. К.: Знання України, 2006. С. 56-57.
} 
проблематичніше для України) світоглядної компетентності, від якої безпосередньо залежить те, на що спрямовують свої професійні знання, уміння, навички, досвід його суб'єкти: на творення добра чи зла; для використання займаної посади на розвиток суспільства і підвищення благополуччя народу чи на задоволення власних інтересів.

Автор у своїх публікаціях багато років поспіль актуалізує проблему світоглядної компетентності як визначальну причину низької конкурентоспроможності України та їі відставання у цивілізаційному розвитку. Під світоглядною компетентністю ми розуміємо здатність людини бути відповідною власним світоглядом тим статусам, які вона займає, і тим суспільним ролям, які вона має виконувати відповідно до займаного статусу. Наразі в цьому контексті маємо на увазі владні статуси й суспільні ролі, що мають виконувати особи, які займають ці статуси, починаючи із суб'єктів верхніх ієрархічних щаблів українського суспільства й завершуючи керівниками місцевого рівня, установ, організацій тощо.

Соціальна дійсність повсякчас унаочнює верховенство світоглядної компетентності над професійною. Протягом періоду державної незалежності України ми мали можливість багаторазово переконатись у тому як нівелюється у вимірі суспільної справедливості й корисності будь-яка висока професійна грамотність суб'єкта влади, якщо той керується соціально-паразитичним світоглядом. Понад це, чим грамотніший суб'єкт влади, який керується таким світоглядом, тим більшу шкоду він може чинити для суспільства. I навпаки, брак професійної компетентності може бути компенсований світоглядною компетентністю. Яскравим історичним прикладом у цьому сенсі слугує Лех Валенса, який не мав вищої освіти, але у виконанні своєї суспільної ролі керувався громадянсько-державницьким світоглядом, що спонукав його сформувати у Польщі доброчесне коло з інклюзивних політичних та економічних інститутів, завдяки чому Польща вийшла на цивілізований шлях розвитку. Задля цього Л. Валенса згуртував навколо себе команду професіоналів, які були з ним солідарні світоглядно й успішно виконали свою суспільну роль, що відповідає історичній місії з огляду на радикальну трансформацію Польщі з комуністичної країни у демократично-правову, яка відбулася успішно у дивовижно стислий період.

Тож те, що Україна потрапила у полон порочного кола на початковому етапі своєї державної незалежності й донині не може від нього звільнитися $€$ наслідком браку світоглядної компетентності першочергово, у тих, хто сформував таке порочне коло і продовжує утримує донині його непорушним.

Сутність системної причини непорушності такого порочного кола нами була розкрита ще напередодні 20-ї річниці Незалежності України: «Справа в спокусах, які зберігаються в системі вітчизняної влади, що зваблюють тих, хто потрапляє в її структури. Ці спокуси затьмарюють свідомість, паралізують громадянську й політичну волю, урешті засліплюють і не дають можливості побачити бакени фарватеру, яким треба рухатись в демократію. У цьому зв'язку й смисловому контексті доречно нагадати історію про двадцятилітнє блукання Одіссея. 3 міфології ми знаємо, коли необхідно було проходити мимо сирен, які заманюють необачливих мореплавців на смертельні скелі, де неминуча катастрофа, то Одіссей як обачливий капітан заздалегідь попросив свою команду прив'язати його до щогли, щоб він не піддався впливу спокусливих звуків і не повів очолюваний ним корабель на вірну загибель. Абстрагуючись від міфології й перекладаючи цю історію як метафору на нашу соціальну дійсність, нескладно побачити аналогію між сиренами й спокусами, які закладені в системі нашої влади для суб'єктів, що потрапляють у її структури, та путами для капітана й обмеженнями влади від ї̈ спокус. Звідси сам собою напрошується висновок, що потрібно зробити для того, щоб наші навколоцивілізаційні блукання врешті припинились і наш суспільний корабель, ім'я якому Україна, рухався в демократичне майбутнє, а не в тоталітарне минуле. Зазвичай про пута для влади як механізми контролю за їі поточною діяльністю та обмеження від зловживань починають точитись суспільні дискусії перед кожними виборами. А після виборів про ці пута згадують лише ті, хто у владу не потрапляє. Тому й зберігається стабільно недемократичний політичний курс нашої держави. I нагально гострим та без відповіді залишається питання: «Де ж той Одіссей, який має вивести наш суспільний корабель в безпечну акваторію, що в сучасному людстві називається цивілізованим демократичним простором?». Але не забуваймо міфології та азів демократії й пам'ятаймо, що мимо рифів та смертельних скель у безпечну акваторію проводять свої кораблі лише ті капітани, яких їхні команди своєчасно «прив'язали до щогли». Такі нагадування незайві для суспільств, які, ще не очунявши від посттоталітарного синдрому, уперто лізуть в авторитаризм, який неухильно приведе в тоталітарне майбутнє» ${ }^{232}$.

\footnotetext{
232 Рябченко В. І. Мова як засіб творення соціальної дійсності: Світоглядно-просвітницьке видання. К. : Фітосоціоцентр, 2011. С. 193. URL: $\quad$ http://dspace.pnpu.edu.ua/bitstream/123456789/6286/1/\%d0\%a0\%d1\%8f\%d0\%b1\%d1\%87\%d0\%b5\%d0\%bd\%d0\%ba\%d0\%be$\% \mathrm{~d} 0 \% 9 \mathrm{c} \% \mathrm{~d} 0 \% \mathrm{be} \% \mathrm{~d} 0 \% \mathrm{~b} 2 \% \mathrm{~d} 0 \% \mathrm{~b} 0 . \mathrm{pdf}$
} 
Ця публікація виходить на тридцятому році Незалежності України від метрополії. Процитований текст майже за десятиліття поспіль, на жаль, не втратив своєї актуальності, оскільки в Україні не відбулося належних системних змін у суспільних відносинах, які б заблокували можливості зловживання владою, що затьмарюють свідомість і паралізують громадянську й політичну волю та залишають у ній непорушним порочне коло 3 екстрактивних політичних й економічних інститутів. 3 огляду на сучасну українську соціальну дійсність не знаходиться переконливих підстав для спростування раніше визначеної причини непорушності цього порочного кола. У процитованому тексті $€$ потреба лише в уточненні тривалості «блукання Одіссея». За епічною поемою Гомера Одіссей повернувся на батьківщину через двадцять років, з яких десятиліття його відсутності було пов'язане з участю у троянській війни, а власне на саме блукання з чисельними пригодами, в тому числі із проходженням його корабля мимо сирен, він потратив десять років, коли повертався додому. Україна ж дотепер реально блукає у замкненому порочному колі втричі довше міфологічної одіссеї та ніяк не може вирватись з нього, щоб запровадити на своїх теренах доброчесне коло й завдяки цьому успішно розвиватися. В Україні править бал цинічний прагматизм, який брутально нехтує мораллю й совістю та керується соціально-паразитичним світоглядом.

Закликати до моралі й совісті тих, хто керується соціально-паразитичним світоглядом, як показує новітній історичний досвід кружляння України в замкненому порочному колі, $є$ наївною й утопічною, отже, невдячною справою, яка у вимірах цинізму клептоманії вважається дивакуватістю. Цинізм треба долати правдою, яка його привселюдно роздягає. Цинізм не виставляє напоказ своє зло, а одягає його в одежі добра на кшталт того, як вовк рядиться в овечу шкіру: «Щоб потворність зла не замаскувалась в пристойні одежі та зло не видавало себе за добро, його треба роздягати в дзеркалі істини про соціальну дійсність. Тільки таким чином можна запобігти дифузії понять добра й зла як у політичній, так і громадянській свідомості, що має зберігати мораль у суспільстві, а совість у душах людей, які в ньому живуть. Установлювати істину про соціальну дійсність покликані, даруйте тавтологію, істинні вчені, а не політики, які за природою влади не схильні до об'єктивної самооцінки й, зокрема, критичного аналізу власних життєвих виявів, від яких значуще залежить об'єктивація соціальної дійсності» ${ }^{233}$.

Справа в тому, що «чим делікатніше добро, тим нахабніше зло. Коли мовчить правда, на їі місці з'являється брехня. Критерієм істини в соціальній дійсності $€$ правда. I коли правда про соціальну дійсність замовчується чи взагалі нехтується, цим спотворюється істина. Якщо така спекулятивність є в політиці, то це не повинно бути в науці й освіти, які мають прагнути до істини й сповідувати ї̈ та формувати адекватний теоретичний рівень суспільної свідомості. У противному разі наука й освіта стають різновидами політики. Коли науки, які переймаються дослідженням соціальної дійсності, стають спекулятивно угодними політиці, така політика, завдячуючи цим наукам, стає сліпою й неадекватною, оскільки із втратою істини, вона втрачає орієнтири в соціальному просторі й часі, де розповсюджується її вплив. Істину як відповідника соціальної дійсності, тобто того, що діється в соціальному просторі, та соціальної реальності як того, що вже відбулося й зафіксовано в соціальному бутті, можна метафорично порівняти із дзеркалом, у якому, відображаючись у вимірах людської моралі, постає добро й зло, що йде з життєвих виявів людей як суб'єктів об'єктивації соціального буття. Якщо істина не хибна, тоді таке дзеркало не викривлене й у ньому добро відображається в пристойному вигляді, а зло - у потворному. Коли ж навпаки, то це світ кривих дзеркал, де краса й добро стають спотвореними, а потворність зла набуває благопристойного вигляду» ${ }^{234}$.

Правда про нашу соціальну дійсність повинна постійно вивертати назовні цинізм, виставляючи напоказ його потворне нутро й цим самим формувати у свідомості відразу до нього як до непристойного соціального явища, яке потребує неприйняття та відторгнення суспільством в цілому й кожним його соціальним осередком зокрема. Чим більше буде в нашому суспільстві соціальних середовищ окремих організацій й установ, у т. ч. закладів вищої освіти, в яких не буде толеруватись цинічний прагматизм як засіб соціального паразитування, тим соціально здоровішим буде суспільство. Тим більш дієвими будуть у ньому мораль і совість як зовнішній та внутрішній регулятори відносин між людьми та їхньої поведінки. У відносинах, що регулюються мораллю й совістю, стає затребуваною репутація, яка цінується у справжньому людському середовищі дорожче ніж гроші, а тому стає потужним засобом блокування протекціонізму некомпетентності, оскільки він ії дискредитує. Системне культивування в сучасному українському суспільстві протекціонізму некомпетентності якраз і

\footnotetext{
233 Рябченко В. І. Світоглядно-методологічні засади формування й використання поняттєво-термінологічного апарату в науковій, освітній та суспільно-практичній діяльності: монографія. К. : Фітосоціоцентр, 2011. С. 279-280.

234 Рябченко В. І. Світоглядно-методологічні засади формування й використання поняттєво-термінологічного апарату в науковій, освітній та суспільно-практичній діяльності: монографія. К. : Фітосоціоцентр, 2011. С. 278-279.
} 
підтверджує те, що репутація в ньому «ламаного гроша» не варта. Адже у цивілізованому конкурентному середовищі, де цінується мораль і совість, бути моральним вигідно, а протекція некомпетентного протеже або особи із негативною репутацією заплямовує репутацію суб'єкта такої протекції. У країнах з доброчесним колом при незначній загрозі заплямування репутації, навіть без ризиків її втрати, суб'єкти влади, не чекаючи офіційних санкцій чи звичайного морального осуду в соціальному середовищі їхнього перебування, 3 упередженням подають у відставку. Таким чином вони зберігають свою гідність і репутацію.

У нас же навпаки, ті, хто мають негативну у вимірах доброчесності репутацію займають ключові позиції у структурах влади, стають за поняттями сучасного цинічно-кримінального сленгу «рішалами» та «смотрящими», розставляють собі подібних на інші так звані хлібні посади, які стають системно корупційними, отже, паразитуючими. Такі цинічні суб’єкти вигідні для суб'єктів влади, які керуються соціально-паразитичним світоглядом. Тому вони постійно видимо чи невидимо присутні в усіх каденціях української влади незалежно від ротацій різних політичних сил, провідники яких щоразу перед черговими виборами гамселять себе в груди та цинічно клянуться раз і назавжди викорінити корупцію. Прикро й сумно, що такі цинічні суб'єкти й ще більш цинічні, оскільки на них покладається політична відповідальність, офіційно владні суб'єкти, які їх використовують у своєму соціальному паразитуванні, сформували у своїх особах імідж успішних людей у сучасному українському суспільстві та позиціонують себе у ньому національною елітою.

Ще прикріше і сумніше те, що принципові доброчесні громадяни, які керуються громадянськодержавницьким світоглядом, дистанціюються від структур влади, а тих, хто з таких громадян потрапляє у владу й прагне служити у ній народу чесно, вважають диваками й називають «лузерами». Й лише тому, що вони не бажають соціально паразитувати. Таке схиблене сприйняття доброчесності й нечесності демонструє те, що ми живемо у країні кривих дзеркал. А ще Антисфен майже два з половиною тисячоліття тому застерігав, що держави гинуть тоді, коли не можуть відрізнити хороших людей від поганих 235 .

Тому правда має пробуджувати інстинкт самозбереження не лише у можновладців, від волі яких залежить розірвання порочного кола мирним шляхом без майданних протестів, революцій і т. д., а й у широкого загалу громадян України, які прагнуть благополучно й успішно жити у ній як у сучасній цивілізованій країні. Правда про загрози для майбутнього цивілізаційного розвитку України від соціального паразитування і системної корупції, як найзагрозливішого його прояву, та в цілому від олігархічного режиму влади й порочного кола, що він породив і утримує непорушним, викладена вище.

Нижче концептуально актуалізуємо правду, що має пробуджувати інстинкт самозбереження у можновладців, які такими стали завдяки українській державі та народу, якому де-юре належить ця держава, а також у громадян України, які мають формувати активне громадянське суспільство, здатне дієво запобігати зловживанням владою їі суб'єктами у їх поточній діяльності. Адже закономірність «влада свавільна настільки, наскільки їй це дозволяє народ» має універсальний прояв, у т. ч. і в Україні. I ніхто не відміняв і не забирав у народу природного права, яким він може скористатися у разі втрати контролю над владою, оскільки він за тим же неписаним правом, а не лише за Конституцією України де-юре є сувереном у своїй країні.

Український народ у своїй новітній державності вже двічі скористався цим правом. Через Помаранчеву революцію та Революцію гідності руками українського народу як суверена у своїй країні державна влада забиралася від одних суб'єктів і передавалася іншим суб'єктам, які щоразу клялися вірно й доброчесно йому служити. На жаль, не те ставалося, на що сподівався український народ. Після кожної революції все поверталося «на круги своя». В обох цих відбираннях і передаваннях державної влади руками народу було продемонстровано поки що непереборну дію залізного закону олігархії. Гібридний режим влади олігархічного штибу виявився сильнішим за громадянське суспільство, потуги якого забракло, щоб після передачі влади взяти у післяреволюційний період під дієвий і головне результативний контроль суб'єктів влади у їхній поточній діяльності та спрямувати їі на користь українського народу, а не в інтересах можновладців.

Але попри всі розчарування, які отримав український народ від зради тих, кому він обидва рази передавав владу, певні просування в утвердженні демократії все-таки відбулися, зокрема щеплення влади проти ї̈ безмежного свавілля. Український народ з усією переконливістю продемонстрував, що він цього не дозволить. Підтвердженням дієвості такого щеплення слугують президентські та парламентські вибори 2014 і 2019 років, що відбулися в межах формально виписаного права і без грубих порушень процедури їх проведення, які значуще могли вплинути на їх результати.

\footnotetext{
235 Таранов П.С. 120 философов: Жизнь. Судьба. Учение. Мысли: Универсальный аналитический справочник по истории философии : в 2 т. Симферополь : «Реноме», 2002. Т. 1. С. 134-136.
} 
Правда про актуальність самозбереження постає з геополітичної ситуації, в якій нині перебуває Україна, і з перебігу розвитку сучасної цивілізації та ії глобалізації і тих викликів, які з цього постають перед українським народом і його державою. Геополітична ситуація визначається розташуванням України між країнами Західноєвропейської цивілізації і Євразійською Росією, яка одержима неоімперським експансіонізмом середньовічного штибу і ніяким чином не може змиритися з тим, що Україна вирвалася з їі колоніального гніту, який прирікав український народ на втрату етнічної самобутності та національної ідентичності. Окупація Росією Криму й розв' язана нею війна на Донбасі стала можливою у ситуації послаблення української державності, що відбулося у процесі революційного відбирання суспільної влади в одних політичних сил і передавання іншим. Керівництво Росії й вороже налаштована проти України частина її населення з нетерпінням очікують будь-якого послаблення щоб розширити плацдарм своєї експансії. А це може призвести до повної втрати державної незалежності, за якою неминуче відбудеться асиміляція українського народу в конгломераті русифікованих майже двохсот народів й етнічних груп, як це вже сталося з багатьма мільйонами українців, що з тих чи інших причин залишилися жити на колонізованій Московським царством території. Переважна більшість етнічних українців, особливо з числа тих родин, які поселилися там ще за царату, не лише не знають материнської мови, а й утратили свою національну ідентичність, позиціонуючи себе «рускімі». За рахунок таких українців століттями поспіль забезпечувався найбільший механічний приріст «рускіх», чисельність яких завдяки цьому постійно зростала. Навіть тоді, коли природний приріст самих «рускіх» падав.

Для того щоб Україна встояла у цій геополітичній ситуації і вбереглася від чергового колоніального поневолення Росією, наше суспільство має бути, як ніколи раніше, максимально консолідованим. А таким воно може бути за умови, коли в ньому влада не буде відчужуватись від народу й не буде розбрату та радикальних протистоянь і ворожнечі. Новітній досвід в умовах української державної незалежності неодноразово продемонстрував закономірність, яка полягає у тому, що відчуження влади у суспільстві негативно корелює $з$ втратою довіри до неї з боку народу. Чим нижчий рівень довіри до влади, тим більша їі відчуженість від народу і навпаки. Втрата довіри до влади є похідною суспільних розчарувань і невиправданих соціальних очікувань як від результатів її діяльності, так і від того як та в які способи ця діяльність здійснюється, куди вона спрямована і т. д. Інтегральними критеріями діяльності влади є справедливість і рівність всіх перед законом. Як бачимо, протекціонізм некомпетентності аж ніяк не відповідає зазначеним критеріям. 3 цього постає фундаментальна суперечність сучасного українського суспільства, яка прирікає його не на розвиток, а на деградацію. А по іншому не може бути, коли в суспільстві розкручується маховик механізму негативної соціальної селекції.

Соціальне паразитування суб'єктів влади навіть поодиноко через корупцію чи якимось іншими шляхами викликає недовіру до всієї владної команди певної політичної сили, а безкарність корупційних дій може детонувати обвал довіри до всієї влади. Наочним підтвердженням цієї закономірності слугує тотальна недовіра, яку продемонстрував український народ під час президентських і парламентських виборів у 2019 році до політичних сил, що взяли владу на хвилі Революції гідності. Тому чинним суб'єктам владі в умовах існуючої такої зовнішньої загрози треба дбати про збереження довіри з боку народу, усвідомлюючи свою історичну відповідальність, оскільки за втратою довіри неминучою може бути не лише втрата влади, а й утрата Української державності. Цим актуалізується проблема репутації в українському суспільстві, нехтування якою веде до цивілізаційного провалля, всю спільноту, яка в ньому проживає.

Руйнівна дія порочного кола полягає не лише в тому, що воно дозволяє діючим суб'єктам влади безкарно соціально паразитувати і відчужуватися від народу, а й у тому, що сили політичної опозиції стають у ньому деструктивними. Адже сучасна українська соціальна дійсність показує, що більшість з таких сил керуються не шляхетними цілями послужити вірою й правдою громаді, народові та суспільству, а одержимі проникненням будь-якими, у т. ч. неправедними шляхами у владу заради власних меркантильних інтересів. Для таких політичних опозиціонерів керівним світоглядним орієнтиром в оволодінні владою стає принцип «чим гірше в суспільстві, тим легше перехопити в ньому владу з допомогою народу». Деструктивність такої світоглядної орієнтації цілком очевидна. В умовах існуючої геополітичної ситуації політичний реванш шляхом перехоплення влади через навмисне погіршання становища в суспільстві не менш небезпечне ніж втрата довіри і підтримки чинної влади з боку народу. Особливо вражає своїм цинізмом жадоба до такого реваншу політичних сил, у яких український народ забрав суспільну владу через тотальну зневіру в їх доброчесності й порядності. Трагічно для України, що така зневіра у доброчесність і справедливість відбулася до влади, яка взяла курс на євроінтеграцію та сприяла відродженню української ідентичності й захисту власне українського від русифікації. Тому парадоксальним виглядає те, що суб’єкти влади, які втратили довіру в українського народу, очолюють національно-патріотичний рух в Україні. Це його розпорошує й аж ніяк не посилює. Таке цинічне використання національно-патріотичного руху та ідеї євроінтеграції заради політичного реваншу 
підриває віру в доцільність українського відродження і зближення України з країнами, які не лише не зазіхають на її державну незалежність, а навпаки зацікавлені в тому щоб Україна збереглася й успішно розвивалася та була міцним форпостом Західноєвропейської цивілізації на кордоні з агресивно загребущою Росією.

Сутність зазначеного парадоксу полягає у тому, що зневіра українського народу в доброчесності та справедливості проросійської влади в Україні консолідує суспільство навколо проукраїнських політичних сил. А зневіра до влади, що перебуває в руках політичних сил, які зайшли в неї під проукраїнськими гаслами, навпаки, підриває віру в українську національну ідею та самостійну спроможність розбудувати конкурентоспроможну, заможну й успішну Україну. Така зневіра посилює антиукраїнські настрої у нашому суспільстві, активізує проросійські сили в Україні, які підривають із середини ії державність. 3 огляду на перебіг трансформації України в умовах її державної незалежності можна виділити три хвилі національнопатріотичного підйому, який консолідував наше суспільство, і три проросійські наступи після того, як ці хвилі спадали. У результаті другого проросійського наступу Україна втратила на невизначений час Крим й отримала війну з Росією в Донбасі. Нині спостерігається третій проросійський наступ, який несе реальну загрозу державності України. Щоб убезпечитись від такого трагічного історичного для українського народу результату, наше суспільство має бути максимально консолідованим. 3 цих хвиль національно-патріотичних підйомів і проросійських наступів необхідно вилучити повчальні уроки, щоб зберегти українську державність. Аналіз цих історичних уроків висвітлений нами в окремій публікації ${ }^{236}$.

Висловлюємо надію, що в умовах зовнішньої загрози з боку Росії та внутрішнього незадоволення своїм життям і суспільним розвитком з боку народу, у можновладців України має в кінцевому підсумку спрацювати інстинкт самозбереження, який буде мотивувати їх до уникнення експропріації їхнього майна та інших надбань, бодай і здобутих у неправедні способи. Вони все ж таки мають втямити цитовану вище настанову Арістотеля, доцільність і практичність якої багаторазово підтверджена у новітній історії цивілізації. Заздрять багатству не представники середнього класу, а люмпенізовані верстви населення, які залюбки підтримують експропріацію і націоналізацію приватної власності. Такі верстви населення слугують базовим соціальним субстратом для культивування комуністичної ідеології та здійснення пролетарських революцій, які своїм спрямуванням і реалізацією налаштовані на тотальну руйнацію. I аж ніяк на творення і створення чогось нового та кращого. У благополучних країнах завдяки розвиненому середньому класові комуністичні ідеї не приживаються. I пролетарських революцій у таких країнах не може бути за визначенням, оскільки у них немає чисельної верстви пролетарів, яким окрім власних ланцюгів нічого втрачати. Тому українські можновладці заради свого убезпечення раніше чи пізніше змушені будуть створювати сприятливі умови для розвитку середнього класу в Україні. А задля цього необхідно, першочергово, розірвати симбіоз бізнесу й політики та демонополізувати політичну й економічну сфери українського суспільства, сформувавши в ньому цивілізоване конкурентне середовище на основі неухильного дотримання принципу рівності всіх перед законом. Основним і безальтернативним механізмом загнуздання дикого капіталізму й переведення приватного капіталу в русло цивілізованого розвитку $€$ демократично-правова держава. Це доведено країнами-лідерами світової спільноти.

В Україні для її продуктивного успішного суспільного розвитку, підвищення конкурентоспроможності й забезпечення благополуччя та процвітання українського народу нагально важливими $€$ децентралізація управління й запровадження механізмів ефективного врядування та розвинений якісний людський капітал. Рівень розвитку і якості людського капіталу залежить від економічної свободи, за індексом якої Україна серед 180 країн світу посідає 134-е місце, а в європейському регіоні займає останню, 45-ту позицію, входячи у категорію країн «В основному невільні» ${ }^{237}$. Обмеження економічної свободи, невільність продуктивних громадян виникає у наслідок надмірної централізації управління й контролю з боку держави, що в цілому паралізує ї ініціативу, підприємливість, креативність, прагнення до інновацій тощо. Чим більше контролерів, тим більше корупціонерів і соціального паразитування в суспільстві, що неухильно й демонструє наша соціальна дійсність. Це є прямим свідченням того, що українська держава як інститут влади не виконує своєї суспільної місії і не служить народові, який ї̈ започаткував.

\footnotetext{
236 Рябченко В. Протекціонізм некомпетентності як чинник блокування підвищення якості вітчизняної вищої освіти та зниження конкурентоспроможності України // Міжнародний науковий журнал «Університети і лідерство» . 2019. 1(9). С. 149-189. URL: https://ul-journal.org/index.php/journal/article/view/120/111

237 Індекс економічної свободи. Україна піднялася на 13 позицій. URL: https://ua-news.liga.net/economics/news/indeks-ekonomichnoisvobodi-ukraina-pidnyalasya-na-13-pozitsiy
} 
Найважливішою або визначальною складовою людського капіталу є освіта. Чим якісніша освіта, тим вищий рівень конкурентоспроможності людського капіталу. Це аксіома. Тим паче в умовах ноосфери. Локальні та глобальні виклики сучасної техногенної цивілізації мають долати й можуть здолати лише особи з вищою освітою, що потребує від них адекватної цим викликам професійної та особливо світоглядної компетентності, яка може бути сформованою лише в демократичному й доброчесному соціальному середовищі університетів. Вітчизняні заклади вищої освіти у своєму соціальному середовищі віддзеркалюють те, що твориться і сповідується в нашому суспільстві. Тому цілком закономірно те, що в багатьох з них домінує авторитаризм, який не сприяє ні демократизації, ні доброчесності, ані культивуванню цінностей, які корелюють з цілями та принципами сталого розвитку. Автономізація ЗВО, що передбачена новим Законом України «Про вищу освіmу», яка надає значний обсяг повноважень їхнім керівникам, потребує запровадження в управління їх діяльністю механізмів урядування, які б, як мінімум, блокували прояви авторитаризму та свавілля з боку адміністрації, а як максимум, сприяли демократизації їхнього соціального середовища як базової умови розвитку людського капіталу. Автономія закладу вищої освіти - це не лише автономія ректора та його найближчого оточення, а автономія всього його колективу. Автономність ректора й адміністрації повинна адекватно врівноважуватися академічними свободами науково-педагогічних працівників і здобувачів вищої освіти, що забезпечується їхньою незалежністю в реалізації цих свобод.

На тлі викладеного постає актуальне питання: «На яких кваліфікованих фахівців з вищою освітою може розраховувати Україна з огляду на рівень їі соціально-економічного розвитку, заробітної плати, відсутності цивілізованого конкурентного середовища, відкритої кадрової політики тощо?» Першочергово на легітимно дипломованих у вітчизняних ЗВО осіб, які за браком у них конкурентоспроможної компетентності на цивілізованих ринках праці приречені залишатись на вітчизняних теренах і шукати собі ті соціальні ніші, в яких можна влаштуватись за формальною наявністю диплому про вищу освіту без будь-яких чи з мінімумом вимог до їі якості, отже, до реальної компетентності особи, яка володіє цим дипломом. В яких сферах українського суспільства найліпші можливості влаштуватись на посаду, яка формально вимагає вищої освіти, за допомогою протекціонізму некомпетентності, напевно, знають уже і школярі. Принаймні, старших класів. Це бюджетні сфери діяльності, зокрема: політика, державна служба, фіскальні органи, силові структури, освіта, охорона здоров'я, навіть наука т. ін. Чи зможуть такі особи з номінальною вищою освітою підвищити конкурентну спроможність України? І чи прихильними будуть такі особи до чесної і справедливої, отже, цивілізованої конкуренції на відкритій конкурсній основі з особами, які володіють реальною компетентністю? Питання риторичні. Але відкритими залишаються питання: «Скільки дипломованих неуків окупувало ніші в державних сферах українського суспільства? І скільки ще таких осіб з номінальною вищою освітою дипломують вітчизняні 3BO?».

Цілком очевидно, що зазначену тенденцію руйнації України особами з неякісною вищою освітою мала б заблокувати держава як ії̈ основний суспільний інститут. Для цього вона мала б запустити в дію механізм здорової соціальної селекції, який би відбирав кращих з кращих осіб з вищою освітою за критеріями відповідності їхньої світоглядної і професійної компетентності на посади суспільної ієрархії. А для того щоб такий механізм запрацював, необхідно в українському суспільстві сформувати цивілізоване конкурентне середовище. Таке середовище стане можливим лише тоді, коли в Україні будуть демонополізовані політична та економічна сфери. Щоб таке політично-економічне диво сталося, українським можновладцям, які захопили українську державу в середині 90-х років минулого століття і використовують ії для задоволення приватних інтересів, необхідно проявити громадянську й політичну волю, переборовши в собі клептоманію, розпочати керуватись державницьким світоглядом. Якщо ж такого дива не станеться, то українське суспільство лихоманитимуть невігластво, нестабільність, невизначеність, потрясіння, нові майдани та революції. А доти в українському суспільстві діє механізм негативної соціальної селекції, цей виклик належить долати в кожному зокрема вітчизняному ЗВО й на локальних рівнях формувати цивілізоване конкурентне середовище. А для цього потрібно демократизувати університетське середовище шляхом запровадження механізмів ефективного врядування в умовах академічної доброчесності. у наступному підрозділі висвітлюється обґрунтування критеріїв, на які має орієнтуватися університетське врядування, щоб бути результативним та ефективним. 


\section{Критерії результативності та ефективності діяльності закладів вищої освіти, на які має орієнтуватись їх врядування в умовах євроінтеграції}

У нашому науковому дослідженні запровадження ефективного врядування у вітчизняні університети розглядаємо як засіб підвищення якості вищої освіти та результативності й ефективності управління їхньою діяльністю. По-перше, в цьому полягає соціальна значущість результатів наукового дослідження. По-друге, без забезпечення якості вищої освіти, що відповідає світовим вимогам, неможлива успішна інтеграція в Європейський простір вищої освіти і досліджень. Успішність євроінтеграції у кінцевому підсумку знаменується визнанням дипломів тих університетів, що забезпечать належний рівень якості вищої освіти, носіями якої $€$ їхні випускники. Невизнання дипломів Європейським простором вищої освіти означає невизнання компетентності ї власників на цивілізованих ринках праці. А це $\epsilon$ індикатором неконкурентноспроможності українських закладів вищої освіти.

Проблема результативності та ефективності управління діяльністю закладів вищої освіти також не обділена увагою дослідників. Зокрема, їі дослідження висвітлюють у своїх публікаціях І. Грищенко Н. Цимбаленко і Т. Нефедова ${ }^{238}$; М. Жиленко ${ }^{239}$; С. Матюх ${ }^{240}$; О. Моргулець ${ }^{241}$; О. Петренко, Ю. Пелех і Л. Пелех ${ }^{242}$; I. Решетова ${ }^{243}$; Т. Рожнова ${ }^{244}$ та ін. Аналіз публікацій свідчить, що вчені по різному підходять як у висвітленні окремих аспектів проблеми дослідження, так і у визначенні підходів до її розв'язання.

Зокрема, Т. Рожнова у публікації «Критерії та показники оцінювання результативності управління ВН3 на засадах інноваційних технологій» 245 запропонувала критерії результативності управління за базовим, достатнім і високим рівнями проявів інновацій у здійсненні таких основних складових діяльності закладу вищої освіти ${ }^{246}$ :

- зміст та організація навчального процесу;

- забезпеченість науково-педагогічними кадрами;

- забезпечення якості професійного навчання через виховний процес;

- організація науково-методичної роботи;

- матеріально-технічне забезпечення.

Кожна складова діяльності як окремий критерій має від чотирьох до дев'яти конкретних показників, які оцінюються за 12-бальною шкалою. Відповідно, критерії базового рівня оцінюються від 1 до 6 балів, достатнього - від 7 до 9 балів і високого рівня - від 10 до 12 балів.

\footnotetext{
238 Грищенко І.М., Цимбаленко Н.В., Нефедова Т.М. Підвищення ефективності діяльності вищих навчальних закладів як передумова забезпечення потреб ринку праці. Ринок праці та зайнятість населення, 2015. № 2. С. 32-35.

239 Жиленко М. Оцінка ефективності управлінської діяльності керівника закладу вищої освіти. Вісник КНУ імені Тараса Шевченка. 2018. № 1(7). C. 11-14.

240 Матюх С.А. Методика інтегральної оцінки ефективності діяльності вищого навчального закладу. Науковий вісник Херсонського державного університету. Сер. : Економічні науки, Вип. 5(2). С. 167-170.

241 Моргулець О. Б. Методологічні основи управління вищим навчальним закладом як суб'єктом ринку послуг : автореср. дис. ... доктора економічних наук. Київ, 2017. 44 с.

242 Петренко О.Б., Пелех Ю.В., Пелех Л.Р. Інноваційне управління вищими навчальними закладами: теоретичний аналіз проблеми. Інноватика у вихованні, 2017. Вип. 5. С. 31-40.

243 Решетова І. А. Напрями вдосконалення системи управління вищими навчальними закладами. Економіка і суспільство, 2018. Випуск № 17. C. 341-346. DOI: https://doi.org/10.32782/2524-0072/2018-17-50

244 Рожнова Т.Є. Критерії та показники оцінювання результативності управління ВНЗ на засадах інноваційних технологій. Витоки педагогічної майстерності. Збірник наукових праць, 2013. 11. С. 289-295.

245 Рожнова Т.Є. Критерії та показники оцінювання результативності управління ВН3 на засадах інноваційних технологій. Витоки педагогічної майстерності. Збірник наукових праць, 2013. 11. С. 289-295.

246 Рожнова Т.Є. Критерії та показники оцінювання результативності управління ВНЗ на засадах інноваційних технологій. Витоки педагогічної майстерності. Збірник наукових праць, 2013. 11. С. 289-295.
} 
С. Матюх у публікації «Методика інтегральної оцінки ефективності діяльності вищого навчального закладу» ${ }^{247}$ на підставі аналізу методик оцінювання ефективності діяльності закладів вищої освіти акцентує відсутність інноваційно-інтегрального підходу в оцінюванні ефективності усіх видів цієї діяльності. У цьому зв'язку, дослідником пропонується методика розрахунку результуючого коефіцієнта (Кз) інтегральної ефективності як сумарного балу (max 100) чотирьох коефіцієнтів за такими напрямками, як:

- макроекономічна ефективність Км ( $\max 100$, вага коефіцієнта 0,3);

- ринкова ефективність для роботодавця регіонального ринку праці Кр (max 100, вага коефіцієнта $0,4)$;

- мікроекономічна або господарська ефективність Кг (max 100, вага коефіцієнта 0,1);

- та індивідуальна інвестиційна ефективність для абітурієнта/студента/випускника Кi (max 100, вага коефіцієнта 0,2).

За визначенням С. Матюха: «Значення Кз, що знаходиться в інтервалі до 25 балів, говорить про вкрай несприятливу ситуацію у ВН3, діяльність його неефективна. Значення в інтервалі від 25 до 50 балів говорить про низьку інтегральну ефективність ВН3, від 50 до 75 балів ілюструє досить високу ефективність. Значення коефіцієнта вище 75 балів при високій оцінці якісних складових освітнього процесу дозволяє присвоїти ВНЗ статус високоефективного, ведучого в сегменті навчального закладу» ${ }^{248}$.

О. Моргулець у своєму дисертаційному дослідженні «Методологічні основи управління вищим навчальним закладом як суб'єктом ринку послуг» 249 зазначає, що «незважаючи на загальнодержавну економічну кризу в країні, ВНЗ знаходять резерви для функціонування та забезпечення належної якості освітніх послуг. Реорганізація системи вищої освіти, що наразі триває в Україні, дає результати, основними з яких $\epsilon$ зародження нових компетентностей освітніх закладів, а саме: самовиживання та саморозвиток у кризових умовах» ${ }^{250}$.

Одним із визначальних засобів забезпечення ефективності діяльності вітчизняних 3ВО, на думку дослідниці, $€$ автономія університетів як базова передумова. У світлі дослідження проблеми О. Моргулець:

- визначила методологічні основи й концептуальну модель управління ЗВО як суб'єктом ринку послуг;

- розробила модель процесно-цільового управління і механізм внутрішнього забезпечення якості освітньої діяльності 3ВО;

- запропонувала комплексну модель аналітичного обгрунтування ефективності управління і концептуально-математичну модель управління стратегічним розвитком ЗВО як суб'єктом ринку освітніх послуг;

- надала інші рекомендації.

Отримані результати, за думкою вченої, мають забезпечити ефективність діяльності ЗВО на ринку освітніх послуг та його «прогресивний розвиток через максимальне використання потенціалу та задоволення потреб споживачів в освітніх послугах» ${ }^{251}$. Лейтмотивом дослідження О. Моргулець є підприємницький підхід в управлінні 3ВО.

\footnotetext{
247 Матюх С.А. Методика інтегральної оцінки ефективності діяльності вищого навчального закладу. Науковий вісник Херсонського державного університету. Сер. : Економічні науки, 2014. Вип. 5(2). С. 167-170.

248 Матюх С.А. Методика інтегральної оцінки ефективності діяльності вищого навчального закладу. Науковий вісник Херсонського державного університету. Сер. : Економічні науки, Вип. 5(2). С. 169.

249 Моргулець О. Б. Методологічні основи управління вищим навчальним закладом як суб'єктом ринку послуг : автореф. дис. ... доктора економічних наук. Київ, 2017. 44 с.

250 Моргулець О. Б. Методологічні основи управління вищим навчальним закладом як суб'єктом ринку послуг : автореф. дис. ... доктора економічних наук. Київ, 2017. 44 с.

251 Моргулець О. Б. Методологічні основи управління вищим навчальним закладом як суб'єктом ринку послуг : автореф. дис. ... доктора економічних наук. Київ, 2017. 44 с.
} 
I. Грищенко, Н. Цимбаленко і Т. Нефедова у праці «Підвищення ефективності діяльності вищих навчальних закладів як передумова забезпечення потреб ринку праці» 252 визначили підвищення ефективності діяльності ЗВО генеральною метою його управління, досягнення якої забезпечується такими трьома ключовими факторами успіху, як соціальна, економічна та екологічна ефективність. Дослідники констатували, що253:

- соціальна ефективність досягається шляхом підвищенням якості вищої освіти, забезпеченням відповідності освіти потребам ринку праці та мотивацією і розвитком персоналу;

- економічна ефективність - підвищенням ефективності менеджменту, забезпеченням ефективності науково-технічної діяльності та підвищенням ефективності маркетингових комунікацій;

- екологічна ефективність - підвищенням енергоефективності та забезпеченням раціональності використання ресурсів ЗВО.

У публікації «Інноваційне управління вищими навчальними закладами: теоретичний аналіз проблеми» 254 О. Петренко, Ю. Пелех $і$ Л. Пелех стверджують, що «існуюча на сьогодні суперечність між незначним рівнем обізнаності адміністративно-управлінських працівників 3 теоретичними засадами управління вищими навчальними закладами та доцільністю творчого використання цих засад у сучасній управлінській практиці може бути подолана, зокрема, знанням й аналізом основних теорій управління ВН3» ${ }^{255}$. На підставі характеристики класичних теоретичних підходів, зокрема, проектно-орієнтованого, процесного, системного і стратегічного дослідники критично зазначили, що «недоліком схаректиризованих підходів є їх відносна застарілість, оскільки вони не враховують змін, що відбулися у зв'язку з імплементацією у практику управління вищими навчальними закладами положень Закону України «Про вищу освіту»» ${ }^{256}$. Натомість вчені пропонують перейти на інноваційне управління закладами вищої освіти. На думку О. Петренко, Ю. Пелех і Л. Пелех, інноваційне управління «полягає у визначенні перспективних напрямів розвитку навчального закладу, у накопиченні необхідних ресурсів та його інноваційного потенціалу, у розробці і впровадженні розвитку педагогічної креативності та забезпечення конкурентоспроможності закладу» 257.

М. Жиленко у праці "Оцінка ефективності управлінської діяльності керівника закладу вищої освіти» 258 робить наголос на ключовій ролі керівника у забезпеченні ефективності діяльності ЗВО. Зокрема, дослідник звернув увагу на суперечність між вимогами до керівника 3ВО при обранні його за конкурсом, які визначені Законом України «Про вищу освіту», і рівнем компетентності, якою має володіти керівник для ефективної реалізації повноважень, що покладаються на нього цим же Законом. У зв'язку з цим М. Жиленко слушно зазначає: «Сьогодні в Україні відсутня система професійної підготовки керівників 3ВО всупереч тому, що якість та безпека життєдіяльності суспільства значною мірою визначаються ефективністю процесів формування та реалізації людського потенціалу при отриманні вищої освіти» 259. На думку вченого, ця проблема має розв'язуватися через організацію системи формальної, неформальної та інформальної освіти: «В ситуації, коли вибори керівника відбулися і треба в короткі терміни включитись в існуючу систему управління, або створити свою, найбільш продуктивною буде неформальна та інформальна освіта» 260. Дослідником запропонована методика, «яка включає порядок визначення основних компонентів

\footnotetext{
252 Грищенко І.М., Цимбаленко Н.В., Нефедова Т.М. Підвищення ефективності діяльності вищих навчальних закладів як передумова забезпечення потреб ринку праці. Ринок праці та зайнятість населення, 2015. № 2. С.32-35.

253 Грищенко І.М., Цимбаленко Н.В., Нефедова Т.М. Підвищення ефективності діяльності вищих навчальних закладів як передумова забезпечення потреб ринку праці. Ринок праці та зайнятість населення, 2015. № 2. С.32-35.

254 Петренко О.Б., Пелех Ю.В., Пелех Л.Р. Інноваційне управління вищими навчальними закладами: теоретичний аналіз проблеми. Інноватика у вихованні, 2017. Вип. 5. С. 31-40.

255 Петренко О.Б., Пелех Ю.В., Пелех Л.Р. Інноваційне управління вищими навчальними закладами: теоретичний аналіз проблеми. Інноватика у вихованні, 2017. Вип. 5. С. 31.

256 Петренко О.Б., Пелех Ю.В., Пелех Л.Р. Інноваційне управління вищими навчальними закладами: теоретичний аналіз проблеми. Інноватика у вихованні, 2017. Вип. 5. С. 34

257 Петренко О.Б., Пелех Ю.В., Пелех Л.Р. Інноваційне управління вищими навчальними закладами: теоретичний аналіз проблеми. Інноватика у вихованні, 2017. Вип. 5. С. 36.

258 Жиленко М. Оцінка ефективності управлінської діяльності керівника закладу вищої освіти. Вісник КнУ імені Тараса Шевченка, 2018. № 1(7). C. 11-14.

259 Жиленко М. Оцінка ефективності управлінської діяльності керівника закладу вищої освіти. Вісник КНУ імені Тараса Шевченка, 2018. № 1(7). C. 12.

260 Жиленко М. Оцінка ефективності управлінської діяльності керівника закладу вищої освіти. Вісник КНУ імені Тараса Шевченка, 2018. № 1(7). C. 14
} 
управлінської діяльності керівника в закладі вищої освіти, критерії оцінки ії продуктивності, процедуру експертної оцінки діяльності керівника 3 ВО і підрахунку підсумкового результату. Участь на всіх етапах відбору, формулювання критеріїв, ранжування, визначення вагового коефіцієнта, порівняння результатів експертної оцінки й самооцінки надасть керівникові можливість усвідомити рівень власної готовності до управлінської діяльності, визначити і проранжувати за критерієм значущості напрями самовдосконалення на основі внутрішньої мотивації» ${ }^{261 .}$

Підсумовуючи, констатуємо, що здійснений аналіз наукових публікацій виявив плюралізм думок у баченні та розумінні сутності проблеми результативності та ефективності університетського управління, а також підходів до їх розв'язання.

Цим, по-перше, демонструється невизначеність у дослідженнях актуалізованої проблеми.

По-друге, підтверджується той факт, що у вітчизняному науковому дискурсі, пов'язаному з визначенням критеріїв результативності та ефективності університетської діяльності у цілому й управління нею зокрема, домінує орієнтація на формальні показники без опертя і врахування критичного аналізу реального стану системи вищої освіти України, який репрезентують вітчизняні ЗВО.

По-третє, що найголовніше, в епіцентрі цього дискурсу не фігурує розвиток особистісного потенціалу основних суб'єктів (керівників, науково-педагогічних працівників, студентів) університетської діяльності як визначальний чинник забезпечення якості вищої освіти та інтегрований критерій результативності й ефективності управління ЗВО.

Здійснений аналіз публікацій також засвідчує, що вітчизняний науковий дискурс віддзеркалює традиційну парадигму дослідження результативності й ефективності університетської діяльності та управління нею, яка базується на підприємницькому підході та комерційному розрахунку і не орієнтує на забезпечення якості вищої освіти, яка має відповідати сучасним світовим вимогам. На жаль, такої відповідності не спостерігається.

Реальні показники віддзеркалюють суперечливу й навіть парадоксальну тенденцію, яка спостерігається у вітчизняній вищій освіті.

По-перше, на тлі зростання кількісних показників спостерігається неухильне зниження якості вітчизняної вищої освіти на широкий загал осіб, що її здобувають. В кінцевому підсумку такий рівень якості робить їі неконкурентоспроможною, інтегральним критерієм чого $€$ невизнання вітчизняних дипломів на міжнародному рівні.

По-друге, зовсім нелогічним сприймається зниження якості у контексті євроінтеграції, що супроводжується системними реформами вітчизняної вищої освіти, які забезпечують ії відповідність формальним вимогам Європейського простору вищої освіти. Україна офіційно включилася у Болонський процес у 2005 році. І якщо до виходу нового Закону України «Про вищу освіту» у 2014 році ще були підстави для критичних зауважень експертів щодо відсутності системних реформ у вітчизняній вищій освіті, які б наближали ії до Європейського простору вищої освіти, то зараз вже не можна ремствувати з цього приводу. Адже за останні шість років виконано значний обсяг системного інституційного реформування української вищої освіти, яке за формальними ознаками суттєво наблизило її до європейських вимог. Під питанням залишається змістовне наповнення. І очевидною є невідповідність якості вітчизняної вищої освіти сучасним світовим вимогам, першочергово європейським.

Детально познайомитись з показниками, які всебічно характеризують сучасний стан вітчизняної вищої освіти, можна у таких джерелах:

- Річний звіт Національного агентства із забезпечення якості вищої освіти за 2019 рік ${ }^{262}$;

- Вища освіта в Україні: порядок денний для реформ ${ }^{263}$;

- Дослідження сфери освіти в Україні ${ }^{264}$ та ін.

\footnotetext{
261 Жиленко М. Оцінка ефективності управлінської діяльності керівника закладу вищої. Вісник КнУ імені Тараса Шевченка, 2018. № 1(7). C. 14.

262 Річний звіт Національного агентства із забезпечення якості вищої освіти за 2019 рік / за заг. ред. проф. Сергія Квіта. Київ: Національне агентство із забезпечення якості вищої освіти. 2020.244 c. URL: https://naqa.gov.ua/wpcontent/uploads/2020/02/\%D0\%97\%D0\%B2\%D1\%96\%D1\%82-2020.pdf

263 Вища освіта в Україні: порядок денний для реформ. URL: URL:https://www.kas.de/de/web/ukraine/publikationen/einzeltitel/Content/visa-osvita-v-ukraini-poradok-dennij-dla-reform16

264 Дослідження сфери освіти в Україні. URL: http://documents.worldbank.org/curated/en/884261568662566134/pdf/Review-of-theEducation-Sector-in-Ukraine-Moving-toward-Effectiveness-Equity-and-Efficiency-RESUME3.pdf
} 
У цьому контексті наведемо лише деякі показники, що підтверджують суперечність між кількістю та якістю вітчизняної вищої освіти.

Починаючи з останнього десятиліття XX століття відбулася «масовізація» вищої освіти України, яка «завжди перебуває в оберненій залежності від якості вищої освіти та має своїм наслідком зниження фінансування університетів з боку держави, а отже, збільшення плати за навчання для здобувачів вищої освіти. Саме такі наслідки неконтрольованого збільшення кількості університетів у 1990-ті та 2000-ні переживає сьогодні уся система, і не тільки вищої, освіти в Україні» ${ }^{265}$. Ріст кількості вітчизняних 3ВО відбувався «на тлі скорочення кількості здобувачів вищої освіти, що, звісно, має свій вплив на якість. Так, у 1990-1991 н.р. в Україні, відповідно до відкритих у вільному доступі даних Державної служби статистики України, нараховувалося лише 149 3ВО (університети, академії, інститути), в яких навчалося 881300 студентів. Така кількість ЗВО та здобувачів вищої освіти на початку незалежності України були спадком радянської системи вищої освіти, що припинила своє існування.

Рівно через десять років у 2000-2001 н.р. таких 3ВО було вже удвічі більше: 315 університетів, академій, інститутів. Студентів нараховувалося також майже півтора мільйона (1 402900 осіб). До 2010 року кількість 3ВО постійно зростала (насамперед за рахунок приватних закладів і розширення мережі відокремлених структурних підрозділів), незважаючи на суттєве скорочення кількості випускників шкіл і загальний спад економіки країни, яка була не спроможна достатньою мірою профінансувати таку мережу 3ВО.

Водночас, ще однією проблемою стала неможливість збільшення у 2000-х роках кількості саме висококваліфікованих викладачів відповідно до кількості ЗВО. Загальновідомим є факт масової міграції вчителів шкіл до університетів, де не вистачало викладачів для проведення практичних і лабораторних занять, а подекуди навіть лекційних. На цій хвилі бере свій початок ще один важливий процес - «масовізація» аспірантури та різке зростання кількості захищених дисертацій, відверто кажучи, низької наукової якості, що також матиме вплив на загальний стан вищої освіти в Україні. Як наслідок, після 2010 року все голосніше почали говорити про скорочення або об'єднання університетів, інститутів, академій до такої обґрунтованої кількості, яку реально потребує наше суспільство і, що найголовніше, зможе витримати наша економіка. Проте реальних кроків, зокрема й через нерозуміння механізмів закриття або об'єднання закладів вищої освіти, не було здійснено досі. Станом на листопад 2019 року в Україні діяло 671 заклад вищої освіти, що становило 16 ЗВО на 1 млн населення. Тоді як у Нідерландах, Німеччині, Франції, Великій Британії, де якість вищої освіти суттєво вище української, кількість ЗВО на мільйон населення коливається від 4 до 6 » 266.

На невідповідність якості вітчизняної освіти ії кількісним показникам вказує і Л. Шавалюк:

«Для живої та здорової особи фундамент людського капіталу закладається в навчальних закладах - від дитячого садка до університету. А з цим в Україна цікава ситуація. Річ у тім, що в нас одні з найвищих у світі частки населення, які здобули початкову, середню та вищу освіту. За даними СЕФ, у більшості вікових категорій за цими показниками ми входимо до першої двадцятки країн у світі, а за кількома з них посідаємо 4-6-те місця. У нас 22 \% населення має вищу освіту, тобто більш як кожен п'ятий. Тому в одному з чотирьох субіндексів GHCl, що оцінює ємність інтелектуального потенціалу країни, сформовану їі системою освіти, ми на 5-му місці у світі.

Формально це дуже добре. Такими показниками можна було б пишатися. Але коли постає питання якості цієї освіти, наші успіхи виявляються не такими яскравими. Наприклад, за даними СБ за 2017 рік, середній бал узгодженої тестової оцінки українських школярів із різних класів (оцінюють грамотність та навички лічби) становив 490 (можна було набрати від 300 до 625), а це 43-й результат серед 157 країн. І тут є дві новини, добра й погана. Добра полягає в тому, що система освіти деградує не так стрімко, як економіка: за рівнем розвитку останньої ми давно опустилися в другу сотню країн світу. А погана - поки освіта деградує, ми не можемо ставити перед економікою амбітні завдання, бо країна має дедалі менше інтелектуального ресурсу для їхнього виконання. У часи незалежності в Україні було чимало високопосадовців, які заявляли плани увійти в першу двадцятку країн світу за обсягом ВВП. Але в епоху економіки знань та інформації з освітою, яка деградує, такий результат просто недосяжний.

\footnotetext{
265 Річний звіт Національного агентства із забезпечення якості вищої освіти за 2019 рік / за заг. ред. проф. Сергія Квіта. Київ: Національне агентство із забезпечення якості вищої освіти, 2020. C. $11 . \quad$ URL: $\underline{\text { https://naqa.gov.ua/wp- }}$ content/uploads/2020/02/\%D0\%97\%D0\%B2\%D1\%96\%D1\%82-2020.pdf

266 Річний звіт Національного агентства із забезпечення якості вищої освіти за 2019 рік / за заг. ред. проф. Сергія Квіта. Київ: Національне агентство із забезпечення якості вищої освіти. 2020. C. $16 . \quad$ URL: https://naqa.gov.ua/wp-
} content/uploads/2020/02/\%D0\%97\%D0\%B2\%D1\%96\%D1\%82-2020.pdf 
За часткою студентів університетів серед людей відповідного віку Україна посідає 11-те місце у світі. За даними СЕФ, 82,3 \% українців віком 15-24 роки вчиться в університетах. На перший погляд, прекрасний результат. Але всім добре відома якість освіти в наших вишах. У багатьох випадках дипломами просто торгують, як картоплею на базарі, а для роботодавця документи левової частки вищих навчальних закладів не мають ані найменшого значення. Тому коли СЕФ провів опитування серед керівників та власників бізнесу в різних країнах, то відповідь українських менеджерів на запитання «наскільки система освіти у вашій країні відповідає потребам конкурентної економіки?» набрала трохи більш як 50 балів, що забезпечило нам 51-ше місце зі 130. Не надто переконливий результат. Слід згадати й про те, що дедалі більше українців виїжджає вчитися за кордон одразу після закінчення середньої школи. Це свідчення того, що наша система вищої освіти далеко не ідеальна й що підготовка до виходу на ринок праці, яку вона забезпечує, недостатньо потужна. ...

У майбутньому всі ці елементи розвиватимуться й трансформуватимуться в цілісні системи розвитку людського капіталу. Тим часом в Україні про все це ніхто системно не думає. Перед нами стоять зовсім інші виклики: рівень людського капіталу тут суттєво нижчий, ніж у країн, на які треба рівнятися. До того ж за багатьма ознаками він поступово деградує. Якщо мислити категоріями десятиліть, то в нашій державі це одна з найнагальніших проблем, вирішувати яку треба негайно. Наявні індекси людського капіталу чітко показують сильні й слабкі місця, підсвічують оптимальні точки докладання зусиль. Тобто для ухвалення відповідних рішень $€$ вся необхідна інформація. Залишилося знайти політичну волю та посадовців зі значним людським капіталом, здатних і готових усе це зробити» ${ }^{267}$.

Із процитованого тексту постає цілком переконлива аргументація щодо розвитку людського капіталу як визначальної мети діяльності закладів вищої освіти, за рівнем якого має визначатися її результативність та ефективність.

Попри беззаперечну значущість дошкільної і шкільної освіти у формуванні й розвитку особистісного потенціалу людини як капіталу, завдяки реалізації якого вона може бути продуктивною у своєму життєзабезпеченні, провідну роль у суспільно-економічному розвиткові виконують особи з вищою освітою, що проявляється в його основних напрямах. Без вищої освіти унеможливлюється науково-технічний прогрес, який $€$ локомотивом розвитку сучасної цивілізації. Завдяки дипломам, які засвідчують наявність вищої освіти, сучасні мешканці нашої планети отримують право на входження у соціальні ліфти, якими вони можуть піднятися на будь-які щаблі в суспільній і глобальній ієрархії, включаючи найвищі з них.

267 Любомир Шавалюк. Деградація в епоху розвитку. 3 березня, 2020. URL: https://dniprograd.org/2020/03/03/degradatsiya-v-epokhu$\underline{\text { rozvitku } 83367}$ 


\section{Результативність та ефективність університетської діяльності}

Обґрунтування критеріїв результативності та ефективності діяльності університету, на які має орієнтуватися його врядування, висвітлено нами концептуально у відповідному підрозділі аналітичних матеріалів 268 і розлого в окремій статті ${ }^{269}$. У цьому контексті на підставі зробленого обгрунтування концептуалізуємо найважливіші методологічні положення результативності та ефективності університетської діяльності:

1. Результативність університетської діяльності логічно визначати тим, наскільки університет здатний своїми результатами бути відповідним тим запитам і викликам, які постають у суспільному і глобальному контекстах. Звідси постає потреба в орієнтації університетського управління на забезпечення корпоративної компетентності всього університету, яка сумарно визначає рівень його конкурентоспроможності на регіональному, суспільному, європейському і глобальному рівнях. Чим вищий рівень конкурентоспроможності університету, тим вища його корпоративна компетентність як інтегрований системний результат діяльності університету, що забезпечується відповідним управлінням.

Ефективнішим логічно вважати таке управління, яке за наявності однакових ресурсів і можливостей забезпечує кращий результат університетської діяльності або яке за рівнем ефективності, що визначається через співвідношення ефекту до використаних ресурсів, $є$ вищим. Тож результативність університетської діяльності можна визначити як ступінь відповідності забезпеченого нею результату цілі, на досягнення якої спрямовувалась ця діяльність. А ефективність університетської діяльності - це якісний показник, який визначає ступінь використання ресурсів у досягненні певного результату.

2. Серед людських, матеріальних, фінансових та інших ресурсів, якими забезпечується університетська діяльність, людські ресурси є визначальними, оскільки на відміну від інших ресурсів, які невідворотно витрачаються, вони у процесі їх використання самовідновлюються й розвиваються.

Самовідновлення і розвиток людських ресурсів або людського капіталу тим кращий, чим розвиненіший особистісний потенціал учасників університетської діяльності. А рівень розвитку особистісного потенціалу здобувачів вищої освіти $€$ поточним і кінцевим результатом освітньої діяльності університету. Чим 3 розвиненішим особистісним потенціалом будуть його випускники, тим продуктивнішими вони будуть у своїй життєвій кар'єрі, отже, дорожчими у вартісному вираженні й навпаки. Адже, чим продуктивніші особи з вищою освітою, тим продуктивніше суспільство, в якому вони працюють, і тим благополучніше життя в такому суспільстві. Своєю чергою, розвиток особистісного потенціалу здобувачів вищої освіти у процесі навчання залежить безпосередньо від рівня розвитку особистісного потенціалу академічного персоналу, 3 представниками якого вони взаємодіють. Від особистісного потенціалу науково-педагогічних працівників залежить не лише результативність освітньої, а й наукової діяльності.

Отже, людські ресурси в будь-якій діяльності й тим паче в університетській - це не знеособлена маса людських індивідів, а спільнота особистостей викладачів, студентів, управлінців та інших працівників, від потенціалу яких першочергово залежить не лише їхня персональна, а й сумарна результативність діяльності університету. За умов однакового особистісного потенціалу суб'єктів університетської діяльності та рівних інших, не лише ресурсних, можливостей, від яких залежить університетська діяльність, може бути різною корпоративна компетентність університету. Це позитивно корелює з ефективністю управління. Відповідно однакове управління буде результативнішим мірою розвиненішого особистісного потенціалу суб'єктів університетської діяльності.

Розвиток особистісного потенціалу першочергово залежить від можливостей самоактуалізації та самореалізації особистості людини. Як було обгрунтовано у першій частині цього підрозділу, найсприятливіші умови для максимального використання таких можливостей створюються для особистості в демократичному

\footnotetext{
268 Рябченко В. Теоретичні основи впливу соціального середовища на ефективне врядування в українських університетах: світогляднокомпетентнісний аспект. Аналіз провідного вітчизняного та зарубіжного досвіду щодо механізмів реалізації ефрективного врядування в університетах: препринт (аналітичні матеріали) (частина I) / за заг. ред. С. Калашнікової. Київ: Інститут вищої освіти HАПН України, 2018. С. 27. URL: https://ihed.org.ua/wp-content/uploads/2019/09/Analiz_dosvidu_vriaduvania_v_univer_ch1_analit_IVO2018-147p avtors-kolektiv.pdf C. 32-35

269 Рябченко В. Розвиток особистісного потенціалу академічного персоналу і здобувачів вищої освіти як інтегрований критерій результативності та ефективності університетського управління. Міжнародний науковий журнал «Університети і лідерство». 2019. 1(7). C. 65-88. DOI: https://doi.org/10.31874/520-6702-2019-7-1-65-88
} 
соціальному середовищі, коли у неї з'являється свобода вибору для самореалізації та поряд з цим діють механізми соціальної відповідальності за результати персональної діяльності.

3. Методологічно некоректно визначати ефективність університетської діяльності за формальними критеріями, зокрема, за дипломом про вищу освіту безвідносно рівня компетентності й розвитку особистісного потенціалу його власника. Орієнтація управління закладу вищої освіти на досягнення ефективності освітньої діяльності через співвідношення у вартісному вираженні отриманого прибутку до витрат на їі здійснення призводить до девальвації якості вищої освіти. Це підтверджується ринком освітніх послуг у сфері вищої освіти України, який набув гіпертрофованого розміру, що перевищує попит на дипломи про вищу освіту, які не підтверджуються конкурентоспроможною компетентністю їх власників. Комерціалізація наукової діяльності включає механізми погоні за «короткими грошима», який стимулює прикладні дослідження і згортає обсяги фундаментальних досліджень, що потребують довгих грошей тобто інвестицій, які не дають швидкої віддачі. А без фундаментальних досліджень всі прикладні наукові розробки в майбутньому приречені ставати банальними вдосконаленнями існуючих «велосипедів». Комерціалізація наукової діяльності з позицій підприємницького підходу орієнтує управління нею не на перспективну, а на сьогоденну ефективність.

4. У ситуаціях, коли застосування кількісних критеріїв, у тому числі, у вартісному вираженні $\epsilon$ методологічно некоректним, доцільно задіяти якісні критерії результатів, на досягнення яких має орієнтуватись університетське управління. Такі критерії через оцінну шкалу «гірше - краще» мають орієнтувати управління закладу вищої освіти на покращення результатів як його окремих видів діяльності, так і діяльності в цілому. При цьому покращення результатів повинно досягатися за мінімально допустимі ресурси (без погіршання якості результатів). Лише за такого методологічного підходу можна розраховувати на підвищення ефективності університетської діяльності. 3 підвищенням ефективності діяльності звО збільшується його конкурентоспроможність, яку логічно вважати інтегрованим індикатором корпоративної компетентності всіх учасників цієї діяльності.

5. У конкуренції за збереження студентських місць шляхом не «відбору кращих абітурієнтів», а «підбирання усіх бажаючих стати студентами», заклади вищої освіти України надають перевагу створенню популістського іміджу, а декотрі - рекламі неіснуючого іміджу, не дбаючи при цьому за свою репутацію.

Між іміджем і репутацією існує суперечність, яка полягає у різній тривалості їх створення. Якщо імідж, а тим паче рекламу іміджу, з використанням сучасних рекламних та інформаційних технологій можна створити у досить стислі терміни, то для формування репутації потрібен тривалий час.

Репутація університету не за вивіскою, а за сутністю й духом формується багатьма роками й десятиліттями. Звідси постає пріоритет репутації над іміджем. 3 цього пріоритету виходить, що заради іміджу не можна втрачати репутацію. Репутація складається десятиліттями із життєвих здобутків і кар'єрних досягнень випускників університету. Втрата пріоритету орієнтації діяльності університету на розвиток особистісного потенціалу здобувачів вищої освіти неминуче програмує втрати його репутації. Репутація має високу ціну, її на відміну від іміджу за гроші не купиш.

Репутація університету - це результат кропіткої та самовідданої праці багатьох поколінь студентів і не одного покоління академічного персоналу. Тому є всі підстави вважати їі найдорожчим ресурсом університету, який ні в якому разі не можна розмінювати на дріб'язки.

6. Університет як соціальна система функціонує в іпостасях декількох організацій, зокрема, як освітня, наукова та економічна. Кожна з цих організацій структурована й керована відповідними підсистемами університетського управління. У сучасній реальності ЗВО України превалює адміністрування, як найбільш консервативна управлінська парадигма. Цим зумовлюється і домінування авторитарного стилю управління у всіх зазначених вище підсистемах університетського управління.

Якщо адміністрування і відповідно жорстка вертикаль можуть бути певним чином виправдані в управлінні 3ВО як економічною організацією, то не знаходиться достатніх підстав для такого виправдання в управлінні закладом як освітньою й науковою установою. Освітня та наукова діяльність потребують демократизачії соціального середовища, в якому вони здійснюються. 
На наш погляд, комерціалізація університетської діяльності, якою захопилися вітчизняні 3ВО, сприяє та вимагає жорсткішого адміністрування і контролю, що суперечить тенденціям демократизації як запоруки успішного й, головне, безпечного подальшого цивілізаційного розвитку не лише України, а й усього людства.

7. Автономізація вітчизняних ЗВО, що надана новим Законом України «Про вищу освіту», яка передбачає делегування значного обсягу повноважень керівникам закладів, потребує запровадження в управління ними механізмів врядування. Ці механізми повинні, як мінімум, блокувати прояви авторитаризму і свавілля з боку адміністрації, а як максимум, сприяти демократизації соціального середовища 3 ВО як базової умови для розвитку особистісного потенціалу суб'єктів їхньої діяльності.

Зроблені застереження небезпідставні. Адже за роки державної незалежності авторитаризм 3 вітчизняних закладів вищої освіти нікуди не подівся. Навпаки, у багатьох з них він навіть посилився. Понад це, у відносинах з адміністрацією ЗВО викладачі і студенти стали менш захищеними у порівнянні з тим, як це було в радянський період, принаймні, в його останні два десятиліття. Така незахищеність спостерігається як у трудових й освітніх відносинах викладачів і студентів зі своєю адміністрацією, так і у проявах ними академічних свобод, зокрема, у виставленні викладачами та отриманні студентами справедливих оцінок за результати навчання.

Залежність викладачів і студентів від адміністрації ЗВО змушує їх вдаватися до конформізму заради того, щоб не втратити роботу або залишитися в лавах студентів. За такої залежності їхнє представництво у виборних органах, які можна ототожнювати з представницьким врядуванням, набуває суто номінального характеру, оскільки вони не можуть у разі необхідності займати принципову позицію у відстоюванні своїх інтересів, яка суперечить позиції чи точці зору адміністрації.

Однією з причин залежності викладачів і студентів від адміністрації $€$ низький рівень компетентності у роботі перших та успішності в навчанні других. Чим менш компетентна особа, тим більше вона залежна від адміністрації, оскільки зайняття нею посади та перебування на ній визначально залежить не від власної компетентності, а від поблажливого ставлення ії керівництва. Відсутність конкурентоспроможної компетентності перед страхом втратити роботу пробуджує у такої особи інстинкт самозбереження, який спонукає їі до конформізму, підлабузництва та інших форм пристосуванства. I аж ніяк не до прояву критичної, конструктивної, принципової громадянської позиції щодо проявів зловживань і свавілля з боку своєї адміністрації.

8. 3 огляду на комерціалізацію освітнього процесу, яка девальвувала якість вітчизняної вищої освіти, нами запропоновано, обґрунтовано й продемонстровано дещо іншу парадигму дослідження проблеми результативності та ефективності управління університетською діяльністю ${ }^{270}$. У форматі цієї парадигми визначено результативність університетської діяльності як рівень відповідності результатів діяльності університету сучасним глобальним викликам, що першочергово визначається через рівень відповідності компетентності його випускників вимогам цивілізованих ринків праці, критерієм цивілізованості яких $\epsilon$ здорова соціальна конкуренція.

9. Під ефективністю університетської діяльності ми розглядаємо якісний показник, що визначає ступінь використання ресурсів (людських, матеріальних, фінансових та ін.) у досягненні певного результату. При цьому звернено увагу на методологічну некоректність визначення ефективності університетської діяльності за формальними критеріями. Зокрема, за дипломом про вищу освіту безвідносно до рівня компетентності й розвитку особистісного потенціалу його власника.

Доведено неможливість коректної диференціації у вартісному вираженні результатів освітньої та наукової діяльності університету. Актуалізовано необхідність визначення та обґрунтування альтернативних критеріїв, які $б$ орієнтували управління на забезпечення результативної і водночас ефективної діяльності закладу вищої освіти. Запропоновано у разі некоректного апелювання до кількісних критеріїв орієнтувати управління на оцінні критерії у визначенні результатів університетської діяльності. Рекомендовано оцінні шкали такої відповідності, які мають орієнтувати управління закладу вищої освіти на покращення результатів його діяльності. При цьому покращення результатів необхідно досягати не за будь-які витрати ресурсів, а за

\footnotetext{
270 Рябченко В. Розвиток особистісного потенціалу академічного персоналу і здобувачів вищої освіти як інтегрований критерій результативності та ефективності університетського управління. Міжнародний науковий журнал «Університети і лідерство», 2019. № 1(7). C. 79. DOI: https://doi.org/10.31874/520-6702-2019-7-1-65-88
} 
мінімально допустимі без погіршання їх якості. Зазначено, що лише за такого методологічного підходу можна розраховувати на підвищення ефективності діяльності університету як запоруки його конкурентоспроможності. Запропоновано конкурентоспроможність університету вважати інтегрованим індикатором корпоративної компетентності всіх учасників його діяльності, у тому числі, управлінців, науковопедагогічних працівників і здобувачів вищої освіти.

10. У процесі наукового дослідження нами виявлено декілька особливостей, які мають бути враховані при запровадженні механізмів ефективного врядування в соціальне середовище ЗВО України, а саме:

Автономізація вітчизняних університетів, зумовлена імплементацією відповідних положень нового Закону України «Про вищу освіту», потребує запровадження в управління ними механізмів врядування, які повинні, як мінімум, блокувати прояви авторитаризму і свавілля з боку їх адміністрації, а як максимум, сприяти демократизації їхнього соціального середовища як базової умови розвитку особистісного потенціалу суб'єктів їх діяльності.

У конкуренції за абітурієнтів вітчизняними ЗВО надається перевага створенню популістського іміджу або рекламі неіснуючого іміджу над формуванням чи збереженням власної репутації, яка складається десятиліттями із життєвих здобутків і кар'єрних досягнень випускників університету, що є результатом кропіткої та самовідданої праці багатьох поколінь студентів і не одного покоління викладачів.

При запровадженні закладами вищої освіти України інституційних рейтингів викладачів показники освітнього процесу не є пріоритетними. За таких умов у науково-педагогічних працівників втрачається мотивація до підвищення якості викладання. У зв'язку з цим, варто наголосити, що репутація сучасного університету в суспільстві формується не тільки завдяки індексам цитувань у престижних / іміджевих наукових виданнях, а і за рахунок здобутків і кар'єрних успіхів випускників університету.

11. У результаті дослідження виявлено закономірності, які необхідно враховувати при запровадженні механізмів ефективного врядування у ЗВО України, зокрема наступні:

1) дієвість та ефективність врядування в університеті позитивно корелює з рівнями якості науковопедагогічних працівників і контингенту студентів, які інтегровано визначаються рівнями розвитку їх особистісного потенціалу;

2) орієнтація управління 3ВО на досягнення ефективності освітньої діяльності через співвідношення у вартісному вираженні отриманого прибутку до витрат на її здійснення призводить до девальвації якості вищої освіти. Це підтверджується ринком освітніх послуг у сфері вищої освіти України за рахунок відкриття найменш ресурсних спеціальностей, який набув гіпертрофованого розміру, що перевищує попит на дипломи про вищу освіту, які не підтверджуються конкурентоспроможною компетентністю їх власників;

3) комерціалізація наукової діяльності з позицій підприємницького підходу орієнтує управління нею не на перспективну, а на сьогоденну ефективність, оскільки вона включає механізми погоні за «короткими грошима», яка стимулює прикладні дослідження і згортає обсяги фундаментальних досліджень, що потребують «довгих грошей» тобто інвестицій, які не дають швидкої віддачі, але без яких прикладні наукові розробки згодом приречені ставати банальними вдосконаленнями існуючих «велосипедів» і зводити таку комерціалізацію нанівець;

4) на відміну від інших ресурсів, які невідворотно витрачаються, людські ресурси у процесі їх використання самовідновлюються та розвиваються. Самовідновлення й розвиток людських ресурсів або людського капіталу тим кращий, чим розвиненіший особистісний потенціал учасників університетської діяльності. Рівень розвитку особистісного потенціалу здобувачів вищої освіти $€$ поточним і кінцевим результатом освітньої діяльності ЗВО. Адже, чим з розвиненішим особистісним потенціалом будуть його випускники, тим продуктивнішими вони будуть у своїй життєвій кар'єрі, отже, дорожчими у вартісному вираженні. І навпаки: чим продуктивніші особи з вищою освітою, тим продуктивніше суспільство, в якому вони працюють, і тим благополучніше життя у такому суспільстві. Своєю чергою розвиток особистісного потенціалу здобувачів вищої освіти у процесі навчання залежить безпосередньо від рівня особистісного потенціалу академічного персоналу, з представниками якого вони взаємодіють. Від особистісного потенціалу науковопедагогічних працівників залежить не лише результативність освітньої, а й наукової діяльності. 
12. Базовою умовою для ефективного врядування, як уже неодноразово акцентувалося у цьому розділі та інших наших публікаціях $€$ доброчесність сочіального середовища, в якому запроваджуються його механізми. Правомірність зазначеної умови з огляду на інтегрований критерій результативності та ефективності діяльності університетів підтверджується рекомендаціями Національного агентства із забезпечення якості вищої освіти України (далі - Нацагенство): «Однією з ключових складових внутрішньої системи забезпечення якості у закладах вищої освіти $€$ університетська система забезпечення академічної доброчесності, яка визначає загальноприйняті світовою спільнотою стандарти здійснення освітньої та наукової діяльності здобувачами вищої освіти і співробітниками університету й створює середовище нульової терпимості до порушень академічної доброчесності та етики академічних взаємовідносин» ${ }^{271}$. Цими рекомендаціями Нацагенства визначена система забезпечення академічної доброчесності, яка поділяється на такі складові як ${ }^{272}$ :

1) нормативна база, що на системному рівні описує механізми впровадження принципів академічної доброчесності в науковий та освітній процеси, заходи із забезпечення дотримання цих принципів та процедури попередження й боротьби з порушеннями принципів академічної доброчесності. Основними елементами нормативної бази визначені базові нормативні документи, зокрема: Кодекс корпоративної культури; Кодекс академічної доброчесності; Положення про академічну доброчесність та етику академічних взаємовідносин; Положення про Комісії з академічної доброчесності й університетську Комісію з етики та управління конфліктами; Положення про групу сприяння академічної доброчесності;

2) структурні підрозділи та уповноважені комісії, які забезпечують популяризацію принципів академічної доброчесності, їх впровадження в освітньо-наукову діяльність закладу вищої освіти, а також виконують наглядову та контролюючу функції, зокрема: група сприяння академічній доброчесності; постійно діюча Комісія з етики та управління конфліктами; комісії з академічної доброчесності;

3) інформаційна база, за допомогою якої здійснюється популяризація принципів академічної доброчесності та підвищення рівня обізнаності всіх учасників освітньо-наукової діяльності в університеті у питаннях академічної доброчесності, основними складовими якої $є$ : сайт (рубрика сайту) «Академічна доброчесність»; інформаційні та методичні матеріали, присвячені інформаційній грамотності та попередженню плагіату, які створені спільно з представниками компаній-розробників програм перевірки діяльностей на унікальність; інформаційні матеріали щодо корпоративної культури на робочому місці та переваг чесного навчання, які створені спільно з представниками роботодавців; матеріали присвячені популяризації принципів академічної доброчесності серед здобувачів вищої освіти;

4) інструменти впровадження принципів академічної доброчесності в освітню й наукову діяльність університету, які несуть просвітницьку функцію та за допомогою яких стає можливим попередження випадків порушення принципів академічної доброчесності, у тому числі: інформаційно-консультативне супроводження співробітників закладу вищої освіти та здобувачів вищої освіти; масові відкриті онлайн-курси за тематикою академічної доброчесності та основ інформаційної грамотності; реалізація програми підвищення кваліфікації науково-педагогічних і педагогічних працівників; лекції основних стейкхолдерів вищої освіти (відомих випускників, роботодавців, експертів тощо) з тематики переваг чесного навчання та реалізації наукових досліджень, цикли тренінгів з академічної доброчесності тощо;

5) інструменти контролю додержання академічної доброчесності в освітній і науковій діяльності закладу вищої освіти, які, зокрема, передбачають здійснення анкетування учасників наукового та освітнього процесів на предмет порушення академічної доброчесності, а також обов'язкову перевірку наукових, навчально-методичних, кваліфікаційних та навчальних робіт на наявність ознак академічного плагіату відповідно до створеної нормативної бази.

\footnotetext{
271 Рекомендації для закладів вищої освіти щодо розробки та запровадження університетської системи забезпечення академічної доброчесності. Затверджено Рішенням Національного агентства із забезпечення якості вищої освіти від 29 жовтня 2019 року, протокол № 11. C. 2. URL: https://naqa.gov.ua/wp-content/uploads/2019/10/Рекомендації-зВО-система-забезпечення-академічноїдоброчесності.рdf

272 Рекомендації для закладів вищої освіти щодо розробки та впровадження університетської системи забезпечення академічної доброчесності. Затверджено Рішенням Національного агентства із забезпечення якості вищої освіти від 29 жовтня 2019 року, протокол № 11. C. 4-5. URL: https://naqa.gov.ua/wp-content/uploads/2019/10/Рекомендації-зВО-система-забезпечення-академічноїдоброчесності.рdf
} 
3 огляду на структуру визначеної Нацагенством системи забезпечення академічної доброчесності у соціальному середовищі закладів вищої освіти України $€$ очевидним, що ії формування визначається нормативною базою. Слідуючи такій логіці, нами був здійснений аналіз наявності основних нормативних документів, що визначені рекомендаціями Нацагенства, у перших шести університетах за рейтингом «ТОП-200 Україна» ${ }^{273}$ (за 2019 р.) та у шести останніх закладах вищої освіти за цим же рейтингом. Цей аналіз висвітлено в аналітичних матеріалах другого етапу нашого наукового дослідження 274 .

Проведений аналіз наявності нормативної бази із забезпечення академічної доброчесності у дванадцяти університетах та інших закладах вищої освіти України показав, що найкраща забезпеченість у цьому сенсі нормативними документами, а також найлегша доступність до них забезпечена у Сумському державному університеті. Наявні нормативні документи в цьому університеті за своїми назвами майже повністю співпадають з тим переліком назв документів, які рекомендує Нацагенство. I це не випадково. Рекомендації з цього приводу Нацагенство підготувало на підставі вивчення зарубіжного досвіду та кращих практик вітчизняних 3ВО, до яких належить і Сумський державний університет. Це підтверджується відповідними посиланнями у рекомендаціях НАЗяВО і джерельною базою, якою скористалися розробники.

Але в одинадцяти інших закладах вищої освіти, як показав наш аналіз, такого переліку нормативних документів, які передбачає Нацагенство у своїх рекомендаціях, немає. Наразі невідомо, наскільки цей перелік $\epsilon$ обов'язковим і чи буде Нацагенство вимагати від вітчизняних ЗВО створення системи академічної доброчесності в їхньому соціальному середовищі за тією структурою, що передбачена його рекомендаціями. Сподіваємося, що Нацагенство не буде вдаватися до надмірної формалізації та бюрократизації формування академічної доброчесності, яка закладена чи запрограмована у його розроблених і затверджених рекомендаціях, що адресовані закладам вищої освіти України. Підставою для таких сподівань $\epsilon$ певні застереження, на які варто звернути увагу.

По-перше, не спостерігається позитивної кореляції між наявністю нормативних документів, які забезпечують систему академічної доброчесності в соціальному середовищі закладів вищої освіти, і місцями в рейтингу «ТОП-200 Україна», які вони посідають.

По-друге, і це найголовніше, доброчесність, у тому числі академічна, залежить від моралі, яка сповідується у соціальному середовищі ЗВО, та від совісті тих, хто належить до цього середовища, і першочергово та визначально, від суб'єктів, які у ньому мають владу. Якщо керівництво, починаючи з ректора та його команди, сповідує подвійні моральні стандарти, допускає у своїх діях нечесність, бодай приховану від університетської спільноти, ніякі формальні унормування академічної доброчесності та жорсткі вимоги і контролі щодо їі дотримання, як то передбачено рекомендаціями Нацагенства, не зроблять доброчесним підвладне їм соціальне середовище.

Логіка підказує, що контроль за чесністю й порядністю суб'єктів влади ЗВО має бути більш дієвим у забезпеченні системи академічної доброчесності, аніж контроль за наявністю документів, які їі формально унормовують. Звідси постає питання стосовно суб'єктів такого дієвого контролю. В оптимумі такими суб'єктами мають бути як внутрішні, так і зовнішні стейкхолдери на чолі з МОН і Нацагенством України. Якщо зовнішні стейкхолдери відносно незалежні від керівництва закладів вищої освіти, щоб здійснювати моніторинг за доброчесністю його суб'єктів, то така незалежність внутрішніх зацікавлених осіб, зокрема, науковопедагогічних працівників і здобувачів вищої освіти у нашій соціальній дійсності, на жаль, знаходиться під великим знаком питання. I саме цим питанням актуалізується проблема демократизації соціального середовища вітчизняних 3ВО, яка розв'язується шляхом запровадження в їхнє управління механізмів ефективного врядування.

\footnotetext{
273 Рейтинг університетів «ТОП-200 Україна» у 2019 р. URL: https://osvita.ua/vnz/rating/64884/

274 Аналіз провідного вітчизняного та зарубіжного досвіду щодо механізмів реалізації ефективного врядування в університетах: препринт (аналітичні матеріали) (частина II) / Авторський колектив: І. Драч, О. Паламарчук, В. Рябченко, Л. Червона; за заг. ред. С. Калашнікової - Київ: Інститут вищої освіти НАПН України, 2019. - 96 c. URL: https://ihed.org.ua/wpcontent/uploads/2020/04/Analiz dosvidu vriaduvania v univer ch2 analit IVO-2019-96p avtors-kolektiv.pdf
} 
13. Нами ще на першому етапі наукового дослідження зроблений порівняльний аналіз моралі і права як регуляторів відносин між людьми і чинників впливу соціального середовища на ефективне врядування в університетах України в умовах євроінтеграції ${ }^{275}$. Зокрема, обгрунтований принцип взаємозумовленості врядування та демократичності соціального середовища, який проявляється у тому, що врядування з однієї сторони сприяє демократизації соціального середовища, а з іншої - стає реально можливим та найбільш ефективним лише в демократичному середовищі.

На підставі порівняльного аналізу нами зроблений висновок, який полягає в наступному: «Прийняття моралі як базового регулятора відносин у соціальному середовищі університету не скасовує і не заперечує запровадження необхідних нормативно-правових механізмів врядування, які зазвичай прописуються і фіксуються у відповідних документах. Але при цьому беремо до уваги, що правове регулювання передбачає примус, обмеження та зовнішній контроль, що певною мірою суперечить сутності й самій природі врядування як самоуправління, в якому обсяг повноважень і відповідальності першої особи в адміністративній вертикалі, на паритетних засадах розподіляється між учасниками колегіальних органів врядування і частково делегується на нижчі ієрархічні рівні системи управління. Маємо усвідомлювати, що нормативно-правове регулювання є базовою основою для бюрократичного управління та жорсткого адміністрування, яке укорінилося й не погано себе почуває у більшості вітчизняних ЗВО. Але ж ми рухаємося в Європейський простір вищої освіти і вважаємо, що таке управління не $є$ ефективним у сучасних цивілізаційних умовах і прагнемо його замінити більш ефективним врядуванням, зразки якого вивчаємо в західноєвропейських університетах і прагнемо їх запровадити в управління вітчизняних університетів. Тому пояснений вище механізм регулювання відносин між людьми за допомогою моралі необхідно вважати базовим, без запровадження якого всі інші механізми врядування, скільки 6 їх не запроваджувалось в університетське управління, не запрацюють. Принаймні, реально. На папері можуть бути виписаними, як то робиться в західноєвропейських університетах, будь-які механізми врядування, що вдосконалюють університетське управління. На підставі прописаного і нормативнорегламентованого можна створити відповідні організаційні структури, які не будуть відрізнятися від західноєвропейських аналогів. Але більшість задуманого й запропонованого так і залишиться на папері, а організаційні структури виявляться недієвими, якщо в університетах не буде сформоване реальне доброчесне академічне середовище, яке базуватиметься на моралі та совісті кожного з учасників освітнього процесу, а не забезпечуватиметься штучно одними лише адміністративними контролями й санкціями» ${ }^{276 .}$

Доречно застерегти від надмірної фетишизації документів і сліпої віри в їхню дієвість, навіть за умов повної відповідності їх змісту європейським вимогам. Особливо недопустима така сліпа віра в наукових дослідженнях, які здійснюються у контексті нашої соціальної дійсності. Документи не гарантують бажаного результату, якщо їхні норми не будуть втілюватися у життя. Це підтверджується як міжнародним, так і вітчизняним досвідом.

Як приклад, що підтверджує вище зазначене, наведемо розбіжності між тим, на що націлюють основні положення та норми нового Закону України «Про вищу освіту», і реальним станом вітчизняної вищої освіти, зокрема їі якістю.

З часу введення у дію зазначеного Закону минув уже шостий рік. За цей період проведено великий обсяг роботи з розроблення і запровадження в рамках Закону України «Про вищу освіту» нормативних документів, якими унормувалися запровадження його основних положень у життя. І зміст цього закону, і його підзаконні акти відповідають вимогам Європейського простору вищої освіти, отже, націлюють на європейську якість вищої освіти. Але й дотепер не спостерігається позитивної кореляції між цими документами та якістю вітчизняної вищої освіти. Принаймні, автору не довелось знайти жодного соціологічного дослідження та публікації, в яких би спростовувалось це твердження.

\footnotetext{
275 Рябченко В. Теоретичні основи впливу соціального середовища на ефективне врядування в українських університетах: світогляднокомпетентнісний аспект. Аналіз провідного вітчизняного та зарубіжного досвіду розвитку щодо механізмів реалізації ефективного врядування в університетах: препринт (аналітичні матеріали) (частина I) / за заг. ред. С. Калашнікової. Київ: Інститут вищої освіти НАПН України, 2018. С. 6-58. https://ihed.org.ua/wp-content/uploads/2019/09/Analiz dosvidu_vriaduvania_v_univer ch1_analit IVO2018-147p avtors-kolektiv.pdf

276 Рябченко В. Розвиток особистісного потенціалу академічного персоналу і здобувачів вищої освіти як інтегрований критерій результативності та ефективності університетського управління. Міжнародний науковий журнал "Університети і лідерство», 2019. № 1(7). C. 79. DOI: https://doi.org/10.31874/520-6702-2019-7-1-65-88.
} 
Така парадоксальна тенденція може давати підстави для певного скепсису щодо доцільності здійснюваних інституційних реформ вітчизняної вищої освіти та курсу на євроінтеграцію. Але причина не в реформах і тим паче не в євроінтеграції, до вимог якої більшості ЗВО України ще потрібно рости й рости. Здійснювані інституційні реформи доцільні та інтеграція в Європейський простір вищої освіти необхідна, оскільки вона зробить конкурентоспроможними ті ЗВО, які зростуть до рівня вимог цього простору й успішно в нього інтегруються. Причини зазначеної тенденції вкорінені в суспільному контексті, отже, за межами вищої освіти як соціального інституту. Тому долати негативний вплив українського суспільства необхідно на локальних рівнях у межах соціальних середовищ закладів вищої освіти.

У цьому контексті доречна цитата, яка рефреном проходить у наших публікаціях: «Справжній, а не віртуальний заклад вищої освіти своїм соціокультурним потенціалом цілком спроможний запропонувати студентам спрямованість на добро, створити умови, аби вони не через повчання та менторські настанови, а своїм світовідчуттям, світосприйняттям, світорозумінням і світобаченням за роки навчання в такому альтернативному до негативних реалій суспільства середовищі змогли відчути себе людьми. І через власні самовизначення та вибір дійти до усвідомлення в цьому відчутті найвищої цінності, яка слугувала б їм мірилом і дороговказом у проектуванні та здійсненні життя» 277.

Доброчесність, демократія, порядність, справедливість як і їхні антиподи розпочинаються в соціальному середовищі ЗВО з його керівництва - ректора та його команди. I не з їхніх слів і настанов, а з їхніх дій і прикладів, що демонструють цінності, якими вони керуються у своїй життєдіяльності.

277 Рябченко В. І. Вища школа України в загальноцивілізаційному контексті: соціально-філософський аналіз з позицій світогляднокомпетентнісного підходу. http://dglib.nubip.edu.ua:8080/bitstream/123456789/2770/1/monogr Visha shkola UA v zagaln- 
Передбачається, що запровадження механізмів реалізації ефективного врядування в університетах України створить у їхньому середовищі сприятливі умови для розвитку особистісного потенціалу керівників, науково-педагогічних працівників і студентів, що в кінцевому підсумку має підвищити результативність їхньої діяльності та рівень конкурентоспроможності як у вітчизняному, так і в європейському соціальному просторі.

Ці рекомендації, як і викладені вище теоретичні положення і світоглядно-методологічні засади, можуть стати у нагоді тим університетам України, які прагнуть успішно інтегруватися в Європейський простір вищої освіти і науки та бути в ньому конкурентоспроможними.

1. Щоб не дезорієнтувати теоретичну свідомість тих, хто досліджує проблематику врядування, і практичну свідомість тих, хто запроваджує механізми врядування у практику, рекомендуємо вийти з порочного кола термінологічного дискурсу й не ототожнювати між собою врядування з різними прикметниками, на кшталт, «відкрите», «демократичне», «добре», «ефективне», «належне», «нове», «публічне», «розподілене», «чутливе» тощо. Варто зупинятися на одному якомусь словосполученні як термінові, роблячи при цьому обґрунтування доцільності та сутності використання саме такого прикметника як визначника, а не інакшого. У всіх інших контекстах, коли не виникає необхідності в такому акцентуванні, використовувати термін «врядування» без будь-яких прикметників і додаткових визначників, оскільки базові принципи однакові у всіх різновидах врядування.

У нашому науковому дослідженні ми керувалися наступним визначенням цього терміну: «Врядування це демократична форма соціального управління, яке базується на принципах відкритості, відповідальності, партнерства, порядності, справедливості та розподіленого лідерства».

2. Задля прискорення реального втілення врядування у життя українського суспільства та його соціальні осередки, до яких входять і заклади вищої освіти, рекомендуємо розгорнути широкий суспільний дискурс навколо проблем, які стримують дієву реалізацію принципів врядування на різних рівнях суспільної ієрархії України, в тому числі, вітчизняних університетів.

3. Для забезпечення ефективного врядування рекомендуємо створити у своєму соціальному середовищі максимально сприятливі умови для повноцінної реалізації в ньому базових принципів врядування.

4. Базовою умовою для реалізації механізмів ефективного врядування у закладах вищої освіти України $є$ доброчесність ї соціального середовища. Можливості дотримання доброчесності в освітньому процесі першочергово залежать від якості контингенту студентів та їхньої вмотивованості до здобуття конкурентоспроможної компетентності та професіоналізму науково-педагогічних працівників, їхньої справедливої вимогливості до результатів навчання здобувачів вищої освіти.

Які можливості у цьому сенсі має конкретний заклад вищої освіти, достеменно знають суб'єкти його діяльності. Для орієнтації на певні критерії такої самооцінки пропонуємо до розгляду три варіанти моделей діяльності вітчизняних ЗВО в умовах демографічної кризи та гіпертрофованого ринку освітніх послуг, ліцензований обсяг прийому якого перевищує кількість випускників українських шкіл. Всі інші моделі знаходяться між трьома, що пропонуються.

Найгіршу модель діяльності репрезентують ті заклади вищої освіти, які нездатні сформувати якісний контингент студентів і заробляють виключно на легітимізованій видачі дипломів про вищу освіту, зберігаючи в нечесні академічні способи максимально можливу для них чисельність студентів. Для керівництва ЗВО, яке дотримується такої моделі діяльності, демократизація соціального середовища їхнього закладу і прояви академічних свобод у ньому з боку викладачів і студентів невигідні. А вигідні в такому середовищі культивування конформізму, подвійних моральних стандартів та академічної нечесності. За такої моделі будьякі нормативні документи з доброчесності та врядування приречені на «мертвонародження». Скільки б їх не було створено і якої б найвищої досконалості вони не були, вони не запрацюють у такому соціальному середовищі.

Посередня модель демонструється тими ЗВО, які маючи достатньо якісний академічний персонал, перш за все науково-педагогічних працівників і необхідну матеріально-технічну базу, залучають на навчання значну чисельність конкурентоспроможних студентів, але поряд з цим на умовах контракту за мінімальними 
вимогами до рівня знань підбирають усіх бажаючих стати номінальними студентами та отримати легітимний диплом про вищу освіту. Конкурентоспроможні студенти як здобувачі вищої освіти підтримують успішний імідж закладу своїми досягненнями у навчанні, предметних олімпіадах та науковій роботі, мобільністю у зарубіжних університетах тощо. А інша категорія осіб як отримувачів дипломів, заповнюючи студентські місця в межах ліцензованих обсягів прийому, дає можливість певною мірою зберегти штатну чисельність академічного персоналу 3ВО. Така модель надання освітніх послуг, напевно, виправдовується з позицій тактики виживання в умовах жорсткої конкуренції за абітурієнтів, що зумовлена зазначеною диспропорцією між попитом і пропозицією у сфері вищої освіти. Але ця модель не знімає проблеми культивування в соціальному середовищі ЗВО, який їі застосовує, конформізму, подвійних моральних стандартів та академічної нечесності. Адже вмотивовані до здобуття конкурентоспроможної на цивілізованих ринках праці компетентності й зовсім не вмотивовані чи взагалі нездатні отримати мінімальні знання студенти перебувають в одному соціальному середовищі, навчаються в одних академічних групах і потоках.

Занижені вимоги до результатів навчання номінальних студентів не мотивують до напруженої навчальної роботи сильних студентів, які здатні до набуття конкурентоспроможної компетентності. А виставлення однакових оцінок тим студентам, які навчаються, і тим особам, які не навчаються, а лишень номінально числяться у списках студентів, певною мірою деморалізує студентське середовище. І не тільки його, а й соціальне середовище факультету або і ЗВО в цілому. Адже у такій легітимізованій фальсифікації вищої освіти за мовчазною згодою задіяні всі основні суб'єкти освітньої діяльності - адміністрація, науковопедагогічні працівники та студенти. Тому в таких моделях діяльності 3ВО, які спонукають до культивування в соціальному середовищі подвійних моральних стандартів, запровадження механізмів демократизації набуватиме номінального характеру. Це коли необхідні демократичні механізми формально є, а реальної демократії в соціальному середовищі немає. Не знаходиться достатньо підстав сподіватись на доброчесне соціальне середовище у таких посередніх 3ВО.

Тож найсприятливішою для демократизації соціального середовища й утвердження в ньому академічної доброчесності, відповідно до нормативних документів чи без них неформально, може бути лише така модель діяльності ЗВО, управління якою забезпечує формування якісного академічного персоналу й контингенту студентів та орієнтується на створення умов для максимально можливого розвитку особистісного потенціалу всіх суб'єктів цієї діяльності. А такі умови стають можливими лишень у демократичному соціальному середовищі. Така модель діяльності формує позитивну репутацію закладу вищої освіти.

За запропонованими нами критеріями цих трьох моделей кожен вітчизняний заклад вищої освіти шляхом критичної самооцінки може визначити стан доброчесності у своєму соціальному середовищі та свої перспективи щодо конкурентоспроможності у Європейському просторі вищої освіти. Той ЗВО, який за своїми показниками й устремліннями у своїй діяльності тяжіє до найсприятливішої моделі для демократизації та утвердження доброчесності у своєму соціальному середовищі, може реально претендувати і на високий рейтинг і на успішну євроінтеграцію, отже, на міжнародне визнання своїх дипломів.

5. Для реалізації ефективного врядування в університеті пропонуємо керуватися моделлю (рис. 1). 


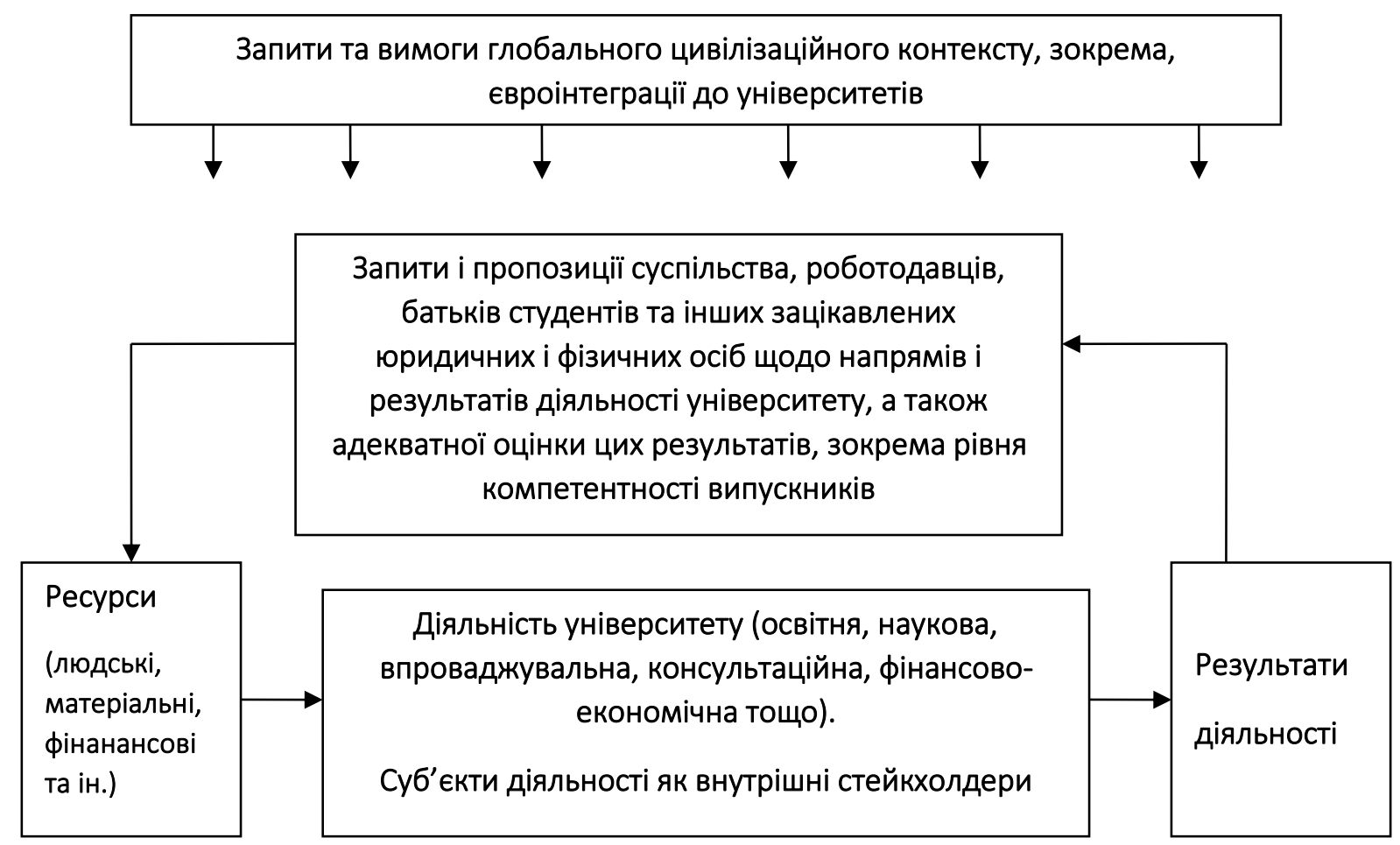

Рис. 1. Модель забезпечення реалізації ефективного університетського врядування

Запропонована блок-схема відображає університет як самодостатню та самоврядну інституцію, що знаходиться під безпосереднім впливом суспільного контексту та опосередкованим впливом глобального цивілізаційного контексту, зокрема чинників євроінтеграції.

Блок-схема логічно унаочнює алгоритм визначення механізмів реалізації ефективного врядування за кінцевими результатами діяльності університету, яка структурована його місією, візією, профілем у відповідності до запитів і вимог суспільства та глобального цивілізаційного контексту.

При оцінюванні ефективності запровадження врядування в управління університетом маємо виходити 3 того, що врядування не $є$ самоціллю, а дієвим засобом розвитку особистісного потенціалу студентів, науковопедагогічних працівників, керівників, усіх працівників університету як його сукупного людського капіталу й головного ресурсу. Рушійною силою, а відповідно і дієвим механізмом розвитку особистісного потенціалу має слугувати розкріпачення ініціативи названих суб'єктів та пробудження у них відповідальності завдяки демократизації соціального середовища університету. А інтегральним мотивуючим чинником розвитку особистісного потенціалу має бути цивілізоване конкурентне середовище на ринках праці в усіх сферах діяльності українського суспільстава, що слугуватиме потужним зворотним зв'язком для розвитку людського капіталу університету т підвищення його конкурентоспроможності.

6. Рекомендуємо робити експертну самооцінку свого закладу вищої освіти крізь матрицю варіантів ситуацій, що ілюструють вплив тих чи інших чинників на розвиток особистісного потенціалу здобувачів вищої освіти як інтегрованого результату діяльності 3ВО.

За умови наявності на вході однакових матеріальних, фінансових ресурсів, академічного персоналу тощо потенційні можливості для досягнення кращого результату будуть у того 3ВО, який сформував якісніший контингент студентів. I навпаки, за однакових зазначених умов рівень таких можливостей буде тим нижчим, чим гіршим буде контингент студентів.

За однакових ресурсів, включаючи й контингент студентів, кращого результату досягне той 3ВО, у якому будуть створені ліпші можливості для всебічного розвитку особистісного потенціалу здобувачів вищої освіти. Брак таких можливостей буде нівелювати чи навіть блокувати розвиток особистості студента. Створення чи, навпаки, звуження таких можливостей - це задача, вирішення якої безпосередньо залежить від управління діяльністю ЗВО. 
За наявністю однакового контингенту студентів рівень результативності буде залежати від якості академічного персоналу, наявності матеріальних і фінансових ресурсів. При цьому якість академічного персоналу логічно вважати визначальним чинником досягнення кращого результату.

Низький рівень якості академічного персоналу та контингенту студентів, брак матеріальних і фінансових ресурсів, програмують найгірший результат діяльності 3ВО.

Через порівняльний критичний аналіз із зазначеними ситуаціями реального стану свого зВО таку самооцінку за бажання можуть зробити не лише суб'єкти управління, які достеменно знають що й як в ньому діється, а й інші учасники його діяльності, включаючи здобувачів вищої освіти.

7. Щоб бути методологічно коректним у визначенні всебічного розвитку особистості студента, необхідно робити порівняльний аналіз того, з чим або з яким рівнем розвитку особистість випускника виходить у самостійне професійне життя, з тими набутками, з якими вона свого часу входила на навчання у цей заклад вищої освіти. Найкоректніший аналіз шляхом самооцінки розвитку власної особистості за роки навчання здатні зробити лише студенти. Адже кожен з них достеменно знає, з якими здобутками в розвитку власної особистості поступав на навчання і з якими набутками і втратами у цьому сенсі завершив його. Набутки визначають позитивну, а втрати - негативну дельту в розвиткові особистісного потенціалу. Спираючись на таку самооцінку, шляхом опитування студентів можна робити критичний аналіз як наявності, так і відсутності тих чи інших можливостей соціокультурного середовища у сприянні гармонійному розвиткові їхніх особистостей у конкретному 3ВО. Чим більше таких можливостей буде створюватися, тим збільшуватиметься загал студентів, які зможуть ними скористатися для розвитку власного особистісного потенціалу. I навпаки, обмеженість чи повна відсутність таких можливостей не сприятиме такому розвитку. 


\section{Висновки}

1. На нинішньому етапі розвитку сучасної цивілізації, тим паче у їі майбутньому, пріоритетним є і буде залишатись не проблема продукування нових знань і винайдення новітніх технологій, маховик яких розкручений до нестями, а проблема того як дати раду знанням і технологіям. Тим, які вже $\in$ й тим, які ще з'являться. Адже знання мають однакову силу як для творення добра, так і зла у земному бутті як осередку мешкання людського роду. Тож проблема полягає у запобіганні руйнації цього буття, яка здійснюється з використанням знань і технологій та збільшується мірою зростання сили останніх. Це з усією очевидністю підтверджує характер перебігу науково-технічного прогресу. Звідси випливає, що цю проблему неможливо розв'язати лишень якимись новими знаннями і технологіями суто технократично.

Ця проблема, перш за все, має розв'язуватись на світоглядному рівні як проблема морального вибору між добром і злом. Усіма суб'єктами, які застосовують знання, технології, інші набутки науково-технічного прогресу у своїх життєвих виявах, розпочинаючи з банальних побутових та локально професійних виявів, і завершуючи виявами регіонального та глобального масштабів.

Цим зумовлюється актуальність світоглядної компетентності, якою мають володіти випускники сучасних університетів і яка б блокувала будь-які негативні прояви не лише професійної, а й іншої їхньої життєдіяльності. Звідси постає одна із визначальних складових місії сучасних і майбутніх університетів. Як свого часу класичні університети сприяли своїм народам утвердити й розбудувати національні держави, так на нинішньому етапі глобалізації університети мають посприяти зійти глобальній земній спільноті зі шляху самознищення й самовитіснення із земного буття.

Тому попри песимістичний сценарій, за яким розгортається сучасна криза класичних університетів, альтернативи їм як соціальним інститутам немає. Таке категоричне твердження базується на тому, що не проглядається жодної іншої соціальної інституції, яка 6 могла їх замінити без катастрофічних наслідків для подальшого існування сучасної цивілізації. І здолати цю кризу зможуть ті університети, які у виконанні своєі цивілізаційної місії зійдуть з позицій технократизму й цинічного прагматизму та забезпечать пріоритет формуванню світоглядної компетентності в осіб, які здобувають у них вищу освіту. Цим власне й пояснюється необхідність зміщення пріоритету у здійсненні місії сучасними університетами, що вимагає від них сходження з позицій технократизму у формуванні компетентності у своїх здобувачів вищої освіти.

Тому нині, а тим паче в майбутньому, університети мають посилювати не лише фахову суто професійну підготовку студентів, а й прищеплювати цінності, які 6 сприяли їм у набутті належної світоглядної компетентності, яка 6 відповідала як їхнім соціальним статусам і ролям, так і вимогам до компетентності у глобальному вимірі.

Але на відміну від знань, які можна вивчити і володіти ними, цінності треба прожити й пережити, пропустивши через своє серце і душу, та продемонструвати володіння ними не знаннями про них, а власним відношенням до світу. Як заохочення, так і блокування демонстрації тих чи інших світоглядних цінностей у життєвих проявах особистості людини багато в чому залежить від соціального середовища, в якому вона перебуває. Зокрема, базовою цінністю світогляду людини як істоти розумної і фундаментальною умовою безпечного існування та розвитку ноосфери $€$ моральність. Цим актуалізується вимога до моральності університетського середовища. Адже цинічне середовище, в якому нехтуються норми моралі й культивуються подвійні моральні стандарти, не може прищепити моральні цінності особистості. В такому середовищі для особистості постає протилежна проблема - як зберегти в собі раніше набуті моральні чесноти.

2. Надзвичайної актуальності в умовах ноосфери набуває проблема відповідальності сучасної людини. Досвід соціальної еволюції людства та його цивілізаційного розвитку переконливо довів, що почуття відповідальності як світоглядної цінності найліпше формується особистістю у демократичному середовищі. Відповідальність і порядок в соціальному середовищі, які доволі швидко досягаються авторитарними методами, мають ефемерний характер, оскільки вони тримаються не на внутрішньому усвідомленні особистістю відповідальності, а на зовнішніх примусах, контролях і санкціях. Як тільки останні послаблюються або зникають, то зникає відповідальність і порядок в життєвих проявах людей, які звикли жити й працювати в авторитарному соціальному середовищі. Понад це, люди, в особистостях яких не сформований внутрішній стрижень відповідальності, за відсутністю зовнішнього примусу й контролю схильні до свавілля й безпорядку у своїх життєвих проявах. Авторитарне соціальне середовище блокує свободу людини. А у несвободі вільного громадянина не виховаєш. Хіба що раба. 
Цим зумовлюється потреба у демократизації університетського середовища. Одним із засобів демократизації та розподілу відповідальності між членами університетської спільноти за прийняття рішень, які визначають розвиток університету та його основні напрямки діяльності, $є$ механізми реалізації ефективного врядування в університетах.

Запровадження таких механізмів $є$ надзвичайно актуальним для вітчизняних закладів вищої освіти, оскільки у багатьох з них утвердився авторитаризм, якого навіть не було, як це не парадоксально, у радянський період. Це підтверджується рівнем демократичності у відносинах викладачів і студентів з адміністрацією закладу вищої освіти, а також рівнем зловживань владою його адміністраторами, починаючи з ректора й закінчуючи методистами деканатів і комендантами гуртожитків. У радянський період, принаймні в останні його два десятиліття, викладачі були більш захищеними, ніж нині, у трудових відносинах з адміністрацією. Нині ж системного характеру набуло утримання викладачів на короткій мотузці адміністрації у вигляді короткотермінових зарахувань їх на посади без відкритого конкурсу. Така пряма залежність від адміністрації блокує академічну свободу викладача, зокрема у зайнятті ним принципової позиції не лише в університетському врядуванні, а й, що найголовніше, в адекватній оцінці результатів навчання студентів.

3. Зроблений у науковому дослідженні порівняльний аналіз моралі та права як регуляторів відносин між людьми спрямований на обґрунтування теоретичних основ впливу соціального середовища на ефективне врядування в університетах України в умовах євроінтеграції. Цей аналіз дає достатньо обгрунтованих підстав для теоретичного визначення моралі як базової основи соціального середовища і необхідної передумови для реалізації ефективного врядування в університетах. Виходимо з того, що врядування $\epsilon$ різновидом децентралізованого управління, яке передбачає колегіальне напрацювання рішень і персональну відповідальність за їх прийняття та успішну реалізацію, і в якому збалансовано на паритетних засадах беруть участь внутрішні та зовнішні стейкхолдери університету. При цьому беремо до уваги принцип взаємозумовленості врядування й демократичності соціального середовища, який проявляється в тому, що врядування з однієї сторони сприяє демократизації соціального середовища, а з іншої - стає реально можливим та найбільш ефективним лише у демократичному середовищі. В авторитарному середовищі врядування стає бутафорією, отже, несправжнім.

Прийняття моралі як базового регулятора відносин у соціальному середовищі університету не скасовує і не заперечує запровадження необхідних нормативно-правових механізмів врядування, які зазвичай прописуються і фіксуються у відповідних документах. Але при цьому потрібно пам'ятати, що правове регулювання передбачає примус, обмеження та зовнішній контроль, що певною мірою суперечить сутності й самій природі врядування як самоуправління, в якому обсяг повноважень і відповідальності першої особи в адміністративній вертикалі, на паритетних засадах розподіляється між учасниками колегіальних органів врядування і частково делегується на нижчі ієрархічні рівні системи управління. Маємо усвідомлювати, що нормативно-правове регулювання $€$ базовою основою для бюрократичного управління та жорсткого адміністрування, яке укорінилося й не погано себе почуває у більшості вітчизняних ЗВО. Але ж ми рухаємося в Європейський простір вищої освіти і вважаємо, що таке управління не є ефективним у сучасних цивілізаційних умовах і прагнемо його замінити більш ефективним врядуванням, зразки якого вивчаємо в західноєвропейських університетах і прагнемо їх запровадити в управління вітчизняних університетів.

Тому пояснений у науковому дослідженні механізм регулювання відносин між людьми за допомогою моралі необхідно вважати базовим, без запровадження якого всі інші механізми врядування, скільки $б$ ї не запроваджувалось в університетське управління, не запрацюють. Принаймні, реально. На папері можуть бути виписаними, як то робиться в західноєвропейських університетах, будь-які механізми врядування, що вдосконалюють університетське управління. На підставі прописаного і нормативно-регламентованого можна створити відповідні організаційні структури, які не будуть відрізнятися від західноєвропейських аналогів. Але більшість задуманого й запропонованого так і залишиться на папері, а організаційні структури виявляться недієвими, якщо в університетах не буде сформоване реальне доброчесне академічне середовище, яке базуватиметься на моралі та совісті кожного з учасників освітнього процесу, а не забезпечуватиметься штучно одними лише адміністративними контролями й санкціями.

4. Порівнюючи характер впливу західноєвропейських суспільств на університети з впливом українського суспільства на вітчизняні університети, мусимо констатувати невтішний для нас висновок. Інтегральна сутність цього висновку може бути зведеною до того, що західноєвропейські університети виконують свою місію завдяки сприятливому впливу своїх суспільств, а нашим університетам доводиться долати негативний вплив 
багатьох чинників свого суспільного контексту. 3 цієї суперечності між «завдяки» і «всупереч» постає першочергова, оскільки має світоглядний характер, проблема на шляху інтеграції вищої освіти України у Європейський простір вищої освіти. Виходячи зі стану українського суспільства та його соціального середовища, маємо адекватно оцінювати можливості такої інтеграції. Доки в українському суспільстві не буде розбудована демократично-правова держава, доти годі сподіватись на успішну інтеграцію вітчизняної вищої освіти у форматі всього суспільного інституту.

А поки український народ справиться з успішним вирішенням цієї історичної задачі, від якого залежить його майбутнє - процвітаюче життя у власній незалежній країні або, у разі невирішення, чергове повернення у пригноблене існування у складі імперії з повною втратою української ідентичності, нам необхідно максимально задіяти особистісний потенціал студентів, науково-педагогічних працівників та інституційні можливості кожного зокрема університету. I не заради рекрутування кращих з кращих співвітчизників на цивілізовані ринки праці, а задля розбудови європейського життя на теренах України, що стане можливим лише тоді, коли в українському суспільстві будуть домінувати європейські цінності. А щоб це сталося, українські університети мають стати осередками та розсадниками загальнолюдських цінностей. Таке завдання до снаги студентам, вмотивованим здобувати конкурентоспроможну компетентність, і ректорам та їхнім командам, що керуються цінностями не тактики виживання, а стратегії розвитку свого університетського середовища, яке 6 за можливостями підготовки у ньому фахівців конкурувало із західноєвропейськими університетами.

5. 3 огляду на фундаментальну суперечність між розвитком соціального й технічного, яка надзвичайно загострилася в умовах техногенної цивілізації, $є$ переконливі підстави стверджувати, що від рівня розвитку особистісного потенціалу студентів як безпосередньо, так і опосередковано залежить рівень суспільного розвитку країн, в яких вони будуть працювати після здобуття вищої освіти, а в кінцевому підсумку й майбутнє сучасного людства. Адже саме завдяки дипломам, які засвідчують наявність вищої освіти, сучасні мешканці нашої планети отримують право на входження в соціальні ліфти, якими вони можуть піднятися на будь-які щаблі в суспільній і глобальній ієрархії, включаючи найвищі з них. Саме на особах з вищою освітою лежить основна відповідальність за успішне подолання локальних і глобальних викликів, які постають перед державами, наддержавними утвореннями та земною цивілізацією в цілому.

Тому оцінювання результативності й ефективності університетської діяльності та управління нею доцільно робити з огляду на те, як поліпшується розвиток особистості студента, першочергово завдяки набуттю світоглядної компетентності, за період здобуття вищої освіти.

6. Аналіз досвіду управління в університетах України виявив системні вади, які характерні для багатьох з них. Ці вади, у свою чергу, зумовлюють результативність діяльності 3ВО, яка не відповідає суспільним і глобальним цивілізаційним викликам. А саме ці виклики належить долати особам з вищою освітою, щоб підняти на належний рівень конкурентоспроможність України як запоруку ї̈ успішного суспільно-економічного розвитку. До таких системних вад ми, зокрема, відносимо наступні:

Домінування адміністрування (яке тяжіє до авторитарного стилю) в управлінні університетською діяльністю блокує або робить номінальним запровадження механізмів врядування у соціальне середовище закладу освіти.

Зміщення пріоритетів в управлінні різновидами університетської діяльності від основних (освітня, науково-інноваційна діяльність) до обслуговуючих (економічна, комерційно-фінансова).

Комерціалізація університетської діяльності сприяє і вимагає жорсткішого адміністрування та контролю, що суперечить демократизації соціального середовища, яка має відбуватися завдяки запровадженню механізмів врядування.

Здійснення контролю в управлінні за кількісними показниками і критеріями супроводжується надмірною формалізацією та бюрократизацією.

7. Пропонується задіяти якісні критерії результатів, на досягнення яких має орієнтуватись університетське управління. Пам'ятаймо, що з підвищенням ефективності діяльності ЗВО збільшується його конкурентоспроможність, яку до речі логічно вважати інтегрованим індикатором корпоративної компетентності всіх учасників цієї діяльності. 
8. Діяльність ЗВО забезпечується людськими, матеріальними, фінансовими та іншими ресурсами, визначальна роль серед яких належить людським. На відміну від інших ресурсів, які невідворотно витрачаються, людські ресурси у процесі їх використання самовідновлюються й розвиваються.

Самовідновлення й розвиток людських ресурсів або людського капіталу тим кращий, чим розвиненіший особистісний потенціал учасників університетської діяльності.

Тому саме на покращення розвитку особистісного потенціалу учасників університетської діяльності й має безпосередньо орієнтуватись управління нею.

9. Репутація університету - це результат кропіткої і самовідданої праці багатьох поколінь студентів і не одного покоління академічного персоналу. Тому $є$ всі підстави вважати її найдорожчим ресурсом університету, який ні в якому разі не можна розмінювати на дріб'язки.

10. Розв'язання проблеми підвищення якості вітчизняної вищої освіти до рівня світових вимог має здійснюватися з орієнтацією на дослідження й усунення причин актуалізованої проблеми, які породжує сучасне українське суспільство. Відсторонення від цих причин, замкнутість у внутрішньому інституційному форматі та ізольованість на локальних рівнях прирікають на неуспіх реформування вищої освіти України та на низьку результативність досліджень проблем якості вищої освіти.

Проблеми якості вищої освіти виходять за межі предметного поля педагогіки, а тому їх не можна адекватно дослідити та розв'язати у форматі традиційної педагогічної парадигми. 
Завершення нашого наукового дослідження співпало з процесами розроблення проєкту Стратегії розвитку вищої освіти в Україні на 2021-2030 роки (далі - Стратегія). Результати наукового дослідження та зроблені на їх підставі висновки дозволяють зробити певні концептуальні зауваження щодо цієї Стратегії, яка оприлюднена у проєкті для публічного обговорення.

1. У першому розділі Стратегії визначено, що «головною проблемою розвитку вищої освіти залишається відсутність довгострокової стратегії соціально-економічного розвитку України, що ускладнює створення моделі вищої освіти, адекватної цілям майбутнього країни» ${ }^{278}$. Не знаходиться підстав, принаймні в автора, для заперечення зазначеної проблеми. Але залишається відкритим питання щодо того, чи є ця проблема головною, зокрема, для розвитку вищої освіти. Адже сама стратегія розвитку будь-чого - це ще не сам розвиток де-факто. Тим паче наявність моделі розвитку в уяві чи на папері та інших носіях інформації не гарантує того, що вища освіта буде розвиватися у відповідності до неї.

Стратегія соціально-економічного розвитку та адекватна їй модель вищої освіти - це першочергово документи, а не реальний розвиток. А в нашій пострадянській ментальності папір як носій інформації все терпить. Ще простіше у цьому сенсі з електронними документами. Наша деформована у морально-правовому вимірі соціальна дійсність демонструє, що правильних і важливих документів, які спрямовують на поліпшення цієї дійсності плодиться багато. Але дійсність, на поліпшення якої спрямовані ті чи інші документи, на жаль, від цього не покращується.

Це свідчить про номінальність і низьку дієвість документів, у т. ч. стратегій та моделей, у соціальному просторі сучасного українського суспільства. За інформацією Г. Рябцева, який досліджував українську бюрократію, в Україні, починаючи з 1991 року, написано та розроблено величезний корпус документів, які не виконувалися, зокрема такі: 3 стратегічні документи соціально-економічного розвитку, 153 стратегії, 591 концепція, 774 державні програми, 35 напрямів реформування і 21 стратегія розвитку регіонів ${ }^{279}$.

На наш погляд, головною причиною, отже й проблемою, плачевного результату соціально-економічного розвитку України $\epsilon$ не відсутність стратегії такого розвитку, а порочне коло екстрактивних політичних та економічних інститутів, запроваджене гібридним режимом влади, у полоні якого опинилося українське суспільство.

Тому адекватність моделі розвитку вищої освіти забезпечується не тим, що може бути визначено та прописано в стратегії соціально-економічного розвитку України, а їі реальним станом і розвитком.

2. Другий розділ Стратегії присвячений ідентифікації проблем розвитку вищої освіти в Україні. Ключова теза цього розділу концептуально збігається з нашим баченням основної причини низької якості вітчизняної вищої освіти: «Узагальненою проблемою системи вищої освіти $€$ незатребуваність вищої освіти українським суспільством як інституту і головного ресурсу розвитку країни, що у поєднанні з масифікацією вищої освіти викликає спотворення освітнього процесу і незадовільні результати діяльності 3ВО» 280.

Але на жаль, ця теза має декларативний характер, оскільки у змісті Стратегії не ідентифіковані причини, що породжують зазначену проблему. Відповідно не проглядаються і шляхи усунення цих причин.

У підрозділі 2.1 першою проблемою ідентифікована все таж «невизначеність довгострокових пріоритетів, відсутність стратегії соціально-економічного розвитку України, відсутність чітко виражених пріоритетів державної економічної політики», формальна сутність якої була з'ясована вище.

Окрім цієї проблеми ідентифікована ціла низка гострих проблем, які стримують розвиток вітчизняної вищої освіти. Але більшість з цих проблем $є$ наслідками причин, що укорінені в суспільному контексті. Не усунувши таких першопричин, ми прирікаємо себе на постійне подолання їх наслідків. Для того щоб усунути першопричини, їх спочатку потрібно ідентифікувати.

\footnotetext{
278 Стратегія розвитку вищої освіти в Україні на 2021-2031 роки. - C. $5 . \quad$ URL: https://mon.gov.ua/storage/app/media/rizne/2020/09/25/STRATEHIYA_ROZVYTKU VYSHCHOYI_OSVITY V_UKRAYINI_PROYEKT.pdf 279 Генадій Рябцев. За весь період незалежності чиновники написали 1574 стратегічні документи, а виконали - 1 / http://nova.net.ua/zaves-period-nezalezhnosti-chynovnyky-napysaly-1574-stratehichni-dokumenty-a-vykonaly-1/

280 Стратегія розвитку вищої освіти в Україні на 2021-2031 роки. https://mon.gov.ua/storage/app/media/rizne/2020/09/25/rozvitkuvishchoi-osviti-v-ukraini-02-10-2020.pdf
} 
3. У третьому розділі Стратегії висвітлюються світові тренди розвитку вищої освіти. Зокрема, акцентовано три мегатренди, що впливають на майбутнє освіти ${ }^{281}$ : глобалізація; цифровізація; старіння населення.

У контексті мегатренду глобалізації зазначається: «Протягом найближчих десяти років більшість населення світу складатиметься з середнього класу - тенденція, що здебільшого визначається Китаєм та Індією, в яких буде сконцентровано 90 \% середнього класу світу. Це не тільки посилить тиск стосовно забезпечення кращої освіти для більшої кількості людей, а й щодо задоволення очікувань від освіти з боку більш вимогливих клієнтів. У країнах ОЕСР прогнозується, що спочатку це вплине саме на системи вищої освіти, оскільки їм доведеться докладати більше зусиль для залучення кращих студентів на набагато більш мобільному та конкурентному ринку» ${ }^{282}$. Таким чином саме середній клас визначально формуватиме попит на якісну вищу освіту, що спонукає ОЕСР, яку вважають товариством багатих країн, конкурувати на ринку освітніх послуг за задоволення цього попиту. Зазначений тренд як основний чинник підвищення якості вищої освіти й конкурентоспроможності університетів повністю резонує з обґрунтованими положеннями, результатами та висновками, висвітленими у нашому розділі монографії. Цей тренд підтверджує релевантність розглянутої моделі оптимальної взаємодії та розвитку суспільства та закладів вищої освіти.

Але дисонансом до значущості середнього класу в розвитку вищої освіти сприймається індиферентна констатація: «Щодо глобальної тенденції зростання середнього класу, то Україна не відноситься до країн, де прогнозуються такі явища протягом найближчих десяти років» 283 , яка зроблена нижче у цьому розділі Стратегії.

Байдужість до такого визначального чинника у підвищенні рівня розвитку вищої освіти та ї̈ якості у зробленій констатації можна було б певною мірою нівелювати словосполученням «на жаль». Оскільки цього не було зроблено, то виходить, що розробники Стратегії не вважають відсутність середнього класу в Україні проблемою як її успішного соціально-економічного розвитку в цілому, так і розвитку вітчизняної вищої освіти зокрема. 3 цього постає курйоз, який полягає в тому, що відсутність стратегії соціально-економічного розвитку України за визначенням Стратегії $€$ головною проблемою у розвитку вищої освіти, а відсутність середнього класу як визначального чинника одного й другого розвитку не ідентифікується як проблема.

Відсутність в Україні такого дієвого чинника буде значуще гальмувати підвищення попиту на якісну вищу освіту, отже й конкуренцію за ії надання між вітчизняними ЗВО. А без такої конкуренції не відбудеться й природної селекції між закладами вищої освіти, яка має залишити на ринку освітніх послуг кращих з них. Це означає, що оптимізацію чисельності вітчизняних 3ВО, яка вже багато років стоїть на порядку денному нашого суспільного життя, доведеться здійснювати шляхом адміністрування, отже, суб'єктивно через позбавлення ліцензій на підготовку фахівців через низьку якість їхньої освіти. Такий шлях устелений ризиками корупції, а тому не гарантує, що позбавляти ліцензій будуть найслабших.

281 Trends Shaping Education 2019, OECD Publishing, 2019, 107 p. https://www.google.com/search?client=firefox-bd\&q=Trends+Shaping+Education+2019\%2C+OECD+Publishing $\% 2 C+2019 \% 2 C+107+p$.

282 Стратегія розвитку вищої освіти в Україні на 2021-2031 роки. URL:

https://mon.gov.ua/storage/app/media/rizne/2020/09/25/rozvitku-vishchoi-osviti-v-ukraini-02-10-2020.pdf

283 Стратегія розвитку вищої освіти в Україні на 2021-2031 роки. URL:

https://mon.gov.ua/storage/app/media/rizne/2020/09/25/rozvitku-vishchoi-osviti-v-ukraini-02-10-2020.pdf 
1. Аджемоґлу Дарон, Робінсон Джеймс. Чому нації занепадають. Походження влади, багатства та бідності / пер. з англ. Олександр Дем'янчук. 4-те вид. К. : Наш формат, 2019. 440 с.

2. Академічна чесність як основа сталого розвитку університету / за заг. ред. Т.В. Фінікова, А.Є. Артюхова. К. : Таксон, 2016. 234 с.

3. Алалі Ахмад. Ефективне врядування («Good Governance») у контексті розвитку сучасного політичного менеджменту. Вісник Львівського університету. Серія філос.-політол. студії. 2018. Випуск 18. С. 245-250.

4. Арістотель. Природа людини і форми державного устрою. Демократія: Антологія / упоряд. О. Проценко. К. : Смолоскип, 2005. С. 230.

5. Белей І. Зарубіжний досвід демократичного врядування та можливості його застосування в українській практиці. Державне управління та місцеве самоврядування. Збірник наукових праць. Дніпропетровський регіональний інститут державного управління. 2010. Вип. 2(5). URL: http://www.dridu.dp.ua/vidavnictvo/2010/2010 02(5)/10bimzup.pdf

6. Братко М. Структура освітнього середовища вищого навчального закладу. Наукові записки Кіровоградського державного педагогічного університету імені Володимира Винниченка. Сер. : Педагогічні науки, 2015. Вип. 135. С. 67-72.

7. Будапештсько-Віденська декларація про створення Європейського простору вищої освіти (12 березня 2010 року). URL: http://www.edupolicy.org.ua/files/Budapest-Vienna Declaration(2010).pdf

8. В Україні скорочується середній клас, - доповідь ПPOOH. URL: https://rubryka.com/2020/01/11/v-ukrayiniskorochuyetsya-serednij-klas-dopovid-proon/

9. В уряді підрахували, скільки українців виїхало за кордон від початку десятиліття. URL: https://hromadske.ua/posts/majzhe-10-naselennya-v-uryadi-pidrahuvali-skilki-ukrayinciv-viyihalo-za-kordonvid-pochatku-desyatilittya

10. Велика хартія університетів (Magna Charta Universitatum). URL: http://www.edupolicy.org.ua/files/Magna_Charta_Universitatum.pdf

11. Вивчаємо Стратегію доброго врядування разом! Громадська організація «Філософрія серця» . URL: http://fs.edukit.vn.ua/news/id/327/vn

12. Винокуров В. Економіка України у 2019 році зросла на 3,2\% - Держстат. 20 березня, 2020 17:03. URL: https://hromadske.ua/posts/ekonomika-ukrayini-u-2019-roci-zrosla-na-32-derzhstat

13. Вища освіта в Україні: порядок денний для реформ. URL: URL:https://www.kas.de/de/web/ukraine/publikationen/einzeltitel/-/content/visa-osvita-v-ukraini-poradokdennij-dla-reform16

14. Від соціалізму до заможної країни: 16 графіків про економіку Польщі. Опубліковано 26 лютого 2019 в 2:01. Украина в инфографике. URL: https://businessviews.com.ua/ru/economy/id/ekonomika-polschi-1930/

15. Генадій Рябцев. За весь період незалежності чиновники написали 1574 стратегічні документи, а виконали - 1 / http://nova.net.ua/za-ves-period-nezalezhnosti-chynovnyky-napysaly-1574-stratehichni-dokumenty-avykonaly-1/

16. Грицяк Н.В. Демократичне врядування: політико-правові засади. Розвиток публічного адміністрування на засадах менеджменту: європейський контекст : матер. наук.-практ. конф., Дніпропетровськ, 15-16 трав. 2009 р. Дніпропетр.: ДРІДУ НАДУ, 2009. С.37-38.

17. Грищенко І.М., Цимбаленко Н.В., Нефедова Т.М. Підвищення ефективності діяльності вищих навчальних закладів як передумова забезпечення потреб ринку праці. Ринок праці та зайнятість населення, 2015. № 2. С. 32-35.

18. Дарчук С. Демократичний рейтинг України дещо зріс, але перед нею стоять виклики в дотриманні демократії - Freedom House. 06 травня 2020. Радіо Свобода. Політика. URL: https://www.radiosvoboda.org/a/freedom-house-nations-in-transit/30594646.html

19. Джон С. Мілль. Представницьке врядування. Демократія: Антологія. К.: Смолоскип, 2005. XXVIII. 1108 с.

20. Добко Т., Турчиновський В. Академічна культура та доброчесність як соціальний капітал сучасного університету. Академічна чесність як основа сталого розвитку університету / за заг. ред. Т.В. Фінікова, А.Є. Артюхова. К. : Таксон, 2016.С. 37.

21. Добре демократичне врядування на місцевому рівні. Centre of expertise for local government reform, Council of Europe. URL: https://www.youtube.com/watch?v=75RCUFtSMRw 
22. Дойчик М. Академічна чесність: данина моді чи життєва позиція? Академічна чесність як основа сталого розвитку університету /за заг. ред. Т.В. Фінікова, А.Є. Артюхова. К. : Таксон, 2016. С. 97-99.

23. Дослідження сфери освіти в http://documents.worldbank.org/curated/en/884261568662566134/pdf/Review-of-the-Education-Sector-inUkraine-Moving-toward-Effectiveness-Equity-and-Efficiency-RESUME3.pdf

24. Європейське врядування. Біла книга. Брюсель. 2001. С. 11-12. URL: http://brdo.com.ua/wpcontent/uploads/2016/01/Bila-knyga-YEvropey-ske-vryaduvannya.pdf

25. Єзеров А., Батан Ю. Належне врядування й надання адміністративних послуг органами місцевого самоврядування. Юридичний вісник. 2016. № 2. С. 109-116.

26. Жиленко М. Оцінка ефективності управлінської діяльності керівника закладу вищої освіти. Вісник КНУ імені Тараса Шевченка. 2018. № 1(7). С. 11-14.

27. Загальна декларація прав людини. URL: // https://zakon.rada.gov.ua/laws/show/995 015

28. Закон України «Про вищу освіту»: станом на 29 жовтня 2014 року. Право, 2014. С. 23-32.

29. Закон України «Про вищу освіту» від 1 липня 2014 року № 1556-VII. URL: https://zakon.rada.gov.ua/laws/show/1556-18\#Text

30. Зозуля В.О. Демократичне врядування: сутність, основні концепції, підходи. Вісник НАДУ при Президентові України (Серія «Державне управління»). 2017. № 3. С. 32-37.

31. Зручний доступ до актуальних даних про позиції України у ключових міжнародних рейтингах. https://voxukraine.org/longreads/ratings/index.html

32. Індекс економічної свободи. Україна піднялася на 13 позицій. URL: https://uanews.liga.net/economics/news/indeks-ekonomichnoi-svobodi-ukraina-pidnyalasya-na-13-pozitsiy

33. Калашнікова С.А., Жданова К.О. Врядування у вищій освіті: сутність, виміри, тенденції. Вища освіта України. 2013. № 3 (дод. 2). Тематичний випуск «Європейська інтеграція вищої освіти України в контексті Болонського процесу». С. 73.

34. Квіт С. Якісна вища освіта. Виступ на Міжнародній конферениії. «Розбудова системи забезпечення якості вищої освіти в Україні», 11-12 червня 2019, KHTEУ. URL: http://education-ua.org/ru/articles/1343-yakisnavishcha-osvita-vistup-na-mizhnarodnij-konferentsiji-rozbudova-sistemi-zabezpechennya-yakosti-vishchojiosviti-v-ukrajini-11-12-chervnya-2019-knteu

35. Керницький О.М. Освітнє середовище вищого навчального закладу як педагогічний феномен. Проблеми інженерно-педагогічної освіти, 2013. № 38-39. С. 43-50. URL: http://library.uipa.edu.ua/images/data/zbirnik/kernskiy.pdf

36. Кодекс суддівської етики. URL:https://court.gov.ua/userfiles/Kodex\%20sud\%20etiki(1).pdf

37. Козлов К. Нове публічне врядування та спільне вироблення благ. Харківський національний університет радіоелектроніки. Науковий журнал «Новий колегіум» . 2017. №2. С.30-32.

38. Колодій А. Концепція публічного (нового) врядування в її застосуванні до демократичних і перехідних систем. «Демократичне врядування». Науковий вісник. 2012. Вип. 10. URL: http://nbuv.gov.ua/UJRN/DeVr $2012 \quad 103$.

39. Комюніке конференції європейських міністрів вищої освіти, Льовен та Лювен-ля-Ньов, 28-29 квітня 2009 року. URL: http://www.edupolicy.org.ua/files/Magna Charta Universitatum.pdf

40. Красносільська А. Відкрите врядування в Україні: як це відбувається на практиці? Український незалежний центр політичних досліджень. URL: content/uploads/2016/11/zvit za_rezultatamy doslidzhennya.pdf

41. Кухарева Г.П. Належне урядування як шлях до становлення дієвої системи публічного управління в Україні. C. 2. URL: http://www.kbuapa.kharkov.ua/e-book/tpdu/2015-3/doc/1/12.pdf

42. Лібанова Е.М. Нерівність в українському суспільстві: витоки та сучасність. "Економіка України» . 2014. №3 (628). C.8-9. URL: file:///C:/Users/user/AppData/Local/Temp/EkUk 2014_3_2.pdf

43. Ломоносова Т. 11\% зростання ВВП Польщі забезпечили українські мігранти. 24 грудня, 2019. Політична критика. Видання на перетині політики, науки та культури. URL: https://politkrytyka.org/2019/12/24/11zrostannya-vvp-polshhi-zabezpechyly-ukrayinski-migranty/

44. Мартиненко В. Демократичне врядування: проблеми теорії і практики. Публічне управління. URL: http://www.kbuapa.kharkov.ua/e-book/putp/2010-1/doc/1/03.pdf

45. Матюх С.А. Методика інтегральної оцінки ефективності діяльності вищого навчального закладу. Науковий вісник Херсонського державного університету. Сер. : Економічні науки, Вип. 5(2). С. 167-170. 
46. Мельниченко А. Прояви академічної нечесності. Академічна чесність як основа сталого розвитку університету /за заг. ред. Т.В. Фінікова, А.Є. Артюхова. К. : Таксон, 2016. С. 108.

47. Меморандум про гарантії безпеки у зв'язку з приєднанням України до Договору про нерозповсюдження ядерної зброї. 1994. URL: https://zakon.rada.gov.ua/laws/show/998 158

48. Мінаков М. Поступ демократії в Україні (1991-2019). URL: http://sg-sofia.com.ua/postup-demokratii-vukraini-1991-2019

49. Моргулець О. Б. Методологічні основи управління вищим навчальним закладом як суб'єктом ринку послуг : автореф. дис. ... доктора економічних наук. Київ, 2017. 44 с.

50. Національна команда експертів 3 реформування вищої освіти 2019. URL: https://erasmusplus.org.ua/erasmus/ka3-pidtrymka-reform/natsionalna-komanda-ekspertiv-here.html

51. Нодія Г., Ченуша Д., Мінаков М. На шляху до демократії європейського зразка. Боротьба за належне врядування у Східній Європі. Центр європейських політичних досліджень (CEPS). Брюссель. 2018. С. 3-4.

52. Орлов Ю.Ю. Запобігання корупції: синергетичний вимір. URL: https://cutt.ly/ChyhfNb

53. Пан Л. В. Роль дослідження середовища функціонування вищого навчального закладу у системі управління. Бізнес-освіта як бізнес : якість послуг і соціальна відповідальність : матеріали п'ятої щоріч. міжнар. конф. "Розбудова менеджмент-освіти в Україні». (м. Харків, 13-15 листоп. 2003 р.). К. : Консорціум із удосконалення менеджмент-освіти в Україні, 2003. С. 23-35.

54. Паризьке комюніке. $25 \quad 2018 . \quad$ травня URL: https://mon.gov.ua/storage/app/media/news/\%D0\%9D\%D0\%BE\%D0\%B2\%D0\%B8\%D0\%BD\%D0\%B8/2018/06/ 06/12/paris-communiqueenua2018.pdf

55. Петренко О.Б., Пелех Ю.В., Пелех Л.Р. Інноваційне управління вищими навчальними закладами: теоретичний аналіз проблеми. Інноватика у вихованні, 2017. Вип. 5. С. 31-40.

56. Петруняк В. Основні проблеми вищої освіти і навчального процесу в Україні: причини, наслідки та способи подолання. Науково-аналітичний журнал «Наша перспектива» . січень-березень 2016. №16-18. С. 26. URL: https://www.perspektyva.in.ua/2016-rik/13-15-16-18-sichen-berezen-2016-r/

57. Полякова Г. Розвиток середовищного підходу у вищій освіті в умовах глобальних змін. Педагогічні науки: теорія, історія, інноваційні технології, 2018. №4 (78). С. 189-199. URL: https://pedscience.sspu.sumy.ua/wp-content/uploads/2018/09/19.pdf

58. Публічна політика, публічне врядування й адміністрування: питання теорії, методології, практики: наук. розробка / авт. кол. : А. Ф. Колодій, М. З. Буник, П. І. Шевчук, та ін.. К.: НАДУ, 2015. 48 с.

59. Рейтинг університетів «ТОП-200 Україна» у 2019 р. URL: https://osvita.ua/vnz/rating/64884/

60. Рекомендації для закладів вищої освіти щодо розробки та впровадження університетської системи забезпечення академічної доброчесності. Затверджено Рішенням Національного агентства із забезпечення якості вищої освіти від 29 жовтня 2019 року, протокол №11. С. 2-5. URL: https://naqa.gov.ua/wp-content/uploads/2019/10/Рекомендації-3ВО-система-забезпечення-академічноїдоброчесності.pdf

61. Решетова І. А. Напрями вдосконалення системи управління вищими навчальними закладами. Економіка $i$ суспільство, 2018. Випуск № 17. С. 341-346. DOI: https://doi.org/10.32782/2524-0072/2018-17-50

62. Рівень довіри до суспільних інститутів та електоральні орієнтації громадян України. Разумков Центр, 27 березня 2019. Соиіологія. URL: http://razumkov.org.ua/napriamky/sotsiologichni-doslidzhennia/riven-dovirydo-suspilnykh-instytutiv-ta-elektoralni-oriientatsii-gromadian-ukrainy-2

63. Річний звіт Національного агентства із забезпечення якості вищої освіти за 2019 рік / за заг. ред. проф. Сергія Квіта. Київ: Національне агентство із забезпечення якості вищої освіти. 2020. 244 с. URL: https://naqa.gov.ua/wp-content/uploads/2020/02/\%D0\%97\%D0\%B2\%D1\%96\%D1\%82-2020.pdf

64. Рожнова Т.Є. Критерії та показники оцінювання результативності управління ВНЗ на засадах інноваційних технологій. Витоки педагогічної майстерності. Збірник наукових праць, 2013. 11. С. 289-295.

65. Рябченко В. Аналіз з позицій світоглядно-компетентнісного підходу впливу соціального середовища на ефективне врядування в університетах України в умовах євроінтеграції. Аналіз провідного вітчизняного та зарубіжного досвіду розвитку щодо механізмів реалізації ефективного врядування в університетах: препринт (аналітичні матеріали) (частина II) / Авторський колектив: І. Драч, С. Калашнікова, О. Паламарчук, В. Рябченко, Л. Червона; за заг. ред. С. Калашнікової. Київ: Інститут вищої освіти НАПН України, 2019. С. 6. URL: https://ihed.org.ua/wpcontent/uploads/2020/04/Analiz dosvidu vriaduvania v univer ch2 analit IVO-2019-96p avtorskolektiv.pdf 
66. Рябченко В. Вплив соціального середовища на ефективне врядування в українських університетах: світоглядно-компетентнісний аспект. Механізми реалізації ефективного врядування в університетах України в умовах євроінтеграції : методичні рекомендації / І. Драч, С. Калашнікова, О. Паламарчук, В. Рябченко, Л. Червона; за ред. С. Калашнікової. Київ : Інститут вищої освіти НАПН України, 2019. С. 25-33. URL: https://ihed.org.ua/wp-content/uploads/2020/07/Mekhanizmy vriaduvania univ UA metodychni IVO2019-93p avtors-kolektiv.pdf

67. Рябченко В. І. Вища школа України в загально цивілізаційному контексті: соціально-філософський аналіз 3 позицій світоглядно-компетентнісного підходу. К. : Фітосоціоцентр, 2015. С. 122-123. URL: http://dglib.nubip.edu.ua:8080/bitstream/123456789/2770/1/monogr Visha shkola UA v zagalncivilizac konteksti Ryabchenko 2015 674s.pdf

68. Рябченко В. Врядування в закладах вищої освіти та критерії його дієвості, результативності й ефективності // Problems and prospects of higher education system development in modern society: monograph / $\mathrm{H}$. Lebedynets, V. Levkulych, V. Muromets, O. Orzhel, O. Palamarchuk, V. Riabchenko, N. Salnikova, Yu. Skyba, K. Tryma, N. Fialko, L. Chervona. Sofia: VUZF Publishing House "St. Grigorii Bogoslov", 2020. - P. 26-52. URL: https://philarchive.org/archive/LEBPAP-3

69. Рябченко В.І.Мова як засіб творення соціальної дійсності: Світоглядно-просвітницьке видання. К. : Фітосоціоцентр, $2011 . \quad-244 \quad 24$ C. http://dspace.pnpu.edu.ua/bitstream/123456789/6286/1/\%d0\%a0\%d1\%8f\%d0\%b1\%d1\%87\%d0\%b5\%d0\%bd \%d0\%ba\%d0\%be-\%d0\%9c\%d0\%be\%d0\%b2\%d0\%b0.pdf

70. Рябченко В. Особистість студента і заклад вищої освіти в суспільному та глобальному контекстах: концептуальні проблеми взаємодії та розвитку / Особистість студента і соціокультурне середовище університету в суспільному контексті. Матеріали Всеукраїнської науково-практичної конференції. - 2 червня 2017р., м. Київ: Вступне слово В.І. Рябченка. - Київ, 2017. - С. 61-62. URL: https://ihed.org.ua/wpcontent/uploads/2019/01/Konferentsiya-Student-Materialy 2017.pdf

71. Рябченко В. Протекціонізм некомпетентності як чинник блокування підвищення якості вітчизняної вищої освіти та зниження конкурентоспроможності України // Міжнародний науковий журнал «Університети і лідерство» . 2019. 1(9). C. 149-189. URL: https://ul-journal.org/index.php/journal/article/view/120/111

72. Рябченко В. І. Світоглядно-методологічні засади формування й використання поняттєво-термінологічного апарату в науковій, освітній та суспільно-практичній діяльності: монографія. К. : Фітосоціоцентр, 2011. 468 c.

73. Рябченко В. Протекціонізм некомпетентності в українському суспільстві як чинник демотивації студентів у здобутті ними якісної вищої освіти. Збірник наукових праць IV Всеукраїнської науково-практичної конференції. Особистість студента та соціокультурне середовище університету в суспільному контексті. Київ, 2020. С. 90. URL: https://ihed.org.ua/wp-content/uploads/2020/07/IV Vseukr.konf 18-052020 Zbirnyk.pdf

74. Рябченко В. Розвиток особистісного потенціалу академічного персоналу і здобувачів вищої освіти як інтегрований критерій результативності та ефективності університетського управління. Міжнародний науковий журнал «Університети і лідерство». 2019. 1(7). C. 65-88. DOI: https://doi.org/10.31874/5206702-2019-7-1-65-88

75. Рябченко В. Теоретичні основи впливу соціального середовища на ефективне врядування в українських університетах: світоглядно-компетентнісний аспект. Аналіз провідного вітчизняного та зарубіжного досвіду щодо механізмів реалізації ефективного врядування в університетах: препринт (аналітичні матеріали) (частина I) / за заг. ред. С. Калашнікової. Київ: Інститут вищої освіти НАПН України, 2018. С. 78.

URL:

https://ihed.org.ua/wpcontent/uploads/2019/09/Analiz dosvidu vriaduvania v univer ch1 analit IVO-2018-147p avtorskolektiv.pdf

76. Рябченко В.І. Технократизм і доля українського села: Занепад сучасного села як системна криза укр. соціуму: соц.-філос. аналіз проблеми. К.: Знання України, 2006. - 76 с.

77. Словник іншомовних слів: 23000 слів та термінологічних словосполучень / уклад. Л. О. Пустовіт та ін. К.: Довіра, 2000. 1018 с. (Б-ка держ. службовця. Держ. мова і діловодство).

78. Соціологія: короткий енциклопедичний словник / уклад.: В.І. Волович, В.І. Тарасенко, М.В. Захаренко та ін.; під заг. ред. В.І. Воловича. К.: Укр. Центр духовн. Культури, 1998. С. 320.

79. Список країн за ВBП (номінал) на душу населення. URL: https://cutt.ly/ohyg8xa

80. Стратегія розвитку вищої освіти в Україні на 2021-2031 роки. URL: 
https://mon.gov.ua/storage/app/media/rizne/2020/09/25/STRATEHIYA ROZVYTKU VYSHCHOYI_OSVITY V U KRAYINI PROYEKT.pdf

81. Таранов П.С. 120 философов: Жизнь. Судьба. Учение. Мысли: аналитический справочник по истории философии : в 2 т. Симферополь : «Реноме», 2002. Т. 1. С. 134-136.

82. Толкованов В.В. Стандарти та принципи доброго врядування на місцевому і регіональному рівнях як загальноєвропейська цінність. Електронний журнал "Державне управління: удосконалення та розвиток». URL: http://www.dy.nayka.com.ua/?op=1\&z=565

83. Українців визнали однією з найбідніших націй у світі. Слово і діло. Аналітичний портал. URL: https://www.slovoidilo.ua/2018/10/19/novyna/suspilstvo/ukrayincziv-vyznaly-odniyeyu-najbidnishyx-naczij$\underline{\text { sviti }}$

84. Филиппова Е. Сколько лет закону сохранения материи. Парламентская газета. Издание Федерального собрания Российской Федерации. URL: https://www.pnp.ru/social/skolko-let-zakonu-o-sokhraneniimaterii.html

85. Фініков Т. Академічна доброчесність: глобальний контекст та національна потреба. Академічна чесність як основа сталого розвитку університету / за заг. ред. Т.В. Фінікова, А.Є. Артюхова. К. : Таксон, 2016. C. 32.

86. Хмара О. Що робити, аби в Україні врядування насправді стало відкритим. Transparency International Україна, спеціально для УП. 01 квітня 2015. URL: https://www.pravda.com.ua/columns/2015/04/1/7063290/

87. Хмарський В. Academic integrity в США: кілька спостережень 2015 року. Академічна чесність як основа сталого розвитку університету /за заг. ред. Т.В. Фінікова, А.Є. Артюхова. К. : Таксон, 2016. С. 57-58.

88. Чисельність населення Землі сягнула 7,8 млрд осіб. URL: https://lb.ua/world/2020/07/10/461598 chiselnist naselennya zemli syagnula.html 


\title{
Розділ 3. Управління дослідницькою діяльністю в системі університетського врядування
}

\author{
Ірина Драч, \\ доктор педагогічних наук, доцент, \\ перший заступник директора \\ Інституту вищої освіти НАПН України \\ https://orcid.org/0000-0001-7501-4122
}

\section{Анотація}

Необхідність посилення дослідницької спроможності вітчизняних університетів для повноцінного входження України до Європейського простору вищої освіти та Європейського дослідницького простору зумовлює необхідність модернізації системи управління дослідженнями. У даному розділі монографії представлено результати проведеного трирічного дослідження щодо управління дослідницькою діяльністю в системі університетського врядування.

Для пошуку сучасних механізмів управління дослідженнями проаналізовано документи Європейського простору вищої освіти та наукові праці, встановлено актуальність використання парадигми врядування в управлінні університетами, зокрема і в управлінні дослідницькою діяльністю. Проаналізовано сутність врядування та особливості його реалізації, що дало змогу, окрім запропонованих науковцями раніше таких характеристик врядування, як багаторівневість, багатоакторність та багатосекторність, додати четверту багатопроцедурність. Авторська позиція ґрунтується на основі аналізу як наукових праць, так і практичного досвіду реалізації дослідницького врядування у провідних університетах Великої Британії - країні-лідері європейської та світової системи вищої освіти. Врядування характеризується також зв'язком з ключовими цінностями Європейського простору вищої освіти та Європейського дослідницького простору; взаємозв'язком із здатністю університету виконувати свою місію; балансом між самостійністю та підзвітністю, довірою і контролем, ефективністю та якістю; прозорістю прийняття рішень; гнучкістю організаційних структур.

Розкрито сутність поняття «дослідницьке врядування в університеті» та визначено його цінності і принципи. Проаналізовано моделі та тенденції університетського врядування в європейських системах вищої освіти, інституційну політику та функції органів дослідницького врядування в європейських університетах. Охарактеризовано досвід Великої Британії щодо підтримки дослідницької доброчесності в університетах на національному рівні. Запропоновано модель дослідницького врядування в університеті. 
Наприкінці XX - початку XXI століття університети є одними з прискорювачів історії через посилення дослідницької компоненти, інкубування інновацій та трансфер технологій, а також банком людського капіталу ${ }^{284}$.

Посилення дослідницької спроможності університетів актуалізує використання в управлінні дослідницькою діяльністю сучасної парадигми врядування, яке передбачає розроблення чітко визначених правил і процедур для проведення досліджень та поширення його результатів, активне і широке залучення стейкхолдерів до моніторингу результатів досліджень та використання коштів на їх проведення ${ }^{285}$.

Однією зі складових дослідницького врядування є дослідницька доброчесність, яка відповідно до Європейської хартії дослідників ${ }^{286}$ передбачає дотримання дослідниками загальновизнаних етичних норм та фундаментальних етичних принципів у їх дисципліні (дисциплінах), так само як і дотримуватися етичних стандартів, зафіксованих у різноманітних національних, галузевих та інституційних кодексах.

Про те, що проблеми трансформації управління університетами (від управління, заснованого на «жорсткій вертикалі», до управління на засадах взаємодії та партнерства із зовнішніми і внутрішніми стейкхолдерами) та забезпечення академічної доброчесності в університетському середовищі як складової дослідницького врядування залишаються актуальними свідчить звіт Світового банку щодо результатів огляду сектора освіти в Україні «Review of the Education Sector in Ukraine. Moving towards Effectiveness, Equity and Efficiency» (2019)287. Наведемо основні положення зазначеного документа, що дотичні до дослідницького врядування, зокрема, і до забезпечення в університетах доброчесності у дослідженнях:

«Реформи в галузі освіти відповідно до Закону «Про вищу освіту» ${ }^{288}$, запроваджені з 2014 р., $є 3$ начним відходом від минулого і відповідають багатьом передовим практикам у високоефективних системах освіти в європейських та інших країнах. Децентралізація і демократизація системи освіти викликала великий оптимізм. Однак масштабні трансформації залишаються на стадії зародження ${ }^{289}$.

«Надання ЗВО більшої автономії за відсутності механізмів підзвітності, стратегії розвитку вищої освіти призвело до того, що окремі з них використовують їх самостійність для досягнення індивідуальних цілей, а не для досягнення мети для всієї системи і нації в цілому» 290.

«До пріоритетних напрямів для забезпечення ефективності реформ у вищій освіті України віднесено наступні: посилення спроможності внутрішнього управління закладів вищої освіти; забезпечення академічної доброчесності та антикорупції» 291.

\footnotetext{
284 Майбутнє університетів. Частина 1. Еволюція університетів: на порозі невідомого майбутнього»: доповідь / С. Бабак та ін.; Україна. ін-т майбутнього. Київ, 2018. 126 с. С. 105. URL: https://www.uifuture.org/publications/reports/24475-maybutnie/universytetiv. C.8.

285 Драч І. Управління дослідницькою діяльністю в системі університетського врядування: аналіз провідного вітчизняного та зарубіжного досвіду. Аналіз провідного вітчизняного та зарубіжного досвіду щодо механізмів реалізації ефективного врядування в університетах: препринт (аналітичні матеріали) (частина II) / Авторський колектив: І. Драч, О. Паламарчук, В. Рябченко, Л. Червона; за заг. ред. С. Калашнікової. Київ: Інститут вищої освіти НАПН України, 2019. URL: https://ihed.org.ua/wpcontent/uploads/2020/04/Analiz dosvidu vriaduvania v univer ch2 analit IVO-2019-96p avtors-kolektiv.pdf. C. 38.

286 Європейська хартія дослідників. URL: http://h2020.com.ua/wp-content/uploads/2015/11/Book.pdf. C. 8.

287 Review of the Education Sector in Ukraine. Moving towards Effectiveness, Equity and Efficiency (RESUME3). Overview. World Bank Group. (4) URL: http://documents.worldbank.org/curated/en/360951568662377063/pdf/Overview.pdf.

288 Закон України «Про вищу освіту». URL: https://zakon.help/law/1556-VII/.

289 Review of the Education Sector in Ukraine. Moving towards Effectiveness, Equity and Efficiency (RESUME3). Overview. World Bank Group. (4) URL: http://documents.worldbank.org/curated/en/360951568662377063/pdf/Overview.pdf. P. 12.

${ }^{290}$ Review of the Education Sector in Ukraine. Moving towards Effectiveness, Equity and Efficiency (RESUME3). Overview. World Bank Group.

(4) URL: http://documents.worldbank.org/curated/en/360951568662377063/pdf/Overview.pdf. P. 13.

${ }^{291}$ Review of the Education Sector in Ukraine. Moving towards Effectiveness, Equity and Efficiency (RESUME3). Overview. World Bank Group.

(4) URL: http://documents.worldbank.org/curated/en/360951568662377063/pdf/Overview.pdf. P. 12.
} 
Посилення спроможності внутрішнього управління закладів вищої освіти 292 :

У звіті зазначено, що ЗВО стикаються з проблемами в управлінні у зв'язку із наданою ним автономією відповідно до Закону України «Про вищу освіту» (2014р.) ${ }^{293}$. Багато ЗВО показало обмежений потенціал для прийняття демократичних і стратегічних рішень.

Одним із варіантів посилення спроможності університетів та авторитету його органів управління відповідно до загальноєвропейської практики $є$ включення до Наглядових рад представників відомих міжнародних академічних установ, суспільства та влади.

Керівні органи, до яких включено стейкхолдерів, повинні мати репутацію та повноваження здійснювати стратегічне управління, координувати зусилля для досягнення визначених цілей та забезпечувати незалежну оцінку прогресу 3ВО.

Забезпечення академічної доброчесності та антикорупиії 294 :

Констатується, що в Україні наявна масова зневага до академічної доброчесності та висока толерантність до порушень принципів академічної доброчесності. Ці випадки є звичайним явищем і не сприймаються як зловживання. Враховуючи те, що вища освіта $є$ головним чинником для розвитку державного і приватного секторів, цей виклик залишається головною проблемою системи вищої освіти 295.

Наголошується на необхідності посилення стимулів академічної доброчесності та використання інструментів нагляду.

Надзвичайно важливим для розв'язання проблеми забезпечення академічної доброчесності відзначається посилення потенціалу МОН України та створеного Національного агентства із забезпечення якості вищої освіти.

Важливою інституцією, яка може допомогти посилити стимули до академічної доброчесності, $\epsilon$ створений відповідно до Закону «Про освіту» 296 (2017р.) Офіс освітнього омбудсмена. Це відомство має, зокрема, створити механізми розгляду скарг щодо порушень принципів академічної доброчесності. У звіті зазначається, що Офіси освітнього омбудсмена можуть бути створені і у закладах вищої освіти.

Рекомендується також вжити наступних заходів на національному рівні ${ }^{297}$ :

- переглянути та запровадити більш сильне законодавство щодо покарання за порушення принципів академічної доброчесності, включаючи ретроспективну перевірку на плагіат наукових праць осі, які претендують на посади високого рівня у 3ВО;

- створити Національний репозитарій академічних текстів - електронну базу, що міститиме тексти дисертацій, інших наукових робіт, робіт здобувачів вищої освіти;

- поширювати інформацію про забезпечення академічної доброчесності в університетах на основі опитувань студентів. Такий інструмент допоможе ідентифікувати випадки порушення принципів академічної доброчесності та поширювати кращий досвід серед 3ВО;

- безпосередньо співпрацювати зі студентами, викладачами та управлінцями університетів для розширення поінформованості щодо принципів академічної доброчесності.

292 Review of the Education Sector in Ukraine. Moving towards Effectiveness, Equity and Efficiency (RESUME3). Overview. World Bank Group.

(4) URL: http://documents.worldbank.org/curated/en/360951568662377063/pdf/Overview.pdf. P. 15.

293 Закон України «Про вищу освіту». URL: https://zakon.help/law/1556-VII/.

${ }^{294}$ Review of the Education Sector in Ukraine. Moving towards Effectiveness, Equity and Efficiency (RESUME3). Overview. World Bank Group.

(4) URL: http://documents.worldbank.org/curated/en/360951568662377063/pdf/Overview.pdf. P. 15.

295 Review of the Education Sector in Ukraine. Moving towards Effectiveness, Equity and Efficiency (RESUME3). Overview. World Bank Group.

(4) URL: http://documents.worldbank.org/curated/en/360951568662377063/pdf/Overview.pdf. P.7.

296 Закон України «Про освіту». URL: https://zakon.rada.gov.ua/laws/show/2145-19\#Text.

297 Review of the Education Sector in Ukraine. Moving towards Effectiveness, Equity and Efficiency (RESUME3). Overview. World Bank Group.

(4) URL: http://documents.worldbank.org/curated/en/360951568662377063/pdf/Overview.pdf. P.22. 
Актуальність модернізації системи управління у ЗВО в Україні констатується також у документі «Заключний звіт незалежного європейського аудиту національної системи досліджень та інновацій України» ${ }^{298}$, підготовленому європейськими експертами у 2017 році.

У розділі 3 зазначеного документа містяться рекомендації щодо необхідності підвищення якості та ефективності наукової бази, що передбачає підвищення ефективності наукових досліджень в університетах та підвищення рівня автономності (п. 3.3), а також розвиток талантів і створення потенціалу (п. 3.6).

Відповідно до рекомендації 16 зазначеного звіту «адміністративне управління дослідженнями має стати менш затратним та ефективнішим, а також забезпечувати боротьбу з тяганиною, неефективністю та корупцією» 299.

Про необхідність забезпечення академічної доброчесності у системі дослідницького врядування в закладах вищої освіти України свідчать «Огляди ОЕСР на тему доброчесності в освіті: Україна 2017» 300. Огляд, який підготувала міжнародна команда експертів, ґрунтувався на:

- вивченні української законодавчої та регуляторної бази;

- зборі та аналізі освітніх даних;

- відвідуваннях закладів освіти та проведенні фокус-груп зі студентами, викладачами та управлінцями.

У зазначеному документі розглянуто «поширені, вкорінені та системні» порушення доброчесності, які стосуються всієї освітньої галузі країни, зокрема, і вищої освіти.

Міжнародні експерти акцентують увагу на тому, що для розв'язання проблеми академічної недоброчесності у вищій освіті потрібно розробити комплексну стратегію з просування академічної доброчесності. До програми рекомендовано включити вимогу кожному університету розробити, прийняти і просувати етичні хартії. Такі хартії мають визначати норми істандарти поведінки академічної спільноти. Учасниками розроблення хартій мають стати «представники всіх зацікавлених сторін для відчуття ними своєї відповідальності» ${ }^{301}$. Національне агентство забезпечення якості у вищій освіті, у свою чергу, має розглядати наявність хартії доброчесності як одну з вимог при здійсненні акредитації освітніх програм закладів вищої освіти.

Прийняття нових Законів України «Про вищу освіту» (2014р.) та Закону України «Про освіту» (2017р.) значно покращило регуляторну основу запобігання недоброчесності в освіті та дослідженнях.

\section{Закон України «Про вищу освіту» 302}

Декілька статей Закону України «Про вищу освіту» безпосередньо стосуються питання академічної доброчесності.

Стаття 16 (про систему забезпечення якості) затверджує зобов'язання гарантувати «забезпечення дотримання академічної доброчесності працівниками закладів вищої освіти та здобувачами вищої освіти, у тому числі створення і забезпечення функціонування ефективної системи запобігання та виявлення академічного плагіату» (п. 8).

Стаття 32 (про принципи функціонування, основні права і обов'язки закладів вищої освіти) стверджує: «заклади вищої освіти зобов'язані вживати заходів, у тому числі шляхом запровадження відповідних новітніх технологій, щодо запобігання та виявлення академічного плагіату в наукових роботах наукових, науковопедагогічних інших працівників іздобувачів вищої освіти та притягнення їх до дисциплінарної відповідальності» (п. 3).

\footnotetext{
298 Заключний звіт незалежного європейського аудиту національної системи досліджень та інновацій України. Інструмент політичної підтримки програми «Горизонт 2020». - URL: https://publications.europa.eu/en/web/eu-law-and-publications/publication-detail/Lpublication/adb1f077-dedc-11e6-ad7c-01aa75ed71a1/language-uk

299 Заключний звіт незалежного європейського аудиту національної системи досліджень та інновацій України. Інструмент політичної підтримки програми «Горизонт 2020». - C. 52. - URL: https://publications.europa.eu/en/web/eu-law-and-publications/publication-detail//publication/adb1f077-dedc-11e6-ad7c-01aa75ed71a1/language-uk

300 Огляди ОЕСР на тему доброчесності в освіті: Україна 2017. Інститут розвитку освіти. К.: Таксон. 2017.184 с. URL: http://iro.org.ua/uploads/OECDrev ua K+P293 out2 (1).pdf.

301 Огляди ОЕСР на тему доброчесності в освіті: Україна 2017. Інститут розвитку освіти. К.: Таксон. 2017.184 с. URL: http://iro.org.ua/uploads/OECDrev ua K+P293 out2 (1).pdf. C. 152.

302 Закон України «Про вищу освіту». URL: https://zakon.help/law/1556-VII/.
} 
Стаття 69 про права інтелектуальної власності та їхній захист наголошує: «заклади вищої освіти та наукові установи здійснюють заходи із запобігання академічному плагіату - оприлюдненню (частково або повністю) наукових результатів, отриманих іншими особами, як результатів власного дослідження та/або відтворенню опублікованих текстів інших авторів без відповідного посилання».

У Законі України «Про освіту» 303 (стаття 42) дано визначення самому поняттю «академічна доброчесність», яке розглянуто як «сукупність етичних принципів та визначених законом правил, якими мають керуватися учасники освітнього процесу під час навчання, викладання та провадження наукової (творчої) діяльності з метою забезпечення довіри до результатів навчання та/або наукових (творчих) досягнень».

У зазначеній статті Закону також визначено:

- умови дотримання академічної доброчесності педагогічними, науково-педагогічними та науковими працівниками та здобувачами освіти;

- види порушень академічної доброчесності (академічний плагіат, самоплагіат, фабрикація, фальсифікація, списування, обман, хабарництво);

- академічну відповідальність педагогічних, науково-педагогічних та наукових працівників закладів освіти, здобувачів освіти за порушення академічної доброчесності.

У «Середньостроковому плані дій уряду до 2020 року» ${ }^{304}$ зазначено, що для забезпечення ефективної політики у сфері освіти ключовим пріоритетом з реалізації цілі 3 «Розвиток людського капіталу» $є$ «підвищення рівня та оптимізація результатів наукової та академічної діяльності, підтримка процесу ствердження академічної доброчесності у вищих навчальних закладах та наукових установах» ${ }^{305}$.

Відповідно однією з пріоритетних дій уряду визначено створення нової системи управління та фінансування науки для забезпечення ефективної взаємодії представників наукової громадськості, органів виконавчої влади та реального сектору економіки у формуванні та реалізації єдиної державної політики у сфері наукової і науково-технічної діяльності.

Таким чином, аналіз наведених документів свідчить про актуальність підвищення ефективності дослідницької діяльності вітчизняних університетів, що, на наше переконання, має забезпечити імплементація парадигми дослідницького врядування.

\footnotetext{
303 Закон України «Про освіту». URL: https://zakon.rada.gov.ua/laws/show/2145-19/stru.

304 Середньостроковий план пріоритетних дій Уряду до 2020 року. - URL: https://www.kmu.gov.ua/ua/diyalnist/programa-diyalnostiuryadu/serednostrokovij-plan-prioritetnih-dij-uryadu-do-2020-roku-ta-plan-prioritetnih-dij-uryadu-na-2017-rik.

305 Середньостроковий план пріоритетних дій Уряду до 2020 року. - URL: https://www.kmu.gov.ua/ua/diyalnist/programa-diyalnostiuryadu/serednostrokovij-plan-prioritetnih-dij-uryadu-do-2020-roku-ta-plan-prioritetnih-dij-uryadu-na-2017-rik. C. 38.
} 
У наших попередніх публікаціях ${ }^{306}, 307$ нами проаналізовано документи Європейського простору вищої освіти, Європейського дослідницького простору та вітчизняні і зарубіжні наукові праці з проблем врядування, дослідницького врядування та дослідницької доброчесності. Продовжимо аналіз документів та публікацій, які, на нашу думку, є особливо цінними для розуміння особливостей врядування, зокрема, дослідницького, в сучасному університеті.

Ще у 1998 р. G. Paquet у статті "Governance and Social Cohesion: Survivability in the 2/st Century» ${ }^{308}$ стверджував, що «ми вступаємо в епоху, де процес врядування - гра без господаря» (we are entering and era where the governance process is a game without a master) ${ }^{309}$.

Актуальність врядування у вищій освіті підкреслює K. Kennedy у статті «Higher Education Governance as a Key Policy Issue in the 21st Century» ${ }^{310}$ (2003), який визначає саме врядування ключовою проблемою у 21 столітті. Важливою $є$ думка дослідника, яка полягає в наступному: все, що стосується врядування, по суті $\epsilon$ питанням цінностей, і з цієї причини процеси врядування завжди будуть викликати суперечності. Тому врядування не можна розглядати просто як доповнення до мети і відокремлено від соціальних наук. У тій чи іншій мірі управлінські рішення мають потенціал на користь одних і позбавлення права інших («Everything to do with governance is essentially an issue of values and for this reason processes of governance will always be contested because values are always contested. Therefore governance cannot be seen simply as an adjunct to an objective and disinterested social science, since in one way or another governance solutions have the potential to favour some and disenfranchise others») ${ }^{311}$.

Враховуючи потенціал процесів врядування щодо спричинення конфлікту, завдання будь-якої організації, включаючи заклади вищої освіти, полягає у мінімізації конфліктів, посилення відносин між зацікавленими сторонами та забезпечення результатів, які відповідають інтересам усіх, а не деяких співробітників організації. Механізми управління виконують функцію забезпечення системи стримувань і противаг, прозорість прийняття рішень та підзвітність. Важливим висновком статті $є$ визначення актуальності принципу партнерства в університетському врядуванні ${ }^{312}$ : «принцип партнерства $\epsilon$ не просто риторикою. Він підкреслює набір стосунків, які повинні бути відображені у структурах управління університетів у XXI столітті» ( The principle of partnership, therefore, is not simple rhetoric. It underscores a set of relationships that need to be reflected in the governance structures of universities in the twenty-first century»).

\footnotetext{
306 Драч І. Управління дослідницькою діяльністю в системі університетського врядування: теоретичні основи. Аналіз провідного вітчизняного та зарубіжного досвіду розвитку щодо механізмів реалізації ефективного врядування в університетах: препринт (аналітичні матеріали) (частина I) / Авторський колектив: І. Драч, С. Калашнікова, О. Паламарчук, В. Рябченко, Л. Червона; за заг. ред. С. Калашнікової. Київ: Інститут вищої освіти НАПН України. 2018. 147 c. URL: https://ihed.org.ua/wpcontent/uploads/2019/09/Analiz_dosvidu_vriaduvania_v univer_ch1_analit_IVO-2018-147p_avtors-kolektiv.pdf.

307 Драч І. Управління дослідницькою діяльністю в системі університетського врядування: аналіз провідного вітчизняного та зарубіжного досвіду. Аналіз провідного вітчизняного та зарубіжного досвіду щодо механізмів реалізації ефективного врядування в університетах: препринт (аналітичні матеріали) (частина II) / Авторський колектив: І. Драч, О. Паламарчук, В. Рябченко, Л. Червона; за заг. ред. С. Калашнікової. Київ: Інститут вищої освіти НАПН України, 2019. 96 c. URL: https://ihed.org.ua/wpcontent/uploads/2020/04/Analiz_dosvidu_vriaduvania_v_univer_ch2_analit_IVO-2019-96p_avtors-kolektiv.pdf.

308 Paquet G. (1998). Governance and Social Cohesion: Survivability in the 2 lst Century. Paper delivered at the Symposium of the Royal Society of Canada on the theme, Human Survivability in the 21st Century at the Chateau Laurier. Ottawa. November. URL: http://www.gouvernance.ca/publications/99-05.pdf. P.6.

309 Paquet G. (1998). Governance and Social Cohesion: Survivability in the 2lst Century. Paper delivered at the Symposium of the Royal Society of Canada on the theme, Human Survivability in the 21st Century at the Chateau Laurier. Ottawa. November. URL: http://www.gouvernance.ca/publications/99-05.pdf. P.6.

310 Kennedy K. Higher Education Governance as a Key Policy Issue in the 21st Century. URL: https://link.springer.com/content/pdf/10.1023/A:1024468018883.pdf. P. 57.

311 Kennedy K. Higher Education Governance as a Key Policy Issue in the 21st Century. URL: https://link.springer.com/content/pdf/10.1023/A:1024468018883.pdf. P. 57.

312 Kennedy K. Higher Education Governance as a Key Policy Issue in the 21st Century. URL:
} https://link.springer.com/content/pdf/10.1023/A:1024468018883.pdf. P. 68. 
Про важливість належного врядування наголошують A. Fiszbein ma D. Ringold у документі «Benchmarking the governance of tertiary education systems» ${ }^{313}$ (2012), зазначаючи що саме належне врядування $\epsilon$ ключовим аспектом «здоров' я системи вищої освіти і має сильний вплив на її результативність».

A. Kezar у статті «What is more important to effective governance: Relationships, trust, and leadership, or structures and formal processes?» ${ }^{314}$ (2004) шукає відповідь на питання, що є більш важливим у належному врядуванні: відносини, довіра і лідерство чи структури та формальні процеси прийняття рішень. На підставі власних досліджень А. Kezar стверджує, що лідерство, довіра та відносини витісняють структури та формальні процеси прийняття рішень.

До цінностей належного врядування F. Biermann, C. Stevens, S. Bernstein, A. Gupta, N. Kabiri, N. Kanie, M. Levy, M. Nilsson, L. Pintér, M. Scobie ma O. Young у праці «Integrating Governance into the Sustainable Development Goals» ${ }^{315}$ (2015) відносять наступні: широка залученість, прозорість, підзвітність та доступ громадськості до інформації.

На взаємозв'язку належного врядування та здатності університету виконувати свою місію наголошують I. Austin ma G. Jones у статті «Governance of Higher Education: Global Perspectives, Theories, and Practices» ${ }^{316}$ (2016).

Говорячи про університетське врядування, дослідники H. De Boer, J. Enders ma U. Schimank y npaцi «On the way towards new public management?» 317 (2007) виділили п'ять його аспектів, включаючи: держане регулювання, керівництво стейкхолдерами, академічне самоврядування, управлінське самоврядування та конкуренцію за обмежені ресурси. Автори зазначають, що найважливішим компонентом сучасних процесів врядування $€$ довіра, яка означає надійні відносини між різними стейкхолдерами в організації. Якщо всі стейкхолдери не вірять у рівноправність та справедливість у процесах управління, це призводить до конфліктів.

У книзі «European Higher Education Area: The Impact of Past and Future Policies» ${ }^{318}$ у розділі «Multi-Level, Multi-Actor and Multi-Issues Dimensions of Governance of the European Higher Education Area, and Beyond» ${ }^{319}$ експертами M. Vukasovic, J. Jungblut, M.-H. Chou, M. Elken, P. Ravinet запропоновано три характеристики врядування в Європейському просторі вищої освіти - багаторівневість (multi-level), багатоакторність (multiactor) та багатосекторність (multi- issue).

\footnotetext{
313 World Bank. (2012). Benchmarking the governance of tertiary education systems. Washington: World Bank. A Fiszbein, D Ringold - World Bank Group, Washington. 2012. URL: https://documents.worldbank.org/en/publication/documentsreports/documentdetail/423481468272040065/benchmarking-the-governance-of-tertiary-education-systems

${ }^{314}$ Kezar. A. What is more important to effective governance: Relationships, trust, and leadership, or structures and formal processes? ».- URL: https://www.researchgate.net/publication/227876520 What Is More Important to Effective Governance Relationships Trust and Lead ership_or_Structures_and_Formal_Processes.

${ }^{315}$ Biermann F., Stevens C., Bernstein S., Gupta A., Kabiri N., Kanie N., Levy M., Nilsson M., Pintér L., Scobie M., Young O. Integrating Governance into the Sustainable Development Goals. URL: https://collections.unu.edu/eserv/UNU:1825/Post2015 UNU-IAS PolicyBrief3.pdf. P. 2.

${ }^{316}$ Austin, I., \& Jones, G. (2016). Governance of Higher Education: Global Perspectives, Theories, and Practices. New York, NY: Routledge. Pages: 218. ISBN: 978- 0415739757 (paperback) - Canadian Journal of Educational Administration and Policy, 182, 59-61. URL: https://www.taylorfrancis.com/books/9781315816401.

${ }^{317}$ De Boer, H., Enders, J., \& Schimank, U. (2007). On the way towards new public management? The governance of university systems in England, the Netherlands, Austria, and Germany. New forms of governance in research organizations (pp. 137-152). Springer. URL: https://link.springer.com/chapter/10.1007/978-1-4020-5831-8 5.

${ }^{318}$ European Higher Education Area: The Impact of Past and Future Policies. URL: https://link.springer.com/book/10.1007/978-3-319-774077.

$\overline{319}$ European Higher Education Area: The Impact of Past and Future Policies. URL: https://link.springer.com/book/10.1007/978-3-319-774077. P. $321-325$.
} 
Проведений аналіз розуміння сутності врядування ${ }^{220}$ призвів нас до висновку, що до трьох зазначених складових врядування доцільно додати четверту - багатопроцедурність (multi-procedures). Саме розроблення та використання низки чітко визначених процедур дозволяють знаходити баланс між системою цінностей членів академічної спільноти і системою інтересів всіх зацікавлених сторін щодо діяльності університету.

Підтвердження цієї думки знаходимо у документі «Higher Education Governance in Europe Policies, structures, funding and academic staff» ${ }^{321}$, де врядування (governance) визначено як управління, спрямоване на визначення та реалізацію правил та механізмів впливу на рішення різних зацікавлених сторін та їх підзвітності. У контексті вищої освіти врядування означає формальне та неформальне здійснення влади за законами, політикою та правилами, що формулюють права та обов'язки різних суб'єктів, включаючи правила, за якими вони взаємодіють ${ }^{322}$.

В огляді політики щодо інтеграції врядування у Цілі сталого розвитку «Integrating Governance into the Sustainable Development Goals» ${ }^{323}$ F. Biermann, C. Stevens, S. Bernstein, A. Gupta, N. Kabiri, N. Kanie, M. Levy, M. Nilsson, L. Pintér, M. Scobie ma O. Young також зазначають, що «належне врядування орієнтоване на спроможність інституції розв'язувати проблеми державної політики, ... застосовувати ефективні правила».

Як засвідчив здійснений нами у працях $324,325,326$ аналіз інституційних політик провідних (відповідно до даних міжнародних рейтингів Academic Ranking of World Universities ${ }^{327}$, QS World University Rankings ${ }^{328}$ Ta Times Higher Education World University Rankings ${ }^{329}$ за 2019 р.) університетів Великої Британії (країни-лідера європейської вищої освіти) - University of Oxford ${ }^{330}$, University of Cambridge ${ }^{331}$, Imperial College London ${ }^{332}$ багатопроцедурність $€$ ключовою ознакою дослідницького врядування та підґрунтям для забезпечення високоякісних досліджень. У процесі реалізації дослідницького врядування багатопроцедурність у зазначених університетах передбачає:

- розроблення та використання процедур, пов'язаних із правовими, етичними та фінансовими питаннями при проведення досліджень;

- створення умов для здійснення діяльності на принципах прозорості, відповідальності, підзвітності, орієнтації на консенсус, справедливості, ефективності і результативності, академічної доброчесності;

- а також спрямована на колективний контроль над досягненням визначених цілей.

Реалізація врядування на інституційному рівні має узгоджуватися з місією та стратегією закладу вищої освіти та здійснюватися на засадах визначених цінностей. Тому важливими у контексті нашого дослідження $\epsilon$ наступні документи, які пропонуємо проаналізувати:

\footnotetext{
320 Драч І. І. Управління дослідницькою діяльністю в системі університетського врядування: характеристика та закономірності. Вища освіта України. № 3 (70). 2018. С. 60-65.

${ }^{321}$ Higher Education Governance in Europe. Policies, structures, funding and academic staff. Brussels: Euridice, 2008. P. 12.

322 Higher Education Governance in Europe. Policies, structures, funding and academic staff. Brussels: Euridice, 2008. P. 8.

${ }^{323}$ Biermann F., Stevens C., Bernstein S., Gupta A., Kabiri N., Kanie N., Levy M., Nilsson M., Pintér L., Scobie M., Young O. Integrating Governance into the Sustainable Development Goals. URL: https://collections.unu.edu/eserv/UNU:1825/Post2015 UNU-IAS PolicyBrief3.pdf. P. 3.

324 Драч І. І. Досвід управління дослідницькою діяльністю в університетах Великої Британії: філософсько-аналітичний підхід. Університет і лідерство. № 5. 2018. URL: https://ul-journal.org/index.php/journal/issue/view/5.

325 Драч І. І. Філософський аналіз практики дослідницького врядування в університетах Великої Британії. Університет і лідерство. № 6. 2018. URL: https://ul-journal.org/index.php/journal/issue/view/6..

326 Драч І. І. Підтримка дослідницької доброчесності в системі університетського врядування: досвід Великої Британії. Університет і лідерство. № 7. 2019. URL: https://ul-journal.org/index.php/journal/issue/view/7.

${ }^{327}$ Academic Ranking of World Universities. URL: http://www.shanghairanking.com/arwu2019.html.

${ }^{328}$ QS World University Rankings. URL: https://www.topuniversities.com/university-rankings/world-university-rankings/2019.

329 Times Higher Education World University Rankings. URL: https://www.timeshighereducation.com/world-university-rankings/2019/worldranking\#!/page/0/length/25/sort by/rank/sort order/asc/cols/stats.

330 University of Oxford. URL: http://www.ox.ac.uk.

331 University of Cambridge. URL: https://www.cam.ac.uk.

332 Imperial College London. URL: https://www.imperial.ac.uk.
} 
«The European Higher Education Area in 2018. Bologna Process Implementation Report» ${ }^{333}$;

«Council Recommendation on promoting common values, inclusive education, and the European dimension of teaching» ${ }^{334}$;

та «Efficiency, Effectiveness and Value for Money at Universities. A USTREAM report» ${ }^{335}$, підготовлений European University Association ${ }^{336}$ y 2019 poui.

У документі «The European Higher Education Area in 2018. Bologna Process Implementation Report» ${ }^{337}$ (Chapter 1: The European Higher Education Area Landscape («Values and governance»)) констатується принциповість зв'язку між врядуванням у вищій освіті та ключовими цінностями Європейського простору вищої освіти (ЕНЕA) - академічною свободою, інституційною автономією закладів вищої освіти, повагою до верховенства права у відносинах між громадськістю і владою.

Зазначені вище цінності також відповідають і положенням «Council Recommendation on promoting common values, inclusive education, and the European dimension of teaching» ${ }^{338}$, де загальними цінностями та принципами визначено повагу гідності людини, свободу, демократію, рівність, верховенство права та повага до прав людини.

Для визначення особливостей врядування, окрім результатів аналізу наукових праць, нами використовувався і документ «Efficiency, Effectiveness and Value for Money at Universities. A USTREAM report» ${ }^{339}$, який містить результати проведеного аналізу взаємозв'язку автономії, врядування та ефективності університетів за підсумками реалізації проєкту USTREAM («Universities for Strategic, Efficient and Autonomous Management» $\left.{ }^{340}\right)$.

Проєкт здійснювався протягом 2016-2018 років у рамках Erasmus+ Programme of the European Union ${ }^{341}$ у партнерстві з:

- $\quad$ Irish Universities Association (Асоціація університетів Ірландії, IAU) ${ }^{342}$;

- Universities UK (Асоціація університетів Великої Британії, UUK) ${ }^{343}$;

- Central European University (Центрально-Європейський університет, CEU) ${ }^{344}$;

- та Steering Committee European University Association (Наглядовий комітет Європейської асоціації університетів) ${ }^{345}$.

Завдання проєкту полягали у дослідженні концепції ефективності університетів, аналізі ключових чинників та підготовці пропозицій щодо системних інституційних заходів для сприяння її підвищенню, а кінцева мета проєкту - обмін кращими практиками та розроблення рекомендацій для європейської та національних політик та інституційних лідерів у сфері вищої освіти.

\footnotetext{
333 The European Higher Education Area in 2018. Bologna Process Implementation Report. URL: https://eacea.ec.europa.eu/nationalpolicies/eurydice/content/european-higher-education-area-2018-bologna-process-implementation-report en.

334 Council Recommendation on Common values, Inclusive Education and the European Dimension of Teaching. URL: https://eurlex.europa.eu/legal-content/EN/TXT/PDF/?uri=CELEX:32018H0607(01)\&from=.

335 Efficiency, Effectiveness and Value for Money at Universities. A USTREAM report. URL: https://eua.eu/downloads/publications/efficiency\%20effectiveness\%20and\%20value\%20for\%20money.pdf.

${ }^{336}$ European University Association. URL: https://eua.eu/.

337 The European Higher Education Area in 2018. Bologna Process Implementation Report. URL: https://eacea.ec.europa.eu/nationalpolicies/eurydice/content/european-higher-education-area-2018-bologna-process-implementation-report en.

338 Council Recommendation on Common values, Inclusive Education and the European Dimension of Teaching. URL: https://eurlex.europa.eu/legal-content/EN/TXT/PDF/?uri=CELEX:32018H0607(01)\&from=.

339 Efficiency, Effectiveness and Value for Money at Universities. A USTREAM report. URL: https://eua.eu/downloads/publications/efficiency\%20effectiveness\%20and\%20value\%20for\%20money.pdf.

340 Universities for Strategic, Efficient and Autonomous Management. URL: https://www.ceu.edu/project/universities-strategic-efficient-andautonomous-management-0.

${ }^{341}$ Erasmus+ Programme of the European Union. URL: https://ec.europa.eu/programmes/erasmus-plus/node en.

342 Irish Universities Association. URL: https://www.iua.ie/.

343 Universities UK. URL: https://www.universitiesuk.ac.uk/.

${ }^{344}$ Central European University. URL: https://www.ceu.edu/.

345 Working Groups and Steering Committees. URL: https://eua.eu/about/working-groups.html.
} 
За результатами реалізації проєкту основними принципами управління сучасними закладами вищої освіти визначено наступні ${ }^{346}$ :

- стале та адекватне фінансування;

- достатня організаційна, фінансова, кадрова та академічна автономія;

- гнучке управління.

У звіті визначено 9 ключових поглядів на ефективність університетів. Наведемо формулювання тих з них, які є важливими у контексті дослідницького врядування ${ }^{347}$ :

- ідея суто економічної ефективності університетів занадто вузька для складної місії університетів;

- об'єктивна гнучка методологічна база, яка може бути використана як для теоретичного обгрунтування, так і для практичних рекомендацій щодо ефективності університетів, передбачає необхідність зближення діяльності розробників політики та закладів вищої освіти, наявність партнерських стосунків закладів вищої освіти на різних рівнях (система, сектор, інституційний рівень) та в різних сферах управління (стратегічній, операційній та академічній);

- університети повинні бути автономними та здатними самостійно формувати свої структури управління у межах узгоджених рамок підзвітності, щоб мати можливість більш ефективно реагувати на зовнішні виклики, соціальні та економічні потреби суспільства та управляти ресурсами більш стратегічно та ефективно;

- ефективність - це колективна відповідальність усіх стейкхолдерів вищої освіти. Ефективність університету може бути досягнута лише шляхом постійного діалогу щодо політики і спільних дій політиків, університетів та їх мереж.

Вважливими для розуміння сутності врядування у сучасній вищій освіті є наступні позиції авторів звіту:

- основна проблема для розробників політики полягає у розробленні оптимального контексту, що передбачає пошук правильного балансу між самостійністю та підзвітністю, ефективністю (еfficiency) та якістю, справедливістю та результативністю (effectiveness), довірою та контролем, змінами та стабільністю, різноманітністю та стандартизацією, фокусом на виході та вході, підходом зверху вниз та знизу догори 348 .

- підвищення організаційної автономії дозволить університетам адаптувати свої структури управління для забезпечення ефективних процесів прийняття рішень та зв'язків з інноваційною екосистемою ${ }^{349}$.

Узагальнення результатів проведеного аналізу сутності парадигми врядування, його взаємозв'язку з ефективністю та результативністю управлінської діяльності в університеті дала змогу визначити ключові характеристики врядування:

- зв'язок з ключовими цінностями Європейського простору вищої освіти та Європейського дослідницького простору;

- взаємозв'язок із здатністю університету виконувати свою місію;

- багаторівневість, багатоакторність, багатосекторність та багатопроцедурність;

- баланс між самостійністю та підзвітністю, довірою і контролем, ефективністю та якістю;

- прозорість прийняття рішень;

- гнучкість організаційних структур.

Як вже зазначалося нами в попередніх публікаціях ${ }^{350}, 351$ важливою складовою системи університетського врядування є дослідницьке врядування (research governance).

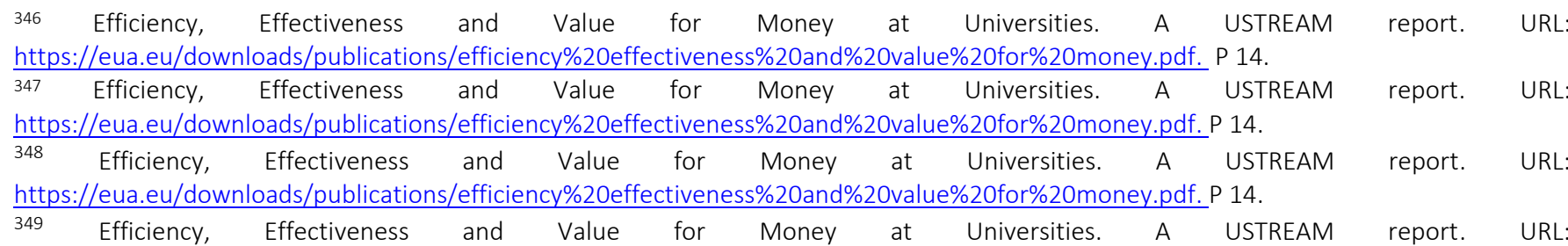
https://eua.eu/downloads/publications/efficiency\%20effectiveness\%20and\%20value\%20for\%20money.pdf. P 17.

350 Драч І. Управління дослідницькою діяльністю в системі університетського врядування: теоретичні основи. Аналіз провідного вітчизняного та зарубіжного досвіду розвитку щодо механізмів реалізації ефективного врядування в університетах: препринт (аналітичні матеріали) (частина I) / Авторський колектив: І. Драч, С. Калашнікова, О. Паламарчук, В. Рябченко, Л. Червона; за заг. ред. С. Калашнікової. - Київ: Інститут вищої освіти НАПН України, 2018. 147 c. URL: https://ihed.org.ua/wpcontent/uploads/2019/09/Analiz dosvidu vriaduvania v univer ch1 analit IVO-2018-147p avtors-kolektiv.pdf. C. 60.

351 Драч І. І. Управління дослідницькою діяльністю в системі університетського врядування: характеристика та закономірності. Вища освіта України. № 3 (70). 2018. С. 60-65. 
Про ефективність використання моделі врядування в управлінні дослідницькою діяльністю стверджують P. Aghion, M. Dewatripont, C. Hoxby, A., Mas-Colell ma A. Sapir у статті "The Governance and Performance of Research Universities: Evidence from Europe and the U.S.» ${ }^{352}$. Дослідники вбачають прямий вплив університетського врядування на показники у Шанхайському рейтингу університетів, пов'язаних 3 дослідженнями. Автори статті обґрунтовують власну позицію тим, що врядування - це механізм реалізації автономії, а саме автономія і конкуренція підвищують ефективність досліджень в університетах ${ }^{353}$.

Підтверджують висновок щодо взаємозв'язку дослідницького врядування з рівнем / якістю досліджень і експерти T. Mashaah, J. Hakim, M. Chidzonga, R. Kangwende, Y. Naik, N. Federspiel, S. Fiorillo, J. Scott, E. Gomo y статті "Strengthening Research Governance for Sustainable Research: Experiences from Three Zimbabwean Universities» ${ }^{354}$.

На необхідності розв'язання проблем організаційних структур, визначення пріоритетів досліджень, залучення зацікавлених сторін та користувачів послуг наголошують M. Yasamy, P. Maulik, M. Tomlinson, C. Lund, M. Van Ommeren ma S. Saxena у статті «Responsible governance for mental health research in low resource countries» ${ }^{355}$.

Завершуючи аналіз зарубіжних наукових публікацій з проблеми університетського врядування в цілому та дослідницького врядування зокрема, вважаємо за доцільне перед аналізом використання організаційних структур дослідницького врядування та їх функцій у системі університетського врядування проаналізувати моделі університетського врядування системах вищої освіти європейських країн.

\footnotetext{
352 Aghion P., Dewatripont M., Hoxby C., Mas-Colell A. The Governance and Performance of Research Universities: Evidence from Europe and the U.S., 2009. URL: http://www.nber.org/papers/w14851.

353 Aghion P., Dewatripont M., Hoxby C., Mas-Colell A. The Governance and Performance of Research Universities: Evidence from Europe and the U.S., 2009. C. 2. URL: http://www.nber.org/papers/w14851.

${ }^{354}$ Mashaah T., Hakim J., Chidzonga M., Kangwende R., Naik Y., Federspiel N., Fiorillo S., Scott J., Gomo E. Strengthening Research Governance for Sustainable Research: Experiences from Three Zimbabwean Universities. URL: https://www.ncbi.nlm.nih.gov/pmc/articles/PMC4116635/. 355 Yasamy M., Maulik P., Tomlinson M., Lund C., Van Ommeren M., Saxena S. Responsible governance for mental health research in low resource countries. URL: http://journals.plos.org/plosmedicine/article?id=10.1371/journal.pmed.
} 
Для розуміння особливостей університетського врядування в європейських системах вищої освіти цінною є стаття E. Pruvot ma T. Estermann «University Governance: Autonomy, Structures and Inclusiveness» 356 (2018). Авторами статті проаналізовано результати огляду сучасного стану управління європейськими університетами та основних тенденцій і еволюцій у цій галузі. Експерти розглянули види та особливості використання інституційних структур врядування у двадцяти двох системах вищої освіти: Австрія, Бельгія, Чеська Республіка, Північна Рейн-Вестфалія (Німеччина), Данія, Естонія, Фінляндія, Хорватія, Угорщина, Ірландія, Ісландія, Італія, Люксембург, Нідерланди, Норвегія, Польща, Португалія, Сербія, Швеція, Словенія, Словаччина, Велика Британія. Особлива увага у публікації приділяється:

- зрушенням у частині розподілу влади та представництва членів університетської спільноти та зовнішніх стейкхолдерів у керівних органах університетів;

- розкриттю рівня автономії європейських університетів, яка дозволяє налаштування моделей управління відповідно до своїх місій;

- розвитку відносин між університетами та державними органами управління.

Проаналізуємо основні положення зазначеної статті.

Дослідники виділили два види основних моделей врядування в європейських системах вищої освіти: унітарні (unitary governance models) та дуальні (dual governance models) і надана їх характеристика.

Унітарна модель врядування характеризується тим, що повноваженнями щодо прийняття рішень в університеті володіє один керівний орган. Цей орган може мати характеристики як органів «senate-tyре» (типу «сенат»), так і органів «board-tyре» (типу «рада»). Відмінності повноважень зазначених органів полягають у наступному: органи типу «сенат», як правило, $є$ компетентними з академічних питань і характеризуються порівняно великими розмірами та академічно орієнтованим членством (academic-oriented membership). Органи типу «рада» зазвичай відповідають за стратегічні інституційні рішення, часто включаючи і фінансові аспекти, часто мають менший розмір, ніж органи типу «сенат», характеризуються більш різноманітним членством.

Дуальна модель врядування передбачає наявність двох структур управління - органу типу «сенат» і органу типу «рада», які поділяють повноваження щодо прийняття рішень. На основі розподілу повноважень виділяються два типи дуальних моделей: традиційна дуальна модель (dual tradition model) та асиметрична дуальна модель (asymmetric dual model).

Традиційна дуальна модель базується на чіткому розподілі повноважень між органом типу «сенат» і органом типу «рада», при цьому кожний орган має не менш важливий спектр обов'язків. Орган типу «сенат», як правило, відповідає за академічні справи, тоді як орган типу «рада» здійснює в основному стратегічний нагляд (strategic oversight) та розподіл бюджету (budget allocation). Однак обидва органи можуть брати участь у процесі прийняття рішень з одних і тих же питань.

Асиметрична дуальна модель також передбачає наявність двох органів управління (типу «сенат» і типу «рада»), однак один з органів $є$ більш важливим при прийнятті рішень. Як правило, домінують органи типу «рада», а органи типу «сенат» мають владні повноваження у виняткових випадках.

Типи моделей врядування, що використовуються в університетах, представлено в таблиці (табл.1).

356 Pruvot E., Estermann T. University Governance: Autonomy, Structures and Inclusiveness». URL: 
Моделі врядування в університетах

\begin{tabular}{|c|c|c|c|}
\hline \multicolumn{2}{|c|}{ Унімарні моделі врядування } & \multicolumn{2}{|c|}{ Дуальні моделі врядування } \\
\hline $\begin{array}{c}\text { Типу «сенат» } \\
\text { (senate-type) }\end{array}$ & $\begin{array}{c}\text { Типу «рада» } \\
\text { (board-type) }\end{array}$ & $\begin{array}{c}\text { Традиційна } \\
\text { (dual tradition model) }\end{array}$ & $\begin{array}{c}\text { Асиметрична } \\
\text { (asymmetric dual model). }\end{array}$ \\
\hline
\end{tabular}

До університетського врядування в проаналізованих системах вищої освіти ${ }^{357}$ залучені як внутрішні (академічний та неакадемічний персонал, студенти), так і зовнішні стейкхолдери. Використання моделей та залученість стейкхолдерів до складу органів врядування в європейських системах вищої освіти представлено в таблиці (табл. 2).

Аналіз наведених у таблиці 2 даних свідчить про те, що унітарну модель врядування використовують у меншості випадків із досліджуваної вибірки (дев'ять з двадцяти двох). В таких університетах частіше використовуються органи типу «рада» (шість з дев'яти: Бельгія, Данія, Ісландія, Нідерланди, Норвегія, Швеція). Однак, як зазначають автори, це не виключає наявність дорадчих органів, які можуть виконувати в університетах додаткові функції органу управління. Зокрема, Данія, Ісландія та Португалія зобов'язують університети мати органи типу «сенат», хоча цей орган не має ефективних повноважень щодо прийняття рішень. Органи типу «сенат» в унітарних моделях як єдина структура прийняття рішень використовується в університетах Естонії, Ірландії та Польщі 358.

Дуальна модель врядування зустрічається у двох третинах проаналізованих європейських університетах. Обидва ії типи (традиційна та асиметртична) присутні майже однаково. Традиційна дуальна модель використовується в Австрії, Північній Рейн-Вестфалії, Італії, Великій Британії, Сербії, Словаччини та Словенії. Асиметрична дуальна модель притаманна університетам Чехії, Хорватії, Фінляндії, Угорщини, Нідерландів та Люксембургу. Як правило, в асиметричній дуальній моделі домінують органи типу «рада», а органи типу «сенат» мають владні повноваження у виняткових випадках (у двох з двадцяти двох проаналізованих систем (Чеська Республіка, Хорватія)) ${ }^{359}$.

Аналіз інформації щодо участі стейкхолдерів в університетському врядуванні показав, що представники стейкхолдерів (академічний та неакадемічний персонал, студенти, зовнішні стейкхолдери) можуть входити до складу як органів типу «рада», так і органів типу «сенат». При цьому представництво груп стейкхолдерів $\epsilon$ різним у різних системах вищої освіти. Найбільшим в органах типу «рада» $є$ представництво груп стейкхолдерів у Бельгії, Данії, Фінляндії, Норвегії, Португалії, Словенії та Великої Британії (до складу зазначених органів входять представники всіх груп стейкхолдерів (як внутрішніх, так і зовнішніх)), найменшим - в Австрії та Чеській Республіці (до складу органів входять представники лише однієї групи - зовнішніх стейкхолдерів). Унікальність системи вищої освіти Нідерландів полягає у тому, що система врядування в університетах складається з двох органів типу «рада».

Щодо представництва груп стейкхолдерів в органах типу «сенат», то найбільшим $€$ їх представництво в Ірландії та Великій Британії (до складу органів правління входять представники всіх груп стейкхолдерів), найменшим - в Словаччині, Словенії, Сербії, Хорватії, Естонії, Чеській республіці (до складу органів типу «сенат» входять представники двох груп стейкхолдерів - академічний персонал та студенти) ${ }^{360}$.

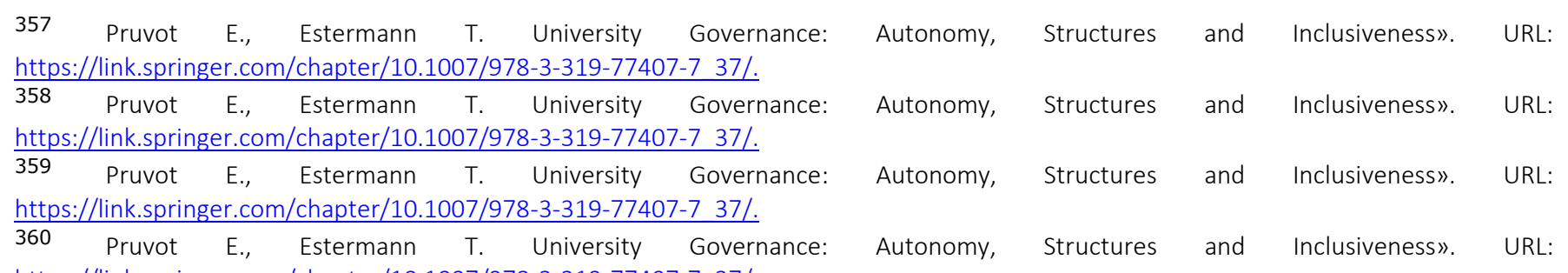


Використання моделей та залученість стейкхолдерів до органів врядування в європейських системах вищої освіти 361

Таблиця 2

\begin{tabular}{|c|c|c|c|c|c|c|c|c|c|}
\hline \multicolumn{6}{|c|}{ Склад органів типу «рада» } & \multicolumn{4}{|c|}{ Склад органів типу «сенат» } \\
\hline $\begin{array}{c}\text { Системи } \\
\text { вищої освіти }\end{array}$ & Модель врядування & $\begin{array}{c}\text { Академічний } \\
\text { персонал }\end{array}$ & $\begin{array}{c}\text { Неакадемічний } \\
\text { персонал }\end{array}$ & Студенти & $\begin{array}{l}\text { Зовнішні } \\
\text { члени }\end{array}$ & $\begin{array}{c}\text { Академічний } \\
\text { персонал }\end{array}$ & $\begin{array}{l}\text { Неакадемічний } \\
\text { персонал }\end{array}$ & Студенти & $\begin{array}{c}\text { Зовнішні } \\
\text { члени }\end{array}$ \\
\hline Австрія & Дуальна традиційна & 0 & 0 & 0 & 1 & 1 & 1 & 1 & 0 \\
\hline Бельгія & $\begin{array}{l}\text { Унітарна } \\
\text { (типу «рада») }\end{array}$ & 1 & 1 & 1 & 1 & & & & \\
\hline $\begin{array}{l}\text { Чеська } \\
\text { Республіка }\end{array}$ & $\begin{array}{lll}\text { Дуальна асиметрична (типу } \\
\text { «сенат») }\end{array}$ & 0 & 0 & 0 & 1 & 1 & 0 & 1 & 0 \\
\hline $\begin{array}{l}\text { Північна Рейн- } \\
\text { Вестфалія } \\
\text { (Німеччина) }\end{array}$ & Дуальна традиційна & 1 & 1 & 0 & 1 & 1 & 1 & 1 & 0 \\
\hline Данія & $\begin{array}{l}\text { Унітарна } \\
\text { (типу «рада») }\end{array}$ & 1 & 1 & 1 & 1 & & & & \\
\hline Естонія & $\begin{array}{l}\text { Унітарна } \\
\text { (типу «сенат») }\end{array}$ & & & & & 1 & 0 & 1 & 1 \\
\hline Фінляндія & $\begin{array}{l}\text { Дуальна асиметрична (типу } \\
\text { «рада») }\end{array}$ & 1 & 1 & 1 & 1 & 1 & 1 & 1 & 0 \\
\hline Хорватія & $\begin{array}{l}\text { Дуальна асиметрична (типу } \\
\text { «сенат») }\end{array}$ & 1 & 0 & 1 & 1 & 1 & 0 & 1 & 0 \\
\hline Угорщина & $\begin{array}{l}\text { Дуальна асиметрична (типу } \\
\text { «рада») }\end{array}$ & 1 & 1 & 0 & 1 & 1 & 1 & 1 & 0 \\
\hline Ірландія & Унітарна (типу «сенат») & & & & & 1 & 1 & 1 & 1 \\
\hline Ісландія & $\begin{array}{l}\text { Унітарна } \\
\text { (типу «рада») }\end{array}$ & 1 & 0 & 1 & 1 & & & & \\
\hline Італія & Дуальна традиційна & 1 & 0 & 1 & 1 & 1 & 1 & 1 & 0 \\
\hline Люксембург & $\begin{array}{l}\text { Дуальна асиметрична (типу } \\
\text { «рада») }\end{array}$ & 1 & 0 & 1 & 1 & 1 & 1 & 1 & 0 \\
\hline Нідерланди & $\begin{array}{l}\text { Дуальна асиметрична (типу } \\
\text { «рада»)* }\end{array}$ & 1 & 1 & 0 & 1 & & & & \\
\hline Норвегія & $\begin{array}{l}\text { Унітарна } \\
\text { (типу «рада») }\end{array}$ & 1 & 1 & 1 & 1 & & & & \\
\hline Польща & Унітарна & & & & & 1 & 1 & 1 & 0 \\
\hline
\end{tabular}

361 Pruvot E., Estermann T. University Governance: Autonomy, Structures and Inclusiveness». URL: https://link.springer.com/chapter/10.1007/978-3-319-77407-7 37/. 


\begin{tabular}{|c|c|c|c|c|c|c|c|c|c|}
\hline & (типу «сенат») & & & & & & & & \\
\hline Португалія & $\begin{array}{l}\text { Унітарна } \\
\text { (типу «рада») }\end{array}$ & 1 & 1 & 1 & 1 & & & & \\
\hline Сербія & Дуальна традиційна & 1 & 0 & 1 & 1 & 1 & 0 & 1 & 0 \\
\hline Швеція & $\begin{array}{l}\text { Унітарна } \\
\text { (типу «рада») }\end{array}$ & 1 & 0 & 1 & 1 & & & & \\
\hline Словенія & Дуальна традиційна & 1 & 1 & 1 & 1 & 1 & 0 & 1 & 0 \\
\hline Словаччина & Дуальна традиційна & & & & 1 & 1 & 0 & 1 & 0 \\
\hline Велика Британія & Дуальна традиційна & 1 & 1 & 1 & 1 & 1 & 1 & 1 & 1 \\
\hline
\end{tabular}


Важливий висновок, сформульований E. Pruvot та T. Estermann за результатами огляду європейських систем вищої освіти, полягає в наступному ${ }^{362}$ : ключовим фактором підвищення ефективності роботи університету $є$ врядування, яке має забезпечувати продуктивні відносини як з державними органами влади, так і вибір адекватних моделей внутрішнього управління. В інституційних моделях врядування важливо досягти правильного балансу між необхідністю широкого залучення до управління різноманітної університетської спільноти та розвитком структур та процесів, які підтримують ефективне прийняття рішень, а отже, гнучкого управління.

Проведений аналіз сучасного стану управління європейськими університетами дозволив E. Pruvot та T. Estermann виділити наступні тенденції врядування в європейських університетах ${ }^{363}$ :

- посилення автономії університетів разом із посиленням участі зовнішніх стейкхолдерів у керівних органах університету;

- існування в одних і тих самих системах вищої освіти різних моделей врядування;

- різноманітність політик щодо складу та чисельності органів врядування, механізмів залучення до них зовнішніх стейкхолдерів;

- участь зовнішніх стейкхолдерів у прийнятті найважливіших рішень в управлінні університетом (у деяких випадках вони набули в органах врядування повністю рівних прав із внутрішніми стейкхолдерами);

- пошук оптимальних моделей організаційної структури університетів та нових процедур призначення керівників;

- посилення гендерної рівності щодо участі у керівних органах університетів жінок (у деяких країнах на законодавчому рівні встановлено, що до роботи у керівних органах мають бути залучено щонайменше 40-50 \% жінок). 


\section{Особливості дослідницького врядування в сучасному університеті}

Особливості дослідницького врядування як важливої складової університетського врядування пов'язані 3 тим, що як ми вже зазначали раніше ${ }^{364}$, проблема забезпечення якості досліджень в університетах $\epsilon$ багатоаспектною, багатошаровою, «голографічною», оскільки пов'язана з багатьма вимірами.

Проведений нами аналіз ${ }^{365}$ досвіду реалізації дослідницького врядування у провідних університетах Великої Британії - University of Oxford, University of Cambridge, Imperial College London - показав, що дослідницьке врядування вимагає досягнення ключових стандартів у наступних сферах ${ }^{366}$ :

- етика: забезпечення гідності, прав, безпеки та добробуту учасників дослідження;

- наука: забезпечення тематики проектування, методів та проведення досліджень на підставі незалежного огляду експертів у відповідній сфері;

- інформація: забезпечення ефективного розповсюдження результатів досліджень та повного доступу громадськості до інформації щодо дослідження та його висновків;

- охорона здоров'я та безпека: гарантування захисту безпеки учасників дослідження у будь-який час; найважливішим є також турбота про навколишнє середовище при проведенні досліджень;

- правові питання: забезпечення відповідності законодавству при проведенні досліджень;

- фінанси: забезпечення фінансової справедливості;

- академічна доброчесність: запобігання шахрайству та зловживанню в дослідженнях.

Особливостями інституційних політик зазначених університетів щодо дослідницького врядування $\epsilon^{367}$ :

- орієнтація на досконалість досліджень;

- наявність стратегій дослідницької діяльності;

- акцентування уваги на дотримання принципів дослідницької доброчесності;

- широке залучення стейкхолдерів;

- забезпечення прозорості управлінських рішень.

Екстраполяція розуміння сутності врядування на управління дослідницькою діяльністю в університетах, аналіз інституційних політик провідних університетів Великої Британії дали нам змогу запропонувати визначення поняття «дослідницьке врядування в університеті» та виділити ключові цінності, на яких воно має здійснюватися.

Дослідницьке врядування в університеті ми розглядаємо як управління дослідницькою діяльністю, спрямоване на забезпечення досконалості досліджень шляхом:

- розроблення стратегії проведення досліджень із чіткім визначенням цілей, пріоритетів та механізмів;

- упровадження внутрішньої політики щодо створення середовища, в якому дотримуються високих наукових та етичних стандартів при виконанні досліджень;

- широкого залучення зовнішніх і внутрішніх стейкхолдерів;

- забезпечення моніторингу ефективності досліджень та широкого доступу громадськості до нагляду за їх результатами;

- прозорості управлінських рішень.

Дослідницьке врядування реалізується на основі балансу між самостійністю та підзвітністю, довірою і контролем, ефективністю та якістю.

\footnotetext{
364 Драч І. І. Філософський аналіз практики дослідницького врядування в університетах Великої Британії. Університет і лідерство. № 6. 2018. C. 45-57. URL: https://ul-journal.org/index.php/journal/issue/view/6.

365 Драч І. І. Досвід управління дослідницькою діяльністю в університетах Великої Британії: філософсько-аналітичний підхід. Університет і лідерство. № 5. 2018. С. 13-25. URL: https://ul-journal.org/index.php/journal/issue/view/5.

366 Драч І. І. Досвід управління дослідницькою діяльністю в університетах Великої Британії: філософсько-аналітичний підхід. Університет і лідерство. № 5. 2018. С. 13-25. URL: https://ul-journal.org/index.php/journal/issue/view/5.

367 Драч І. І. Досвід управління дослідницькою діяльністю в університетах Великої Британії: філософсько-аналітичний підхід. Університет і лідерство. № 5. 2018. URL: https://ul-journal.org/index.php/journal/issue/view/5.
} 
Цінностями дослідницького врядування є довіра, партнерство, широка залученість, відкритість, прозорість.

Основними принципами реалізації дослідницького врядування нами виділено наступні:

- принцип доброчесності: дотримання дослідниками етичних вимог при проведенні досліджень 3 метою забезпечення довіри до їх результатів;

- принцип відповідальності: забезпечення відповідності досліджень укладеним угодам і термінам, підзвітність професійним органам у галузі досліджень;

- принцип моніторингу: систематичне оцінювання результатів дослідження для проведення поточного аналізу та спрямування процесу на досягнення мети;

- принцип відкритості: інформування та широке залучення громадськості до нагляду за результатами досліджень;

- принцип співробітництва: сприяння відкритому обміну ідеями, методами досліджень, даними та результатами обстеження з іншими дослідниками та інституціями;

- принцип неперервного розвитку дослідників: забезпечення можливостей для розвитку дослідників для проведення досконалих дослідження. 
Інституційна політика та органи дослідницького врядування в європейських університетах

Розглянемо особливості реалізації інституційних політик та діяльності органів дослідницького врядування в європейських університетах. Для цього обрано два університети з різними моделями врядування: дуальною - University of Oxford ${ }^{368}$ (Велика Британія) та унітарною - University of Copenhagen ${ }^{369}$ (Данія).

University of Oxford ${ }^{370}$ (7 позиція в «Academic Ranking of World Universities 2019» ${ }^{371}$ )

В університеті функціонує дуальна традиційна модель врядування. Структура врядування включає 2 органи: Congregation (Сенат) та Council (Рада).

Congregation ${ }^{372}$ (Сенат) - вищий законодавчий орган університету, налічує більше 5 тис. членів, у тому числі академічний персонал, члени керівних органів колегій, дослідники, працівники бібліотеки, адміністративний персонал. Цей орган врядування:

- несе відповідальність за розгляд основних питань інституційної політики, які подаються Council (Радою) або членами Congregation (Сенату);

- обирає членів певних органів управління університетом, включаючи Раду та Комітет з аудиту та контролю;

- затверджує зміни та доповнення до Статутів та положень.

Council ${ }^{373}$ (Рада) $є$ головним виконавчим органом університету, до складу якого входять до 28 членів, зокрема - 4 зовнішніх. Рада відповідає (відповідно до положень Статуту) за управління університетом та управління його фінансами та активами. При здійсненні своїх функцій та повноважень члени Ради керуються усіма резолюціями, прийнятими Сенатом, та всіма іншими діями, зробленими чи рішеннями, прийнятими Конгрегацією відповідно до статутів та правил, і робить усі необхідні дії для їх виконання.

Рада відповідає також перед Higher Education Funding Council for England (HEFCE) ${ }^{374}$ (Радою фінансування вищої освіти Англії) за виконання умов Фінансового меморандуму між університетом та Office for student ${ }^{375}$ (Офісом для студентів).

Перед Радою за відповідними напрямами діяльності звітуються п'ять основних комітетів:

Education Committee ${ }^{376}$ (Комітет з питань освіти);

General Purposes Committee 377 (Комітет із загальних цілей);

Personnel Committee ${ }^{378}$ (Комітет з персоналу);

Planning and Resource Allocation Committee 379 (Комітет з планування та розподілу ресурсів);

та Research \& Innovation Committee 380 (Комітет з досліджень та інновацій).

368 University of Oxford. URL: https://www.ox.ac.uk/about/organisation/governance?wssl=1.

369 University of Copenhagen. URL: https://about.ku.dk/management/board/.

370 University of Oxford. URL: https://www.ox.ac.uk/about/organisation/governance?wssl=1.

${ }^{371}$ Academic Ranking of World Universities 2019. URL: http://www.shanghairanking.com/arwu2019.html.

${ }^{372}$ Congregation. URL: https://governance.admin.ox.ac.uk/congregation.

373 University of Oxford. Council. URL: https://governance.admin.ox.ac.uk/council/home.

374 Higher Education Funding Council for England. URL: https://www.gov.uk/government/organisations/higher-education-funding-council-forengland.

375 Office for student. URL: https://www.officeforstudents.org.uk/.

376 University of Oxford. Education Committee. URL: https://academic.admin.ox.ac.uk/committees-and-panels.

377 University of Oxford. General Purposes Committee. URL: https://governance.admin.ox.ac.uk/general-purposes-committee.

378 University of Oxford. Personnel Committee. URL: https://hr.admin.ox.ac.uk/hr-governance

379 University of Oxford. Planning and Resource Allocation Committee. URL: https://governance.admin.ox.ac.uk/planning-and-resourceallocation-committee.

380 University of Oxford. Research \& Innovation Committee. URL: https://researchsupport.admin.ox.ac.uk/ric 
Діяльність Комітету з досліджень та інновацій, як зазначено у документі «Research \& Innovation Committee. Standing orders» $(2017)^{381}$, грунтується на наступних загальних принципах, визначених Радою, для всіх комітетів:

субсидарність (Subsidiarity) - рішення мають бути делеговані на найнижчий рівень ${ }^{382}$;

чіткість (Clarity) - необхідно чітко визначити процедуру членство в Комітеті та роль його членів, процедури проходження питань (входу та виходу) через Комітет, звітність перед Комітетом та самого Комітету (Раді, Сенату, широкій університетській спільноті);

бізнес-nроцеси (Flow of business) - більшість питань повинні проходити до Ради через один з п'яти комітетів. Якщо питання має розглядатися на декількох комітетах, це має робитися послідовно, щоб лише один звіт надходив до Ради. Причина проходження питання більше, ніж через один комітет, має бути чітко задокументована;

своєчасність (Timeliness) - для забезпечення своєчасного прийняття рішень голова комітету може сам прийняти рішення, про яке має бути повідомлено на наступному засіданні;

інклюзивність (Inclusivity) - необхідно враховувати забезпечення різноманітного членства у комітеті та проходження питань таким чином, щоб заохочувати повну участь та забезпечення всіх членів до ефективного прийняття рішень;

звітування (Reporting) - звіти повинні, насамперед, дозволити членам Ради використовувати ключові стратегічні можливості та / або уникати значних ризиків. Звіти мають бути стислими і зосередженими. Детальна інформація у формі протоколів і супровідних документів доступна членам Ради на сайті.

Проаналізуємо склад та функції Комітету з досліджень та інновацій ${ }^{383}$. До його складу входять ${ }^{384}$ :

- про-віце-канцлер з досліджень (Pro-Vice-Chancellor (Research)), який очолює Комітет;

- про-віце-канцлер з інновацій (Pro-Vice-Chancellor (innovation));

- один з Інспекторів або консультант (Proctors or Assessor);

- дві особи, призначені Радою з її членів;

- чотири особи, призначені Радою, одна з яких є зовнішньою для університету, інші три особи - $з$ підрозділів університету;

- один зовнішній член, призначений Радою;

- дві особи з органів управління кожного підрозділу та по одній особи з працівників саду, бібліотеки, музею;

- два члени керівних органів коледжу;

- два представника аспірантури, призначені студентським союзом, один з яких - з факультету медичних, математичних, фізичних наук та наук про життя, інший - з відділу соціальних або гуманітарних наук.

Таким чином, членами Комітету з досліджень та інновацій $є$ представники як внутрішніх стейкхолдерів (управлінців, викладачів і студентів), так і зовнішніх стейкхолдерів.

Комітет несе відповідальність $3{ }^{385}$ :

- виконання та моніторинг всіх аспектів Стратегічного плану, які стосуються дослідницької діяльності (за погодженням з науковими підрозділами та Комітетом з питань освіти, Комітетом з планування та розподілу ресурсів);

- питання політики і планування діяльності університету, що стосуються досліджень, обміну знаннями та інновацій, комерційного та соціального підприємництва, залучення громадськості до досліджень;

- моніторинг зовнішніх впливів на розвиток наукових досліджень, надання пропозицій Раді щодо наслідків цих розробок для університету;

\footnotetext{
${ }^{381}$ Research \& Innovation Committee. Standing orders. URL: https://researchsupport.admin.ox.ac.uk/ric.

382 Більш детально цей принцип охарактеризовано в Законі України «Про наукову та науково-технічну діяльність»: субсидарність - це взаємодія між різними рівнями в ієрархічній системі управління, за якої вищий рівень управління приймає нові рішення (правила та процедури) тільки за умови їх вищої ефективності, ніж відповідні рішення нижчого рівня», ст. 1, п. 32)

383 Research \& Innovation Committee. URL: https://researchsupport.admin.ox.ac.uk/ric.

${ }^{384}$ Research \& Innovation Committee. URL: https://governance.admin.ox.ac.uk/legislation/part-6-research-and-innovation-committee.

385 Research \& Innovation Committee. URL: https://researchsupport.admin.ox.ac.uk/ric.
} 
- сприяння підготовці до зовнішніх оглядів якості досліджень та їх впливу (спільно з підрозділами університету);

- політику і процедури університету щодо витрат на дослідження (спільно з Комітетом з планування та розподілу ресурсів);

- політику, яка сприяє відповідальному проведенню досліджень та забезпечує відповідність нормативним вимогам, а також за управління ризиками;

- затвердження щорічної заяви щодо відповідності досліджень національному Concordat to Support Research Integrity (Конкордату щодо підтримки дослідницької доброчесності);

- затвердження щорічного звіту Central University Research Ethics Committee (CUREC) (Центрального комітету з дослідницької етики університету);

- призначення членів Центрального комітету з дослідницької етики університету та його підкомітетів;

- одержання інформації з поточних трирічних планів досліджень підрозділів для інформування та визначення пріоритетів на рівні університету;

- сприяння міжфакультетським дослідженням та взаємодії з коледжами у дослідженнях;

- контролювати членство представників університету у міжнародних дослідницьких альянсах;

- розроблення інституційних стратегій університету щодо інновацій, обміну знаннями, та залучення громадськості до досліджень, а також оцінку інституційного прогресу відповідно до стратегій та планів.

Перед Комітетом з досліджень та інновацій звітують:

- Central University Research Ethics Committee (CUREC) (Центральний комітет з дослідницької етики університету);

- Graduate Panel (група випускників);

- Intellectual Property Advisory Group (консультативна група з питань інтелектуальної власності);

- John Fell Fund Committee John Fell (комітет фонду);

- Knowledge Exchange and Impact Sub-Committee (KEISC) (підкомітет з обміну знаннями та впливу);

- Open Access Oxford Project Group (проєктна група відкритого доступу);

- Research Data Management Group (дослідницька група з управління даними);

- Research Information Management and Technology Sub-Committee (RIMTS) (підкомітет з управління інформацією та технологіями);

- REF Project Board (Рада проєкту REF (Research Excellence framework)).

Будучи головним у Раді, Комітет з досліджень та інновацій проводить самооцінювання власної діяльності та ефективності щонайменше кожні п'ять років та повідомляє про свої висновки Раді з рекомендаціями щодо змін, якщо це необхідно ${ }^{386}$.

Таким чином, Комітет з досліджень та інновацій $є$ центром розроблення політики дослідницького врядування університету. До важливих напрямів його діяльності належать також контроль щодо дотримання дослідницької етики та прав інтелектуальної власності університетської спільноти, належного управління даними, оцінювання досконалості досліджень.

Важливим аспектом реалізації дослідницького врядування в University of Oxford $€$ політика щодо забезпечення дослідницької доброчесності, яка розглядається в університеті як основна цінність дослідницької культури та діяльності. Документом «The University of Oxford's Code of practice and procedure on academic integrity in research» ${ }^{387}$ встановлюється вимога до усіх учасників досліджень (персоналу університету, студентів та зовнішніх осіб) щодо дотримання найвищих стандартів доброчесності у всіх аспектах досліджень.

Реалізація політик і процедур щодо забезпечення дослідницької доброчесності здійснюється 3 використанням наступних інституційних документів ${ }^{388}$ :

\footnotetext{
${ }^{386}$ Research and Innovation Committee. Standing Order. URL: https://researchsupport.admin.ox.ac.uk/ric. P.6.

387 The University of Oxford's Code of practice and procedure on academic integrity in research. URL: https://hr.admin.ox.ac.uk/academicintegrity-in-research\#collapse1310981.

${ }^{388}$ Research integrity and ethics policy. URL: https://researchsupport.admin.ox.ac.uk/governance/integrity/policy.
} 
- «Academic integrity in research: code of practice and procedure» ${ }^{389}$;

- "Statement of policy and procedure on conflict of interest» ${ }^{390}$;

- «Policy on the ethical conduct of research involving human participants and personal data»;

- «Policy on the management of data supporting research outputs» ${ }^{391}$;

- «Data protection policy» ${ }^{392}$;

- «Statute XVI: Property, Contracts, and Trusts» ${ }^{393}$;

- «Health and safety policy» ${ }^{394}$;

- «Field» ${ }^{395}$;

- «Bribery and fraud» ${ }^{396}$;

- «University Information Security Policy and Implementation Guidance» ${ }^{397}$;

- «University Policy on the Use of Animals in Scientific Research» ${ }^{398}$;

- «Public interest disclosure (whistle-blowing): code of practice» ${ }^{399}$;

- "Safeguarding 'at risk' adults and children» ${ }^{400}$;

- «Guidance on research involving security-sensitive research material» ${ }^{401}$.

В університеті передбачено також використання зовнішніх політик і процедур, які відображені в документах ${ }^{402}$ : «Concordat to support research integrity» ${ }^{403}$; «UKRI policy and guidelines on governance of good research conduct» ${ }^{404}$; «Rigour, respect and responsibility: a universal ethical code for scientists - Government Office for Science»

405 ;

«European code of conduct for research integrity - ALLEA European Federation of Academies of Science and Humanities» ${ }^{406}$; "Global code of conduct for research in resource-poor settings» ${ }^{407}$;

\footnotetext{
${ }^{389}$ Academic integrity in research: code of practice and procedure. URL: https://hr.admin.ox.ac.uk/academic-integrity-in-research. 390 Statement of policy and procedure on conflict of interest.

URL: https://researchsupport.admin.ox.ac.uk/governance/integrity/conflict/policy.

391 University of Oxford Policy on the management of data supporting research outputs. URL: https://researchdata.ox.ac.uk/university-ofoxford-policy-on-the-management-of-data-supporting-research-outputs/

392 Data protection policy. URL: https://compliance.admin.ox.ac.uk/data-protection-policy.

393 Statute XVI: Property, Contracts, and Trust. URL: https://governance.admin.ox.ac.uk/legislation/statute-xvi-property-contracts-andtrusts\#_Toc28143157.

394 Health and safety policy. URL: https://safety.admin.ox.ac.uk/health-and-safety-policy.

395 Field. URL: https://safety.admin.ox.ac.uk/fieldwork.

396 Bribery and fraud. URL: https://compliance.admin.ox.ac.uk/bribery-and-fraud.

${ }^{397}$ University Information Security Policy and Implementation Guidance. URL: https://infosec.ox.ac.uk/guidance-policy.

398 University Policy on the Use of Animals in Scientific Research. URL: https://www.ox.ac.uk/news-and-events/animal-research/universitypolicy-on-the-use-of-animals-in-scientific-research.

399 Public interest disclosure (whistle-blowing): code of practice. URL: https://hr.admin.ox.ac.uk/public-interest-disclosure-whistle-blowingcode-of-practice.

400 Safeguarding 'at risk' adults and children. URL: https://hr.admin.ox.ac.uk/safeguarding-at-risk-adults-and-children.

401 Research integrity and ethics policy. URL: https://researchsupport.admin.ox.ac.uk/governance/integrity/policy.

402 External policy and guidance. URL: https://researchsupport.admin.ox.ac.uk/governance/integrity/policy.

403 Concordat to support research integrity. URL: https://www.universitiesuk.ac.uk/policy-and-analysis/reports/Documents/2019/theconcordat-to-support-research-integrity.pdf.

404 UKRI policy and guidelines on governance of good research conduct. URL: https://www.ukri.org/files/legacy/reviews/grc/rcuk-grp-policyand-guidelines-updated-apr-17-2-pdf/.

405 Rigour, respect and responsibility: a universal ethical code for scientists - Government Office for Science. URL: https://assets.publishing.service.gov.uk/government/uploads/system/uploads/attachment_data/file/283157/universal-ethical-codescientists.pdf.

406 European code of conduct for research integrity - ALLEA European Federation of Academies of Science and Humanities. URL: https://ec.europa.eu/research/participants/data/ref/h2020/other/hi/h2020-ethics code-of-conduct_en.pdf.

407 Global code of conduct for research in resource-poor settings. URL:

https://ec.europa.eu/research/participants/data/ref/h2020/other/hi/coc research-resource-poor-settings en.pdf.
} 

Integrity» ${ }^{408}$

«Montreal statement on research integrity in cross-boundary research collaborations - developed at the 3rd World Conference on Research Integrity» ${ }^{409}$.

University of Copenhagen ${ }^{410}$ (26 позиція в Academic Ranking of World Universities $2019^{411}$ ).

В університеті функціонує унітарна модель врядування.

Найвищим органом університету, який має повноваження захищати інтереси University of Copenhagen як дослідницької та освітньої інституції $€$ Board 412 (Рада). Рада визначає рамки організаційної структури університету та встановлює довгострокові цілі його діяльності та розвитку. До складу зазначеного органу входять шість зовнішніх та п'ять внутрішніх членів, які працюють чотири роки (це не стосується студентів, які обираються щороку).

Напрями розвитку університету представлено у стратегії «Talent and collaboration. Strategy $2023 »^{413}$. До них віднесено наступні:

- залучення, розвиток та збереження академічного таланту (Attracting, developing and retaining academic talent): для досягнення мети університету бути одним з найкращих світових університетів головне значення має набір, збереження та розвиток талановитого академічного персоналу;

- освіта з тіснішими зв'язками з дослідженнями та практикою (Education with closer ties to research and practice): для підвищення якості програм дослідження повинні пронизувати програми всіх ступенів;

- співпраця та суспільна прихильність на національному та глобальному рівнях (Collaboration and societal commitment - nationally and globally): університет має стати кращим у демонстрації цінності досліджень та освіти;

- єдиний та сфокусований університет (One unified and focused university): візія університету - стати одним з найкращих світових університетів - буде реалізована насамперед завдяки постійному підвищенню якості досліджень та освіти. Усі працівники мають підтримувати досягнення цієї амбітної цілі, колективно прагнучі до ефективної організації, чітко орієнтованої на ії основну діяльність.

Таким чином, всі чотири напрями розвитку університету пов'язані із забезпеченням якісних досліджень.

На сторінці Research. Excellence ${ }^{414}$ стверджується, що університет $є$ одним $з$ найвідоміших наукових установ Європи. Візія University of Copenhagen - бути одним із найкращих світових університетів за якістю досліджень та освіти та бути визнаним за досконалість та інтелектуальну творчість. Зазначено, що університет часто займає перше місце серед скандинавських університетів у міжнародних рейтингах, а дослідники університету отримують великі престижні гранти. За результатами оцінки, проведеною міжнародними групами з 2016 по 2018 роки, зроблено висновок, що дослідження в університеті знаходяться на дуже високому (very high) та досконаломy (excellent) рівнях. Такий же висновок зроблено і за результатами оцінки самим університетом власної наукової діяльності, яка передбачала огляд якості досліджень та визначення потенціалу для її підвищення ${ }^{415}$.

Серед факторів, які забезпечували таку якість досліджень, названо наступні:

- надзвичайно високий рівень дослідників університету;

- великий успіх із залучення зовнішнього фінансування;

- високоякісне обладнання.

408 Singapore statement on research integrity - developed at the 2ndWorld Conference on Research Integrity. URL: https://www.jsps.go.jp/english/e-kousei/data/singapore statement EN.pdf.

${ }^{409}$ Montreal statement on research integrity in cross-boundary research collaborations - developed at the 3rd World Conference on Research Integrity. URL: https://wcrif.org/montreal-statement/file.

410 University of Copenhagen. URL: https://about.ku.dk/management/board/.

${ }^{411}$ Academic Ranking of World Universities 2019. URL: http://www.shanghairanking.com/arwu2019.html).

412 University of Copenhagen. Board. URL: https://about.ku.dk/management/board/.

413 Talent and collaboration. Strategy 2023. URL: https://about.ku.dk/strategy2023/download-pdf/strategy 2023 UK_print.pdf.

414 University of Copenhagen. Research. Excellence. URL: https://research.ku.dk/excellence/.

415 University of Copenhagen. Research Assessment. URL: https://research.ku.dk/excellence/evalueringer/. 
Важливим результатом проведеної оцінки стало визначення сильних сторін та рекомендації щодо усунення слабких сторін дослідницької діяльності університету. До сильних сторін віднесено такі:

- дослідження університету мають значний міжнародний вплив;

- дослідження залишають чіткий суспільний слід;

- університет тісно співпрацює як з державним сектором, так і з компаніями та іншими міжнародними університетами.

Для підвищення ефективності дослідницької діяльності університету рекомендовано наступні дії:

- університет повинен зосередити увагу на забезпеченні гендерної рівноваги, визначенні чітких шляхів кар'єри та різноманітності у підборі дослідників;

- слід розробити більш чіткі дослідницькі стратегії та зосередитися на наданні інформації про їх сильні сторони;

- має бути підвищено рівень міждисциплінарності досліджень.

Безпосередню відповідальність за визначення та здійснення стратегічного розвитку університету в рамках досліджень, інновацій, PhD програм та співробітництва з бізнесом несе Research and Innovation Council ${ }^{416}$ (Рада 3 досліджень та інновацій), що працює відповідно до стратегічних цілей університету, встановлених у контракті університету з Ministry of Science, Innovation and Higher Education ${ }^{417}$ (Міністерством освіти, науки, інновацій та вищої освіти Данії). Мета діяльності Ради з досліджень та інновацій полягає у забезпеченні збільшення фінансування досліджень, визначенні пріоритетів зовнішньої діяльності та розширенні співпраці з державними та приватними структурами. Рада з досліджень та інновацій складається 3 відповідних деканів факультетів університету, а також з проректора та директора з досліджень та інновацій. До ії повноважень належить пропозиція загальних та міждисциплінарних ініціатив в галузі досліджень та інновацій, які можуть доповнювати ініціативи факультетів, а також координація роботи з досліджень та інновацій, яка здійснюється на факультетах; внесення пропозиції щодо вдосконалення діяльності служб, орієнтованих на дослідження.

У процесі дослідницького врядування в університеті використовується наступні документи:

- «Code of Conduct for Responsible Research» (2018) ${ }^{418}$, який базується на "Danish Code of Conduct for Research Integrity» (2015) ${ }^{419}$;

- «University of Copenhagen - Code for Authorship» (2017) ${ }^{420}$;

- «Code of good scientific practice in research collaborations with external partners» (2016) ${ }^{421}$;

- «Code for public sector collaboration» (2016) ${ }^{422}$;

- «Academic Freedom at the University of Copenhagen» ${ }^{423}$;

- «Policy on research data» ${ }^{424}$;

- «Guidelines for publication for employees» ${ }^{425}$.

416 University of Copenhagen. Research and Innovation Council. URL: https://fi.ku.dk/english/kufir/.

417 Ministry of Science, Innovation and Higher Education. URL: https://ufm.dk/en/the-ministry/organisation/the-ministry.

418 Code Conduct for Responsible Research.

https://research.ku.dk/integrity/documents/code_of_conduct_for_responsible_research_2018_.pdf.

419 Danish Code of Conduct for Research Integrity. URL: http://eneri.eu/wp-content/uploads/2018/10/The-danish-code-of-conduct-forresearch-integrity-pub.pdf.

420 University of Copenhagen - Code for Authorship. URL: https://research.ku.dk/integrity/documents/code for_authorship.pdf. 421

Code of good scientific practice in research collaborations with external partners.

URL:

https://research.ku.dk/integrity/documents/ucph code of good scientific practice in research collaborations 2016 .pdf. 422 Code for public sector collaboration. URL: https://research.ku.dk/integrity/code-of-conduct/.

423 Academic Freedom the University of Copenhagen.

https://research.ku.dk/integrity/documents/academic freedom at the university of copenhagen.pdf.

424 Policy on research data.

- URL: https://research.ku.dk/integrity/documents/university of copenhagen s policy on research data.pdf.

${ }^{425}$ Guidelines for publication for employees. URL: https://research.ku.dk/integrity/documents/guidelines for publication.pdf. 
Політику щодо забезпечення дослідницької доброчесності як складової дослідницького врядування в університеті відображено в розділі «Research Misconduct and Breaches of Responsible Conduct of Research» документа «Code of Conduct for Responsible Research» ${ }^{426}$.

Підсумовуючи результати аналізу інституційних політик, структури та функцій органів дослідницького врядування в двох європейських університетах (University of Oxford тa University of Copenhagen), зазначимо, що незважаючи на різні моделі врядування (дуальної та унітарної), спільним в реалізації політики в університетах $\epsilon$ наступне:

багаторівневість: діяльність Комітету / Ради з досліджень та інновацій як головного центру розроблення політики дослідницького врядування університету підпорядкована вищому органу управління університетом, водночас перед цим органом звітують інші комітети та групи (University of Oxford) або до його повноважень належить координація роботи з досліджень та інновацій, яка здійснюється на факультетах (University of Copenhagen);

багатоакторність: до складу органів дослідницького врядування обох університетів входять як внутрішні (представники всіх ланок управління), так і зовнішні стейкхолдери;

багатосекторність: дослідницьке врядування спрямовано на продуктивні відносини як з державними органами влади, так і вибір адекватних моделей внутрішнього управління;

багатопроцедурність: використання в університетах політик і процедур національного та інституційного рівнів щодо дослідницького врядування, зокрема, щодо визначення вимог до членства в органах управління дослідженнями та ролі їх членів; дослідницької етики; управління даними тощо;

акцентування уваги на забезпеченні дослідницької доброчесності як основної цінності дослідницької культури та діяльності.

426 Code for Responsible Research. https://research.ku.dk/integrity/documents/code of conduct for responsible research 2018 .pdf. 


\section{Підтримка дослідницької доброчесності в університетах на національному рівні: досвід Великої Британії}

Як зазначалося вище, однією з важливих складових дослідницького врядування в університеті $€$ забезпечення дослідницької доброчесності, для формування культури якої актуальною є підтримка цього процесу на національному рівні. Проаналізуємо досвід підтримки дослідницької доброчесності в закладах вищої освіти на національному рівні на прикладі Великої Британії. Увага до системи управління дослідницькою діяльністю в університетах Великої Британії зумовлена їх високими позиціями в міжнародних університетських рейтингах, які ґрунтуються, зокрема, і на високій якості досліджень в університетах цієї країни. Так, за оцінками міністра університетів і науки $D$. Willetts, представлених у документі «The concordat to support research integrity» 427, британські дослідники, які складають 4 \% від кількості світових дослідників, публікують понад 6 \% всіх наукових статей. Цитованість їх робіт складає 11 \% від усіх цитат, у тому числі 14 \% - найбільш цитованих наукових робіт. Така висока якість досліджень, як ми зазначали раніше ${ }^{428}$, забезпечується впровадженням у британських університетах дослідницького врядування, яке передбачає, зокрема, опис політик і процедур дотримання принципів дослідницької доброчесності (research integrity) як на національному, так і на інституційному рівнях.

На національному рівні вагому роль у системі забезпечення дослідницької доброчесності у Великій Британії відіграє UK Research Integrity Office (UKRIO) ${ }^{429}$ (Офіс дослідницької доброчесності). Підготовлені UKRIO документи створюють надійне підґрунтя для розроблення університетами власних політик та процедур щодо розвитку культури дослідницької доброчесності в університетському середовищі. Охарактеризуєм діяльність та основні документи UKRIO. Представимо результати аналізу, здійсненого шляхом узагальнення інформації, оприлюдненої на офіційних веб-сайтах зазначеної інституції.

UKRIO створений у 2006 році як незалежна благодійна організація, що надає підтримку громадськості, дослідникам та організаціям для подальшої успішної практики в наукових дослідженнях. Цілями діяльності UKRIO $\epsilon^{430}$ :

- сприяння ефективному врядуванню, менеджменту та проведенню академічних, наукових та медичних досліджень;

- поширення кращого досвіду щодо вирішення проблем, пов'язаних з неприйнятною практикою, неправомірними діями та неетичною поведінкою;

- надання конфіденційних, незалежних та експертних консультацій з конкретних дослідницьких проектів, випадків, проблем та питань.

UKRIO накопичив значний і унікальний досвід надання допомоги організаціям, дослідникам та громадськості з питань проведення досліджень у всіх предметних областях, від мистецтва та гуманітарних наук до охорони здоров'я та біомедицини. Наприклад, у 2014 році UKRIO допоміг з більш ніж 90 випадками, а використання послуг з кожним роком продовжує зростати. Опубліковані UKRIO рекомендації були використані чи прийняті багатьма організаціями, включаючи понад 50 університетів, і схвалені органами фінансування та професійними організаціями.

Для допомоги університетам Великої Британії пропонуються низка розроблених UKRIO документів, які носять рекомендаційний характер: документи можуть використовуватися або в запропонованому вигляді, або при розробленні власних політик дослідницького врядування.

427 The concordat to support research integrity. URL: https:/www.universitiesuk.ac.uk/policy-and-analysis/reports/Documents/2012/theconcordat-to-support-research-integrity.pdf/.

428 Драч І. І. (2018). Управління дослідницькою діяльністю в системі університетського врядування: характеристика та закономірності. Вища освіта України, № 3 (70), 60-65.

429 UK Research Integrity Office. URL: https://ukrio.org.

430 UK Research Integrity Office. URL: https://ukrio.org. 
Серед основних документів виокремимо такі:

- «Code of Practice for Research» (2009) ${ }^{431}$ («Кодекс практики досліджень»);

- «The concordat to support research integrity» (2012) ${ }^{432}$ («Конкордат для підтримки дослідницької доброчесності»);

- «Procedure for the investigation of misconduct in research» (2008) ${ }^{433}$ («Процедура розслідування порушень в дослідженнях»);

- «Self-Assessment Tool for The Concordat to Support Research Integrity» (2014) ${ }^{434}$ («lнструмент самооцінювання для «Конкордату з підтримки дослідницької доброчесності»).

Наведені документи утворюють «каркас» для формування та підтримки дослідницької доброчесності у британських університетах. Тому аналіз їх основних положень $€$ важливим з точки зору можливості їх використання при розробленні політик і процедур щодо дослідницької доброчесності в університетах України.

«Code of Practice for Research» («Кодекс практики досліджень») ${ }^{435}$ (далі - Кодекс) розроблений для просування належної практики та запобігання неправомірним діям при проведенні досліджень в університетах. У цьому документі ${ }^{436}$ :

- наведено рекомендований контрольний список питань до дослідників (Recommended Checklist for Researchers), на які мають бути надані відповіді перед дослідженням, під час проведення та після закінчення дослідження;

- визначено та охарактеризовано принципи та стандарти належної практики досліджень, яких мають дотримуватися дослідники та дослідницькі організації. Зауважується, що дослідницькі організації можуть використовувати принципи та стандарти, які викладені в цьому документі, як орієнтири при складанні чи перегляді власних, більш детальних документів. Кодекс охоплює сфери кращої практики в дослідженнях і покликаний допомогти дослідницьким організаціям у виконанні вимог регуляторного, фінансового забезпечення для того, щоб важливі питання не залишилися поза увагою.

Кодекс може поширюватися і на студентів. У такому випадку це має бути чітко визначено в інституційній політиці, а організації повинні передбачити підготовку, нагляд і підтримку, яку вони повинні надавати студентам-дослідникам.

На особливу увагу у контексті забезпечення дослідницької доброчесності заслуговує розділ Кодексу «Misconduct in research» («Неправомірна поведінка в дослідженнях»), в якому надано перелік та характеристика неправомірних дій у дослідженнях. Неправомірними діями в дослідженнях визначено наступні 437:

- фабрикація;

- фальсифікація;

- неправильне представлення даних та / або інтересів та / або участі;

- плагіат;

- невиконання прийнятих процедур для:

о уникнення невиправданого ризику або шкоди щодо: людей і тварин, які використовуються в дослідженні, та середовища;

○ належного використання інформації про осіб, зібраної під час дослідження.

\footnotetext{
${ }^{431}$ Code of Practice for Research. URL: https://ukrio.org/wp-content/uploads/UKRIO-Code-of-Practice-for-Research.pdf

432 The concordat to support research integrity. URL: https://www.universitiesuk.ac.uk/policy-and-analysis/reports/Documents/2012/theconcordat-to-support-research-integrity.pdf

433 Procedure for the investigation of misconduct in research. URL: https://ukrio.org/wp-content/uploads/UKRIO-Procedure-for-theInvestigation-of-Misconduct-in-Research.pdf.

${ }^{434}$ Self-Assessment Tool for The Concordat to Support Research Integrity. URL: https://ukrio.org/self-assessment-tool-concordat-supportresearch-integrity./

${ }^{435}$ Code of Practice for Research. URL: https://ukrio.org/wp-content/uploads/UKRIO-Code-of-Practice-for-Research.pdf.

${ }^{436}$ Code of Practice for Research. URL: https://ukrio.org/wp-content/uploads/UKRIO-Code-of-Practice-for-Research.pdf.

${ }^{437}$ Code of Practice for Research. URL: https://ukrio.org/wp-content/uploads/UKRIO-Code-of-Practice-for-Research.pdf.
} 
У зазначеному розділі Кодексу університетам також рекомендується розробити та оприлюднити процедуру розслідування заяв про неправомірну поведінку в дослідженнях і забезпечити, щоб такі звинувачення були ретельно, справедливо і своєчасно розслідувані. В університеті має бути визначений один або більше співробітників, на яких покладена відповідальність за розслідування звинувачень у неналежній поведінці у дослідженнях та з якими можна контактувати з будь-яких проблем при проведенні досліджень. Зауважується, що в організаціях мають переконатися, що персонал, який розслідує звинувачення, має необхідну підготовку, ресурси та підтримку для виконання цієї ролі. Передбачається відповідальність дослідників за будь-які неправомірні дії в дослідженнях - для них можуть вживатися дії дисциплінарного провадження. Оскільки дослідники є представниками регульованої професії, у випадках серйозних порушень інформація про них (порушення) має бути надана органу, що регулює їхню професію.

Дослідники повинні визнавати, що належна практика у дослідженнях включає звітність щодо проведення досліджень. Окрім того, що дослідники повинні:

- знати, що є неправомірним поведінкою у дослідженні;

- мають повідомляти організацію про будь-які підозрілі неправомірні дії через відповідну процедуру, як тільки вони дізнатися про це;

- співпрацювати з розслідування будь-яких неправомірних дій у дослідженні, коли це вимагається.

Таким чином, вимога до британських дослідників бути небайдужими до проявів дослідницької недоброчесності є обов'язковою, оскільки це пов'язано з репутацією всієї установи.

Зобов'язання, які мають взяти на себе дослідники для того, щоб забезпечити найвищі стандарти точності та доброчесності, представлені у «The concordat to support research integrity» («Конкордаті для підтримки дослідницької доброчесності») ${ }^{438}$ (далі - Конкордат), опублікованому у 2012 році. Про вагомість цього документу свідчить його підписання представниками:

Department for Employment and Learning (Департаменту зайнятості та навчання);

Higher Education Funding Council for England (Ради фінансування вищої освіти в Англії);

Higher Education Funding Council for Wales (Ради фінансування вищої освіти для Уельсу);

National Institute for Health Research (Національного інституту досліджень здоров'я;

Research Councils UK (Дослідницьких рад Великої Британії);

Scottish Funding Council (Шотландської Ради з фінансування);

організації Universities UK (Університети Великої Британії), яка представляє 136 університети Англії, Шотландії, Уельсу та Північної Ірландії;

та організації Welcome Trust (незалежного міжнародного благодійного фонду для фінансування медично-біологічних досліджень).

у Конкордаті визначено та описано п'ять зобов'язань, які мають взяти на себе дослідники, щоб забезпечити найвищі стандарти точності та доброчесності. Такими зобов'язаннями $\epsilon^{439}$ :

- підтримка найвищих стандартів точності та доброчесності в усіх аспектах досліджень;

- забезпечення проведення досліджень відповідно до діючих етичних, юридичних та професійних рамок, зобов'язань і стандартів;

- підтримка дослідницького середовища, яке спирається на культуру доброчесності на основі належного управління, найкращої практики та підтримки розвитку дослідників;

- використання прозорих, надійних і справедливих процесів для розгляду заяв про порушення у дослідженнях, якщо вони виникнуть;

- спільна робота з метою посилення дослідницької доброчесності та регулярного і відкритого оцінювання прогресу.

Перелічені ключові зобов'язання стосуються як дослідників, так і їх роботодавців та органів, які фінансують дослідження.

438 The concordat to support research integrity. URL: https:/www.universitiesuk.ac.uk/policy-and-analysis/reports/Documents/2012/theconcordat-to-support-research-integrity.pdf.

439 The concordat to support research integrity. URL: https://www.universitiesuk.ac.uk/policy-and-analysis/reports/Documents/2012/theconcordat-to-support-research-integrity.pdf. 
Важливим документом, який характеризує вплив Конкордату на систему вищої освіти Великої Британії та інших країн, є підготовлений UKRIO «The concordat to support research integrity a progress report» («Звіт щодо прогресу у використанні Конкордату для підтримки дослідницької доброчесності») ${ }^{440}$ (далі - Звіт). у Звіті ретельно проаналізовано досвід використання Конкордату у британських університетах з липня 2012 р. по червень 2016 р. на основі узагальнення інформації, отриманої за допомогою різноманітних засобів, включаючи: інтерв'ю з представниками інституцій; аналізу прикладів, що описують діяльність з реалізації, та виклики; письмові подання від представників інституцій тощо.

У Звіті представлено розділи ${ }^{441}$ :

- розповсюдження та інформованість (dissemination and awareness of the concordat);

- погляди на підхід Конкордату (views on the concordat approach);

- підходи до імплементації (approaches to implementation);

- переваги Конкордату (benefits of the concordat);

- значення організаційної культури (importance of organization culture);

- «тягар» імплементації ('burden of implementation);

- розуміння відповідності (understanding compliance);

- публічне інформування щодо дослідницької доброчесності та ії порушень (public information on research integrity and misconduct).

3 огляду на важливість інформації, представленої у Звіті, для розбудови системи формування культури дослідницької доброчесності в університетах України, проаналізуємо зазначені розділи детальніше.

У розділі «Розповсюдження та інформованість» подано інформацію щодо щомісячної кількості завантажень Конкордату з липня 2012 р. по червень 2016 р. Зазначено, що про актуальність використання Конкордату свідчить те, що у цей період з веб-сайту Universities UK ${ }^{442}$ було завантажено понад 42 тис. примірників конкордату, а також університети отримали 2,5 тис. примірників Конкордат у друкованому вигляді.

Розділ «Погляди на підхід Конкордату» присвячено аналізу вплив підходу, який втілює Конкордат, на системи вищої освіти в усьому світі. Так, при підготовці подібних публікацій іншими національними науководослідницькими організаціями або організаціями з фінансування досліджень вони безпосередньо посилаються на Конкордат. Це, наприклад, «Кодекс поведінки для дослідницької доброчесності» (Данія, 2014), розроблений Міністерством вищої освіти і науки; «Національна політика щодо забезпечення дослідницької доброчесності» (Ірландія, 2014) тощо.

У розділі «Підходи до імплементації» розглянуто інституційні підходи до впровадження Конкордату на прикладах великого науково-інтенсивного університету (large, research-intensive university) та сучасного університету з профілем досліджень, який перебуває на стадії становлення (modern university with emerging research profile).

У розділі «Переваги Конкордату» зазначається, що Конкордат:

- слугує обміну найкращими практиками проведення дослідницької діяльності;

- сприяє формуванню прозорої і відкритої дослідницької культури, яка дозволяє продемонструвати точність, доброчесність і якість методів дослідження та результатів.

Про важливість створення дослідницького середовища, яке сприяє передовій практиці і де доброчесність $€$ ключовою частиною інституційної культури наголошується у розділі «Значення організаційної культури». Зазначено, що створення цієї культури і середовища має бути процесом безперервного вдосконалення, де завжди $є$ можливості для вивчення, розвитку та вдосконалення.

Розділ ««Тягар» імплементації?» присвячено аналізу ресурсів для впровадження Конкордату, оскільки прийняття будь-якої нової політики та вжиття заходів до ії впровадження несуть за собою витрати. Зауважується, що досить поширеною відповіддю щодо імплементації Конкордату була його позитивна оцінка з боку університетів. Однак, окрім позитивного результату, акцентується увага на необхідних інвестиціях.

440 The concordat to support research integrity a progress report. URL: https://www.universitiesuk.ac.uk/policy-andanalysis/reports/Pages/concordat-research-integrity-progress-report.aspx. 441 The concordat to support research integrity a progress report. URL: https://www.universitiesuk.ac.uk/policy-andanalysis/reports/Pages/concordat-research-integrity-progress-report.aspx.

442 Universities UK. URL: https://www.universitiesuk.ac.uk/. 
Ключові виклики впровадження Конкордату стосуються часу і ресурсу, необхідних для спілкування, навчання, підтримки та порад, щоб забезпечити знання його вимог у дослідницькому середовищі. Це призводить до короткострокового збільшення адміністративного навантаження.

У розділі «Розуміння відповідності» акцентується увага на тому, що дотримання Конкордату для підтримки дослідницької доброчесності є вимогою для фінансування досліджень відповідними організаціями. Використання такої вимоги як умови надання фінансування допомогло підвищенню рівня поінформованості про необхідність підтримки зусиль щодо дотримання найвищих стандартів точності та доброчесності у всіх аспектах досліджень.

Розділ «Публічне інформування щодо дослідницької доброчесності та ї̈ порушень» містить аналіз інформації, представленої на 131 інституційних веб-сайтах університетів. Так:

- 67 з них оцінені як «хороші» або «відмінні»;

- для 64 було встановлено, що інформування потребує поліпшення.

Результати аудиту веб-сайтів свідчать про те, що багатьом університетам необхідно зробити невеликі, але важливі удосконалення, які підвищать видимість їх роботи щодо дослідницької доброчесності. Встановлено, що:

- більше трьох чвертей (77 \%) інституційних веб-сайтів мали відкриту публічну веб-сторінку, орієнтовану на дослідницьку доброчесність та/або етику досліджень. Водночас якість та обсяг інформації, що надаються, є різною;

- 85 \% веб-сайтів мали загальнодоступні політичні документи, пов'язані з дослідницькою доброчесністю, етикою та / або процедурами зловживань у дослідженні;

- 37 \% мали принаймні одного призначеного члена персоналу з контактними даними для запитів щодо дослідницької доброчесності;

- $26 \%$ мали принаймні один щорічний загальнодоступний огляд щодо дослідницької доброчесності;

- 23 \% мали деякі загальнодоступні навчальні матеріали, пов'язані 3 дослідницькою доброчесністю для учасників досліджень.

у Звіті 443 також наведені кроки для підтримки дослідницької доброчесності в університетському середовищі. Зазначається, що основні особливості Конкордату ${ }^{444}$ повинні бути збережені. Він має розглядатися як відповідний, пропорційний та ефективний механізм для наукових організацій та їх персоналу в забезпеченні відповідності систем і процесів цілям. Підписанти Конкордату не повинні прагнути диктувати дослідницьким організаціям заходи щодо підтримки / сприяння формуванню культури дослідницької доброчесності. Це $\epsilon$ справою автономних інституцій, науковців та академічної спільноти. Підписанти повинні спільно висловлювати свої очікування щодо дотримання принципів доброчесності у дослідженнях. Рекомендується, щоб ці очікування були зосереджені на більшій прозорості та підзвітності. Як мінімум, дослідницькі організації повинні мати:

- спеціальну та відкриту веб-сторінку про дослідницьку доброчесність;

- вказані контакти для можливості перевірки щодо дотримання принципів дослідницької доброчесності та встановлення порушень;

- загальнодоступне щорічне повідомлення, в якому викладено кроки, які вжиті для сприяння формуванню дослідницької доброчесності.

У Конкордаті необхідно представляти приклади найкращої практики. Для збереження імпульсу, який був створений в науковому співтоваристві, підписанти повинні підтримувати цей процес шляхом розроблення щорічних рекомендацій до розробленого Конкордату та здійснення перевірки прогресу через три роки.

443 The concordat to support research integrity a progress report. URL: https://www.universitiesuk.ac.uk/policy-andanalysis/reports/Pages/concordat-research-integrity-progress-report.aspx.

444 The concordat to support research integrity. URL: https://www.universitiesuk.ac.uk/policy-and-analysis/reports/Documents/2012/theconcordat-to-support-research-integrity.pdf. 
Аналіз інформації, поданої у Звіті ${ }^{445}$, свідчить про те, що, як показує досвід інших європейських країн, Конкордат ${ }^{446}$ може використовуватися і в Україні при розробленні політики щодо забезпечення дослідницької доброчесності як на національному, так і на інституційному рівнях. Використання Конкордату сприятиме формуванню прозорої та відкритої дослідницької культури, яка дозволяє продемонструвати точність, доброчесність і якість методів дослідження та результатів. Важливими чинниками забезпечення високих етичних стандартів у дослідженнях $€$ публічне інформування про дотримання політики дослідницької доброчесності та ії порушень на веб-сайтах університетів, а також систематичне оцінювання прогресу у формуванні культури дослідницької доброчесності в університетському середовищі. Водночас, слід усвідомлювати, що реалізація політики дослідницької доброчесності передбачає короткострокове збільшення адміністративного навантаження.

Для запобігання шкідливим наслідкам у разі неправомірної поведінки в дослідженнях UKRIO підготовлено «Procedure for the investigation of misconduct in research» («Процедуру розслідування неправомірної поведінки в дослідженнях» 447 (далі - Процедура). Хоча Процедура була розроблена для досліджень у сфері охорони здоров'я та біомедицини, рекомендовано їі використання для розслідування можливих порушень у будь-якій сфері досліджень. Процедура розроблена як типова для університетів і інших дослідницьких організацій, які можуть здійснювати розслідування неправомірних дій у дослідженнях. У Процедурі описані своєчасні, ретельні та об'єктивні дії, які повинні дозволити роботодавцям проводити повне і справедливе для всіх сторін розслідування такої поведінки. Оскільки формування культури дослідницької доброчесності в українських університетах має передбачати, зокрема, і чіткі дії у разі виявлення порушень їі принципів, проаналізуємо основні положення Процедури детальніше.

В описі Процедури зазначено ${ }^{448}$, що вона використовується з метою:

- забезпечити ретельне та справедливе розслідування;

- продемонструвати, що використання узгодженого стандартного процесу зменшує кількість помилок в проведенні розслідувань;

- запевнити тих, чия поведінка досліджується, у тому, що процес розслідування буде відповідати стандартній процедурі, прийнятої на національному рівні університетами та іншими дослідницькими організаціями.

Прийнявши та дотримуючись Процедури, необхідно:

- встановити характер і механізми, за допомогою яких можна належним чином розслідувати неправомірну поведінку в дослідженні;

- дозволити групі експертів визначити, чи мають місце твердження про неправомірні дії в дослідженнях;

- дозволити групі експертів встановити, на підставі балансу ймовірностей, докази щодо твердження про неналежну поведінку в наукових дослідженнях (як навмисну, так і необережну);

- скласти звіт, на підставі якого організація може ініціювати відповідні дії.

У ситуаціях, коли звинувачення мають серйозний характер, офіційні кроки повинні бути реалізовані негайно. Після ініціювання Процедура має бути завершеною незалежно від таких подій, як ${ }^{449}$ :

- позивач скасував заяву на будь-якій стадії;

- відповідач визнав неправомірні дії повністю або частково;

- відповідач або позивач подають у відставку.

445 The concordat to support research integrity a progress report. URL: https://www.universitiesuk.ac.uk/policy-andanalysis/reports/Pages/concordat-research-integrity-progress-report.aspx.

446 The concordat to support research integrity. URL: https://www.universitiesuk.ac.uk/policy-and-analysis/reports/Documents/2012/theconcordat-to-support-research-integrity.pdf

447 Procedure for the investigation of misconduct in research. URL: https://ukrio.org/wp-content/uploads/UKRIO-Procedure-for-theInvestigation-of-Misconduct-in-Research.pdf.

448 Procedure for the investigation of misconduct in research. URL: https://ukrio.org/wp-content/uploads/UKRIO-Procedure-for-theInvestigation-of-Misconduct-in-Research.pdf. P.5.

449 Procedure for the investigation of misconduct in research. URL: https://ukrio.org/wp-content/uploads/UKRIO-Procedure-for-theInvestigation-of-Misconduct-in-Research.pdf. P.15. 
Процедура передбачає, що дослідницька організація повинна визначити відповідальну особу за розслідування та особу, яка має діяти в його / їі відсутність. Крім того, організація повинна призначити відповідальних осіб у відділах кадрів, фінансів, досліджень (в ідеалі з певним досвідом досліджень), які повинні підтримувати зв'язок з призначеною особою для розслідування звинувачень у неправомірній поведінці у дослідженнях.

Процедура містить три розділи та вісім додатків. У розділах описано:

- передумови для використання Процедури;

- підготовчі етапи;

- докладні відомості про те, як слід застосовувати процедуру для розслідування заяв щодо неправомірних дій в дослідженнях.

У додатках представлено:

- принципи, яких необхідно дотримуватися при використанні Процедури;

- визначення термінів, що використовуються в Процедурі;

- форму для повідомлення UKRIO про хід розслідування за повідомленнями про неправомірну поведінку у дослідженнях;

- рекомендації для групи перевірки та групи розслідування;

- пропозиції щодо дій та результатів після завершення розслідування;

- загальні рекомендації щодо зв'язку та ведення обліку під час процедури;

- джерела, які використовувалися при розробленні Процедури.

Для допомоги університетам у визначенні відповідності власних дослідницьких практик, систем та політик, процедур розвитку дослідників, моніторингу вимогам та рекомендаціям Конкордату використовується розроблений UKRIO "Self-Assessment Tool for The Concordat to Support Research Integrity» («Iнструмент самооцінювання для Конкордату 3 підтримки дослідницької доброчесності» 450 (далі - Інструмент самооцінювання). Якщо Конкордат ${ }^{451}$ стосується трьох ключових зацікавлених сторін, які беруть участь у дослідженні (дослідник, роботодавець та фінансист), то в Інструменті самооцінювання 452 увага зосереджується на відповідальності установ, які залучають дослідників. Рекомендації надаються з кожного аспекту Конкордату, але особливу увагу в Інструменті самооцінювання було приділено тим з них, з яких були найчастіші звернення до UKRIO щодо передачі досвіду науковому співтовариству.

Зважаючи та те, що Конкордат встановлює п'ять зобов'язань, які мають взяти на себе дослідники для забезпечення найвищих стандартів точності та доброчесності, Інструмент самооцінювання визначає п'ять ключових тем, які стосуються цих зобов'язань, а також питання для самооцінювання, які відповідають одному або декільком зобов'язанням Конкордату.

Самооцінювання здійснюється за напрямами ${ }^{453}$ :

- політика та системи;

- розповсюдження;

- культура і розвиток;

- розв'язання проблем, пов'язаних з порушеннями дослідницької доброчесності;

- моніторинг та звітність.

У процесі проведення самооцінювання пропонується на лише надавати відповіді на питання, а і представляти можливі докази для аргументації відповіді, заповнюючи таблицю (табл. 3).

450 Self-Assessment Tool for The Concordat to Support Research Integrity. URL: https://ukrio.org/self-assessment-tool-concordat-supportresearch-integrity/.

451 The concordat to support research integrity. URL: https://www.universitiesuk.ac.uk/policy-and-analysis/reports/Documents/2012/theconcordat-to-support-research-integrity.pdf.

${ }^{452}$ Self-Assessment Tool for The Concordat to Support Research Integrity. URL: https://ukrio.org/self-assessment-tool-concordat-supportresearch-integrity/.

453 Self-Assessment Tool for The Concordat to Support Research Integrity. URL: https://ukrio.org/self-assessment-tool-concordat-supportresearch-integrity/. 
Таблиця 3

Самооцінювання стану забезпечення дослідницької доброчесності в університеті

\begin{tabular}{|c|c|c|}
\hline Відповідні зобов'язання & Питання самооцінювання & Можливі докази \\
\hline & & \\
\hline
\end{tabular}

Розробники Інструменту самооцінювання акцентують увагу на його консультативній, а не нормативній ролі. Його мета полягає не в тому, щоб запропонувати підхід, однаковий для всіх або нав'язати негнучкість рішення. Інструмент самооцінювання може допомогти університетам розглянути, як Конкордат найкраще реалізувати в умовах конкретного університету для просування та підтримки дослідницької доброчесності.

UKRIO ${ }^{454}$ рекомендовано університетам також готувати та публікувати щорічний звіт до Комітету з науки та технологій Палати громад Британського парламенту (Commons Science and Technology Committee of the House of Commons UK Parliament) щодо дотримання Конкордату, який повинен містити короткий, але ґрунтовний опис діяльності, що проводиться в університеті для підтримки дослідницької доброчесності, включаючи дії щодо розслідування будь-яких звинувачень у неправомірних діях. Якщо з якоїсь причини необхідний стандарт не виконується, у звіті має бути короткий виклад того, що зроблено та визначено термін для вирішення цього питання. Наприклад: «Публічно доступна інформація на веб-сайті щодо політики дослідницької доброчесності та призначеної особи для отримання тверджень про неправомірну поведінку поки що не розміщена. Це буде виправлено до початку наступного семестру» ${ }^{455}$. У звіті рекомендовано також відображати не лише перелік заходів, що проводяться, але і вплив вжитих заходів та результат.

Проведений аналіз ключових документів, розроблених UKRIO ${ }^{456}$ для підтримки дослідницької доброчесності, дає змогу виокремити основні ідеї, які пропонуються для реалізації в університетах Великої Британії відповідно до зазначених документів. На нашу думку такими $€$ наступні положення:

- проведення досліджень має здійснюватися відповідно до діючих етичних, юридичних та професійних рамок, зобов'язань та стандартів;

- необхідно підтримувати найвищі стандарти точності та доброчесності в усіх аспектах досліджень;

- розвиток культури дослідницької доброчесності має відбуватися на основі належного управління, використання найкращих практик та підтримки розвитку дослідників;

- рекомендується, щоб процеси, пов'язані з дотриманням принципів дослідницької доброчесності, були якомога більше прозорими і підзвітними. Як мінімум, дослідницькі організації повинні мати: спеціальну веб-сторінку про дослідницьку доброчесність; вказані контакти осіб для звернення у разі підозр щодо дотримання принципів дослідницької доброчесності;

- для забезпечення ретельного та справедливого розслідування підозр / звинувачень у неправомірній поведінці при проведенні досліджень в університетах необхідно мати відповідну власну Процедуру (або використовувати Процедуру, розроблену Офісом дослідницької доброчесності). Заходи із розслідування підозр / звинувачень у неправомірній поведінці при проведенні досліджень мають здійснюватися за обов'язкового дотримання принципів справедливості, конфіденційності, доброчесності, запобігання шкоди та балансу;

- дослідники не лише повинні знати, що $€$ неправомірним поведінкою у дослідженні, а і мають повідомляти організацію про будь-які підозрілі неправомірні дії через відповідну процедуру, як тільки вони дізнатися про це; співпрацювати з розслідування будь-яких неправомірних дій у дослідженні, коли це вимагається;

- необхідно усвідомлювати, що впровадження політик і процедур з розвитку культури дослідницької доброчесності, потребує часу і ресурсу, необхідних для спілкування, навчання, підтримки та порад. Це призводить до короткострокового збільшення адміністративного навантаження;

454 UKRIO. URL: https://ukrio.org/.

455 UKRIO. URL: https://ukrio.org/.

456 UKRIO. URL: https://ukrio.org/. 
- рекомендується публікувати загальнодоступний щорічний звіт, в якому викладено кроки щодо для сприяння формуванню культури дослідницької доброчесності, а також регулярно і відкрито оцінювати прогрес.

Детально охарактеризовані основні положення ключових документів, які забезпечують підтримку дослідницької доброчесності в системі університетського врядування у Великій Британії, можуть використовуватися при розробленні політик і процедур в університетах України. 


\section{Модель дослідницького врядування в університеті}

Соціальний запит на підвищення рівня та оптимізацію результатів наукової діяльності університетів актуалізує пошук сучасних механізмів управління дослідницькою діяльністю в системі університетського врядування університетах. Актуальність імплементації парадигми врядування у вищій освіті підкреслено як в проаналізованих раніше документах Європейського простору вищої освіти, так і в наукових працях вітчизняних і зарубіжних дослідників. Здійснений аналіз особливостей теоретичних основ парадигми "врядування», визначення сутності дослідницького врядування, а також аналіз досвіду провідних європейських та вітчизняних університетів щодо його реалізації дав змогу запропонувати модель дослідницького врядування (рис. 1).

Як зазначалося раніше, реалізація дослідницького врядування має здійснюватися на засадах визначених цінностей, до яких нами віднесено наступні: довіра, партнерство, широка залученість, відкритість, nрозорість. Ці цінності узгоджуються із ключовими цінностями Європейського простору вищої освіти академічною свободою, інституційною автономією закладів вищої освіти, повагою до верховенства права у відносинах між громадськістю і владою.

Проведений аналіз наукових праць та особливостей дослідницького врядування у провідних університетах Великої Британії 457 дав змогу виокремити основні принципи його реалізації:

- принцип доброчесності: дотримання дослідниками етичних вимог при проведенні досліджень 3 метою забезпечення довіри до їх результатів;

- принцип відповідальності: забезпечення відповідності досліджень укладеним угодам і термінам, підзвітність професійним органам у галузі досліджень;

- принцип моніторингу: систематичне оцінювання результатів дослідження для проведення поточного аналізу та спрямування процесу на досягнення мети;

- принцип відкритості: інформування та широке залучення громадськості до нагляду за результатами досліджень;

- принцип співробітництва: сприяння відкритому обміну ідеями, методами досліджень, даними та результатами обстеження з іншими дослідниками та інституціями;

- принцип неперервного розвитку дослідників: забезпечення можливостей для розвитку дослідників для проведення досконалих дослідження.

Дослідницьке врядування передбачає розроблення та впровадження політик і процедур щодо створення середовища, в якому дотримуються високих наукових та етичних стандартів при виконанні досліджень. Інституційна політика має реалізовуватися через чітко визначені прочедури за наступними напрямами:

- планування та проведення досліджень на всіх етапах;

- права та обов'язки всіх учасників досліджень;

- збирання та зберігання даних;

- моніторинг та аудит, експертний огляд на всіх етапах дослідження;

- ідентифікація конфліктів інтересів при проведенні досліджень;

- охорона здоров'я та безпека;

- забезпечення дослідницької доброчесності;

- захист прав інтелектуальної власності;

- особливості проведення досліджень за участі людей і тварин, використання людських матеріалів, особистих даних людини;

- вимоги до дослідників; фінансування досліджень.

457 Драч І. І. Досвід управління дослідницькою діяльністю в університетах Великої Британії: філософсько-аналітичний підхід. Університет і лідерство. № 5. 2018. С. 13-25._URL: https://ul-journal.org/index.php/journal/issue/view/5. 


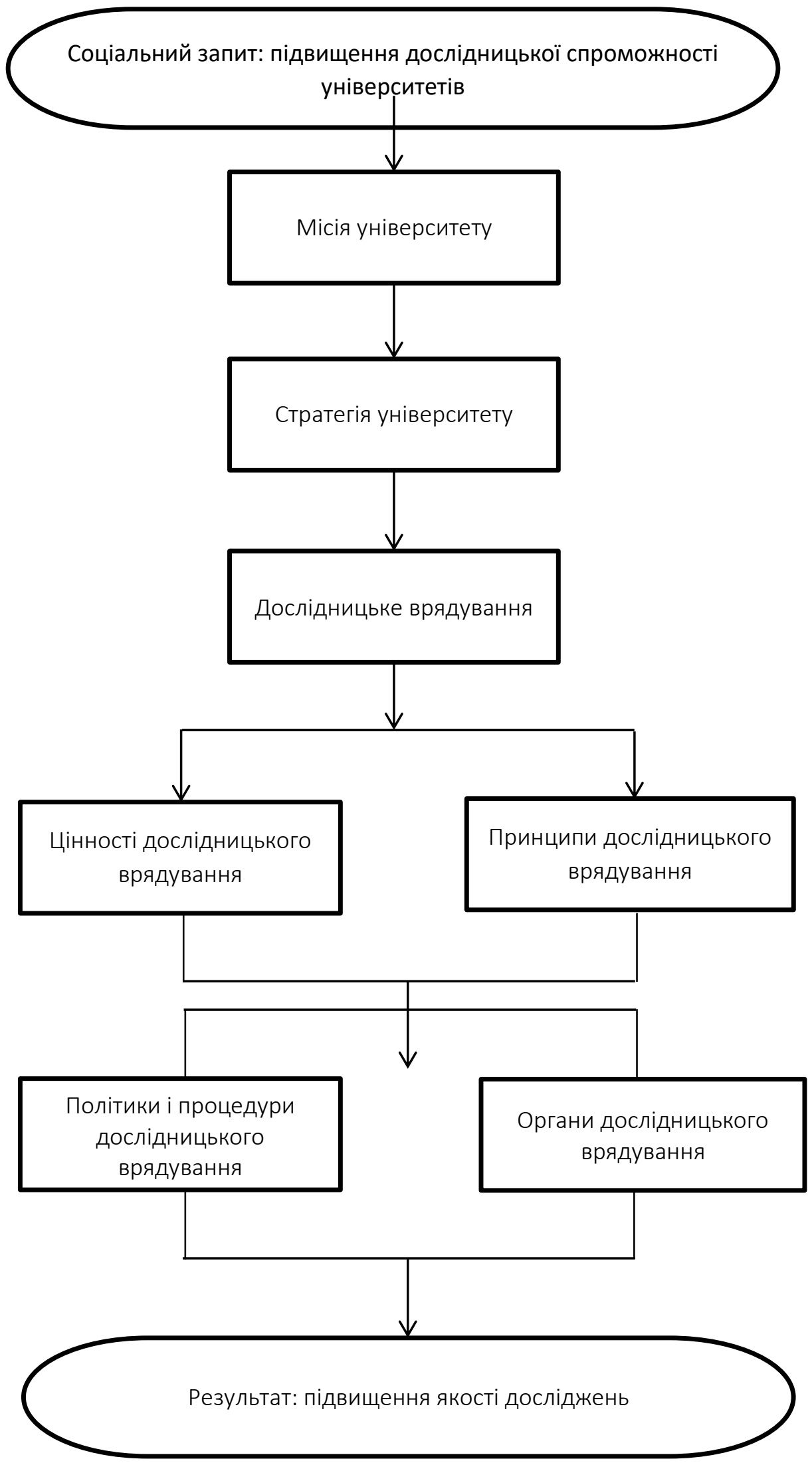

Рис.1. Модель дослідницького врядування в університетах 
Здійснений аналіз досвіду університетів Великої Британії та України щодо механізмів реалізації інституційних політик і процедур дослідницького врядування дав змогу зробити висновок щодо доцільності розроблення та використання наступних документів: «Кодексу проведення досліджень» та «Рамки дослідницького врядування» ${ }^{558}$.

«Кодекс проведення досліджень» має виконувати функцію стандарту досліджень. У зазначеному документі доцільно передбачити опис процедур щодо:

- збирання та зберігання даних;

- моніторингу та аудиту із залученням стейкхолдерів на всіх етапах дослідження;

- ідентифікації конфліктів інтересів при проведенні досліджень;

- захисту інтелектуальної власності;

- особливостей проведення досліджень за участі людей і тварин;

- використання людських матеріалів, особистих даних людини.

«Рамка дослідницького врядування» має містити опис політики та процедур щодо:

- визначення дизайну та методології дослідження;

- дотримання високих стандартів дослідницької доброчесності;

- безпеки та здоров'я учасників дослідження;

- інформаційного менеджменту дослідження;

- фінансового забезпечення дослідження;

- вимог до дослідників.

Важливою характеристикою інституційних політик дослідницького врядування має стати прозорість та відкритість щодо дотримання етичних принципів при проведенні досліджень, що передбачає:

- обов'язковість наявності контактів всіх осіб, залучених до ії реалізації;

- оприлюднення рішень етичних комісій;

- публічність інформування про порушення політики дослідницької доброчесності.

Політики і процедури формування культури дослідницької доброчесності в університетському середовищі мають бути орієнтовані на:

- широке залучення членів університетської спільноти до цього процесу;

- здійснення щорічного самооцінювання стану забезпечення дослідницької доброчесності в університеті;

- забезпечення можливостей для систематичного навчання та наявність загальнодоступних навчальних матеріалів для учасників досліджень, отримання ними кваліфікованих консультацій для уникнення можливих порушень при проведенні досліджень.

Проведений аналіз моделей врядування в сучасних європейських університетах дав змогу зробити висновок щодо актуальності використання в управлінні закладами вищої освіти, зокрема і в управлінні дослідженнями, дуальної моделі.

458 Драч І. Управління дослідницькою діяльністю в системі університетського врядування: методичні рекомендації. Механізми реалізації ефективного врядування в університетах України в умовах євроінтеграції : методичні рекомендації / І. Драч, С. Калашнікова, О. Паламарчук, В. Рябченко, Л. Червона; за ред. С. Калашнікової. Київ : Інститут вищої освіти HAПн України, 2019. 93 с. URL: https://ihed.org.ua/wp-content/uploads/2020/07/Mekhanizmy vriaduvania univ UA metodychni IVO-2019-93p avtors-kolektiv.pdf. 
Ключовими органами дослідницького врядування у вітчизняних університетах мають стати Вчена рада та Наглядова рада університету.

Вчена рада відповідно до Закону «Про вищу освіту» $є$ колегіальним органом управління закладу вищої освіти і визначає стратегію і перспективні напрями розвитку освітньої, наукової та інноваційної діяльності закладу вищої освіти. Перед цим органом мають звітувати, зокрема, структурні підрозділи університету, до повноважень яких належить координація роботи з досліджень та інновацій.

Наглядова рада закладу вищої освіти має сприяти «розв'язанню перспективних завдань його розвитку, залученню фінансових ресурсів для забезпечення його діяльності з основних напрямів розвитку і здійснення контролю за їх використанням, ефективній взаємодії закладу вищої освіти з державними органами та органами місцевого самоврядування, науковою громадськістю, суспільно-політичними організаціями та суб'єктами господарської діяльності в інтересах розвитку та підвищення якості освітньої діяльності і конкурентоспроможності закладу вищої освіти» (ст. 36, 37). Таким чином, Наглядова рада закладу вищої освіти покликана здійснювати громадський контроль за його діяльністю, зокрема, і за дослідницькою.

Результатом впровадження моделі дослідницького врядування має стати підвищення якості досліджень в університеті. 


\section{Висновки}

1. Аналіз документів Європейського простору вищої освіти та наукових праць, присвячених проблемам управління у вищій освіті, дає змогу зробити висновок, що ключовим фактором підвищення ефективності діяльності сучасного університету є врядування, яке має забезпечувати як продуктивні відносини з державними органами влади, так і вибір адекватних моделей внутрішнього управління. Європейський вибір України, приєднання вітчизняної системи вищої освіти до Європейського простору вищої освіти зумовлюють актуальність імплементації парадигми врядування у вітчизняній системі вищої освіти.

2. Узагальнення результатів проведеного аналізу сутності врядування, його взаємозв'язку 3 ефективністю та результативністю управлінської діяльності в університеті дала змогу визначити ключові характеристики врядування:

- зв'язок з ключовими цінностями Європейського простору вищої освіти та Європейського дослідницького простору;

- взаємозв'язок із здатністю університету виконувати свою місію;

- багаторівневість, багатоакторність, багатосекторність та багатопроцедурність;

- баланс між самостійністю та підзвітністю, довірою і контролем, ефективністю та якістю;

- прозорість прийняття рішень;

- гнучкість організаційних структур.

3. В європейських системах вищої освіти реалізуються два види основних моделей врядування: унітарні (unitary governance models) та дуальні (dual governance models). До університетського врядування залучаються як внутрішні (академічний та неакадемічний персонал, студенти), так і зовнішні стейкхолдери. Важливим в інституційних моделях врядування $€$ досягнення балансу між широкою залученістю до управління різноманітної спільноти та розвитком структур і процесів, які підтримують ефективне прийняття рішень, і таким чином забезпечують гнучкого управління.

4. Розгляд особливостей врядування дозволив екстраполювати розуміння його сутності на управління дослідницькою діяльністю в університетах та запропонувати визначення поняття «дослідницьке врядування в університеті».

Дослідницьке врядування в університеті ми розглядаємо як управління дослідницькою діяльністю, спрямоване на забезпечення досконалості досліджень шляхом:

- розроблення стратегії проведення досліджень із чіткім визначенням цілей, пріоритетів та механізмів; впровадження внутрішньої політики щодо створення середовища, в якому дотримуються високих наукових та етичних стандартів при виконанні досліджень; широкого залучення зовнішніх і внутрішніх стейкхолдерів; забезпечення моніторингу ефективності досліджень та широкого доступу громадськості до нагляду за їх результатами; прозорості управлінських рішень.

Дослідницьке врядування реалізується на основі балансу між самостійністю та підзвітністю, довірою і контролем, ефективністю та якістю.

5. Цінностями дослідницького врядування $€$ довіра, партнерство, широка залученість, відкритість, прозорість.

6. Основними принципами реалізації дослідницького врядування нами виділено наступні:

- принцип доброчесності: дотримання дослідниками етичних вимог при проведенні досліджень з метою забезпечення довіри до їх результатів;

- принцип відповідальності: забезпечення відповідності досліджень укладеним угодам і термінам, підзвітність професійним органам у галузі досліджень; 
- принцип моніторингу: систематичне оцінювання результатів дослідження для проведення поточного аналізу та спрямування процесу на досягнення мети;

- принцип відкритості: інформування та широке залучення громадськості до нагляду за результатами досліджень;

- принцип співробітництва: сприяння відкритому обміну ідеями, методами досліджень, даними та результатами обстеження з іншими дослідниками та інституціями;

- принцип неперервного розвитку дослідників: забезпечення можливостей для розвитку дослідників для проведення досконалих дослідження.

7. Проведений аналіз досвіду реалізації дослідницького врядування у провідних університетах Великої Британії - University of Oxford, University of Cambridge, Imperial College London - показав, що дослідницьке врядування вимагає досягнення ключових стандартів у наступних сферах:

- етика: забезпечення гідності, прав, безпеки та добробуту учасників дослідження;

- наука: забезпечення тематики проектування, методів та проведення досліджень на підставі незалежного огляду експертів у відповідній сфері;

- інформація: забезпечення ефективного розповсюдження результатів досліджень та повного доступу громадськості до інформації щодо дослідження та його висновків;

- охорона здоров'я та безпека: гарантування захисту безпеки учасників дослідження у будь-який час; найважливішим є також турбота про навколишнє середовище при проведенні досліджень;

- правові питання: забезпечення відповідності законодавству при проведенні досліджень;

- фінанси: забезпечення фінансової справедливості;

- академічна доброчесність: запобігання шахрайству та зловживанню в дослідженнях.

8. Одним з важливих завдань дослідницького врядування $\epsilon$ забезпечення дослідницької доброчесності як основної цінності дослідницької культури та діяльності. У формуванні культури дослідницької доброчесності в університетах актуальною є підтримка цього процесу на національному рівні.

Для підтвердження зазначеної тези проаналізовано досвід Великій Британії, де вагому роль у системі забезпечення дослідницької доброчесності в університетському середовищі відіграє Офіс дослідницької доброчесності. Увага до системи управління дослідницькою діяльністю в університетах Великої Британії зумовлена їх високими позиціями в міжнародних університетських рейтингах, які грунтуються, зокрема, і на високій якості університетських досліджень цієї країни. Детально охарактеризовані основні положення ключових документів Офісу дослідницької доброчесності Великої Британії, які на національному рівні забезпечують підтримку дослідницької доброчесності в системі університетського врядування, можуть використовуватися при розробленні відповідних політик і процедур в університетах України.

9. Здійснений аналіз особливостей теоретичних основ парадигми врядування, визначення сутності дослідницького врядування, а також аналіз досвіду провідних європейських університетів щодо його реалізації дав змогу запропонувати модель дослідницького врядування, в якій представлено складові дослідницького врядування та їх взаємозв'язки. 
1. Драч І. Управління дослідницькою діяльністю в системі університетського врядування: методичні рекомендації. Механізми реалізації ефективного врядування в університетах України в умовах євроінтеграції : методичні рекомендації / І. Драч, С. Калашнікова, О. Паламарчук, В. Рябченко, Л. Червона; за ред. С. Калашнікової. Київ : Інститут вищої освіти НАПН України, 2019. - 93 с. URL: https://ihed.org.ua/wpcontent/uploads/2020/07/Mekhanizmy vriaduvania univ UA metodychni IVO-2019-93p avtors-kolektiv.pdf.

2. Драч І. І. (2018). Управління дослідницькою діяльністю в системі університетського врядування: характеристика та закономірності. Вища освіта України, № 3 (70), 60-65.

3. Драч І. І. Досвід управління дослідницькою діяльністю в університетах Великої Британії: філософськоаналітичний підхід. Університет і лідерство. № 5. 2018. С. 13-25. URL: https://uljournal.org/index.php/journal/issue/view/5.

4. Драч І. І. Підтримка дослідницької доброчесності в системі університетського врядування: досвід Великої Британії. Університет і лідерство. № 7. 2019. URL: https://ul-journal.org/index.php/journal/issue/view/7.

5. Драч І. І. Філософський аналіз практики дослідницького врядування в університетах Великої Британії. Університет і лідерство. № 6. 2018. C. 45-57. URL: https://ul-journal.org/index.php/journal/issue/view/6.

6. Драч І. Управління дослідницькою діяльністю в системі університетського врядування: теоретичні основи. Аналіз провідного вітчизняного та зарубіжного досвіду розвитку щодо механізмів реалізації ефективного врядування в університетах: препринт (аналітичні матеріали) (частина I) / Авторський колектив: І. Драч, С. Калашнікова, О. Паламарчук, В. Рябченко, Л. Червона; за заг. ред. С. Калашнікової. Київ: Інститут вищої освіти НАПН України, 2018. - 147 с. - URL: https://ihed.org.ua/wpcontent/uploads/2019/09/Analiz dosvidu vriaduvania v univer ch1 analit IVO-2018-147p avtorskolektiv.pdf.

7. Драч І. Управління дослідницькою діяльністю в системі університетського врядування: аналіз провідного вітчизняного та зарубіжного досвіду. Аналіз провідного вітчизняного та зарубіжного досвіду щодо механізмів реалізації ефективного врядування в університетах: препринт (аналітичні матеріали) (частина II) / Авторський колектив: І. Драч, О. Паламарчук, В. Рябченко, Л. Червона; за заг. ред. С. Калашнікової. Київ: Інститут вищої освіти НАПН України, 2019. - С. 38. URL: https://ihed.org.ua/wpcontent/uploads/2020/04/Analiz dosvidu vriaduvania v univer ch2 analit IVO-2019-96p avtorskolektiv.pdf.

8. Європейська хартія дослідників URL: http://h2020.com.ua/wp-content/uploads/2015/11/Book.pdf. C. 8.

9. Заключний звіт незалежного європейського аудиту національної системи досліджень та інновацій України. Iнструмент політичної підтримки програми «Горизонт 2020». URL: https://publications.europa.eu/en/web/eu-law-and-publications/publication-detail/-/publication/adb1f077dedc-11e6-ad7c-01aa75ed71a1/language-uk.

10. Закон України «Про вищу освіту». URL: https://zakon.help/law/1556-VII/.

11. Закон України «Про наукову та науково-технічну діяльність». URL: https://zakon.rada.gov.ua/laws/show/84819\#Text.

12. Закон України «Про освіту». URL: https://zakon.rada.gov.ua/laws/show/2145-19\#Text.

13. Бабак С. Майбутнє університетів. Частина 1. Еволюція університетів: на порозі невідомого майбутнього. IнT майбутнього. Київ, 2018. С. 105. URL: https://www.uifuture.org/publications/reports/24475maybutnie/universytetiv. C.8.

14. Огляди ОЕСР на тему доброчесності в освіті: Україна 2017. Інститут розвитку освіти. К.: Таксон. 2017. 184 с. URL: http://iro.org.ua/uploads/OECDrev ua K+P293 out2 (1).pdf.

15. Середньостроковий план пріоритетних дій Уряду до 2020 року. URL: https://www.kmu.gov.ua/ua/diyalnist/programa-diyalnosti-uryadu/serednostrokovij-plan-prioritetnih-dijuryadu-do-2020-roku-ta-plan-prioritetnih-dij-uryadu-na-2017-rik.

16. Academic Freedom at the University of Copenhagen. URL: https://research.ku.dk/integrity/documents/academic freedom at the university of copenhagen.pdf. 
17. Academic integrity in research: code of practice and procedure. URL: https://hr.admin.ox.ac.uk/academicintegrity-in-research.

18. Academic Ranking of World Universities 2019. URL: http://www.shanghairanking.com/arwu2019.html.

19. Aghion P., Dewatripont M., Hoxby C., Mas-Colell A. The Governance and Performance of Research Universities: Evidence from Europe and the U.S., 2009. URL: http://www.nber.org/papers/w14851.

20. Austin, I., \& Jones, G. (2016). Governance of Higher Education: Global Perspectives, Theories, and Practices. New York, NY: Routledge. Pages: 218. ISBN: 978- 0415739757 (paperback). Canadian Journal of Educational Administration and Policy, 182, 59-61. URL: https://www.taylorfrancis.com/books/9781315816401.

21. Biermann F., Stevens C., Bernstein S., Gupta A., Kabiri N., Kanie N., Levy M., Nilsson M., Pintér L., Scobie M., Young $O$. Integrating Governance into the Sustainable Development Goals. URL: https://collections.unu.edu/eserv/UNU:1825/Post2015 UNU-IAS PolicyBrief3.pdf.

22. Bribery and fraud. URL: https://compliance.admin.ox.ac.uk/bribery-and-fraud.

23. Central European University. URL: https://www.ceu.edu/.

24. Code of Conduct Responsible Research. URL: https://research.ku.dk/integrity/documents/code of conduct for responsible research 2018 .pdf.

25. Code of Practice for Research. URL: https://ukrio.org/wp-content/uploads/UKRIO-Code-of-Practice-forResearch.pdf.

26. Code for public sector collaboration. URL: https://research.ku.dk/integrity/code-of-conduct/.

27. Code of good scientific practice in research collaborations with external partners.

URL: https://research.ku.dk/integrity/documents/ucph code of good scientific practice in research collaboratio ns 2016 .pdf.

28. Concordat to support research integrity. URL: https://www.universitiesuk.ac.uk/policy-andanalysis/reports/Documents/2019/the-concordat-to-support-research-integrity.pdf.

29. Council Recommendation on Common values, Inclusive Education and the European Dimension of Teaching. URL: https://eur-lex.europa.eu/legal-content/EN/TXT/PDF/?uri=CELEX:32018H0607(01)\&from=

30. Danish Code of Conduct for Research Integrity. URL: http://eneri.eu/wp-content/uploads/2018/10/The-danishcode-of-conduct-for-research-integrity-pub.pdf.

31. Data protection policy. URL: https://compliance.admin.ox.ac.uk/data-protection-policy.

32. De Boer, H., Enders, J., \& Schimank, U. (2007). On the way towards new public management? The governance of university systems in England, the Netherlands, Austria, and Germany. New forms of governance in research organizations (pp. 137-152). Springer. URL: https://link.springer.com/chapter/10.1007/978-1-4020-5831-8 5.

33. Efficiency, Effectiveness and Value for Money at Universities. A USTREAM report. URL: https://eua.eu/downloads/publications/efficiency\%20effectiveness\%20and\%20value\%20for\%20money.pdf.

34. Erasmus+ Programme of the European Union. URL: https://ec.europa.eu/programmes/erasmus-plus/node en.

35. European code of conduct for research integrity - ALLEA European Federation of Academies of Science and Humanities. URL: https://ec.europa.eu/research/participants/data/ref/h2020/other/hi/h2020-ethics code-ofconduct en.pdf.

36. European Higher Education Area: The Impact of Past and Future Policies. URL: https://link.springer.com/book/10.1007/978-3-319-77407-7.

37. European University Association URL: https://eua.eu/.

38. External policy and guidance. URL: https://researchsupport.admin.ox.ac.uk/governance/integrity/policy.

39. Field. URL: https://safety.admin.ox.ac.uk/fieldwork.

40. Global code of conduct for research in resource-poor settings. URL: https://ec.europa.eu/research/participants/data/ref/h2020/other/hi/coc research-resource-poorsettings en.pdf.

41. Guidelines for publication for employees. URL: https://research.ku.dk/integrity/documents/guidelines for publication.pdf.

42. Health and safety policy. URL: https://safety.admin.ox.ac.uk/health-and-safety-policy.

43. Higher Education Funding Council for England. URL: https://www.gov.uk/government/organisations/highereducation-funding-council-for-england. 
44. Higher Education Governance in Europe. Policies, structures, funding and academic staff / Brussels: Euridice, 2008. P. 12.

45. Imperial College London. URL: https://www.imperial.ac.uk.

46. Irish Universities Association. URL: https://www.iua.ie/.

47. Kennedy K. Higher Education Governance as a Key Policy Issue in the 21st Century. URL: https://link.springer.com/content/pdf/10.1023/A:1024468018883.pdf. P. 57.

48. Kezar. A. What is more important to effective governance: Relationships, trust, and leadership, or structures and formal

processes?».

URL:

https://www.researchgate.net/publication/227876520 What Is More Important to Effective Governance Relationships Trust and Leadership_or Structures and Formal Processes.

49. Mashaah T., Hakim J., Chidzonga M., Kangwende R., Naik Y., Federspiel N., Fiorillo S., Scott J., Gomo E. Strengthening Research Governance for Sustainable Research: Experiences from Three Zimbabwean Universities. URL: https://www.ncbi.nlm.nih.gov/pmc/articles/PMC4116635/.

50. Ministry of Science, Innovation and Higher Education. URL: https://ufm.dk/en/the-ministry/organisation/theministry.

51. Montreal statement on research integrity in cross-boundary research collaborations - developed at the 3rd World Conference on Research Integrity. URL: https://wcrif.org/montreal-statement/file.

52. Office for student. URL: https://www.officeforstudents.org.uk/.

53. Paquet G. (1998). Governance and Social Cohesion: Survivability in the 2lst Century. Paper delivered at the Symposium of the Royal Society of Canada on the theme, Human Survivability in the 21st Century at the Chateau Laurier, Ottawa, November. URL: http://www.gouvernance.ca/publications/99-05.pdf.

54. Planning and Resource Allocation Committee. URL: https://governance.admin.ox.ac.uk/planning-and-resourceallocation-committee.

55. Policy on data. research URL: https://research.ku.dk/integrity/documents/university of copenhagen s policy on research data.pdf.

56. Procedure for the investigation of misconduct in research. URL: https://ukrio.org/wp-content/uploads/UKRIOProcedure-for-the-Investigation-of-Misconduct-in-Research.pdf.

57. Pruvot E., Estermann T. University Governance: Autonomy, Structures and Inclusiveness». URL: https://link.springer.com/chapter/10.1007/978-3-319-77407-7 37/.

58. Public interest disclosure (whistle-blowing): code of practice. URL: https://hr.admin.ox.ac.uk/public-interestdisclosure-whistle-blowing-code-of-practice.

59. QS World University Rankings. URL: https://www.topuniversities.com/university-rankings/world-universityrankings/2019.

60. Research integrity and ethics policy. URL: https://researchsupport.admin.ox.ac.uk/governance/integrity/policy.

61. Review of the Education Sector in Ukraine. Moving towards Effectiveness, Equity and Efficiency (RESUME3). Overview. World Bank Group. http://documents.worldbank.org/curated/en/360951568662377063/pdf/Overview.pdf/.

62. Rigour, respect and responsibility: a universal ethical code for scientists - Government Office for Science. URL: https://assets.publishing.service.gov.uk/government/uploads/system/uploads/attachment data/file/283157/u niversal-ethical-code-scientists.pdf.

63. Safeguarding 'at risk' adults and children. URL: https://hr.admin.ox.ac.uk/safeguarding-at-risk-adults-andchildren.

64. Self-Assessment Tool for The Concordat to Support Research Integrity. URL: https://ukrio.org/self-assessmenttool-concordat-support-research-integrity/.

65. Singapore statement on research integrity - developed at the 2ndWorld Conference on Research Integrity. URL: https://www.jsps.go.jp/english/e-kousei/data/singapore statement EN.pdf.

66. Statement of policy and procedure on conflict of interest. URL: https://researchsupport.admin.ox.ac.uk/governance/integrity/conflict/policy.

67. Statute XVI: Property, Contracts, and Trust. URL: https://governance.admin.ox.ac.uk/legislation/statute-xviproperty-contracts-and-trusts\# Toc28143157. 
68. Talent and collaboration. Strategy 2023. URL: https://about.ku.dk/strategy2023/downloadpdf/strategy 2023 UK_print.pdf.

69. The concordat to support research integrity a progress report. URL: https://www.universitiesuk.ac.uk/policyand-analysis/reports/Pages/concordat-research-integrity-progress-report.aspx.

70. The concordat to support research integrity. URL: https://www.universitiesuk.ac.uk/policy-andanalysis/reports/Documents/2012/the-concordat-to-support-research-integrity.pdf

71. The concordat to support research integrity. URL: https://www.universitiesuk.ac.uk/policy-andanalysis/reports/Documents/2012/the-concordat-to-support-research-integrity.pdf.

72. The European Higher Education Area in 2018. Bologna Process Implementation Report. URL: https://eacea.ec.europa.eu/national-policies/eurydice/content/european-higher-education-area-2018-

bologna-process-implementation-report en.

73. The University of Oxford's Code of practice and procedure on academic integrity in research. URL: https://hr.admin.ox.ac.uk/academic-integrity-in-research\#collapse1310981.

74. Times Higher Education World University Rankings. URL: https://www.timeshighereducation.com/worlduniversity-rankings/2019/world-ranking\#!/page/0/length/25/sort by/rank/sort order/asc/cols/stats.

75. UK Research Integrity Office. URL: https://ukrio.org.

76. UKRI policy and guidelines on governance of good research conduct. URL: https://www.ukri.org/files/legacy/reviews/grc/rcuk-grp-policy-and-guidelines-updated-apr-17-2-pdf/.

77. Universities for Strategic, Efficient and Autonomous Management. URL: https://www.ceu.edu/project/universities-strategic-efficient-and-autonomous-management-0.

78. Universities UK. URL: https://www.universitiesuk.ac.uk/.

79. University Information Security Policy and Implementation Guidance. URL: https://infosec.ox.ac.uk/guidancepolicy.

80. University of Cambridge. URL: https://www.cam.ac.uk.

81. University of Copenhagen $\quad$ C Code for Authorship.

https://research.ku.dk/integrity/documents/code for authorship.pdf.

82. University of Copenhagen. Board. URL: https://about.ku.dk/management/board/.

83. University of Copenhagen. Research and Innovation Council. URL: https://fi.ku.dk/english/kufir/.

84. University of Copenhagen. Research Assessment. URL: https://research.ku.dk/excellence/evalueringer/.

85. University of Copenhagen. Research. Excellence. URL: https://research.ku.dk/excellence/.

86. University of Copenhagen. URL: https://about.ku.dk/management/board/.

87. University of Oxford Policy on the management of data supporting research outputs. URL: https://researchdata.ox.ac.uk/university-of-oxford-policy-on-the-management-of-data-supporting-researchoutputs/.

88. University of Oxford. Congregation. URL: https://governance.admin.ox.ac.uk/congregation.

89. University of Oxford. Council. URL: https://governance.admin.ox.ac.uk/council/home.

90. University of Oxford. Education Committee. URL: https://academic.admin.ox.ac.uk/committees-and-panels.

91. University of Oxford. General Purposes Committee. URL: https://governance.admin.ox.ac.uk/general-purposescommittee.

92. University of Oxford. Personnel Committee. URL: https://hr.admin.ox.ac.uk/hr-governance

93. University of Oxford. Research \& Innovation Committee. URL: https://researchsupport.admin.ox.ac.uk/ric

94. University of Oxford. Research and Innovation Committee. Standing Order. URL: https://researchsupport.admin.ox.ac.uk/ric. P.6.

95. University of Oxford. URL: http://www.ox.ac.uk.

96. University of Oxford. Governance. URL: https://www.ox.ac.uk/about/organisation/governance?wssl=1.

97. University Policy on the Use of Animals in Scientific Research. URL: https://www.ox.ac.uk/news-andevents/animal-research/university-policy-on-the-use-of-animals-in-scientific-research.

98. Working Groups and Steering Committees. URL: https://eua.eu/about/working-groups.html.

99. World Bank. (2012). Benchmarking the governance of tertiary education systems. Washington: World Bank. A Fiszbein, D Ringold - World Bank Group, Washington. $2012 . \quad$ URL: 
https://documents.worldbank.org/en/publication/documents-

reports/documentdetail/423481468272040065/benchmarking-the-governance-of-tertiary-education-systems.

100. Yasamy M., Maulik P., Tomlinson M., Lund C., Van Ommeren M., Saxena S. Responsible governance for mental

health research in low resource countries. URL:

http://journals.plos.org/plosmedicine/article?id=10.1371/journal.pmed. 


\title{
Розділ 4. Роль студентської спільноти у забезпеченні ефективного університетського врядування
}

\author{
Леся Червона, \\ кандидат філософських наук, \\ старший науковий співробітник, \\ провідний науковий співробітник \\ Відділу лідерства та інституційного розвитку вищої освіти, \\ Інститут вищої освіти НАПН України \\ https://orcid.org/0000-0002-3036-3668
}

Анотація

Розділ присвячено аналізу участі студентів у забезпеченні ефективного університетського врядування. Важливість залучення студентів як рівноправних партнерів до процесів реформування вищої освіти, зокрема до участі у структурах врядування, актуалізується у низці європейських документів, спрямованих на побудову Європейського простору вищої освіти (ЄПВО), що стало відправною точкою для розгортання дослідження. На основі аналізу наукових джерел обгрунтовано теоретичні засади участі студентів в університетському врядуванні, а саме демократичні ідеї, що складають основу для побудови моделі ефективного врядування в сучасних університетах. Теоретичним підірунтям для забезпечення участі студентів в університетському врядуванні, на наш погляд, є теорія учасницької (партисипаторної) демократії, що виконує функцію універсального принципу організації університету як соціальної системи. Широка суспільна партисипація полягає у свідомій, активній участі всіх зацікавлених сторін (у тому числі і студентів) у процесах формування, вироблення та реалізації управлінських рішень. Важливим етапом дослідження стало концептуальне уточнення ключових понять: «університет», «врядування», «участь» «залучення студентів» та «голос студентів». Аналіз структур управління провідних європейських та українських університетів дав підстави виділити основні механізми та інструменти для забезпечення студентської участі в університетському врядуванні: студентське представництво; зворотний зв'язок зі студентами; угода про партнерські відносини та політика студентського голосу. Проаналізована розробка шотландських колег «Student partnership staircase» (Сходинки студентського партнерства) дала можливість виокремити варіативність ролей, які може виконувати студентська спільнота у забезпеченні ефективного університетського врядування від найнижчої сходинки «постачальника інформації», до найвищої сходинки - «партнера». 


\section{Актуальність проблеми дослідження}

Потенціал участі студентської спільноти у забезпечення ефективного університетського врядування $\epsilon$ темою, яка все більше досліджується ${ }^{459}$, теоретизується та обговорюється науковою спільнотою не лише в Україні, а й в усьому світі. Україна, інтегруючись до Європейського освітнього простору, реформує вищу освіту відповідно до цілей і завдань Болонського процесу, де студентство розглядається в якості партнера у процесах реформування вищої освіти, зокрема в частині залучення до структур врядування. Саме цей аспект підкреслюється і у низці європейських документів, спрямованих на побудову Європейського простору вищої освіти (ЄПВО).

\section{Prague Communiqué 460}

На міністерській зустрічі у Празі (2001р.) участь студентів у реформуванні вищої освіти вперше визначається як пріоритет Болонського процесу. Міністрами засвідчено, що студенти мають брати участь і впливати на організацію і зміст освіти в університетах: «... студенти $є$ повноправними членами спільноти вищої

освіти» ${ }^{461}$. Крім того, студентів було визнано як «компетентних, активних і конструктивних партнерів» у процесі створення та формування ЄПВО.

\section{Berlin Communiqué 462}

Берлінське комюніке (2003р.) підтвердило первинну роль закладів вищої освіти та студентських організацій у процесі творення Європейського простору вищої освіти: «Міністри підтримують участь закладів вищої освіти та студентства у Болонському процесі і вважають, що лише активна участь усіх партнерів у процесі може забезпечити його довгостроковий успіх. ... Міністри відзначають конструктивну участь студентських спілок у Болонському процесі та наголошують на потребі залучати студентство до подальших дій. Студентство - повноправний партнер в управлінні вищою освітою. Міністри закликають університети і студентство до активнішої участі в управлінні вищою освітою» ${ }^{463}$.

\footnotetext{
459 у даному розділі представлені узагальненні результати трьохрічного дослідження ролі студентської спільноти у забезпеченні ефективного університетського врядування, що проводилась в межах наукової теми відділу лідерства та інституційного розвитку вищої освіти Інституту вищої освіти НАПН України «Механізми реалізації ефективного врядування в університетах України в умовах євроінтеграції» і використано апробовані розробки з авторських препринтів, зокрема: Червона Л. Роль студентської спільноти у забезпеченні ефективного університетського врядування: теоретичні основи. Аналіз провідного вітчизняного та зарубіжного досвіду розвитку щодо механізмів реалізації ефективного врядування в університетах: препринт (аналітичні матеріали) (частина I). Київ: Інститут вищої освіти НАПН України, $2018 . \quad$ C. 76-100 URL: https://ihed.org.ua/wpcontent/uploads/2019/09/Analiz dosvidu vriaduvania_v univer ch1_analit IVO-2018-147p_avtors-kolektiv.pdf ; Червона Л. Роль студентської спільноти у забезпеченні ефективного університетського врядування: аналіз вітчизняних та зарубіжних практик. Аналіз провідного вітчизняного та зарубіжного досвіду розвитку щодо механізмів реалізації ефективного врядування в університетах: препринт (аналітичні матеріали) (частина ІІ). Київ: Інститут вищої освіти НАПН України, 2019. C. 70-94 https://ihed.org.ua/wpcontent/uploads/2020/04/Analiz_dosvidu_vriaduvania_v_univer_ch2_analit_IVO-2019-96p_avtors-kolektiv.pdf ; Червона Л. Роль студентської спільноти у забезпеченні ефективного університетського врядування: методичні рекомендації. Механізми реалізації ефективного врядування в університетах України в умовах євроінтеграції: методичні рекомендації. Київ: Інститут вищої освіти НАПН України, 2019. С. 76-93 URL: https://ihed.org.ua/wp-content/uploads/2020/07/Mekhanizmy vriaduvania univ UA metodychni IVO-201993p avtors-kolektiv.pdf.

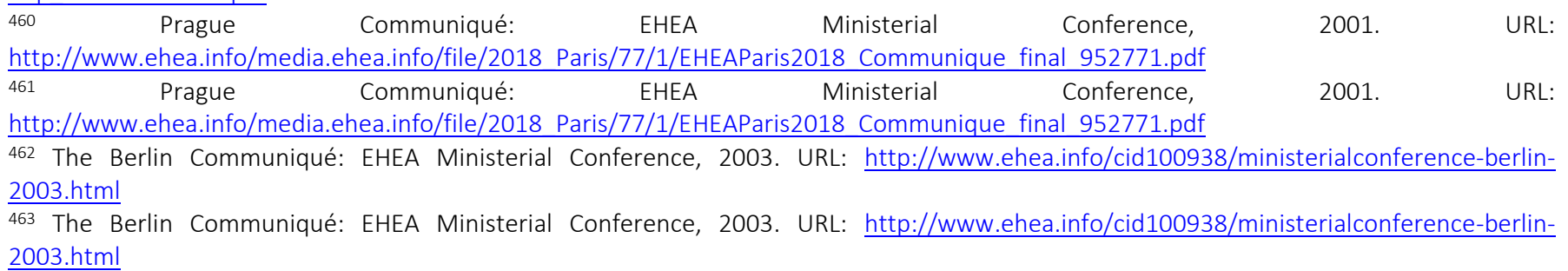
2003.html
} 


\section{Bergen Communiqué 464}

У Бергенському комюніке (2005 р.) наголошується, що критичною є: «...центральна роль закладів вищої освіти, їх співробітників та студентів як партнерів у Болонському процесі. їх роль у реалізації процесу стає більш значущою на етапі, коли значною мірою реалізовані законодавчі реформи; ми закликаємо їх продовжувати і підсилювати діяльність із створення європейського простору вищої освіти» 465.

\section{Leuven Communiqué 466}

У Льовенському комюніке (2009р.) підкреслюється: «...У реформи систем вищої освіти і політики, що проводяться, будуть, як і раніше, включені європейські цінності інституційної автономії, академічна свобода та соціальна справедливість, і це вимагатиме повної участі студентів і персоналу» ${ }^{467}$.

\section{Budapest-Vienna Declaration on the European Higher Education Area 468}

У Будапештсько-Віденській декларації (2011р.) акцентується: «Ми зобов'язуємося працювати над більшим залученням працівників вищої освіти та студентів до запровадження і подальшого розвитку Європейського простору вищої освіти. Ми повністю підтримуємо участь працівників закладів вищої освіти та студентів у структурах, що приймають рішення, на європейському, національному та інституційному рівнях» ${ }^{469}$.

\section{Bucharest Communiqué 470}

У Бухарестському комюніке (2012р.) серед пріоритетів діяльності Європейського простору вищої освіти до 2015 року віднесено наступний: «Створити умови, що сприяють студентоцентрованому навчанню, інноваційним методам викладання та сприятливому робочому й навчальному середовищу, що надихає, продовжуючи в той же час залучати студентів і працівників до структур урядування на всіх рівнях» ${ }^{471}$.

\section{Yerevan Communiqué 472}

Єреванське комюніке (2015р.) засвідчило готовність країн, які підписали Болонську декларацію, підтримувати та захищати студентів і академічну спільноту в їхніх правах на академічну свободу та гарантувати їх представництво як повноправних партнерів в управлінні автономними закладами вищої освіти ${ }^{473}$.

\section{Paris Communiqué ${ }^{474}$}

У Паризькому комюніке (2018р.) міністри підкреслюють: «Ми пишаємось тим, чого досягнув Болонський процес. Ми побудували дещо унікальне: Європейський простір вищої освіти (ЄПВО), в якому цілі та політики узгоджуються на європейському рівні, а потім запроваджуються у національних освітніх системах і закладах вищої освіти. Це простір, де уряди, заклади вищої освіти і стейкхолдери разом формують ландшафт вищої освіти; що демонструє, чого можуть досягти спільні зусилля й постійний діалог між урядами та сферою

\footnotetext{
464 Berger Communiqué: EHEA Ministerial Conference, 2005. URL: http://www.ehea.info/cid101762/bergen.html

465 Berger Communiqué: EHEA Ministerial Conference, 2005. URL: http://www.ehea.info/cid101762/bergen.html

466 Leuven/Louvain-la-Neuve Communiqué: EHEA Ministerial Conference, 2009. URL: http://media.ehea.info/file/2009 Leuven Louvain-laNeuve/06/1/Leuven Louvain-la-Neuve Communique April 2009 595061.pdf

467 Leuven/Louvain-Ia-Neuve Communiqué: EHEA Ministerial Conference, 2009. URL: http://media.ehea.info/file/2009 Leuven Louvain-laNeuve/06/1/Leuven_Louvain-la-Neuve_Communique_April_2009_595061.pdf

468 Budapest-Vienna Ministerial Conference: EHEA Ministerial Conference, 2010. URL: http://www.ehea.info/cid101033/ministerialconference-budapest-vienna-2010.html

469 Budapest-Vienna Ministerial Conference: EHEA Ministerial Conference, 2010. URL: http://www.ehea.info/cid101033/ministerialconference-budapest-vienna-2010.html

${ }^{470}$ Bucharest Communiqué EHEA Ministerial Conference, 2012. http://www.ehea.info/Upload/document/ministerial declarations/Bucharest Communique 2012 610673.pdf

${ }^{471}$ Bucharest Communiqué $\quad$ EHEA Conference,

http://www.ehea.info/Upload/document/ministerial_declarations/Bucharest_Communique_2012_610673.pdf

472Yerevan Communiqué: EHEA Ministerial Conference, 2015. URL: http://www.ehea.info/Uploads/SubmitedFiles/5 2015/112705.pdf

473 Yerevan Communiqué: EHEA Ministerial Conference, 2015. URL: http://www.ehea.info/Uploads/SubmitedFiles/5 2015/112705.pdf

474Paris communiqué: $\quad$ MHEA Conference, 2018.

http://www.ehea.info/media.ehea.info/file/2018 Paris/77/1/EHEAParis2018 Communique final 952771.pdf
} 
вищої освіти. Через ЄПВО ми проторували шлях для широкомасштабної студентської мобільності та покращили не лише порівнюваність і прозорість наших систем вищої освіти, а й підвищили їх якість і привабливість. ЄПВО сприяє взаєморозумінню й довірі та посилює співпрацю між нашими системами вищої освіти. Академічна свобода і доброчесність, інституційна автономія, участь студентів і працівників у врядуванні вищої освіти та громадська відповідальність вищої освіти й за вищу освіту становлять основу ЄПВО. Спостерігаючи, як останніми роками деякі з цих фундаментальних цінностей заперечувалися в деяких з наших країн, ми рішуче беремо на себе обов'язок пропагувати й захищати їх у всьому ЄПВО через інтенсивний політичний діалог і співпрацю» ${ }^{475}$.

Для України базовими документами, в яких відображено цілі та окреслено пріоритети розвитку освітньої системи є:

Національна доктрина розвитку освіти ${ }^{476}$ (далі - Національна доктрина), яку було затверджено Указом Президента від 17 квітня 2002 р.;

та Національна стратегія розвитку освіти в Україні на період до 2021 року 477 (далі - Національна стратегія), схвалена Указом Президента України від 25 червня 2013 р.

По суті, Національна доктрина є державним документом, що закладає систему принципів і поглядів на розвиток освіти у країні, а Національна стратегія «конкретизує основні шляхи реалізації концептуальних ідей та поглядів розвитку освіти, визначених Національною доктриною розвитку освіти» ${ }^{478}$.

Аналіз цих двох документів через призму проблем, пов'язаних з механізмами реалізації ефективного врядування в університетах України в умовах євроінтеграції та, зокрема участі студентської спільноти в університетському врядуванні, показує, що у Національній доктрині розвитку освіти $є$ розділ X «Управління освітою», в якому чітко прописано, що: «Сучасна система управління сферою освіти розвивається як державногромадська. ... Нова модель системи управління сферою освіти має бути відкритою і демократичною» ${ }^{479}$. А одним із важливих аспектів для забезпечення модернізації управління освітою є «запровадження нової етики управлінської діяльності, що базується на принципах взаємоповаги, позитивної мотивації; а також більш широке залучення до управлінської діяльності талановитої молоді, жінок, а також виховання лідерів у сфері освіти» ${ }^{480}$.

Серед основних напрямків реалізації Національної стратегії виокремлено модернізацію системи управління освітою, зокрема зазначається, що «...управління освітою повинно здійснюватися на засадах інноваційних стратегій відповідно до принципів сталого розвитку, створення сучасних систем освітніх проектів та їх моніторингу; розвитку моделі державно-громадського управління у сфері освіти, в якій особистість, суспільство та держава стають рівноправними суб'єктами і партнерами» ${ }^{481}$.

У вище зазначених положеннях ми курсивом виділили ключові моменти, які роблять наголос на таких аспектах як:

- демократичність та відкритість системи управління сферою освіти;

- широке залучення до управлінської діяльності молоді;

- партнерство в управлінні.

\footnotetext{
475 Paris communiqué: $\quad$ EHEA Conference, 2018.

http://www.ehea.info/media.ehea.info/file/2018_Paris/77/1/EHEAParis2018_Communique_final_952771.pdf

476 Національна доктрина розвитку освіти, затверджена Указом Президента України від 17 квітня 2002 року № 347/2002. URL: https://zakon4.rada.gov.ua/laws/show/347/2002

477 Національна стратегія розвитку освіти в Україні на період до 21 року. Схвалено Указом Президента України від 25 червня 2013 року № 344/2013. URL: https://zakon.rada.gov.ua/laws/show/344/2013

478 Національна стратегія розвитку освіти в Україні на період до 21 року. Схвалено Указом Президента України від 25 червня 2013 року № 344/2013. URL: https://zakon.rada.gov.ua/laws/show/344/2013

479 Національна доктрина розвитку освіти, затверджена Указом Президента України від 17 квітня 2002 року № 347/2002. - URL: https://zakon4.rada.gov.ua/laws/show/347/2002

480 Національна доктрина розвитку освіти, затверджена Указом Президента України від 17 квітня 2002 року № 347/2002. - URL: https://zakon4.rada.gov.ua/laws/show/347/2002

481 Національна стратегія розвитку освіти в Україні на період до 21 року. Схвалено Указом Президента України від 25 червня 2013 року № 344/2013. - URL: https://zakon.rada.gov.ua/laws/show/344/2013
} 
Усі перелічені аспекти, постають як теоретичне підґрунтя і водночас важливі умови для розроблення механізмів реалізації ефективного врядування в університетах України в умовах євроінтеграції, а також забезпечення студентської участі у процесах університетського врядування.

Від моменту ухвалення Національної стратегії минуло вже майже 10 років, і наразі, відбувається громадське обговорення проєкту «Стратегія розвитку вищої освіти в Україні на 2021-2031 роки» ${ }^{482}$.

Ми можемо зазначити, що попри велику роботу по реформуванню системи вищої освіти в Україні яка була проведена, стратегічною ціллю номер один для розвитку вищої освіти в Україні на наступні десять років залишається:

«Покращення системи управління освітою і забезпечення автономії ЗВО», а операційною ціллю 1.1.3. $\epsilon$ «Забезпечення посилення ролі академічної громади (студенти, викладачі, дослідники) і громадськості в управлінні 3ВО» ${ }^{483}$.

Означене лише підкреслює той факт, що участь студентів в університетському врядуванні є достатньо різною (як за змістом, так і за якістю) у різних університетах України.

Автономія закладу вищої освіти відповідно до Закону України «Про вищу освіту» 484 передбачає «... самостійність, незалежність і відповідальність вищого навчального закладу у прийнятті рішень стосовно розвитку академічних свобод, організації освітнього процесу, наукових досліджень, внутрішнього управління, економічної та іншої діяльності, самостійного добору і розстановки кадрів...» (ст. 46) ${ }^{485}$. Надана університетам автономія відкриває широку варіативність щодо участі студентів у процесах університетського врядування, яка може коливатися у різних аспектах, наприклад, формах, рівнях, перспективах та характері участі, варіюватися за своїми типами та рівнями інтенсивності. Тому попри те, що участь студентів в управлінні сучасним університетом широко дискутується в освітянському колі, все ще залишається багато проблемних питань, які потребують ретельного вивчення і наразі постають предметом нашого дослідження.

Отже, зважаючи на актуалізацію питання ролі студентської спільноти у забезпеченні ефективного університетського врядування у ключових європейських та вітчизняних документах у сфері вищої освіти, а також зважаючи на доволі інтенсивну теоретичну дискусію і практичні здобутки, ми можемо говорити про важливість дослідження даної проблеми залучення студентів до університетського врядування в якості рівноправних партнерів.

482 Стратегія розвитку вищої освіти України на 2021-2031 роки. Міністерств освіти і науки України, 2020. URL: https://mon.gov.ua/storage/app/media/rizne/2020/09/25/rozvitku-vishchoi-osviti-v-ukraini-02-10-2020.pdf

483 Стратегія розвитку вищої освіти України на 2021-2031 роки. Міністерств освіти і науки України, 2020. URL: https://mon.gov.ua/storage/app/media/rizne/2020/09/25/rozvitku-vishchoi-osviti-v-ukraini-02-10-2020.pdf

484 Закон України «Про вищу освіту» від 1 липня 2014 року № 1556-VII. URL: : https://zakon.rada.gov.ua/laws/show/1556-18\#Text

485 Закон України «Про вищу освіту» від 1 липня 2014 року № 1556-VII. URL: : https://zakon.rada.gov.ua/laws/show/1556-18\#Text 


\section{Аналіз наукових джерел з проблем участі студентів в університетському врядуванні}

Варто зазначити, що проблеми пов'язані з участю студентів в університетському врядуванні вже не один рік перебувають у полі зору зарубіжних дослідників. У зарубіжних наукових публікаціях з цієї проблеми увага акцентується на таких питаннях як:

- рівні можливості для студентів залучатися до процесів врядування;

- розуміння поняття «студентський голос» та «залучення студентів»;

- рішення реальних проблем і відповідно розвиток навичок критичного мислення;

- володіння студентами необхідними знаннями для прийняття обґрунтованих рішень;

- студентська відповідальність при розробленні й реалізації рішень;

- мотивація студентів, механізми та інструменти зворотного зв'язку зі студентами;

- моделі й механізми студентського голосу тощо.

Теоретичне підґрунтя проблем участі студентів в університетському врядуванні складають праці, присвячені висвітленню проблем, пов'язаних з формуванням залученості студентів у вищій освіті. Зокрема, у статті E. Kahu «Framing student engagement in higher education» ${ }^{886}$, розглядаються й аналізуються чотири домінуючих підходи до залучення студентів: поведінковий; психологічний; соціокультурний та цілісний.

Окремий інтерес для нашого дослідження становлять дослідження і документи розміщені на таких інтернет-ресурсах як, наприклад, Sparqs ${ }^{487}$ (Student Partnerships in Quality Scotland - студентська участь у процесах забезпечення якості в Шотландії).

Це агентство, ставить студентів у центр при прийнятті рішень, пов'язаних з якістю освіти та управлінням студентським досвідом, що має на меті «просувати освіту шляхом створення середовища, в якому студенти можуть вносити позитивні й корисні зміни у свій власний і чужий освітній досвід» ${ }^{488}$. У 2011-2012 poках Sparqs провели велику дослідницьку роботу, з'ясовуючи серед співробітників і студентів університетів та коледжів Шотландії, що, на їхню думку, означає участь студентів. Ідея проведення подібного дослідження виникла через існування безлічі різних тлумачень, того, що означає «участь студентів». Результатом даного опитування став документ "A student engagement framework for Scotland» 489, який забезпечив основу для інтерпретації, вивчення та розвитку практик залучення студентів закладах освіти, студентських асоціаціях і секторі у цілому.

Цікавою в контексті нашої теми є праця «The Civic University: The Policy and Leadership Challenges» ${ }^{490}$, в якій розглядаються проблеми лідерства та врядування. Авторами публікації розроблена модель громадського університету як академічної концепції та проаналізовано кілька практик врядування університетами з метою висвітлення механізмів побудови громадської активності в середині університету. Для досягнення мети автори порівнюють досвід врядування у восьми університетах Великої Британії, Нідерландів та Фінляндії.

\footnotetext{
486 Kahu E. R. Framing student engagement in higher education. Studies in Higher Education, 2013. 38:5. P. 758-753. https://doi.org/10.1080/03075079.2011.598505

487 Sparqs. URL: https://www.sparqs.ac.uk/

488 Sparqs. URL: https://www.sparqs.ac.uk/

${ }^{489}$ A student engagement framework for Scotland. URL: https://www.sparqs.ac.uk/upfiles/SEFScotland.pdf

490 Goddard, John, Hazelkorn, Ellen, Kempton, Louise, \& Vallance? Paul (2016). The Civic University: The Policy and Leadership Challenges. Cheltenham, UK: Edward Elgar. https://doi.org/10.4337/9781784717728
} 
Нашу увагу привернув звіт присвячений теоретичним і практичним аспектам участі студентів в університетському врядуванні «Making Student Engagement a Reality: Turning Theory into Practice» ${ }^{491}$. Даний звіт підготовлений GuildHE 492 (Спілкою вищої освіти Великої Британії, яка $\epsilon$ одним 3 двох офіційних представницьких органів вищої освіти в країні), у співпраці з TSEP ${ }^{493}$ (The Student Engagement Partnership), організацією яка створена для підтримки, розвитку, та популяризації активного залучення студентів до вищої освіти у Великій Британії. У звіті представлено 12 тематичних досліджень, написаних в основному співробітниками та студентами університетів, які $€$ членами GuildHE, і присвячених реальним практикам в університетах щодо залучення студентів. У дослідженнях показано, як університети та студенти сприяли розвитку партнерських відносин та визначили власний підхід до залучення студентів. Врешті партнерські відносини між університетом і студентами, на думку авторів, викликають значні зміни у таких сферах, як ${ }^{494 .}$

- освітні програми та інституційна політика;

- викладання та навчання;

- створення репрезентативних систем і зворотного зв'язку.

У публікації стверджується: «Тематичні дослідження членів GuildHE, для яких залучення студентів $\epsilon$ основною цінністю, роблять цю публікацію корисним і практичним інструментом. Дослідження надихають та пропонують ідеї для закладів вищої освіти, які бажають залучати студентів у кожному аспекті університетського життя - коротко кажучи, вони спрямовані на те, щоб залучати студентів до реальності» 495.

Робота визнаного у всьому світі дослідника, який спеціалізується на питаннях студентської участі, A. Fletcher «Student Voice Revolution: The Meaningful Student Involvement Handbook» 496, орієнтована на студентський голос, залучення студентів, партнерські відносини в освіті з метою посилення їх прихильності до навчання, університетської спільноти й демократії. Дана книга висвітлює унікальні підходи, детальну та критичну оцінку діяльності освітнього середовища та присвячена студентам, викладачам, керівникам закладів освіти та прихильникам освітніх реформ.

Ще одним відомим дослідником $\in R$. Quaglia, в якого вийшла низка робіт з проблем студентської участі, зокрема: «Student Voice: Ensuring a Sense of Self-Worth for Your Students» 497, "Principal Voice: Listen, Learn, Lead» 498, "Student Voice: The Instrument of Change» 499 та інші. Всі його роботи ґрунтуються на розумінні та переконанні, що студенти повинні займати центральне місце у будь-якій програмі освітніх реформ. На думку R. Quaglia, студентський голос $є$ інструментом змін, а розвивати його можна за допомогою підходу «слухай, вчися і керуйся» ${ }^{500}$ : питай у молодих людей їхні думки й щиро слухай, вчися на тому, що говорять студенти, і використовуй те, про що дізнаєшся, щоб бути ефективним лідером змін. У своїх працях R. Quaglia намагається побудувати схему успішного партнерства між педагогами й студентами, наповнюючи свої книжки прикладами з опитувань студентів, фокус-груп, спостережень, інтерв'ю тощо.

\footnotetext{
491 Wait R. and Bols A. (2015) Making Student Engagement a Reality: Turning Theory into Practice. London: Guild HE. Available at. URL: http://www.guildhe.ac.uk/blog/makingstudent-engagement-a-reality-turning-theory-into-practice / (Accessed 22nd Jul 2017)

492 GuildHE. URL: https://guildhe.ac.uk/about/

493 The Student Engagement Partnership. URL: https://tsep.org.uk/

494 Wait R. and Bols A. (2015) Making Student Engagement a Reality: Turning Theory into Practice. London: Guild HE. Available at. URL: http://www.guildhe.ac.uk/blog/makingstudent-engagement-a-reality-turning-theory-into-practice / (Accessed 22nd Jul 2017).

495 Wait R. and Bols A. (2015) Making Student Engagement a Reality: Turning Theory into Practice. London: Guild HE. Available at. URL: http://www.guildhe.ac.uk/blog/makingstudent-engagement-a-reality-turning-theory-into-practice / (Accessed 22nd Jul 2017)

${ }^{496}$ Fletcher A. F. C. Student Voice Revolution: The Meaningful Student Involvement Handbook Paperback. Common Action Publishing, 2017. URL: https://www.amazon.com/gp/product/0692954449/ref=as_li_ss_tl?ie=UTF8\&linkCode=sl1\&tag=soundout20\&linkld=a310eb5b7077bf\%2084a817e577369d295cc

497 Quaglia R. J. Student Voice: Ensuring a Sense of Self-Worth for Your Students. Corwin Press, 2015. 45 p.

498 Quaglia R. J. Principal Voice: Listen, Learn, Lead. Corwin, 2016. 75 p.

499 Quaglia R. J., Corso M. J. Student Voice: The Instrument of Change. Corwin, 2014. 216 p.

500 Quaglia R. J. Principal Voice: Listen, Learn, Lead. Corwin, 2016. 75 p.
} 
Корисними в контексті нашого дослідження є матеріали «Bologna with student eyes» ${ }^{501}$ (Болонья очима студентів), які починаючи з 2003 року публікує European Students' Union (скорочено - ESU).

Ці звіти засновані на даних національних студентських спілок і спрямовані підкреслити нинішній статус, успіхи й майбутні проблеми, які студенти бачать у реалізації реформ, доповнюючи тим самим погляди та думки представлені іншими зацікавленими сторонами й самими урядами, наприклад, представленими у звітах Європейського простору вищої освіти (ЕНЕA ${ }^{502}$ ).

Збираючи матеріали для «Bologna with student eyes», European Students' Union проводить опитування студентської спільноти через національні студентські союзи за такими показниками: участь студентів у врядуванні, соціальний аспект, забезпечення якості, визнання, мобільність і інтернаціоналізація, структурні реформи та фінансування вищої освіти тощо.

Зокрема, для з'ясування ситуації щодо участі студентів в університетському врядуванні в опитувальник European Students' Union включаються наступні запитання ${ }^{503 .}$

- На якому рівні у вашій країні існують правові або конституційні механізми, що забезпечують студентське представництво у системі управління вищою освітою?

- Яка участь студентського представництва у відповідних органах?

- Чи існує мінімальна юридична або конституційна вимога щодо представлення студентів?

- Чи мають студенти право голосу у відповідних органах управління?

- Які права студентські представницькі органи мають на різних рівнях (право: вето; апеляції, ініціювання, погодитися, формувати думку, немає прав)

- Яким чином студенти оцінюють курси та / або програми своїх закладів вищої освіти? Чи існують ініціативи та / або заходи щодо залучення студентів на цей час?

- Чи ви відчуваєте ступінь залучення студентів до врядування в університеті?

- Назвіть 5 основних сфер, до яких мають бути залучені студенти? Як їх слід покращити?

Подібні опитування, на наш погляд, можна вважати комплексною системою студентського спостереження щодо реалізації цінностей і завдань, пов'язаних з побудовою Європейського простору вищої освіти в різних вимірах і зокрема, відносно студентської участі в університетському врядуванні. Опитування студентів є цінним з точки зору збирання, оброблення, систематизації та аналізу інформації, у тому числі і про стан студентської участі в університетському врядуванні. Це своєю чергою, дає можливість університетам оцінювати й прогнозувати можливі зміни, розробляти обґрунтовані рекомендації для прийняття управлінських рішень.

Ще одним прикладом досліджень є публікації, присвячені залученню студентів до університетського врядування в окремих країнах. Так, наприклад, робота "The Status of Student Involvement in University Governance in Kenya: The Case of Public and Private Universities» 504, спрямована на дослідження стану участі студентів в університетському управлінні в Кенії з використанням досвіду одного державного та одного приватного університету.

\footnotetext{
501 Bologna with student eyes. URL: https://www.esu-online.org/publications/bologna-student-eyes-2018-2/

502 EHEA. URL: http://www.ehea.info/

503 Bologna process between Prague and berlin Report to the Ministers of Education of the signatory countries Berlin, September 2003. URL: http://www.ehea.info/media.ehea.info/file/ESU/27/5/Bologna-With-Student-Eyes_2003 565275.pdf

504 Munyae M. Mulinge, Josephine N. Arasa, Violet Wawire. The Status of Student Involvement in University Governance in Kenya: The Case of Public and Private Universities. CODESRIA, Dakar, 2017, 252 p.
} 
Отже, усвідомлення того факту, що конкурентоспроможність університетів у XXI столітті значною мірою залежатиме від ефективності врядування, призвело до пошуку дієвих механізмів, які здатні реально забезпечити їх ефективність. У цьому контексті важливого значення набувають питання пов' язані з залученням студентської спільноти для забезпечення ефективного університетського врядування, де ключовим акцентом $\epsilon$ підтримка та захист студентів в їхніх правах на академічну свободу, та гарантії їх представництва як повноправних партнерів в управлінні автономними закладами вищої освіти.

Актуальність даної проблеми підкреслюється, у низці європейських документів, спрямованих на побудову ЄПВО, а також в українських законотворчих документах, пов'язаних з розвитком вищої освіти.

Крім того, проблеми теорії та практики, пов'язані з участю студентів в університетському врядуванні, вже не один рік перебувають у полі зору як вітчизняних, так і зарубіжних дослідників, які ґрунтовно досліджують теоретичні й практичні аспекти участі студентів в університетському врядуванні.

Ще одним висновком $є$ твердження про те, що попри те, що на сьогодні, українське законодавство відкриває широкі можливості для розвитку студентських організацій в українських університетах, існує ряд, проблем, що стримують розвиток партнерських відносин зі студентською спільнотою в університетах. 


\section{Теоретичне підґрунтя участі студентів в університетському врядуванні}

Теоретичним підґрунтям участі студентів в університетському врядуванні $€$ демократична теорія, в межах якої партисипаторна (або учасницька демократія), становить основу для побудови моделі ефективного врядування у сучасних університетах, що передбачає участь всіх стейкхолдерів у справах університету, з певною системою прав (та обов'язків) членів спільноти. Причому, ключового значення набувають спільні університетські цінності, які зумовлюють правила поведінки, як у середині спільноти, так і у стосунках з тими, хто безпосередньо чи опосередковано є дотичним до університету.

До спільних універсальних європейських цінностей апелюють практично всі документи Європейського Союзу, які стосуються освіти. У ст. 1а документу «Treaty of Lisbon amending the Treaty on European Union and the Treaty establishing the European Community» 505 (Договору про Європейський Союз) зазначені спільні європейські цінності, які лежать в основі Європейського Союзу: людська гідність, свобода, демократія, рівність, верховенство закону і повага до прав людини.

Основними аксіологічними передумовами реформування вищої освіти виступають такі універсальні домінанти, як певний рівень свідомості та свобода суб'єктів освітнього процесу, що в цілому можна розглядати крізь призму демократичної теорії. На наш погляд, все те, що становить основу ЄПВО: академічна свобода $і$ доброчесність, інституційна автономія, участь студентів і працівників у врядуванні вищої освіти та громадська відповідальність вищої освіти й за вищу освіту, є вихідними ідеями демократії.

Демократія, у сучасному світі, визнається найкращою формою врядування ${ }^{506}$, ефективною моделлю, головні позиції в якій займають верховенство права та ідея справедливості (як найвищої міри сумісності різних інтересів або максимум свободи для якомога більшої кількості індивідів). Ефективною демократична модель може бути лише за умови, коли людей об'єднує спільна система цінностей, яка врешті визначає їх поведінку.

Демократію можна визначити також як модель врядування, яка ґрунтується на участі всіх членів спільноти у справах громади, з певною системою прав (та обов'язків) членів громади. Причому порушення цих прав з одного боку, та невиконання членами громади своїх обов'язків, з іншого боку, ставить під сумнів демократичність врядування.

Розумінню демократії як участі у справах громади, сучасники можуть завдячувати стародавнім грекам, зокрема яскравому прикладу афінської демократії: «Центром діяльності в античній Греції, що не була об'єднана єдиним урядуванням, був самоврядний поліс (polis), тобто місто-держава. Афіни, найбільший поліс, - це найкращий приклад демократичного міста-держави. Протягом більшої частини другої половини $V$ століття до н. е., періоду, відомого як золота доба Афін, афіняни називали свій поліс демократією. Не кожен доброхіть погоджувався з таким станом, але ті, хто погоджувався, були, здається, завзятими прихильниками демократії.

Це стає очевидним зі слів, які приписують Періклові, найславетнішому лідеру афінської демократії, що виголосив їх в одній надгробній промові: «У нас держаний устрій не схожий на спосіб життя наших сусідів: ми, скорше, самі даємо зразок іншим, ніж наслідуємо їх. Отже, і називається він «демократія» через те, що основа його не меншість, а більшість громадян. Вона, згідно з нашими законами, дає всім громадянам рівні права, що ж до суспільної поваги, то в нас кожний користується нею, але не тому що якась частина громадян його підтримує, а тому що сам він має певну доброчесність. А коли хтось зробив щось добре для міста, то навіть бідність не позбавляє його поваги». Перікл натякає своїми словами на тертя між аристократами і демократами в античних Афінах. Аристократи загалом вважали, що тільки статечні громадяни, які заможні й мають зв'язки зі шляхетними родинами, досить розважливі, щоб урядувати. Проте Перікл і демократи вважали, що врядувати спроможні більшість громадян, якщо тільки вони можуть дозволити собі відібрати час у свого господарства та роботи. Саме тому афінська демократія виплачувала громадянам середній денний заробіток, щоб вони - як

\footnotetext{
505 Treaty of Lisbon amending the Treaty on European Union and the Treaty establishing the European Community. URL: https://eurlex.europa.eu/legal-content/EN/TXT/?uri=CELEX\%3A12007L\%2FTXT\#

506 Partnership for Sustainable Global Growth. Interim Committee. Declaration Washington, D.C. September 29, 1996. URL: https://www.imf.org/external/np/exr/dec.pdf
} 
бідні, так і багаті - мали змогу ходити на збори та визначати політику безпосереднім голосуванням. Громадянам платили й за те, щоб вони служили як судді, інколи навіть протягом року. Ще одним свідченням «віри в демос» було те, що на чимало політичних посад афіняни призначали громадян не голосуванням, а навмання вибираючи їх своєрідним жеребкуванням. У надгробній промові Перікла згадано про ще одну відмінність, яка мала вкрай важливе значення для афінян: відмінність між громадянами, сповненими громадянського духу (polites), та егоїстичними індивідами, що віддавали перевагу приватному життю (idiotes). В Афінах, казав Перікл, «доводиться людям і про свої хатні справи, і про державні справи дбати, а всім іншим, що віддані своїм власним справам, розумітися, так чи інакше, і на державних справах. Лише ми самі вважаємо того, хто не бере участі в них, не ледачим, а некорисним. I ми самі судимо наші вчинки або намагаємося правильно оцінити їх» ${ }^{507}$.

I хоча афінська демократія є справою минулого, ми не можемо заперечувати, що ключові ідеї такі як: самоврядування, рівні права, суспільна повага, доброчесність, ідея служіння громаді, участь членів громади у спільних справах задля спільного блага тощо не лише не втратили своєї актуальності, але й набувають нового сучасного звучання.

Крізь призму зазначеного хотілось би поглянути і на питання участі студентів в університетському врядуванні, які на наш погляд, концептуально «вписуються» у контекст демократичних ідей. Як ми вже зазначали, питання участі студентів в університетському врядуванні є сьогодні одним із важливих у контексті побудови Європейського простору вищої освіти (ЄПВО) та реформування освітньої системи України. Питання «участі» набули нової актуальності у вищій освіті у зв'язку з намаганнями подолати кризу сучасного університету. I тому виникли питання:

- Якою має бути сучасна освіта?

- Яким має бути сучасний університет?

- Чому і як навчати?

- Які знання потрібні сучасній людині?

- та багато інших, для вирішення яких важливою $є$ як думка всіх зацікавлених сторін освітнього процесу, так і їх активна та свідому участь у ньому.

Марно сподіватися, що лише зусиллями держави у цьому відношенні, або лише адміністрацією чи студентами окремого університету можуть бути вирішені ці питання, які мають системний характер і врешті стосуються не лише освітньої сфери, а пов'язані з питаннями розвитку всієї держави. Але, якщо намагатися спільним зусиллями шукати шляхи розвитку, то є більше шансів подолати всі виклики.

Не зупиняючись детально на проблемах глобального чи державного рівня, спробуємо зрозуміти витоки та можливості студентської участі на інституційному рівні, на рівні окремого університету. У сучасному контексті змінюється структура та умови роботи університету, але якщо поглянути на університет як на певного роду «афінський поліс», то можна побачити, що символи античної демократії такі як: верховенство закону, рівність, та рішення спільних питань більшістю членів спільноти, також можуть відповідати демократичній моделі сучасного університету. Але вихідне, без чого, на наш погляд, не можлива була б афінська демократія це спільні цінності, які поділяли всі жителі міста та певний рівень свідомості (яка передбачає і відповідальність, і високий рівень участі у спільних справах). Тому і для університетської спільноти цінності постають вихідним положенням.

Багато світових університетів приділяють питанню цінностей значну увагу. Наприклад, Uniwersytet Jagielloński ${ }^{508}$, має «Akademicki Kodeks Wartości» (Академічний кодекс цінностей): «Створення "Akademicki Kodeks Wartości» стало необхідністю оскільки такі цінності як: правда, відповідальність, надійність навчання та свобода навчання, знаходяться під загрозою. Автори «Akademicki Kodeks Wartości» також взяли до уваги той факт, що відсутність поваги до академічних цінностей призводить до недосконалої освіти, що, своєю чергою, призводить до того, що студенти отримують неповноцінні знання та навички. Результатом порушення

\footnotetext{
507 Демократія. Антологія / упорядник О. Проценко. К.: Смолоскип, 2005. 1108 с.

508 Uniwersytet Jagielloński. URL: https://www.uj.edu.pl/uniwersytet-z-collegium-medicum/kodeks-wartosci
} 
академічних цінностей $€$ також створення наукових праць низької пізнавальної цінності. Порушення академічних стандартів негативно впливає на все суспільство та прогрес науки, тому їх захист є предметом загального соціального значення. Створено перелік фундаментальних принципів, які протягом століть створювали авторитет науки, виявляючи моральну силу академічного світу та сенс місії науковців у просуванні етичних та громадянських чеснот. Їхня присутність у ставленні, поведінці членів академічної спільноти, у взаєминах університету гарантує збереження основних морально-етичних цінностей, які формувалися багатовіковою університетською традицією» ${ }^{509}$.

B «Akademicki Kodeks Wartości» перераховано та описано конкретні речі (цінності), які визнаються головними (значущими) саме для цього конкретного університету. I хоча більшість з них $є$ універсальними, але проголошені, прописані (конкретизовані), прийняті та оприлюднені вони легітимізовані у цій університетській спільноті. Попри те, що вони не є законом в юридичному розумінні цього слова, коли за порушення певних норм передбачено покарання, вони є законом, з точки зору моралі, і недотримання проголошених цінностей засуджується університетською спільнотою і $\epsilon$ неприйнятною для членів даної спільноти. Сприйняття і поділення цих цінностей $є$ добровільним для кожного (від студента до професора), а це, як ми вже говорили, передбачає певний рівень свідомості. І коли більшість (спільноти) поділяє ці цінності та діє відповідно до них, причому добровільно, а не лише через можливе покарання, тоді складається певний тип університетського середовища, яке можна вважати ідеальним для реалізації ефективного врядування і зокрема студентської участі.

Інший підхід університетської громади до спільних цінностей, це «Codice etico e di comportamento» (Кодекс етики та поведінки), який діє в Università di Bologna ${ }^{510}$. На противагу «Akademicki Kodeks Wartości» в Uniwersytet Jagielloński, в якому просто перераховані та описані цінності, «Codice etico е di comportamento» в Università di Bologna нагадує нормативний документ, в якому прописуються як правила поведінки засновані на конкретних цінностях, так і визначена дисциплінарна відповідальність за порушення положень цього Кодексу.

«Codice etico e di comportamento» подає принципи, які приймають та поділяють усі члени університетської спільноти та всі, хто встановлює відносини з університетом. «Codice etico e di comportamento» визначає основні цінності університетської спільноти та правила, спрямовані на уникнення будь-якої форми дискримінації та зловживань, а також регулює випадки конфлікту інтересів та інтелектуальної власності. «Codice etico e di comportamento» - свого роду довідник з врегулювання внутрішніх і зовнішніх відносин Університету з етичної точки зору. В ньому задекларовані принципи, які приймають і поділяють викладачі, дослідники, керівники й адміністративний персонал, студенти й всі хто має відношення до діяльності університету. Усі члени університетської спільноти несуть однакову відповідальність за захист і повне застосування правил етики та поведінки університету ${ }^{511}$.

Як бачимо, практики в університетах бувають різні, але в будь-якому разі, мова йде про визначення основних цінностей університетської спільноти, які складають основу, на якій ґрунтуються і встановлюються відносини між членами цієї спільноти, що призводить до створення певного типу університетського середовища. Важливість спільних університетських цінностей полягає також у тому, що вони сприяють визнанню і повазі прав та свобод людини, а також усвідомленню певних обов'язків, етичної та соціальної відповідальності кожного, як стосовно університету, так і по відношенню один до одного. Цінності зумовлюють правила поведінки, як у середині спільноти, так і у стосунках з тими, хто безпосередньо чи опосередковано $\epsilon$ дотичним до університету.

\footnotetext{
509 Uniwersytet Jagielloński. URL: https://www.uj.edu.pl/uniwersytet-z-collegium-medicum/kodeks-wartosci

510 Università di Bologna. URL: https://www.unibo.it/it/ateneo/chi-siamo/codice-etico-e-di-comportamento

511 Codice etico e di comportamento. URL: http://www.normateneo.unibo.it/codice etico.html
} 
Як ми, вже зазначали вище, демократія це - спільні цінності та певний рівень свідомості (яка передбачає і відповідальність, і високий рівень участі у спільних справах). У цьому аспекті, ми можемо розглядати теорію партисипаторної (або учасницької) демократії як основу для побудови моделі ефективного врядування у сучасних університетах.

Партисипаторна теорія трактує демократію як універсальний принцип організації всіх галузей суспільного життя, а широка суспільна партисипація проявляється у свідомій, активній участі членів громади (спільноти) у процесах формування, виробленні та реалізації життєво важливих рішень. Тобто в основі цієї теорії $\epsilon$ переконання, що члени спільноти, здатні не лише брати участь у виборах чи референдумах, а безпосередньо залучатися до процесу вироблення рішень (підготовці, прийнятті, впровадженні тощо). Ці ж ідеї можуть бути застосовані й при розробленні ефективної моделі університетського врядування, де сама ідея широкого залучення усіх учасників університетської спільноти до процесів формування, вироблення та реалізації життєво важливих рішень $є$ необхідною умовою побудови ЄПВО. Разом з тим, слід наголосити, що залучення до врядування - че не вимушена участь, а свідома, активна участь усіх учасників університетської спільноти у процесах формування, вироблення та реалізації рішень, що є результатом досягнення певного рівня свідомості.

Прихильники демократії участі, вважають, що «... ірраціональність і пасивність людей в політичній сфері - це результат їх недостатньої освіти й відсутності рівних можливостей для участі в політиці. Тому суспільству належить створити всі умови для активної політичної соціалізації кожного індивіда» ${ }^{512}$. На наш погляд, якщо пасивність (низька участь) проявляється в університетській спільноті, то це навряд чи можна пов'язати 3 недостатньою освітою, а швидше за все з особливостями конкретного університетського середовища і реальними цінностями цього середовища. Отже, ми можемо говорити, що рівні права на свободу і саморозвиток, можливі лише в певному типі університетського середовища, яке можна назвати «учасницьким університетським середовищем». Лише у такому середовищі виховується почуття дієвості, пробуджується інтерес до спільних проблем, формується обізнана у своїх правах та відповідальності особистість, здатна постійно виявляти зацікавленість та брати участь в університетському житті, і зокрема в процесах пов'язаних 3 університетським врядуванням. 


\section{Ключові терміни та поняття}

Розглядаючи участь студентів в університетському врядуванні (крізь призму партисипаторної моделі демократичної теорії), не можна обійти увагою такі вихідні для нашого дослідження поняття (університет, врядування), а також завдання теоретичного уточнення ключових термінів і понять, які вживаються європейськими дослідниками при дослідженні проблеми студентської участі: «student engagement» студентське залучення (участь) та «voice student» - голос студентів.

Університетське врядування є інституційним рівнем врядування, тому термін «університет», який ми використовуємо в нашому дослідження, розуміється не як певний тип закладу вищої освіти 513 , а як узагальнене поняття, що уособлює у собі сучасне розуміння закладу вищої освіти, як певної автономної одиниці, як окремої інституції, яка діє в певній освітній системі й разом з тим є окремою цілісною системою.

Крім того, на наш погляд, важливо зробити акцент на тлумаченні терміну «врядування», який теж $\epsilon$ доволі неоднозначним, з огляду на наукову полеміку.

При аналізі терміну «врядування» можна стикнутися з застосуванням найрізноманітніших його інтерпретацій, таких як: «публічне врядування», «добре врядування», «системне врядування», «належне врядування», «демократичне врядування», «європейське врядування», «ефективне врядування» тощо. Більшість з них розроблялися і застосовуються у політичних та економічних науках. Разом з тим, необхідність управління існує у будь-який час, коли група людей об'єднує зусилля для досягнення певної мети, а врядування полягає у тому, як у тій чи іншій інституції (організації, установі тощо) організовуються процеси, правила та норми поведінки для прийняття рішень.

Варто зазначити, що англійське слово "governance» доволі часто перекладають і як врядування, і як управління, і як адміністрування: «Це своєю чергою може викликати певну плутанину у вживанні даних термінів, в кожному з яких закладено різне концептуальне значення. Один з наявних підходів у визначенні змісту «врядування» інтерпретує його як «форму багатоорганізаційних дій... та доповнюється поглядами на врядування як «взаємодію» (interaction) між різними соціальними акторами, що репрезентують тих, ким керують, і тих, хто керує. Сутність цього процесу досить влучно, як нам здається відображає розуміння "governance» як «скерування». Функція координації розподіляється серед усіх «соціальних акторів». Ключова ідея концепції «мережевого врядування» - розгляд суспільства крізь призму трьох його «визначальних рис» різноманітність, динамізм та комплексність (складність). Вони характеризують контекст взаємодії між «соціальними акторами» в системі управління. При цьому жодному із них не віддається перевага... Концептуальний наголос на взаємодії означає, що не актори, чи структури є визначальними факторами, а «взаємовідносини між елементами, акторами та процесами» в соціальних системах управління. I зміни, і стабільність - результат «взаємодії». Їх адекватне розуміння - вирішальна запорука ефективного врядування... Врядування (governance) - це скоріше результат взаємодії учасників процесу управління, що впливають один на одного» ${ }^{514}$.

Отже, у контексті нашого дослідження ми розглядатимемо врядування, як процес прийняття рішень $в$ університеті шляхом залучення різних зацікавлених сторін, з акцентом на партнерських взаємовідносинах між цими сторонами. Залучення можна розглядати як добровільну участь, яка тісно пов'язана з активністю і рівнем свідомості особистості. Серед вагомих передумов участі студентів в університетському врядуванні $€$ обізнаність у процесах університетського врядування та інтерес до них. Якщо студенти не цікавляться університетськими проблемами та не мають необхідних знань про механізми врядування, то вони приречені бути об'єктами врядування, а не повноправними партнерами, як того вимагає демократична модель ефективного врядування. I навпаки, студенти, які мають достатній рівень зацікавленості (інтересу) і які обізнані в механізмах та процесах університетського врядування, здатні стати суб'єктами, тобто активними акторами, дійовими особами процесу університетського врядування.

\footnotetext{
513 як відомо, згідно з Законом України «Про вищу освіту», в Україні діють різні типи закладів вищої освіти: університети, академії, інститути коледжі)

514 Андрущенко В., Савельєв В. Освітня політика (огляд порядку денного). К.: «МП Леся», 2010. 364 с.
} 


\section{«Student engagement»}

Вивчаючи зарубіжний досвід щодо участі студентів в університетському врядуванні доволі часто в публікаціях зустрічаємо вислів "student engagement», який дослівно можна перекласти як: залучення або участь студентів. Однак серед дослідників немає однозначності щодо визначення «student engagement», тому ми вживаємо слово «дефініція», оскільки епістомологічно воно означає «встановлення меж» на відміну від наукового терміну, який має точно й однозначно визначати чітко окреслене спеціальне поняття.

«Участь», в академічному тлумачному словнику української мови визначається як: «виконання разом 3 ким-небудь якоїсь роботи, здійснення якоїсь справи; спільна дія, діяльність кого-, чого-небудь» ${ }^{515}$. Сфери участі, можуть мати багато спрямувань, наприклад, політична участь, громадянська участь, фінансова участь, студентська участь тощо.

Студентську участь, умовно можна розглядати у рамках двох основних підходів: з точки зору інструментальної теорії, та з точки зору теорії розвитку.

У межах інструментальної теорії участь розглядається як комплекс засобів, за допомогою яких досягається певна мета, наприклад, захист прав та інтересів студентів. Акцентуючи увагу на захисній функції участі, інструментальна теорія схильна розглядати участь як ефективний спосіб протидії авторитарним тенденціям, та бюрократії.

3 точки зору теорії розвитку, участь у першу чергу постає, як важлива частина розвитку здібностей особистості, та є свого роду самоціллю. Ключовою тезою теорії розвитку є розуміння участі як важливої частини моральної та політичної освіти. Освіта в цьому сенсі має закладати в особистості почуття відповідальності, яка до речі, може розвинутися лише через користування нею.

На наш погляд, сфера студентської участі в університетському врядуванні, є симбіозом цих двох підходів. 3 одного боку, свідома активна участь у процесах прийняття рішень захищає студентів від нав' язування рішень «зверху», або як пише A. Obondoh: «коли члени університетської спільноти беруть участь у прийнятті рішень, їх індивідуальні, групові та організаційні потреби, і потреби більш зовнішніх зацікавлених сторін, швидше за все, будуть враховані» ${ }^{516}$. 3 іншого боку, за словами A. Sahin: «через участь студентів в управлінні покращується не лише їх компетентність, упевненість або особистий розвиток. Участь студентів у прийнятті рішень розвиває у них певні цінності, навички зважування думок, ведення переговорів та інакомислення...» 517.

Далі варто розглянути різні визначення «student engagement».

На комплексному, безкоштовному онлайн-ресурсі «The Glossary of education reform for journalists, parents, and community members» 518 (Глосарій реформи освіти для журналістів, батьків та членів громади), описуються широко вживані терміни, концепції та стратегії реформи освіти у Сполучених Штатах. У даному глосарії зазначено, що «...в освіті «student engagement» означає ступінь уваги, допитливості, інтересу, оптимізму і бажання, які студенти виявляють під час навчання, що простягається до рівня мотивації.... Загалом, концепція «залучення студентів» заснована на переконанні, що навчання покращується, коли студенти допитливі, зацікавлені та натхненні, і що навчання має тенденцію до погіршення, коли студенти нудьгують, безпристрасні, незадоволені або іншим чином «відсторонені». Посилення залучення студентів $€$ загальними навчальними цілями, висловленими педагогами... Однак у багатьох контекстах залучення студентів може також стосуватися способів, яким керівники, педагоги тощо можуть «повніше» залучати студентів до процесів управління та прийняття рішень в закладі освіти, до розробки програм та можливостей навчання або до активної громадської діяльності». ${ }^{519}$

515 Словник української мови. Академічний тлумачний словник (1970-1980). URL: http://sum.in.ua/s/uchastj

516 Obondoh A. The politics of participatory decision making in campus governance. Accra-North, Ghana : Association of African Universities, 2003. 13 p.

517 Sahin A. Perceptions of student council members on their participation in decision-making in higher education. URL: http://etd.lib.metu.edu.tr/upload/12606546/index.pdf

518 The Glossary of education reform for journalists, parents, and community members. URL: https://www.edglossary.org/about/

519 Engagement student. The glossary of reform for journalists, parents, and community members. URL: https://www.edglossary.org/studentengagement/ 
Британські дослідники C. Bryson, G. Cooper ma C. Hardy припускають, що залучення $є$ і процесом, і результатом. У першому випадку, це те, що роблять заклади вищої освіти, і повинно бути позначено як «залучення студентів». Тоді як у другому, це те, що роблять студенти, і повинно бути позначено, як «залучені студенти». Більш чіткою відмінністю було б визнати, те, що вважається процесом, не є залученням, натомість це сукупність факторів, які впливають на залучення студентів (як правило, більш безпосередні інституційні чинники), тоді як результатом $є$ залучені студенти (індивідуальний психологічний стан з трьома аспектами: афекту, пізнання та поведінки) ${ }^{520}$.

V. Trowler зазначав, що «...залученість студентів пов'язана із взаємодією між часом, зусиллями та іншими відповідними ресурсами, що вкладаються як студентами, так і їхніми закладами освіти, з метою оптимізації студентського досвіду та підвищення результатів навчання і розвитку студентів, ефективності та репутації закладу» ${ }^{521}$.

««Student engagement» - це психосоціальний процес, під впливом інституційних та особистісних факторів, який вбудований у більш широкий соціальний контекст, інтегрує соціокультурну перспективу 3 обговорюваними психологічними та поведінковими поглядами» ${ }^{522}$. Авторка наведеного визначення E. Kahu, розбираючи питання формування залучення студентів у вищій освіті запропонувала певну структуру, яка, на їі погляд, може бути корисним інструментом для цілеспрямованого втручання, спрямованого на підвищення залученості студентів (рис.1).

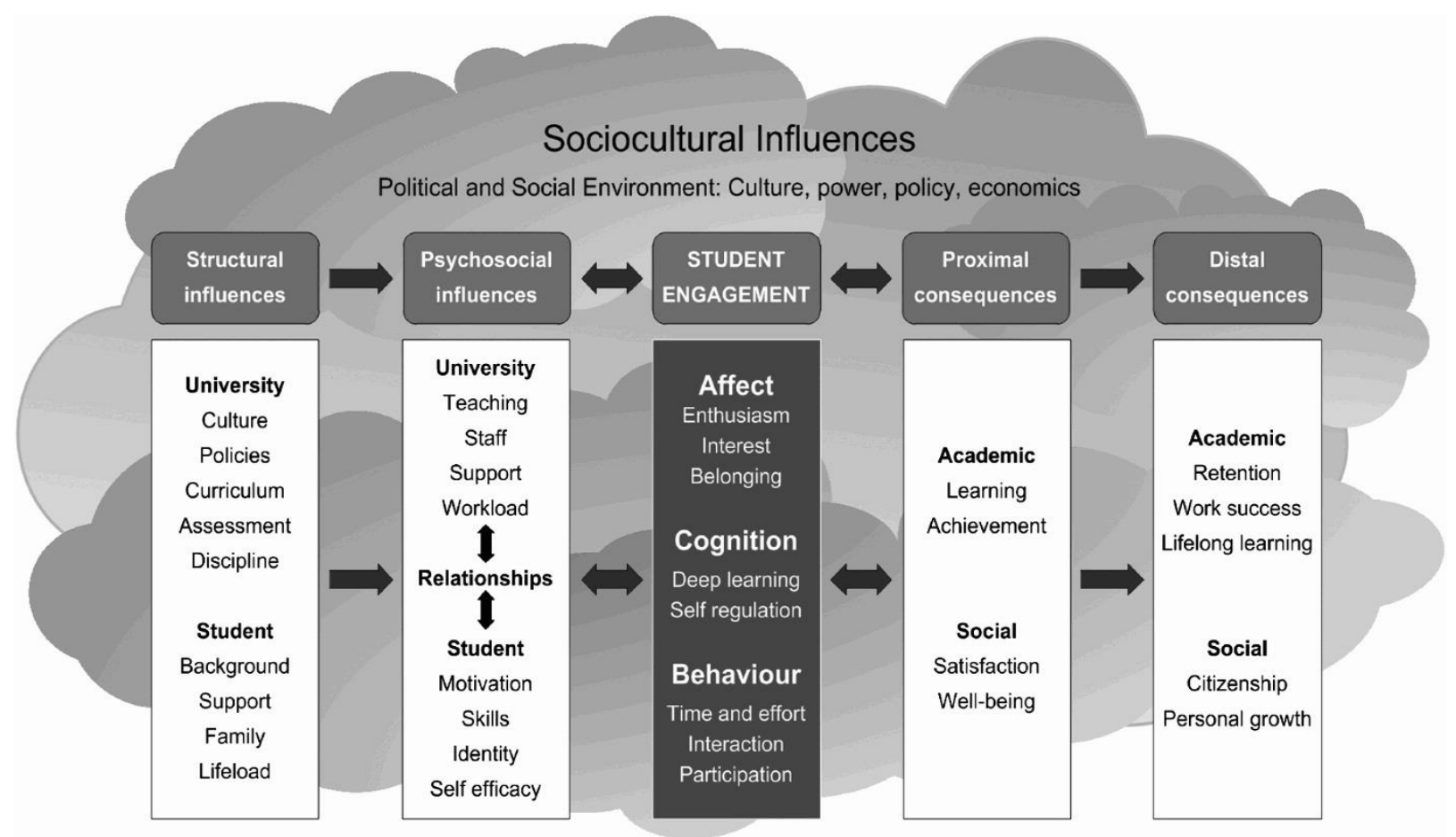

Рис.1. Концептуальні рамки взаємодії, передумови й наслідки ${ }^{523}$.

\footnotetext{
${ }^{520}$ Bryson C., Cooper G., Hardy C. Reaching a common understanding of the meaning of student engagement. Paper presented at Society of Research into Higher Education Conference. 2010. December 14-16.

521 Trowler V. Student Engagement Literature Review. The Higher Education Academy: Lancaster University, 2010. P. 3. URL: https://www.heacademy.ac.uk/system/files/StudentEngagementLiteratureReview_1.pdf

522 Kahu E. R. Framing student engagement in higher education. Studies in Higher Education, 2013. 38:5, P. 758-773. https://doi.org/10.1080/03075079.2011.598505

523 Kahu E. R. Framing student engagement in higher education. Studies in Higher Education, 2013. 38:5. P. 758-773. https://doi.org/10.1080/03075079.2011.598505
} 
Результат пошуку ясності щодо «student engagement» та концептуальне відображення його сутності призвів до виокремлення чотирьох різних підходів до розуміння «еngagement»:

- поведінковий підхід, який фокусується на ефективній практиці викладання;

- психологічний - при якому залучення розглядається як внутрішній індивідуальний процес;

- соціокультурний підхід, що розглядає критичну роль соціокультурного контексту;

- і, нарешті, цілісний підхід, який прагне об'єднати всі інші524.

Partnership):

Ще одна думка щодо «student engagement» приведена на сайті TSEP ${ }^{525}$ (The Student Engagement

«Student engagement полягає у наданні можливостей студентам формувати власний навчальний досвід та створювати найоптимальніше викладання та навчання у зв'язаній та згуртованій спільноті вищої освіти. Ми виявили, що не існує єдиного, фіксованого, універсального визначення чи моделі залучення студентів; це щось, що внутрішньо пов'язане і сформовано контекстом вищої освіти, в якому воно знаходиться. Варто розмежовувати практику участі студентів за контекстом, за трьома категоріями:

- академічна - залучення, пов'язане з навчанням;

- соціальна - залучення до діяльності в соціокультурному середовищі;

- вдосконалення (enhancement) - залучення до процесів, таких як якість, управління тощо» ${ }^{226}$.

Вище наведені визначення свідчать на користь таких тверджень:

- серед науковців не існує єдиного, фіксованого, універсального визначення або моделі залучення студентів;

- студентська участь нерозривно пов'язана і формується у контексті конкретного університету (університетського середовища) ${ }^{527}$.

У нашому дослідженні ми розглядаємо «участь студентів в університетському врядуванні» як: діяльність студентів (пряму чи опосередковану), спрямовану на те, щоб впливати на процес прийняття управлінських рішень у межах університету. Уточнимо, що, ми підходимо до «student engagement» (студентського залучення), як до взаємного процесу вдосконалення (тобто зусилля, як з боку університету, так і з боку студента(ів)), результатом якого мають бути позитивні зміни (вдосконалення, покращення), як для університету як інституції (вироблення ефективних політик, покращення управлінських структур тощо), так і для студента як особистості (отримання досвіду, навичок тощо).

\section{"Student voice»}

Ще однією розповсюдженою дефініцією серед зарубіжних дослідників при розгляді питань вищої освіти $\epsilon-$ «student voice» (голос студента).

$\mathrm{V}$ "The Glossary of education reform for journalists, parents, and community members» ${ }^{528} €$ окреме визначення «voice» (голоc): «як філософська позиція, так і стратегія вдосконалення школи, концепція «voice» в освіті стає все більш популярною в останні десятиліття. Загалом, « vоісе» може розглядатися як альтернатива більш ієрархічним формам управління, при яких адміністрація закладів освіти може приймати односторонні, виконавчі рішення практично без участі студентів, викладачів та батьків. Розуміння «Уоісе», також засноване

\footnotetext{
524 Kahu E. R. Framing student engagement in higher education. Studies in Higher Education, 2013. 38:5. P. 758-753. https://doi.org/10.1080/03075079.2011.598505

525 TSEP. URL: https://tsep.org.uk/what-we-do/

526 Student engagement. URL: https://tsep.org.uk/what-we-do/

527 Червона Л. Роль студентської спільноти у забезпеченні ефективного університетського врядування: теоретичні основи. Аналіз провідного вітчизняного та зарубіжного досвіду розвитку щодо механізмів реалізації ефективного врядування в університетах: препринт (аналітичні матеріали) (частина I). Київ: Інститут вищої освіти HАПН України, 2018. C. 76-100. URL: https://ihed.org.ua/wpcontent/uploads/2019/09/Analiz dosvidu vriaduvania $v$ univer ch1 analit IVO-2018-147p avtors-kolektiv.pdf

528 The Glossary of education reform for journalists, parents, and community members. URL: https://www.edglossary.org/about/
} 
на переконанні або визнанні того, що заклад освіти буде більш успішним, якщо адміністрація закладу освіти враховує цінності, думки, переконання та погляди всіх стейкхолдерів» ${ }^{529}$.

За визначенням A. Fletcher, «student voice» - це «будь-яке виявлення, будь-якого студента до всього, що пов'язане з освітою» ${ }^{530}$.

D. Harper, наголошує на тому, що «Студентський голос надає студентам можливість впливати на навчання, включаючи політику, програми, контексти й принципи» ${ }^{531}$.

Необхідність студентського голосу, як важливої умови успішного інституційного розвитку в освіті, обгрунтовував у своїх працях, ще Дж. Дьюї, який писав: “... чисто зовнішнє керівництво неможливе середовище у крайньому разі може надати стимули, які здатні викликати ті чи інші реакції. 3 іншого боку, самі реакції ґрунтуються на тенденціях, які вже є в індивіда ... Найбільш фундаментальними засобами управління $\epsilon$ не прямі особисті вказівки з боку інших людей, не повчання, а вплив на розум, що відбивається у звичках розуміння, що складається у процесі узгодженого з іншими людьми використання предметів. Це відбувається або як співробітництво і співдія, або як суперництво і змагання.. Досягти внутрішнього управління через залучення особистості до інтересів і уявлень спільноти й $€$ мета освіти» ${ }^{532}$.

Як відголос на ідеї Дж. Дьюї, бачимо визначення на сайті «The OU Students Association»: «Студентський голос - це думки та погляди студентів про навчання. Більшість закладів вищої освіти Великої Британії мають студентський голос, де студенти консультуються щодо їхнього досвіду навчання або дискусійних питань, які стосуються студентів. В університеті зазвичай $є$ міцні представницькі та студентські структури участі, студентські профспілки, гільдії чи асоціації, які дбають, щоб до студентів ставилися справедливо, щоб студенти були рівноправними партнерами у процесах прийняття рішень тощо. Студентський голос - це можливості для студентів отримувати неабиякий навчальний досвід та відчувати себе повноважними та активними членами академічної спільноти у процесах вдосконалення закладів освіти» ${ }^{533}$.

Традиційно в розумінні поняття «студентський голос» виокремлюють два аспекти. По-перше, це участь молоді, яка навчається, у процесах врядування, виробленні політики університету, прийнятті рішень, починаючи від стратегічних напрямів і закінчуючи вибором методики навчання за певною освітньою програмою: «Голос студентів дає студентам можливість впливати на навчання, включаючи політику, програми, контексти та принципи» ${ }^{534}$.

Другий підхід, сформований у практичній освітній діяльності університетів, як відзначають H. Young та L. Jerome 535, «зводить розуміння студентського голосу до циклу зворотного зв'язку. Відповідно до цього підходу студенти висловлюють свої думки щодо певних освітніх питань, університет приймає їх, певним чином реагує, потім, замикаючи коло, звітує студентам про реакцію на їх відгуки» ${ }^{536}$.

\footnotetext{
529 Voice. The Glossary of education reform for journalists, parents, and community members. URL: https://www.edglossary.org/voice/

530 Fletcher A. The Guide to Student Voice. Olympia, WA: Common Action Publishing. 2014. P. 2.

531 Harper D. Students as Change Agents: The Generation Y Model. Olympia, WA: Generation Y. 2000.

532 Дьюи Дж. Демократия и образование. М.: Педагогика пресс. 2000, 384 с.

533 The OU Students Association. URL: https://www.oustudents.com/what-is-student-voice

534 Harper, D. (2000). Students as Change Agents: The Generation Y Model. Generation Y.

535 Young, H. \& Jerome, L. (2020). Student voice in higher education: Opening the loop. British Educational Research Journal, 46 (3), $688-705$. 10.1002/berj.3603

536 Young, H. \& Jerome, L. (2020). Student voice in higher education: Opening the loop. British Educational Research Journal, 46 (3), $688-705$. 10.1002/berj.3603. P. 688
} 
538 :

L. Templeton та ін. ${ }^{537}$ констатують, що визначення студентського голосу має два основних компоненти

По-перше, «голос студента» означає, що студенти відчувають свою свободу волі у своїй здатності брати участь у прийнятті рішень в університетах.

По-друге, університети докладають зусиль, щоб прислухатися до голосу студентів, щоб думка студентів була не просто висловлена, а була почута, розглянута та врахована при прийнятті рішень.

Опираючись на публікації, дослідження та практику, National Campus Leadership Council ${ }^{539}$ розробила узагальнене визначення для «student voice» та означила ключові принципи:

««Student voice - це студентське агентство для реалізації та інституційного включення думок, ідей та переконань у спільне управління, а також до пов'язаних з прийняттям рішень процесів.

Основні принципи голосу студентів полягають у наступному:

- студентський голос має на меті представляти колективні думки, ідеї та погляди всіх студентів;

- представники голосу повинні володіти здатністю та мати можливість ділитися цими думками, ідеями та поглядами;

- лідери, які приймають рішення для закладу, повинні прислухатися до цих думок, ідей та поглядів.

Студентський голос - це коли студенти мають однакові можливості не просто бути почутими, але й діяти відповідно до своїх вимог» ${ }^{540}$.

J. Tyrrell ma S. Varnham описують різні моделі та механізми реалізації «студентського голосу», зазначаючи при цьому, що не існує єдиної найбільш ефективної моделі; кожен університет застосовує найбільш прийнятну для себе ${ }^{541}$ :

- представництво студентів в органах управління університету - Ради університету, інституту, факультету;

- діяльність студентів у керівних групах освітніх програм, обговорення процесів розроблення та реалізації освітніх програм;

- опитування студентів, фокус-групи тощо;

- співпраця з сильною і добре фінансованою незалежною студентською організацією;

- регулярні неформальні дискусії між студентами й викладачами та керівництвом університету (в рамках навчання, наставництва, підтримки чи окремих зустрічей).

Підсумовуючи, можемо зазначити, що "Student voice» $\epsilon$ загальною філософською й управлінською концепцією, яка заснована на визнанні того, що студенти мають власний унікальний погляд на освіту $i$ повинні мати можливість робити свій внесок у розвиток освіти та бути долученими до процесів прийняття рішень, висловлюючи свої погляди, впливаючи на результати та просуваючи свої ідеї.

\footnotetext{
537 Templeton, L., Smith A. \& MacCracken, A. A. (2019). Study on Student Voice in Higher Education. Diversity \& Democracy, 22 (1). https://www.aacu.org/diversitydemocracy/2019/winter/templeton

538 Templeton, L., Smith A. \& MacCracken, A. A. (2019). Study on Student Voice in Higher Education. Diversity \& Democracy, 22 (1). https://www.aacu.org/diversitydemocracy/2019/winter/templeton

539 National Campus Leadership Council. URL: https://www.campusleaders.org/nclc/about-us

540 Templeton L., Smith A., MacCracken A. A Study on Student Voice in Higher Education. Diversity \& Democracy, 2019. 22. № 1. URL: https://www.aacu.org/diversitydemocracy/2019/winter/templeton.

541 Tyrrell, J., Varnham, S. (2015). The student voice in university decision-making. In Varnham S., Kamvounias, P. \& Squelch, J. (Eds), Higher Education and the Law, (pp. 30-40). The Federation Press.
} 


\section{Участь студентів в університетському врядуванні: основні механізми та інструменти}

Виходячи з аналізу практик університетського врядування європейських та українських університетів ми виокремили два основних механізми, які забезпечують залучення та участь студентської спільноти в університетському врядуванні, це:

- механізм студентського представництва;

- та механізм зворотного зв'язку зі студентами.

До головних інструментів, які використовуються у межах вказаних механізмів для активізації участі студентів у процесах врядування в університетах ми віднесли: інформаційну підтримку студентів (інформування, навчання, консультування тощо) та затвердження на інституційному рівні певних документів, які складають політику партнерських відносин між студентами і університетом.

Питання, пов'язані з участю студентів в університетському врядуванні у кожній країні, в першу чергу регулюються законодавчими актами.

Наприклад, в Англії, це «The Higher Education and Research Act 2017» ${ }^{542}$, у Шотландії - «Higher Education Governance (Scotland) Act 2016» ${ }^{543}$, в Україні - Закон України «Про вищу освіту» ${ }^{544}$. У цих актах у загальному вигляді закріплюється право участі студентів в університетському врядуванні на інституційному рівні.

Так, наприклад, у Законі України «Про вищу освіту» 545 закріплені деякі аспекти участі студентів в університетському врядуванні через органи студентського самоврядування, а саме: «органи студентського самоврядування беруть участь в управлінні закладом вищої освіти у порядку, встановленому цим Законом та статутом закладу вищої освіти; беруть участь в обговоренні та вирішенні питань удосконалення освітнього процесу, науково-дослідної роботи, призначення стипендій, організації дозвілля, оздоровлення, побуту та харчування; беруть участь у заходах (процесах) щодо забезпечення якості вищої освіти; делегують своїх представників до робочих, консультативно-дорадчих органів; беруть участь у вирішенні питань забезпечення належних побутових умов проживання студентів у гуртожитках та організації харчування студентів; вносять пропозиції щодо змісту навчальних планів і програм; вносять пропозиції щодо розвитку матеріальної бази закладу вищої освіти, у тому числі з питань, що стосуються побуту та відпочинку студентів» (ст. 40, п. 5$)^{546}$.

Ґрунтуючись на наданих відповідним законодавчим актом можливостях, кожний університеті може використовувати власний набір механізмів та інструментів у частині студентського залучення до університетського врядування. Разом з тим, проаналізувавши практики студентського залучення деяких європейських та українських університетів ми побачили, що $є$ такі механізми, які тою чи іншою мірою застосовуються в кожному університеті, це: механізм студентського представництва та механізм зворотного зв'язку зі студентами.

Найпоширенішим механізмом залучення студентів до процесів університетського врядування $\epsilon$ студентське представництво. Цей механізм, по суті забезпечує взаємодію студентів із закладами освіти через представницькі структури та процеси, що функціонують насамперед як студентські організації (союзи, асоціації тощо). Фактично мова йде про забезпечення незалежного голосу студентів у рамках механізмів забезпечення якості та управління закладом. Цей елемент втілюється представництвом студентів у різних університетських структурах, але важливою $є$ не лише присутність студентів при прийнятті рішень, йдеться про підхід до участі студентів, який забезпечує залучення студентів до змін у партнерстві з усіма зацікавленими сторонами в їхніх установах.

\footnotetext{
542 The Higher Education and Research Act 2017. URL: http://www.legislation.gov.uk/ukpga/2017/29/contents

543 Higher Education Governance (Scotland) Act 2016. URL: http://www.legislation.gov.uk/asp/2016/15/contents

544 Закон України «Про вищу освіту» від 1 липня 2014 року № 1556-VII. URL: https://zakon.rada.gov.ua/laws/show/1556-18\#Text

545 Закон України «Про вищу освіту» від 1 липня 2014 року № 1556-VII. URL: : https://zakon.rada.gov.ua/laws/show/1556-18\#Text

546 Закон України «Про вищу освіту» від 1 липня 2014 року № 1556-VII. URL: : https://zakon.rada.gov.ua/laws/show/1556-18\#Text
} 
У загальному вигляді, студентське представництво в університетському врядуванні організоване як «пірамідальна система» із прямою демократією в основі та демократією делегатів (представників) на кожному наступному рівні. На низовому рівні - у студентській групі - застосовується пряма демократія, тобто всі студенти групи беруть участь у процесах обговорення та прийняття рішень (загальна влада), а на вищому рівні (інституту (факультету), відділення, гуртожитку, закладу вищої освіти) обрані представники від студентів виступають в ролі посередників при формуванні загальної думки (принцип представництва).

На практиці, структура студентських організацій в університетах України формується приблизно однаково, варіюються лише: назви органів, наприклад сенат, студентський парламент тощо; кількість комітетів; порядок формування тощо.

Колишній Голова студентської організації Київського національного університету культури $i$ мистецтв ${ }^{547}$ описував формування структури студентського самоврядування таким чином: «...Структура студентського самоврядування починає своє творення з академічної групи. Кожна група обирає свого представника до Студентського парламенту - старосту. Старости, своєю чергою, формують студентську раду факультету і обирають студентського декана як представника факультету в рамках діяльності президії студентського парламенту. Президія Студпарламенту обирає голову Студентського парламенту (президента), а президент обирає віце-президента (заступника), кандидатура якого також виноситься на голосування і має бути ухвалена президією. До президії входять голови комітетів Студентського парламенту. Комітетів у Студпарламенті 10, серед них: навчально-виховний, благодійний, соціально-побутовий, інформаційний, культурно-творчий, спортивно-оздоровчий, науковий, туристичний та ін. Представники Студентського парламенту входять до складу Вченої ради університету і мають право голосу...» ${ }^{548}$.

У цілому, до механізму студентського представництва відносяться такі процеси як:

- вибори та демократичні процеси, які відбирають та інформують студентських лідерів;

- системи, процеси та події для забезпечення зв'язку зі студентами та студентськими поглядами, що виникають в інших сферах участі студентів (наприклад, представники факультету, студентські конференції);

- формальне представництво в інституційних комітетах та участь у процесах забезпечення та підвищення якості;

- неформальний зв'язок із керівництвом університету, стратегічні дні, регулярні основні групи зв'язку тощо;

- інституційна підтримка розвитку та діяльності студентських організацій.

Для того, щоб студентські представники могли ефективно виконувати свої представницькі функції, та для активізації участі студентів в процесах врядування в університетах застосовуються різні інструменти: інформаційна підтримка, консультації тощо.

Наприклад, в University of Cambridge ${ }^{549}$ на сайті Cambridge University Student Union (CUSU) ${ }^{550}$ (Сою3 студентів), розміщена розгалужена мережа інформації та підтримки для студентів. А саме:

Guide to Being a Rep - посібник для всіх студентських представників:

- що має на меті ознайомити студента з його роллю на обраній посаді, показати це у ширшому контексті структури університету;

- навчає як бути успішним представником студентства;

- розповідає про події та обов'язки, про можливі питання та проблеми, з якими може стикнутися студентський представник та як можливі проблеми можна вирішувати.

Network and training - інформаційний ресурс на якому подається інформація про тренінги, різні інші заходи, які заплановані на рік.

\footnotetext{
547 Київський національний університет культури і мистецтв. URL: http://knukim.edu.ua/

548 Студентське самоврядування - важливий фактор розвитку якісної освіти. URL: http://knukim.edu.ua/studentske-samovryaduvannyavazhliviy-faktor-rozvitku-yakisnoyi-osviti/

549 University of Cambridge. URL:https://www.cam.ac.uk/

550 Cambridge University Student Union. URL: https://www.cusu.co.uk/
} 
Resources Hub - центр ресурсів, на якому представлено широкий перелік документів, необхідних для практичної роботи студентського представника.

Окрім інформаційної підтримки для представників студентів, $€$ й інші ресурси для студентів, наприклад:

«- студентський шлюз (The Student Gateway) - допомагає студентам орієнтуватися у складній інституційній структурі університету; Page);

- сторінка академічних ресурсів Служб студентських послуг (Student Advice Service Academic Resources

- портал навичок університету пропонує презентації, путівники та тренінги для вдосконалення навичок навчання;

- Transkills - працює з викладачами та студентами, щоб полегшити перехід магістрантів першого курсу від попереднього досвіду навчання до навчання в університеті;

- Training@Cama - забезпечує підготовку до всіх видів навичок, включаючи веб-дизайн, управління фінансами або вступ до Microsoft Excel. Більшість з них доступні безкоштовно» ${ }^{551}$.

Ще одним центром підтримки для студентів у цьому університеті $€$ «The Students' Union' Advice Service» 552 - Консультативна служба «Союзу студентів», яка надає конфіденційні, незалежні та неупереджені послуги студентам університету.

B University of Oxford ${ }^{553} \in$ кілька інструментів спрямованих на підтримку студентів.

University Student Handbook 2019/20 (Довідник студента університету 2019/20) ${ }^{554}$. Видається на кожний навчальний рік і $€$ у відкритому доступі на сайті університету. В довіднику надається загальна інформація та рекомендації, які можуть знадобитися студентам для максимального використання можливостей в університеті. У довіднику також є пояснення кодексів, правил та процедур університету;

Student Advice Service (служба консультацій для студентів) або Student Advice (довідка для студентів) ${ }^{555}$. Student Advice - це єдина незалежна консультативно-інформаційна послуга, доступна виключно студентам University of Oxford. Кожен студент може переглядати бази даних довідки або подати електронний лист, щоб поговорити з радником.

Resource Hub ${ }^{556}$ (ресурсний центр), де розміщено багато електронних ресурсів (тренінги, посібники, відеоуроки) на найрізноманітніші теми, що можуть бути корисними або цікавими для студентів. У тому числі посібники для обраних студентських представників та для студентів, які мають бажання бути обраними представниками тощо.

В University of Edinburg 557 Асоціація студентів запровадила студентські нагороди, для відзначення досягнень студентів у різних номінаціях, наприклад, нагорода студентського партнерства або нагорода за внесок у розвиток місцевих громад тощо ${ }^{558}$.

Відносно інформаційної роботи та роботі з підтримки студентів в університетах України, зазначимо, що у кожному університеті є власні напрацювання.

Наприклад, у Київському національному університеті імені Тараса Шевченка 559 - це проєкт «Студкуратор» від Студентського парламенту Університету (СПУ):

551 Navigating resources and support at both the University and your College might seem complex. URL: https://www.cusu.co.uk/support/welfare/academic-resources/

552 The Students' Union' Advice Service. URL: https://www.cusu.co.uk/support/students-unions-advice-service/

553 University of Oxford. URL: https://www.ox.ac.uk/

554 University Student Handbook 2019/20. URL: https://www.ox.ac.uk/students/academic/student-handbook?wssl=1

555 Student help. URL: https://www.oxfordsu.org/wellbeing/student-advice/

556 Resource Hub. URL: https://www.oxfordsu.org/resourcehub/

557 The University of Edinburg. URL: https://www.ed.ac.uk

558 Student Awards. URL: https://www.eusa.ed.ac.uk/studentawards/

559 Київський національний університету імені Тараса Шевченка. URL: http://knu.ua 
«створений для наших першокурсників. Це люди, які допомагають новеньким адаптуватися до студентства, дізнатися особливості життя в гуртожитку та університеті» ${ }^{560}$.

У Національному технічному університеті України «Київський політехнічний інститут імені Ігоря Сікорського» ${ }^{561}$ - це «Шпаргалки для студентів»:

«... проєкт покликаний поліпшити життя КПІшників. Це корисні поради з різних питань, які стануть у пригоді кожному студенту» ${ }^{562}$.

У Харківському національному університеті імені В.Н. Каразіна 563 реалізовано «Пам'ятки для студентів з питань освітньої та позаосвітньої діяльності». Це документ, в якому зібрана важлива інформація для студентів, така, як ${ }^{564}$ :

визначення основних термінів (студент, академічна відпустка, академічна недоброчесність);

питання, пов'язані з оцінюванням знань під час навчання (система оцінювання, як діяти студенту якщо він не згоден з отриманою оцінкою);

права студентів, серед яких:

- участь в обговоренні та вирішенні питань удосконалення освітнього процесу, науково-дослідної роботи, призначення стипендій, організації дозвілля, побуду оздоровлення;

- участь у діяльності органів громадського самоврядування університету, факультетів (навчальнонаукових інститутів, центрів), вченої ради університету, вчених рад факультетів, органів студентського самоврядування» та їх обов'язки;

заходи, що вживаються за порушення академічної доброчесності;

обов'язки куратора групи;

правила відрахування та поновлення навчання в університеті;

житлово-побутові питання;

інформація про студентські організації університету: профспілкову організацію студентів, аспірантів і докторантів та студентське самоврядування (де серед основних напрямів діяльності вказується участь в управлінні університетом, участь в обговоренні та вирішенні питань удосконалення освітнього процесу, у забезпеченні та контролі якості освітнього процесу, внесення пропозицій щодо вдосконалення змін у навчальних планах і програмах) тощо.

Створення та розповсюдження подібних проєктів є гарним прикладом того, як університет може сприяти інформаційній підтримці власних студентів. Дуже важливо, щоб студенти:

- знали свої права та обов'язки під час навчання в університеті та розуміли, яким чином ці права можуть бути реалізовані;

- усвідомлювали власну відповідальність (що є невіддільним атрибутом свободи);

- були ознайомлені з організацією освітнього процесу в університеті, правилами призначення стипендій тощо.

Звісно, вище зазначена інформація $€$ у Положеннях та Правилах університету, $є$ публічною та доступною, але зібрана в одному документі, вона значно полегшує доступ студентам до важливих для них знань щодо їх освіти, від яких, на наш погляд, значною мірою залежить розвиток демократичного університетського середовища. Останнє, у свою чергу, $\epsilon$ необхідною умовою розвитку механізму представництва та партнерських відносин зі студентами.

560 Студкуратор. Київський національний університету імені Тараса Шевченка. URL: http://sp.knu.ua/studkurator-2/

561 Національний технічний університет України «Київський політехнічний інститут імені Iгоря Сікорського». URL: https://kpi.ua

562 Шпаргалки для студентів. Національний технічний університет України «Київський політехнічний інститут імені Ігоря Сікорського». URL: https://kpi.ua/scholarships-about

563 Харківський національний університет імені B.H. Каразіна. URL: https://www.univer.kharkov.ua

${ }^{564}$ Пам'ятка для студентів. Харківський національний університет імені B.H. Kapaзіна. URL: https://www.univer.kharkov.ua/docs/work/pamyatka2018.pdf 
Щодо рекомендацій для покращення такої підтримки, на наш погляд, також варто було б додати посилання на розширені інформаційні ресурси. Наприклад, проголошуючи право студентів брати участь в обговоренні та вирішенні питань удосконалення освітнього процесу, слід прояснити механізми, як саме це право може бути застосовано на практиці, адже поки що вони залишаються незрозумілими для студента.

Дієвим інструментом для забезпечення участі студентів в університетському врядуванні $\epsilon$ вироблення і затвердження на інституиійному рівні певних документів, які складають політику партнерських відносин між студентами й університетом.

Наприклад, в шотландському університеті University of Edinburg ${ }^{565}$ розроблено і прийнято «Угоду про nартнерство зі студентами» (Student Partnership Agreement) ${ }^{566}$, в якій викладені цінності, підходи до партнерства та пріоритети співпраці.

Загалом, зобов'язання працювати у партнерстві зі студентами можуть бути в загальному вигляді сформульовані в таких документах як:

- Стратегічний план університету;

- Стратегія навчання та викладання в університеті.

Поряд з цим прийняття окремої Угоди про партнерство зі студентами дає можливість більш чітко визначати та врегульовувати різні аспекти цього партнерства та окреслити мету задля якої це робиться та основні принципи.

Для прикладу, в «Угоді про партнерство зі студентами» в University of Edinburg зазначається, що «співробітники університету працюють у партнерстві з Асоціацією студентів для того, щоб студенти займали центральне місце в:

- управлінні та прийнятті рішень;

- забезпеченні якості та підвищення якості,

- наданні студентам можливостей стати активними учасниками процесів врядування,

- сприянні співпраці студентів та персоналу» 567.

У цьому ж документі серед основних принципів партнерства зі студентами названі досконалість, запит, спільнота та включення / інклюзія, відповідальність. Деталізація змісту цих принципів $\in$ такою ${ }^{568}$ :

«Досконалість (Excellence) - ми прагнемо досконалості в освіті, очікуємо найвищих стандартів наших викладачів і студентів, визнаємо високу якість навчання. Ми хочемо бути відомими на національному та міжнародному рівнях за якість нашого викладання та якість наших випускників.

Запит (Inquiry) - в університеті підтримується підхід до навчання, заснований на запитах та дослідженнях. В університеті вітаються та заохочуються незалежні, критичні дослідники. Наша досконалість у дослідженні покращує наше навчання і ми вважаємо, що кожен студент є активним дослідником.

Спільнота (Community) - усі ми є членами спільноти, що базується на співпраці, взаємодії та підтримці один одного. Наш зв'язок поширюється на різні дисципліни й за межами університету до наших випускників та зовнішніх партнерств ...

Включення (Inclusion) - ми відзначаємо різноманітність нашої університетської спільноти. Цінуємо і поважаємо один одного. Створюємо сприятливе середовище, в якому всі члени нашої громади мають можливість реалізувати свій потенціал.

Відповідальність (Responsibility) - в університеті пропагуються найвищі стандарти індивідуальної поведінки та особистої підзвітності, гарантуючи, що ми діємо етично. Усі ми несемо відповідальність за розвиток студентського досвіду, включаючи конструктивне залучення та отримання зворотного зв'язку, щоб позитивно покращити досвід університету для нинішніх та майбутніх студентів».

565 University of Edinburg. URL: https://www.ed.ac.uk

566 Student Partnership Agreement. URL: https://www.ed.ac.uk/files/atoms/files/studentpartnershipagreement.pdf

567 Student Partnership Agreement. URL: $\underline{\text { https://www.ed.ac.uk/files/atoms/files/studentpartnershipagreement.pdf }}$

568 Student Partnership Agreement. URL: https://www.ed.ac.uk/files/atoms/files/studentpartnershipagreement.pdf 
569 :

Також в Угоді наводяться приклади роботи в партнерстві як на рівні університету, так і на рівні студентів

«Залучення університетського рівня:

- система представництва студентів;

- участь студентів у комітетах усіх рівнів університету;

- участь студентів у групах із завданнями та проєктами;

- участь студентів у процесі внутрішнього періодичного огляду, включаючи повне членство оглядових

груп.

Ініціативи, що проводяться студентами, включаючи, але не обмежуючись ними:

- навчання та підтримка однолітків;

- індивідуально створені курси для студентів (SLICC);

- нагороди за вплив, визнаючи видатних студентських лідерів та партнерські стосунки студентів та співробітників на кампусі;

- нагороди за діяльність, щоб відзначити та продемонструвати, що робить університет привабливим місцем для досвіду, який він пропонує і визнати внесок, який товариства та волонтерство вносять в університет та університетську громаду;

- студентські групи, які надають підтримку та представництво для маргіналізованих та недостатньо представлених студентських спільнот».

В університетах України політика партнерських відносин між студентами й університетом ще не вийшла на рівень прийняття угод про партнерство зі студентами. Проте у таких документах як етичний кодекс чи стратегічний план розвитку університету, прямо чи опосередковано підіймаються питання партнерства зі студентами.

Наприклад, в «Етичному кодексі університетської спільноти» Київського начіонального університету імені Тараса Шевченка, дається визначення:

«Університетська спільнота - професорсько-викладацький склад, адміністрація Університету та його структурних підрозділів, наукові працівники, слухачі підготовчих відділень, студенти, аспіранти, докторанти, навчально-допоміжний персонал, працівники адміністративно-господарської частини» 570 .

У Кодексі також прописано, що порушення етичних принципів і норм передбачає відповідальність члена університетської спільноти, описана процедура розгляду порушень та склад «Комісії з етики» - «з дев' яти осіб: трьох представників професорсько-викладацького складу та наукових працівників, двох представників студентів, одного представника аспірантів та докторантів, одного представника адміністрації та двох представників навчально-допоміжного персоналу» ${ }^{571}$. Як бачимо, і студенти, і викладачі, і адміністрація визначаються як рівні, ставляться на один щабель, і попри відсутність прямого згадування про партнерські відносини між членами університетської спільноти, ми можемо говорити, що сама ідея партнерства в соціокультурному просторі університету вже закладена.

У Кодексі честі Національного технічного університету України «Київський політехнічний інститут імені Ігоря Сікорського» вже у Загальних положеннях прямо говориться про партнерство між студентами й викладачами ${ }^{572}$ :

\footnotetext{
569 Student Partnership Agreement. URL: https://www.ed.ac.uk/files/atoms/files/studentpartnershipagreement.pdf

570 Етичний кодекс університетської спільноти. Ухвалений на Конференції трудового колективу Київського національного університету імені Тараса Шевченка. Протокол № 2 від 27.12.2017 року. URL: http://www.univ.kiev.ua/pdfs/official/ethical-code/Ethical-code-of-theuniversity-community.pdf

571 Етичний кодекс університетської спільноти. Ухвалений на Конференції трудового колективу Київського національного університету імені Тараса Шевченка. Протокол № 2 від 27.12.2017 року. URL: http://www.univ.kiev.ua/pdfs/official/ethical-code/Ethical-code-of-theuniversity-community.pdf

572 Кодекс честі Національного технічного університету України «Київський політехнічний інститут імені Ігоря Сікорського». (2015). Ухвалений Конференцією трудового колективу НТУУ «КПІ» 09 квітня 2015 року. URL: https://kpi.ua/code
} 
«... Принцип партнерства і взаємодопомоги. 3 метою підвищення якості навчальних та дослідницьких результатів представники університетської громади орієнтуються на суб'єкт-суб'єктну або партнерську взаємодію».

У прописаних нормах етичної поведінки студентів і працівників НТУУ «КПІ» наголошується на важливості «сприяти становленню та розвитку партнерських відносин між викладачами й студентами університету» ${ }^{573}$.

Таким чином, сама ідея партнерства та залучення студентів до процесів врядування в українських університетах закладена переважно на ціннісному рівні та $€$ першою сходинкою на шляху вироблення і затвердження документів, що надалі складатимуть політику партнерських відносин між студентами та університетом.

Важливим механізмом участі студентів в університетському врядуванні є зворотний зв'язок зі студентами або реагування на студентський голос. Найпоширенішими інструментами для отримання зворотного зв'язку в університетах $€$ опитування, анкетування, фокус-групи, онлайн-платформи через які кожний студент може подати свою пропозицію (ідею), заповнивши спеціальну форму тощо.

На сайті University of Oxford ${ }^{574} \in$ веб-сторінка Student engagement (студентське залучення) де представлені інструменти залучення, які по суті є реальними практиками поширеними в даному університеті 575 , опис яких подано нижче.

Чай з віце-канилером (Tea with the Vice-Chancellor). Віце-канцлер проводить серію пообідніх чаїв, для того, щоб зустрітися зі студентами різних коледжів. Чаї проходять протягом усього навчального року. Вони організовуються студентськими, аспірантськими і дослідницькими групами коледжів, які і обирають студентів для участі у цих заходах. Віце-канцлер проводить відкриті годинні зустрічі чотири рази на рік. Але студенти університету можуть запросити 15-хвилинну зустріч для обговорення будь-якої теми. Зустрічі проводяться в Офісі віце-канцлера. Інформацію про майбутні дати й запити на зустріч можна дізнатися на веб-сайт університету (сторінка віце-канцлера).

Cтудентський барометр (Student Barometer). Це внутрішньо університетське опитування всіх студентів та аспірантів, яке дає можливість висловитися всім студентам і отримати повну картину щодо різних аспектів університетського життя. Результати опитування студентського барометра публікуються на сайті університету та аналізуються на конфіденційній та анонімній основі широким спектром кафедр / факультетів, коледжів та центральних служб в університеті. При цьому враховуються як кількісні, так і якісні відгуки. Студентські коментарі дають можливість оцінити досвід та побачити напрямки для змін та вдосконалень.

Студентський барометр - випуск фіналістів (Student Barometer - Finalist Edition). Студентський Барометр «Випуск Фіналіста» це опитування студентів, які знаходяться на останньому курсі навчання. Це опитування проводиться окремо від Національного опитування студентів (NSS) і підтримується Oxford SU. Результати опитування публікуються на сайті університету. Кафедри та факультети проводять опитування щодо окремих навчальних дисциплін і використовують анкети, щоб отримати відгуки про якість занять.

Думки студентів також представлені спільними консультативними комітетами студентів і аспірантів. Коледжі збирають відгуки від студентів за допомогою анкет.

Student Advisory Group (Консультативна група для студентів) ${ }^{576}$. Студентська консультативна група працює спільно з Oxford SU 577 (Оксфордським студентським союзом) та University's Academic Administration Division $^{578}$ (Відділом академічної адміністрації університету). Це група до 40 студентів, які збираються один раз

\footnotetext{
573 Кодекс честі Національного технічного університету України «Київський політехнічний інститут імені Ігоря Сікорського». (2015). Ухвалений Конференцією трудового колективу НТУУ «КПI» 09 квітня 2015 року. URL: https://kpi.ua/code

574 University of Oxford. URL: https://www.ox.ac.uk/

575 Student engagement. URL: https://www.ox.ac.uk/students/life/student-engagement?wssl=1

576 Student Advisory Group. URL: https://www.ox.ac.uk/students/life/student-engagement?wssl=1

577 Oxford SU. URL: https://www.oxfordsu.org/

578 University's Academic Administration Division. URL: https://academic.admin.ox.ac.uk/about/aad
} 
на семестр, щоб обговорити студентські заходи, нові ініціативи, зміни в університетських процесах тощо. Члени групи обрані для представлення студентської когорти університету. Між зустрічами члени групи також контактують для повного опитування, пов'язаного з їхнім університетським досвідом. Відгуки групи сприяють покращенню комунікацій, засобів та послуг університету. Члени групи вибираються за відповідним досвідом та готовністю брати активну участь у групі, намагаючись водночас забезпечити якомога різноманітніший спектр студентів. Робота консультативної групи сприяє покращенню комунікації, засобів і можливостей університету.

В університеті University of Cambridge 579 поширеними практиками, що забезпечують зворотний зв'язок зі студентами є наступні:

- кафедри та викладачі зазвичай використовують форми оцінювання для своїх навчальних дисциплін;

- представники від студентів є у більшості університетських комітетів;

- часто проводяться фокус-групи зі студентами з актуальних питань;

- проводяться комплексні опитування студентів університету.

Під час останнього курсу студентам пропонують взяти участь у щорічному загальнонаціональному опитуванні студентів National Student Survey (NSS) ${ }^{580}$. Дане опитування $є$ анонімним і проводиться для того, щоб студенти оцінили якість навчання. Для цього пропонується певний перелік питань по таким темам як:

- можливості навчання;

- оцінювання і зворотний зв'язок;

- академічна підтримка;

- організація і врядування;

- навчальні ресурси;

- навчальна спільнота;

- студентський голос;

- загальний рівень задоволеності.

Кожен університет також може додати до опитування до 6 наборів додаткових запитань з банку NSS i два запитання для конкретного закладу вищої освіти.

Студентів, які навчаються не на останньому курсі, просять взяти участь в опитуванні Student Barometer 581 (SB). Це опитування призначене для того, щоб допомогти університету підвищити якість шляхом систематичного і зручного збору відгуків від студентів, які ще навчаються. Онлайн-опитування пропонує студентам оцінити їх рівень задоволеності і надати коментарі з різних аспектів студентського життя Слід зазначити, що результати опитувань не лише ретельно вивчаються Комітетом з освіти та оприлюднюються на сайті університету, але робляться конкретні кроки по поліпшенню ситуації з тих питань, які викликають незадоволення студентів.

Ще одним механізмом реагування на студентський голос $є$ інструмент «l have an idea» ${ }^{582}$. Це онлайнплатформа на сайті Cambridge University Students' Union (CUSU), через яку кожний студент може подати свою пропозицію (ідею), заповнивши спеціальну форму. Задум такого звернення ґрунтується на можливості для кожного студента бути почутим та впровадити в життя свої пропозиції чи ідеї, спрямовані на зміни в університеті.

\footnotetext{
579 University of Cambridge. URL:https://www.cam.ac.uk/

580 National Student Survey. URL: https://www.educationalpolicy.admin.cam.ac.uk/student-engagement/university-wide-surveys/nss

581 Student Barometer. URL: https://www.educationalpolicy.admin.cam.ac.uk/student-engagement/university-wide-surveys/studentbarometer-survey

${ }^{582}$ I have an idea. CUSU. URL: https://www.cusu.co.uk/?s=l+have+an+idea
} 
Університети України також застосовують різні інструменти для забезпечення зворотного зв'язку зі своїми студентами.

«Електронна приймальня університету», яка розміщена на веб-сайті Київського національного університету імені Тараса Шевченка.

Дана онлайн платформа дає можливість «...надіслати звернення, що стосуються всіх сфер діяльності університету: навчального процесу, наукової діяльності, міжнародних зв'язків, фінансової діяльності та отримати на них відповідь.

Для цього потрібно натиснути на кнопку «Надіслати звернення» й заповнити реєстраційну форму. Протягом декількох днів на Вашу електронну пошту надійде відповідь, а найбільш поширені звернення разом із відповідями будуть опубліковані в розділі «Популярні запитання» ${ }^{583}$.

В університеті $€$ також окреме «Положення про роботу Електронної приймальної Київського національного університету імені Тараса Шевченка» та визначені правила, в яких детально прописується процедура подання та розгляду звернення.

Інформаційно-телекомунікаційна система «Електронний кампус», що діє в Національному технічному університеті України «Київський політехнічний інституті імені Ігоря Сікорського» являє собою 584 .

«...прикладне програмне забезпечення, яке $\epsilon$ елементом інформаційно-телекомунікаційного середовища університету та використовується для інформаційної підтримки повсякденної діяльності студентів, викладачів, співробітників університету, а так само для інформаційної підтримки всіх видів інноваційної діяльності в університеті (далі - ІТС ЕК).

ITC ЕК об'єднує внутрішні інформаційні ресурси (навчальні, методичні та інші), надає централізований доступ до них на основі єдиних системних і технологічних рішень та забезпечує їх використання для ефективного управління та планування науково-освітнім процесом.

ITC ЕК забезпечує виконання таких основних функцій:

- багатобічна комунікація між студентами, викладачами, науковою спільнотою;

- формування єдиного інформаційного ресурсу, що показує стан науково-освітнього процесу університету;

- забезпечення своєчасного та оперативного розміщення повної, об'єктивної, достовірної та несуперечливої інформації про освітній процес університету;

- розповсюдження інформації про майбутні події й заходи та інші довідкові відомості;

- забезпечення централізованого і зручного доступу до відомостей про діяльність ректорату і підрозділів університету;

- забезпечення навігації по всьому інформаційному наповненню ITC ЕК;

- організація взаємодії та інформаційного обміну між ITC ЕК та іншими інформаційними ресурсами і системами університету.

У системі ITC ЕК розроблені віртуальні кабінети за профілями користувачів: студент, викладачнауковець, методист кафедри».

583 Електронна приймальна університету. Київський національний університету імені Тараса Шевченка. URL: https://office.knu.ua/

584 Електронний кампус. Національний технічний університет України «Київський політехнічний інститут імені Iгоря Сікорського». URL: https://ecampus.kpi.ua/about 
В європейських університетах набуває поширення практика збору, оброблення інформації та реагування на голос студента (індивідуальні та колективні погляди студентів).

В університеті University of Edinburg ${ }^{585}$ розроблено окремий документ Student Voice Policy (Політика студентського голосу) ${ }^{586}$, в якому описані ключові принципи збору думок студентів, деталізуються різні аспекти студентського опитування, описані механізми зворотного зв'язку зі студентами та участь студентів у внутрішніх періодичних оглядах з підтримки студентів, їх вивчення, а головне реагування на голос студентів.

Зокрема у документі зазначається, що «... основна мета збору думок студентів - забезпечити якість навчання, викладання та обслуговування студентів, а також підвищити студентський досвід. ... Методи, що використовуються для опитування думки студентів, не повинні обмежувати участі жодного студента, а також мають забезпечити однакові можливості для всіх студентів ... Опитування студентів повинно проводитися в рамках суворих етичних правил. Цілісність даних повинна підтримуватися шляхом систематичних підходів до збору та управління. Необхідно забезпечити конфіденційність та анонімність респондентів. Студенти повинні бути поінформовані про мету опитування та використання даних, які можуть бути використані» 587.

Надзвичайно важливо, щоб зворотний зв'язок зі студентами в університеті не обмежувався збором думок студентів, а щоб дії, вжиті у відповідь на опитування думок студентів чи їхні звернення, були чітко та ефективно передані студентам. Інформування студентів про те, як їх відгуки вплинули на поліпшення університетської інфраструктури чи освітнього процесу, по суті $€$ «замиканням циклу» зворотного зв'язку зі студентами в університеті. «Замикання циклу» надає механізму зворотного зв’язку вигляду завершеного циклу, а також забезпечує студентам відчуття, що їх відгуки оцінюються, розглядаються та використовуються для вдосконалення і вони чітко розуміють дії, які вживає університет у відповідь на їх відгуки.

Таким чином, університети застосовують різні механізми та інструменти для забезпечення студентської участі в університетському врядуванні. Водночас, попри наявність чи відсутність того чи іншого механізму, роль яка відводиться студентам в університеті може бути різною.

Унаочнюючим прикладом різних ролей студентів $\epsilon$ розроблені шотландськими колегами Student partnership staircase (Сходинки студентського партнерства) ${ }^{588}$ (рис. 2).

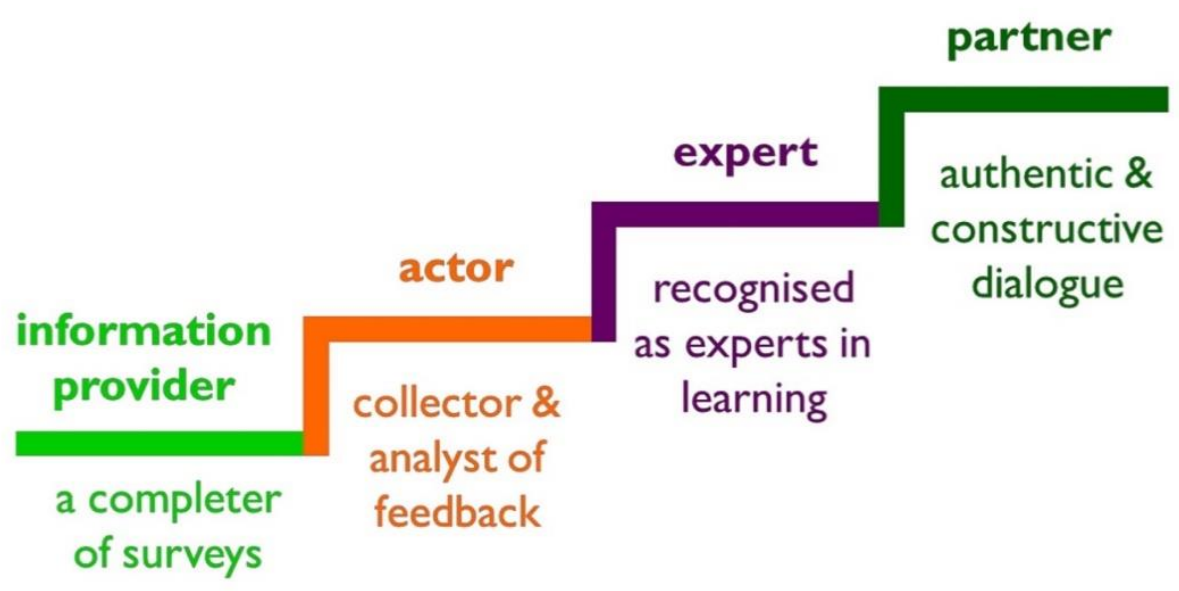

Puc. 2. Student partnership staircase

\footnotetext{
585 The University of Edinburg. URL: https://www.ed.ac.uk

586 Student Voice Policy. URL: https://www.ed.ac.uk/files/atoms/files/studentvoicepolicy.pdf

587 Student Voice Policy. URL: https://www.ed.ac.uk/files/atoms/files/studentvoicepolicy.pdf

588 Student partnership staircase. URL: https://www.sparqs.ac.uk/ch/Student\%20partnership\%20staircase.pdf
} 
Сходинки показують рівні залучення студентів до процесів університетського врядування, а смае визначають чотири таких рівні:

- Постачальник інформації (участь в опитуваннях).

- Актор (контролює й аналізує зворотний зв'язок).

- Експерт (визнаний експертами в навчанні).

- Партнер (автентичний та конструктивний діалог).

Перший рівень, це коли студенти можуть на базовому рівні просто надавати інформацію своєму навчальному закладу шляхом заповнення опитування. Другий рівень передбачає, що студент бере на себе більш просунуті ролі, такі як володіння інструментами зворотного зв'язку. Третій рівень, коли студент має законний голос у якості експерта щодо навчання. I четвертий рівень, це роль реального партнера діалозі задля покращення і розвитку університету.

Іншими словами, Сходинки студентського партнерства візуалізують динаміку, за якою може розвиватися роль студентів від найнижчої сходинки «постачальник інформації», коли залучення студентів зводиться до участі в опитуваннях, до найвищої сходинки - «партнера», коли участь студентів відбувається на рівні конструктивного діалогу. I хоча не кожен студент буде виступати у якості партнера весь час, а деякі можуть ніколи не робити більше, ніж бути постачальником інформації, ці Сходинки є основою для обговорення способів, за допомогою яких університети та студентські асоціації можуть міркувати про роль, яку студенти відіграють і повинні відігравати, а також про структури і культуру, які сприяють розвитку партнерства ${ }^{589}$.

589 Student partnership staircase. URL: https://www.sparqs.ac.uk/resource-item.php?item=254 


\section{Висновки}

1. Участь студентів у творенні Європейського простору вищої освіти (ЄПВО) розглядається як критично важлива характеристика вищої освіти в Європі, а залучення студентів та інших зацікавлених сторін до процесів університетського врядування $€$ заявленою цінністю Болонського процесу та умовою побудови ЄПВО.

Україна є учасницею цих процесів, тому проблеми й питання, пов'язані з участю студентства у реалізації ефективного врядування в університетах України, на часі актуальні. Крім того, важливо акцентувати увагу на тому, що завдання реформування університетського врядування з метою досягнення його найбільшої ефективності, враховуючи, з одного боку, реалії українського суспільства, а з іншого - світові освітні тенденції, $€$ можливим лише за умови концентрації зусиль усіх стейкхолдерів вищої освіти, починаючи від держави, адміністрації університету, викладацького складу, студентства, батьків, роботодавців тощо.

Даний аспект підкреслено і у проєкті «Стратегії розвитку вищої освіти в Україні на 2021-2031 роки»: «Забезпечення посилення ролі академічної громади (студенти, викладачі, дослідники) і громадськості в управлінні 3ВО» 590 .

Спільна відданість справі - побудувати ефективне врядування в університетах - може стати суттєвим фактором відновлення довіри до університетів України та усвідомлення й зростання їх ролі як стратегічно важливих соціокультурних інституцій сучасного суспільства, що, своєю чергою, забезпечить підтримку з боку громадськості відповідних реформ. На наш погляд, участь (англ. participation) всіх зацікавлених сторін в управлінні університетом постає як важливий аспект в контексті змін, що відбуваються в університетському управлінні, з акцентуванням на понятті «партнерство». Співучасть в управлінні побудована на партнерстві, $\epsilon$ освітнім і соціальним процесом, і обов'язково повинна бути взята до уваги на всіх щаблях освітньої системи.

2. Студентська спільнота відіграє важливу роль у забезпеченні ефективного університетського врядування. У суспільній свідомості поступово відбувається зміна розуміння ролі студентів в освітньому процесі. Із суб'єктно-об'єктної парадигми у відношеннях між студентами й університетом, в якій студентам відводилась роль пасивного об'єкта, відбувається перехід до суб'єкт-суб'єктних відносин, де студенти розглядаються як повноправні партнери в освітній сфері.

Основу для побудови моделі ефективного врядування у сучасних університетах складають демократичні ідеї. А теоретичним підґрунтям для забезпечення участі студентів в університетському врядуванні, на наш погляд, постає теорія учасницької (партисипаторної) демократії, виконуючи функцію універсального принципу організації університету, як соціальної системи, коли широка суспільна партисипація втілюється у свідомій, активній участі всіх зацікавлених сторін (в тому числі й студентів) у процесах формування, вироблення та реалізації управлінських рішень.

Крім того, вихідною концептуальною ідеєю для аналізу проблем, пов'язаних з участю студентів в університетському врядуванні, $є$ ідея партнерства у контексті університетського середовища. Тобто, лише коли в університетській спільності студенти сприймаються як партнери, і самі студенти відчувають цю роль, ми можемо говорити про ефективність створених можливостей (політик, механізмів, процедур, інструментів тощо) для участі студентів з боку університету і про особистісну мотивацію самих студентів долучатися до університетського врядування. Такий підхід, найбільш відповідає одному з завдань у побудові ЄПВО, а саме широкому залученню усіх учасників університетської спільноти до процесів формування, вироблення та реалізації життєво важливих рішень.

590 Стратегія розвитку вищої освіти України на 2021-2031 роки (проєкт). Міністерств освіти і науки України, 2020. URL: https://mon.gov.ua/storage/app/media/rizne/2020/09/25/rozvitku-vishchoi-osviti-v-ukraini-02-10-2020.pdf 
3. Важливим є концептуальне уточнення ключових понять, які вживаються дослідниками при вивченні теми студентської участі.

Участь студентів в університетському врядуванні, є діяльністю студентів (прямою чи опосередкованою), спрямованою на те, щоб впливати на процеси прийняття управлінських рішень у межах університету. Уточнимо, що, ми підходимо до студентського залучення / участі («student engagement») як до взаємного процесу вдосконалення (тобто зусилля прикладаються, як з боку університету, так і з боку студента(ів)). Результатом мають бути позитивні зміни (вдосконалення, покращення) для університету як інституції (вироблення ефективних політик, покращення управлінських структур тощо) та для студента як особистості (отримання досвіду, навичок тощо).

Відтак і студентський голос («student voice») постає як загальна філософська і управлінська концепція, яка заснована на визнанні того, що студенти мають власний унікальний погляд на освіту і повинні мати можливість робити свій внесок у розвиток освіти та бути долученими до процесів прийняття рішень, висловлюючи свої погляди, впливаючи на результати та просуваючи свої ідеї.

4. Виходячи з аналізу практик університетського врядування європейських та українських університетів ми виокремили два основних механізми, які забезпечують залучення та участь студентської спільноти в університетському врядуванні: механізм студентського представництва та механізм зворотного зв'язку зі студентами.

До головних інструментів, які використовуються у межах вказаних механізмів для активізації участі студентів у процесах врядування в університетах нами віднесено: інформаційну підтримку студентів (інформування, навчання, консультування тощо) та затвердження на інституційному рівні певних документів, які складають політику партнерських відносин між студентами і університетом.

Розглянувши практики студентського залучення в європейських університетах, ми побачили, що представники студентів $€$ невід'ємною частиною структури управління в університеті. В університетах постійно йде робота над тим, щоб виявляти сильні й слабкі сторони в усіх сферах університетського життя, маючи на меті покращувати ситуацію для того, щоб студенти отримували кращий досвід під час навчання в університеті, залучалися до процесів прийняття рішень і головне - відчували, що їх думка має значення й має реальний вплив на ситуацію. Тобто студенти мають відчувати, що їх цінують і ставляться до них як до партнерів.

В університетах України, цілісних політик, спрямованих на те, щоб забезпечити студентам центральне місце в процесах врядування поки що немає. Але разом з тим ми побачили, що в університетах існують різні практики, які позитивно впливають на участь студентів у процесах університетського врядування. Крім того, на рівні документів, таких, як Стратегічний план розвитку університету, Етичний кодекс, Статут університету, розроблені окремі положення, в яких йдеться про той чи інший аспект студентського залучення.

5. Для утвердження шляхів співпраці між університетом та студентами, доцільним вбачається розроблення на інституційному рівні «Угоди про партнерство зі студентами». Угода про партнерство зі студентами в університеті може бути одним з механізмів удосконалення врядування на інституційному рівні, слугувати віддзеркаленням можливостей студентів в університеті та діяти як інструмент для розвитку взаємодії та партнерських відносин між університетом та студентами.

Перед розробленням Угоди про партнерство зі студентами рекомендується зробити певну діагностику відносно розуміння «партнерства» в конкретному університеті. Задля унаочнення динаміки, за якою може розвиватися роль студентів у конкретному університеті - від найнижчої сходинки «постачальник інформації», коли залучення студентів зводиться до участі в опитуваннях, до найвищої сходинки - «партнера», коли участь студентів відбувається на рівні конструктивного діалогу - рекомендуємо такий інструмент як «Сходинки студентського партнерства». Даний інструмент може слугувати основою для обговорення засобів, за допомогою яких університети та студентські організації можуть визначати роль, яку студенти відіграють і повинні відігравати в університетському врядуванні, поліпшувати структуру відносин, а також культуру, які сприяють розвитку партнерства. 


\section{Список використаних джерел}

1. Андрущенко В., Савельєв В. Освітня політика (огляд порядку денного). К.: «МП Леся», 2010. 364 с.

2. Демократія. Антологія / упорядник О. Проценко. К.: Смолоскип, 2005. 1108 с.

3. Дьюи Дж. Демократия и образование. М.: Педагогика пресс. 200, 3084 с.

4. Електронна приймальна університету. Київський національний університету імені Тараса Шевченка. URL: https://office.knu.ua/

5. Електронний кампус. Національний технічний університет України «Київський політехнічний інститут імені Ігоря Сікорського». URL: https://ecampus.kpi.ua/about

6. Етичний кодекс університетської спільноти. Ухвалений на Конференції трудового колективу Київського національного університету імені Тараса Шевченка. Протокол № 2 від 27.12.2017 року. URL: http://www.univ.kiev.ua/pdfs/official/ethical-code/Ethical-code-of-the-university-community.pdf

7. Закон України «Про вищу освіту» від 1 липня 2014 року № 1556-VII. URL: https://zakon.rada.gov.ua/laws/show/1556-18\#Text

8. Київський національний університет культури і мистецтв. URL: http://knukim.edu.ua/

9. Київський національний університету імені Тараса Шевченка. URL: http://knu.ua

10. Кодекс честі Національного технічного університету України «Київський політехнічний інститут імені Ігоря Сікорського». (2015). Ухвалений Конференцією трудового колективу НTУУ «КПІ» 09 квітня 2015 року. URL: https://kpi.ua/code

11. Національний технічний університет України «Київський політехнічний інститут імені Ігоря Сікорського». URL: https://kpi.ua

12. Пам'ятка для студентів. Харківський національний університет імені В.H. Каразіна. URL: https://www.univer.kharkov.ua/docs/work/pamyatka2018.pdf

13. Словник української мови. Академічний тлумачний словник (1970-1980). URL: http://sum.in.ua/s/uchastj

14. Стратегія розвитку Національного технічного університету України «Київський політехнічний інститут імені Ігоря Сікорського» на 2020-2025 роки (проєкт). URL: https://data.kpi.ua/sites/default/files/files/20202025-strategy.pdf

15. Стратегія розвитку вищої освіти України на 2021-2031 роки (проєкт). Міністерств освіти і науки України, 2020. URL: https://mon.gov.ua/storage/app/media/rizne/2020/09/25/rozvitku-vishchoi-osviti-v-ukraini-0210-2020.pdf

16. Студентське самоврядування - важливий фактор розвитку якісної освіти. URL: http://knukim.edu.ua/studentske-samovryaduvannya-vazhliviy-faktor-rozvitku-yakisnoyi-osviti/

17. Студкуратор. Київський національний університету імені Тараса Шевченка. URL: http://sp.knu.ua/studkurator-2/

18. Теорія партисипаторної демократії. Вікіпедія. Вільна енциклопедія. URL: https://uk.wikipedia.org/wiki/\%D0\%A2\%D0\%B5\%D0\%BE\%D1\%80\%D1\%96\%D1\%8F \%D0\%BF\%D0\%B0\%D1\%8 0\%D1\%82\%D0\%B8\%D1\%81\%D0\%B8\%D0\%BF\%D0\%B0\%D1\%82\%D0\%BE\%D1\%80\%D0\%BD\%D0\%BE\%D1\%97 \%D0\%B4\%D0\%B5\%D0\%BC\%D0\%BE\%D0\%BA\%D1\%80\%D0\%B0\%D1\%82\%D1\%96\%D1\%97

19. Харківський національний університет імені В.Н. Каразіна. URL: https://www.univer.kharkov.ua

20. Червона Л. Роль студентської спільноти у забезпеченні ефективного університетського врядування: теоретичні основи. Аналіз провідного вітчизняного та зарубіжного досвіду розвитку щодо механізмів реалізації ефективного врядування в університетах: препринт (аналітичні матеріали) (частина I). Київ: Інститут вищої освіти НАПН України, 2018. С. 76-100. URL: https://ihed.org.ua/wpcontent/uploads/2019/09/Analiz dosvidu vriaduvania v univer ch1 analit IVO-2018-147p avtors-

kolektiv.pdf

21. Червона Л. Роль студентської спільноти у забезпеченні ефективного університетського врядування: аналіз вітчизняних та зарубіжних практик. Аналіз провідного вітчизняного та зарубіжного досвіду розвитку щодо механізмів реалізації ефективного врядування в університетах: препринт (аналітичні матеріали) (частина II). Київ: Інститут вищої освіти НАПН України, 2019. С. 70-94. URL: 
https://ihed.org.ua/wp-content/uploads/2020/04/Analiz dosvidu vriaduvania v univer ch2 analit IVO2019-96p avtors-kolektiv.pdf

22. Червона Л. Роль студентської спільноти у забезпеченні ефективного університетського врядування: методичні рекомендації. Механізми реалізації ефективного врядування в університетах України в умовах євроінтеграції: методичні рекомендації. Київ: Інститут вищої освіти НАПН України, 2019. С. $76-$ $93 . \quad$ URL: https://ihed.org.ua/wpcontent/uploads/2020/07/Mekhanizmy vriaduvania univ UA metodychni IVO-2019-93p_avtorskolektiv.pdf

23. Шпаргалки для студентів. Національний технічний університет України «Київський політехнічний інститут імені Ігоря Сікорського». URL: https://kpi.ua/scholarships-about

24. A student engagement framework for Scotland. URL: https://www.sparqs.ac.uk/upfiles/SEFScotland.pdf

25. Berger Communiqué: EHEA Ministerial Conference, 2005. URL: http://www.ehea.info/cid101762/bergen.html

26. Bologna process between Prague and berlin Report to the Ministers of Education of the signatory countries Berlin, September 2003. URL: http://www.ehea.info/media.ehea.info/file/ESU/27/5/Bologna-With-StudentEyes 2003 565275.pdf

27. Bologna with student eyes. URL: https://www.esu-online.org/publications/bologna-student-eyes-2018-2/

28. Bryson C., Cooper G., Hardy C. Reaching a common understanding of the meaning of student engagement. Paper presented at Society of Research into Higher Education Conference. 2010. December 1416.

29. Bucharest Communiqué EHEA Ministerial Conference, $2012 . \quad$ URL: http://www.ehea.info/Upload/document/ministerial_declarations/Bucharest_Communique_2012 610673.p $\underline{\mathrm{df}}$

30. Budapest-Vienna Ministerial Conference: EHEA Ministerial Conference, 2010. URL: http://www.ehea.info/cid101033/ministerial-conference-budapest-vienna-2010.html

31. Cambridge University Student Union. URL: https://www.cusu.co.uk/

32. Codice etico e di comportamento. URL: http://www.normateneo.unibo.it/codice etico.html

33. EHEA. URL: http://www.ehea.info/

34. Engagement student. The glossary of reform for journalists, parents, and community members. URL: https://www.edglossary.org/student-engagement/

35. Fletcher A. F. C. Student Voice Revolution: The Meaningful Student Involvement Handbook Paperback. Common Action Publishing, $2017 . \quad$ URL: https://www.amazon.com/gp/product/0692954449/ref=as li ss tl?ie=UTF8\&linkCode=sl1\&tag=soundout20\&linkld=a310eb5b7077bf\%2084a817e577369d295c

36. Fletcher A. The Guide to Student Voice. Olympia, WA: Common Action Publishing. 2014. P. 2.

37. Goddard, John, Hazelkorn, Ellen, Kempton, Louise, \& Vallance? Paul (2016). The Civic University: The Policy and Leadership Challenges. Cheltenham, UK: Edward Elgar. DOI: https://doi.org/10.4337/9781784717728

38. GuildHE. URL: https://guildhe.ac.uk/about/

39. Harper D. Students as Change Agents: The Generation Y Model. Olympia, WA: Generation Y. 2000.

40. Higher Education Governance (Scotland) Act 2016. URL: http://www.legislation.gov.uk/asp/2016/15/contents

41. I have an idea. CUSU. URL: https://www.cusu.co.uk/?s=I+have+an+idea

42. Kahu E. R. Framing student engagement in higher education. Studies in Higher Education, 2013. 38:5. P. 758753. https://doi.org/10.1080/03075079.2011.598505

43. Leuven / Louvain-la-Neuve Communiqué: EHEA Ministerial Conference, 2009. URL: http://media.ehea.info/file/2009 Leuven Louvain-la-Neuve/06/1/Leuven Louvain-la-

Neuve Communique April 2009 595061.pdf

44. Munyae M. Mulinge, Josephine N. Arasa, Violet Wawire. The Status of Student Involvement in University Governance in Kenya: The Case of Public and Private Universities. CODESRIA, Dakar, 2017, 252 p.

45. National Campus Leadership Council. URL: https://www.campusleaders.org/nclc/about-us

46. National Student Survey. URL: https://www.educationalpolicy.admin.cam.ac.uk/studentengagement/university-wide-surveys/nss 
47. Navigating resources and support at both the University and your College might seem complex. URL: https://www.cusu.co.uk/support/welfare/academic-resources/

48. Obondoh A. The politics of participatory decision making in campus governance. Accra-North, Ghana : Association of African Universities, 2003. 13 p.

49. Oxford SU. URL: https://www.oxfordsu.org/

50. Paris communiqué: EHEA Ministerial Conference, $2018 . \quad$ URL: http://www.ehea.info/media.ehea.info/file/2018 Paris/77/1/EHEAParis2018 Communique final 952771.pd $\underline{f}$

51. Partnership for Sustainable Global Growth. Interim Committee. Declaration Washington, D.C. September 29, 1996. URL: https://www.imf.org/external/np/exr/dec.pdf

52. Prague Communiqué: EHEA Ministerial Conference, $2001 . \quad$ URL: http://www.ehea.info/cid100256/ministerialconference-prague-2001.html

53. Quaglia R. J. Principal Voice: Listen, Learn, Lead. Corwin, 2016. 75 p.

54. Quaglia R. J. Student Voice: Ensuring a Sense of Self-Worth for Your Students. Corwin Press, 2015. 45 p.

55. Quaglia R. J., Corso M. J. Student Voice: The Instrument of Change. Corwin, 2014. 216 p.

56. Resource Hub. URL: https://www.oxfordsu.org/resourcehub/

57. Sahin A. Perceptions of student council members on their participation in decision-making in higher education. URL: http://etd.lib.metu.edu.tr/upload/12606546/index.pdf

58. Sparqs. URL: https://www.sparqs.ac.uk/

59. Student Advisory Group. URL: https://www.ox.ac.uk/students/life/student-engagement?wssl=1

60. Student Awards. URL: https://www.eusa.ed.ac.uk/studentawards/

61. Student Barometer. URL: https://www.educationalpolicy.admin.cam.ac.uk/student-engagement/universitywide-surveys/student-barometer-survey

62. Student engagement. URL: https://tsep.org.uk/what-we-do/

63. Student help. URL: https://www.oxfordsu.org/wellbeing/student-advice/

64. Student Partnership Agreement. URL: https://www.ed.ac.uk/files/atoms/files/studentpartnershipagreement.pdf

65. Student partnership staircase. URL: https://www.sparqs.ac.uk/resource-item.php?item=254

66. Student Voice Policy. URL: https://www.ed.ac.uk/files/atoms/files/studentvoicepolicy.pdf

67. Templeton L., Smith A., MacCracken A. A Study on Student Voice in Higher Education. Diversity \& Democracy, 2019. 22. № 1. URL: https://www.aacu.org/diversitydemocracy/2019/winter/templeton.

68. Templeton, L., Smith A. \& MacCracken, A. A. (2019). Study on Student Voice in Higher Education. Diversity \& Democracy, 22 (1). URL: https://www.aacu.org/diversitydemocracy/2019/winter/templeton

69. The Berlin Communiqué: EHEA Ministerial Conference, $2003 . \quad$ URL: http://www.ehea.info/cid100938/ministerialconference-berlin-2003.html

70. The Glossary of education reform for journalists, parents, and community members. URL: https://www.edglossary.org/about/

71. The OU Students Association. URL: https://www.oustudents.com/what-is-student-voice

72. The Student Engagement Partnership. URL: https://tsep.org.uk/

73. The Students' Union' Advice Service. URL: https://www.cusu.co.uk/support/students-unions-advice-service/

74. The University of Edinburg. URL: https://www.ed.ac.uk

75. The Higher Education and Research Act 2017. URL: http://www.legislation.gov.uk/ukpga/2017/29/contents

76. Treaty of Lisbon amending the Treaty on European Union and the Treaty establishing the European Community. URL: https://eur-lex.europa.eu/legal-content/EN/TXT/?uri=CELEX\%3A12007L\%2FTXT\#

77. Trowler V. Student Engagement Literature Review. The Higher Education Academy: Lancaster University, 2010. P. 3. URL: https://www.heacademy.ac.uk/system/files/StudentEngagementLiteratureReview 1.pdf

78. TSEP. URL: https://tsep.org.uk/what-we-do/

79. Tyrrell, J., Varnham, S. (2015). The student voice in university decision-making. In Varnham S., Kamvounias, P. \& Squelch, J. (Eds), Higher Education and the Law, (pp. 30-40). The Federation Press.

80. Università di Bologna. - URL: https://www.unibo.it/it/ateneo/chi-siamo/codice-etico-e-di-comportamento 
81. University of Cambridge. URL:https://www.cam.ac.uk/

82. University of Edinburg. URL: https://www.ed.ac.uk

83. University of Oxford. URL: https://www.ox.ac.uk/

84. University Student Handbook 2019/20. URL: https://www.ox.ac.uk/students/academic/studenthandbook?wssl=1

85. Uniwersytet Jagielloński. URL: https://www.uj.edu.pl/uniwersytet-z-collegium-medicum/kodeks-wartosci

86. University's Academic Administration Division. URL: https://academic.admin.ox.ac.uk/about/aad

87. Voice. The Glossary of education reform for journalists, parents, and community members. URL: https://www.edglossary.org/voice/

88. Wait R. and Bols A. (2015) Making Student Engagement a Reality: Turning Theory into Practice. London: Guild HE. Available at. URL: http://www.guildhe.ac.uk/blog/makingstudent-engagement-a-reality-turning-theoryinto-practice/ (Accessed 22nd Jul 2017)

89. Yerevan Communiqué: $\quad$ EHEA Ministerial Conference, $2015 . \quad$ URL: http://www.ehea.info/Uploads/SubmitedFiles/5 2015/112705.pdf

90. Young, H. \& Jerome, L. (2020). Student voice in higher education: Opening the loop. British Educational Research Journal, 46 (3), 688-705. 10.1002/berj.3603 


\title{
Розділ 5. Участь академічного персоналу в ефективному врядуванні університету
}

\author{
Ольга Паламарчук, \\ кандидат педагогічних наук, \\ старший науковий співробітник \\ Відділу лідерства та інституційного розвитку вищої освіти, \\ Інститут вищої освіти НАПН України \\ https://orcid.org/0000-0002-5703-5496
}

\section{Анотація}

Розділ монографії присвячений розгляду участі академічного персоналу в ефективному врядуванні університету та встановленні моделі колегіального врядування як першого кроку у закладах вищої освіти України для успішного переходу від управління до врядування. Зазначено, що питання ефективного врядування та залучення усіх сторін, зокрема академічного персоналу, широко обговорюється у зарубіжних наукових публікаціях. Особливо гостро це питання стоїть у тих країнах, які тільки почали переходити від адміністративного управління з традиційною системою до врядування та переходу до нових форм функціонування університету. До таких країн у нашому дослідженні відносяться Румунія та Хорватія. Встановлено, що на етапі переходу від управління до врядування вони пропонують використовувати колегіальне та корпоративне врядування, яке фокусується на залученні академічного персоналу як основних гравців даного процесу. Таке бачення пояснюється тим, що країни вбачають в академічному персоналі експертизу, компетентність та знання, які допоможуть ширше бачити діяльність університету.

Рекомендовано закладам вищої освіти України більше уваги приділяти цінностям, одним із основних яких $€$ довіра між усіма гравцями освітнього процесу. В умовах розширення участі академічного персоналу у прийнятті рішень на рівні університету, стає актуальним питання щодо прозорості та відкритості діяльності університетів. Рекомендується закладам вищої освіти України мати відкритий електронний доступ до положень, офіційних документів і процесів, які відбуваються в університетах України. 
Питання залучення працівників закладів вищої освіти до процесів врядування в університетах постійно акцентується у ключових документах Європейського простору вищої освіти ${ }^{591}$.

Зокрема, у Будапештсько-Віденській декларації ${ }^{592}$ (Budapest-Vienna Declaration, 2010) про створення Європейського простору вищої освіти наголошується про зобов'язання працювати над більшим залученням працівників вищої освіти та студентів до запровадження і подальшого розвитку Європейського простору вищої освіти. Наголошено на участі працівників закладів вищої освіти та студентів у структурах, що приймають рішення (на європейському, національному та інституційному рівнях).

у Бухарестському комюніке 593 (Bucharest Communiqué, 2012) підтверджується відповідальність держави за вищу освіту та визнається необхідність відкрити діалог щодо фінансування та урядування (governance) у вищій освіті. Наголошується на важливості розвитку більш ефективних структур урядування (governance) та управління (management) у закладах вищої освіти. Констатовано зобов' язання підтримувати залучення студентів і працівників до структур урядування на всіх рівнях.

у Єреванському комюніке 594 (Yerevan Communiqué, 2015) року наголошено на підтримці та захисті студентів і академічної спільноти в їхніх правах на академічну свободу, забезпечується їх представництво як повноправних партнерів в управлінні автономними закладами вищої освіти. Констатовано, що участь студентів та академічного персоналу у демократичному врядуванні (democratic governance) університету $\epsilon$ однією із цінностей (values) Європейського простору вищої освіти.

У Паризькому комюніке 595 (Paris Communiqué, 2018) наголошується на важливості зростаючої ролі в успіху Болонського процесу основних стейкхолдерів, до складу яких входить академічний персонал та студенти. Акцентовано ключові цінності Європейського простору вищої освіти: академічна свобода, доброчесність, інституційна автономія, участь студентів і академічного персоналу у врядуванні.

У звіті "The European Higher Education Area in 2018. Bologna Process Implementation Report» 596 акцентовано увагу на питаннях цінностей у врядуванні, важливості академічної свободи та інституційної автономії, відповідальності прийняття рішень.

У проєкті «Стратегії розвитку вищої освіти в Україні на 2021-2031 роки» ${ }^{597}$ одними із пріоритетних принципів розвитку вищої освіти в Україні виділяють колегіальність, залученість та розподілену відповідальність, також звертається увага на прозорість та відкритість управління, партнерство. Однією із стратегічних цілей щодо покращення системи управління освітою і забезпечення автономії ЗВО є посилення ролі академічної громади (студентів, викладачів, дослідників) в управління закладом вищої освіти.

591 Аналіз провідного вітчизняного та зарубіжного досвіду щодо механізмів реалізації ефективного врядування в університетах: препринт (аналітичні матеріали) (частина ІІ) / Авторський колектив: І. Драч, О. Паламарчук, В. Рябченко, Л. Червона; за заг. ред. С. Калашнікової - Київ: Інститут вищої освіти НАПН України, 2019. - 96 с.

592 Budapest- Vienna Declaration, 2010. URL: http://www.ehea.info/cid101033/budapest-vienna-declaration.html

593 Ministerial conference Bucharest Communique. URL: https://www.ehea.info/cid101043/ministerial-conference-bucharest-2012.html

594 Yerevan Communiqué: EHEA Ministerial Conference, 2015. URL: http://www.ehea.info/Uploads/SubmitedFiles/5 2015/112705.pdf

595 Paris Communiqué: EHEA Ministerial Conference, 2018. URL: http://www.ehea2018.paris/Data/ElFinder/s2/Communique/EHEAParis2018Communique-final.pdf

596 The European Higher Education Area in 2018. Bologna Process Implementation Report. - URL:// https://eacea.ec.europa.eu/nationalpolicies/eurydice/sites/eurydice/files/bologna internet_0.pdf

597 Стратегія розвитку вищої освіти в Україні на 2021-20131 роки. URL: https://mon.gov.ua/storage/app/media/rizne/2020/09/25/rozvitkuvishchoi-osviti-v-ukraini-02-10-2020.pdf 
Таким чином, питання участі академічного персоналу в ефективному врядуванні університету широко обговорюється у європейських та вітчизняних документах. Залученість усіх сторін освітнього процесу до врядування університету є одним із принципів Європейського простору вищої освіти ${ }^{598}$.

\section{Emanu дослідження проблеми участі академічного персоналу в ефективному врядуванні університету}

Дослідження участі академічного персоналу в ефективному врядуванні університету проходило у три етапи.

На першому етапі здійснено загальний огляд зарубіжних та вітчизняних джерел з проблеми, було виявлено теоретичні основи, серед яких визначено принципи, поняття, моделі ефективного врядування.

На другому emani проаналізовано кращий досвід зарубіжних і вітчизняних університетів. Основним критерієм відбору країн для аналізу університетів було безпосереднє успішне застосування врядування та лідерські позиції серед інших країн. Таким чином для аналізу були обрані університети Великої Британії. Також для нашого аналізу було обрано такі країни як Франція, Фінляндія, Данія, які мають успішний досвід проходження шляху переходу від адміністративного управління до ефективного врядування. При аналізі університетів України було обрано топ 3 університети з рейтингу Топ-200.

Ha mpemьому еmani дослідження було виявлено механізми запровадження успішного врядування за участі академічного персоналу в університетах України, надано практичні рекомендації щодо переходу від управління до врядування в університетах України та розроблено авторську модель реалізації врядування в університетах за участю академічного персоналу.

\section{Методи дослідження}

Під час роботи над проблемою участі академічного персоналу в ефективному врядуванні для реалізації мети та виконання поставлених завдань використано комплекс методів наукового дослідження:

- пошуково-бібліографічний - для вивчення нормативних документів (статутів, кодексів та положень університетів, документів Європейського простору вищої освіти), вітчизняних та європейських наукових праць, сайтів зарубіжних університетів та університетів України;

- аналіз та синтез - з метою узагальнення, систематизації та класифікації зібраного матеріалу й оброблення автентичного матеріалу;

- порівняльно-аналітичний - для науково-педагогічного аналізу вітчизняної та зарубіжної літератури;

- системний аналіз - для виявлення механізмів участі академічного персоналу в ефективному врядуванні університету, розроблення моделі переходу від управління до врядуванні в університетах України та надання практичних рекомендацій щодо реалізації ефективного врядування в університетах України.

\footnotetext{
598 Аналіз провідного вітчизняного та зарубіжного досвіду щодо механізмів реалізації ефективного врядування в університетах: препринт (аналітичні матеріали) (частина ІІ) / Авторський колектив: І. Драч, О. Паламарчук, В. Рябченко, Л. Червона; за заг. ред. С. Калашнікової - Київ: Інститут вищої освіти НАПН України, 2019. - 96 с.
} 


\section{Аналіз зарубіжних наукових публікацій з проблеми участі академічного персоналу в ефективному врядуванні університету}

Проблема залученості академічного персоналу до процесів університетського врядування перебуває у центрі уваги зарубіжних науковців. Аналіз дозволив нам виявити низку публікацій, в яких питання залучення академічного персоналу до врядування тісно пов'язані з проблемою підвищення ефективності діяльності закладів вищої освіти.

У праці E. Bacon "Neo-collegiality: restoring academic engagement in the managerial university» 599 зазначається, що академічний персонал - основний ресурс університетів. У вищій освіті, де все частіше вимагають і бажають поновити акцент на суті залучення студентів до університетів, академічний персонал знаходиться на відстані від центрального керівництва. Водночас саме академічний персонал найкраще розуміється щодо вирішення конкретних питань, які стосуються студента. Академічний персонал може сприяти індивідуально і колегіально розв'язанню та розгляду проблем на інституційному рівні.

E. Bacon наголошує на даних дослідження, у рамках якого було проведено опитування серед академічного персоналу. Дослідження показало низький рівень залученості академічного персоналу до процесів прийняття рішень в університеті. Результати опитування також засвідчили бажання академічного персоналу бути залученими до процесів колегіального врядування. Автор дослідження провокує читачів на роздуми щодо повернення до врядування з більш удосконаленим підходом відповідно до нових вимог часу. E. Bacon запроваджений новий термін «нео-колегіальність» ${ }^{600}$.

K. Sahlin ma U. Eriksson-Zetterquist у статті «Collegiality in modern universities - the composition of governance ideals and practices» ${ }^{601}$, досліджуючи досвід врядування в університетах Швеції, відзначають, що колегіальність - це сучасна, ефективна та практична форма врядування, але вона ніколи не працює самостійно, а швидше взаємодіє з іншими формами врядування.

На відміну від університетів у багатьох інших країнах, шведські університети не мають академічних органів, що приймають рішення на університетському рівні, таких як сенати. Історична структура Консисторій (яка складається з професорів) як орган найвищого рівня прийняття рішень, був трансформований у корпоративні органи з великою кількістю зовнішніх членів.

Дослідники розглядають колегіальність у першу чергу як робочий процес ${ }^{602}$. Основний принцип колегіального врядування нагадує академічний семінар, на якому приймаються рішення. Так само, як і під час семінару, обговорення та представлення результатів, дискусії, критика та аргументація висновків, на думку вчених, $€$ основними рисами колегіального врядування. Колегіальна організація та прийняття рішень вимагають часу та вимагають залучення академічного персоналу. Таким чином, залучення професійної спільноти, в тому числі академічного персоналу, $є$ основою колегіального врядування.

Цікавою є думка дослідників про те, що колегіальність - це робочий процес, заснований на науковому аргументі.

599 Bacon E. Neo-collegiality: restoring academic engagement in the managerial university. URL: www. Ifhe.uk

600 Bacon E. Neo-collegiality: restoring academic engagement in the managerial university. URL: www. Ifhe.uk

601 Kerstin Sahlin \& Ulla Eriksson-Zetterquist (2016) Collegiality in modern universities - the composition of governance ideals and practices, Nordic Journal of Studies in Educational Policy, 2016:2-3, 33640, DOI: 10.3402/nstep.v2.33640

602 Kerstin Sahlin \& Ulla Eriksson-Zetterquist (2016) Collegiality in modern universities - the composition of governance ideals and practices, Nordic Journal of Studies in Educational Policy, 2016:2-3, 33640, DOI: 10.3402/nstep.v2.33640 
У статті "Academic staff participation in university governance: internal responses to external quality demands" ${ }^{603}$ V. Kovac, J. Ledic ma B. Rafajac представили результати опитування серед академічного персоналу, яке здійснювалося з метою вивчити університетське врядування через призму сприйняття академічного персоналу.

Опитування засвідчило, що академічний персонал високо цінує колегіальне прийняття рішень. Важливою $є$ виявлена залежність, яка полягає у тому, що загальне задоволення процесами врядування прямо пропорційне до ступеня залученості у процес. Кращі стосунки між керівництвом, на думку академічного персоналу, можуть бути покращені через комунікацію та інформаційні потоки. Також академічні працівники вважають за необхідне посилити командну роботу та співпрацю між академічним персоналом.

У статті A. Marioara, C. Dragusin "Organisation of Romanian Universities on the Principles of Corporate Governance" 604 автори зазначають про складний перехід від традиційної системи управління в університетах Румунії до врядування на принципах корпоративного врядування. Частина принципів корпоративного врядування була взята з OECD і адаптована чинним законодавством Румунії. Принципи, які регулюють вищу освіту в Румунії є наступними:

- прозорість;

- прийняття рішень на основі діалогу та консультацій;

- децентралізація;

- освіта, орієнтована на бенефіціара;

- принцип поваги до права студента мати свою думку;

- участь та відповідальність батьків;

- університетська автономія;

- управлінська та фінансова ефективність;

- академічна свобода та суспільна надійність.

A. Marioara ma C. Dragusin зазначають, що дані принципи корпоративного врядування недостатньо впроваджуються в систему вищої освіти Румунії і вбачають в цьому причину укорінену традиційну систему вищої освіти.

M. Dobbins ma C. Knill у своїй праці «Higher education governance in France, Germany, and Italy: Change and variation in the impact of transnational soft governance» ${ }^{605}$ здійснили порівняльний аналіз змін структури врядування вищою освітою у трьох країнах: Франції, Німеччині та Італії. У статті наголошується на ролі та збалансуванні влади між державою, університетом, участі академічного персоналу у врядуванні університетом та зовнішніми стейкхолдерами.

У праці S. Boffo, P. Dubois, R. Moscati "Changes in University Governance in France and in Italy» ${ }^{006}$ наголошено на результатах інтерв'ю ректорів / президентів університетів Франції та Італії щодо нової системи врядування, особливість якої полягає у залученні всіх учасників університетів, включаючи академічний персонал. У дослідженні виявлено, що академічний персонал не підтримує залучення до врядування у власних університетах зовнішніх експертів.

603 V. Kovac, J. Ledic, B. Rafajac "Academic staff participation in university governance: internal responses to external quality demands", 2003. URL:

https://www.researchgate.net/publication/251215990 Academic Staff Participation in University Governance Internal Responses to Ext ernal Quality Demands

604 A. Marioara, C. Dragusin. Organisation of Romanian Universities on the Principles of Corporate Governance. 2013. URL: https://ideas.repec.org/a/cbu/jrnlec/y2013v6p38-43.html

605 Dobbins M., Knill C. Higher education governance in France, Germany, and Italy: Change and variation in the impact of transnational soft governance. Policy and Society. 2017. Vol. 36, no. 1, 67-88.

606 Boffo S., Dubois P., Moscati R. Changes in University Governance in France and in Italy. Tertiary Education and Management. 2018.

Vol. 14, no. 1, 13-26 
У статті L. Giovanna "University Governance at the Crossroads: The Italian Case» ${ }^{607}$ зазначається про використання різних моделей університетського врядування. Закон про вищу освіту (Gelmini Law) ${ }^{608}$ запустив реформу, відповідно до якої італійські університети змінили організаційну структуру та склад своїх колегіальних органів. Ключовим моментом реформи вищої освіти в Італії є участь «незалежних» членів керівних органів. Ці члени визначаються серед італійських та іноземних громадян, мають володіти відповідними управлінськими навичками та високим професійним досвідом. L. Giovanna розглядає різні моделі врядування та участь представників в органах врядування, які з'явилися після прийняття Закону.

У статті зроблено детальний аналіз врядування за участі академічного персоналу (university governance by the academic staff).

Більш традиційна модель врядування університетом передбачає, що університети повинні включати на інституційному рівні академічний персонал та прислухатися до його думки у прийнятті рішень (ця модель іноді ототожнюється з «колегіальним врядуванням»). Основним аргументом на користь вибору цієї моделі $€$ те, що академічний персонал найкраще розуміє цілі університету та знає як їх досягти. Італійські університети приймають дану модель врядування, проте вони мають обмежену автономію. На думку автора статті дана модель врядування зазвичай призводить до негативних результатів щодо ефективності, прозорості та прийняття рішень.

Для оптимального вирішення проблеми врядування в університеті L. Giovanna пропонує використання поряд з традиційною й інші моделі врядування (корпоративне, бізнес та врядування стейкхолдерами) в одну так звану модель «амальгама». На думку дослідника, залученість усіх зацікавлених сторін зробить врядування італійськими університетами більш ефективним ${ }^{609}$.

Схожу класифікацію моделей врядування запропонував L. Trakman у своїй статті «Modelling University Governance» ${ }^{610}$. Перелік моделей університетського врядування, запропонований L. Trakman $€$ наступним:

- Врядування академічним персоналом - домінує влада академічного персоналу та його безпосередній вплив на органи врядування.

- Корпоративне врядування - поширене серед університетів, в яких функціонує невеликий склад органів врядування та значно менша фінансова та адміністративна відповідальність.

- Врядування довіреною особою. Такий тип врядування відрізняється від інших тим, що він базується на довірі до органів врядування.

- Врядування стейкхолдерами - базується на визначенні груп інтересів, які повинні брати участь в врядуванні університету для забезпечення збалансованої системи, де всі озвучують свої інтереси.

- Амальгама врядування - поєднує у собі вище зазначені чотири моделі врядування.

L. Giovanna на той час не бачив чіткого алгоритму дій щодо застосування «амальгама врядування» (поєднання різних моделей врядування).

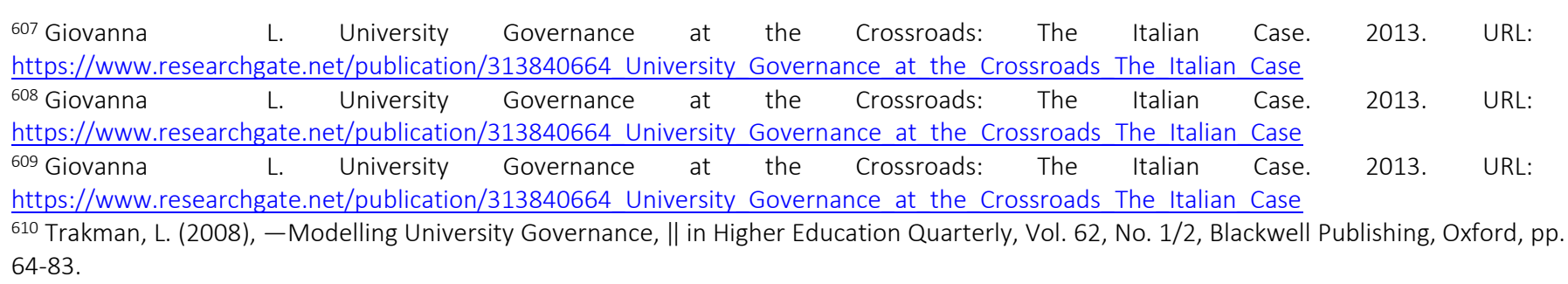


У звіті Європейської асоціації університетів «Efficiency, Effectiveness and Value for Money at Universities» 611 експертами T. Estermann ma V. Kupriyanova досліджено:

- ефективність діяльності університету на системному та інституційному рівнях;

- ефективність в академічних питаннях (дослідження, викладання і навчання);

- та ефективність у стратегічному врядуванні.

У звіті запропоновано ключові повідомлення рекомендаційного характеру щодо збільшення ефективності університетів. Важливим здобутком дослідження є запропоновані методологічні основи, які включають в себе наступні положення ${ }^{612}$ :

- Суб'єкти вищої освіти інтерпретують ефективність по-різному, але ефективність, дієвість і співвідношення ціни і якості нерозривно пов'язані та однаково важливі, оскільки чисто економічна ідея ефективності занадто вузька для складної місії університетів.

- Об'єктивна, гнучка методологічна основа, яка може використовуватися як для теоретичних міркувань ефективності, так і для практичного керівництва по ефективності, включає зближення дій політиків, закладів вищої освіти та їх партнерства на різних рівнях (системному, галузевому та інституційному) і у різних сферах (стратегічна, операційна і академічна).

- Університети потребують стійкого, адекватного державного фінансування, щоб мати можливість інвестувати в потенціал і можливості (наприклад, людські ресурси та інструменти), необхідні для досягнення економії, ефективності, результативності, якості та співвідношення ціни і якості.

- Університети повинні бути автономними і мати можливість самостійно формувати свої структури управління в рамках узгоджених механізмів підзвітності, щоб мати можливість більш ефективно реагувати на зовнішні виклики, вирішувати соціальні та економічні потреби і управляти ресурсами більш стратегічно, ефективно і результативно.

- Низькі показники успіху і висока вартість участі у програмах фінансування ЄС для досліджень, інновацій та вищої освіти підривають довгострокову фінансову стійкість університетів. Істотне спрощення схеми фінансування ЄС має бути переорієнтовано на практику і процеси бенефіціарів, які сприяють синергії між ЄС і національною політикою і схемами фінансування.

- Спільне використання матеріальних і нематеріальних ресурсів $€$ важливою рушійною силою співробітництва університетів у періоди фінансового та кадрового тиску. Міркування ефективності необхідно більш цілісно інтегрувати в цілі міжвідомчого партнерства.

- Університетському сектору необхідно взяти на себе відповідальність і формувати національні програми підвищення ефективності, щоб забезпечити розроблення оптимальних рамок вищої освіти.

- Порядок денний інституційної ефективності залежить від здатності керівників університетів підходити до цієї теми стратегічно та оперативно, щоб забезпечити внутрішню підтримку та мобілізувати ресурси для інвестування у сучасні можливості та кваліфікований персонал, щоб скористатися перевагами ефективного та результативного управління університетом.

Ми повністю поділяємо думку авторів, щодо того, що ефективність - це колективна відповідальність усіх зацікавлених сторін вищої освіти. Ефективні та результативні університети і рамки можуть бути досягнуті лише шляхом постійного діалогу і спільної дії політиків, університетів та їх мереж.

611 T. Estermann, V. Kupriyanova «Efficiency, Effectiveness and Value for Money at Universities», 2019. URL: https://eua.eu/downloads/publications/efficiency\%20effectiveness\%20and\%20value\%20for\%20money.pdf

612 T. Estermann, V. Kupriyanova «Efficiency, Effectiveness and Value for Money at Universities», 2019. URL: https://eua.eu/downloads/publications/efficiency\%20effectiveness\%20and\%20value\%20for\%20money.pdf 
V. Kupriyanova, T. Estermann, N. Sabic y npaui «Efficiency of Universities: Drivers, Enablers and Limitations» 613 проаналізували підходи до розуміння ефективності у сфері вищої освіти. Дослідниками зокрема виділено два підходи: Resource-oriented (ресурсний) та Value-based (ціннісний).

Ресурсно-орієнтований підхід ${ }^{614}$ орієнтований на продуктивність університетських операцій і ступінь досягнення мети діяльності при мінімізації використання ресурсів. Іншими словами, особливо підкреслюється взаємозв'язок між отриманими результатами у порівнянні з використовуваними ресурсами. Головне питання полягає в тому, чи може одна система або організація досягти кращих результатів при тих же або менших ресурсах: «викладачі, студенти та інші учасники вищої освіти роблять вибір, який визначає, чи будуть ці ресурси використовуватися ефективно чи неефективно» ${ }^{615}$.

Підхід, заснований на чінностях ${ }^{616}$, робить акцент на результати, досягнуті для кінцевих користувачів, включаючи студентів, роботодавців, місцеве співтовариство і суспільство в цілому, з урахуванням вартості продукту або послуги. При цьому підході до уваги беруться як на матеріальних, так і на нематеріальних аспектах ефективності. Таким чином ефективність полягає в тому, як використовувати ресурси для максимально повного просування цілей суспільства ${ }^{617}$.

Автори дослідження описують різні приклади показують, що засвідчують важливість для вищої освіти як економії так і ефективності та результативності.

V. Kupriyanova, T. Estermann ma N. Sabic визначають виміри ефективності (efficiency dimensions), до яких відносять ${ }^{618}$ :

- operational efficiency (операційна ефективність). Операційна ефективність обумовлена необхідністю впорядкування бізнес-процесів і оптимізації використання ресурсів. Вона поєднує в собі широкий спектр дій або заходів, виконуваних для забезпечення ефективної реалізації повсякденній діяльності університету, включаючи управління об'єктами і приміщеннями, закупівлі, фінанси, управління персоналом і послуги 3 підтримки студентів;

- efficiency in academic matters (ефективність в академічних справах). Ефективність в академічних питаннях (ефективність у дослідженнях, викладанні і навчанні) охоплює процеси, пов'язані з організацією викладання і досліджень, наприклад цифровизація діяльності;

- efficiency in strategic governance (ефрективність у срері стратегічного врядування). Ефективність у стратегічному врядуванні пов'язана з широким спектром заходів, пов'язаних із творенням інституційної «культури ефективності», включаючи розвиток лідерства, інвестиції в навички та технології, нарощування потенціалу, ефективна внутрішня комунікація тощо.

V. Kupriyanova, T. Estermann ma N. Sabic стверджують, що ефективність діяльності університетів залежить від збалансованої роботи трьох вимірів - стратегічного врядування, академічних питань та впорядкування бізнес-процесів і оптимізації використання ресурсів.

\footnotetext{
613 V. Kupriyanova, T. Estermann, N. Sabic у праці «Efficiency of Universities: Drivers, Enablers and Limitations», 2018. URL: https://www.researchgate.net/publication/326167933 Efficiency of Universities Drivers Enablers and Limitations

614 V. Kupriyanova, T. Estermann, N. Sabic у праці «Efficiency of Universities: Drivers, Enablers and Limitations», 2018. URL: https://www.researchgate.net/publication/326167933 Efficiency of Universities Drivers Enablers and Limitations

615 Hoenach, S. A. (1982). Pricing and Efficiency in Higher Education. Journal of Higher Education, 53(4), $403-418$.

616 V. Kupriyanova, T. Estermann, N. Sabic у праці «Efficiency of Universities: Drivers, Enablers and Limitations», 2018. URL: https://www.researchgate.net/publication/326167933_Efficiency_of_Universities_Drivers_Enablers_and_Limitations

617 V. Kupriyanova, T. Estermann, N. Sabic у праці «Efficiency of Universities: Drivers, Enablers and Limitations», 2018. URL: https://www.researchgate.net/publication/326167933 Efficiency of Universities_Drivers Enablers and Limitations

618 V. Kupriyanova, T. Estermann, N. Sabic у праці «Efficiency of Universities: Drivers, Enablers and Limitations», 2018. URL: https://www.researchgate.net/publication/326167933 Efficiency of Universities Drivers Enablers and Limitations
} 
У звіті T. Estermann, V. Kupriyanova «Insight from Ireland and other countries» ${ }^{619}$ аналізується розвиток вищої освіти Ірландії та ї̈ спрямування на підвищення ефективності діяльності університетів. Значну увагу авторами приділено академічній автономії та розвитку вдосконалення викладання і навчання. У зв'язку з цим в Ірландії було проведено Національний форум для викладання та навчання, на якому обговорювалися сертифікація здібностей у викладанні, розвиток цифрових ресурсів у викладанні, налагодження зв'язків серед колег та однодумців, створення простору для спілкування та обміну думок, залучення студентів до процесу вдосконалення викладання і навчання.

У рамках Форуму:

- зібрані ключові онлайн викладацькі та дослідницькі ресурси;

- визначені маршрути для сертифікованого розвитку цільових навичок;

- створені спеціалізовані цифрові ресурси для вдосконалення;

- наявні широкі можливості для спілкування, консультацій, залучення студентів до покращення викладання та навчання.

У публікації T. Estermann ma V. Kupriyanova «Efficiency, Leadership and Governance: Closing the gap between strategy and execution» 620 акцентується увага на масштабах змін, які $€$ важливим фактором в університеті. Зазначається, що університети повинні мати можливість проходити плавний, безперервний процес змін, задля підвищення ефективності та спрямування ресурсів на покращення викладання і навчання. Іншими словами, виникає необхідність переосмислення ідеї зміни, сприйняття змін як нової реальності та будує інституційну культуру, засновану на змінах.

Корисними для нашого дослідження є усвідомлення того, що перешкоджає змінам, скористатися порадами щодо того, як подолати існуючі бар'єри та зосередитися на факторах успіху, які ведуть до реалізації змін в університеті.

Таким чином, питання ефективного врядування та залучення до нього усіх сторін, зокрема академічного персоналу, широко обговорюється у зарубіжних наукових публікаціях. Особливо гостро це питання стоїть у тих країнах, які тільки почали переходити від традиційного адміністративного управління до врядування, зокрема Румунія та Хорватія. На етапі переходу від управління до врядування експерти пропонують використовувати колегіальне та корпоративне врядування, яке фокусується на залученні академічного персоналу як основних гравців даного процесу, враховуючи їх експертизу та залученість у життя університету.

У кожної країни спостерігаємо свій перехід від управління до врядування. Наприклад, Італія, яка теж спочатку використовувала колегіальне врядування зараз використовує модель «амальгамма», яка поєднує в собі різні види врядування, що в свою чергу передбачає залучення різних гравців. У Франції та Німеччині університети болісно переходять на новий рівень залучення зовнішніх експертів до внутрішньої системи врядування університету.

Університети Великої Британії займають лідерські позиції щодо впровадження не просто врядування, розглядаючи ефективне врядування як один із показників ефективності діяльності університетів. Британські вчені розрізняють ефективність у стратегічному врядуванні, ефективність у академічних питаннях та операційну ефективність.

\footnotetext{
619 Thomas Estermann, Veronika Kupriyanova and Michael Casey (2018). Efficiency, Effectiveness and Value for Money: Insights from Ireland and Other Countries. URL: https://eua.eu/resources/publications/756:efficiency,-effectiveness-and-value-for-moneyinsights-from-irelandand-other-countries.html

620 Thomas Estermann, Veronika Kupriyanova (2018). Efficiency, Leadership and Governance: Closing the gap between strategy and execution. URL: https://eua.eu/downloads/publications/final\%20ustream\%20report\%202018.pdf
} 


\section{Теоретичні основи дослідження проблеми участі академічного персоналу в ефективному врядуванні університету}

\section{Поняття «академічний персонал»}

Відповідно до «Modernization of Higher Education: Academic Staff» ${ }^{621}$ академічний персонал (academic staff): визначається за основними функціями в університеті - викладання, дослідження або поєднання цих двох функцій; має право на академічну свободу, яка включає в себе свободу викладання, дослідження, публікування та право на свободу брати участь в органах врядування університету.

OECD $з$ цього приводу констатує наступне: «Академічний персонал включає персонал, однією 3 основних функцій якого є викладання, дослідження. До нього входять професор, доцент, старший викладач, асистент. Також входить директор, декан, заступник декана, голова відділу, якщо їхня основна діяльність $\epsilon$ викладання або дослідження» ${ }^{622 .}$

Відповідно до рекомендацій UNESCO ${ }^{623}$ академічний персонал університету ${ }^{624}$ :

- означає всіх осіб у закладах вищої освіти, які залучаються для тренінгів (training), проведення досліджень, надання освітніх послуг для студентів або громади в цілому;

- має право обирати представників академічних органів закладів вищої освіти;

- повинен виконувати відповідні обов'язки, необхідні для колегіального управління закладами вищої освіти та професійними органами;

- повинен мати право і можливість відповідно до своїх здібностей брати участь у керівних органах закладів вищої освіти, критикуючи їх діяльність і поважаючи право інших учасників академічної спільноти.

F. Hénard, A. Mitterle у праці «Governance and quality guidelines in Higher Education» ${ }^{625}$ зазначають, що опис академічного персоналу $€$ різним у кожній країні. В англосаксонській системі вищої освіти використовуються поняття «академічний персонал», «службовці», «академічні працівники». Континентальноєвропейські дослідники виділяють дві групи. Перша група складається з академічного персоналу, який здебільшого переймається своїми дослідженнями та викладанням. Вони не є членами центральних рад і не займаються академічним самоврядуванням ${ }^{626}$. Друга група складається з академічного персоналу, який активно залучений у процеси врядування університету. Останню групу називають «академічною олігархією» або «Академічною елітою».

В Україні відповідно до Закону України «Про вищу освіту» ${ }^{627}$ (2014р.) замість терміну «академічний персонал» (academic staff) вживається термін «науково-педагогічні працівники», а поняття «врядування» (governance) визначається через термін «управління закладом вищої освіти».

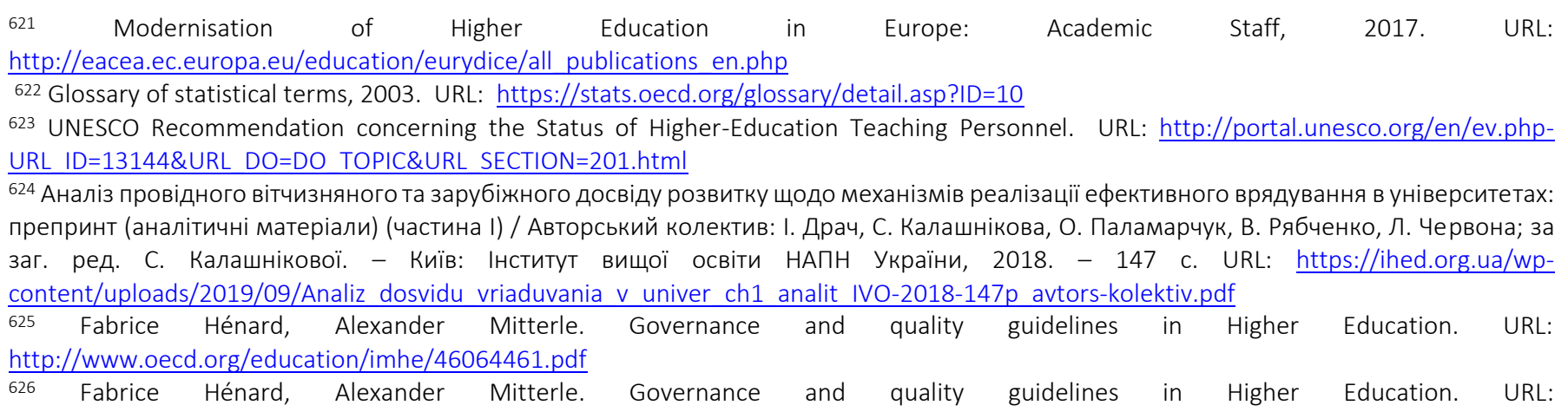
http://www.oecd.org/education/imhe/46064461.pdf

627 Закон України «Про вищу освіту» від 01.07.2014 № 1556-VII. URL: http://zakon4.rada.gov.ua/laws/show/1556-18 


\section{Врядування у вищій освіті}

I. McNay ${ }^{628}$ у врядуванні у вищій освіті виділяє три рівні.

1. Системний (національний, державний) рівень врядування.

Зазвичай має безпосереднє відношення до фінансування та захисту прав. Для прикладу, для Великої Британії це зафіксовано таким чином: «Ефективне регулювання має важливе значення для забезпечення відповідальності за державні кошти, захисту інтересів студентів та захисту репутації вищої освіти Великобританії» .

До ключових характеристик, що забезпечують ефективність врядування на даному рівні віднесено ${ }^{629}$ :

«Реакція на зміни - здатність реагувати на кризу та здатність оперативно змінювати політику.

Орієнтація на результат - зосередження на результатах продукту або послуги.

Передбачуваність - чітка структура, яка гарантує, що прийняті рішення не є спонтанними або примхливими.

Пропорційність-адаптивність дотриманих ризиків.

Незалежність - коли правила встановлені, їх застосування має бути незалежним від політики чи грошей».

2. Інституційне врядування.

Відбувається на корпоративному рівні. До нього віднесено завдання визначати та забезпечувати ${ }^{630:}$

«Напрямок - цінності та місія.

Розподіл влади та прийняття рішень у структурі.

Перевірки та противаги - процеси та представлення.

Оцінювання та підзвітність (внутрішньо - до академічного персоналу та студентів; зовнішньо зацікавленим сторонам, у тому числі урядовим та іншим спонсорам).

Зв'язок - у багатьох напрямках».

3. Академічне врядування. Пов'язано з рішеннями про внутрішнє регулювання та роботою вчених. Академічне врядування охоплює питання, які стосуються викладання і навчання, дослідження, оцінювання освітнього процесу та інших питань, пов'язаних зі студентами.

Додатково врядування у вищій освіті поділяють на зовнішнє і внутрішнє. Внутрішнє - здійснюється через інституційні процеси, координуються через Сенат чи Академічну раду. Зовнішнє - здійснюється через акредитацію національними регулюючими та професійними органами.

У пошуку ключових принципів, на яких має здійснюватися врядування у вищій освіті, I. MсNaу зазначає: «існують цінності, що поділяються у всій вищій освіті, і без яких вища освіта, як ми їі розуміємо, не може існувати. Такі цінності включають: зобов'язання шукати істину; відповідальність щодо обміну знаннями; свобода думки та вільне висловлення думки; суворий аналіз доказів та використання обгрунтованих аргументів, щоб зробити висновок; готовність слухати альтернативні погляди і судити їх по своїх заслугах; врахування того, як власні аргументи будуть сприйматися іншими; зобов'язання розглянути етичні наслідки різних висновків або практики» ${ }^{631}$.

\footnotetext{
628 Ian McNay. Governance, Leadership and Management in the UK Universities, $2016 . \quad-$ URL: http://www.srhe.ac.uk/conference2009/abstracts/0292.pdf

629 Ian McNay. Governance, Leadership and Management in the UK Universities, $2016 . \quad-$ URL: http://www.srhe.ac.uk/conference2009/abstracts/0292.pdf

630 Ian McNay. Governance, Leadership and Management in the UK Universities, $2016 . \quad-$ URL: http://www.srhe.ac.uk/conference2009/abstracts/0292.pdf

631 Ian McNay. Values, Principles and Integrity: Academic and Professional Standards for Higher Education, $2006 . \quad-$ URL: https://www.researchgate.net/publication/227461418 Values Principles and Integrity Academic and Professional Standards in Higher Education
} 
У пошуках відповіді на питання про результати ефективного (належного) врядування звернемося до джерела «Reviewing Academic Governance in Higher Education: a framework» ${ }^{632}$, яке констатує такий перелік ${ }^{633}$ :

- «Впевненість у тому, що стратегічний план виконано.

- Фінансова стабільність досягнута.

- Впевненість у тому, що всі дії були виконані відповідно до законодавства та є люди, які беруть за це відповідальність.

- Забезпечення якості в академічному середовищі.

- Ефективне прорахування ризиків та підтримка інновацій.

- Покращення інституційної репутації та конкурентоспроможності університету.

- Надання рішучості дій в інституційному врядуванні (providing confidence in institutional governance)

- Конструктивна підтримка ректора».

Зазначений документ також пропонує так звану «Enablers of Effective Governance» (Рамку ефективного врядування) ${ }^{634}$ :

- «Ефективне лідерство та динаміка органів врядування.

- Ефективна структура та процес врядування.

- Ефективне членство в органах врядування.

- Відданість візії, організаційній культурі та цінностям.

- Ефективний моніторинг та оцінка показників.

- Ефективна комунікація та надання інформації».

632 Reviewing Academic Governance in Higher Education: a framework. - URL: www.lfhe.ac.uk/AcademicGov

633 Reviewing Academic Governance in Higher Education: a framework. - URL: $\underline{\text { www.Ifhe.ac.uk/AcademicGov }}$

634 Reviewing Academic Governance in Higher Education: a framework. - URL: www. Ifhe.ac.uk/AcademicGov 


\section{Моделі врядування в Європейському просторі вищої освіти}

Відповідно до «University Autonomy III» ${ }^{635}$ в Європейському просторі вищої освіти вирізняють дві моделі врядування - дуальну (dual) та унітарну (unitary).

Дуальна модель: має два органи врядування - Board / Council (рада) та Senate (сенат)). До країн, в яких діє дуальна система врядування належать Італія, Велика Британія ${ }^{636}$.

Унітарна модель: має один орган врядування - Сенат (Естонія, Ірландія, Латвія, Польща) або Рада (Португалія, Бельгія, Норвегія, Швеція) ${ }^{637}$.

Незважаючи на наявність широкого різноманіття у функціонуванні моделей університетського врядування, виділяють певні спільні риси та тенденції. Зокрема такими є:

- Участь у органах врядування визначається інституційними політиками та реалізується відповідними процедурами та інструментами.

- Членами органів врядування університету є: незалежні або «зовнішні» експерти; персонал і студенти університету. До внутрішніх працівників, які можуть брати участь у органах врядування, зазвичай належать керівники, академічний та адміністративний персонал.

- Фактично всі органи врядування вимагають участі представників академічного персоналу.

- Академічний персонал обирається або призначається терміном на два або три роки і вони мають можливість бути переобраними або знову призначеними.

- Якщо академічний персонал може брати участь у органах врядування на довші терміни, то студенти призначаються лише на один рік.

- Академічний персонал та студенти стикаються з різними проблемами, приймаючи участь у органах управління. Але спільним для них $є$ «розуміння того, що вони не повинні діяти як делегати від академічного персоналу чи студентів, а приймати рішення на основі своїх обов'язків як члена системи врядування університету» ${ }^{638}$.

\footnotetext{
635 University Autonomy in Europe, 2017. - URL: https://eua.eu/resources/publications.html

636 University Autonomy in Europe, 2017. - URL: https://eua.eu/resources/publications.html

637 University Autonomy in Europe, 2017. - URL: https://eua.eu/resources/publications.html

638 Governor Briefing Note: Joining a Governing Body. - URL: https://www.Ifhe.ac.uk/en/governance-new/governance-briefing$\underline{\text { notes/index.cfm }}$
} 


\section{Органи врядування}

Для визначення завдань і повноважень органів університетського врядування звернемося до документу "The Scottish Code of Good Higher Education Governance» ${ }^{639}$, який рамку відповідальності та повноважень органів врядування університету окреслює таким чином ${ }^{640}$ :

«Органи врядування відповідають за діяльність університету та за всі прийняті рішення, які стосуються його функціонування. (The governing body is unambiguously and collectively accountable for institutional activities, taking all final decisions on matters of fundamental concern within its remit).

Органи врядування захищають репутацію університету, забезпечуючи чітку політику та процедури, що відповідають етичним та законодавчим нормам. (The governing body protects institutional reputation by being assured that clear regulations, policies and procedures that adhere to legislative and regulatory requirements are in place, ethical in nature, and followed).

Органи врядування забезпечують стабільність університету, працюючи безпосередньо з ректором університету для встановлення стратегії та місії університету. (The governing body ensures institutional sustainability by working with the Executive to set the institutional mission and strategy).

Органи врядування забезпечують ефективну роботу академічного врядування, співпрацюючи 3 Сенатом / Академічною радою. (The governing body receives assurance that academic governance is effective by working with the Senate / Academic Board or equivalent as specified in its governing instruments).

Органи врядування співпрацюють з ректором університету для забезпечення ефективного контролю та належного виконання роботи в університеті. (The governing body works with the Executive to be assured that effective control and due diligence take place in relation to institutionally significant external activities.)

Органи врядування повинні надавати рівні можливості та різноманітність в університеті. (The governing body must promote equality and diversity throughout the institution, including in relation to its own operation).

Органи врядування повинні переконуватися, що структура та процес врядування здійснюється належним чином. (The governing body must ensure that governance structures and processes are fit for purpose by referencing them against recognised standards of good practice)».

639 The Scottish Code of Good Higher Education Governance, 2013. - URL: http://www.scottishuniversitygovernance.ac.uk/the-2013-code-2/ 640 The Scottish Code of Good Higher Education Governance, 2013. - URL: http://www.scottishuniversitygovernance.ac.uk/the-2013-code-2/ 


\section{Університетське врядування у Великій Британії: участь академічного персоналу}

Для аналізу практик врядування в університетах Великої Британії скористаємося інформацією, представленою в «Guide for Members of Governing Bodies of Universities and Colleges in England, Wales and Northern Ireland ${ }^{641}$.

Відповідно до даного документу система університетського врядування включає Сенат та Раду університету.

Сенат складається з 23-х членів ${ }^{642}$ : 2 Pro-Chancellors (про-канцлери); Президент та проректор; Honorary Treasurer (почесний скарбник); 2 представники від Academic Council (Академічна Рада); 2 представники академічного персоналу; 2 представника Support staff (допоміжний персонал); 1 представник Ради студентського об'єднання (Student Union); 10 Lay members (зовнішні експерти).

University Council (Рада університету) - це орган врядування, що опікується загальними питаннями університету. Рада складається з 22 членів, більшість з яких - зовнішні члени. До складу Ради входять також ${ }^{643}$ : 2 представники від академічного персоналу (elected staff members among other academic staff); 1 особа від trade union (профспілки); 1 особа від Academic Board (Академічна рада).

Додатково уточними, що вище зазначена Academic Board ${ }^{644}$ (Академічна рада), у свою чергу, відповідає за академічні питання (стандарти, дослідження, розвиток академічної діяльності університету). Академічна рада університету складається з 30 осіб (але допустимою є кількість до 40 осіб). До складу Академічної ради входить академічний персонал та студенти ${ }^{645}$.

Щодо розуміння процедурних питань органів врядування університетів великої Британії звернемося до документу «Guide for Members of Higher Education Governing Bodies in the UK (Committee of University Chairs)» 646. У документі зазначається:

Орган врядування повинен збиратися не менше чотирьох разів на рік.

Порядок денний та супровідні документи повинні бути надіслати заздалегідь, а прийняті рішення занесені до протоколу.

Члени повинні брати участь у всіх засіданнях, де це можливо.

Орган врядування чітко встановлює кількість, необхідну для кворуму.

Для ефективного функціонування органу врядування повинні бути встановлені правила поведінки на його засіданнях. Питання, для яких потрібні правила, включають, але не обмежуються цим: процедури голосування, скасування рішень, скликання позачергових засідань; вимоги до кворуму; частота зустрічей.

Орган врядування виконує свої обов'язки в колегіальній манері, тобто рішення приймаються колективно усіма членами.

641 Guide for Members of Governing Bodies of Universities and Colleges in England, Wales and Northern Ireland, 2000. - URL: https://dera.ioe.ac.uk/4503/2/01_20.pdf

642 Guide for Members of Governing Bodies of Universities and Colleges in England, Wales and Northern Ireland, 2000. - URL: https://dera.ioe.ac.uk/4503/2/01 20.pdf

643 Guide for Members of Governing Bodies of Universities and Colleges in England, Wales and Northern Ireland, 2000. - URL: https://dera.ioe.ac.uk/4503/2/01 20.pdf

644 Guide for Members of Governing Bodies of Universities and Colleges in England, Wales and Northern Ireland, 2000. - URL: https://dera.ioe.ac.uk/4503/2/01_20.pdf

645 Guide for Members of Governing Bodies of Universities and Colleges in England, Wales and Northern Ireland, 2000. - URL: https://dera.ioe.ac.uk/4503/2/01_20.pdf

646 Guide for Members of Higher Education Governing Bodies in the UK (Committee of University Chairs), 2009. - URL: https://www.ncl.ac.uk/executive/assets/documents/CUCSUMMARYGUIDE.pdf 
Association of Governing Boards of Universities and Colleges ${ }^{647}$, яка функціонує у Великій Британії наголошує на важливості реалізації в університетському середовищі моделі розподіленого врядування (shared governance) та визначає дане поняття таким чином:

«Розподілене врядування як рівність голосів, що означає, що розподіленим врядуванням забезпечується та гарантується те, що факультети, персонал (академічний та адміністративний) має рівне право голосу у всіх питаннях університетського врядування. Рішення не може бути прийнято поки не буде досягнуто консенсусу усіх сторін» ${ }^{648}$.

«Розподілене врядування як консультативний орган. Принцип роботи полягає у тому, що усі органи, які приймають рішення, повинні консультуватися з іншими органами та враховувати їхню позицію» ${ }^{649}$.

«Розподілене врядування як правило залучення усіх. Розподілене врядування включає у себе набір правил, до яких відноситься різноманітні ролі органів врядування, академічного та адміністративного персоналу щодо прийняття академічних, фінансових рішень, рішень щодо вибору президента та інших оперативних рішень» ${ }^{650}$.

«Розподілене врядування як система визначення пріоритетів. Розподілене врядування включає у себе систему відкритої комунікації задля забезпечення та створення культури розподіленої відповідальності, мета якої $\epsilon$ визначення та окреслення пріоритетів задля благополуччя та досягнення спільної мети університету» ${ }^{651}$.

Члени Асоціації апелюють до модель врядування вищої освіти, розробленої H. Boer, J. Enders ma U. Schimank та представленої у праці «Comparing Higher Education Governance Systems in Four European Countries» 652. Ця модель включає п'ять компонентів врядування ${ }^{653}$.

- державне регулювання;

- рекомендації зацікавлених сторін - засвідчують вплив стейкхолдерів не за допомогою директив, а через постановку цілей та надання порад;

- академічне самоврядування - стосується ролі академічного персоналу у врядуванні університету. Їх вплив відбувається через колегіальне прийняття рішень та самоуправління академічних спільнот на основі експертної оцінки;

- у управлінське самоврядування - включає ступінь та розвиток внутрішнього управління ієрархіями університетів та внутрішнє встановлення цілей, регулювання та повноваження щодо прийняття рішень ключовими дійовими особами, такими як ректори, президенти та декани;

- конкуренція, яка в умовах обмеженості ресурсів (кошти, персонал) та за допомогою якісних показників (рейтинг, оцінка ефективності, задоволеність споживачів тощо) впливає на врядування університету.

Розробники моделі підкреслюють, що вище зазначені компоненти врядування є незалежними один від одного. Це означає, що радикальні зміни в одному компоненту не впливають на інші.

${ }^{647}$ Association of Governing Boards of Universities and Colleges (AGB, Annual Report,2017). -URL: https://www.agb.org/about-agb 648 Association of Governing Boards of Universities and Colleges (AGB, Annual Report,2017). -URL: https://www.agb.org/about-agb. C. 1.

${ }^{649}$ Association of Governing Boards of Universities and Colleges (AGB, Annual Report,2017). -URL: https://www.agb.org/about-agb

650 Association of Governing Boards of Universities and Colleges (AGB, Annual Report,2017). -URL: $\underline{\text { https://www.agb.org/about-agb }}$

${ }^{651}$ Association of Governing Boards of Universities and Colleges (AGB, Annual Report,2017). -URL: $\underline{\text { https://www.agb.org/about-agb }}$

652 Boer, H. de, J. Enders and U. Schimank (2008), -Comparing Higher Education Governance Systems in Four European Countries, II in N. C. Soguel and P. Jaccard (eds.) Governance and Performance of Higher Education Systems, Springer, Dordrecht, pp. 35-54.

653 Boer, H. de, J. Enders and U. Schimank (2007) - On the Way Towards New Public Management? The Governance of University Systems in England, the Netherlands, Austria, and Germanyll, in D. Jansen (ed.) New Forms of Governance in Research Organizations. Disciplinary Approaches, Interfaces and Integration, Springer, Dordrecht, pp. 135-152 
Committee on Standards of Public Life (Комітет зі стандартів суспільного життя) ${ }^{654} \in$ недержавним органом, який відстежує та звітує про етичні стандарти, що стосуються поведінки на державних посадах.

В основу діяльності Комітету покладено Nolan Principles (Принципи Нолана). Сім принципів, прописаних лордом Ноланом у 1995 році застосовується до всіх, хто є державним службовцем ${ }^{655}$. Підкреслимо, що у Великій Британії академічний персонал, залучений до діяльності органів університетського врядування, повинен бути обізнаний та чітко дотримуватися Принципів Нолана 656.

У пошуку прикладу адаптації цих Принципів до вищої освіти та відповідно їх застосування ми звернулися до документу «Scottish Code of Good Higher Education Governance ${ }^{657}$.

Зазначений документ деталізує Принципи таким чином ${ }^{658}$ :

«1. Самовідданість. Учасники органів врядування повинні працювати виключно в інтересах університету. (Selflessness - Holders of public office should act solely in terms of the public interest. They should not do so in order to gain financial or other benefits for themselves, their family or their friends).

2. Цілісність. Учасники органів врядування повинні уникати впливу людей або організацій, які негативно впливають на їхю роботу. Учасники не повинні діяти чи приймати рішення виключно заради фінансової або іншої вигоди для себе, для своїх родичів та друзів. Учасники повинні працювати неупереджено та не заводити ніяких особистих зв'язків. (Integrity - Holders of public office should not place themselves under any financial or other obligation to outside individuals or organisations that might seek to influence them in the performance of their official duties).

3. Об'єктивність. Учасники органів врядування повинні приймати рішення об'єктивно, чесно та нікого не дискримінуючи. (Objectivity - In carrying out public business, including making public appointments, awarding contracts, or recommending individuals for rewards and benefits, holders of public office should make choices on merit).

4. Відповідальність. Учасники органів врядування беруть на себе відповідальність за публічність прийнятих ними рішень та дій і повинні бути готові до детального пояснення та за необхідності відстоювання прийнятих рішень. (Accountability - Holders of public office are accountable for their decisions and actions to the public and must submit themselves to whatever scrutiny is appropriate to their office).

5. Відкритість. Учасники органів врядування повинні приймати рішення відкрито та прозоро. Ненадання інформації відкритості та доступності повинно мати за собою законні підстави (Openness - Holders of public office should be as open as possible about all the decisions and actions they take. They should give reasons for their decisions and restrict information only when the wider public interest clearly demands).

6. Чесність. Учасники органів врядування повинні бути правдиві та чесні. (Honesty - Holders of public office have a duty to declare any private interests relating to their public duties and to take steps to resolve any conflicts arising in a way that protects the public interest).

7. Лідерство. Учасники органів врядування повинні дотримуватися усіх Принципів Нолана у своїй поведінці та нейтралізувати невідповідну поведінку у інших. (Leadership - Holders of public office should promote and support these principles by leadership and example)».

У цьому ж документі (Scottish Code of Good Higher Education Governance) ${ }^{659}$ акцентується увага га етичних засадах університетського врядування та відповідно зазначається:

«Для того, щоб зберегти репутацію університету, орган врядування повинен дотримуватися найвищих стандартів етичної поведінки серед своїх членів, які повинні етично поводитися у суспільному житті та гідно представляти інтереси університету (... in order to preserve the reputation of the university, the governing body

${ }^{654}$ Committee on Standards of Public Life. - URL: https://www.gov.uk/government/organisations/the-committee-on-standards-in-public-life

655 Governor Briefing Note: Values and Ethics. - URL: https://www.Ifhe.ac.uk/en/governance-new/governance-briefing-notes/governancebriefing-note-21.cfm

656 The Scottish Code of Good Higher Education Governance, 2013. - URL: http://www.scottishuniversitygovernance.ac.uk/the-2013-code-2/

657 The Scottish Code of Good Higher Education Governance, 2013. - URL: http://www.scottishuniversitygovernance.ac.uk/the-2013-code-2/

658 The Scottish Code of Good Higher Education Governance, 2013. - URL: http://www.scottishuniversitygovernance.ac.uk/the-2013-code-2/

659 The Scottish Code of Good Higher Education Governance, 2013. - URL: http://www.scottishuniversitygovernance.ac.uk/the-2013-code-2/ 
must adhere to the highest standards of ethical conduct among its members who must ethically conduct themselves in a social life and be worthy of representing the interests of the university) $\gg{ }^{660}$.

Кодекс зазначає ще один важливий принцип про те, що академічний персонал та студенти «мають однакову юридичну відповідальність та зобов'язання як і інші члени органів врядування і не повинні бути виключені з обговорення. Якщо рішення прийнято, то усі без винятку повинні дотримуватися його та приймати колективну відповідальність» ${ }^{661}$.

Додатково до вище означених принципів Scottish Code of Good Higher Education Governance ${ }^{662}$ визначає ще низку принципів для забезпечення ефективного університетського врядування а саме ${ }^{663}$ :

- «академічна свобода, високоякісне дослідження та навчання і викладання;

- захист інтересів студента через ефективне врядування;

- висвітлення точної та прозорої інформації, яка доступна кожному;

- досягнення рівності можливостей та різноманітності в університеті;

- вища освіта повинна бути доступна усім, хто візьме з неї користь;

- повна та прозора відповідальність щодо коштів університету».

Для розуміння ролі академічного персоналу у врядуванні університетами Великої Британії, скористаємося джерелом "Academic Role Description Manual» ${ }^{664}$, що визначає це таким чином ${ }^{665}$ :

- «розглядати питання з усіх точок зору;

- надавати експертну оцінку ситуації;

- надавати незалежну оцінку внутрішнім конфліктам інтересів;

- надавати корисні контакти та заводити необхідні зв'язки;

- надавати зовнішню оцінку питанням університету».

Важливим аспектом у питанні участі академічного персоналу у забезпеченні ефективного врядуванні університету $є$ якості, якими необхідно володіти академічному персоналу, обраному до органів врядування університету.

Governor Briefing Note: Size, Composition and Skills available in the Governing Bodies ${ }^{666}$ відповідає на вище означене питання таким чином: 667

«Здібності та якості, необхідні для участі у органах врядування, зазвичай, складаються зі знань (що відносяться до сектору відповідного бізнесу) та безпосереднього набору загальних компетентностей. У результаті це призводить до того, що до органів врядування обирають людей з глибокими знаннями певної області та тих, у кого є серйозний досвід управлінської діяльності. Такий набір здібностей у людей дає можливість органам врядування оцінювати університет з двох позицій, з позиції вищої освіти та з позиції бізнесу».

\footnotetext{
660 The Scottish Code of Good Higher Education Governance, 2013. - URL: http://www.scottishuniversitygovernance.ac.uk/the-2013-code-2/ 661 The Scottish Code of Good Higher Education Governance, 2013. - URL: http://www.scottishuniversitygovernance.ac.uk/the-2013-code-2/ 662 The Scottish Code of Good Higher Education Governance, 2013. - URL: http://www.scottishuniversitygovernance.ac.uk/the-2013-code-2/ 663 The Scottish Code of Good Higher Education Governance, 2013. - URL: http://www.scottishuniversitygovernance.ac.uk/the-2013-code-2/ ${ }^{664}$ Academic Role Description Manual, 2016. - URL: https://www.salford.ac.uk/ data/assets/pdf file/0011/877106/Academic-Roles-Manualv1-8-2016.pdf

${ }^{665}$ Academic Role Description Manual, 2016. - URL: https://www.salford.ac.uk/_data/assets/pdf file/0011/877106/Academic-Roles-Manualv1-8-2016.pdf. - C. 45 .

666 Governor Briefing Note: Size, Composition and Skills available in the Governing Bodies. - URL: https://www.Ifhe.ac.uk/en/governancenew/governance-briefing-notes/governance-briefing-note-12.cfm

667 Governor Briefing Note: Size, Composition and Skills available in the Governing Bodies. - URL: https://www.Ifhe.ac.uk/en/governance$\underline{\text { new/governance-briefing-notes/governance-briefing-note-12.cfm }}$
} 
Academic Role Description Manual ${ }^{668}$, у свою чергу, пропонує такий перелік якостей академічного персоналу, необхідних для ефективної участі у роботі органів університетського врядування ${ }^{669}$ :

- Розуміння культури та діяльності університету.

- Дотримання 7 Принципів Нолана (самовідданість, цілісність, відповідальність, об'єктивність, відкритість, чесність та лідерство).

- Пропаганда цінностей академічної свободи, відданість студенту та важливості дослідження.

- Прийняття колективної відповідальності щодо рішень колегіальних органів.

Відповідно до положень документу «Academic Governance: Case Studies» ${ }^{670}$ основна передумова для забезпечення ефективної діяльності органів університетського врядування - це належна культура членів органів врядування та його керівної команди щодо відкритості, довіри та поваги.

Продемонструємо реалізацію вище означених особливостей участі академічного персоналу в університетському врядуванні на прикладі кількох британських університетів.

\section{City University ${ }^{671}$}

Особливістю діяльності City University ${ }^{672} €$ залученість та ознайомлення нових членів академічного персоналу та зовнішніх представників з роботою університету, а також ряд подальших вступних зустрічей - 3 віце-канцлером, головним фінансовим директором та іншими членами виконавчої команди. Також однією 3 умов участі $€$ відвідування у ролі спостерігача засідання Сенату. Нові члени також повинні зробити презентацію відповідного змісту.

Додатково зазначимо, що специфічною рисою врядування City University $€$ той факт, що Сенат університету створений як формальний Комітет Наглядової ради. Рада делегувала Сенату відповідальність за стандарти та питання якості. Відповідно академічні показники діяльності університету розглядаються Радою за основі щорічного звіту від Сенату.

Цікавою особливістю роботи Ради університету є так звані «пленарні вечері». Вони проводяться тричі на рік, ввечері безпосередньо перед засіданнями Наглядової ради. Ці вечері відвідують усі члени Ради. Такий формат комунікації дозволяє глибше розглянути питання, що цікавлять Раду, але формальні рішення на вечері не приймаються ${ }^{673}$.

\section{University of Cambridge 674}

Важливою складовою процесів врядування в University of Cambridge ${ }^{675} €$ «обговорення». Цей процес здійснюється у форматі форуму, на якому члени університету, в тому числі і академічний персонал, можуть публічно коментувати справи університету. Зокрема, на цьому форумі представники академічного персоналу університету можуть коментувати доповіді чи звіти, що виносяться на розгляд органів врядування університету. Повідомлення для обговорення видаються Віце-канцлером університету та публікуються в «The University Reporter» ${ }^{676}$, як правило, за два тижні до засідання відповідного органу.

Обговорення $є$ важливим засобом, за допомогою якого органи врядування University of Cambridge отримують зворотний зв'язок. Обговорення є важливою частиною процесу прийняття рішень в University of Cambridge. Органи врядування розглядають зауваження та пропозиції від академічного персоналу. Обговорення доповідей відбувається до того, як Регентський дім здійснює затвердження рішення. Таким чином, надані академічним персоналом університету зауваження та пропозиції впливають на прийняті рішення

\footnotetext{
${ }^{668}$ Academic Role Description Manual, 2016. - URL: https://www.salford.ac.uk/ data/assets/pdf file/0011/877106/Academic-Roles-Manualv1-8-2016.pdf

${ }^{669}$ Academic Role Description Manual, 2016. - URL: https://www.salford.ac.uk/ data/assets/pdf file/0011/877106/Academic-Roles-Manualv1-8-2016.pdf

670 Academic Governance: Case Studies. URL: www.Ifhe.ac.uk/AcademicGov

${ }^{671}$ City University. URL: https://www.city.ac.uk

672 City University. URL: https://www.city.ac.uk

673 City University. URL: https://www.city.ac.uk

674 University of Cambridge. URL: https://www.cam.ac.uk

675 University of Cambridge. URL: https://www.cam.ac.uk

676 University of Cambridge. URL: https://www.cam.ac.uk
} 
Таким чином, проаналізувавши досвід університетів Великої Британії, можемо виокремити такі основні функції академічного персоналу в органах врядування:

- зв'язок та комунікація серед академічного персоналу та студентів;

- прийняття рішень, що вимагають академічного судження;

- залучення у розроблення, перегляд та затвердження академічної стратегії;

- участь у складанні щорічного звіту;

- розгляд скарг студентів та прийняття рішень щодо усунення підстав для їх виникнення;

- залучення у розвиток довгострокової репутації університету;

- співпраця з зовнішніми організаціями;

- надання експертних консультацій та порад;

- участь у незалежній оцінці інших інститутів.

Для ефективної реалізації зазначених функцій важливими $€$ певні якості, якими повинні володіти представники академічного персоналу, які долучаються до роботи в органах університетського врядування. До таких якостей варто віднести:

- розуміння культури та специфіки діяльності університету;

- вміння бачити питання з різних позицій та в різних аспектах;

- володіння корисними зв'язками та контактами;

- наявність незалежної точки зору щодо питань, які розглядаються;

- неупереджене ставлення до можливих внутрішніх конфліктів;

- вірність цінностям академічної свободи,

- відданість студенту та важливості дослідження;

- готовність поділяти колективну відповідальність за рішення колегіальних органів, у прийнятті яких брав участь.

Університети Великої Британії демонструють різні моделі врядування та залучення академічного персоналу до цих процесів. Ефективність кожної моделі обумовлена цілим комплексом факторів, ключовим з яких є академічна культура. 
Участь академічного персоналу в ефективному врядуванні університету: зарубіжний

$$
\text { досвід }
$$

У праці F. Hénard, A. Mitterle "Governance and quality guidelines in Higher Education» ${ }^{677}$ зроблено ґрунтовний аналіз того, як зарубіжні країни та завдяки яким механізмам пройшли шлях від врядування до ефективного врядування.

У роботі описані теоретичні моделі врядування, їх ефективне застосування на практиці, використання рекомендацій, принципів та етичних кодів поведінки. Одним із механізмів ефективного врядування є автономія університету, залученість усіх зацікавлених сторін та стосунки, засновані на довірі. Автори виділяють три види врядування:

1) врядування, яке демонструє бажання університету показати ефективно використану надану їм автономію;

2) застосування механізмів для прийняття корпоративного врядування відповідно до філософії New Public Management;

3) готовність захищати університети, формуючи свою автономію та надаючи поради іншим установам.

Повністю погоджуємося з думкою авторів про те, всі механізми ефективного врядування, в першу чергу, базуються на довірі.

Цінними для нашого дослідження $€$ описані у зазначеній публікації кращі практики ефективного врядування в університетах зарубіжних країн.

677 Fabrice Hénard, Alexander Mitterle. Governance and quality guidelines in Higher Education. URL: http://www.oecd.org/education/imhe/46064461.pdf 


\section{Досвід Ірландії}

У звіті T. Estermann та V. Kupriyanova «Insight from Ireland and other countries» ${ }^{678}$ аналізується розвиток вищої освіти Ірландії та її досвід з метою підвищення ефективності діяльності університетів.

Задля досягнення ефективності діяльності університетів акцентовано увагу на кількох ключових складових освітньої діяльності університету.

\section{Удосконалення викладання та навчання ${ }^{679}$}

Покращення викладання та навчання через співпращю створює широкі можливості для кращого використання ресурсів і покращення досвіду студентів. Заклади вищої освіти Ірландії досягли значного прогресу у напрямі вдосконалення викладання та навчання, зокрема через реалізацію ініціативи Національний форум сприяння викладанню та навчанню у вищій освіті.

Національний форум ${ }^{680}$ ставить за мету підвищити якість навчального досвіду для всіх студентів, об'єднавши всіх тих, хто бере участь у формуванні викладання та навчання, щоб підтримати та розвинути відмінні практики. Створення Форуму було зумовлене розумінням важливості академічного лідерства та професійного розвитку для викладання та навчання.

Національний форум є національною цифровою платформою. Серед перших важливих результатів Форуму є наступні:

1) розроблена та апробована Національна рамка професійного розвитку;

2) розроблена та апробована Рамка цифрових навичок;

3) розроблена та апробована перша багатовимірна Національна система нагород ${ }^{681}$;

4) розроблено теми для вдосконалення навчання та навчання в Ірландії;

5) встановлено маршрути для сертифікованого розвитку цілеспрямованих навчальних навичок (наприклад, використання «цифрових значків»);

6) створено спеціалізовані цифрові ресурси для вдосконалення викладання;

7) створено мережу для спілкування, консультацій та поширення кращого досвіду;

8) мобілізовано та залучено студентів до покращення викладання та навчання.

\section{Залучення студентів ${ }^{682}$}

Використання інструментів для опитування студентів надає значні переваги як на інституційному, так і на національному рівнях, підсилюючи процеси забезпечення якості через відгуки та залучення студентів.

Ірландське опитування участі студентів (ISSE) ${ }^{683}$ розроблено на виконання завдання Національної стратегії вищої освіти до 2030 року - створення всеосяжної та анонімної системи зворотного зв'язку студентів.

678 Thomas Estermann, Veronika Kupriyanova and Michael Casey (2018). Efficiency, Effectiveness and Value for Money: Insights from Ireland and Other Countries. URL: https://eua.eu/resources/publications/756:efficiency,-effectiveness-and-value-for-moneyinsights-from-irelandand-other-countries.html

679 Thomas Estermann, Veronika Kupriyanova and Michael Casey (2018). Efficiency, Effectiveness and Value for Money: Insights from Ireland and Other Countries. URL: https://eua.eu/resources/publications/756:efficiency,-effectiveness-and-value-for-moneyinsights-from-irelandand-other-countries.html

680 Thomas Estermann, Veronika Kupriyanova and Michael Casey (2018). Efficiency, Effectiveness and Value for Money: Insights from Ireland and Other Countries. URL: https://eua.eu/resources/publications/756:efficiency,-effectiveness-and-value-for-moneyinsights-from-irelandand-other-countries.html

681 Thomas Estermann, Veronika Kupriyanova and Michael Casey (2018). Efficiency, Effectiveness and Value for Money: Insights from Ireland and Other Countries. URL: https://eua.eu/resources/publications/756:efficiency,-effectiveness-and-value-for-moneyinsights-from-irelandand-other-countries.html

682 Thomas Estermann, Veronika Kupriyanova and Michael Casey (2018). Efficiency, Effectiveness and Value for Money: Insights from Ireland and Other Countries. URL: https://eua.eu/resources/publications/756:efficiency,-effectiveness-and-value-for-moneyinsights-from-irelandand-other-countries.html

683 Thomas Estermann, Veronika Kupriyanova and Michael Casey (2018). Efficiency, Effectiveness and Value for Money: Insights from Ireland and Other Countries. URL: https://eua.eu/resources/publications/756:efficiency,-effectiveness-and-value-for-moneyinsights-from-irelandand-other-countries.html 
ISSE - це онлайн-опитування студентів (першого та середніх курсів) та викладачів, які збирають інформацію про залучення студентів.

Студентів запитують про їх досвід у таких сферах:

- академічні виклики;

- активне навчання;

- студентський колектив;

- взаємодія та інтегроване в роботу навчання;

- результати навчання;

- готовність до кар'єри;

- загальне задоволення.

Результати опитування, яке проводиться щорічно та досягає середніх показників відповіді понад 25\%, надають відповідну інформацію щодо інституційного управління на рівні закладу вищої освіти, а також щодо національних процесів розроблення та реалізації політики та забезпечення якості вищої освіти. 


\section{Досвід Фінляндії}

\section{University of Helsinki ${ }^{684}$}

На прикладі інституційної трансформації University of Helsinki експертами сформульовано низку цінних рекомендацій щодо реалізації системних змін в університеті: «Це вимагає переосмислення ідеї зміни від прийняття рішення до перспективи, яка сприймає зміни як нову реальність та будує інституційну культуру, засновану на змінах» 685 .

Визначено основні бар'єри щодо змін в університетському середовищі, до яких віднесено:

- відсутність залученості, мотивації та стимулу;

- опір змінам / реформам;

- необхідність зміни думок та менталітету;

- зміна навичок та інструментів управління на всіх рівнях;

- недостатня можливість внутрішньої комунікації;

- попередній негативний досвід;

- відсутність достатніх фінансових ресурсів для належного фінансування програм змін;

- побоювання зірвати або відкласти існуючі проєкти;

- упередження на користь «місцевих», а не «інституційних» потреб / інтересів;

- відсутність загального інституційного майбутнього інвестиційного підходу;

- невідповідність стратегічного планування та розвитку;

- відсутність довіри між академічним персоналом та адміністрацією;

- ризик повернення до старої практики.

686:

3 метою забезпечення успішної імплементації змін в університеті експертами надано такі рекомендації

- старші академічні та адміністративні керівники повинні вміти працювати в командах;

- керівникам потрібно вміти розмежовувати представницьке керівництво, до якого входять академічний персонал, та основне керівництво університету;

- враховуючи різноманітність дисциплінарного та управлінського досвіду керівників університетів, потрібно знаходити спільну мову з усіма;

- лідери повинні розвивати у собі здатність керувати конфліктами, що виникають внаслідок великих змін. Такі конфлікти часто є особистими і можуть бути дуже агресивними, для подолання яких потрібні конкретні навички;

- молодші «агенти змін», уповноважені приймати ініціативи щодо змін на місцевому рівні, повинні мати відповідні знання та навички;

- оцінювання сильних і слабких сторін старшої команди перед початком трансформації допоможе вирівняти членів команди, оскільки допоможе вигравати за рахунок сильних сторін учасників;

- вкладення коштів у правильно організовані вправи з побудови команд допоможуть вирівняти управлінську команду;

- вкладення коштів у розвиток лідерства для наступного покоління лідерів створить умови для більшої єдності в досягненні мети у довгостроковій перспективі.

До факторів успіху, які сприяють реалізації змін в університеті, експертами віднесено ${ }^{687}$ :

- автентичне, лідерство, створене на довірі;

- робота з академічною культурою та розумінням культури академічної спільноти;

684 University of Helsinki. URL: https://www.helsinki.fi/en

685 Thomas Estermann, Veronika Kupriyanova (2018). Efficiency, Leadership and Governance: Closing the gap between strategy and execution. URL: https://eua.eu/downloads/publications/final\%20ustream\%20report\%202018.pdf

686 Thomas Estermann, Veronika Kupriyanova (2018). Efficiency, Leadership and Governance: Closing the gap between strategy and execution. URL: https://eua.eu/downloads/publications/final\%20ustream\%20report\%202018.pdf

687 Thomas Estermann, Veronika Kupriyanova (2018). Efficiency, Leadership and Governance: Closing the gap between strategy and execution. URL: https://eua.eu/downloads/publications/final\%20ustream\%20report\%202018.pdf 
- спілкування з офіційними та неформальними агентами змін (людям із доброю справою, розуміння викладачів чи громади,);

- створення «каталогу ідей» для всіх працівників університету для консультацій та збору відгуків ;

- визначення основних довгострокових цілей;

- залучення членів Наглядової ради університету у процеси змін у ролі «критичного друга»;

- докладання зусиль для створення команди, моніторингу динаміки команди, збалансування компетентностей, посилення довіри та підтримки;

- делегація та розширення прав і можливостей у команді;

- визнання роботи / досягнень / результатів людей;

- узгодження між адміністрацією та науковцями для підвищення розуміння, надання платформи для неформальних комунікацій, забезпечення довіри шляхом встановлення чітких ролей.

На наш погляд, запропонований кейс $€$ критично актуальним для університетської спільноти. 


\section{Досвід Франції}

Модель врядування вищої освіти Франції є дуальною (асиметричною) ${ }^{688}$.

3 метою визначення ролі і функцій академічного персоналу в університетах Франції ми розглянули системи врядування у чотирьох провідних університетах Франції за результатами вступу абітурієнтів ${ }^{689}$ : Université Paris-Dauphine, Institute Louis Bachelier, Institute Curi ma Universite Sorbonne.

Аналіз зазначених систем університетського врядування дозволив встановити, що відповідно до Закону Франції «Про вищу освіту» (2013р.) у закладах вищої освіти Франції були створені органи врядування, які в різних університетах можуть мати різну назву, але за розподілом повноважень поділяються на стратегічні (наприклад, Рада директорів) та консультативні (наприклад, Наукова рада, Рада академічного та студентського життя) органами.

Академічний персонал входить до усіх органів врядування університетів та відіграє у них ключову роль. Основними функціями академічного персоналу $є$ :

- участь у прийнятті рішень на рівні керівних органів університету;

- участь у обговореннях фінансових і стратегічних питань;

- прийняття рішень щодо діяльності студентських об'єднань і студентського життя;

- експертна позиція щодо питань з досліджень і викладання.

Здійснений аналіз досвіду врядування університетів Великої Британії, Ірландії, Фінляндії та Франції дозволяє нам сформулювати певні висновки.

1. Кожна країна та і кожний університет обирають та вибудовують свої оптимальні моделі університетського врядування, що обумовлюються національними традиціями, законодавчими рамками, домінуючими цінностями та культурою, пріоритетами розвитку тощо.

2. Університети Великої Британії демонструють широкий спектр моделей врядування, можливостей і шляхів залучення у ці процеси академічного персоналу. У той же час, дослідником Е. Bacon констатована тенденція до розбудови моделі університетського врядування у Великій Британії, яку вчений назвав як «неоколегіальність».

3. Університети Франції демонструють більш централізований підхід щодо реалізації моделі колегіального врядування. Поряд із цим, академічний персонал $є$ активним учасником процесів: прийняття рішень на рівні керівних органів університету; участь у обговореннях фінансових і стратегічних питань; прийняття рішень щодо діяльності студентських об'єднань і студентського життя; вирішення питань щодо досліджень і викладання.

4. Досвід Фінляндії зазначає, що масштаб змін є важливим фактором в університетах. Університети повинні мати можливість пройти плавний, безперервний процес змін, що забезпечує ефективність та надає ресурси для викладання та навчання. Це вимагає переосмислення ідеї зміни від прийняття рішення до перспективи, яка сприймає зміни як нову реальність та будує інституційну культуру, засновану на змінах. Закладам вищої освіти потрібно звернути увагу на зміни в університетах, залучення усіх учасників до подолання кризи під час змін, налагодження комунікації, розроблення плану дій задля виходу на новий рівень врядування в університетах.

5. Досвід університетів Ірландії є цікавим щодо удосконалення викладання та навчання, створення Національного форуму викладання та навчання, в якому зібрані ключові онлайн викладацькі та дослідницькі ресурси

688 University Autonomy in Europe, 2017. URL: https://eua.eu/resources/publications.htm/

689 Паламарчук О. та ін. Участь академічного персоналу в ефективному врядуванні університету . Аналіз провідного вітчизняного та зарубіжного досвіду щодо механізмів реалізації ефективного врядування в університетах. Препринт (аналітичні матеріали II): К: Інститут вищої освіти НАПН України. 2019. С. 62-69. URL: https://ihed.org.ua/wpcontent/uploads/2020/04/Analiz dosvidu vriaduvania v univer ch2 analit IVO-2019-96p avtors-kolektiv.pdf 


\section{Участь науково-педагогічних працівників в університетському врядуванні: досвід України}

Перейдемо до розгляду практик залучення академічного персоналу (науково-педагогічних працівників) в університетах України. 3 цією метою ми проаналізували документи (стратегії розвитку університетів, статути, положення, кодекси), розміщені на офіційних сайтах трьох провідних університетів України (за Рейтингом університетів «ТОП-200 Україна» 2019 року) ${ }^{690}$.

Відповідно до Закону України «Про вищу освіту» управління у сфері вищої освіти України здійснюється вченою радою закладу вищої освіти (ст. 36) та органами самоврядування закладів вищої освіти (ст. 39).

До Вченої ради входять виборні представники, які представляють наукових, науково-педагогічних працівників і обираються серед завідувачів (начальників) кафедр, професорів, докторів філософії, докторів наук. При цьому не менш як 75 \% складу вченої ради повинні становити наукові, науково-педагогічні працівники закладу вищої освіти (ст. 36).

Вищим колегіальним органом громадського самоврядування закладу вищої освіти є загальні збори (конференція) трудового колективу, до складу якого повинні входити наукові, науково-педагогічні та педагогічні працівники закладу вищої освіти, які працюють у цьому закладі на постійній основі (ст.3 9).

Науково-педагогічні працівники мають право брати участь в управлінні закладом вищої освіти, у тому числі обирати та бути обраним до вищого органу громадського самоврядування, вченої ради закладу вищої освіти чи його структурного підрозділу (ст. 57).

\section{Київський національний університет імені Тараса Шевченка}

Київський національний університет імені Тараса Шевченка займає перші позиції у рейтингу Топ-200 університетів України за даними 2018/2019 навчального року 691 як за показником індексу науковопедагогічного потенціалу $(40,95)$, так і за оцінкою якості навчання $(22,32)$. Університет засвідчує високі показники ефективності освітньої діяльності університету та є лідером на ринку вищої освіти України.

Нами виявлено два документи, що описують політики на рівні університету та мають відповідні положення щодо участі науково-педагогічних працівників у процесах врядування.

Зокрема, у Статуті Київського національного університету імені Тараса Шевченка $є$ Концепція освітньої діяльності університету ${ }^{692}$ :

пункт 2.2. Концепції констатує: «... встановлення відповідальності всіх учасників навчального процесу, залучення всіх категорій працівників Університету та студентів до заходів із забезпечення якості освітніх програм»;

пункт 2.4. Концепції наголошує, що «реалізація цілей освітньої діяльності Університету здійснюється шляхом створення процедур зворотних зв'язків між учасниками освітнього процесу».

В «Етичному кодексі університетської спільноти» Київського національного університету імені Тараса Шевченка констатовано ${ }^{693}$ :

«Університетська спільнота - професорсько-викладацький склад, адміністрація Університету та його структурних підрозділів, наукові працівники, слухачі підготовчих відділень, студенти, аспіранти, докторанти, навчально-допоміжний персонал, працівники адміністративно-господарської частини».

\footnotetext{
690 Рейтинг закладів вищої освіти «Топ-200 Україна» - 2018/2019. URL: https://ru.osvita.ua/vnz/rating/64884/.

691 Рейтинг закладів вищої освіти «Топ-200 Україна» - 2018/2019. URL: https://ru.osvita.ua/vnz/rating/64884/.

692 Статут Київського Національного університету імені Тараса Шевченка. Погоджено конференцією трудового колективу Київського національного університету імені Тараса Шевченка. Протокол від 08.11.2016 року № 2. URL: http://www.univ.kiev.ua/pdfs/statut/statut-22-02-17.pdf

${ }^{693}$ Етичний кодекс університетської спільноти. Ухвалений на Конференції трудового колективу Київського національного університету імені Тараса Шевченка. Протокол № 2 від 27.12.2017 року. URL: http://www.univ.kiev.ua/pdfs/official/ethical-code/Ethical-code-of-theuniversity-community.pdf
} 
Національний технічний університет України «Київський політехнічний інститут імені Ігоря Сікорського»

У Cmpamezії розвитку Національного технічного університету України «Київський політехнічний інститут імені Ігоря Сікорського» на 2020-2025 роки (проєкт) серед переліку ключових завдань визначено наступне (п. 1.14) ${ }^{694}$ :

«На наступному етапі розвитку КПІ необхідно суттєво розширити автоматизацію управлінських функцій університету, підвищити ефективність та розширити можливості використання автоматизованої інформаційної системи «Електронний кампус», створити нову платформу інформаційних сервісів та діалогу між студентами, співробітниками і адміністрацією з метою оперативного вирішення поточних проблем в режимі зворотного зв'язку на усіх рівнях управління КПІ».

Важливою складовою Стратегії університету $\epsilon$ запровадження діалогу між усіма учасниками освітнього процесу у прийнятті рішень. Сприяння цьому завданню констатовано у низці положень Стратегії, зокрема:

п. 1.16 «Має підсилюватися мотивація співробітників-новаторів, які забезпечують прискорений розвиток університету, вдосконалюватися принципи “безсуб'єктності» в управлінні персоналом, механізми захисту гідності і академічних свобод студентів, викладачів, науковців, співробітників, свободи їх волевиявлення»

п. 1.17 «Важливо продовжити вдосконалення програмно-цільової системи прийняття колективних угод на усіх рівнях управління університетом, яка забезпечувала неперервний розвиток КПІ, стабільність колективу і відсутність в ньому конфліктів і суперечностей протягом усіх років незалежності України».

Академічна свобода, прийняття колективних угод є одними із основних принципів врядування, зокрема колегіального врядування. У Національного технічного університету України «Київський політехнічний інститут» $€$ Кодекс честі, який встановлює «загальні моральні принципи та правила етичної поведінки осіб, що працюють і навчаються в університеті, якими вони мають керуватись у своїй діяльності» ${ }^{695}$.

Загальними моральними принципами, якими мають керуватися члени університетської громади, є:

- принцип законності;

- принцип взаємної довіри - атмосфера довіри заохочує вільний обмін ідеями та інформацією в університетському середовищі;

- принцип чесності та порядності;

- принцип справедливості;

- принцип компетентності та професіоналізму;

- принцип відповідальності;

- принцип партнерства і взаємодопомоги;

- принцип взаємоповаги;

- принцип прозорості;

- принцип безпеки та добробуту громади НТУУ «КПІ».

Дотримання зазначених вище принципів має бути справою честі всіх без винятку членів університетського співтовариства. Дані принципи свідчать про ціннісний підхід врядування в університеті.

Зазначимо, що принципи, наведені у Кодексі честі Національного технічного університету перекликаються та в певній мірі з Принципами Нолана (самовідданість, цілісність, об'єктивність, відповідальність, відкритість, чесність, лідерство) ${ }^{696}$, про які ми вже зазначали раніше.

\footnotetext{
${ }^{694}$ Стратегія розвитку національного технічного університету України «Київський політехнічний інститут імені Ігоря Сікорського» на 20202025 роки (проєкт). URL: https://data.kpi.ua/sites/default/files/files/2020-2025-strategy.pdf

695 Кодекс честі Національного університету України “Київського політехнічного інституту імені Ігоря Сікорського», 2015. URL:https://kpi.ua/files/honorcode.pdf

696 The Scottish Code of Good Higher Education Governance, 2013. URL: http://www.scottishuniversitygovernance.ac.uk/the-2013-code-2/
} 


\section{Харківський національний університет імені В.Н. Каразіна}

У Харківському національному університеті імені В.Н. Каразіна існують постійно діючі комісії, до складу яких входять науково-педагогічні працівники, а саме 697

- Комісія з нагляду за дотриманням норм законодавства та Статуту університету;

- Комісія з етики виробничих відносин;

- Комісія з контролю фінансової діяльності;

- Комісія з трудових спорів (відповідно до законодавства про працю).

Науково-педагогічні працівники у складі вище зазначених комісій беруть участь обговоренні, винесенні пропозицій та прийняття відповідних рішень.

Перспективи подальшої розбудови університетського врядування можна прослідкувати через аналіз «Cтратегії розвитку Каразінського університету на 2019-2025 роки». Зокрема, у переліку «Проєкти з реалізації стратегічного бачення» знаходимо:

Проєкт 5.8. «Університетська громадська думка» (організація постійного вивчення та врахування в управлінні думки науково-педагогічних працівників і студентів із залученням сучасних електронних технологій)» ${ }^{698}$.

Університет демонструє діючі практики залучення академічного персоналу про процесів врядування.

Зокрема, на офіційному сайті університету розміщено веб-сторінку «Проєкти для обговорення», на якій представлені різні проєкти (наприклад, проєкти освітніх програм, стратегії розвитку університету, Правил внутрішнього розпорядку тощо), дата винесення на обговорення та термін закінчення внесення пропозицій. Також вказується електронна адреса, на яку можна висилати пропозиції, коментарі або зауваження.

Досвід передових вітчизняних університетів передбачає зародження цінностей, діалогу та довіри між усіма учасниками освітнього процесу, в тому числі академічного персоналу (науково-педагогічних працівників). В основному такі цінності та демократичне управління прописане в стратегії університету, кодексі честі та передбачає запровадження таких дій у майбутньому.

${ }^{697}$ Статут Харківського національного університету імені В.H. Каразіна, 2016. URL: http://www.univer.kharkov.ua/docs/statute/ukstatut2016.pdf

698 Стратегія розвитку Каразінського університету на 2019-2025 роки. Затверджено рішенням Конференції трудового колективу університету від 27 грудня 2018 року. URL: https://www.univer.kharkov.ua/docs/work/strategiya-rozvytku-universitetu-2019-2025-2.pdf 


\section{Рекомендації щодо участі академічного персоналу в ефективному врядуванні університетів України}

1. Розширення термінологічного апарату. В Україні відповідно до Закону України «Про вищу освіту» 699 (2014р.) немає терміну «академічний персонал» (academic staff) та «врядування» (governance), а замість нього вживається терміни «науково- педагогічні працівники» та «управління закладом вищої освіти». Водночас вище зазначені терміни - академічний персонал та врядування - $є$ базовими в європейському просторі вищої освіти. У зв'язку з означеним висловлюємо рекомендацію введення в термінологічний апарат вищої освіти України, у тому числі на рівні стратегічних і нормативно-правових документів, понять «академічний персонал» та «врядування»

2. Задля сприяння успішному переходу від процесів централізованого управління до процесів врядування у закладах вищої освіти України рекомендуємо університетам розробляти та використовувати такі інструменти:

- Рамка відповідальності та повноважень органів врядування;

- Рамка ефективного врядування.

3. Рекомендуємо закладам вищої освіти України приділяти детальну увагу розвитку відповідних здібностей та якостей науково-педагогічних працівників, які обираються та беруть участь в органах університетського управління.

4. При залученні та безпосередній участі науково-педагогічних працівників у органах врядування університетів рекомендуємо розробляти відповідні принципи, основою яких можуть слугувати Принципи Нолана. Не менш критичним завданням вбачається популяризації та роз'яснення колегіальних принципів та підходів.

5. Також в університетах України повинен бути чітко прописаний та зазначений важливий принцип про те, що академічний персонал та студенти мають однакову юридичну відповідальність та зобов'язання як і інші члени органу врядування і не повинні бути виключені з обговорення. Якщо рішення прийнято, то усі без винятку повинні дотримуватися його та приймати колективну відповідальність.

6. В умовах розширення участі академічного персоналу у прийнятті рішень на рівні університету, стає актуальним питання щодо прозорості та відкритості роботи університетів. У зв'язку з означеним рекомендується закладам вищої освіти України мати відкритий електронний доступ до положень, офіційних документів та процесів, які відбуваються в університетах України.

7. Закладам вищої освіти України потрібно звернути увагу на реалізацію змін в університетах, залучення усіх учасників до подолання кризи під час змін, налагодження комунікації, розроблення плану дій задля виходу на новий рівень врядування в університетах.

Задля успішного впровадження інституційних змін можна рекомендувати закладам вищої освіти України наступне:

- важлива ключова чітка стратегія з узгодженими цілями;

- гнучкість, орієнтація на ціль мають вирішальне значення;

- важливо виявити та залучити управлінський персонал, який має відповідні навички для реалізації змін, і мобілізувати його до процесу інституційного розвитку;

- зовнішня експертна підтримка може бути корисною, оскільки вона забезпечує незалежний погляд на речі.

699 Закон України «Про вищу освіту» від 01.07.2014 № 1556-VII. URL: http://zakon4.rada.gov.ua/laws/show/1556-18 


\section{Висновки}

1. Актуальність дослідження участі академічного персоналу в ефективному врядуванні університету засвідчується низкою документів Європейського простору вищої освіти, починаючи 3 Будапештсько-Віденської декларації 2010 року, в якій наголошувалося на «всебічній залученості викладачів до процесів університету», і закінчуючи Римським комюніке 2020 року, в якому зазначається про «дотримання інституційної автономії, академічної свободи та доброчесності, участі студентів і академічного персоналу у врядуванні вищої освіти».

2. Чинний Закон України «Про вищу освіту» (2014р. ) значно розширює повноваження та обов'язки науково-педагогічних працівників закладів вищої освіти України, зокрема щодо їх участі в університетському врядуванні (управлінні університетом на засадах врядування).

3. У проекті Стратегії розвитку вищої освіти в Україні на 2021-2031 роки однією із стратегічних цілей $\epsilon$ посилення ролі науково-педагогічних працівників в управлінні ЗВО та формування у них зацікавленості в успішності всіх аспектів діяльності університету.

4. Творення в університетах України моделі ефективного врядування, яка 6 відповідала вимогам і тенденціям Європейського простору вищої освіти, актуалізує потребу вивчення досвіду європейських країн щодо участі представників академічного персоналу в університетському врядуванні.

5. Теоретичну основу дослідження проблеми участі академічного персоналу в університетському врядуванні визначають і базові поняття.

Визначаємо академічний персонал як прачівників закладу вищої освіти, однією з найголовніших функцій яких є не лише викладання й дослідження, а й активна участь в органах врядування, де вони беруть участь у прийнятті рішень на відповідних рівнях інституційної ієрархії та несуть за че відповідальність перед університетською спільнотою.

6. Здійснене дослідження засвідчило тенденцію зростанні ролі врядування в управлінні університетами та його впливу на підвищення ефективності університетської діяльності, що актуалізує запровадження механізмів ефективного врядування в управління закладами вищої освіти.

7. Пропонується наступна модель переходу від управління до ефективного врядування в університетах України:

1. Визначення цінностей університету.

2. Академічне врядування (залучення академічного персоналу у врядуванні).

3. Колегіальне врядування (прийняття рішень з урахування усіх сторін).

4. Модель «амальгамма» (застосування різних видів врядування).

5. Ефективне врядування. 


\section{Список використаних джерел}

1. Автономія та врядування у вищій освіті: монографія / О.П. Воробйова, Т.О. Горецька, Н.М. Дем'яненко, С.А. Калашнікова, О.М. Коваленко, В.І. Луговий, О. Сич, О.М. Слюсаренко, Ж.В. Таланова, В.П. Ткаченко. К.: Інститут вищої освіти НАПН України, 2015. 192 с. URL: https://ihed.org.ua/wpcontent/uploads/2018/09/Avtonomiya-ta-vryaduv-VO monogr IVO-2015-192p avtors-kolektiv.pdf

2. Аналіз провідного вітчизняного та зарубіжного досвіду розвитку щодо механізмів реалізації ефективного врядування в університетах: препринт (аналітичні матеріали) (частина I) / Авторський колектив: І. Драч, С. Калашнікова, О. Паламарчук, В. Рябченко, Л. Червона; за заг. ред. С. Калашнікової. - Київ: Інститут вищої освіти НАПН України, 2018. 147 с. URL: https://ihed.org.ua/wpcontent/uploads/2019/09/Analiz_dosvidu_vriaduvania_v_univer_ch1_analit_IVO-2018-147p_avtorskolektiv.pdf

3. Аналіз провідного вітчизняного та зарубіжного досвіду щодо механізмів реалізації ефективного врядування в університетах: препринт (аналітичні матеріали) (частина II) / Авторський колектив: І. Драч, О. Паламарчук, В. Рябченко, Л. Червона; за заг. ред. С. Калашнікової. Київ: Інститут вищої освіти НАПН України, 2019. $96 \quad$ с. $\quad 96$ UR content/uploads/2021/02/Analiz dosvidu vriaduvania v univer ch1-2 analit IVO-2020-241p avtorskolektiv.pdf

4. В. Рябченко Розвиток особистісного потенціалу академічного потенціалу і здобувачів вищої освіти як інтегрований критерій результативності та ефективності університетського управління, 2019. URL: file:///C:/Users/\%D0\%9E\%D0\%BB\%D1\%8F/Downloads/82-Article\%20Text-154-1-10-20190617.pdf

5. Етичний кодекс університетської спільноти. Ухвалений на Конференції трудового колективу Київського національного університету імені Тараса Шевченка. Протокол № 2 від 27.12.2017 року. URL: http://www.univ.kiev.ua/pdfs/official/ethical-code/Ethical-code-of-the-university-community.pdf

6. Закон України «Про вищу освіту» від 01.07.2014 № 1556-VII.

URL: http://zakon4.rada.gov.ua/laws/show/1556-18

7. Кодекс честі Національного університету України “Київського політехнічного інституту імені Ігоря Сікорського», 2015. URL:https://kpi.ua/files/honorcode.pdf

8. Паламарчук О. та ін. Участь академічного персоналу в ефективному врядуванні університету. Аналіз провідного вітчизняного та зарубіжного досвіду щодо механізмів реалізації ефективного врядування в університетах. Препринт (аналітичні матеріали ІІ): К: Інститут вищої освіти НАПН України. 2019. С. 62-69. URL:

https://ihed.org.ua/wpcontent/uploads/2020/04/Analiz dosvidu vriaduvania v univer ch2 analit IVO-2019-96p avtorskolektiv.pdf

9. Рейтинг закладів вищої освіти «Топ-200 Україна». 2018/2019. URL: https://ru.osvita.ua/vnz/rating/64884/.

10. Результати загальнонаціонального опитування «Перспективи та потреби розвитку університетів України у процесі реформування вищої освіти у контексті європейської інтеграції» / Авторський колектив; за заг. ред С. Калашнікової. - Київ: Інститут вищої освіти НАПН України, 2019. - 77 с. Міжнародний науковий журнал «Університети і лідерство». № 2(8) (2019). С. 144-220. URL: https://uljournal.org/index.php/journal/article/view/105/98

11. С. Матюх. Методика інтегральної оцінки ефективної діяльності вищого навчального закладу, 2014. URL: http://www.ej.kherson.ua/journal/economic 05/118.pdf

12. Статут Київського Національного університету імені Тараса Шевченка. Погоджено конференцією трудового колективу Київського національного університету імені Тараса Шевченка. Протокол від 08.11.2016 року № 2. URL: http://www.univ.kiev.ua/pdfs/statut/statut-2202-17.pdf

13. Статут Харківського національного університету імені В.Н.Каразіна, 2016. URL: http://www.univer.kharkov.ua/docs/statute/uk-statut2016.pdf

14. Стратегія розвитку Каразінського університету на 2019-2025 роки. Затверджено рішенням Конференції 
трудового колективу університету від 27 грудня 2018 року. URL: https://www.univer.kharkov.ua/docs/work/strategiya-rozvytku-universitetu-2019-2025-2.pdf

15. Стратегія розвитку національного технічного університету України «Київський політехнічний інститут імені Ігоря Сікорського» на 2020-2025 роки (проєкт). URL: https://data.kpi.ua/sites/default/files/files/20202025-strategy.pdf

16. Н. Хворостяна, А. Гаращенко. Теоретико - методологічні основи визначення ефективності діяльності вищого навчального закладу https://ideas.repec.org/a/scn/032455/15918742.html

17. Червона Л. та ін. Роль студентської спільноти у забезпеченні ефективного врядування . Аналіз провідного вітчизняного та зарубіжного досвіду щодо механізмів реалізації ефективного врядування в університетах. Препринт (аналітичні матеріали II): К: Інститут вищої освіти HАПН України. 2019. С. 70-96. URL: https://ihed.org.ua/wp-content/uploads/2020/04/Analiz dosvidu vriaduvania v univer ch2 analit IVO2019-96p avtors-kolektiv.pdf

18. A. Marioara, C. Dragusin. Organisation of Romanian Universities on the Principles of Corporate Governance. 2013. URL: https://ideas.repec.org/a/cbu/irnlec/y2013v6p38-43.html

19. Academic Governance: Case Studies. URL:www.Ifhe.ac.uk/AcademicGov

20. Academic Role Description Manual, $2016 . \quad$ URL: https://www.salford.ac.uk/ data/assets/pdf file/0011/877106/Academic-Roles-Manual-v1-8-2016.pdf

21. Association of Governing Boards of Universities and Colleges (AGB, Annual Report,2017). URL: https://www.agb.org/about-agb

22. Bacon E. Neo-collegiality: restoring academic engagement in the managerial university. URL: www.Ifhe.uk

23. Boer, H. de, J. Enders and U. Schimank (2008), -Comparing Higher Education Governance Systems in Four European Countries, I| in N. C. Soguel and P. Jaccard (eds.) Governance and Performance of Higher Education Systems, Springer, Dordrecht, pp. 35-54.

24. Boffo S., Dubois P., Moscati R. Changes in University Governance in France and in Italy. Tertiary Education and Management. 2018. Vol. 14, no. 1,13-26

25. Brown et al. (2005) Ethical leadership: A review and future directions. URL: https://www.sciencedirect.com/science/article/pii/S104898430600110X

26. Budapest- Vienna Declaration, 2010. URL: http://www.ehea.info/cid101033/budapest-viennadeclaration.html

27. City University. URL: https://www.city.ac.uk

28. Distributed leadership in organizations: a review of theory and research, 2011. URL: https://www.mnsu.edu/activities/leadership/distributed_leadership.pdf

29. Dobbins M., Knill C. Higher education governance in France, Germany, and Italy: Change and variation in the impact of transnational soft governance. Policy and Society. 2017. Vol. 36, no. 1,67-88.

30. Fabrice Hénard, Alexander Mitterle. Governance and quality guidelines in Higher Education. URL: http://www.oecd.org/education/imhe/46064461.pdf

31. Fletcher, D. E. (2007), -Recent Developments in Governance in the UK Higher Education Sector, II in IAUGB (ed.) 1st Meeting of International Association of University Governing Bodies - Society meets University\|l (Granada 23-24 October 2007), International Association of University Governing Bodies, Madrid, pp. 103-108.

32. Giovanna L. University Governance at the Crossroads: The Italian Case. 2013. URL: https://www.researchgate.net/publication/313840664 University Governance at the Crossroads The Itali an Case

33. Glossary of statistical terms, 2003. URL: https://stats.oecd.org/glossary/detail.asp?ID=10

34. Governor Briefing Note: Joining a Governing Body. - URL: https://www.lfhe.ac.uk/en/governancenew/governance-briefing-notes/index.cfm

35. Governor Briefing Note: Size, Composition and Skills available in the Governing Bodies. URL: https://www.Ifhe.ac.uk/en/governance-new/governance-briefing-notes/governance-briefing-note-12.cfm

36. Governor Briefing Note: Values and Ethics. URL: https://www.Ifhe.ac.uk/en/governance-new/governancebriefing-notes/governance-briefing-note-21.cfm

37. Guide for Members of Governing Bodies of Universities and Colleges in England, Wales and Northern Ireland, 
2000. URL: https://dera.ioe.ac.uk/4503/2/01 20.pdf

38. Hernandez et al. (2011) Exploring a more comprehensive view of leadership theory. URL: https://www.sciencedirect.com/science/article/pii/S1048984311001561

39. Hoenach, S. A. (1982). Pricing and Efficiency in Higher Education. Journal of Higher Education, 53(4), 403-418

40. Ian McNay. Governance, Leadership and Management in the UK Universities, 2016. URL: http://www.srhe.ac.uk/conference2009/abstracts/0292.pdf

41. Ian McNay. Values, Principles and Integrity: Academic and Professional Standards for Higher Education, 2006. URL:

https://www.researchgate.net/publication/227461418 Values Principles and Integrity Academic and Prof essional Standards in Higher Education

42. Kerstin Sahlin \& Ulla Eriksson-Zetterquist (2016) Collegiality in modern universities - the composition of governance ideals and practices, Nordic Journal of Studies in Educational Policy, 2016:2-3, 33640, DOI: 10.3402/nstep.v2.33640

43. Ministerial conference Bucharest Communique. URL: https://www.ehea.info/cid101043/ministerialconference-bucharest-2012.html

44. Modernisation of Higher Education in Europe: Academic Staff, 2017. URL: http://eacea.ec.europa.eu/education/eurydice/all publications en.php

45. Reviewing Academic Governance in Higher Education: a framework. URL: www.Ifhe.ac.uk/AcademicGov

46. T. Estermann, V. Kupriyanova «Efficiency, Effectiveness and Value for Money at Universities», 2019. URL: https://eua.eu/downloads/publications/efficiency\%20effectiveness\%20and\%20value\%20for\%20money.pdf

47. The European Higher Education Area in 2018. Bologna Process Implementation Report. URL:// https://eacea.ec.europa.eu/nationalpolicies/eurydice/sites/eurydice/files/bologna internet 0.pdf

48. The Scottish Code of Good Higher Education Governance, $2013 . \quad$ URL: http://www.scottishuniversitygovernance.ac.uk/the-2013-code-2/

49. Thomas Estermann, Veronika Kupriyanova (2018). Efficiency, Leadership and Governance: Closing the gap between strategy and execution. URL: https://eua.eu/downloads/publications/final\%20ustream\%20report\%202018.pdf

50. Thomas Estermann, Veronika Kupriyanova and Michael Casey (2018). Efficiency, Effectiveness and Value for Money: Insights from Ireland and Other Countries. URL: https://eua.eu/resources/publications/756:efficiency,effectiveness-and-value-for-moneyinsights-from-ireland-and-other-countries.html

51. Trakman, L. (2008), -Modelling University Governance, II in Higher Education Quarterly, Vol. 62, No. 1/2, Blackwell Publishing, Oxford, pp. 64-83.

52. UNESCO Recommendation concerning the Status of Higher-Education Teaching Personnel. URL: http://portal.unesco.org/en/ev.php-URL ID=13144\&URL DO=DO TOPIC\&URL SECTION=201.html

53. University Autonomy in Europe, 2017. URL: https://eua.eu/resources/publications.html

54. University of Cambridge. URL: https://www.cam.ac.uk

55. V. Kovac, J. Ledic, B. Rafajac "Academic staff participation in university governance: internal responses to external quality demands", 2003. https://www.researchgate.net/publication/251215990 Academic Staff Participation in University Governa nce Internal Responses to External Quality Demands

56. V. Kupriyanova, T. Estermann, N. Sabic. Efficiency of Universities: Drivers, Enablers and Limitations», 2018. URL: https://www.researchgate.net/publication/326167933 Efficiency of Universities Drivers Enablers and Lim itations

57. Yerevan Communiqué: EHEA Ministerial Conference, 2015. URL: http://www.ehea.info/Uploads/SubmitedFiles/5 2015/112705.pdf 